\title{
Preservation of Ecosystems of International Watercourses and the Integration of Relevant Rules
}

Lee, Jing

Award date:

2012

Link to publication

\section{General rights}

Copyright and moral rights for the publications made accessible in the public portal are retained by the authors and/or other copyright owners and it is a condition of accessing publications that users recognise and abide by the legal requirements associated with these rights.

- Users may download and print one copy of any publication from the public portal for the purpose of private study or research.

- You may not further distribute the material or use it for any profit-making activity or commercial gain

- You may freely distribute the URL identifying the publication in the public portal

Take down policy

If you believe that this document breaches copyright please contact us providing details, and we will remove access to the work immediately and investigate your claim. 


\title{
DOCTOR OF PHILOSOPHY \\ Preservation of Ecosystems of International Watercourses and the Integration of Relevant Rules
}

\author{
Jing Lee
}

2013

University of Dundee

Conditions for Use and Duplication

Copyright of this work belongs to the author unless otherwise identified in the body of the thesis. It is permitted to use and duplicate this work only for personal and non-commercial research, study or criticism/review. You must obtain prior written consent from the author for any other use. Any quotation from this thesis must be acknowledged using the normal academic conventions. It is not permitted to supply the whole or part of this thesis to any other person or to post the same on any website or other online location without the prior written consent of the author. Contact the Discovery team (discovery@dundee.ac.uk) with any queries about the use or acknowledgement of this work. 


\title{
Preservation of Ecosystems of International Watercourses and the Integration of Relevant Rules
}

\author{
Lee Jing
}

\section{PhD International Water Law IHP-HELP Centre for Water Law, Policy and Science University of Dundee}


Table of Contents

ACKNOWLEDGEMENTS

SIGNED DECLARATION FOR SUBMISSION OF POSTGRADUATE THESIS ................................................. II

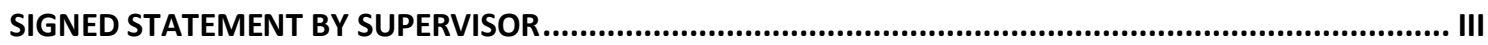

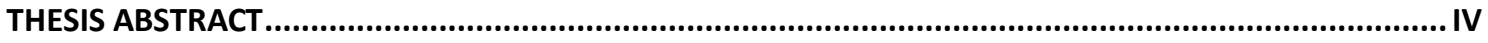

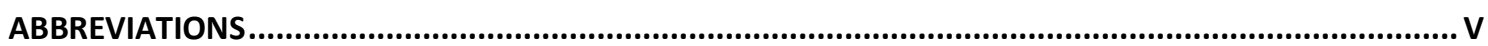

TABLE OF INTERNATIONAL TREATIES AND OTHER INSTRUMENTS...................................................... VII

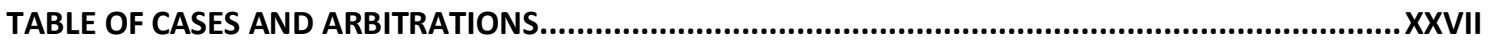

1

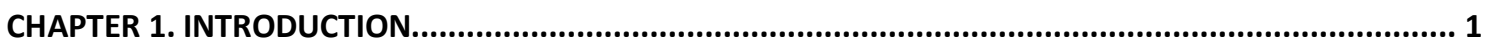

1.1 Context: Environmental Protection of International Watercourses: A ReVieW ........................... 1

1.1.1 Article 20 of the 1997 UN Watercourses Convention .............................................. 7

1.1.2 Current State of Environmental Protection in International Water Law: An Analysis of the

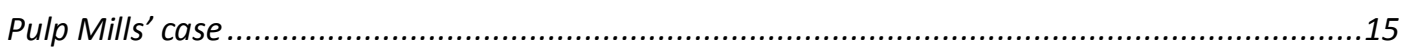

1.2 Problematique: Fragmentation of International LaW ........................................................ 18

1.2.1 Jurisprudence of International Courts and Tribunals.............................................21

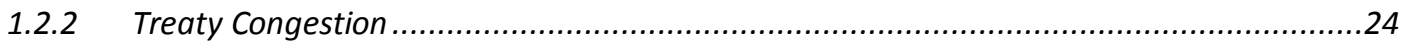

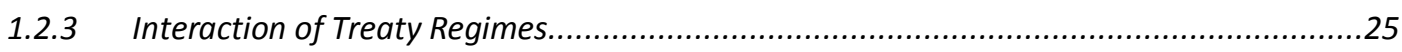

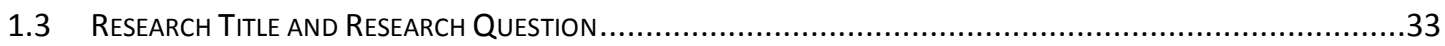

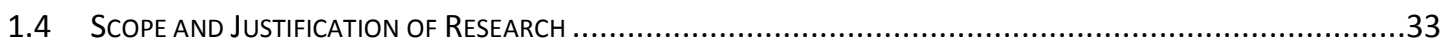

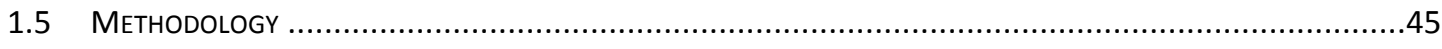

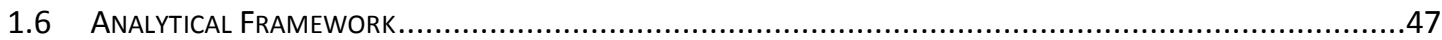

1.6.1 Article 31(3)(c) of the 1969 Vienna Convention on the Law of Treaties: Preliminary Review 48

1.6.2 The Potential of Article 31(3)(c) as an Integration Tool............................................60

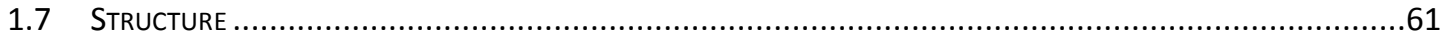

2 .64

CHAPTER 2. RELEVANT: PRESERVATION OF ECOSYSTEMS OF INTERNATIONAL WATERCOURSES - AN

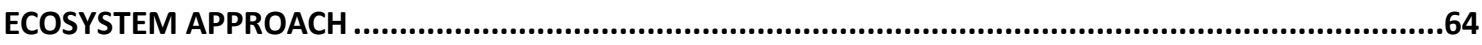

2.1 The Emergence of An Ecosystem Approach ..................................................................64

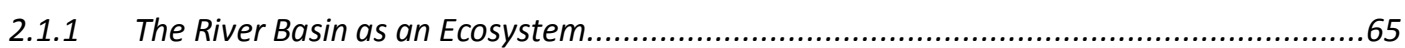

2.1.2 The Ecosystem Approach in International Policy ....................................................67

2.1.3 The Ecosystem Approach in International Law .....................................................68

2.1.4 The Ecosystem Approach and Its Normative Standard .............................................69 


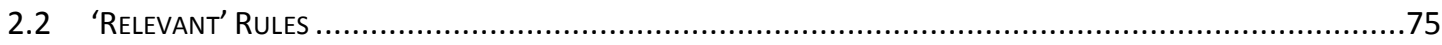

2.2.1. Doctrine In Pari Materia .................................................................................. 79

2.2.2 Normative Parallelism and the Parallelism of Treaty .....................................................80

2.2.3 Multi-Sourced Equivalent Norms (MSENs) ..........................................................8

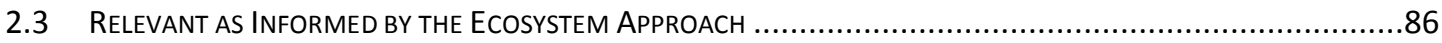

2.3.1 The 1971 Ramsar Convention on Wetlands...............................................................89

2.3.2 The 1992 Convention on Biological Diversity..........................................................93

2.4 A Discussion on the Implication of the Climate Change Regime.............................................98

2.4.1 Climate Change Regime - Its Aims, Objectives and Context....................................99

2.4.2 Climate Change Regime and the Obligation to Preserve ...........................................100

2.4.2.1 1992 United Nations Framework Convention on Climate Change ....................................... 100

2.4.2.2 1997 Kyoto Protocol to the United Nations Framework Convention on Climate Change .... 101

2.4.3 Compatibility of the Climate Change Regime with the Obligation to Preserve...............105

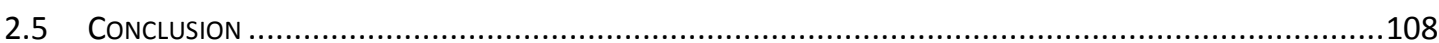

3. .110

CHAPTER 3. RULES OF INTERNATIONAL LAW APPLICABLE IN THE RELATIONS BETWEEN THE PARTIES: A

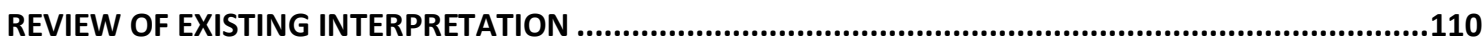

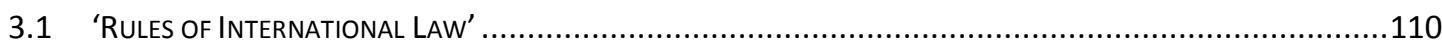

3.2 'Applicable in the Relations between the Parties' ...........................................................118

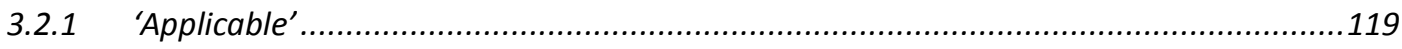

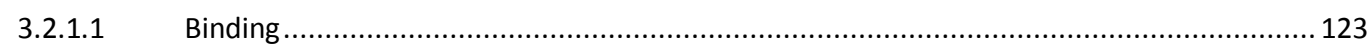

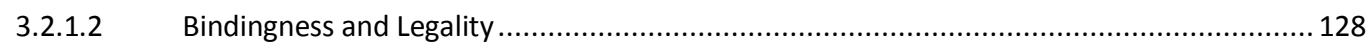

3.2.1.3 Requirement of 'Bindingness' for 'Applicable' Not Supported by Both Textual Analysis and

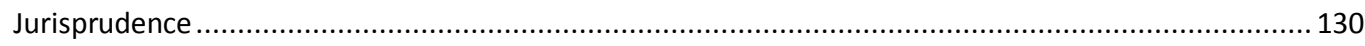

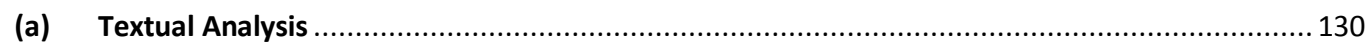

(b) Jurisprudence of International Courts and Tribunals ....................................................... 132

3.2.2 In the Relations between 'the Parties' .............................................................138

3.2.2.1 The Four Possible Constructions of 'the Parties' ........................................................... 148

3.3 Rules of International law Applicable in the Relations between the Parties: Reflection and

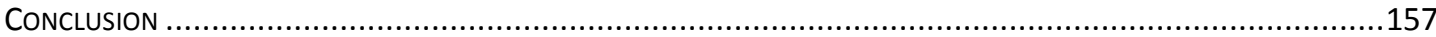

4. .162

\section{CHAPTER 4. RULES OF INTERNATIONAL LAW APPLICABLE IN THE RELATIONS BETWEEN THE PARTIES:}

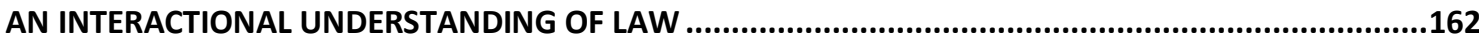

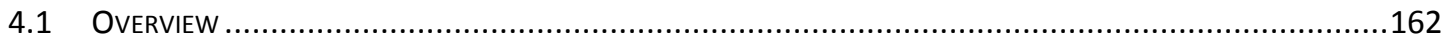

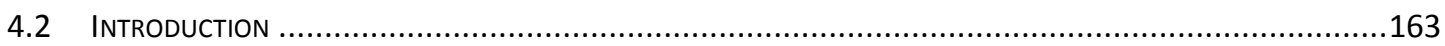

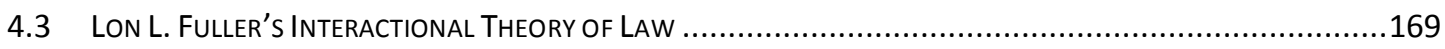

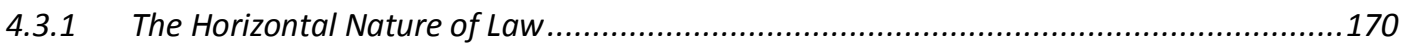




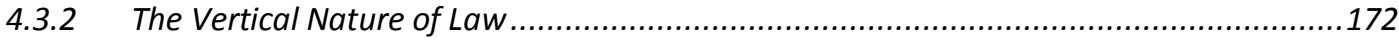

4.4 A FRAMEWORK FOR AN INTERACTIONAL THEORY OF INTERNATIONAL LAW .......................................173

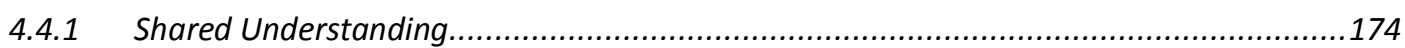

4.4.1.1 The Horizontal Feature of Shared Understanding....................................................... 175

4.4.1.2 The Vertical Feature of Shared Understanding............................................................. 176

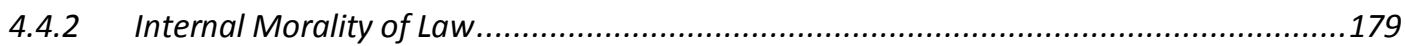

4.4.2.1 Internal Morality of Law - A Commentary .................................................................. 186

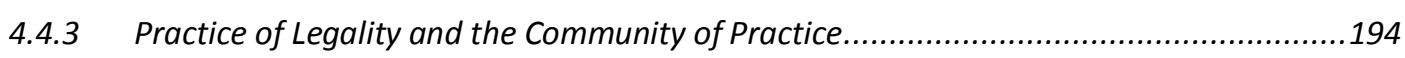

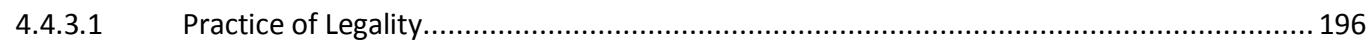

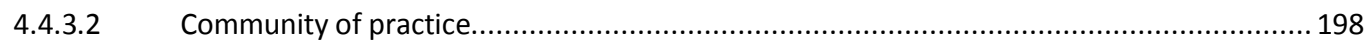

4.5 DisCUSSIONS AND A SUGgESTION FOR REINTERPRETATION..........................................................202

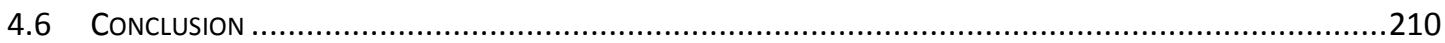

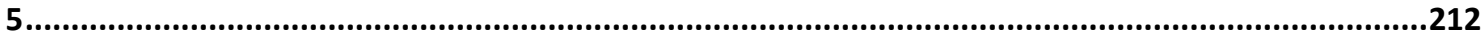

CHAPTER 5. RULES OF INTERNATIONAL LAW APPLICABLE IN THE RELATIONS BETWEEN THE PARTIES:

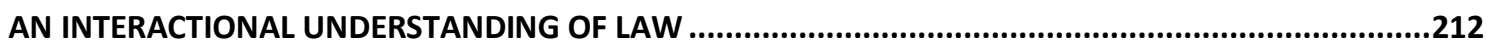

PART II: OPERATION - 1971 RAMSAR CONVENTION ON WETLANDS ............................................212

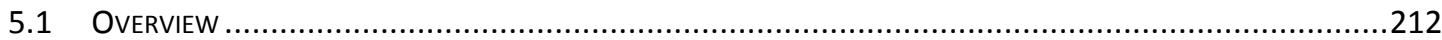

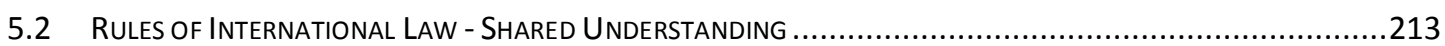

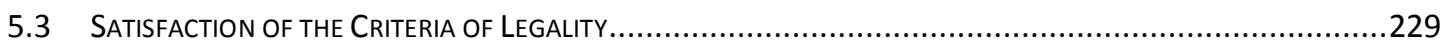

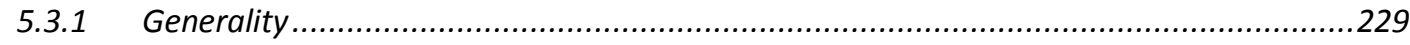

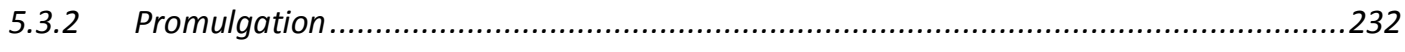

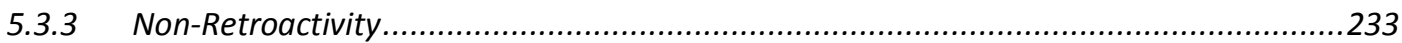

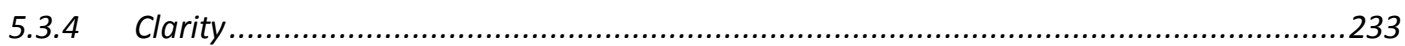

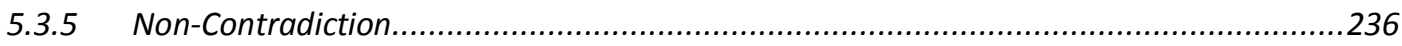

5.3.6 Law Not Requiring the Impossible - Reasonableness.............................................238

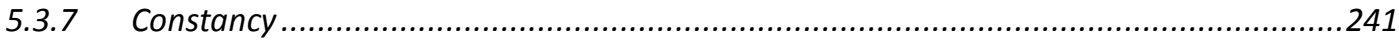

5.3.8 Congruence between Official Action and Declared Rules - the Observation of the Rule of Law 243

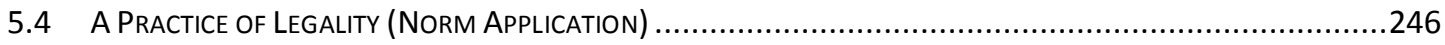

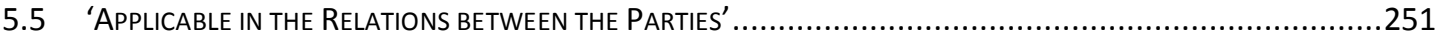

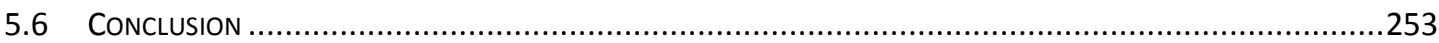

6.

CHAPTER 6. RULES OF INTERNATIONAL LAW APPLICABLE IN THE RELATIONS BETWEEN THE PARTIES:

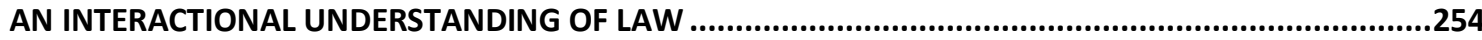

PART II: OPERATION - 1992 CONVENTION ON BIOLOGICAL DIVERSITY ...........................................254

6.1 Overview. 


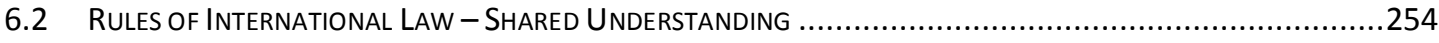

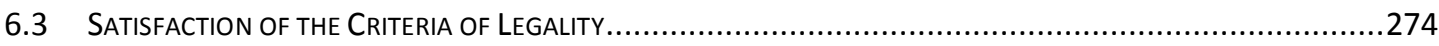

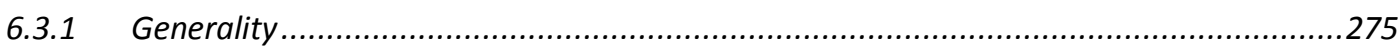

6.3.2 Promulgation .............................................................................................27

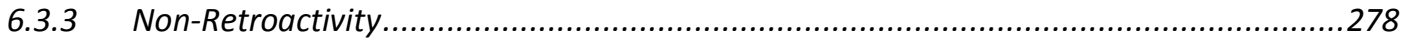

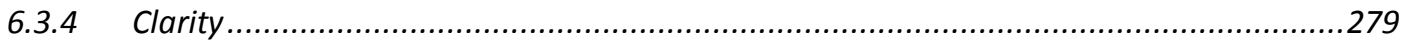

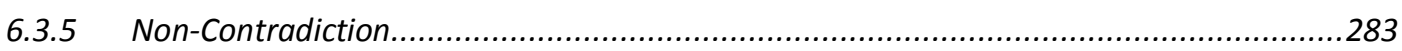

6.3.6 Law Not Requiring the Impossible - Reasonableness..............................................286

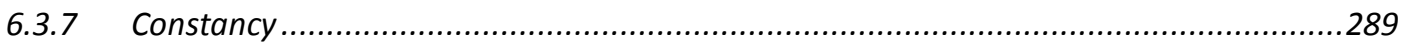

6.3.8 Congruence between Official Action and Declared Rules - the Observation of the Rule of Law 292

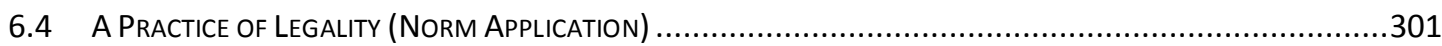

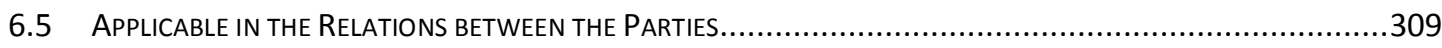

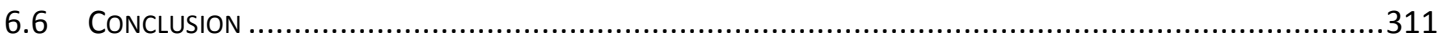

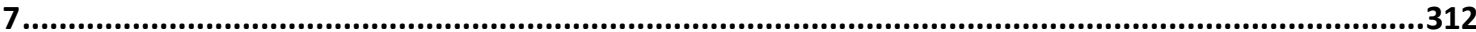

CHAPTER 7. SHALL TAKE INTO ACCOUNT, TOGETHER WITH THE CONTEXT - SYSTEMIC INTEGRATION:

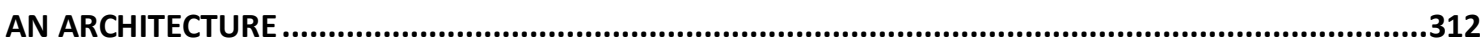

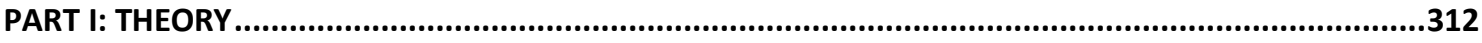

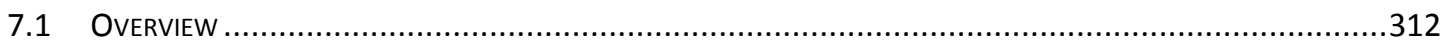

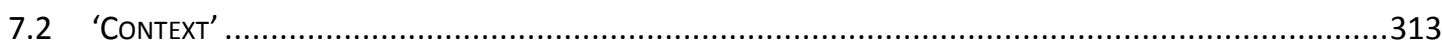

7.2.1 'Context' in the 1969 Vienna Convention on the Law of Treaties ..............................315

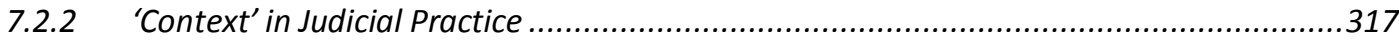

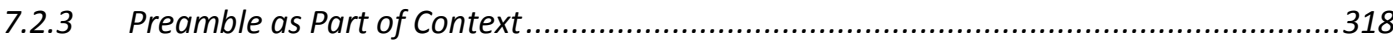

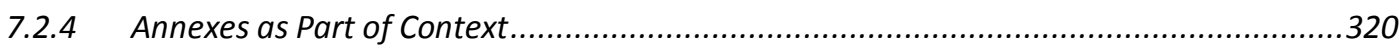

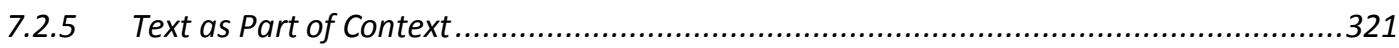

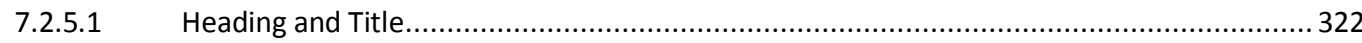

7.2.5.2 The structure and scheme underlying the provision and the treaty as a whole .................. 325

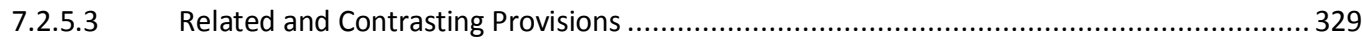

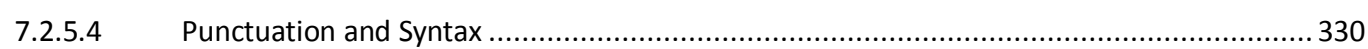

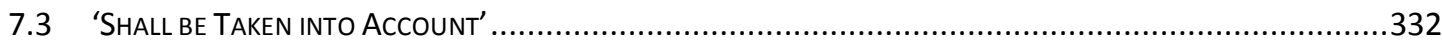

7.4 'Shall be Taken into Account, Together With the ConteXt' - CaSe Analyses ................................338

7.4.1 The Case of Oil Platforms in the International Court of Justice...................................338

7.4.2 The Case of Esphahanian's Claims in the Iran-US Claims Tribunal................................347

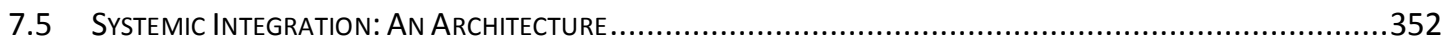

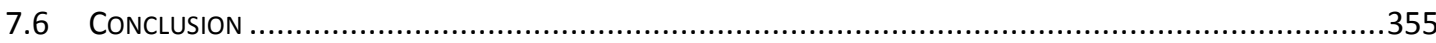

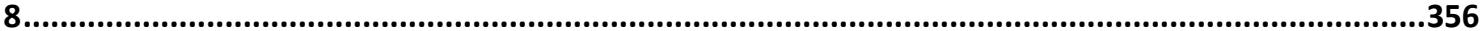

CHAPTER 8. SYSTEMIC INTEGRATION: AN OPERATIONALISATION .................................................356 
PART II: OPERATION

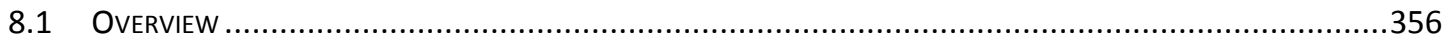

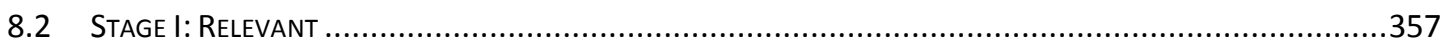

8.3 Stage II: Rules of International Law Applicable in the Relations between the Parties ...................360

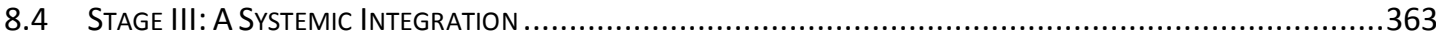

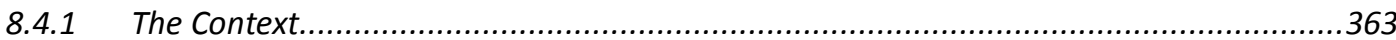

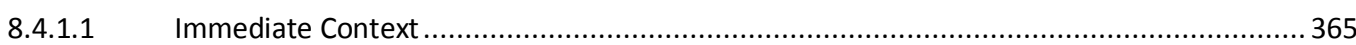

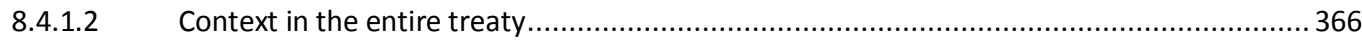

8.4.2 Article 31(3) There shall be Taken into Account, Together with the Context ... (c) Any Relevant Rules of International Law Applicable in the Relations between the Parties ...................368

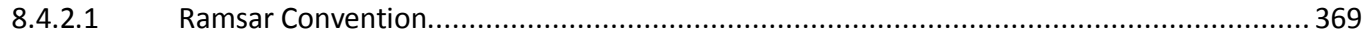

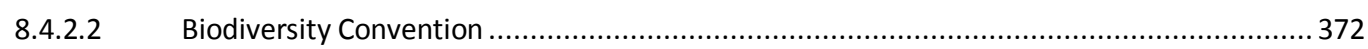

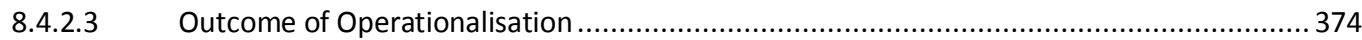

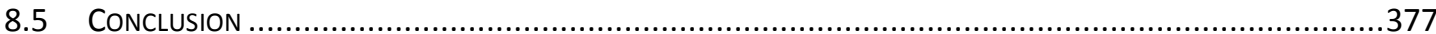

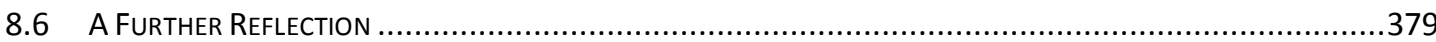

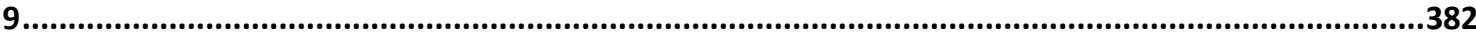

CHAPTER 9. PRESERVATION OF ECOSYSTEMS OF INTERNATIONAL WATERCOURSES AND THE INTEGRATION OF RELEVANT RULES: REFLECTION AND CONCLUSION.............................................382

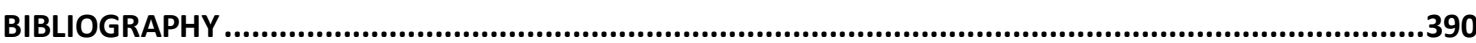




\section{Acknowledgements}

I would like to express my profound gratitude to the Ministry of Higher Education, Government of Malaysia, and The National University of Malaysia for funding this research. I am deeply grateful to Prof. Dr. Mazlin Mokhtar and fellow Lestarians; and Puan Normah Adam and her team for their support.

I would like to express my sincerest gratitude to my supervisors Prof. Dr. Patricia Wouters and Dr. Sarah Hendry for their valuable advice, unwavering support and constant encouragement. In particularly, I would like to express my heartfelt gratitude to Dr. Sarah Hendry for being my pillar of strength and comfort throughout my studies (especially during my revision). For this, I am very grateful.

I would like to thank my examiners, Prof. Attila Tanzi and Dr. Alistair RieuClarke for considering my thesis, and for imparting words of wisdom that will continue to inspire me for years to come. My heartfelt gratitude to my convenor Prof. Colin Reid for his utmost patience and attention to details throughout the revision process.

I would like to thank all the academic and research staff at the IHP-HELP Centre for Water Law, Policy and Science, especially Prof. Chris Spray, and Mr. Andrew Allan, and also Monica Garcia Quesada, Armelle Guignier, and Vishnu Rao for their advice. I am grateful to the $\mathrm{PhD}$ Seminar team for conducting such wonderful training programmes, especially the unwavering support of Dr. Sarah Hendry, Dr. Melaku Desta, Dr. Janet Liao and Dr. Shawn Mu. Thank you to the Librarians of the University of Dundee Library, especially Mairi Robb, for their unwavering support and incredible patience.

There are no words to describe how grateful I am towards Dinara Ziganshina and Hugo Tremblay, who are with me through thick and thin. I am greatly indebted to all friends and colleagues who have helped me in one way or another, especially Yumiko Yasuda, Ana Maria Daza Vargas, Musa Abseno, Tran Tran, Mohamad Mova Al'Afghani, Bjørn-Oliver Magsig, Norfadhilah Mohamad Ali, Christopher Len, Julius Nayak, and Daniel Behn. A special thank to Komuniti Melayu Dundee for embracing me into their big family; and to Elizabeth Kirk and Gerard Briscoe for their advice.

I owe my greatest debt to my mentor, Prof. Madya Datin Noor Aziah $\mathrm{Hj}$. Mohd. Awal, and my family for their encouragement, patience, understanding, and love. 


\section{Signed Declaration for Submission of Postgraduate Thesis}

I, the candidate, hereby acknowledge:

(a) I am the author of this thesis;

(b) Unless other stated, all references cited have been consulted;

(c) The work of which this thesis is a record has been done by the candidate;

(d) The work has not been previously accepted for a higher degree.

Signed:

Date: 


\section{Signed Statement by Supervisor}

I, the supervisor, hereby acknowledge that the conditions of the relevant

Ordinance and Regulations have been fulfilled.

Signed:

Date: 


\section{Thesis Abstract}

The unprecedented degradation of freshwater ecosystems due to the rampant exploitation of water resources re-establishes the importance of preserving freshwater ecosystems in order to ensure their continued viability that supports the attainment of sustainable development. This concern is addressed in Article 20 of the 1997 Watercourses Convention that specifically provides for the preservation of ecosystems of international watercourses.

However, the interpretation and the subsequent application of this obligation are complicated by the proliferation of international instruments concerning the environment, which leads to the fragmentation of international law. In response to the apprehension raised over the undesirable consequences of the fragmentation of international law, the potential of Article 31(3)(c) of the 1969 Vienna Convention as an interpretative mechanism that enables the systemic integration of rules has come into the limelight.

The objective of the present thesis, titled 'Preservation of Ecosystems of International Watercourses and the Integration of Relevant Rules' is to develop a interpretative framework for the operationalisation of Article 31(3)(c) that allows the full realisation of its potential as a tool of integration. A three-tier operationalisation framework that reinterprets the salient features of Article 31(3)(c) through the prism of an interactional understanding of international law is developed and executed through Chapters Two to Eight, where Chapter Nine provides a general conclusion of the thesis.

The reconstruction of existing interpretation of Article 31(3)(c) provides a new understanding of this Article, which enables the realisation of its systemic integration potential. The application of this framework of operationalisation in the interpretation of the obligation to preserve ecosystems of international watercourses stipulated under Article 20 reflects contemporaneous development in international environmental law, and enhances the normative content and scope of Article 20. 


\section{Abbreviations}

AB Appellate Body

Art Article

ASEAN Association of Southeast Asian Nations

CARU Administrative Commission of the River Uruguay

CBD Convention on Biodiversity

CDM Clean Development Mechanism

CETS Council of Europe Treaty Series

CMP Conference of the Parties Serving as the Meeting of the Parties

CTR Claims Tribunal Reports

Ch Chapter

EC European Community

ECE Economic Commission for Europe

ECT Energy Charter Treaty

EEC European Economic Community

ETS European Treaty Series

GA General Assembly

GAOR General Assembly Official Records

GATT General Agreement on Tariffs and Trade

ICJ International Court of Justice

ICSID International Centre for Settlement of Investment Disputes

ICTY International Tribunal for the Prosecution of Persons Responsible for Serious Violations of International Humanitarian Law Committed in the Territory of the Former Yugoslavia since 1991

IGOs Intergovernmental organisations

ILA International Law Association

ILC International Law Commission

ILM International Legal Materials

ILR International Law Reports

IPCC Intergovernmental Panel on Climate Change

ITLOS International Tribunal of the Law of the Sea

IUCN International Union for Conservation of Nature and Natural Resources

MA Millennium Ecosystem Assessment

MEAs Multilateral Environmental Agreements 
MSENs Multi-Sourced Equivalent Norms

NGOs Non-governmental organisations

OSPAR Convention for the Protection of the Marine Environment of the North-East Atlantic

Para Paragraph

PCA Permanent Court of Arbitration

PCIJ Permanent Court of International Justice

Res Resolution

SBSTTA Subsidiary Body on Scientific, Technical and Technological Advice

SCM Subsidy and Countervailing Measures Agreement

Agreement

Stat United States Statutes at Large

Supp Supplement

STRP Scientific and Technical Review Panel (Ramsar Convention)

TRIPs Agreement on Trade-Related Aspects of Intellectual Property Rights

Agreement

TS

Treaty Series

TIAS Treaties and other International Agreements (US)

UKHL United Kingdom House of Lords

UN United Nations

UNCED United Nations Conference on Environment and Development

UNCLOS United Nations Convention on the Law of the Sea

UNDESA United Nations Department of Economic and Social Affairs

UNEP United Nations Environmental Environment Programme

UNESCO United Nations Educational, Scientific and Cultural Organisation

UNFCCC United Nations Framework Convention for Climate Change

UNGA United Nations General Assembly

UNSC United Nations Security Council

UNTS United Nations Treaty Series

UNU United Nations University 


\section{Table of International Treaties and Other Instruments}

1930

League of Nations, Convention on Certain Questions Relating to the Conflict of Nationality Law (13 April 1930) League of Nations, Treaty Series, vol 179, p 89, No 4137 <http://www.unhcr.org/refworld/docid/3ae6b3b00.html> accessed 18 November 2012

1945

Statute of the International Court of Justice (1945) 29 American Journal of International Law Supp 215; 3 Bevans 1179; 59 Stat 1031; TS 993

Charter of the United Nations (26 June 1945, entered into force 24 October 1945) 59 Stat 1031; TS 993; 3 Bevans 1153 (UN Charter)

1957

Gerard Fitzmaurice, 'Second Report on the Law of Treaties by Gerald Fitzmaurice, Special Rapporteur' (15 March 1957) UN Doc A/CN.4/107 (1957) II Yearbook of International Law Commission 16 - 70, Art 19, pp 54 and 55, paras $124-128$ <http://untreaty.un.org/ilc/documentation/english/a cn4 107.pdf> accessed 16 November 2012

1958

Gerard Fitzmaurice, 'Third Report on the Law of Treaties by Gerald Fitzmaurice, Special Rapporteur', (18 March 1958) UN Doc A/CN.4/115 and Corr.1 (1958) II Yearbook of International Law Commission $20-46$, <http://untreaty.un.org/ilc/documentation/english/a cn4 115 corr1.pdf > accessed 16 November 2012

1964

ILC 'Third Report on the Law of Treaties by Sir Humphrey Waldock, Special Rapporteur' (3 March, 9 June, 12 June and 7 July 1964) UN Doc A/CN.4/167 and Add. 


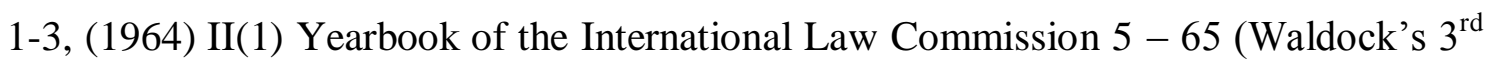
Report)

ILC, 'Report of the International Law Commission on the Work of Its $16^{\text {th }}$ Session, 11 July 1964, Official Records of the General Assembly, $19^{\text {th }}$ Session, Supplement (A/5809)' Doc A/CN.4/173 (1964) II Yearbook of International Law Commission 173 227 , at p 199 <http://untreaty.un.org/ilc/reports/english/a_cn4_173.pdf> accessed 17 November 2012 (Draft Articles 1964)

1966

ILC, 'Draft Articles on the Law of Treaties: Text as Finally Adopted by the Commission on 18 July 1966 (Reproduced at Para 38 of Document A/6309/Rev 1)' Doc A/CN.4/190 (1966) II Yearbook of International Law Commission 177 - 274, at p 46, para 13 <http://untreaty.un.org/ilc/documentation/english/a_cn4_190.pdf> accessed 17 November 2012

ILC, 'Report of the International Law Commission on the Work of Its Eighteenth Session, 4 May - 19 July 1966' (ORGA, $21^{\text {st }}$ Session Supp No 9) A/6309/Rev.1, [1966]

II Yearbook of International Law Commission 169 - 363, at p 222, para 16 <http://untreaty.un.org/ilc/reports/english/a_cn4_191.pdf> accessed 16 November 2012 (Draft Articles 1966)

ILC, 'Draft Articles on the Law of Treaties with Commentaries' (Text as adopted by the ILC at its $18^{\text {th }}$ Session) [1966] II Yearbook of International Law Commission $187-274$ (VCLT Commentaries)

<http://untreaty.un.org/ilc/texts/instruments/english/commentaries/1_1_1966.pdf> accessed 14 February 2013

ILA 'Helsinki Rules on the Uses of the Waters of International Rivers' (Report of the $52^{\text {nd }}$ Conference, Helsinki 1966)

1969

Vienna Convention on the Law of Treaties (adopted 23 May 1969, entered into force 27 January 1980) 1155 United Nations Treaty Series 331 (Vienna Convention) 
UNGA Res. 2669 (XXV) (8 December 1970)

UNGA Res. 2625 (XXV) 'Declaration on Principles of International Law Concerning Friendly Relations and Co-operation among States in accordance with the Charter of the United Nations' $\left(1883^{\text {rd }}\right.$ Plenary Meeting, 24 October 1970) <http://www.un.org/ga/search/view_doc.asp?symbol=A/RES/2625(XXV)> accessed 14 February 2013

1971

Convention on Wetlands of International importance Especially as Waterfowl Habitat (entered into force 21 December 1975) 996 UNTS 245; TIAS 11084; (1972) 11 ILM 963 (Ramsar Convention) <http://www.ramsar.org/cda/en/ramsar-documents-textsconvention-on/main/ramsar/1-31-38\%5E20671_4000_0_>, accessed 13 September 2011

1972

Convention Concerning the Protection of the World Cultural and Natural Heritage (entered into force 17 December 1975) 1037 UNTS 151; 27 United States Treaties and other International Agreements (UST) 37; (1972) 11 ILM 1358 (World Heritage Convention)

1973

Convention on International trade in Endangered Species of Wild Fauna and Flora 1973 (CITES) (entered into force 1 July 1975) 27 UST 1087; TIAS 82249; 993 UNTS 243; (1973) 12 ILM 1088 (CITES)

1974

UNGA, 'Resolution 3232 (XXIX) Review of the Role of the International Court of Justice' (12 November 1974)

Great Lakes Water Quality Agreement of 1978, United States-Canada, 30 UST 1383, TIAS No 9257 (Great Lakes Agreement) 
Convention on Long-Range Transboundary Air Pollution and Protocols (concluded 13 November 1979, entered into force 16 March 1983) TIAS 10541; 1302 UNTS 217; (1979) 18 ILM 1442

Convention on the Conservation of Migratory Species of Wild Animals (concluded 23 June 1979, entered into force 1 November 1983) 1651 UNTS 333; (1980) 19 ILM 15 (CMS)

1980

ILA 'Articles on the Relationship between Water, Other Natural Resources and the Environment'(Report of the Fifty-ninth Conference, Belgrade, 1980) in Slavko Bogdanović, Contribution of the International Law Association (1954 - 2000) (Kluwer Law International, The Hague, 2001)

UNGA, 'Draft World Charter for Nature' (Resolution 35/7, 49 ${ }^{\text {th }}$ Plenary Meeting, 30 October 1980)

1981

UNGA, 'Draft World Charter for Nature', (41 ${ }^{\text {st }}$ Plenary Meeting, 27 October 1981) UN Doc A/RES/36/6 <http://www.un.org/documents/ga/res/36/a36r006.htm> accessed 22 June 2011

1982

Stephen M Schwebel 'Third Report on the Law of Non-navigational Uses of International Watercourses' (11 December 1981) [1982] II(1) Yearbook of International Law Commission 65 - 191, UN Doc A/CN.4/348 and Corr.1 (Schwebel $3^{\text {rd }}$ Report)

UNGA, 'World Charter for Nature' (48 ${ }^{\text {th }}$ Plenary Meeting, 28 October 1982) UN Doc A/RES/37/7 <http://www.un.org/documents/ga/res/37/a37r007.htm> accessed 22 June 2011

1983

ILC 'Report of the International Law Commission on the Work of Its Thirty-fifth Session, 3 May - 22 July 1983' (Thirty-eighth Session, GAOR, Supplement No 10) UN Doc A/38/10 [1983] II(2) Yearbook of International Law Commission 1 - 91 
Convention on the Transfer of Sentenced Persons (concluded 21 March 1983, entered $\begin{array}{lllllll}\text { into } & \text { force } & 1 & \text { July } & \text { 1985) } & \text { CETS } & \text { No }\end{array}$ <http://conventions.coe.int/Treaty/en/Treaties/Html/112.htm> accessed 18 November 2012

1985

ASEAN Agreement on the Conservation of Nature and Natural Resources (adopted at Kuala Lumpur on 9 July 1985) <http://www.aseansec.org/1490.htm> accessed 22 June 2011 (ASEAN Agreement)

Convention for the Protection of the Ozone Layer (concluded 22 March 1985, entered into force 22 September 1988) TIAS No11097; 1513 UNTS 323; (1987) 26 ILM 1529

1987

Montreal Protocol on Substances that Deplete the Ozone Layer (concluded 16 September 1987, entered into force 1 January 1989) 1522 UNTS 3; (1987) 26 ILM 1550

Ramsar Convention, 'Recommendation 3.3: Wise Use of Wetlands' $\left(3^{\text {rd }}\right.$ Meeting of the Conference of the Contracting Parties, Regina, Canada 27 May - 5 June 1987) <http://www.ramsar.org/pdf/rec/key_rec_3.03e.pdf > accessed 15 November 2012

1989

Basel Convention on the Control of Transboundary Movements of Hazardous Wastes and Their Disposal (concluded 22 March 1989, entered into force 5 May 1992) 1673 UNTS 126; (1989) 28 ILM 657

1990

UNGA, 'Protection of Global Climate for Present and Future Generations of Mankind' (Report of the $71^{\text {st }}$ Plenary Meeting, 21 December 1990) UN Doc A/RES/45/212 <http://www.un.org/documents/ga/res/45/a45r212.htm> accessed 14 September 2011

IPCC, 'First Assessment Report Overview Chapter' <http://www.ipcc.ch/ipccreports/1992\%20IPCC\%20Supplement/IPCC_1990_and_1992 _Assessments/English/ipcc_90_92_assessments_far_overview.pdf> $>$ accessed 15 September 2011 
Convention on the Protection and Use of Transboundary Watercourses and International Lakes (done at Helsinki, 17 March 1992) $<$ http://www.unece.org/env/water/pdf/watercon.pdf $>$ accessed 27 June 2011

UN Conference on Environment and Development (Rio de Janeiro, 3-14 Jun 1992), 'Rio Declaration on Environment and Development' (1 Jan 1993), UN Doc A/CONF.151/26/Rev.1 (Vol I) (1992 Rio Declaration)

UN Conference on Environment and Development (Rio de Janeiro, 3-14 Jun 1992), 'Agenda 21: A Programme for Action for Sustainable Development' (1 Jan 1993) UN Doc A/CONF.151/26/Rev.1 (Vol I) (Agenda 21)

UN Framework Convention on Climate Change (adopted 9 May 1992, entered into $\begin{array}{lllllll}\text { force } & 21 & \text { Mar } & 1994) & 1771 & \text { UNTS } & 107\end{array}$ 〈http://treaties.un.org/doc/Publication/UNTS/Volume\%201771/v1771.pdf > accessed 12 December 2011 (UNFCCC).

Convention on Biological Diversity (entered into force 29 December 1993) 1760 UNTS 79; (1992) 31 ILM 818 (Biodiversity Convention)

Convention for the Protection of the Marine Environment of the North-East Atlantic (concluded 22 September 1992, entered into force 25 March 1998) 2354 UNTS 67;

<http://www.ospar.org/html_documents/ospar/html/OSPAR_Convention_e_updated_te xt_2007.pdf> accessed 2 January 2011 (OSPAR Convention).

Protocol Amending the 1978 Agreement between the United States of America and Canada on Great Lakes Water Quality (as amended on 16 October 1993)

UNECE, 'Part One Guidelines on the Ecosystem Approach in Water Management' (December 1993)

ECE/ENVWA/31

<http://www.unece.org/fileadmin/DAM/env/water/publications/documents/Library/Old documents found library/ECE ENVWA 31 eng.pdf> accessed 10 February 2013 
ILC 'Draft Articles on the Law of the Non-navigational Uses of International Watercourses and Commentaries thereto and Resolution on Transboundary Confined Groundwater' (Report of the International Law Commission on the Works of Its Fortysixth Session, 2 May - 22 July 1994, Official Records of the General Assembly, Fortyninth Session, Supplement No 10) UN Doc A/49/10 [1994] II(2) Yearbook of International Law Commission 1 - 182 (1994 Draft Articles and Commentaries)

Convention to Combat Desertification in Those countries Experiencing Serious Drought and/or Desertification Particularly in Africa (entered into force 26 December 1996) 1954 UNTS 3; (1994) 33 ILM 1328 (CCD)

CBD, 'Rules of Procedure for Meetings of the Conference of the Parties to the Convention on Biological Diversity' (Annexed to Decision I/1 and Decision V/20) <http://www.cbd.int/doc/legal/cbd-rules-procedure.pdf> accessed 10 August 2012

1995

Agreement on the Cooperation for the Sustainable Development of the Mekong River $\begin{array}{lllllll}\text { Basin (Entered into Force } 5 & \text { April 1995) } 2069 & \text { UNTS } & \text { I-35844 }\end{array}$ <http://treaties.un.org/doc/Publication/UNTS/Volume\%202069/v2069.pdf> accessed 15 February 2013

UNFCCC, 'Report of the Conference of the Parties on Its First Session' (First Session of the Conference of the Parties of the, Berlin, 28 March - 7 April 1995) (16 June 1995) UN Doc FCCC/CP/1995/7/Add.1 <http://unfccc.int/resource/docs/cop1/07a01.pdf> accessed 15 September 2011

CBD, 'COP 2 Decision II/7 Consideration of Articles 6 and 8 of the Convention' (Second Meeting of the Conference of the Parties to the Convention on Biological Diversity, Jakarta, Indonesia, $6-17$ November 1995) UNEP/CBD/COP/2/19 $\langle$ http://www.cbd.int/doc/decisions/cop-02/full/cop-02-dec-en.pdf $>$ accessed 30 July 2012

CBD, 'Decision II/8. Preliminary Consideration of Components of Biological Diversity Particularly Under Threat and Action which could be Taken under the Convention' (Second Ordinary Meeting of the Conference of the Parties to the Convention on Biological Diversity, Jakarta, Indonesia, 6 - 17 November 1995) UN Doc 
en.pdf> accessed 23 March 2011

Institut de Droit International, 'Problems Arising from a Succession of Codification Conventions on a Particular Subject' (Lisbonne 1995) < http://www.idiiil.org/idiE/resolutionsE/1995 lis 01 en.pdf> accessed 9 April 2012

1996

CBD, 'COP 3 Decision III/9 Implementation of Articles 6 and 8 of the Convention' (Third Ordinary Meeting of the Conference of the Parties to the Convention on Biological Diversity, Buenos Aires, Argentina, 4 - 15 November 1996) UNEP/CBD/COP/3/38 <http://www.cbd.int/doc/decisions/cop-03/full/cop-03-decen.pdf> accessed 31 July 2012

Memorandum of Cooperation between The Bureau of the Convention on Wetlands of International Importance especially as Waterfowl Habitat and The Secretariat of the Convention on Biological Diversity (signed 19 January 1996)

\section{7}

CBD, 'Annex 1. Recommendations of the SBSTTA at Its Third Meeting' (Third Meeting of the SBTTA, $1-5$ September 1997, Montreal, Canada) UNEP/CBD/COP/4/2 <http://www.cbd.int/doc/recommendations/sbstta-03/full/sbstta03-rec-en.pdf $>$ accessed 31 July 2012

Convention on the Law of Non-Navigational Uses of International Watercourses (adopted 21 May 1997, not yet entered into force) reprinted in (1997) 36 ILM 700 (Watercourses Convention)

Kyoto Protocol to the UN Framework Convention on Climate Change (adopted 11 Dec $\begin{array}{llllllll}1997, & \text { entered into force } 16 & \text { Feb } & 2005) & 2303 & \text { UNTS } & 148\end{array}$ <http://treaties.un.org/doc/Publication/UNTS/Volume\%202303/v2303.pdf > accessed 12 December 2011 (Kyoto Protocol)

Ramsar Convention, 'Minutes of the $20^{\text {th }}$ Meeting of the Standing Committee, Fourth Day, 3 October 1997' (20 ${ }^{\text {th }}$ Meeting of the Standing Committee, Gland, Switzerland, 29 September -3 October 1997) Agenda Item 16.6 Conference Budget and Fundraising, 
para $257 \quad<$ http://www.ramsar.org/cda/en/ramsar-documents-standing-minutes-of20th/main/ramsar/1-31-41\%5E21668 $4000 \quad 0 \quad>$ accessed 17 November 2012

UNGA, '99 ${ }^{\text {th }}$ Plenary Meeting' (51 ${ }^{\text {st }}$ Session of the General Assembly, 21 May 1997) A/51/PV.99, at p 8 <http://www.un.org/ga/search/view doc.asp?symbol=A/51/PV.99> accessed 18 August 2012

1998

CBD, 'Decision IV/15 The Relationship of the Convention on Biological Diversity with the Commission on Sustainable Development and Biodiversity-related Conventions, Other International Agreements, Institutions and Processes of Relevance' (Fourth Ordinary Meeting of the Conference of the Parties to the Convention on Biological Diversity, Bratislava, Slovakia, $4 \quad-\quad 15 \quad$ May 1998) <http://www.cbd.int/doc/decisions/cop-04/full/cop-04-dec-en.pdf $>$ accessed 31 July 2012

CBD, 'Decision IV/4 Status and Trends of the Biological Diversity of Inland Water Ecosystems and Options for Conservation and Sustainable Use' (Fourth Ordinary Meeting of the Conference of the Parties to the Convention on Biological Diversity, 4 15 May 1998, Bratislava, Slovakia) <http://www.cbd.int/doc/decisions/cop-04/full/cop04-dec-en.pdf> accessed 31 July 2012

Convention on Access to Information, Public Participation in Decision-Making and Access to Justice in Environmental Matters (concluded 28 June 1998, entered into force 30 October 2001) 2161 UNTS 447; (1999) 38 ILM 517 (Aarhus Convention) <http://www.unece.org/fileadmin/DAM/env/pp/documents/cep43e.pdf $>$ accessed 16 November

1999

CBD, 'Annex 1. Recommendations of the SBSTTA at Its $3^{\text {rd }}$ Meeting' (Recommendation III/1, Third Meeting of the Subsidiary Body on Scientific, Technical and Technological Advice, Montreal, Canada, 21 - 25 June 1999) UNEP/CBD/COP/4/2 Ramsar Convention, 'Resolution VII.18: Guidelines for Integrating Wetland Conservation and Wise Use into River Basin Management' (San José, Costa Rica, 10 - 
18 May 1999) < http://www.ramsar.org/cda/en/ramsar-documents-resol-resolution-vii18/main/ramsar/1-31-107\%5E20586 $4000 \quad 0 \quad>$ accessed 18 July 2012

CBD, 'Decision V/2. Progress Report on the Implementation of the Programme of Work on the Biological Diversity of Inland Water Ecosystems' (Annex III to the Decisions Adopted by the Conference of the Parties to the Convention on Biological Diversity at Its Fifth Meeting, Nairobi, 15 - 26 May 2000) UNEP/CBD/COP/5/23 <http://www.cbd.int/doc/decisions/cop-05/full/cop-05-dec-en.pdf $>$ accessed 3 August 2012

CBD, 'Decision V/20 Operations of the Convention' (Decisions adopted by the Conference of the Parties to the Convention on Biological Diversity at Its Fifth Meeting, Nairobi, 15 - 26 May 2000) UNED/CBD/COP/5/23, para 37 - 41 <http://www.cbd.int/doc/decisions/cop-05/full/cop-05-dec-en.pdf> accessed 10 August 2012

CBD, 'Decision V/6. Ecosystem Approach' (Fifth Ordinary Meeting of the Conference of the Parties to the Convention on Biological Diversity, Nairobi, Kenya, 15 - 26 May 2000) at Annex, p 104, para 3 <http://www.cbd.int/doc/decisions/cop-05/full/cop-05dec-en.pdf $>$ accessed 14 November 2012 (Decision V/6)

Gerhard Hafner, 'Risk Ensuing from Fragmentation of International Law', ILC, 'Report on the Work of its 52 ${ }^{\text {nd }}$ Session 1 May - 9 June and 10 July - 18 August 2000' (Annex of GAOR 55 ${ }^{\text {th }}$ Session Supplement No 10 ) UN Doc A/58/10, (2000) II(2) Yearbook of the International Law Commission

Attila Tanzi, 'The Relationship between the 1992 UNECE Convention on the Protection and Use of Transboundary Watercourses and International Lakes and the 1997 UN Convention on the Law of the Non Navigational Uses of International Watercourses' (Report of the UNECE Task Force on Legal and Administrative Aspects, Geneva, February 2000) $<$ http://www.unece.org/fileadmin/DAM/env/water/publications/documents/conventiont otal.pdf> accessed 10 February 2013 
ILC, 'Draft Articles on Prevention of Transboundary Harm from Hazardous Activities' (Report of the International Law Commission on the Work of its Fifty-third Session) UNGAOR Supp. No 10, UN Doc A/56/10

ILC, 'Draft Articles on the Responsibility of States for Internationally Wrongful Acts' (Report of the International Law Commission on the Work of its Fifty-third Session, UN GAOR, Supp No 10) UN Doc A/56/10 <http://untreaty.un.org/ilc/texts/instruments/english/draft\%20articles/9 6 2001.pdf > accessed 14 November 2012

International Treaty on Plant Genetic Resources for Food and Agriculture (FAO Conference at Its Thirty-first Session) (concluded 3 November 2001, entered into force 29 June 2004) Registered with the UN on 13 December 2006, I-43345

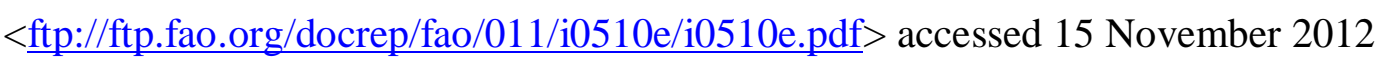

Stockholm Convention on Persistent Organic Pollutants (concluded 22 May 2001, entered into force 17 May 2004) 2256 UNTS 119; (2001) 40 ILM 532

2002

CBD, 'Decision VI/2 Biological Diversity of Inland Waters' (incorporated as Annex to the Sixth Ordinary Meeting of the Conference of the Parties to the Convention on Biological Diversity, The Hague, Netherlands, $7-19$ April 2002) UNEP/CBD/COP/6/20 <http://www.cbd.int/doc/decisions/cop-06/full/cop-06-decen.pdf> accessed 3 August 2012

Plan of Implementation of the World Summit on Sustainable Development (Report of World Summit on Sustainable Development, Johannesburg, South Africa, 26 August -4 September 2002) UN Doc A/Conf.199/20

Ramsar Convention, 'Resolution VIII.14: New Guidelines for Management Planning for Ramsar Sites and Other Wetlands' (Valencia, Spain, 18 - 26 November 2002) <http://www.ramsar.org/cda/en/ramsar-documents-resol-resolution-viii-14new/main/ramsar/1-31-107\%5E21393_4000_0_> accessed 18 July 2012 (New Guidelines for Management Planning for Ramsar Sites and Other Wetlands)

Ramsar Convention, 'Resolution VIII.24. UNEP's Guidelines for Enhancing Compliance with Multilateral Environmental Agreements, and Guidelines for National 
Enforcement, and International Cooperation in Combating Violations, of Laws Implementing Multilateral Environmental Agreements' $\left(8^{\text {th }}\right.$ Meeting of the Conference of the Contracting Parties to the Convention on Wetlands (Ramsar, Iran, 1971) Valencia, Spain, 18 - 26 November 2002) 〈http://www.ramsar.org/pdf/res/key res viii 24 e.pdf $>$ 23 July 2012

2003

IUCN, 'Message of the $\mathrm{V}^{\text {th }}$ IUCN World Parks Congress to the Convention on Biological Diversity' (V ${ }^{\text {th }}$ IUCN World Parks Congress, 8 - 17 September, Durban, South Africa)

UNECE, 'Amendment to Articles 25 and 26 of the Convention' (Meeting of the Parties to the Convention on the Protection and Use of Transboundary Watercourses and International Lakes) $\quad$ ECE/MP.WAT/14 (12 January 2004) <http://www.unece.org/fileadmin/DAM/env/documents/2004/wat/ece.mp.wat.14.e.pdf> accessed 10 February 2013

2004

CBD, 'Decision VII/11 Ecosystem Approach' (Seventh Meeting of the Conference of the Parties to the Convention on Biological Diversity, Kuala Lumpur, $9-20$ and 27 February 2004) UNEP/CBD/COP/DEC/VII/11 (13 April 2004)

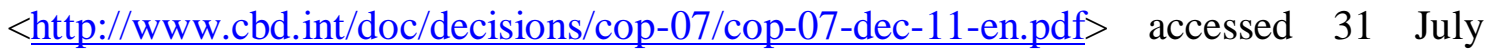
2012

CBD, 'Decision VII/11 Ecosystem Approach' (Seventh Meeting of the Conference of the Parties to the Convention on Biological Diversity, Kuala Lumpur, $9-20$ and 27 February 2004) UNEP/CBD/COP/DEC/VII/11 (13 April 2004) at p 1, para 2 $\langle$ http://www.cbd.int/doc/decisions/cop-07/cop-07-dec-11-en.pdf $>$ accessed 31 July 2012

CBD, 'Decision VII/28 Protected Areas (Articles 8(a) to (e))' (Seventh Meeting of the Conference of the Parties to the Convention on Biological Diversity, Kuala Lumpur, 9 20 and 27 February 2004) UNEP/CBD/COP/DEC/VII/28 (13 April 2004) $\langle$ http://www.cbd.int/doc/decisions/cop-07/cop-07-dec-28-en.pdf $>$ accessed 31 July 2012 
CBD, 'Decision VII/4 Biological Diversity of Inland Water Ecosystems' (Seventh Meeting of the Conference of the Parties to the Convention on Biological Diversity, Kuala Lumpur, 9 - 20 and 27 February 2004) UNEP/CBD/COP/DEC/VII/4 (13 April 2004) <http://www.cbd.int/doc/decisions/cop-07/cop-07-dec-04-en.pdf> accessed 31 July 2012

CBD, 'Protected Areas. Message of the Fifth World Parks Congress to the Convention on Biological Diversity. Note by the Executive' (Seventh Meeting of the Conference of the Parties to the convention on Biological Diversity, 9 - 20 and 27 February 2004) $\mathrm{UNEP} / \mathrm{CBD} / \mathrm{COP} / 7 / \mathrm{INF} / 36$

<http://www.cbd.int/doc/meetings/cop/cop-07/information/cop-07-inf-36-en.pdf> accessed 16 October 2012

ILA, 'Report of the Conference on Water Resources Law' (adopted at the $71^{\text {st }}$ Conference, Berlin, August 2004) (Berlin Rules)

Secretariat of the Convention on Biological Diversity, 'The Ecosystem Approach (CBD Guidelines)' (Secretariat of the Convention on Biological Diversity, Montreal, 2004) (CBD Guidelines)

UNGA, 'Resolution 58/217 International Decade for Action, "Water for Life", 2005 2015, (9 February 2004) UN Doc A/RES/58/217 <http://www.un.org/ga/search/view doc.asp?symbol=A/RES/58/217> accessed 18 November 2012

European Union Guidelines on Promoting Compliance with International Humanitarian Law [2005] OJ C327/04 lex.europa.eu/LexUriServ/LexUriServ.do?uri=OJ:C:2005:327:0004:0007:EN:PDF>, accessed 16 September 2011

Ramsar Convention, 'Resolution IX.1 Annex A. A Conceptual Framework for the Wise Use of Wetlands and the Maintenance of Their Ecological Character' $\left(9^{\text {th }}\right.$ Meeting of the Conference of the Parties to the Convention on Wetlands (Ramsar, Iran, 1971) Kampala, Uganda, 8 - 15 November 2005) <http://www.ramsar.org/cda/en/ramsardocuments-resol-resolution-ix-1-annex-a/main/ramsar/1-31-107\%5E23536_4000_0_> accessed 14 November 2012 
Ramsar Convention, 'Resolution IX.3 Engagement of the Ramsar Convention on Wetlands in Ongoing Multilateral Processes Dealing with Water' $\left(9^{\text {th }}\right.$ Meeting of the Conference of the Parties to the Convention on Wetlands (Ramsar, Iran, 1971) Kampala, Uganda, 8 - 15 November 2005) 〈http://www.ramsar.org/pdf/res/key res ix 03 e.pdf $>$ accessed 17 November 2012

2006

CBD, 'Decision VIII/24. Protected Areas' (Eighth Meeting of the Conference of the Parties to the Convention on Biological Diversity, Curitiba, Brazil, 20 - 31 March 2006) at $\mathrm{p}$ 2, para 4 <http://www.cbd.int/doc/decisions/cop-08/cop-08-dec-24-en.pdf> accessed 17 November 2012

ILC 'Conclusions of the Work of the Study Group on the Fragmentation of International Law: Difficulties Arising from the Diversification and Expansion of International Law' (adopted by the International Law Commission at Its Fifty-eighth Session 1 May -9 June and 3 July - 11 August 2006, Geneva) UN GAOR 61 ${ }^{\text {st }}$ Session Supp No 10 UN Doc A/61/10 (Conclusion on <http://untreaty.un.org/ilc/texts/instruments/english/draft\%20articles/1 9 2006.pdf > accessed 2 November 2012

ILC 'Report of the Study Group of the International Law Commission. Fragmentation of International Law: Difficulties Arising from the Diversification and Expansion of International Law. Finalized by Martti Koskenniemi' (Fifty-eighth Session, 1 May - 9 June and 3 July - 11 August 2006, Geneva) (13 April 2006) UN Doc A/CN.4/L.682 (Fragmentation Report)

UN, 'Situation of Detainees at Guantánamo Bay', Report of the Commission on Human Rights, Sixty-second Session, (27 February 2006) UN Doc E/CN.4/2006/120 <http://www.unhcr.org/refworld/country,,UNCHR,,CUB, 45377b0b0,0.html > accessed 11 August 2011

UNECE, 'Recommendations on Payments for Ecosystem Services in Integrated Water Resources Management' (United Nations, New York and Geneva, 2007) <http://www.unece.org/fileadmin/DAM/env/water/publications/documents/PES_Recom mendations_web.pdf $>$ accessed 10 February 2013 
UNFCCC, 'Decision 16/CMP.1 Land Use, Land-use Change and Forestry' (Report of the Conference of the Parties Serving as the Meeting of the Parties to the Kyoto Protocol on its First Session, Montreal, Canada, 28 November - 10 December 2005, 30 March 2006)

FCCC/KP/CMP/2005/8/Add.3 <http://unfccc.int/resource/docs/2005/cmp1/eng/08a03.pdf > accessed 15 September 2011

UNFCCC, 'Decisions 2 -6/CMP.1' (Report of the Conference of the Parties Serving as the Meeting of the Parties to the Kyoto Protocol on its First Session, Montreal, Canada, 28 November - 10 December 2005, 30 March 2006) FCCC/KP/CMP/2005/8Add.1 <http://unfccc.int/resource/docs/2005/cmp1/eng/08a01.pdf> accessed 15 November 2012

UNGA 'Report of the International Law Commission of Its Fifty-fourth Session (29 April - 7 June and 22 July - 16 August 2002)' UN GAOR 57 ${ }^{\text {th }}$ Session Supp No 10 UN Doc A/57/10

UNGA 'Report of the Study Group of the International Law Commission. Fragmentation of International Law: Difficulties Arising from the Diversification and Expansion of International Law' (Fifty-eighth Session, 1 May - 9 June and 3 July - 11 August 2006, Geneva) (18 July 2006) UN Doc A/CN.4/L.702 (Report of ILC)

$$
2008
$$

CBD, 'Decision IX/9 Process for the Revision of the Strategic Plan' (Decision Adopted by the Conference of the Parties to the Convention on Biological Diversity at Its Ninth Meeting, Bonn, 19 - 30 May 2008) UNEP/CBD/COP/DEC/IX/9 (9 October 2008) <http://www.cbd.int/doc/decisions/cop-09/cop-09-dec-09-en.pdf $>$ accessed 4 August 2012

Ramsar Convention, 'Resolution X.1. The Ramsar Strategic Plan $2009-2015^{\prime}$ (10 ${ }^{\text {th }}$ Meeting of the Conference of the Parties to the Convention on Wetlands, Changwon, Republic of Korea, 28 October - 4 November 2008) 〈http://www.ramsar.org/pdf/res/key_res_x_01_e.pdf> accessed 19 July 2012 (The Ramsar Strategic Plan 2009 - 2015)

Ramsar Convention, 'Resolution X.19. Wetlands and River Basin Management: Consolidated Scientific and Technical Guidance', $\left(10^{\text {th }}\right.$ Meeting of the Conference of 
the Parties to the Ramsar Convention, Changwon, 28 October - 4 November 2008) <http://www.ramsar.org/pdf/res/key res x 19 e.pdf $>$ accessed 19 July 2012

\section{9}

UNECE, 'Integrated Management of Water and Related Ecosystems. Draft Guide to Implementing the Convention (Draft Guide by the Chairperson of the Legal Board, Meeting of the Parties to the Convention on the Protection and Use of Transboundary Watercourses and International Lakes, Fifth Session, Geneva, 10 - 12 November 2009) ECE/MP.WAT/2009/L.2 August 2009) <http://www.unece.org/fileadmin/DAM/env/documents/2009/Wat/MOP5/ECE.MP.WA T.2009.L.2 EN.pdf> accessed 10 February 2013

Ramsar Convention, 'Rules of Procedure for Meetings of the Conference of the Contracting Parties to the Convention on Wetlands of International Importance especially as Waterfowl Habitat (Ramsar, Iran, 1971)' (adopted by the $10^{\text {th }}$ Meetings of the Conference of the Contracting Parties, Changwon, Republic of Korea, 29 October 2009) <http://www.ramsar.org/cda/en/ramsar-documents-rules-rules-of-procedure-of21056/main/ramsar/1-31-114\%5E21056 $4000 \quad 0 \quad>$ accessed 20 July 2012

Ramsar Convention, 'Strategic Framework and Guidelines for the Future Development of the List of Wetlands of International Importance of the Convention on Wetlands (Ramsar, Iran, 1971)' (3 ${ }^{\text {rd }}$ edn, as adopted by Resolution VII.11 (COP 7, 1999) and has been amended by Resolutions VII.13 (1999), VIII.11 and VIII.33 (COP8, 2002), IX.1 Annexes A and B (COP 9, 2005), and X.20 (COP10, 2008) 2009) <http://www.ramsar.org/pdf/key_guide_list2009_e.pdf> accessed 23 July 2012 (2009 Strategic Framework and Guidelines)

CBD, 'Decision X/2. The Strategic Plan for Biodiversity 2011 - 2020 and the Aichi Biodiversity Targets' (Decision Adopted by the Conference of the Parties to the Convention on Biological Diversity at Its Tenth Meeting, Nagoya, Japan 18 - 29 October 2010) UNEP/CBD/COP/DEC/X/2 (29 October 2010) 〈http://www.cbd.int/doc/decisions/cop-10/cop-10-dec-02-en.pdf> accessed 4 August 2012 
CBD, 'Decision X/5 Implementation of the Convention and the Strategic Plan' (Tenth Meeting of the Conference of the Parties to the Convention on Biological Diversity, Nagoya, Japan 18 - 29 October 2010) UNEP/CBD/COP/DEC/X/5 (29 October 2010) at p 1 <http://www.cbd.int/doc/decisions/cop-10/cop-10-dec-05-en.pdf > accessed 17 August 2012

CBD, 'In-Depth Review of the Programme of Work on the Biological Diversity of Inland Water Ecosystems. Draft Recommendation Submitted by the Chair of Working Group I' (Subsidiary Body on Scientific, Technical and Technological Advice, Fourteenth Meeting, 10 - 21 May 2010, Nairobi, Working Group I, Agenda Item 3.1.2) (11 May 2010) UNEP/CBD/SBSTTA/14/WG.1/CRP.3

CBD, 'Qualified Bodies or Agencies, whether Governmental or Non-Governmental, which have Informed the Secretariat of Their Wish to be Represented as Observers at the $10^{\text {th }}$ Meeting of the COP to the CBD' (19 October 2010) (Tenth Meeting of the Conference of the Parties to the Convention on Biological Diversity, Nagoya, 18 - 29 October 2010) UNEP/CBD/COP/10/INF/41 <http://www.cbd.int/doc/meetings/cop/cop10/information/cop-10-inf-41-en.pdf > accessed 28 March 2012

CBD, 'The Joint Work Programme (JWP) between the CBD and the Ramsar Convention on Wetlands (Ramsar, Iran, 1971): Progress with Implementation and Development of the Fifth Joint Work Programme (2011 Onwards)' (Tenth Meeting of the Conference of the Parties to the Convention on Biological Diversity, Nagoya, 18 29 October 2010) UNEP/CBD/COP/10/INF/38 (19 October 2010) <http://www.cbd.int/doc/meetings/cop/cop-10/information/cop-10-inf-38-en.pdf $>$ accessed 17 November 2012

CBD, 'Updated Analysis of Information in the Fourth National Reports' (Tenth Meeting of the Conference of the Parties of the Convention on Biological Diversity, Nagoya, Japan 18 - 29 October 2010) UNEP/CBD/COP/10/INF?2 (22 September 2010) at p 1, para 1 <http://www.cbd.int/doc/meetings/cop/cop-10/information/cop-10-inf-02en.pdf> accessed 17 August 2012

CBD, 'X/28 Inland Waters Biodiversity' (Decision Adopted by the Conference of the Parties to the Convention on Biological Diversity at Its Tenth Meeting, Nagoya, Japan, 18 - 29 October 2010) UNEP/CBD/COP/DEC/X/28 (29 October 2010) at 
〈http://www.cbd.int/doc/decisions/cop-10/cop-10-dec-28-en.pdf $>$ accessed 11 August 2012

\section{2}

CBD, 'Advance Unedited Copy of COP-11 Decision' (Eleventh Meeting of the Conference of the Parties to the Convention on Biological Diversity, $8-19$ October 2012, Hyderabad, India) <http://www.cbd.int/cop/cop-11/doc/2012-10-24-advancedunedited-cop-11-decisions-en.pdf $>$ accessed 7 November 2012

CBD, 'Protected Areas: Progress in the Implementation of the Programme of Work and Achievement of Aichi Biodiversity Target 11' (23 July 2012) (Eleventh Meeting of the Conference of the Parties to the Convention on Biological Diversity, Hyderabad, India,

19 October 2012)

$\mathrm{UNEP} / \mathrm{CBD} / \mathrm{COP} / 11 / 26$ <https://www.cbd.int/doc/meetings/cop/cop-11/official/cop-11-26-en.pdf> accessed 17 November 2012 (hereinafter: 'Progress in the Implementation of the Programme of Work and Achievement of Aichi Biodiversity Target 11')

CBD, 'Recommendation 4/1 Implementation of the Strategic Plan for Biodiversity 2011 - 2020 and Progress towards the Aichi Biodiversity Targets' (Fourth Meeting of the Ad Hoc Open-Ended Working Group on Review of Implementation of the Convention , Montreal 7 - 11 May 2012) UNEP/CBD/WF-RI/REC/4/1 (21 June 2012) 〈http://www.cbd.int/doc/recommendations/WGRI-04/wgri-04-rec-01-en.pdf $>$ accessed 18 August 2012

CBD, 'Review of Progress in Achieving Aichi Biodiversity Target 11 and CapacityBuilding Initiatives under the Programme of Work on Protected Areas. Note by the Executive Secretary' (Fourth Meeting of the Ad Hoc Open-Ended Working Group on Review of Implementation of the Convention, Montreal, 7 - 11 May 2012) $\mathrm{UNEP} / \mathrm{CBD} / \mathrm{WG}-\mathrm{RI} / 4 / \mathrm{INF} / 5$ April

<http://www.cbd.int/doc/meetings/wgri/wgri-04/information/wgri-04-inf-05-en.pdf> accessed 13 August 2012

CBD, 'Review of Progress in Implementation of the Strategic Plan for Biodiversity 2011 - 2020, Including the Establishment of National Targets and the Updating of National Biodiversity Strategies and Action Plans' (Eleventh Meeting of the Conference of the Parties to the Convention on Biological Diversity, Hyderabad, India, $8-19$ 
October 2012) UNEP/CBD/COP/11/12 (20 July 2012) 〈http://www.cbd.int/doc/meetings/cop/cop-11/official/cop-11-12-en.pdf> accessed 16 August 2012 (Review of Progress by Executive Secretary)

Ramsar Convention, 'Report of the Chairperson of the Standing Committee' $\left(11^{\text {th }}\right.$ Meeting of the Conference of the Parties to the Convention on Wetlands (Ramsar, Iran, 1971) Bucharest, $\quad$ Romania, $6 \quad-\quad 13$ July 2012) <http://www.ramsar.org/pdf/cop11/doc/cop11-doc05-e-sc.pdf $>$ accessed 22 July 2012

Ramsar Convention, 'Report of the Secretary General on the Implementation of the Convention at the Global Level' (Ramsar COP 11 DOC.7, $11^{\text {th }}$ Meeting of the Conference of the Parties to the Convention on Wetlands (Ramsar, Iran, 1971) Bucharest, Romania, $6-13$ July 2012) at $\mathrm{p} 2$, para 5 <http://www.ramsar.org/pdf/cop11/doc/cop11-doc07-e-sg.pdf> accessed 22 July 2012

Ramsar Convention, 'Resolution XI.3. Adjustment to the Strategic Plan 2009 - 2015 for the 2013 - 2015 Triennium' ( $11^{\text {th }}$ Meeting of the Conference of the Parties to the Convention on Wetlands (Ramsar, Iran, 1971) Bucharest, Romania, 6 - 13 July 2012) <http://www.ramsar.org/pdf/cop11/res/cop11-res03-e.pdf> accessed 20 July 2012

Ramsar Convention, 'Resolution XI.4. The Status of Sites on the List of Wetlands of International Importance' $\left(11^{\text {th }}\right.$ Meeting of the Conference of the Parties to the Convention on Wetlands (Ramsar, Iran, 1971) Bucharest, Romania, 6 - 13 July 2012) <http://www.ramsar.org/pdf/cop11/res/cop11-res04-e.pdf> accessed 31 October 2012

Ramsar Convention, 'Resolution XI.6. Partnerships and Synergies with Multilateral Environmental Agreements and other Institutions' $\left(11^{\text {th }}\right.$ Meeting of the Conference of the Parties to the Convention on Wetlands (Ramsar, Iran, 1971) Bucharest, Romania, 6 - 13 July 2012) <http://www.ramsar.org/pdf/cop11/res/cop11-res06-e.pdf> accessed 31 July 2012

Ramsar Convention, Handbook 14. Data and Information Needs. A Framework for Ramsar Data and Information Needs $\left(4^{\text {th }}\right.$ edn, Ramsar Handbooks, Ramsar Convention, 2010) <http://www.ramsar.org/pdf/lib/hbk4-14.pdf> accessed 19 July 2012

UN Security Council, 'Maintenance of International Peace and Security. Impact of Climate Change' $\left(6587^{\text {th }}\right.$ Meeting, 20 July 2011, New York) S/PV.6587 
$<$ http://www.un.org/ga/search/view doc.asp?symbol=S/PV.6587> accessed

September 2012

United Nations 'The Future We Want' (Rio+20 United Nations Conference on Sustainable Development, Rio de Janeiro, Brazil, 20 -22 June 2012) (19 June 2012,

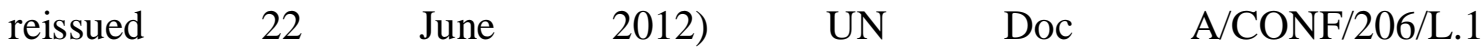
<http://www.stakeholderforum.org/fileadmin/files/FWWEnglish.pdf $>$ accessed 21 July 2012. Also: UNGA, 'The Future We Want' (Rio+20 Outcome Document, Draft Resolution Submitted by the President of the General Assembly at its Sixty-Sixth Session) UN Doc A/66/L.56 (24 July 2012) $<$ http://www.un.org/en/ga/president/66/Letters/PDF/Rio+20\%20Draft\%20Resolution24\%20July.pdf> $>\quad$ accessed $\quad 15 \quad$ November $\quad 2012 ; \quad$ and <http://www.uncsd2012.org/content/documents/727The\%20Future\%20We\%20Want\% 2019\%20June\%201230pm.pdf> accessed 17 November 2012

United Nations Secretary-General Ban Ki-moon, 'Remarks at the High-level Event on Biodiversity' (High-level Event on Biodiversity, New York, 22 September 2010) <http://www.un.org/apps/sg/sgstats.asp?nid=4791> accessed 20 July 2012

\section{3}

Ramsar Convention Secretariat, The Ramsar Convention Manual: A Guide to the Convention on Wetlands (6th edn, Ramsar Convention Secretariat, Gland, Switzerland, 2013) at p 102 <http://www.ramsar.org/pdf/lib/manual6-2013-e.pdf> accessed 17 February 2013 


\section{Table of Cases and Arbitrations}

A and Others $v$ Secretary of State for the Home Department (No 2) [2006] 1 All England Law Reports 575

Aegean Sea Continental Shelf (Greece v Turkey)(Judgment on the Merits) [1978] ICJ Reports 3 <http://www.icj-cij.org/docket/files/62/6245.pdf> accessed 18 November 2012 (Aegean Sea Continental Shelf)

Ambatielos Case (Jurisdiction) (Greece v United Kingdom) (Preliminary Objection) (1 July 1952) (1952) ICJ Reports 28, at p 43 <http://www.icjcij.org/docket/files/15/1965.pdf $>$ accessed 17 November 2012 (Ambatielos)

Anglo-Iranian Oil Co Case (United Kingdom v Iran) (Preliminary Objection, Judgment of 22 July 1952) [1952] ICJ Reports 93 <http://www.icj-cij.org/docket/files/16/1997.pdf> accessed 18 November 2012 (Anglo-Iranian Oil Co)

Anglo-Iranian Oil Co. Case (United Kingdom v Iran) (Preliminary Objection, Judgment of 22 July 1952) [1952] ICJ Reports 93 〈http://www.icj-cij.org/docket/files/16/2001.pdf> accessed 7 September 2012

Arbitral Tribunal Constituted Pursuant to Article 287, and Article 1 of Annex VII, of the United Nations Convention on the Law of the Sea for the Dispute Concerning the MOX Plant, International Movements of Radioactive Materials, and the Protection of the Marine Environment of the Irish Sea. The MOX Plant Case (Ireland v. UK) (Order No. 3, Award of 24 June 2003) reprinted in (2003) 42 International Legal Materials 1187 1199

Arbitration regarding the Iron Rhine ('Ijzeren Rijn') Railway (Belgium/Netherlands) (Award of 24 May 2005) 〈http://untreaty.un.org/cod/riaa/cases/vol_XXVII/35-125.pdf> accessed 15 November 2012

Armed Activities on the Territory of the Congo (Democratic Republic of the Congo $v$. Uganda) (Judgment of 19 December 2005) [2005] ICJ Reports 168 <http://www.icjcij.org/docket/files/116/10455.pdf> accessed 12 August 2011 (Congo v Uganda case)

Asylum Case (Columbia v Peru) (Judgment of 20 November 1950) [1950] ICJ Reports 266 <http://www.icj-cij.org/docket/files/7/1849.pdf> accessed 17 November 2012 (Asylum) 
Xxviii

Border and Transborder Armed Actions (Nicaragua $v$ Honduras) (Jurisdiction and Admissibility, Judgement of 20 December 1988) [1988] ICJ Reports 69, at p 106, para 97 <http://www.icj-cij.org/docket/files/74/6591.pdf> accessed 17 November 2012 (Border and Transborder Armed Actions)

British-American Claims Commission, Cayuga Indians (Great Britain) v United States (22 January 1926, pages 307 - 331) (1926) VI Reports of International Arbitral Awards 173 - 190, at p 184 <http://untreaty.un.org/cod/riaa/cases/vol VI/173-190 Cayuga.pdf> accessed 16 November 2012

Case Concerning Military and Paramilitary Activities In and Against Nicaragua (Nicaragua v United States of America) (Judgment on the Merits 27 June 1986) [1986] ICJ Reports 14 <http://www.icj-cij.org/docket/files/70/6503.pdf> accessed 18 November 2012 (Nicaragua)

Case Concerning Oil Platforms (Islamic Republic of Iran v United States of America) (Preliminary Objection, Judgment of 12 December 1996) (1996) ICJ Reports 803 <http://www.icj-cij.org/docket/files/90/7287.pdf> accessed 17 November 2012 (Oil Platforms)

Case Concerning Pulp Mills on the River Uruguay (Argentina v. Uruguay) (Judgment of 20 April 2010) [2010] ICJ Reports 14 (Pulp Mills')

Case Concerning Rights of Nationals of the United States of America in Morocco (France v United States of America) (Judgment of 28 August 1952) [1952] ICJ Reports 176 <http://www.icj-cij.org/docket/files/11/1927.pdf> accessed 10 April 2012 (United States Nationals in Morocco)

Case Concerning the Arrest Warrant of 11 April 2000 (Democratic Republic of the Congo v. Belgium) (Judgment of 14 February 2002) [2002] ICJ Reports 3 (Arrest Warrant case)

Case Concerning the Arrest Warrant of 11 April 2000 (Democratic Republic of the Congo v Belgium) (Judgment) 14 February 2002 (2002) ICJ Reports 3 <http://www.icjcij.org/docket/files/121/8126.pdf> accessed 9 April 2012 (Arrest Warrant)

Case Concerning the Barcelona Traction, Light and Power Company, Limited (Belgium v Spain) (Judgment of 5 February 1970) [1970] ICJ Reports 3; (1970) 46 ILR 178 
〈http://www.icj-cij.org/docket/files/50/5387.pdf $>$ accessed 17 November 2012 (Barcelona Traction)

Case Concerning the Right of Passage over Indian Territory (Portugal v. India) (Preliminary Objections Judgment of 26 November 1957) [1957] ICJ Reports 125 (Right of Passage case)

Commissioner of Internal Revenue v National Carbide Corp 167 F 2d 304 at 306 (US Court of Appeals, $2^{\text {nd }}$ Circuit) (31 March 1948) (Commissioner of Internal Revenue)

Competence of Assembly Regarding Admission to the United Nations (Advisory Opinion of 3 March 1950) [1950] ICJ Reports 4 <http://www.icjcij.org/docket/files/9/1883.pdf> accessed 10 April 2012 (Competence of the General Assembly for the Admission of a State to the United Nations)

Constitution of the Maritime Safety Committee of the Inter-Governmental Maritime Consultative Organisation (Advisory Opinion of 8 June 1960) [1960] ICJ Reports 150 〈http://www.icj-cij.org/docket/files/43/2419.pdf> accessed 17 November 2012 (Constitution of the Maritime Safety Committee of the Inter-Governmental Maritime Consultative Organisation)

Corfu Channel Case (Great Britain v. Albania) (Judgment of 9 April 1949) [1949] ICJ Report 4 <http://www.icj-cij.org/docket/files/1/1645.pdf> accessed 14 November 2012 Czech Republic v. CME, SVEA Court of Appeals, (2003) 42 ILM 919

Dispute Concerning Filleting within the Gulf of St Lawrence ('La Bretagne') (Canada/French) (1986) 82 ILR 591 (La Bretagne)

Dispute regarding Navigational and Related Rights (Costa Rica v Nicaragua) (Judgment, 13 July 2009) [2009] ICJ Reports 213 (Navigational and Related Rights' case)

European Court of Human Rights, Case of Demir and Baykara v Turkey App No 34503/97 (Grand Chamber, Strasbourg, 12 November 2008) $\langle$ http://www.ictu.ie/download/pdf/case_of_demir_baykara_v_turkey_apr_09.pdf $>$ accessed 18 September 2012 (Demir) 
European Court of Human Rights, Case of Marckx v Belgium App No 6833/74 (Court (Plenary), Strasbourg, $13 \quad$ June 1979) <http://hudoc.echr.coe.int/sites/eng/pages/search.aspx?i=001-57534> accessed 16 November 2012 (Marckx v Belgium)

European Court of Human Rights, Golder v United Kingdom, Application No 4451/70 (Strasbourg, February 1975)

<http://hudoc.echr.coe.int/sites/eng/pages/search.aspx?i=001-57496> accessed 17 November 2012 (Golder)

European Court of Human Rights, HN v Poland, Application No 77710/01 (Strasbourg, 13 September 2005) <http://www.humanrights.is/the-human-rightsproject/humanrightscasesandmaterials/cases/regionalcases/europeancourtofhumanrights/ $\underline{\mathrm{nr} / 2601}>$ accessed 8 January 2011

Fisheries Case (United Kingdom v Norway) 18 December 1951 [1951] ICJ Reports 116 <http://www.icj-cij.org/docket/files/5/1809.pdf> accessed 12 January 2011 (AngloNorwegian Fisheries)

Gabčikovo-Nagymaros Project (Hungary/Slovakia) (Judgment of 25 September 1997) [1997] ICJ Reports 7 <http://www.icj-cij.org/docket/files/92/7375.pdf> accessed 19 November 2012.

Georges Pinson (France v. United Mexican States) (Award of 13 April 1928) (1928) V Reports of International Arbitral Awards 327 - 466 (George Pinson case)

ICTY, Prosecutor v. Dragoljub Kunarac, Radomir Kovac and Zoran Vukovic (Judgment of 22 February 2001) (Case No.: IT-96-23-T and IT-96-23/1T) 〈http://www.icty.org/x/cases/kunarac/tjug/en/kun-tj010222e.pdf > accessed 12 August 2011 (Kunarac case)

Iran-US Claims Tribunal, Amoco International Finance Corporation v The Government of the Islamic Republic of Iran, National Iranian Oil company, National Petrochemical Company and Kharg Chemical Company Limited, 15 Iran-US CTR 189 <http://www.trans-lex.org/231900> accessed 19 June 2012 (Amoco) 
Iran-US Claims Tribunal, Nasser Esphahanian, Claimant v. Bank Tejarat, Respondent (Case No. 157) (Chamber Two, 29 March 1983) Award No 31-157-2 (1983) 2 Iran-US CTR 157

Iran-US Claims Tribunal, Nasser Esphahanian, Claimant v. Bank Tejarat, Respondent (Case No. 157) Chamber Two, 29 March 1983 [2] AWARD NO. 31-157-2 2 Iran-US Claims Tribunal Reports 157 (Esphahanian v Bank Tejarat)

Island of Palmas Case (Netherlands, USA) (Award of 4 April 1928) (1928) II Reports of International Arbitral Awards 829 - $871 \quad<$ http://www.pcacpa.org/upload/files/Island\%20of\%20Palmas\%20award\%20only\%20+\%20TOC.pdf> accessed 26 January 2011 (Island Palmas case)

ITLOS, Southern Bluefin Tuna Cases (New Zealand and Australia $v$ Japan) $\begin{array}{lllll}\text { (Provisional } & \text { Measures) } & 27 & \text { August } & 1999\end{array}$ $\langle$ http://www.itlos.org/index.php?id=62\&L=1\%2F> accessed 30 December 2011 (Bluefin Tuna Provisional Measure)

Kasikili/Sedudu Island (Botswana/Namibia) (Judgment of 13 December 1999) [1999] ICJ Reports 1045 <http://www.icj-cij.org/docket/files/98/7577.pdf> accessed 17 November 2012 (Kasikili/Sedudu Island)

Kirin-Amgen Inc and Others (Appellants) v Hoechst Marion Roussel Ltd and Others (Respondents). Kirin-Amgen Inc and Others (Respondents) v Hoechst Marion Roussel Limited and Others (Appellants) (Conjoined Appeals) (21 October 2004) [2004] UKHL 46 <http://www.bailii.org/uk/cases/UKHL/2004/46.html> accessed 16 April 2012 (Kirin-Amgen)

Legal Consequences for States of the Continued Presence of South Africa in Namibia (South West Africa) notwithstanding Security Council Resolution 276 (1970) (Advisory Opinion of 21 June 1971) [1971] ICJ Reports 16 <http://www.icjcij.org/docket/files/53/5595.pdf> accessed 26 January 2011 (Namibia case)

Legal Consequences of the Construction of A Wall in the Occupied Palestinian Territory (Advisory Opinion of 9 July 2004) [2004] ICJ Reports 136, at p 46, para 106 <http://www.icj-cij.org/docket/files/131/1671.pdf> accessed 11 August 2011 (Palestine Wall case) 
Legality of the Threat or Use of Nuclear Weapons, (Advisory Opinion of 8 July 1996) [1996] ICJ Report 226 <http://www.icj-cij.org/docket/files/95/7495.pdf> accessed 14 November 2012

North Sea Continental Shelf Cases (Germany/Denmark; Germany/Netherlands) (Judgment of 20 February 1969 (1969) ICJ Reports 3 <http://www.icjcij.org/docket/files/52/5561.pdf> accessed 17 November 2012 (North Sea Continental Shelf)

Nuclear Test Case (New Zealand v. France) (Judgment of 20 December 1974) (1974) ICJ Report 457 〈http://www.icj-cij.org/docket/files/59/6159.pdf> accessed 14 November 2012

PCA, Arbitral Tribunal Constituted Pursuant to Article 287, and Article 1 of Annex VII, of the United Nations Convention on the Law of the Sea for the Dispute concerning the MOX Plant, International Movements of Radioactive Materials, and the Protection of the Marine Environment of the Irish Sea (Ireland v United Kingdom) Order No 3 (24 June 2003) (hereinafter: 'UNCLOS Mox Plant')

PCA, Dispute Concerning Access to Information under Article 9 of the OSPAR Convention, (Ireland v UK and Northern Ireland) (Final Award, 2 July 2003) <http://untreaty.un.org/cod/riaa/cases/vol_XXIII/59-151.pdf> accessed 4 March 2013 (OSPAR Proceeding)

PCIJ, Competence of the International Labour Organisation in Regard to International Regulation of the Conditions of Labour of Persons Employed in Agriculture (Advisory Opinion) 12 August 1922 (PCIJ, Series B, Nos 2 and 3) <http://www.worldcourts.com/pcij/eng/decisions/1922.08.12_ILC_competence1.htm> accessed 10 April 2012 (Competence of the International Labour Organisation)

Plama v Bulgaria, (Decision on Jurisdiction, 8 February 2005) ICSID Case No ARB/03/24, <http://italaw.com/documents/plamavbulgaria.pdf> accessed 17 April 2012 (Plama v Bulgaria)

Polish Postal Service in Danzig (Advisory Opinion) 16 May 1925, PCIJ Series B, No 11, at $\quad p \quad 39 \quad$ h $\quad 3$ http://www.icjcij.org/pcij/serie_B/B_11/01_Service_postal_polonais_a_Danzig_Avis_consultatif.pdf> accessed 10 April 2012 (Polish Postal Service in Danzig) 
xxxiii

$R v$ Secretary of State for the Home Department, Ex parte Read [1989] Appeal Cases 1014 <http://www.publications.parliament.uk/pa/ld200001/ldjudgmt/jd001219/adan-

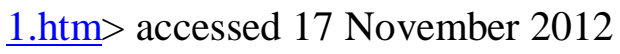

Solomon v Commissioners of Customs and Excise [1967] 2 Queen's Bench 116

Southern Bluefin Tuna case (Australia and New Zealand/Japan) (Award on Jurisdiction and Admissibility of 4 August 2000) (2004) XXIII UNRIAA 1 $<$ http://icsid.worldbank.org/ICSID/FrontServlet?requestType=ICSIDPublicationsRH\&a $\underline{\text { ctionVal=ViewAnnouncePDF \&AnnouncementType }=\text { archive } \& A n n o u n c e N o=7 \_10 . p d f}>$ accessed 9 November 2012 (Bluefin Tuna case)

Sovereignty over Pulau Ligitan and Pulau Sipadan (Indonesia v Malaysia) (Judgment of 17 December 2002) [2002] ICJ Reports $625 \quad$ <http://www.icjcij.org/docket/files/102/7698.pdf> accessed 17 November 2012

Trail Smelter Case (United States, Canada) (Award of 16 April 1938 and 11 March 1941) (1941) III Reports of International Arbitral Awards 1905 - 1982 <http://untreaty.un.org/cod/riaa/cases/vol_III/1905-1982.pdf> accessed 14 November 2012 (Trail Smelter case)

WTO, Canada - Measures Affecting the Export of Civilian Aircraft - Report of the Appellate Body (AB-1999-2) (2 August 1999) WT/DS70/AB/R <http://www.worldtradelaw.net/reports/wtoab/canada-aircraft(ab).pdf> accessed 15 November 2012 (Canada - Aircraft)

WTO, Canada - Term of Patent Protection (Report of the Appellate Body) (18 September 2000) WT/DS170/AB/R <http://www.wto.org/english/tratop_e/dispu_e/170abr_e.pdf $>$ accessed 17 November 2012 (Canada - Patent)

WTO, Chile - Price Band System and Safeguard Measures Relating to Certain Agricultural Products - Report of the Appellate Body (23 September 2002) WT/DS207/AB/R $\quad<$ http://www.worldtradelaw.net/reports/wtoab/chileagproducts(ab).pdf $>$ accessed 17 November 2012 (Chile - Price Band) 
xxxiv

WTO, EC - Measures Concerning Meat and Meat Products (Hormones) - Report of the Appellate Body (adopted 16 January 1998) WT/DS26/AB/R and WT/DS48/AB/R (EC - Hormones)

WTO, European Communities - Customs Classification of Certain Computer Equipment - Report of the Appellate Body (5 June 1998) WT/DS62/AB/R, WT/DS67/AB/R，WT/DS68/AB/R <http://www.worldtradelaw.net/reports/wtoab/ec-

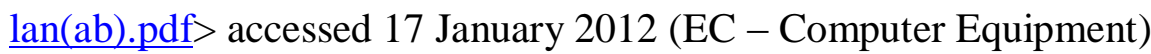

WTO, European Communities and Certain Member States - Measures Affecting Trade in Large Civil Aircraft (Appellate Body Report, 18 May 2011) WT/DS316/AB/R (EC Aircraft)

WTO, European Communities: Measures Affecting the Approval and Marketing of Biotech Products - Report of the Panel (29 September 2006) WT/DS291/R, WT/DS292/R, and WT/DS293/R <http://www.worldtradelaw.net/reports/wtoab/usgasoline(ab).pdf> accessed 9 November 2012 (EC - Biotech)

WTO, Japan - Taxes on Alcoholic Beverages - Report of the Appellate Body (4 October 1996) WT/DS8/AB/R; WT/DS10/AB/R; WT/DS11/AB/R <http://www.mofa.go.jp/policy/economy/wto/cases/WTDS8ABR.pdf> accessed 17 November 2012 (Japan Alcohol)

WTO, United States - Import Prohibition of Certain Shrimp and Shrimp Products Report of the Appellate Body (12 October 1998) WT/DS58/AB/R <http://www.wto.org/english/tratop_e/dispu_e/58abr.pdf> accessed 16 November 2012 (Shrimp Turtle)

WTO, United States - Imports of Certain Automotive Spring Assemblies (Report of the Panel) L/5333 - $30 \mathrm{~S} / 107 \quad$ (26 May 1983) at para 56 $<$ http://www.worldtradelaw.net/reports/gattpanels/usspringassemblies.pdf $>$ accessed 21 April 2012

WTO, United States - Imports of Certain Automotive Spring Assemblies - Report of the

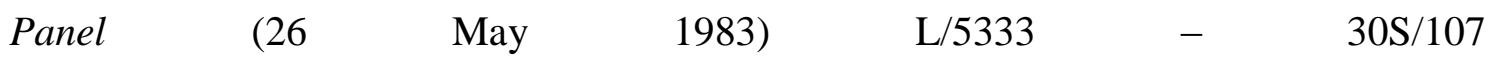
<http://www.worldtradelaw.net/reports/gattpanels/usspringassemblies.pdf $>$ accessed 21 April 2012 
WTO, United States - Restrictions on Imports of Tuna - Report of the Panel (16 June $\begin{array}{llll}\text { 1994) DS29/R, } & \text { at } & \text { para }\end{array}$ <http://www.worldtradelaw.net/reports/gattpanels/tunadolphinII.pdf $>$ accessed 16 November 2012 (Tuna/Dolphin)

WTO, US - Standards for Reformulated and Conventional Gasoline - Report of the $\begin{array}{llllll}\text { Appellate } & \text { Body } & (29 & \text { April } & \text { 1996) } & \text { WT/DS2/AB/R }\end{array}$ <http://www.worldtradelaw.net/reports/wtoab/us-gasoline(ab).pdf $>\quad$ accessed 9 November 2012 


\section{Chapter 1. Introduction}

\subsection{Context: Environmental Protection of International Watercourses: A Review}

'In the field of environmental protection, vigilance and prevention are required on account of the often irreversible character of damage to the environment and of the limitations inherent in the very mechanism of reparation of this type of damage. 1

The degradation of freshwater ecosystems has heightened the need for an effective regime within the management of water resources, especially in the advent of climate change that has serious implications on water availability, thereby directly affecting the utilisation of watercourses. ${ }^{2}$ Scholars have described the global dimension of environmental degradation, especially of river ecosystems, as a matter of 'environmental security' ${ }^{3}$ where a significant amount of environmental degradation in transboundary watercourses is caused by mismanagement and over-exploitation. ${ }^{4}$

${ }^{1}$ Gabčikovo-Nagymaros Project (Hungary/Slovakia) (Judgment of 25 September 1997) [1997] ICJ Reports 7, at p 78, para 141 <http://www.icj-cij.org/docket/files/92/7375.pdf> accessed 24 August 2012 <http://www.icj-cij.org/docket/files/92/7375.pdf> accessed 24 August 2012 (hereinafter: 'GabčíkovoNagymaros'). This was reiterated in the recent pulp mills case between Argentina and Uruguay over the construction of two pulp mills along River Uruguay, Case Concerning Pulp Mills on the River Uruguay (Argentina v Uruguay) (Judgment of 20 April 2010) [2010] ICJ Reports 14 (hereafter: the 'Pulp Mills' case'), at p 76, para 185 .

2 UN, 'International Decade for Action "Water For Life" 2005-2015' (undated) <http://www.un.org/waterforlifedecade/quality.shtml> accessed 2 November 2012. The UN Secretary General stated that - 'Our indispensable resources have proven themselves to be greatly resilient, but they are increasingly vulnerable and threatened. Our growing population's need for water for food, raw materials and energy is increasingly competing with nature's own demands for water to sustain already imperilled ecosystems and the services on which we depend ... Clean water has become even scarcer with the onset of climate change'. In UNEP, 'The UN-Water Status Report on the Application of Integrated Approaches to Water Resources Management' (UNEP, 2012) <http://www.unwater.org/downloads/UNW_status_report_Rio2012.pdf > accessed 3 November 2012. The $\mathrm{UN}-$ Water report stated, at $\mathrm{p} 3$ that 'as water is the principle medium through which climate change expresses itself, adaptation to climate change - and the need to build resilience - is increasingly being approached through water management initiatives'.

${ }^{3}$ See Jutta Brunnée and Stephen J Toope, 'Environmental Security and Freshwater Resources: A Case for International Environmental Law’ (1994) 5 Yearbook of International Environmental Law 41 - 76, at 41 -52 .

${ }^{4}$ Sandara Postel, Dividing the Waters: Food Security, Ecosystem Health, and the New Politics of Scarcity (Worldwatch Paper 132, Worldwatch Institute 1996) at pp 26 - 35. Stephen M Schwebel 'Third Report on the Law of Non-navigational Uses of International Watercourses' (11 December 1981) [1982] II(1) Yearbook of International Law Commission 65 - 191, UN Doc A/CN.4/348 and Corr.1 (hereinafter: 'Schwebel $3^{\text {rd }}$ Report') at $p$ 141. Selected summaries from the Global 2000 Report quoted extensively in the $3^{\text {rd }}$ Special Rapporteur's report highlighted the increasingly critical state of earth's water resources. Some of the statements are 'water problems resulting from deforestation have appeared in 16 countries in the form of critical water shortages, and in 10 countries in the form of increased flooding. Some countries 
The issue of environmental protection is a major concern in international water instruments, where the obligation to protect the environment is found in a plethora of water specific instruments ${ }^{5}$ such as the regional 1992 Helsinki Convention, ${ }^{6}$ and the 1995 Agreement on the Mekong River Basin. ${ }^{7}$ The robust development of international law through the multiplication of international instruments on international watercourses has contributed to the emergence of a specialised regime known as international water law, or international law on water resources. ${ }^{8}$

These international instruments inform the body of knowledge of the obligation to protect the international watercourses environment, where the incorporation of this obligation in water-specific international instruments leads to the crystallisation of this obligation in the international legal regime on international watercourses. ${ }^{9}$ The recognition of this specialised body of international law on the non-navigational uses of international watercourses by the international community has culminated in the codification and progressive development of this area of law by the International Law Commission (ILC), subsequently adopted by the United Nations General Assembly (UNGA). ${ }^{10}$

shared both drought and flooding'; and 'the disruption of water systems is the most certain environmental consequence of forest elimination. Deforestation is most rapid in the very region where water systems are most vulnerable: the equatorial (tropical) belt ... receives almost half the glove's total terrestrial rainfall... and the rain is substantially more erosive than elsewhere in the world ... Deforestation of this belt will have serious effects on the flows in the major river systems such as the Mekong, the Ganges, the Amazon, the Congo, and their tributaries'. In Ian R Calder, Blue Revolution: Integrated Land and Water Resources Management ( $2^{\text {nd }}$ edn, Earthscan, UK and the USA, 2005) at $\mathrm{p}$ 5: 'Soil degradation [due to removal of natural vegetation, overgrazing and etc] may in turn affect the quantity and quality of water as it infiltrates and moves through the soil profile, and thus alter the hydrological response of catchments and the hydrological cycle'.

${ }^{5}$ For examples of some water-specific international instruments, see infra n 66.

${ }^{6}$ See infra n 67. Art 2(d) provides that 'the Parties [to prevent, control and reduce any transboundary impact] shall, in particularly, take all appropriate measures to ensure conservation and, where necessary, restoration of ecosystems'.

${ }^{7}$ Agreement on the Cooperation for the Sustainable Development of the Mekong River Basin (Entered

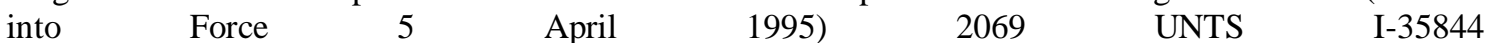
<http://treaties.un.org/doc/Publication/UNTS/Volume\%202069/v2069.pdf> accessed 15 February 2013. Art 3 of the Mekong Agreement addresses the protection of the environment and ecological balance where it provides that 'to protect the environment, natural resources, aquatic life and conditions, and ecological balance of the Mekong River Basin from pollution or other harmful effects resulting from any development plans and uses of water and related resources in the Basin'.

${ }^{8}$ On structurisation of international law through interaction and interplay of norms, refer to infra Section 1.2.3 and $\mathrm{n} 140$.

${ }^{9}$ The structurisation of international water law will be elaborated in Sections 1.1 .1 and 1.2.3, in particularly n 70 and n 141. Some international water instruments constituting the corpus of law on international watercourses are mentioned in supra $\mathrm{n} 66$.

${ }^{10}$ UNGA, '99 ${ }^{\text {th }}$ Plenary Meeting' (51 ${ }^{\text {st }}$ Session of the General Assembly, 21 May 1997). Refer to infra $\mathrm{n}$ 41. 
Apart from the multiplication of international water-specific instruments on the obligation to protect the environment, the obligation to protect the environment is a major concern of other non-water specific Multilateral Environmental Agreements (MEAs), ${ }^{11}$ such as the Biodiversity Convention ${ }^{12}$ and the Ramsar Convention on Wetlands. ${ }^{13}$ The proliferation of international instruments on the environment and its protection, triggered by the United Nations Conference on Environment and Development (UNCED) held in Rio de Janeiro in 1992, which exist parallel to each other "without the benefit of consideration being given to potential conflicts with other agreements either during their negotiation or at a later stage of their existence', has given rise to a situation known as 'a multitude of parallel'. ${ }^{14}$

Due to the interdependence of ecological processes, the parallel MEAs that substantially or partially overlap and collide with each other, in the absence of an overarching architecture of administration, lead to treaty congestion and conflicts that could have the undesirable effects of conflicts, contradictions, and the doubling of efforts that diminish the effectiveness of international environmental law. ${ }^{15}$ These conflicts, analysed by the ILC under the discourse of 'fragmentation of international law', ${ }^{16}$ recognise the familiar ways conflicts are dealt with in every legal order, such as the maxims of lex specialis or lex posterior known to most legal systems. ${ }^{17}$

The ILC explained that 'conflict-ascertainment and conflict-resolution are a part of [a purposive activity ${ }^{18}$ of] legal reasoning, that is, of the pragmatic process through which

${ }^{11}$ On examples of non-water specific international instruments on the protection of international watercourse environment, see infra $\mathrm{n} 52$.

${ }^{12}$ Convention on Biological Diversity (entered into force 29 December 1993) 1760 UNTS 79; (1992) 31 ILM 818 (hereinafter: 'Biodiversity Convention').

${ }^{13}$ Convention on Wetlands of International importance Especially as Waterfowl Habitat (entered into force 21 December 1975) 996 UNTS 245; TIAS 11084; (1972) 11 ILM 963 (hereinafter: 'Ramsar Convention').

${ }^{14}$ Rüdiger Wolfrum and Nele Matz, Conflicts in International Environmental Law (Springer-Verlag Berlin, Heidelberg, New York, 2003) at p 2. The authors, at pp $2-3$ commented that 'The phenomenon of a multitude of parallel, substantially or partially overlapping and colliding agreements in international environmental law, exacerbated by the practice of negotiating ever more binding instruments, has been labelled "treaty congestion".

${ }^{15}$ Wolfrum and Matz, Conflicts in International Environmental Law, at pp 3 - 4. The problématique shrouding the fragmentation of international law is discussed in infra Section 1.2, n 107.

${ }^{16}$ The problems arising due to the fragmentation of international law is further elaborated in Section 1.2 of the thesis.

${ }^{17}$ ILC, 'Report of the Study Group of the International Law Commission. Fragmentation of International Law: Difficulties Arising from the Diversification and Expansion of International Law' (Fifty-eighth session, 1 May - 9 June and 3 July - 11 August 2006, Geneva, Finalized by Martti Koskenniemi) (13 April 2006) UN Doc A/CN.4/L.682 (hereafter: 'Fragmentation Report') at p 20, para 26. For further discussion on the fragmentation of international law see Section 1.2.

${ }^{18}$ Fragmentation Report, supra n 17, at p 23, para 34. 
lawyers go about interpreting and applying formal law', whereby legal rules are deemed to be in a relationship with each other ${ }^{19}$ within the 'system' of law. ${ }^{20}$ It is within this context that legal interpretation (where principles of interpretation are codified under Articles 31 - 32 of the 1969 Vienna Convention on the Law of Treaties), ${ }^{21}$ and thus legal reasoning, are crucial to the resolution of conflict posed by the multiplication of parallel norms, where interpretation 'builds systemic relationships' between norms that form 'part of the human effort or purpose'. 22

The multitude of international instruments relating to the environmental protection of international watercourses could lead to the fragmentation of international law. The resolution of a situation of fragmented norms through legal reasoning entails either the determination of a relationship of interpretation that seeks to harmonise apparently conflicting standards; or in the event that harmonisation is inappropriate, ${ }^{23}$ the establishment of definite relationships of priority between conflicting norms where conflict-resolution techniques become useful. ${ }^{24}$ However, bearing in mind the ecological interdependencies of the environment, there is a need to seek harmonisation of parallel norms that operate simultaneously on states, where states are obliged to comply.

From the perspective of resolving the undesirable consequences of the fragmentation of international law, there is a need to seek harmonisation of parallel norms through the legal mechanism of interpretation, where the fragmentation of norms could not be

\footnotetext{
${ }^{19}$ Fragmentation Report, supra n 17, at p 20, para 27.

${ }^{20}$ Fragmentation Report, supra n 17, at p 23, para 33. At p 25, para 36, the ILC stated that 'Instead of a random collection of directives, the law

begins to assume the shape of a purposive (legal) system'.

${ }^{21}$ ILC, in Fragmentation Report, supra n 17, at p 25, para 37, stated that 'In international law, there is a strong presumption against normative conflict. Treaty interpretation is diplomacy, and it is the business of diplomacy to avoid or mitigate conflict. This extends to adjudication as well'. The general rule of interpretation is codified under Articles 31 - 32 of the 1969 Vienna Convention on the Law of Treaties, infra $\mathrm{n} \mathrm{31.} \mathrm{For} \mathrm{a} \mathrm{detailed} \mathrm{elaboration} \mathrm{of} \mathrm{treaty} \mathrm{interpretation,} \mathrm{the} 1969$ Vienna Convention and the principles of legal interpretation of treaties, refer infra Section 1.6.1.

${ }^{22}$ Fragmentation Report, supra n 17, at p 24, para 35.

${ }^{23}$ Situations where harmonisation could be in appropriate in the resolution of fragmented norms include, a situation of 'genuine conflicts' (as stated by ILC in the Fragmentation Report, supra n 17, at p 27, para 42); or a situation where the relationship of lex generalis-lex specialis occurs and it is prudent to apply the lex specialis rule, where the specific rule is read and understood within the confines or against the background of the general standard (Fragmentation Report, supra n 17, at p 35, para 56). The ILC is of the opinion that conflicts between general law and a particular law, which involves an unorthodox interpretation of general law (Fragmentation Report, supra n 17, at p 30, para 47(a)), 'falls strictly speaking outside the Commission study [on fragmentation of international law]' by distinguishing this type of normative conflict from 'genuine conflict' that produces the undesirable consequences of a fragmentation of international law.

${ }^{24}$ Fragmentation Report, supra n 17, at pp $24-25$, para 36.
} 
addressed through the application of the lex specialis rule. ${ }^{25}$ Despite the multiplication of water-specific international instruments that impinges on the obligation to protect the environment, the problems arising from the fragmentation of international law are less likely to occur._This is because coherency would be observed through the application of the lex specialis rule, where lex specialis would be interpreted and applied within the confines of the lex generalis. ${ }^{26}$ However, conflicts might arise between the international water law regime and the multitude of MEAs that make up the regime of international environmental law, where states have simultaneous commitments to comply. ${ }^{27}$

In this context, a strong presumption against normative conflict necessitates an integration of parallel rules that are relevant ${ }^{28}$ to the obligation to protect and preserve the environment of international watercourses, where legal interpretation is recommended as a means to 'avoid or mitigate conflict'. ${ }^{29}$ In particular, the principle of systemic integration, ${ }^{30}$ which finds expression in Article 31(3)(c) of the 1969 Vienna Convention, ${ }^{31}$ is recognised as an interpretative mechanism to manage the fragmentation of international law due to the parallel existence of rules of international law in different areas of specialisation (i.e., water and non-water specific), in a legalprofessional way. ${ }^{32}$

In light of the recognition of the conceptualisation of the environment as functional unit of ecological systems in international law, increasing importance is placed on the obligation to preserve as a measure of environment protection. ${ }^{33}$ Article 20 of the 1997 Watercourses Convention represents the international consensus of the obligation to preserve at the global level, where particular emphasis is placed on the preservation of the natural status of ecosystems of international watercourses through a special

\footnotetext{
${ }^{25}$ In reference to the discussion in supra $\mathrm{n} 23$, the existence of regionalised and basin-specific international instruments on water resources would not be classified as 'genuine conflict' that brings forth the concerns due to the fragmentation of international law.

${ }^{26}$ On the complementary relationship of lex specialis-lex generalis within the international water law regime, refer to Section 1.4 of this thesis.

${ }^{27}$ Further justification is provided in Section 1.4 of this thesis.

${ }^{28}$ On the criteria for the establishment of a relationship of 'relevance', refer to Chapter 2 of this thesis.

${ }^{29}$ Fragmentation Report, supra n 17, at p 25, para 37.

${ }^{30}$ The principle of systemic integration is elaborated by the ILC in Fragmentation Report, supra $\mathrm{n}$ 17, at $\mathrm{p}$ 137, para 271. The ILC stated that 'relevant instruments should always be read as compatible with each other (i.e. the principle of systemic integration) within an overall obligation to cooperate'.

${ }^{31}$ Vienna Convention on the Law of Treaties (adopted 23 May 1969, entered into force 27 January 1980) (hereafter '1969 Vienna Convention') 1155 UNTS 331. On treaty interpretation and the 1969 Vienna Convention, see Section 1.6.1 of this thesis.

${ }^{32}$ Fragmentation Report, supra n 17, at p 15, para 17.

${ }^{33}$ On the obligation to preserve, refer to Section 1.1.1 and Chapter 2 of this thesis.
} 
management regime. ${ }^{34}$ It provides a suitable foundation for the ascertainment of the normativity of the obligation to preserve ecosystems of international watercourses, where the interpretation of this obligation provided under Article 20 of the 1997 Watercourses Convention is undertaken in light of other parallel relevant rules of international law within its normative environment.

Hence, this thesis will focus on the interpretation of the obligation to preserve ecosystems of international watercourses provided under Article 20 of the 1997 Watercourses Convention ${ }^{35}$ and proposes a framework of interpretation that operationalises Article 31(3)(c) of the 1969 Vienna Convention. This framework endeavours to realise the full potential of Article 31(3)(c) as an integration tool that expresses the principle of systemic integration. An integrated approach in the interpretation of a treaty provision is particularly crucial in light of the fragmentation of international law on the environment, especially in striking the balance between conservation and use, and between sustainability and development. These concerns, as reflected in the two introductory paragraphs, underlie the objective of this research and will be further developed throughout this thesis.

In response to the need for 'international water law [to] become aware of [the] covert hegemonic practices', ${ }^{36}$ the thesis acknowledges the political asymmetries and sensitivities inherent in the cooperation of states over the shared international watercourses, especially in the Nile, Jordan, Tigris and Euphrates river basins; ${ }^{37}$ and China's hydro-supremacy in the Asian region. ${ }^{38}$ The pivotal role that shared legal understanding (the implicit dimension underlying a rule of international law) plays in the conceptualisation of international law through an interactional perspective proposed

\footnotetext{
${ }^{34}$ Schwebel $3^{\text {rd }}$ Report, supra $\mathrm{n} 4$, at p 190, para 518. Refer infra $\mathrm{n} 56$ for an elaboration of the obligation to preserve.

35 Convention on the Law of Non-Navigational Uses of International Watercourses (adopted 21 May 1997, not yet entered into force) (hereafter: '1997 Watercourses Convention') reprinted in (1997) 36 ILM 700 .

${ }^{36}$ Melvin Woodhouse and Mark Zeitoun, 'Hydro-hegemony and International Water Law: Grappling with the Gaps of Power and Law’ (2008) 10 (supp 2) Water Policy 103 - 119, at p 103.

${ }^{37}$ Mark Zeitoun and Jeroen Warner, 'Hydro-hegemony - A Framework for Analysis of Trans-boundary Water Conflicts' (2006) 8(5) Water Policy 435 - 460.

38 Brahma Chellaney, 'China's Hydro-Hegemony' (The Opinion Pages, The New York Times, New Delhi, 7 February 2013) < http://www.nytimes.com/2013/02/08/opinion/global/chinas-hydrohegemony.html? r=0 > accessed 16 February 2013.
} 
in this thesis could serve as a platform to accommodate or even assist the cooperation of states, where willingness to cooperate is a major concern. ${ }^{39}$

This chapter commences with the background of the topic of research and the problem it seeks to address, followed by the research title and research question developed for this thesis. Thereafter, the chapter proceeds to delimit the scope of, and presents the justifications for the research. The subsequent sections in this chapter will address the methodology engaged in this thesis, and the analytical framework developed to address the research question proposed in the chapter via the structure outlined in the final sections of this chapter.

The next section introduces the legal status of the protection and preservation of ecosystems of international watercourses as codified in Article 20 of the 1997 Watercourses Convention, and elaborates how the obligation to protect and preserve has been applied to the recent Pulp Mills' case.

\subsubsection{Article 20 of the 1997 UN Watercourses Convention}

The inability of piecemeal rules to address legal problems arising from conflict of competing uses of freshwater resources prompted the UNGA to request the ILC to look into the codification and progressive development of international watercourses law on the non-navigational uses of international watercourses. This took into account recent application in state practice and international adjudication of the law of international watercourses, and inter-governmental and non-governmental studies on the subject matter. ${ }^{40}$ The Draft Resolution A/51/L.72, which is now the 1997 Watercourses Convention, was adopted by the UNGA by 103 votes to three, with 27 abstentions (Resolution 51/229). ${ }^{41}$

Article 20 of the 1997 Watercourses Convention provides that 'Watercourses States shall, individually and, where appropriate, jointly, protect and preserve the ecosystems of international watercourses'. ${ }^{42}$ It sets forth the obligation to protect and preserve ecosystems of international watercourse states regardless of whether transboundary harm is caused, and imposes on states the initiative to act individually in the protection

\footnotetext{
${ }^{39}$ This aspect will be addressed further in Section 8.6 of this thesis.

${ }^{40}$ UNGA Res 2669 (XXV) (8 December 1970).

${ }^{41}$ UNGA, '99 ${ }^{\text {th }}$ Plenary Meeting' (51 ${ }^{\text {st }}$ Session of the General Assembly, 21 May 1997) A/51/PV.99, at p 8 <http://www.un.org/ga/search/view_doc.asp?symbol=A/51/PV.99> accessed 18 August 2012.

421997 Watercourses Convention, supra n 35, Art 20.
} 
and preservation of the ecosystem of an international watercourse, and cooperate with other states where appropriate. ${ }^{43}$

The term 'ecosystem' was adopted as it was believed to have a 'more precise scientific and legal meaning' than the environment. ${ }^{44}$ It generally refers to 'an ecological unit consisting of living and non-living components that are interdependent and function as a community'. ${ }^{45}$ The acknowledgment of the conceptualisation of the environment in ecosystem terminology, together with the underlying context of Chapter IV of the 1997 Watercourses Convention, implies that the surrounding areas, which form an ecological whole with the system concerned, are encompassed within the meaning of the 'ecosystems of international watercourses'. ${ }^{46}$

The terms 'protect' and 'preserve' were qualified and explained in the 1994 Draft Articles and Commentaries where 'protection' of ecosystems of international watercourses, as stipulated in Article $5,{ }^{47}$ requires the Watercourses States to shield the

${ }^{43}$ Chapter IV of the 1997 Watercourses Convention deals with the protection, preservation and management aspect of the non-navigational uses of international watercourses. Art 20 stated 'Watercourses States shall, individually and, where appropriate, jointly, protect and preserve the ecosystems of international watercourses'.

${ }^{44}$ It was defined in the 1994 Draft Articles and Commentaries, supra $\mathrm{n}$ 44, in reference to the work of the Economic Commission for Europe (ECE) as 'a spatial unit of Nature in which living organisms and the non-living environment interact adaptively'. See ILC 'Draft Articles on the Law of the Non-navigational Uses of International Watercourses and Commentaries thereto and Resolution on Transboundary Confined Groundwater' (Report of the International Law Commission on the Works of Its Forty-sixth Session, 2 May - 22 July 1994, ORGA, Forty-ninth Session, Supplement No 10) UN Doc A/49/10 [1994] II(2) Yearbook of International Law Commission $1-182$ (hereinafter: '1994 Draft Articles and Commentaries') at $\mathrm{p}$ 118. It is stated in the commentaries to Art 20 that: 'environment can be interpreted quite broadly to apply to areas surrounding the watercourses that have minimal bearing on the protection and preservation of the watercourse itself. Furthermore, the term has implication to areas outside the watercourse, which is not the intention of the Commission. For these reasons, the Commission preferred to utilise the term "ecosystem" which is believed to have a more precise scientific and legal meaning ... as the term generally refers to an ecological unit consisting of living and non-living components that are interdependent and function as a community'. Schwebel $3^{\text {rd }}$ Report, supra $\mathrm{n} 4$, at $\mathrm{p}$ 136, para 286. It is stated that "For some purposes, "environment" is described, or defined, as the "assemblage of material factors (internal and external) and conditions surrounding the living organism and its component parts"'. In the external environment, inanimate objects and the forces associated with them constitute the physical environment and the living things and their derivatives with which the animal may be associated constitute the organic environment. In modern practice, aesthetics and vegetation and even bacterial populations are embraced. Many industrial processes, and perhaps more significantly "human habitats", involve substantial control of the environment, while in the field of environmental protection, preserving or restoring the free state of nature is the fundamental focus, plus the special feature of improving the "quality of life" for man'.

451994 Draft Articles and Commentaries, supra n 44, at p 118, para 2.

${ }^{46}$ ILC 'Report of the International Law Commission on the Work of Its Thirty-fifth Session, 3 May - 22 July 1983' (Thirty-eighth Session, GAOR, Supplement No 10) UN Doc A/38/10 [1983] II(2) Yearbook of International Law Commission 1 - 91, at para 256.

${ }^{47}$ Art 5(1) of the 1997 Watercourses Convention, supra n 35, provides 'international watercourse shall be used and developed ... to attain optimal and sustainable utilisation and benefits ... consistent with 
watercourse from harm and damage, and imposes a duty to protect the watercourse from a significant threat of harm. ${ }^{48}$ The obligation to 'preserve', however, applies in particular to the protection of freshwater ecosystems in their 'pristine and unspoilt condition $^{49}$ against harm and damage in order to maintain their natural state. ${ }^{50}$

The ILC explained that the purpose of the obligation imposed on watercourse states to protect and preserve the 'aquatic ecosystems' is to ensure the continued viability of the ecosystem to support life in attaining sustainable development. ${ }^{51}$ The ILC acknowledged that -

'in ecosystems, everything depends on everything else ... An external impact affecting one component of an ecosystem causes reactions among other components and may disturb the equilibrium of the entire ecosystem, ${ }^{52}$

The term 'environment' was removed and replaced with 'ecosystems' due to the concern of members of the ILC on the possible incorporation of terrestrial area. ${ }^{53}$ However, if ecosystem is understood as a dynamic system, where everything is interdependent and in which an external impact affecting one component of an ecosystem will cause reactions among other components and may disturb the equilibrium of the entire ecosystem, the scope of ecosystem is not less expansive than

adequate protection of the watercourse' (author's emphasis). Art 5(2) provides 'participation includes ... the duty to cooperate in the protection and development'.

481994 Draft Articles and Commentaries, supra n 44, at para 3, p 119. The ILC stated that 'The obligation to "protect" the ecosystem of international watercourses is a specific application of the requirement contained in Article 5 that watercourse States are to use and develop an international watercourse in a manner that is consistent with adequate protection thereof'. See Attila Tanzi and Maurizio Arcari, The United Nations Convention on the Law of International Watercourses. A Framework for Sharing (Kluwer Law International, London, The Hague, Boston, 2001) at p 245.

491994 Draft Articles and Commentaries, supra n 44, at p 119, paras 3 and 4.

${ }^{50}$ Schwebel $3^{\text {rd }}$ Report, supra $\mathrm{n} 4$, at $\mathrm{p} 122$, para 247. It is stated that 'it is not possible to subsume all environmental problems under the rubric of pollution. ... it may be said that, for watercourse systems, pollution involves the use of water by man ... and the impact upon water of other activities for which man is responsible, with consequent detrimental effect. Whereas for environmental damage, commonly perceived, is harm to nature in a broader sense, more especially, perhaps, to biological complexes of myriad sorts. The impact of such damage upon man, while probable, even if in the very long run, may be highly indirect or not even ascertainable.' He went on to elaborated that environmental protection involves much more than the quality of water. He stated that accounts must be taken of the 'effect through water, on wildlife, including endangered species, on the flora of the area reached by waters, on the genetic resources and on the biotic potentials of the region' although none of these constitute 'use' of the water. Schwebel $3^{\text {rd }}$ Report, supra $\mathrm{n}$ 4, at p 136, para 285.

511994 Draft Articles and Commentaries, supra n 44, at p 119, para 3.

521994 Draft Articles and Commentaries, supra n 44, at p 118, para 2.

${ }^{53}$ Refer supra n 44 on an elaboration on the replacement of the term 'environment' with 'ecosystem'. 
the term 'environment'. ${ }^{54}$ This indicates the recognition of the Commission of the fact that freshwater ecosystems do not merely cover the aquatic component, but also other components (including terrestrial ecosystems) in the basin. ${ }^{55}$

Schwebel observed that the obligation to preserve ecosystems of international watercourses is an important portion of environmental protection, ${ }^{56}$ as evidenced in the recent extension of the conservation movement in the designation of watercourses as wild or scenic rivers. ${ }^{57}$ This supports Schwebel's assertion that -

'environmental damage measurable within the territory of a system State may arguably fall under international regulation because the legal presumption is that preservation of the environment in the large is a licit concern of all nations'. ${ }^{58}$

The emphasis on the role of national boundaries to protect ecosystems is recognised in the recent Earth Summit 2012 where the Summit recognised the key role of ecosystems in the maintenance of water quantity and quality, and fully supported the actions of states within their respective national boundaries in the protection and management of these ecosystems. ${ }^{59}$ This explains the order of the provision where the obligation to protect and preserve ecosystems of international watercourses codified in the 1997 Watercourses Convention imposes firstly that 'watercourse States shall, individually,

\footnotetext{
54 This is supported by the recognition of a basin approach by the ILC in reference to the medium-term plan of the United Nations for the period 1992-1997 that implies that the acknowledgment of the Commission of the fact that freshwater ecosystem does not merely covers the 'aquatic ecosystem' component, but also other components (including terrestrial ecosystem) in the basin as well. 1994 Draft Articles and Commentaries, supra n 44, at p 118, para 2. The ILC quoted 'water basin development activities can have negative impacts leading to unsustainable development' from the medium-term plan of the United Nations for the period 1992-1997.

55 Apart from that, the ILC quoted the medium-term plan of the United Nations for the period 1992-1997 that 'water basin development activities can have negative impacts leading to unsustainable development' to strengthen the assertion that all activities conducted on the basin (including the terrestrial area) will have an impact on the sustainable development of a watercourse. 1994 Draft Articles, at p 118, para 2.

${ }^{56}$ The preservation of the natural state of international watercourses will enable the maintenance of the ecological balance of the aquatic ecosystems of international watercourses. 1994 Draft Articles, at p 121, para 8.

${ }^{57}$ Schwebel $3^{\text {rd }}$ Report, supra n 4, at p 190, para 518. The Special Rapporteur explained that 'while the creation and management of [national or international parks where the wildlife and scenery are removed from the operation of ordinary legislation and are reserved, under special regimes, for controlled, limited use as preserves] is a widely accepted practice of States, the protective designation of a watercourse as a wild or scenic river is a relatively recent extension of the conservation movement'. It is further commented, in para 521 that 'Unspoiled and unmarred rivers have become as much as an endangered species [for] an untouched land that gives beauty and pleasure ... [and forms a part of our heritage]'.

${ }^{58}$ Schwebel $3^{\text {rd }}$ Report, supra $\mathrm{n} 4$, at p 123, para 247.

${ }^{59}$ UN, 'The Future We Want' (Rio+20 United Nations Conference on Sustainable Development, Rio de Janeiro, Brazil, 20 -22 June 2012) (19 June 2012, reissued 22 June 2012) UN Doc A/CONF/206/L.1, at para 122 <http://www.stakeholderforum.org/fileadmin/files/FWWEnglish.pdf> accessed 21 July 2012 (hereinafter: 'The Future We Want').
} 
protect and preserve the ecosystems of international watercourses' (author's emphasis). ${ }^{60}$ Only then, and where appropriate shall these watercourse states 'jointly protect and preserve' these ecosystems. ${ }^{61}$

The codification of the obligation to preserve in the 1997 Watercourses Convention gave explicit recognition to the fact that environmental protection in the context of watercourse systems goes beyond the quality of water and the treatment of water pollution. ${ }^{62}$ It includes the effects on wildlife and the flora of the area reached by water, and the impacts on the genetic resources and biotic potentials of the region. ${ }^{63}$

Article 20 was located in Chapter IV of the 1997 Watercourses Convention that deals with the protection, preservation and management aspect of non-navigational uses of international watercourses. It found its way into the 1997 Watercourses Convention as a reflection of the conviction of parties for a framework convention that ensure not only the utilisation and development of international watercourses, but also their conservation, management and protection to ensure optimal and sustainable utilisation. ${ }^{64}$ The obligation to preserve is an unusual aspect of environmental protection that has gradually generated international legal recognition, and will likely gain broader recognition in the governance and management of international or other transboundary watercourses in the immediate future. ${ }^{65}$

In light of the development of the ecosystem approach in the scientific community and its increased recognition by the legal community, the most identifiable provision under the 1997 Watercourses Convention for the maintenance of the ecosystem integrity of international watercourses is found in Article 20. The obligation set forth under Article 20 for the protection and preservation of the ecosystems of international watercourses suggested that the state parties agreed to adopt an ecosystem-oriented approach in the protection of the watercourses environment.

\footnotetext{
601997 Watercourses Convention, supra n 35, Art 20.

611997 Watercourses Convention, supra n 35, Art 20.

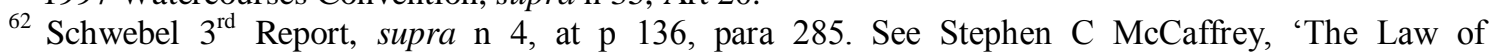
International Watercourses: Some Recent Development and Unanswered Questions' (1989) 17 Denver Journal of International Law and Policy 505, at p 514. The author opined that environmental protection and preservation goes further than the 'no appreciable harm' rule even when no transboundary harm is caused by pollution to other States.

${ }^{63}$ Schwebel $3^{\text {rd }}$ Report, supra $\mathrm{n} 4$, at p 136, para 285.

${ }^{64} 1997$ Watercourses Convention, supra n 35, Preamble.

${ }^{65}$ Schwebel $3^{\text {rd }}$ Report, supra n 4, at p 190, para 517.
} 
The ILC traced the precedent of Article 20, from the initial imposition of an obligation to protect the environment, to the recent recognition of an ecosystem approach in the practice of states and international organisations. ${ }^{66}$ In particular, the 1992 Helsinki Convention gave explicit recognition to the adoption of an ecosystem approach in Article 3(1)(i). The parties are required to 'develop, adopt, implement and, as far as possible, render compatible relevant legal, administrative, economic, financial and technical measures, in order to ensure that ... sustainable water-resources management, including the application of the ecosystems approach, is promoted' for the prevention, control and reduction of transboundary impact. ${ }^{67}$

Robust development in the operationalisation of an ecosystem approach is undertaken by the UNECE within the treaty regime of the 1992 Helsinki Convention, evidenced in the development of guidelines on the application of the ecosystem approach in water

${ }^{66} 1994$ Draft Articles and Commentaries, supra n 44, at p 119, para 5 et seq. International instruments concluded by states concerning the protection of the ecosystems of international watercourses, cited as example in para 6, include, the 1975 Statute of the Uruguay River; 1978 Convention Relating to the Status of the River Gambia; the 1963 Act Regarding Navigation and Economic Cooperation between the States of the Niger Basin; the 1978 Agreement on Great Lakes Water Quality between Canada and the United States. Early instruments are cited in para 7, including 1863 Final Act on the Delimitation of the International Frontier of the Pyrenees between France and Spain; 1887 Convention between Switzerland and the Grand Duchy of Baden and Alsace-Lorraine; 1906 Convention between Switzerland and Italy Establishing Provisions in Respect of Fishing in Frontier Waters; 1904 Convention between the French Republic and the Swiss Confederation for the Regulation of Fishing in Frontier Waters; 1958 Treaty between the Soviet Union and Afghanistan Concerning the Regime of the Soviet-Afghan State Frontier; and the 1956 Convention concerning the Canalisation of the Moselle between the Federal Republic of Germany, France and Luxembourg. The works of international organisations that recognises the need to protect and preserve ecosystems of international watercourses, listed in para 8, are the Act of Asunció adopted by the $4^{\text {th }}$ Meeting of Foreign Ministers of the River Plate Basin States in 1971; and the United Nations Water Conference held at Mar del Plata in 1977. Para 9 cited other non-international watercourses instruments that address the protection and preservation of environment, and nonwatercourses ecosystems in general, such as African Convention on the Conservation of Nature and Natural Resources; 1985 ASEAN Agreement on the Conservation of Nature and Natural Resources; United Nations Convention on the Law of the Sea; Convention for Cooperation in the Protection and Development of the Marine and Coastal Environment of the West and Central African Region; the Convention for the Prevention of Marine Pollution from Land-based Sources; Convention on the Protection of the Marine Environment of the Baltic Sea Area; Convention for the Protection of the Mediterranean Sea Against Pollution and its Protocol of 1980; and the Kuwait Regional Convention for Cooperation on the Protection of the Marine Environment from Pollution.

${ }^{67}$ Art 3(1)(i), Convention on the Protection and Use of Transboundary Watercourses and International Lakes (done at Helsinki, 17 March 1992) (hereinafter: '1992 Helsinki Convention'). At the time of the revision of this thesis, the 1992 Helsinki Convention, initially negotiated as a regional instrument, has turned into a global legal framework for transboundary water cooperation by virtue of the entry into force of the 2003 amendment on 6 February 2013 that allows accession by all the United Nations Member States. It is expected that non-ECE countries will be able to join the Convention as of end of 2013. See UNECE, 'The UNECE Water Convention, Helsinki, 17 March 1992' (undated) <http://www.unece.org/env/water/> accessed 10 February 2013. See UNECE, 'Amendment to Articles 25 and 26 of the Convention' (Meeting of the Parties to the Convention on the Protection and Use of Transboundary Watercourses and International Lakes, 12 January 2004) ECE/MP.WAT/14 <http://www.unece.org/fileadmin/DAM/env/documents/2004/wat/ece.mp.wat.14.e.pdf $>$ accessed 10 February 2013. 
management in $1993 .{ }^{68}$ In particular, the 1993 UNECE guidelines recommend policies and strategies that aim at 'furthering all measures and behaviours to maintain and improve conditions and functions of aquatic ecosystems including the conservation of aquatic biotic communities and the rehabilitation of damaged ecosystem components' ${ }^{69}$

The working group of the 1992 Helsinki Convention has drafted Recommendations on Payments for Ecosystem Services in Integrated Water Resources Management to facilitate the internalisation of environmental costs and benefits in decision making through the recognition of the true value of services supplied by water-related ecosystems in the form of payments for ecosystem services (PES). ${ }^{70}$ The recent adoption of the Guide to Implementing the 1992 Helsinki Convention by the parties to the Convention demonstrates the commitment of parties to conserve ecosystems via an ecosystem approach. $^{71}$

Despite a plurality of sources of law ${ }^{72}$ concerning watercourses' utilisation and protection due to the $a d$ hoc and sectoral nature of this legal order, ${ }^{73}$ there seems to be an emerging 'structurisation' ${ }^{74}$ of international water law. The concept of 'the

${ }^{68}$ UNECE, 'Part One Guidelines on the Ecosystem Approach in Water Management' (December 1993) ECE/ENVWA/31

$<$ http://www.unece.org/fileadmin/DAM/env/water/publications/documents/Library/Old_documents_foun d_library/ECE_ENVWA_31_eng.pdf> accessed 10 February 2013.

${ }^{69}$ UNECE, 'Part One Guidelines on the Ecosystem Approach in Water Management', supra $\mathrm{n}$ 68, at $\mathrm{p} 1$, para (a).

${ }^{70}$ Foreword by Marek Belka, at p iii. UNECE, 'Recommendations on Payments for Ecosystem Services in Integrated Water Resources Management' (United Nations, New York and Geneva, 2007) $<$ http://www.unece.org/fileadmin/DAM/env/water/publications/documents/PES_Recommendations_web. pdf $>$ accessed 10 February 2013.

${ }^{71}$ UNECE, 'Integrated Management of Water and Related Ecosystems. Draft Guide to Implementing the Convention' (Draft Guide by the Chairperson of the Legal Board, Meeting of the Parties to the Convention on the Protection and Use of Transboundary Watercourses and International Lakes, Fifth Session, Geneva, 10 - 12 November 2009) ECE/MP.WAT/2009/L.2 (31 August 2009) $<$ http://www.unece.org/fileadmin/DAM/env/documents/2009/Wat/MOP5/ECE.MP.WAT.2009.L.2_EN.p df $>$ accessed 10 February 2013 (hereinafter 'Guide to Implementing the 1992 Helsinki Convention').

$\overline{72}$ For a discussion on plurality of sources of law, and its subtle difference with legal pluralism, see William Twinning, 'Normative and Legal Pluralism: A Global Perspective' (Seventh Annual Herbert L Bernstein Memorial Lecture in International and Comparative Law, Duke University School of Law 7 April 2009) at p 487 <http://scholarshiplaw.duke.edu/cgi/viewcontent.cgi?article=1049\&context=dicil> accessed 1 November 2012. See also Baudouin Dupret, 'Legal Pluralism, Plurality of Laws, and Legal Practices: Theories, Critiques, and Praxiological Re-specification', European Journal of Legal Studies: Issue 1 (An Open Access Initiative by EUI Legal Researchers) < http://halshs.archivesouvertes.fr/docs/00/17/84/22/PDF/2007EjlsLegPlur.pdf> accessed 1 November 2012.

${ }^{73}$ The sectoral nature of the legal order of international water law, which explains the plurality of sources of international water law, is found in the form of a multitude of bilateral, basin-wide or regional agreements on transboundary watercourses. Castro labelled the fragmented nature of international water law as normative bric- à-brac. See Paulo Canelas De Castro, The Future of International Water Law (Luso-American Foundation, Shared Water Systems and Transboundary Issues, with Special Emphasis on the Iberian Peninsula, Lisbon, Portugal, 2000) (hereinafter: 'Castro, The Future of IWL') at p 158.

${ }^{74}$ Castro, The Future of IWL, supra $\mathrm{n} 73$, at $\mathrm{p} 158$, para (e). 
fundamental continuity of the legal universe ${ }^{75}$ prevails where the normative bric-à-brac is starting to evolve into an emerging normative system akin to 'an eclectic regulatory continuum ... secured by principles that are common to other segments of the international law of natural resources and the environment'. ${ }^{76}$

Schwebel argued that the normative principle of environmental protection in international water law is 'born of sharpened awareness of the vast ramifications consequence upon man's tampering with the intricate relationships among the elements and agents of nature', ${ }^{77}$ which makes the protection of the environment a universal duty. ${ }^{78}$ Apart from committing themselves to the protection of freshwater ecosystems from pollution, the state parties did not contest the incorporation of the obligation to preserve pristine ecosystems of international watercourses.

Article 20 re-affirmed the position of the international community through the recognition that there is an obligation to preserve the natural state of the environment against degradation as part of the effort to protect the ecosystem integrity of international watercourses in accordance with the ecosystem approach. ${ }^{79}$ The current development of the obligation to preserve since its codification in the 1997 Watercourses Convention can be seen in the discussion of the Pulp Mills' case in the next section.

${ }^{75}$ Castro, The Future of IWL, supra $\mathrm{n} 73$, at p158, para (d),

${ }^{76}$ Castro, The Future of IWL, supra $\mathrm{n} 73$, at $\mathrm{p} 158$.

${ }^{77}$ Schwebel $3{ }^{\text {rd }}$ Report, supra n 4, at p 123, para 246

781994 Draft Articles and Commentaries, supra n 44, at pp $120-121$, para 8 . The protection of 'essential ecological processes' is not novel and is evidenced in a number of declarations and resolutions concerning the preservation of the environment. This position can be seen in several instruments and work of international organisations, conferences and meetings concerning the protection and preservation of the ecosystems of international watercourses.

${ }^{79}$ For more, see Charles Odidi Okidi, " "Preservation and Protection" Under the 1991 ILC Draft Articles on the Law of International Watercourses' (1992) 3 Colorado Journal International Environmental Law and Policy 143- 174; Iris M Korhonen, 'Riverine Ecosystems in International Law' (1996) 36 Natural Resources Journal 481 - 519; Brunnée and Toope, 'Environmental Security and Freshwater Resources: Ecosystem Regime Building' supra n 3; Stephen C McCaffrey, The Law of International Watercourses ( $2^{\text {nd }}$ edn, Oxford University Press, Oxford, 2007) at pp 381 - 396; Joseph W Dellapenna, 'Foreword: Bringing the Customary International Law of Transboundary Waters into the Era of Ecology' (2001) 1 International Journal of Global Environmental Issues 243 - 249; Tanzi and Arcari, The United Nations Convention on the Law of International Watercourses. A Framework for Sharing, supra $\mathrm{n}$ 48; Owen McIntyre, "The Emergence of an "Ecosystem Approach" to the Protection of International Watercourses under International Law' (2004) 13 Review of European Community and International Environmental Law 1 - 14; Alistair S Rieu-Clarke, Patricia Wouters, Flavia Loures, 'The Role and Relevance of the UN Convention on the Law of the Non-Navigational Uses of International Watercourses to the EU and Its Member States' (UNESCO Centre for Water Law, Policy and Science, undated) 〈http://www.internationalwaterlaw.org/bibliography/WWF/RA_European_Union.pdf> accessed 25 October 2010. 


\subsubsection{Current State of Environmental Protection in International Water Law: An Analysis of the Pulp Mills' case}

The recent Pulp Mills' case ${ }^{80}$ illustrates the development of international water law on the obligation to protect the environment through the adjudication of the bilateral 1975 River Uruguay Treaty. The dispute is important in the context of the environmental protection of watercourses, especially the obligation to protect and preserve the riverine or freshwater ecosystem. This obligation to preserve is implicit in the assessment of whether the Parties complied with Articles 35, 36 and 41 of the River Uruguay Statute.

Article 35 exhibits the most explicit recognition of the ecosystem approach where the River Uruguay Statute acknowledges the interdependence and impact of terrestrial ecosystems and land-use activities on the 'regime of the river' and water quality. A breach of Article 35 required evidentiary support that a 'deleterious relationship' existed between the major eucalyptus planting operations and the quality of the water of the river, of which the Court concluded that 'Argentina has not established its contention on this matter' ${ }^{81}$ However, it is important to note that the application of the ecosystem approach in Article 35 strengthens the emergence of this approach in international water law.

The obligation to protect the environment against pollution, which includes the obligation to preserve, is further strengthened through the imposition of the obligation to coordinate through the Administrative Commission of the River Uruguay (CARU). ${ }^{82}$ The promulgation of standards by CARU through Sections E3 and E4 of the CARU Digest, developed in accordance with Articles 36, 37, 38, and 39, aimed to 'protect and preserve the water and its ecological balance'. ${ }^{83}$ The Court gave explicit recognition to the importance of the obligation to preserve where it enunciated that -

\footnotetext{
${ }^{80}$ Pulp Mills' case, supra n 1, at para 65.

${ }^{81}$ Pulp Mills' case, supra n 1, at p 54, paras 180 and 185.

${ }^{82}$ Pulp Mills' case, supra $\mathrm{n} 1$, at p 55, para 183.

${ }^{83}$ Pulp Mills' case, supra n 1, at p 55, para 184. Owen McIntyre, 'The Proceduralisation and Growing Maturity of International Water Law. Case Concerning Pulp Mills on the River Uruguay (Argentina v. Uruguay), ICJ, 20 April 2010' [2010] 22(3) Journal of Environmental Law 475 - 497. At p 480, the author reflects that the 'due diligence nature of the substantive obligations contained [in the obligation to prevent transboundary harm in Art 7 of the 1997 Watercourses Convention] requires that this obligation must be made normatively operational by means of a number of procedural requirements'. The concept of due diligence in the implementation of the substantive obligations of the 1997 Watercourses Convention will be further elaborated in Chapter Seven. Tanzi and Arcari, The United Nations Convention on the Law of International Watercourses. A Framework for Sharing, supra n 48, at pp 152, 154 and 246. At p 246, Arcari remarked on the standard of responsibility involved in the obligation to protect and preserve the
} 
'This vigilance and prevention [to exercise due diligence in acting through the Commission for the necessary measures to preserve the ecological balance of the river] is all the more important in the preservation of the ecological balance, since the negative impact of human activities on the waters of the river may affect other components of the ecosystem of the watercourse such as its flora, fauna, and soil'. ${ }^{84}$

Apart from an implicit acknowledgement of the need to preserve the water of River Uruguay and its ecological balance in light of the recognition of the ecosystem approach, the obligation to preserve is implicit in Article 41 of the River Uruguay Statute. ${ }^{85}$ The Court opined that the parties have a duty to protect the fauna and flora of the river 'as part of their obligation to preserve the aquatic environment'. ${ }^{86}$ Moreover, the Court highlighted the need for an integrated approach in the interpretation of Article 41. It is of the opinion that -

'the rules and measures which they have to adopt under Article 41 should also reflect their international undertakings in respect of biodiversity and habitat protection, in addition to the other standards on water quality and discharges of effluent' ${ }^{87}$

The adjudication of the compliance of Uruguay with its obligations under Articles 35, 36, and 41 contributes towards the development of the normative content of the obligation to protect the environment. The application of an ecosystem approach highlighted the importance to preserve the ecological balance of the water of River Uruguay. The jurisprudence that develops as a result of the Court's assessment of whether the operation of the pulp mills contravenes these Articles strengthens the normativity of the obligation to preserve the aquatic ecosystems of River Uruguay.

ecosystems of international watercourses that 'Although no express indication is provided either in Art 20, or in the relevant ILC commentary, it may be excluded that this obligation is one of an absolute character. As pointed out by McCaffrey, this is rather an obligation to exercise due diligence to protect and preserve river ecosystems. This conclusion is corroborated by a passage of the 1994 Draft Articles and Commentaries to draft Article 21(2) according to which: as with the obligation to "protect" ecosystem under Article 20, the obligation to prevent pollution that may cause significant harm includes the duty to exercise due diligence to prevent the threat of such harm'.

${ }^{84}$ Pulp Mills' case, supra n 1, at p 56, paras $187-188$.

${ }^{85}$ Pulp Mills' case, supra n 1, at pp 56-75, paras 190 - 266, especially para 195.

${ }^{86}$ Pulp Mills' case, supra n 1, at p 74, para 262.

${ }^{87}$ Pulp Mills' case, supra n 1, at p 74, para 262 
Such development at the bilateral level contributes toward the emergence of the obligation to protect the environment of international watercourses in general through the structurisation of international water law. In particularly, the explicit reference to the need to preserve aquatic ecosystem of international watercourses emphasises the significance and importance of not just the protection, but also the preservation of ecosystems of international watercourses. ${ }^{88}$ The Court enunciated the need to interpret the 1975 River Uruguay Statute in accordance with Article 31(3)(c) of the 1969 Vienna Convention, where measures adopted under Article 41 should 'reflect their international undertakings in respect of biodiversity and habitat protection'. ${ }^{89}$ However, it has decisively rejected the contention submitted by Argentina, that it should take into account recent developments in international law on biodiversity and habitat protection for the adjudication of Uruguay's compliance with Article 41 of the River Uruguay Statute. $^{90}$

The Pulp Mills' case is not only important in the illustration of the emergence of the obligation of environmental protection of international watercourses, it is instrumental in indicating the need for an integrated approach in the interpretation and application of the obligation stipulated under the 1975 Statute. The problem of fragmentation in terms of the existence of multiple regimes relevant to the dispute at hand paves the foundation for the operationalisation of Article 31(3)(c) of the Vienna Convention. ${ }^{91}$ This Article is deemed to express the principle of systemic integration, and has the potential to inform the interpretation of a treaty provision in the light of the multiplicity of treaties addressing the same subject matter.

\footnotetext{
${ }^{88}$ The Court explicitly stated that 'as part of their obligation to preserve the aquatic environment, the Parties have a duty to protect the fauna and flora of the river. The rules and measures which they have to adopt under Article 41 should also reflect their international undertakings in respect of biodiversity and habitat protection, in addition to the other standards on water quality and discharges of effluent'. Pulp Mills' case, supra n 1, at p 74, para 262.

${ }^{89}$ Pulp Mills' case, supra $\mathrm{n} 1$, at p 74, para 262.

${ }^{90}$ Pulp Mills' case, supra n 1, at pp 29 - 30, paras $64-66$. At p 30, para 66, the Court concluded that the rules of general international law or contained in multilateral conventions to which the two States are parties, nevertheless has no bearing on the scope of the jurisdiction conferred on the Court under Article 60 of the 1975 Statute, which remains confined to disputes concerning the interpretation or application of the Statute'.

${ }^{91}$ This issue is dealt with more specifically in the subsequent Section 1.4 of this thesis.
} 
The complications due to the fragmentation of international law as a result of the multiplication of multilateral environmental treaties will be addressed below via the discourse on fragmentation of international law. ${ }^{92}$

\subsection{Problématique: Fragmentation of International Law}

The rise of new and special types of law, known as 'self-contained regimes" ${ }^{93}$ and geographically or functionally limited treaty-systems, ${ }^{94}$ known as 'functional differentiation" ${ }^{95}$ developed as distinctive bodies of law armed with their own respective principles and institutions peculiar to that particular regime. ${ }^{96}$ The emergence of 'specialised and relatively autonomous spheres of social action and structure' ${ }^{97}$ due to their extensive expansion in an uncoordinated fashion and their problem-solving orientation leads to the fragmentation of international law. The phenomena of increased legal pluralism leading to the creation of competing multi-sourced equivalent norms regulating the same situation or fact presents another facet of fragmentation. ${ }^{98}$

Although the fragmented state of international law, leading to increased normative density and intensity in international relations ${ }^{99}$ is part of the process of globalisation, ${ }^{100}$

92 The issue of fragmentation and the need for an integrated approach in the interpretation of the obligation to protect the environment as highlighted in the Pulp Mills' case will be further developed in Section 1.4 of this chapter.

${ }^{93}$ Examples of self-contained regimes are the environmental regime, trade regime or a natural resource regime.

${ }^{94}$ Regimes seen as geographically or functionally limited include treaty regimes that are applicable to a certain river basin, or part of it; or certain region, such as the United Nations Economic Council of Europe (UNECE); or for the utilisation of watercourses, human rights, the wetlands, the forests, the biological diversity, components of the environment or the climate etc.

${ }_{95}^{95}$ Fragmentation Report, supra n 17, at para 204

${ }^{96}$ Fragmentation Report, supra n 17, at p 22, para 31. See Alexander Orakhelashvili, 'The Interaction between Human Rights and Humanitarian Law: Fragmentation, Conflict, Parallelism, or Convergence?' (2008) 19(1) The European Journal of International Law 161 - 182, at p 162. These separate systems includes 'trade law', 'human rights law', 'environmental law', 'law of the sea', 'European law', 'investment law', and 'international refugee law'. Fragmentation Report, supra n 17, at p 11, para 8. See also UNGA 'Report of the International Law Commission of Its Fifty-fourth Session (29 April - 7 June and 22 July - 16 August 2002)' UN GAOR 57 ${ }^{\text {th }}$ Session Supp No 10 UN Doc A/57/10, at paras $492-494$. UNGA, 'Fragmentation of International Law: Difficulties Arising from the Diversification and Expansion of International Law' (Report of the Study Group of the International Law Commission, Fifty-Eighth Session, Geneva, 1 May - 9 June and 3 July - 11 August 2006) A/CN.4/L.702 (18 July 2006) (hereafter: 'Report of ILC') at $\mathrm{p} 1$, para 1.

${ }^{97}$ Report of ILC, supra $\mathrm{n} 96$, at para5.

${ }^{98}$ Miguel Poiares Maduro, 'Foreword', in Tomer Broude and Yuval Shany, Multi-Sourced Equivalent Norms in International Law (Hart Publishing, Oxford and Portland, Oregon, 2011), at p vii. The author further stated that the multiplication of legal regimes and adjudication fora, conflicting jurisdictions among different legal orders that generate interpretative competition and adjudication giving rise to possible externalities, are constructed as being the origin of fragmentation in international law.

99 Yuval Shany, 'The First MOX Plant Award: The Need to Harmonize Competing Environmental Regimes and Dispute Settlement Procedures', (2004) 17 Leiden Journal of International Law 815 - 827 , at $\mathrm{p}$ 823. Yuval Shany and Tomer Broude, 'The International Law and Policy of Multi-Sourced 
it embeds a latent risk. There is a danger in the creation of "conflicting and incompatible rules, principles, rule-systems and institutional practices' ${ }^{101}$ despite the positive implications resulting from the "pluralisation and expansion of international lawmaking'. ${ }^{102}$ Such a development entails several theoretical and practical challenges in law and legal policy, and leads to more problems than solutions. ${ }^{103}$ It is capable of undermining the coherence and uniformity of international law, ${ }^{104}$ and thus justifies the need to provide a framework 'through which the fragmentation may be assessed and managed in a legal professional way'. ${ }^{105}$

The successful conclusion of a large number of international environmental instruments ${ }^{106}$ that sought to address various environmental problems leads to the

Equivalent Norms' pp $1-15$ in Shany and Broude (eds) Multi-Sourced Equivalent Norms in International Law, supra $\mathrm{n} 98$, at $\mathrm{p} 3$.

${ }^{100}$ Joost Pauwelyn, Conflict of Norms in Public International Law (Cambridge Studies in International and Comparative Law, Cambridge University Press, Cambridge, 2003) at pp 19 - 20.

${ }^{101}$ Report of ILC, supra n 96, at p 5, para 9.

102 José E Alvarez, 'The New Treaty Makers' (Keynote Address in a Symposium at Boston College law School, given in honour of Professor Cynthia Lichtenstein, 2 November 2001) 〈http://www.bc.edu/dam/files/schools/law/lawreviews/journals/bciclr/25_2/03_FMS.htm> accessed 24 August 2012. The pluralisation and expansion of international law-making has positive implications in light of the 'ever-rising movements of people, goods, and capital across borders' and to regulate the 'positive and negative externalities, [especially the threat to the global commons], that arises from such a flow'.

${ }^{103}$ Shany and Broude (ed) Multi-Sourced Equivalent Norms in International Law, supra n 98, at pp 3 - 4. See also Shany, 'The First MOX Plant Award', supra n 99, at p 823.

${ }^{104}$ Report of ILC, supra n 96, at p 5. See also Pauwelyn, Conflict of Norms in Public International Law, supra $\mathrm{n}$ 100. Interestingly, Margaret A Young commented in her article, 'Fragmentation or Interaction: the WTO, Fisheries Subsidies, and International Law' (2009) 8 World Trade Review 477 - 515 that there is a need for "greater analysis of the notion and operation of "regimes"... there is much scope for international lawyers to contribute understanding and ideas about collaboration and cohesion in rule making within regimes as there is a focus on ex post rules determining priority in later disputes'. At p 481, it stated that 'an analysis of regime interplay during rule making may even contribute to a different understanding of conflicting norms and of the way regimes interact after rules are made'. Report of ILC, supra $\mathrm{n}$ 96, at $\mathrm{p} 3$ recognised that the expansion in international legal regulation has been accompanied by the emergence of specialised rules, legal institutions and (semi)-autonomous field of operations, inter alia, 'environmental law', 'law of the sea' (and probably, international law on shared watercourses). The ILC, at $\mathrm{p} 4$ recognised at the outset that fragmentation does raise both institutional and substantive problems. It is noted in Jörg Kammerhofer, 'Systemic Integration, Legal Theory and the ILC' (2008) 19 Finnish Yearbook of International Law 157 - 182; 〈http://papers.ssrn.com/sol3/papers.cfm?abstract_id=1534086> (29 November 2009), at p 174 that: 'In taking up the topic of "fragmentation of international law", the ILC has forayed into the realm of legal theory. The questions to be discussed were the relationship of norms in a legal system and the cognition of legal norms'.

${ }^{105}$ Report of ILC, supra n 96, at p 6, para 12.

${ }^{106}$ Harro van Asselt, 'Managing the Fragmentation of International Environmental Law: Forests at the Intersection of the Climate and Biodiversity Regimes' (2012) 44 International Law and Politics 1205 1278, at p 1208. The International Environmental Agreements (IEA) Database Project revealed, in the Annual Count of Agreements in the IEA Database, the numbers of Multilateral Environmental Agreements from 1950 to 2012 amounts to a total of 1077 treaties. Ronald B Mitchell, 'Annual Count of Agreements in the IEA Database. Multilateral Environmental Agreements 1950 - 2012' (2002 - 2012) <http://iea.uoregon.edu/page.php?query=summarize by year\&yearstart=1950\&yearend=2012\&inclusion =MEA $>$ accessed 2 November 2012. See Data from Ronald B Mitchell, 'International Environmental 
expansion of international law on the environment. The limited resources and capacity of the international community shadow the positive implication of such diversification of international law, where the problem of treaty congestion leads to operational inefficiency. ${ }^{107}$ The lack of cooperation on the issues of environment and sustainable development, despite the successful establishment of a modern international environmental law regime is most pronounced in the failure of Rio+5. ${ }^{108}$

The need for reform was clearly enunciated by the Secretary-General of the United Nations (UN) who commented that 'a major challenge to policy-makers is to develop a more integrated approach, identifying the natural synergies between different aspects of our environment and exploring the potential for more effective policy coordination'. ${ }^{109}$ A comprehensive approach that harmonises international rights and obligations regulating the same subject matter is necessary, and it would better serve the coherence, effectiveness and perceived legitimacy of international law. ${ }^{110}$

This section will explore the phenomenon of the fragmentation of international law through three perspectives: (1) The approach adopted by international courts and tribunals; (2) The phenomenon of fragmentation through the lens of treaty congestion; and (3) The interaction of treaty regimes due to fragmentation of international law, which results in treaty congestion.

Agreements Database Project (Version 2012.1)' (2002-2012) 〈http://iea.uoregon.edu/> accessed 2 November 2012.

${ }^{107}$ Edith Brown-Weiss, 'International Environmental Law: Contemporary Issues and the Emergence of a New World Order', (1993) 81 Georgetown Law Journal 675 - 710, at pp 697 - 702. Donald K Anton, "'Treaty Congestion" in Contemporary International Environmental Law' pp 651 - 665, in Shawkat Alam, Md Jahid Hossain Bhuiyan, Tareq MR Chowdhury and Erika J Techera (eds) Routledge Handbook of International Environmental Law (Routledge, London and New York, 2013) at pp 653 - 657. This point will be taken further in Section 1.2.2 of this Chapter.

${ }^{108} \mathrm{~W}$ Bradnee Chambers, Interlinkages and the Effectiveness of Multilateral Environmental Agreements (United Nations University Press, Tokyo, 2008) at p 3. The author commented that 'by 1997, the failure of Rio+5 [which refers to the Fifth Anniversary of the United Nations Conference on Environment and Development held in Rio de Janeiro, Brazil, 1992] showed the ugly side of the lack of cooperation on issues of environment and sustainable development'.

${ }^{109}$ Quoted in Chambers, Interlinkages and the Effectiveness of Multilateral Environmental Agreements, supra $\mathrm{n}$ 108, at $\mathrm{p} 3$. Kofi Annan, the United Nations Secretary-General gave a speech on the occasion of the 1999 UNU Conference on Synergies and Coordination among Multilateral Environmental Agreements, which is on file with the author.

${ }^{110}$ Shany, 'The First MOX Plant Award', supra n 99, at p 823. 


\subsubsection{Jurisprudence of International Courts and Tribunals}

Although the jurisdiction of the International Court of Justice (ICJ) is sometimes 'infuriatingly transactional' 111 in nature, it is extremely important to observe the convergence of jurisprudence on the adjudication of environmental litigation. It is important for the determination of the normative strength of environmental protection in international law, be it international environmental law, or international watercourses law, of which their "categorisation is in some cases a matter only of choice and perspective'. ${ }^{112}$ Thus, it is increasingly important that the resolution of international environmental problems, however categorised, 'entails the application of international law as a whole, in an integrated manner'. ${ }^{113}$

The MOX plant ${ }^{114}$ and the Bluefin Tuna ${ }^{115}$ disputes demonstrated the difficulties that arise due to the parallelism of treaties and the multiple but coexisting international judicial fora with overlapping jurisdiction. As each regime is constituted by its own "principles, its own form of expertise and its own "ethos", 116 that is not all the time similar to the other regimes, the jurisprudence of each specialisation will naturally diverge from each other in their aim to attain their own respective, specific objectives, seen from their respective perspective of specialisation. This outcome is apparent in the

\footnotetext{
${ }^{111}$ See Bruno Simma, 'Universality of International Law from the Perspective of a Practitioner', (2009) 20 European Journal of International Law 265 - 297.

${ }^{112}$ See Patricia Birnie, Alan Boyle and Catherine Redgwell, International Law and the Environment, $\left(3^{\text {rd }}\right.$ edn, Oxford University Press, Oxford 2009) at p 3. The authors, at pp $2-3$ elaborated that 'the expression "international environmental law" is thus used simply as a convenient way to encompass the entire corpus of international law, public and private, relevant to environmental problems ... Used in this sense, "international environmental law" is of course different from international human-rights law, the law of the sea, natural resources law, or international economic law, inter alia, but there are significant overlaps and interactions with these categories, and the categorization is in some cases a matter only of choice and perspective'.

${ }^{113}$ See Birnie, Boyle and Redgwell, International Law and the Environment, supra n 112, pp 2 - 4.

114 The Mixed Oxide Fuel (MOX) Plant dispute arises under three substantive conventional regimes that resulted in jurisdictional overlap, of the United Nations Convention on the Law of the Sea (UNCLOS); The Convention for the Protection of the Marine Environment of the North-East Atlantic (OSPAR) and the Treaty establishing the European Community. See Volker Röben, 'The Order of the UNCLOS Annex VII Arbitral Tribunal to Suspend Proceedings in the Case of the MOX Plant at Sellafield: How Much Jurisdictional Subsidiarity' (2004) 73 Nordic Journal of International Law 223 - 245, at p 223.

${ }^{115}$ Cesare Romano, 'The Southern Bluefin Tuna Dispute: Hints of a World to Come ... Like It or Not' (2001) 32 Ocean Development and International Law 313 - 348. At p 317, Cesare noted that the dispute on the unilateral actions of Japan could be brought to at least three fora: an ad hoc Arbitral Tribunal constituted under Art 16 of the 1993 Convention, the International Court of Justice (ICJ), or the dispute settlement procedures of the UNCLOS.

${ }^{116}$ Report of ILC, supra n 96, para 10. See also Martti Koskenniemi, 'International Law: Between Fragmentation and Constitutionalism' (Paper presented at the Australia National University, Canberra, 27 November 2006) <http://www.helsinki.fi/eci/Publications/Koskenniemi/MCanberra-06c.pdf > accessed 9 November 2012.
} 
trade and environment conundrum, where the aspiration for consistency in the WTO regime is sought at the cost of the consistency of international law. ${ }^{117}$

There is an inclination towards a normative harmonisation in the construction of substantive provisions applied by specialised international tribunals and courts in their decisions ${ }^{118}$ in light of all relevant international norms on the matter in accordance with Article 31(3)(c) of the 1969 Vienna Convention. ${ }^{119}$ Indeed, a harmonious approach should be adopted in order to sustain the coherence of international law and reduce the tensions associated with special regimes.

The Bluefin Tuna arbitral tribunal award in $2000{ }^{120}$ and the arbitral panel in the UNCLOS MOX Plant case in June 2003, ${ }^{121}$ evidenced the favourable inclination of the

\footnotetext{
${ }^{117}$ Koskenniemi, 'International Law: Between Fragmentation and Constitutionalism', supra n 116, at p 6, para 11. This is seen in the case of WTO, EC - Measures Concerning Meat and Meat Products (Hormones) - Report of the Appellate Body (adopted 16 January 1998) WT/DS26/AB/R and WT/DS48/AB/R (hereinafter: 'EC - Hormones'). The Appellate Body (AB) found that 'It was unnecessary, and probably imprudent to take a position on the important, but abstract question of whether the precautionary principle constitutes customary international law whereby the status of the precautionary principle beyond the field of international environmental law, still "awaits authoritative formulation"". The $\mathrm{AB}$ concluded that the status of the precautionary principle gained in the environmental sphere is not binding on the WTO is the ultimate illustration of the existence of these separate 'boxes' that international law comes in, (at para 123). This approach is repeated in the case of WTO, European Communities: Measures Affecting the Approval and Marketing of Biotech Products Report of the Panel (29 September 2006) WT/DS291/R, WT/DS292/R, and WT/DS293/R (hereafter: 'EC - Biotech'). The Panel refused to adjudicate the dispute under the Cartagena Protocol on the ground that one of the Parties in dispute is not a party to the Protocol concerned.

118 These decisions include WTO, US - Standards for Reformulated and Conventional Gasoline - Report of the Appellate Body (29 April 1996) WT/DS2/AB/R (hereinafter: 'US - Gasoline') at p 621 where it is stated that: 'The General Agreement is not to be read in clinical isolation from public international law'; and the dissenting opinion of Mr. Gavan Griffith, PCA, Dispute Concerning Access to Information under Article 9 of the OSPAR Convention, (Ireland $v$ UK and Northern Ireland) (Final Award, 2 July 2003) < http://untreaty.un.org/cod/riaa/cases/vol_XXIII/59-151.pdf> accessed 4 March 2013 (hereinafter: 'OSPAR Proceeding') at p 73, para 23. Mr. Griffith argued that Art 9 should be construed in the light of the relevant EC directives and the case law of the ECJ regarding their application as: 'the ordinary principles of comity and interpretation may here be invoked to suggest that the same State parties broadly may be assumed to understand similarly or identically worded obligations in the same way'.

${ }^{119}$ See Philippe Sands, 'Treaty, Custom and the Cross-fertilization of International Law', (1998) 1 Yale Human Rights and Development Law Journal $85-105$.

120 Southern Bluefin Tuna case (Australia and New Zealand/Japan) (Award on Jurisdiction and Admissibility of 4 August 2000) (2004) XXIII UNRIAA 1 (hereinafter: 'Bluefin Tuna' case) <http://icsid.worldbank.org/ICSID/FrontServlet?requestType=ICSIDPublicationsRH\&actionVal=ViewA nnouncePDF\&AnnouncementType=archive\&AnnounceNo=7_10.pdf $>$ accessed 9 November 2012. It is cited at p 42, para 54 that: 'To find that, in this case, there is a dispute actually arising under UNCLOS which is distinct from the dispute that arose under the CCSBT [1993 Convention on the Conservation of Southern Bluefin Tuna] would be artificial'.

${ }^{121}$ PCA, Arbitral Tribunal Constituted Pursuant to Article 287, and Article 1 of Annex VII, of the United Nations Convention on the Law of the Sea for the Dispute concerning the MOX Plant, International Movements of Radioactive Materials, and the Protection of the Marine Environment of the Irish Sea (Ireland v United Kingdom) Order No 3 (24 June 2003) (hereinafter: 'UNCLOS MOX Plant' case). A compatible view was expressed by the Arbitral Tribunal constituted pursuant to Art 287, and Art 1 of Annex VII of UNCLOS. It is stated, at $\mathrm{p} \mathrm{8,} \mathrm{para} 26$ that: 'There is no certainty that any such provisions would in fact give rise to a self-contained and distinct dispute capable of being resolved by the Tribunal'.
} 
tribunals towards a harmonious construction of international conventions as a more acceptable method of regulating interaction between overlapping norms. ${ }^{122}$ The UNCLOS Tribunal in the MOX Plant case seemed to take cognisance of such systemic concerns and decided that a procedure that might result in two conflicting decisions on the same issue would not be helpful to the resolution of the dispute between the parties. $^{123}$

Despite the problems of coordination, the risk of incompatible decisions, and the damaging possibility of a 'procedural battle of injunctions' 124 between various international courts and tribunals addressing the same dispute, the self-contained regime approach taken by the World Trade Organisation (WTO) Dispute Settlement Bodies is echoed in several recent international tribunal decisions. ${ }^{125}$ The rejection of certain international courts and tribunals of adopting a system-sensitive harmonious approach neglects the risk generated by contemporaneous related proceedings, including unnecessary litigation, opening the door for manipulation of the international legal process, and inconsistent judicial decisions that threaten the coherency of the international legal order. ${ }^{126}$

In realisation of the complications that arise from conflicting jurisprudence, judicial bodies are increasingly urged to promote the integration and coordination between different legal orders through interpretation of rules of a particular international legal regime into another international legal regime. ${ }^{127}$

At an operational level, the administration of the obligations committed by parties will be encumbered by the conclusion of a multitude of treaty regimes. The fragmentation of international law on the environment, where each component of the environment, the management responses in addressing the problems and the feedback on environmental due to management intervention are interlinked, will result in normative overlap known as the phenomenon of treaty congestion. The next section will elaborate on the resulting

\footnotetext{
${ }^{122}$ Shany, 'The First MOX Plant Award', supra n 99, at p 824.

${ }^{123}$ UNCLOS MOX Plant, at p 9, para 28. See Shany, 'The First MOX Plant Award', supra n 99, at p 825.

124 Shany, 'The First MOX Plant Award', supra n 99, at p 825.

${ }^{125}$ See for example Czech Republic v. CME, SVEA Court of Appeals, (2003) 42 International Legal Materials 919, at pp 953 - 954. Thomas Wälde, 'Introductory Note to Svea Court of Appeals: Czech Republic v CME Czech Republic BV' (2003) 42 International Legal Materials 915.

${ }_{126}^{12}$ Shany, 'The First MOX Plant Award', supra n 99, at pp 826-827.

${ }^{127}$ Maduro, 'Foreword', supra n 98, at p viii.
} 
treaty congestion as in inevitable consequence of the proliferation of treaty regimes on subject matter relating to the environment.

\subsubsection{Treaty Congestion}

In light of the intricate connections between freshwater resources and the related component of the environment due to indivisible unitary nature of the environment, ${ }^{128}$ one may observe various interrelationships between the water law regime and the environmental law regimes. Complications arise when the international law on the environment is in a state of fragmentation ${ }^{129}$ and 'congestion', ${ }^{130}$ as a result of the proliferation of environmental treaties addressing the environment. Environmental treaties were concluded without taking into consideration the interconnectedness of all components of ecosystems and their relationships as a whole in the environment. ${ }^{131}$ Given these circumstances, it is not unusual to witness some degree of normative interaction and overlap that requires an integrated effort in terms of coordination and synergies on their interpretation and application.

The fragmentation of the international legal order had overlooked the need to attain uniformity and legal unity, ${ }^{132}$ and might bring about the dreaded 'erosion of

\footnotetext{
${ }^{128}$ Xue Hanqin, 'Commentary. Relativity in International Water Law' (1992) 3 Colorado Journal of International Environmental Law and Policy 45 - 57, at p 47.

${ }^{129}$ See further Chambers, Interlinkages and the Effectiveness of Multilateral Environmental Agreement, supra n 108; Tim Stephens, "Multiple International Courts and the "Fragmentation" of International Environmental Law' (Legal Studies Research Paper No. 07/14, Sydney Law School, The University of Sydney, March 2007); and Konrad von Moltke, Whither MEAs? The Role of International Environmental Management in the Trade and Environment Agenda (International Institute for Sustainable Development Canada, 2001).

${ }^{130}$ For problems caused by treaty congestion, see Edith Brown-Weiss, 'International Environmental Law: Contemporary Issues and the Emergence of a New World Order', supra n 107, at pp 697 - 702 . Harro van Asselt notes the phenomenon of treaty congestion in 'Managing the Fragmentation of International Environmental Law: Forests at the Intersection of the Climate and Biodiversity Regimes', supra n 106, at pp 1209 - 1210. The author reiterated the possible consequences that could be resulted from the treaty congestion in international environmental law due not only to the substantive incompatibilities among different environmental treaties, but also to the operational inefficiency being one of the key problems. See also the comments of Bethany Lukitsch Hicks, 'Treaty Congestion in International Environmental Law: The Need for Greater International Coordination' (1998-1999) 32 University of Richmond Law Review 1643 - 1675.

${ }^{131}$ There are rapid legal developments in the field of international environmental law, with approximately 900 treaties (binding and non-binding) that have provisions substantively addressing the environment. See Weiss, 'International Environmental Law' at p 679. Harro van Asselt, 'Managing the Fragmentation of International Environmental Law: Forests at the Intersection of the Climate and Biodiversity Regimes' (2012) 44 International Law and Politics 1205 - 1278, supra n 106, at p 1208. The author noted the emergence of environmental treaties in a piecemeal fashion led to a multiplication of multilateral, regional and bilateral treaties in the field, with some estimates of almost 3,000 environmental treaties adopted.

${ }^{132}$ See Joost Pauwelyn, 'Bridging Fragmentation and Unity: International Law as a Universe of InterConnected Islands' (2004) 25 Michigan Journal of International Law 903 - 916, at pp 915 - 916 . It is
} 
international law, emergence of conflicting jurisprudence and forum shopping that generally threaten legal security'. ${ }^{133}$ In order to seek an answer to the question on how different norms of international law interact with each other in situations, and what is to be expected in the event of conflict, the issue of management of the fragmented state of international law is increasingly important. ${ }^{134}$

However, the ILC is confident that legal techniques are able to resolve these conflicts posed by the existence of different specialised branches of law where it stated that -

'The very effort to canvass a coherent legal professional technique on a fragmented world expresses the conviction that conflicts between specialised regimes may be overcome by law. Even though the law may not go much further than to require a willingness to listen to others, [it will] take their points of view into account and to find a reasoned resolution at the end'. ${ }^{135}$

Despite a sombreness of the situation, there arises opportunity for robust interaction between the treaty regimes that promotes synergies and coordination, which will be illustrated in the next section.

\subsubsection{Interaction of Treaty Regimes}

Rieu-Clarke has suggested that -

'Central to this analysis [of linkages between treaty provisions, but also the relationship between treaties at various governance levels] is a greater understanding of the role that global conventions, ... and regional conventions ...

stated that 'Because it is largely consent-based, international law is fragmented. A wide range of different treaty regimes and courts and tribunals exist. This is not necessarily a bad thing. Crucially, however, these different islands of international law must be inter-connected and considered in unison through the prism of general international law. [...] Especially before a particular court or tribunal, it is important to include all international law binding between the parties as part of the applicable law, even if the jurisdiction of the adjudicator is limited to a given treaty. If all courts and tribunals follow this approach, it would mean that, although they may have jurisdiction to examine different claims, in so doing they would apply the same law. Hence, in theory, no conflict should arise. [...] Thinking of international law in this way, as a universe of inter-connected islands, should go a long way toward bridging the conflicting realities of both fragmentation and unity in modern international law."

${ }^{133}$ Report of ILC, supra n 96, at p 8, para 7. The UN Security Council has to deal with human rights and war crimes. The World Bank needs to address environmental sustainability in their developmental projects. The World Health Organisation (WHO) must now be mindful of environmental concerns in the negotiation of a treaty regulating the sale of tobacco products. See Pauwelyn, Conflict of Norms in Public International Law, supra $\mathrm{n} 100$, at $\mathrm{p} 2$.

${ }^{134}$ There is a need to develop new technique for the coordination of the negotiation, and the implementation of related agreements, in particularly the administrative, monitoring and financial provisions. Weiss, 'International Environmental Law', at pp 678-679.

${ }^{135}$ Fragmentation Report, supra n 17, at p 246, para 487. 
have at basin or sub-basin level. Similarly, when conducting basin level analyses, the impact of non-water specific treaties at various levels on basin practice ... should be noted. A range of national laws will also affect state behaviour at the (international) basin level., ${ }^{, 136}$

The acute need for integration has been phrased in policy terms in recognition of the looming ecological crisis of many dimensions that could 'jeopardise the globe's lifesupport systems'. ${ }^{137}$ The InterAction Council reiterated the need for an integrated and holistic approach in addressing environmental problems because 'environmental problems are multi- dimensional and can only be solved by multi-dimensional measures'. ${ }^{138}$

The InterAction Council went further to state that the 'ongoing dilution of ideological divides may facilitate the emergence of a one-world-conscience and improve prospects for effective environmental action at all levels towards a sustainable economy and development'. ${ }^{139}$ This can be translated to mean that the de-fragmentation in environmental governance ideologies will be able to improve efforts aiming at resolving environmental problems.

The recognition of the need for a systematic interpretation of the universal, regional and basin level laws applicable in the area of international freshwater resources 'because each of them forms part of the international legal system and they function and interact in the context of the system as a whole ${ }^{140}$ supports the assertion of a structurisation of international water law. ${ }^{141}$ More specifically, the UNECE Task Force on Legal and

\footnotetext{
${ }^{136}$ Alistair Rieu-Clarke, 'The Role of Treaties in Building International Watercourse Regimes: A Legal Perspective on Existing Knowledge', (2010) 12 Water Policy 822 - 831, at p 829. The author suggested that existing knowledge and understanding from various perspectives provides useful insights into the role of treaties in managing conflict and enhance cooperation over international watercourses.

${ }^{137}$ InterAction Council, 'Ecology and the Global Economy' (Chaired by Miguel de la Madrid, Hurtado, 10 - 11 February 1990, Amsterdam, Netherlands) at para 1 〈http://www.interactioncouncil.org/node/77> accessed 12 September 2012.

${ }^{138}$ InterAction Council, 'Ecology and the Global Economy', supra n 137, at para 3.

${ }^{139}$ InterAction Council, 'Ecology and the Global Economy', supra n 137, at para 3. The InterAction Council further this point, in para 6 that 'The challenge of the decade of the 1990s is to integrate environmental policies into economic policies and to make traditional social-economic policy objectives compatible with environment policy objectives'.

${ }^{140}$ Laurence Boisson de Chazournes, 'Freshwater and International Law: The Interplay between Universal, Regional and Basin Perspectives' (The United Nations World Water Assessment Programme, United Nations World Water Development Report 3: Water in a Changing World, Insights, UNESCO, UN-Water, 2009) <http://unesdoc.unesco.org/images/0018/001850/185080E.pdf> accessed 10 February 2013.

${ }^{141}$ Refer supra $\mathrm{n} 74$ on structurisation of international water law. For the emergence of regional and basin level laws applicable in the area of international freshwater resources, see in general Section 1.1.1. See de
} 
Administrative Aspects prepared a comprehensive report on the relationship between the 1992 Helsinki Convention and the 1997 Watercourses Convention where the two Conventions are compared and differentiated. ${ }^{142}$ It is asserted that the two instruments are complementary in their mutual relationship, and would contribute towards the crystallisation and consolidation of norms on international water law in the ongoing process of an emergence of international customary law.

The obligation to preserve ecosystems of international watercourses in the overall context of their protection has also been addressed in non-water specific international instruments on the environment. ${ }^{143} \mathrm{~A}$ study conducted on the interaction between Multilateral Environmental Agreements (MEAs) and water resources management revealed that the ecological inter-dependence of different components of environment specifically addressed in each agreement rendered the resulting normative overlap compatible and complementary, where a coordinated approach in their implementation promotes synergies and improves efficiency.

Several attempts at striking interlinkages ${ }^{144}$ between the MEAs are initiated by the Biodiversity Convention, but all failed to provide concrete solutions to the problem

Chazournes, 'Freshwater and International Law: The Interplay between Universal, Regional and Basin Perspectives', supra n 140. See also Salman MA Salman, 'The Helsinki Rules, the UN Watercourses Convention and the Berlin Rules: Perspectives on International Water Law' (2007) 23(4) Water Resources Development 625 - 640 on a study of interactions between different instruments that purport to state the rules of international water law.

${ }^{142}$ Attila Tanzi, 'The Relationship between the 1992 UNECE Convention on the Protection and Use of Transboundary Watercourses and International Lakes and the 1997 UN Convention on the Law of the Non Navigational Uses of International Watercourses' (Report of the UNECE Task Force on Legal and Administrative Aspects, Geneva, February 2000) <http://www.unece.org/fileadmin/DAM/env/water/publications/documents/conventiontotal.pdf $>$ accessed 10 February 2013.

${ }^{143}$ See McCaffrey, The Law of International Watercourses, supra n 79, p 393. Also Birnie, Boyle and Redgwell, International Law and the Environment, supra n 112, p 561; Laurence Boisson de Chazournes, 'Eaux internationals et droit international', at p 41; Korhonen, 'Riverine Ecosystems in International Law', supra n 79, at p 489. The Foundation for International Environmental Law and Development (FIELD) conducted a detailed study in 2005 on the implementation of Multilateral Environmental Agreements (MEAs) for Efficient Water Management in determining the extent of overlap and conflicts of various MEAs in the efficient management of water. FIELD, 'Implementation of Multilateral Environmental Agreements for Efficient Water Management' (April 2005) (on file with author). See also Ramsar Convention, 'Synergies with Other Environment-Related Conventions and Organisations' (4 September 2009) <http://www.ramsar.org/cda/en/ramsar-about-synergy/main/ramsar/1-36-192_4000_0_> accessed 20 May 2010.

${ }^{144}$ See W Bradnee Chambers, 'Interlinkages and the Effectiveness of Multilateral Environmental Agreements; UNU, Inter-Linkages. Synergies and Coordination between Multilateral Environmental Agreements' (UNU, Tokyo, 1999) <http://archive.unu.edu/inter-linkages/1999/docs/UNUReport.PDF> accessed 25 September 2012; Sálvano Briceño, 'Institutional Linkages among Multilateral Environmental Agreements: An Organizational and Educational Development Perspective' (Prepared for " Interlinkages" International Conference on Synergies and Coordination between Multilateral Environmental Agreements, 
posed. ${ }^{145}$ The fragmentation of international law on the environment that leads to treaty congestion arises from the lack of synergy between these treaty agreements, ${ }^{146}$ hence the need for increased coordination and cooperation between different regime institutions. ${ }^{147}$ In addition to that, the disparity of commitments amongst parties to one

14 - 16 July 1999, UNU Tokyo) 〈http://archive.unu.edu/inter-linkages/1999/docs/Briceno.PDF> accessed 25 September 2012.

Lee A Kimball, 'Institutional Linkages among Multilateral Environmental Agreements: A Structured Approach Based on Scale and Function' (Prepared for 'Interlinkages' International Conference on Synergies and Coordination between Multilateral Environmental Agreements, UNU Tokyo, 14 - 16 July 1999) <http://archive.unu.edu/inter-linkages/1999/docs/Kimball.pdf > accessed 25 September 2012; Jacob D Werksman, 'Formal Linkages and Multilateral Environmental Agreements' (Background Paper prepared for the International Conference on Synergies and Co-ordination between Multilateral Environmental Agreements, UNU Tokyo 14 - 16 July 1999) <http://archive.unu.edu/interlinkages/1999/docs/jake.PDF> accessed 25 September 2012. Jerry Velasquez, 'UNU "Interlinkages Initiative" Aims at Coherent Sustainable Development' (Environment and Development: A Three-Decade Timeline, UNU Tokyo, 1999) 〈http://archive.unu.edu/inter-linkages/docs/Articles/Diplomat_times.pdf> accessed 25 September 2012.

${ }^{145}$ CBD, 'Annex 1. Recommendations of the SBSTTA at Its $3^{\text {rd }}$ Meeting' at p 30 para I(b). Ramsar Convention, 'Memorandum of Cooperation between The Bureau of the Convention on Wetlands of International Importance especially as Waterfowl Habitat and The Secretariat of the Convention on Biological Diversity' (19 January 1996) <http://www.ramsar.org/cda/en/ramsar-documents-mousmemorandum-of/main/ramsar/1-31-115\%5E16060_4000_0_> accessed 25 September 2012. For more institutional coordination between MEAs see in general UNEP, 'Guideline 34. International Cooperation and Coordination' (Manual on Compliance with and Enforcement of Multilateral Environmental Agreement, Division of Environmental Law and Conventions, UNEP) <http://www.uneporg/dec/onlinemanual/Compliance/InternationalCooperation/tabid/415/Default.aspx > accessed 25 September 2012; and UNEP, 'Synergies between the Ramsar Convention and Other MEAs' $<$ http://www.uneporg/delc/> accessed 25 September 2012. See Sabine Brels, David Coates, Flavia Loures, Transboundary Water Resources Management: the Role of International Watercourse Agreements in Implementation of the CBD (CBD Technical Series No 40, Secretariat of the CBD, Montreal, Canada 2008); S Blumenfeld, C Lu, T Chistophersen, and D Coates, Waters, Wetlands and Forests. A Review of Ecological, Economic and Policy Linkages (CBD Technical Series No 47, Secretariat of the CBD and Secretariat of the Ramsar Convention on Wetlands, Montreal and Gland 2009); and CBD, 'In-Depth Review of the Programme of Work on the Biological Diversity of Inland Water ecosystems. Draft Recommendation Submitted by the Chair of Working Group I' (Subsidiary Body on Scientific, Technical and Technological Advice, Fourteenth Meeting, 10 - 21 May 2010 Nairobi, Working Group I, Agenda Item 3.1.2) (11 May 2010) UNEP/CBD/SBSTTA/14/WG.1/CRP3.

${ }^{146}$ FIELD, 'Implementation of Multilateral Environmental Agreements for Efficient Water Management', at pp $25-26$.

${ }^{147}$ It is foresee that there is a need for integration of the environmental regime when 'at no time has the entire structure of international environmental management ever been reviewed with the goal of developing optimum architecture'. Moltke, Whither MEAs? supra n 129, at p 15. Different approaches towards coordination were explored through an institutional perspective of the establishment of a world environment organisation, world environmental court and the clustering of MEAs. See Steve Charnovitz, 'A World Environment Organization' (UNU Institute of Advanced Studies Project on International Environmental Governance Reform, UNU Tokyo, 2002) <http://archive.unu.edu/interlinkages/docs/IEG/Charnovitz.pdf> accessed 25 September 2012; Ellen Hey, Reflections on an International Environmental Court (Kluwer Law International, The Hague, The Netherlands, 2000); and Sebastian Oberthür, 'Clustering of Multilateral Environmental Agreements: Potentials and Limitations' (UNU Institute of Advanced Studies Project on International Environmental Governance Reform, UNU Tokyo, 2002) 〈http://archive.unu.edu/inter-linkages/docs/IEG/Oberthur.pdf> accessed 25 September 2012. 
or more international environmental treaties is a fact that is impossible to be ignored in the contemplation of the interpretation and application of these treaties. ${ }^{148}$

The effectiveness of such efforts in addressing the protection and preservation of freshwater ecosystems, despite the mushrooming of interlinkages projects implemented via clustering of programmes under different themes, or institutional cooperation predicated on synergies, is still extremely vague. ${ }^{149}$ It is obvious that the overlapping of objectives and requirements of various MEAs, and the interlinkages effort initiated by various MEAs under different themes, could lead to a duplication of efforts, where the possibility of operational conflicts could arise.

Various international legal scholars have dealt at length more generally on the normative interactions, or regime-collisions caused by the fragmentation of international law, and most of these scholars undertook an extensive overview of all possible methods and mechanisms for the management of fragmentation. ${ }^{150}$ The ILC compiled and studied an extensive range of scholarship on the issue of fragmentation, summarised the existing body of knowledge on this pressing issue, and explored the legal means and methods in tackling this phenomenon inevitably caused by the diversification and expansion of international law. ${ }^{151}$ The focus of these international scholars in the normative fragmentation scholarship was mostly on the various legal mechanisms that dealt with situations of conflict or interpretation regarding the substance of the law ex post the making of the law. ${ }^{152}$

As opposed to the more ex post approach as a means to address the problem of fragmentation in international law, the discussions on the management of the

\footnotetext{
${ }^{148}$ See Duncan French, 'Treaty Interpretation and the Incorporation of Extraneous Legal Rules' (2006) 55 International Comparative Law Quarterly 281 - 314, 307. Moreover, Principle 7 of Rio Declaration stated that States have common but differentiated responsibility in their cooperation to conserve, protect and restore the health and integrity of the Earth's ecosystem UN Conference on Environment and Development (Rio de Janeiro, 3-14 Jun 1992), 'Rio Declaration on Environment and Development' (1 Jan 1993) UN Doc A/CONF.151/26/Rev.1 (Vol I) (hereinafter: 'Rio Declaration'). This in turn, will compound the difficulty of a harmonised integration of MEAs.

149 Karen N Scott, 'International Environmental Governance: Managing Fragmentation through Institutional Connection' (2011) 12 Melbourne Journal of International Law 1 - 40, at pp $14-35$.

${ }^{150}$ Pauwelyn frames the normative interaction in international law through a conceptual lens of conflict. Joost Pauwelyn, Conflict of Norms in Public International Law, supra $\mathrm{n} 100$.

${ }^{151}$ ILC, 'Conclusions of the Work of the Study Group on the Fragmentations of International Law: Difficulties Arising from the Diversification and Expansion of International Law' (adopted by ILC at its $59^{\text {th }}$ Session and submitted to the General Assembly as part of the Commission's report, 2006) UN Doc A/61/10, para $251<$ http://untreaty.un.org/ilc/texts/instruments/english/draft\%20articles/1_9_2006.pdf> accessed 2 November 2012.

${ }^{152}$ Margaret A Young, 'Fragmentation or Interaction: The WTO, Fisheries Subsidies, and International Law', supra n 104, at p 481.
} 
fragmentation of international law on the environment have also adopted an ex ante approach, which is influenced by the need to increase the effectiveness of environmental governance. Scholars have advocated various methodologies that increase interactions and cooperation between treaty regimes, which complement the interlinkages initiatives taken at the institutional level by the treaty bodies. ${ }^{153}$ After the evaluation of existing ex ante approaches proposed by scholars, van Asselt concluded that autonomous institutional actions are the most fruitful approach aimed at enhancing synergies between the conflicting regimes. ${ }^{154}$ Institutional reforms are advocated through the diversification of institutional arrangements based on networks of partnerships between state, public and private stakeholders in addressing the disconnect

\footnotetext{
${ }^{153}$ Elizabeth Kirk proposed the mechanism of 'cross-referencing of reports and information between regimes and organisations and a continued exchange of information between autopoietic regimes' in order to sustainably manage a sectoral marine regime plagued by problems created by the expansion of maritime jurisdiction she called 'creeping jurisdiction'. Elizabeth Kirk, 'Maritime Zones and the Ecosystem Approach: A Mismatch?' (1999) 8(1) Review of European Community and International Environmental Law $67-72$, at p 70. Moltke, Whither MEAs? supra n 129, at p 16 went a step further in recommending for more structural interactions as compared to the more administrative interchange suggested by Kirk. He explicated the desirability of the institutional clustering of international environmental regime to improve effectiveness that strengthens international environmental governance, and proposed the strengthening of regime institutions through organisational change. Proceeding on the same theme on institutional interactions and linkages, Oberthür elaborated on the potential, problems and limitation of multilateral environmental agreements clustering in the attempt to improve the effectiveness of the environmental governance regimes, and expanded his research to look at the interactions between international and European Union policies. See Sebastian Oberthür, 'Clustering of Multilateral Environmental Agreements: Potentials and Limitations' (United Nations University Institute of Advanced Studies Project on International Environmental Governance Reform, 2002) http://archive.unu.edu/interlinkages/docs/IEG/Oberthur.pdf accessed 14 December 2011. Other similar publications by the same author include Sebastian Oberthür, Thomas Gehring, and Oran R Young (eds), Institutional Interaction in Global Environmental Governance: Synergy and Conflict among International and EU Policies (MIT Press, Cambridge, 2006); and Sebastian Oberthür and Olav Schram Stokke (eds), Managing Institutional Complexity: Regime Interplay and Global Environmental Change (MIT Press, Cambridge, 2011). Moltke's proposal was reiterated in greater depth and detail 10 years later where Scott proposed the engagement of institutional cooperation and integration for the management of fragmentation that exploits the overlaps and synergies existed between multilateral environmental treaties, in Scott, 'International Environmental Governance: Managing Fragmentation through Institutional Connection', supra $\mathrm{n}$ 149. Young introduced a different aspect of regime interactions by advocating for a participatory approach in the interactions of institutional that can pre-empt further legal fragmentation. Young, 'Fragmentation or Interaction: The WTO, Fisheries Subsidies, and International Law', supra n 104, at p 513. Young furthered her proposal for alternative responses via regime interaction through a research agenda that focuses on the institutional and normative interplay of the governance of climate change, in Margaret A Young, 'Climate Change Law and Regime Interaction' (2011) 2 Carbon and Climate Law Review' 147 - 157.

${ }^{154}$ Harro van Asselt, 'Managing the Fragmentation of International Environmental Law: Forests at the Intersection of the Climate and Biodiversity Regimes' (7 February 2011). New York University Journal of International Law and Politics (JILP) (forthcoming) <http://ssrn.com/abstract=1703186> accessed 12 December 2011, pp 42 - 46. Now published as Harro van Asselt, 'Managing the Fragmentation of International Environmental Law: Forests at the Intersection of the Climate and Biodiversity Regimes', supra $\mathrm{n} 106$, at pp 1212, and 1268 - 1274. Fragmentation of international law, regime interactions and climate change governance are recurring themes of discussion for van Asselt, see Harro van Asselt, Francesco Sindico, and Michael A Mehling, 'Global Climate Change and the Fragmentation of International Law’ (2008) 30(4) Law and Policy 423.
} 
between the current system of environmental governance and the effective application of the ecosystem approach. ${ }^{155}$ Such arrangements are deemed more flexible, resilient, and capable of providing the required multi-functional landscapes for the application of an ecosystem approach. ${ }^{156}$

The quest to solve the problems posed by the fragmentation of law, whether it be from a traditional school of international law that engages existing legal mechanisms to deal with the problem, or from a more revolutionary approach that promotes the development of regime towards institutional interactions and cooperation, has raised a pertinent issue concerning the interpretation and application of rules. The two approaches are not mutually exclusive because a more interactive law-making process will strengthen the common understanding of a law, and enable a more integrative interpretation of the law that is less prone to conflict.

In light of the fragmentation of international law concerning the environment, and the proliferation of a multitude of international watercourses instruments, it is increasingly important to ensure some form of uniformity, consistency and unity in the international legal order, ${ }^{157}$ which "provides the international players a secure framework to work on'. ${ }^{158}$ A systemically integrated approach is of paramount importance in achieving the

${ }^{155}$ Alison R Holt, Jasmin A Godbold, Piran CL White, Anne-Michelle Slater, Eduardo G Pereira and Martin Solan, 'Mismatches between Legislative Frameworks and Benefits Restrict the Implementation of the Ecosystem Approach in Coastal Environments' (2011) 434 Marine Ecology Progress Series 213 - 228 , at $\mathrm{p} 215$.

${ }^{156}$ Alison R Holt et al, 'Mismatches between Legislative Frameworks and Benefits Restrict the Implementation of the Ecosystem Approach in Coastal Environments', supra $\mathrm{n}$ 155, at p 224.

${ }^{157}$ Initiative by Gerhard Hafner, 'Risk Ensuing from Fragmentation of International Law', ILC, 'Report on the Work of its 52 ${ }^{\text {nd }}$ Session 1 May - 9 June and 10 July - 18 August 2000' (Annex of GAOR 55 ${ }^{\text {th }}$ Session Supplement No 10 ) UN Doc A/58/10, (2000) II(2) Yearbook of the International Law Commission, at $\mathrm{p}$ 149. It is stated that: "In light of the growing factual integration of world community on the one hand, and the proliferation of subsystems on the other, it is to be expected that the need to take measures to ensure the unity of the international legal order will increase".

158 Gilbert Guillaume, 'The Proliferation of International Judicial Bodies: The Outlook for the International Legal Order' (Speech by His Excellency Judge Gilbert Guillaume, President of the ICJ to the Sixth Committee of the UNGA, 27 October 2000) <http://www.icj-

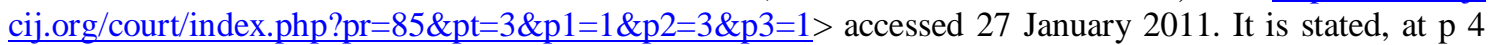
that 'Certainly, international law must adapt itself to the variety of fields with which it has to deal, as national law has done. It must also adapt itself to local and regional requirements. Nonetheless, it must preserve its unity and provide the players on the international stage with a secure framework'. Some initiatives on interlinkages and synergies have been undertaken by the Biodiversity Convention. See Brels, Coates, and Loures, Transboundary Water Resources Management: the Role of International Watercourse Agreements in Implementation of the CBD, supra $\mathrm{n}$ 145, and Blumenfeld, Lu, Chistophersen, and Coates, Waters, Wetlands and Forests. A Review of Ecological, Economic and Policy Linkages, supra $\mathrm{n}$ 145. See also CBD, 'Decision VII/4 Biological Diversity of Inland Water Ecosystems' (Seventh Meeting of the Conference of the Parties to the Convention on Biological Diversity, Kuala Lumpur, 9 20 and 27 February 2004) UNEP/CBD/COP/DEC/VII/4 (13 April 2004) <http://www.cbd.int/doc/decisions/cop-07/cop-07-dec-04-en.pdf > accessed 31 July 2012. 
ultimate aim of maintaining a continued and sustainable provision of ecosystem services. ${ }^{159}$

Schwebel observed the interdependence of an international watercourse within its system, which necessitates the formation of general rules of international law that foster the essential cooperation needed for a broad approach to the rational management of international water resources. ${ }^{160}$ Agenda 21 of the United Nations Conference on Environment and Development (UNCED) in 1992 called for the adoption of a holistic approach in the conservation and use of water resources. ${ }^{161}$ Thus, it is extremely important that the interaction of regimes that have an impact on the protection and preservation of freshwater ecosystems should be looked at in a comprehensive way.

An integrated approach in the rational management of international water resources could be realised through an integrated interpretation of the obligation of protection and preservation of freshwater ecosystems, where a coherent interpretation of obligation enables the fostering of essential cooperation. This thesis seeks to address the challenges faced by the interpreter in the management of the fragmented and congested state of rules applicable to the preservation of freshwater ecosystems through a nuanced analysis of Article 31(3)(c) of the Vienna Convention. The actual and potential application of this article as an expression of the principle of systemic integration is explored in this research in the context of the preservation of freshwater ecosystem. This serves to offer a prospect in the promotion of coherence within and among the 'impressive federation of special areas ${ }^{162}$, especially in the aversion of apparent conflict of norms and to achieve harmonisation of rules of international law.

In light of the difficulties arising from the fragmentation of international law on the environment as elaborated in the previous sections, the next section lays out the title

\footnotetext{
159 Alan E Boyle, 'Relationship between International Environmental Law and Other Branches of International Law' 125 - 146, in Daniel Bodansky and others (eds), The Oxford Handbook of International Environmental Law (Oxford University Press 2007) at pp 127 - 128. It stated that 'What then matters is that the regulation of international environmental concerns, however categorised, generally entails the application of international law as a whole. The sometimes difficult question is how to do so in an integrated and coherent manner.'

${ }^{160}$ Schwebel $3^{\text {rd }}$ Report, supra $\mathrm{n} 4$, at para 311.

161 Agenda 21, UNCED (Rio de Janeiro, 3-14 Jun 1992), 'Agenda 21: A Programme for Action for Sustainable Development' (1 Jan 1993) UN Doc A/CONF.151/26/Rev.1 (Vol I) (hereinafter: 'Agenda 21') Chapter 18.

${ }^{162}$ Campbell McLachlan, 'The Principle of Systemic Integration and Article 31(3)(c) of the Vienna Convention', (2005) 54 International and Comparative Law Quarterly 279 - 230, at p 318.
} 
describing this research, and the question to be answered in this research, and subsequently the scope and justification for the research.

\subsection{Research Title and Research Question}

The title of this thesis is 'Preservation of Ecosystems of International Watercourses and the Integration of Relevant Rules'. The research question posed is 'how could Article 31(3)(c) of the 1969 Vienna Convention be operationalised as an integration tool that better reflects the principle of systemic integration in the context of the preservation of ecosystems of international watercourses?'. The research intends to provide a framework for the operationalisation of Article 31(3)(c) of the 1969 Vienna Convention in order to manifest the actual and potential contribution of this Article in addressing the fragmentation of international law and the congestion of treaties. The framework of operation developed in this thesis for Article 31(3)(c) of the 1969 Vienna Convention deemed to reflect the principle of systemic integration - could be useful in guiding the integration of relevant rules in its systemic environment through the legal technique of interpretation.

It is extremely crucial that the application of rules is linked to their legal environment and that adjoining rules are considered, especially for the critical and constructive development of international and national institutions with law applying tasks, because such an outcome normally articulates the institution's legal-institutional environment its substantive preferences, distributionary choices and political objectives. ${ }^{163}$

\subsection{Scope and Justification of Research}

'If we have a right to benefit from the earth's bounty, then we have the obligation to respect, care for and restore the earth and its natural resources, 164

With increased knowledge on the interconnectedness of the environment, and the need to take a holistic approach to conservation and protection of the environment, environmental agreements directed to this effort must strive to conserve the

\footnotetext{
${ }^{163}$ Fragmentation Report, supra n 17, at p 244, para 480.

${ }^{164}$ InterAction Council, 'A Universal Declaration of Human Responsibility' (Report on the Conclusions and Recommendations by a High-Level Expert Group Meeting Chaired by Helmut Schmidt, 20 - 22 April 1997, Vienna, Austria) at p 4 <http://interactioncouncil.org/sites/default/files/1997\%20UDHR.pdf> accessed 12 September 2012. Oscar Arias Sanchez, 'Some Contributions to a Universal Declaration of Human Obligations' (April 1997) <http://interactioncouncil.org/some-contributions-universaldeclaration-human-obligations> accessed 12 September 2012.
} 
environment as a whole. ${ }^{165} \mathrm{~A}$ narrow focus on pollution control, or a targeted species approach, is no longer the best possible means in the interpretation and implementation of these environmental agreements. Such insight has been evident in the adoption of the 'system approach' or the 'ecosystem approach' in recent international environmental agreements. ${ }^{166}$

Schwebel stated in his Third Special Rapporteur Report in 1982 that not all environmental problems can be 'subsumed under the rubric of pollution'. ${ }^{167}$ The field of environmental protection and improvement 'is not exhausted with treatment of the standard situations of pollution'; but instead, should encompass 'all relationships between man and the earth's ecosystems'. ${ }^{168}$ Furthermore, the customary status of the obligation not to cause transboundary harm has been sufficiently established after the Trail Smelter case ${ }^{169}$ and made explicit in Principle 2 of Rio Declaration that states have the responsibility to 'ensure activities within their jurisdiction does not cause damage to the environment of other States or of areas beyond the limits of national jurisdiction'. ${ }^{170}$

Hence, there is a need to address the protection and preservation of freshwater ecosystems not just against pollution, but also against environmental degradation in its various manifestations. The focus of this research aims to address the gap in this aspect of environmental protection of freshwater ecosystems, especially of adverse, but indirect effect caused by inappropriate land use that does not take into consideration the

\footnotetext{
${ }^{165}$ However, in most cases, the connectivity between the terrestrial ecosystem and the aquatic ecosystem is neglected. See 1994 Draft Articles and Commentaries, supra n 44, for the commentary on Art 20. See also McCaffrey, The Law of International Watercourses, supra $\mathrm{n} 79$, for a range of international water instrument that specify the protection of 'aquatic ecosystem'. See also Agenda 21, supra n 161, at para 18.38. It stated that the maintenance of ecosystem integrity in accordance with the management principle of preserving aquatic ecosystems from any form of degradation on a drainage basin.

${ }^{166}$ Examples includes the ASEAN Agreement on the Conservation of Nature and Natural Resources (adopted at Kuala Lumpur on 9 July 1985); the Secretariat of the Convention on Biological Diversity, 'The Ecosystem Approach (CBD Guidelines)' (Secretariat of the Convention on Biological Diversity, Montreal, 2004); and also the 1992 Helsinki Convention, supra n 67.

${ }^{167}$ Schwebel $3^{\text {rd }}$ Report, supra $\mathrm{n}$ 4, at para 247: 'Pollution involves the use of water by man and the impact upon water of other activities for which man is responsible, with consequent detrimental effect. Commonly perceived, environmental damage is harm to nature in the broader sense, more especially, perhaps, to biological complexes of myriad sorts. The impact of such damage upon man, while probable, even if in the very long run, may be highly indirect or not even ascertainable'.

${ }^{168}$ Schwebel $3^{\text {rd }}$ Report, supra n 4, at p 122, para 244. See Helsinki Rules on the Uses of the Waters of International Rivers, (adopted by the International Law Association at the fifty-second conference, August 1966) Chapter 3. For a detailed account on the development of international environmental law on the prevention against pollution, see Edith Brown-Weiss, 'International Environmental Law: Contemporary Issues and the Emergence of a New World Order', supra $\mathrm{n} 107$.

${ }^{169}$ Trail Smelter Case (United States, Canada) (Award of 16 April 1938 and 11 March 1941) (1941) III Reports of International Arbitral Awards 1905 - $1982<$ http://untreaty.un.org/cod/riaa/cases/vol III/19051982.pdf> accessed 14 November 2012.

${ }^{170} 1992$ Rio Declaration, supra n 148, Principle 2.
} 
interdependence of the environment as a whole. Schwebel proposed articles regarding protection and preservation of freshwater ecosystems that comprehends but distinguishes between the concern against pollution and against environmental damage, by tracing the differences thereof. ${ }^{171}$

The term 'protection' in the 1997 UN Watercourses Convention was contextualise to reflect the specific application of the requirement in Article 5 that watercourse States are to use and develop an international watercourse in a manner that is consistent with adequate protection. ${ }^{172}$ This requires that watercourse states shield the ecosystems of international watercourse from harm or damage, including the duty to protect ecosystems from a significant threat of harm. ${ }^{173}$

The Special Rapporteur's assertion that 'not all environmental problems are pollution ${ }^{174}$ is further elaborated through the insertion of the obligation to preserve in the same article. The term 'preservation' is defined to address the particular circumstance of transboundary freshwater ecosystems 'that are in a pristine or unspoiled condition', which requires a protection approach that 'maintain their condition as much as possible in their natural state'. ${ }^{175}$ In this respect, the normative content and scope of the term 'preservation' seems to indicate a specific protection approach that seeks to maintain the condition of freshwater ecosystems that are still in its natural state.

\footnotetext{
${ }^{171}$ Environmental damage has been defined as 'harm to nature' in Schwebel $3^{\text {rd }}$ Report, supra $\mathrm{n}$ 4, at para 247, p 123. The distinction between 'protection' and 'preservation' is explained the 1994 Draft Articles and Commentaries, supra n 44, at p 119, para 3. It explained that 'The obligation to 'protect' the ecosystems of international watercourses is a specific application of the requirement contained in Art 5 that watercourse States are to use and develop an international watercourse in a manner that is consistent with adequate protection thereof. In essence, it requires that watercourse States shield the ecosystems of international watercourses from harm or damage. It thus includes the duty to protect those ecosystems from a significant threat of harm ... Together, protection and preservation of aquatic ecosystems help to ensure their continued viability as life support systems, thus providing an essential basis for sustainable development'.

${ }^{172}$ Art 5(1) provides that 'Watercourse States shall in their respective territories utilize an international watercourse in an equitable and reasonable manner. In particularly, an international watercourse shall be used and developed by watercourse States with a view to attaining optimal utilization thereof and benefits therefrom consistent with adequate protection of the watercourse'. It is explained the 1994 Draft Articles and Commentaries, supra n 44, at p 97, paras 3 and 4 that "the expression "adequate protection" is meant to cover not only measures such as those relating to conservation, security and water-related disease, but also measures of "control" in the technical, hydrological sense of the term'. The attainment of optimal utilisation and benefits consistent with adequate protection, "while primarily referring to measures undertaken by individual States, does not exclude cooperative measures, works or activities undertaken by States jointly'.

1731994 Draft Articles and Commentaries, supra n 44, at p 119, para 3.

${ }^{174}$ Schwebel $3^{\text {rd }}$ Report, supra $\mathrm{n} 4$ and n 167, at para 247.

${ }^{175}$ Both quotes are paraphrased from the 1994 Draft Articles and Commentaries, supra n 44, at p 119, para 3.
} 
Explicit recognition on the importance of the obligation to preserve resurfaced in light of the rising concern on ecosystem degradation in the advent of the ecosystem approach. This approach highlights the importance of safeguarding and maintaining the structure and functioning of ecosystems to ensure ecosystem integrity. ${ }^{176}$ The InterAction Council highlighted the importance of the need to preserve natural resources in the broad context (and not just the preservation of freshwater ecosystems) where the Council enunciated that 'people's participation in the management and preservation of a country's resources will be decisive for the sustainability of development efforts'. ${ }^{177}$

Although the obligation to protect and preserve is intrinsically linked conceptually, there is still a fine difference between the obligation to protect and the obligation to preserve that warrants a separate research into the obligation to preserve. A focussed interpretation of the obligation of preserve does not purport to negate the nuanced relationship between protection and preservation, nor does it attempt to nullify the importance of protection. Instead, it seeks to complement the current body of knowledge on the obligation to protect phrased mostly in pollution control and prevention terms by exploring the less-researched aspect of preservation as a means of protection. An interpretation of the obligation to preserve will contribute towards the emergence of the universal duty to protect the environment in the broader sense.

The obligation to preserve is a widely accepted practice of states. ${ }^{178}$ This research focuses on Article 20's obligation to preserve freshwater ecosystems of international watercourses in its natural state, ${ }^{179}$ to the exclusion of other protection measures that address prevention of harm, including measures relating to security, water-related

\footnotetext{
${ }^{176}$ Jutta Brunnée and Stephen Toope, 'Environmental Security and Freshwater Resources: A Case for International Ecosystem Law', supra n 3; J Fischer, D Lindenmayer, and A Manning, 'Biodiversity, Ecosystem Function, and Resilience: Ten Guiding Principles for Commodity Production Landscapes' (2006) 4(2) Frontiers in Ecology and the Environment 80 - 86.

${ }^{177}$ InterAction Council, 'Ecology and the Global Economy', supra n 137, at para 9. This importance is highlighted in response to the earlier reference of the Council to the statement by Pope John Paul II, in para 5 that 'The new industrialised States cannot, for example, be asked to apply restrictive environmental standards to their emerging industries unless the industrialised States first apply them, within their own boundaries. At the same time, countries in the process of industrialisation are not morally free to repeat the errors made in the past by others, and recklessly continue to damage the environment through industrial pollutants, radical deforestation or unlimited exploitation of non-renewable resources'.

${ }^{178}$ Schwebel $3^{\text {rd }}$ Report, supra $\mathrm{n} 4$, at p 190, para 518.

${ }^{179}$ Refer supra n 49 and n 50.
} 
disease, measures relating to the technical and hydrological control of watercourses, and other measures on the protection of watercourses. ${ }^{180}$

The increased recognition of the preservation of ecosystems, ${ }^{181}$ under a broader context of the maintenance of ecosystems integrity, necessitates a systemic integration of rules available under a plethora of MEAs that provides for the establishment of protected areas for the preservation and conservation of ecosystems, habitats and the natural surroundings of viable population of species. The underpinning principle engaged in this research is the principle of systemic integration to achieve harmonisation of rules of international law, ${ }^{182}$ as expressed under Article 31(3)(c) of the 1969 Vienna Convention, which provides the foundation of the analytical framework.

Aust enunciated that 'just as construing legislation is the constant concern of the domestic practitioner, treaty interpretation forms a significant part of the day-to-day work of a foreign ministry legal adviser'. ${ }^{183}$ In the analysis of the definitional scope and the normative content of the obligation to preserve the ecosystems of international watercourses as provided under Article 20 of the 1997 Watercourses Convention, there is a need to take into account any relevant rules applicable for the interpretation of the terms of this Convention. ${ }^{184}$

This thesis endeavours to assist water practitioners in their administrative and adjudicative capacities to resolve difficulties arising from the congestion of treaties

\footnotetext{
1801994 Draft Articles and Commentaries, supra n 44, at p 97, para 4. The 'control' measures in the technical, hydrological sense are those taken to regulate flow, to control floods, pollution and erosion, to mitigate drought and to control saline intrusion. Other measures do not exclude cooperative measures, works or activities undertaken by States jointly. On the issue of prevention of harm, including harm caused by pollution, the general duty of prevention of significant transboundary harm under customary international law, as endorsed in Art 7 of the 1997 Watercourses Convention, supra n 35, Principle 2 of the Rio Declaration, supra n 148, and the 2001 Draft Articles on Prevention of Transboundary Harm from Hazardous Activities. International Law Commission, 'Draft Articles on Prevention of transboundary harm from hazardous activities' (Report of the International Law Commission on the Work of its Fiftythird Session, UNGAOR, Supp (No. 10)) UN Doc A/56/10 〈http://untreaty.un.org/ilc/texts/instruments/english/draft\%20articles/9_7_2001.pdf> $\quad$ accessed 6 November 2012.

${ }^{181}$ Bruce Pardy, 'Changing Nature: The Myth of the Inevitability of Ecosystem Management' (2003) 20 Pace Environmental Law Review 675 - 692, at p 676. Pardy commented that 'there are many reasons to desire a natural state in ecosystems. Some reasons are philosophical: "deep ecologists", for example contend that a state of nature is inherently more valuable than one designed by humans. Some are pragmatic: there are risks that ecosystems changed by human action will not function as well as systems in a natural state'. Leopold stressed that 'A thing is right when it tends to preserve the integrity, stability, and beauty of the biotic community. It is wrong when it tends otherwise'. See Aldo Leopold, A Sand County Almanac and Sketches Here and There (Oxford University Press, 1949) at 'The Outlook' (p 2).

${ }^{182}$ McLachlan, 'The Principle of Systemic Integration', supra n 162, at p 318.

${ }^{183}$ Anthony Aust, Modern Treaty Law and Practice (2 ${ }^{\text {nd }}$ edn, Cambridge University Press, 2007) at p 230.

1841969 Vienna Convention, supra n 31, Art 31(3)(c).
} 
through interpretative means, and to operationalise Article 31(3)(c) of the 1969 Vienna Convention, deemed to express the principle of systemic integration, to manage this problem in a legal-professional way. Thus, although the water-specific international instruments discussed above are capable of informing the interpretation of the obligation to preserve, they are not crucial to the problem of fragmentation of international law. This is because these instruments could not demonstrate the significant role of Article 31(3)(c) as an integration tool that enables the systemic integration of parallel and relevant rules of international law applicable in the relations between the parties, amidst a fragmented international legal order.

Hence, the thesis excludes taking into account other water-specific international instruments at the regional and basin level, due to the cogent reason that these instruments are within the regime of international water law ${ }^{185}$ where the legal maxim of lex specialis derogat lege generali, could be applied. ${ }^{186}$ The lex specialis maxim provides that "priority falls on the provision which is "special"" ${ }^{187}$ where the more specific rule should take precedence over a general standard. ${ }^{188}$ An application of the lex

${ }^{185}$ Fragmentation Report, supra n 17, at p 130, para 255. The structurisation of an international water regime is elaborated in general Section 1.1.1, and $\mathrm{n} 74$ and $\mathrm{n} 141$.

${ }^{186}$ Fragmentation Report, supra n 17, at p 34, para 56. As stated in p 36, para 58, a relationship of specific $v s$ general law would be provided by a relationship between a territorially limited general regime and a universal treaty on some specific subject, where 'the specific rule should be read and understood within the confines or against the background of the general standard' (at p 35, para 56). At p 35, para 57, the Fragmentation Report explained that the lex specialis maxim does not operate as a conflict-solution technique as the situation where 'two legal provisions that are both valid and applicable, are in no express hierarchical relationship, and provide incompatible direction on how to deal with the same sets of facts' does not exist. The UNECE Task Force on Legal and Administrative Aspects stated that 'there is no denying that, basically, the two Conventions bear on the same subject-matter'. See Tanzi, 'The Relationship between the 1992 UNECE Convention on the Protection and Use of Transboundary Watercourses and International Lakes and the 1997 UN Convention on the Law of the Non Navigational Uses of International Watercourses', supra n 142, at p 53.

${ }^{187}$ Fragmentation Report, supra n 17, at p 35, para 57.

${ }^{188}$ Fragmentation Report, supra n 17, at p 35, para 56. A specific rule, is explained in p 35, para 57, as 'the rule with a more precisely delimited scope of application'. The ILC further elaborated, at pp 36 - 37, para 60 that - "A special rule is more to the point ("approaches most nearly to the subject in hand") than a general one and it regulates the matter more effectively ("are ordinarily more effective") than general rules ... [S]pecial rules are better able to take account of particular circumstances. The need to comply with them is felt more acutely than is the case with general rules They have greater clarity and definiteness and are thus often felt "harder" or more "binding" than general rules which may stay in the background and be applied only rarely. Moreover, lex specialis may also seem useful as it may provide better access to what the parties may have willed'. It also appears that, where there is no coincidence between the contents of the rules of the two Conventions on the same issue, those of the ECE 92 Convention are generally more stringent than those of the UN 97 Convention. This applies to their material and, even more so, to their procedural rules. As to the substantive rules, the ECE 92 Convention sets out more precise guidelines and advanced standards of conduct for the prevention of transboundary impact ... From a substantive point of view, we have seen that the differences between the two Conventions with regard to specific rules on the same subject-matter are hardly ever a matter of conflicting prescriptions, but one of more, or less, stringency or detailed character of such prescriptions.' 
specialis maxim is supported in the report prepared by the UNECE Task Force on Legal and Administrative Aspects where it expresses that 'as a matter of policy, it is only natural that the law-making process at the universal level yields to lower common denominators than in the less heterogeneous context of the ECE' ${ }^{189}$

The acknowledgement of the 1992 Helsinki Convention seems to be implied where the UNECE Task Force on Legal and Administrative Aspects report concluded that -

'the lex posterior derogat priori rule cannot operate invalidating the ECE 92 Convention due to subsequent ratification, acceptance, approval, or accession to the UN 97 Convention' in light of the 'crystal clear language of art 3, para 1 of the UN 97 Convention'. 190

The aim of this research is to study the issue of fragmentation of international law through the prism of interpretation via Article 31(3)(c) of the 1969 Vienna Convention. The relationship of lex specialis and lex generalis between other water-specific instruments such as the 1992 Helsinki Convention and the 1997 Watercourses Convention where the lex specialis rule applies renders the water-specific instruments unsuitable for the purpose of this research. However, the exclusion of water-specific international instruments in this research does not in any way undermine the usefulness of these instruments to inform state practice in their execution of the obligation to preserve ecosystems of international watercourses. The normative content expressed in these instruments forms part of the corpus of knowledge embodied in Article 20 of the 1997 Watercourses Convention.

See Tanzi, 'The Relationship between the 1992 UNECE Convention on the Protection and Use of Transboundary Watercourses and International Lakes and the 1997 UN Convention on the Law of the Non Navigational Uses of International Watercourses', supra n 142, at p 53.

189 Tanzi, 'The Relationship between the 1992 UNECE Convention on the Protection and Use of Transboundary Watercourses and International Lakes and the 1997 UN Convention on the Law of the Non Navigational Uses of International Watercourses', supra n 142, at p 54.

190 Tanzi, 'The Relationship between the 1992 UNECE Convention on the Protection and Use of Transboundary Watercourses and International Lakes and the 1997 UN Convention on the Law of the Non Navigational Uses of International Watercourses', supra n 142, at p 54. The ascertainment of the general vs special relationship could be clearly observed in Art 3 of the 1997 Watercourses Convention where deference is given to prior agreements in force for a watercourse state, even though Art 3(2) invokes the consideration for the harmonisation of agreements in Art 3(1) where necessary with the basic principles of the 1997 Watercourses Convention. Art 3(3) supports the general nature of the 1997 Watercourses Convention where watercourse states are permitted to enter into agreements that apply and adjust the provisions of the 1997 Watercourses Convention to fit the characteristics and uses of a particular international watercourse. 
Notwithstanding the application of the lex specialis rule, it is noted that even though the 1992 Helsinki Convention provides for the conservation of water resources ${ }^{191}$ and their ecosystems, ${ }^{192}$ it does not specifically provide for the preservation of natural freshwater ecosystems. The Guide Implementing the 1992 Helsinki Convention defines ecosystem conservation to comprise 'measures to maintain viable structures, functions and species compositions within an ecosystem ${ }^{193}$ that often requires pollution prevention. ${ }^{194}$ The primary aim for the prevention, control and reduction of transboundary impact is reiterated in the promotion of the application of an ecosystem approach in Article 3(1)(j) to ensure sustainable water-resources management. ${ }^{195}$ In this respect, the pivotal feature that Schwebel used to distinguish the obligation to prevent and the obligation to preserve is not emphasised in the 1992 Helsinki Convention, which makes it less useful in informing the interpretation of the obligation to preserve under Article 20.

It is reiterated that the focus of the research is to address the fragmentation of international law caused by parallel and equivalent norms through the operationalisation of Article 31(3)(c) of the 1969 Vienna Convention. If it is argued that the 1992 Helsinki Convention is useful in illustrating the operationalisation of Article 31(3)(c), there is a need to determine whether Article 3(1)(j) of the 1992 Helsinki Convention is parallel and equivalent. The regional character in which the 1992 Helsinki Convention is developed vitiates its representativeness of the common intention and shared understanding of all state parties ${ }^{196}$ of the UN, as opposed to the quasi-universal adoption of the 1997 Watercourses Convention by the UNGA. ${ }^{197}$ Due to the regionalised and relatively limited membership of the 1992 Helsinki Convention, there is a need to ascertain whether the relevant provisions under the 1992 Helsinki Convention represent statements of customary international law and not regional customary law. ${ }^{198}$ The ascertainment of whether Article 3(1)(j) of the 1992 Helsinki

\footnotetext{
191 Art 2(2)(b), 1992 Helsinki Convention, supra n 67.

192 Art 2(2)(d), 1992 Helsinki Convention, supra $\mathrm{n} 67$.

193 Guide to Implementing the 1992 Helsinki Convention', supra n 71, at p 36, para 111.

${ }^{194}$ Guide to Implementing the 1992 Helsinki Convention', supra n 71, at p 36, para 112.

195 Art 3(1), 1992 Helsinki Convention, supra n 67.

196 The development of shared understanding of all UN members towards the representativeness of the 1992 Helsinki Convention of the shared understanding of the quasi universal understanding of UN members is undertaken after their accession to the 1992 Helsinki Convention, and not at the point of the entry into force of the 2003 amendment that allows the accession of all UN members. See supra $\mathrm{n} 67$.

${ }^{197}$ UNGA, '99 ${ }^{\text {th }}$ Plenary Meeting', supra $\mathrm{n} 41$.

${ }^{198}$ It is recognised by the ICJ where allowance is made for the concept of regional and local custom at $p$ 96, footnote 364. See GJH van Hoof, Rethinking the Sources of International Law (Kluwer Law and Taxation Publishers, Deventer, The Netherlands, 1983). The author listed the Asylum case, ICJ Reports
} 
Convention represents the shared understanding of the international community goes beyond the scope of the thesis. All the above reasons render the 1992 Helsinki Convention unsuitable for the purpose of this research in view of its scope and limitation.

The phenomenon of the fragmentation of international law on the environment is fully exhibited in the proliferation of MEAs on the environment. ${ }^{199}$ In light of the fragmented nature of international instruments concerning the environment, where states have the simultaneous obligation to undertake the obligations committed under these MEAs, there is a need to explore the relevant rules provided under various treaty regimes for a coherent and consistent interpretation of Article 20 on the preservation of freshwater ecosystems of international watercourses, in accordance with the principle of systemic integration.

The World Heritage Convention provides the protection of natural heritage that can be interpreted to include freshwater, habitats and ecosystems. ${ }^{200}$ The World Heritage Convention uses terms such as 'natural features consisting of physical and biological formations or groups of such formations'; 'geological and physiographical formations'; and 'habitat of threatened species'. ${ }^{201}$ Although they relate to the same subject matter of

(1950), pp 266 - 389; the Right of Passage case, ICJ Reports (1960), pp 6 - 144; the separate opinion of Judge Gros and Judge Ammoun in the Barcelona Traction case, ICJ Reports (1970), pp 3 - 357. The author stated that 'Instead of regional or local custom it would be preferable to employ the term special or specific custom because the common characteristic of the limited number of States to which this type of custom is applicable is not necessarily to be found in geographical criteria but may also be one or more other special circumstances distinguishing them from other States'.

199 At least six major related agreements are identified, namely (1) Convention Concerning the Protection of the World Cultural and Natural Heritage (entered into force 17 December 1975) 1037 UNTS 151; 27 United States Treaties and other International Agreements (UST) 37; (1972) 11 ILM 1358 (hereinafter: 'World Heritage Convention'); (2) Convention on International trade in Endangered Species of Wild Fauna and Flora 1973 (entered into force 1 July 1975) 27 UST 1087; TIAS 82249; 993 UNTS 243; (1973) 12 ILM 1088 (hereinafter: 'CITES'); (3) Convention to Combat Desertification in Those countries Experiencing Serious Drought and/or Desertification Particularly in Africa (entered into force 26 December 1996) 1954 UNTS 3; (1994) 33 ILM 1328 (hereinafter: 'CCD'); (4) The Convention on the Conservation of Migratory Species of Wild Animals 1979 (CMS); and (5) The Biodiversity Convention, supra $\mathrm{n}$ 12; and (6) Ramsar Convention, supra n 13. Douglas E Fisher, 'Freshwater, Habitats, and Ecosystems', 227 - 242, in Shawkat Alam and others (eds), Routledge Handbook of International Environmental Law (Routledge 2013) at p 234.

${ }^{200}$ Art 4 of the World Heritage Convention, supra n 199, provides the duty of each state party to ensure 'the identification, protection, conservation, presentation and transmission to future generations of the cultural and natural heritage situated in its territory, belongs primarily to that State'. Art 2 defines 'natural heritage' to consider 'natural features consisting of physical and biological formations or groups of much formations, which are of outstanding universal value from the aesthetic or scientific point of view; geological and physiographical formations and precisely delineated areas which constitute the habitat of threatened species of animals and plants of outstanding universal value from the point of view of science or conservation'.

${ }^{201}$ World Heritage Convention, supra n 199, Art 2, definition of 'natural heritage'. 
the environment, and possibly ecosystem (due to the expansive meaning of both natural heritage and ecosystem), these phrases do not specifically inform the interpretation of ecosystems and the indication of the application of an ecosystem approach.

The Convention on International Trade in Endangered Species of Wild Fauna and Flora (CITES) recognises the irreplaceable role played by wild fauna and flora in the natural earth systems, but the objective of the Convention is to regulate the over-exploitation of these fauna and flora through international trade. ${ }^{202}$ Despite being cognate on the areas of environment, its specific species-focus is less useful in informing the interpretation of Article 20 of the 1997 Watercourses Convention.

The Convention on Migratory Species (CMS) similarly recognises the irreplaceable role of wild animals that constitutes earth's natural system that necessitates their conservation $^{203}$ where conservation effort should be taken to pay 'special attention to migratory species the conservation status of which is unfavourable, and taking individually or in cooperation appropriate and necessary steps to conserve such species and their habitat'. ${ }^{204}$ The indirect reference to only the biotic component of the ecosystem, and the restriction imposes by 'unfavourable status of conservation', are not particularly relevant to the interpretation of Article 20, especially when the invocation of this Article is not contingent on the conservation status of the ecosystems.

The objective of the Convention to Combat Desertification (CCD) is to 'combat desertification and mitigate the effects of drought in countries experiencing serious drought and/or desertification'. ${ }^{205}$ Although Article 3(c) calls for better understandings of the nature and value of land and scare water resources in affected areas, which indicates some relation to a possible recognition of an ecosystem concept, the problemcentric approach that aspires towards sustainable use ${ }^{206}$ is less useful in informing the interpretation of the obligation to preserve under Article 20.

Apart from the World Heritage Convention that concerns the conservation of natural heritage, including freshwater ecosystems, the other cited conventions undertake to conserve in order to address an environmental problem. Moreover, CITES addresses

\footnotetext{
202 CITES, supra n 199, preamble.

${ }^{203}$ CMS, supra $n$ 199, preamble.

${ }^{204}$ CMS, supra n 199, Art II.1.

${ }^{205}$ CCD, supra n 199, Art 2.1.

${ }^{206}$ CCD, supra n 199, Art 3(c).
} 
over-exploitation of endangered species through trade-related measures, which concerns the environment in general and has implications on the biotic component of the ecosystem, its provisions are less relevant for the interpretation of salient features of Article 20.

Drawing a distinction with the MEAs mentioned above, the Ramsar Convention and the Biodiversity Convention do not only specifically deal with freshwater ecosystems; they also address the conservation, including the preservation, aspect of ecosystem management. The use of 'wetlands' in Ramsar Convention and the specific emphasis on inland water of the Biodiversity Convention heightened the relevance of these Conventions in the interpretation of Article 20. Furthermore, Article 31(3)(c) of the 1969 Vienna Convention stipulates for the taking into account of 'any relevant rules of international law applicable in the relations between the parties' instead of 'all relevant rules' (author's emphasis), this indicates some measure of discretion exercisable by the interpreter undertaking the interpretation.

Based on these reasons, and due to the limitation of this thesis, the scope of the present research limits itself to the identification of rules under the Ramsar Convention and the Biodiversity Convention. ${ }^{207}$ However, in light of the current focus on the advent of climate change, and the predominant influence of the climate change regime ${ }^{208}$ in international environmental law discourse, this thesis outlines the possible implications of the climate change regime on the obligation to preserve addressed in this research.

The role played by the relevant rules of international law applicable in the relations between the parties in the interpretative process is illustrated by Orakhelashvili's general comment on Article 31(3)(c). He noted that 'the purpose of interpreting by reference to 'relevant rules' is, normally, not to defer the provisions being interpreted to the scope and effect of those 'relevant rules', but to clarify the content of the former by referring to the latter, ${ }^{209}$ This is found in the Navigational and Related Rights case ${ }^{210}$

\footnotetext{
${ }^{207}$ The relevance of the two Conventions will be further elaborated in Section 2.3 of this thesis.

208 The climate change regime is consisted of two major instruments, namely the United Nations Framework Convention on Climate Change (concluded 9 March 1992, entered into force 29 December 1992) (1992) 31 ILM 822 (hereinafter: 'UNFCCC'); and the Protocol to the United Nations Framework Convention on Climate Change, UN Doc FCCC/CP/1997/7/Add.1 (concluded 10 December 1997, entered into force 16 February 2005) (1998) 37 ILM 22 (hereinafter: 'Kyoto Protocol').

209 Alexander Orakhelashvili 'Restrictive Interpretation of Human Rights Treaties in the Recent Jurisprudence of the European Court of Human Rights' (2003) 14(3) European Journal Of International Law 529 - 568, at p 537. It is noted however that the difference between law and non-law (which is relevant for the interpretation of a subject matter) is in law's ability to 'steer the outcome or to alter or
} 
where the International Court of Justice (ICJ) presumed that the parties must have the intention to allow the meaning or content of terms used, or at least some of them, to include developments in international law. ${ }^{211}$ The ICJ arrived at this presumption when generic term like 'comercio' in Article VI of the 1858 Treaty are used by the parties in the treaty; ${ }^{212}$ and that the 1858 Treaty 'was entered into for an unlimited duration, which from the outset, was intended to create a legal regime characterised by its perpetuity'. ${ }^{213}$

The ICJ in Pulp Mills illustrated the need for an interpretation of a treaty provision that takes into account subsequent development in international law. The Court is of the view that the rules and measures adopted under Article 41 of the River Uruguay Statute should reflect the parties' international undertakings in respect of biodiversity and habitat protection as part of their obligation to preserve the aquatic environment. ${ }^{214}$ However, the ICJ rejected Argentina's contention to take into account the Ramsar and the Biodiversity Conventions based on the reason that these Conventions have 'no bearing on the scope of the jurisdiction conferred on the Court under Article 60 of the

influence what the law mandates' in an application in an adjudication. Joost Pauwelyn, 'Is it International Law or Not, and Does It Even Matter?' (26 February 2012). Forthcoming in Joost Pauwelyn, Ramses Wessel and Jan Wouters (eds) Informal International Lawmaking (Oxford University Press, 2012) <SSRN: http://ssrn.com/abstract=1950068> or <http://dx.doi.org/10.2139/ssrn.1950068> accessed 11 September 2012. The author, at p 36, stated that there are other views that 'see legal and other norms not as sealed-off compartments and takes the view that non-law may have a whole range of possible effects on what is law and how it should be interpreted and applied'. See further in Joost Pauwelyn, See Ramses A Wessel, and Jan Wouters (eds) Informal International Lawmaking (Oxford University Press Oxford 2012) at pp 153 - 155. Alan E Boyle, 'Some Reflections on the Relationship of Treaties and Soft Law' (1999) 48 International Comparative Law Quarterly 901 - 912. The author, at p 901 noted that 'Once soft law begins to interact with binding treaties its non-binding character may be lost or altered'. Pauwelyn suggested that 'International law, if it falls within international law, will no doubt be applied, as such to support a claim of violation or legal defence by influencing the enforcement of other treaties or the settlement of other disputes through legal interpretation (as referred to in Article 31.3(c) as relevant rules of international law applicable [in the relations] between the parties'.

${ }^{210}$ Dispute regarding Navigational and Related Rights (Costa Rica v Nicaragua) (Judgment, 13 July 2009) \{2009] ICJ Reports 213 (hereinafter: 'Navigational and Related Rights' case') at p 242 para 64 <http://www.icj-cij.org/docket/files/133/15321.pdf> accessed 1 January 2011.

${ }^{211}$ Navigational and Related Rights' case, supra $\mathrm{n}$ 210, at p 244, para 70. The Court concludes that 'the terms by which the extent of Costa Rica's right of free navigation has been defined, including in particularly the term 'comercio', must be understood to have the meaning they bear on each occasion on which the Treaty is to be applied, and not necessarily their original meaning. Thus, even assuming that the notion of 'commerce' does not have the same meaning today as it did in the mid-nineteenth century, it is the present meaning which must be accepted for purposes of applying the Treaty'.

${ }^{212}$ Navigational and Related Rights' case, supra n 210, at p 243, paras 66 and 67.

${ }^{213}$ Navigational and Related Rights' case, supra n 210, at p 243, para 67.

214 Pulp Mills' case, supra n 1, at p 74, para 262. The Court, at pp $60-61$ opined that the obligation to protect and preserve aquatic environment under Art 41(a) and (b) of the River Uruguay Statute has to be interpreted - 'in accordance with a practice, which in recent years has gained so much acceptance among States that it may now be considered a requirement under general international law to undertake an environmental impact assessment where there is a risk that the proposed industrial activity may have a significant adverse impact in a transboundary context, in particularly, on a shared resource'. 
1975 Statute, which remains confined to disputes concerning the interpretation or application of the Statute'. 215

Despite suggesting the need to interpret a treaty provision in accordance with the development of international law, the Court has not showed clearly how a recent development of international law is incorporated or used in the interpretation of a treaty provision. The shortcoming as noted in the case of Pulp Mills confirms the need to provide a necessary mechanism that guides how an external rule of international law developed subsequent to the conclusion of a treaty can be incorporated, or in aid of the interpretation of the terms of a treaty.

In order to undertake the research as described in the preceding paragraphs, the next section presents the methodology undertaken in this research.

\subsection{Methodology}

A doctrinal study on a rule of interpretation is adopted in this research. The focus of research is the operationalisation of Article 31(3)(c) and its application in the systemic integration of rules of international law relevant to the obligation to preserve ecosystems of international watercourses expressed in Article 20 of the 1997 Watercourses Convention through the technique of interpretation. ${ }^{216}$ The analytical framework engages the interpretive technique as a tool of integration in order to address the fragmented and congested state of environmental protection treaties.

This research complements the existing initiatives to enhance synergies and promote coordination in the governance of the environment; and reinforces the interlinkages struck between MEAs. The outcome of this research is desirous of extending the procedural interlinkages in operation to the substantive integration of rules of international law through the technique of interpretation.

\footnotetext{
${ }^{215}$ Pulp Mills' case, supra n 1, at p 30, para 66. This point is elaborated in Section 1.1.2 of this thesis.

${ }^{216}$ Fragmentation Report, supra n 17, at p 207, para 411: '[In order not to render a treaty duly adopted or a custom followed by States to become in some respect altogether without legal effect], this has been achieved in particularly through two techniques. First is the effort to harmonise the apparently conflicting norms by interpreting them so as to render them compatible. Second is the technique whereby the question of validity has been replaced by a question of priority. The norm that will be set aside will remain as it were "in the background", continuing to influence the interpretation and application of the norm to which priority has been given'.
} 
The fragmentation of international law related to the protection and preservation of freshwater ecosystem is examined through an analysis of two key areas of regime overlap:

1. The relationship between the MEAs under the international environmental law regime, bearing in mind the fragmentation of international law within the regime itself whereby although these MEAs operates under the aegis and overarching umbrella of international environmental law, the objectives and purposes of each treaty regime are different; and

2. The interactions between the environmental protection regime of international environmental law and the utilisation of natural resource regime of international water law.

The methodology engaged in the thesis is tiered, and carefully developed through the analytical framework established in this research. The three stages of the methodology developed are -

1. Identification of relevant rules of international law. An ecosystem approach will be undertaken to identify the components of ecosystem in the environment that are related to the protection and preservation of freshwater resources, and the components of the environment that will be affected by the utilisation of the waters. The relevant provisions related to the protection and preservation of the environment or the freshwater ecosystem in particularly will be identified and elaborated. Article 38 of the Statute of International Court of Justice on the determination of source of international law will be used in the determination of what constitute the sources of 'law'.

2. An interactional understanding of law for the determination of the corpus of interpretation of 'rules of international law' and their 'applicability' in the relations between 'the parties'. The relationship between the core text of the treaty instruments used and the accompanying 'peripheral' rules declared in the Conference of Parties or decisions of Commissions will be studied. This stage also determines the normative content of these soft laws in the interpretation and application of the applicable law.

3. Systemic integration. This stage is crucial in illustrating the extent to which systemic integration is permissible under Article 31(3)(c), and the limits imposed by the terms of Article 31(3)(c). The context of the interpreted treaty qualifies and delimits the extent to which external treaties could be incorporated 
in the interpretation of the interpreted treaty terms or provisions, whereby the normative weight of incorporation is set at the level of 'shall be taken into account'. The compulsory nature is evident in the term 'shall', where 'account' denotes a level less than displacement of original term of interpretation. It will be interesting to note the contribution of this process of integrative interpretation on the progressive development of these general principles of international law. $^{217}$

The methodology developed informs the establishment of the analytical framework in the next section that provides the structure in which the research questions, developed in this thesis will be investigated and ultimately answered.

\subsection{Analytical Framework}

There is a need to adopt a system-sensitive, harmonious approach on the obligation to preserve in order to address these problems caused by the fragmentation and congestion of treaties, and promotes and facilitates integration and coordination of rules that originate from different legal orders or treaty regimes. ${ }^{218}$ The engagement of the legal mechanism of treaty interpretation that directs an interpretation of a treaty provision in its normative environment is one such approach in order to attain a systemic integration of rules relevant to the obligation to preserve ecosystems of international watercourses.

The analytical framework for this research is built on Article 31(3)(c) of the 1969 Vienna Convention, which expressed the general principle of treaty interpretation, namely that of 'systemic integration' within the international legal system. ${ }^{219}$ This principle deals with the plurality of rules and principles in the context of treaty interpretation whereby international obligations 'are interpreted by reference to their normative environment (“system"), ${ }^{220}$

\footnotetext{
${ }^{217}$ The importance of the effect of other international treaties or regimes on the interpretation of another treaty regime is highlighted in Rieu-Clarke, 'The Role of Treaties in Building International Watercourse Regimes', supra n 136, at p 829. Quoting the author: 'Last and closely related to the need for more multilevel legal analysis is to a call to understand better the influence of law, not only in articulating the collective interests of states, but also in, "establishing what counts as persuasive argument or rhetoric".' The author raised some questions that this research strived to answer. The questions are: 'can global or regional agreements influence the negotiation of basin-specific treaties and if so how and to what extent? Also, how does the particular process or content of a treaty affect its compliance pull?'

${ }^{218}$ The importance of the issues raised is explored in Maduro, 'Foreword', supra $\mathrm{n} 98$.

${ }^{219}$ McLachlan, 'The Principle of Systemic Integration', supra n 162, at p 280.

${ }^{220}$ Fragmentation Report, supran 17, at p 208, para 413.
} 
The next section provides a preliminary review of the existing interpretation of the salient aspects of Article 31(3)(c), where the prevailing construction of the interpretation of Article 31(3)(c) will be the starting point of analysis presented in subsequent chapters.

\subsubsection{Article 31(3)(c) of the 1969 Vienna Convention on the Law of Treaties: Preliminary Review}

The international law of treaties comes into operation after a state has made the decision to be bound by a treaty as a legal instrument of public international law that takes effect on the international level, where a breach will give rise to an instance of international responsibility. ${ }^{221}$ The Preamble of the 1969 Vienna Convention, which was signed at Vienna, 23 May 1969 and entered into force on 27 January 1980, recalls the fundamental role of treaties as a source of international law. It is a treaty on treaties that could be said to recapitulate the principal rules of public international law 'applicable to treaties between states, and to the mutual relations of states based upon treaties between them'. ${ }^{222}$

Part III of the 1969 Vienna Convention deals with the issue of observance, application and interpretation of treaties that intends to demonstrate the basic principle of pacta sunt servanda underpinning the whole law of treaties. Articles $31-33$ of the 1969 Vienna Convention set out the major rules of treaty interpretation for the interpretation of international treaties 'in good faith in accordance with the ordinary meaning of its terms in their context, in the light of the object and purpose of the treaty'.223

'Despite the care lavished on drafting, and accumulated experience, there is no treaty which cannot raise some question of interpretation'. ${ }^{224}$ The International Law Commission (ILC) asserted that rules appear to be compatible or in conflict 'as a result of interpretation'. ${ }^{225}$ The jurisdiction of the ICJ 'has been most frequently invoked for the purpose of interpreting treaties'. ${ }^{226}$ The practical necessity of the 'imperfections of language and the ineffable quality of human interaction' has thus dictated the

${ }^{221}$ Shabtai Rosenne, Practice and Methods of International Law (Oceana Publications, London, Rome, New York, 1984) at $\mathrm{p} 27$.

${ }_{222}$ Rosenne, Practice and Methods of International Law, supra $\mathrm{n} 221$, at $\mathrm{p} 30$.

${ }^{223}$ Rosenne, Practice and Methods of International Law, supra n 221, at p 33.

${ }^{224}$ Aust, Modern Treaty Law and Practice, supra n 183, at p 230.

${ }^{225}$ Fragmentation Report, supra $\mathrm{n} 17$, at p 207.

${ }^{226}$ Robert Jennings and Arthur Watts (eds), Oppenheim's International Law (Vol I, $9^{\text {th }}$ edn, Longman, Essex, 1992) at p 26. 
importance not of interpretation stricto sensu, 'but in what the interpretation requires: the application of law according to an the lucid adage of "Il n'y a pas d'application sans interpretation", 227 in the resolution of differences in international adjudications over the meaning of treaty provisions. ${ }^{228}$

Interpretation releases 'the exact meaning and the content of the rule of law that is applicable to a given situation ... [as] a sort of "logique au service du droit" concretised by an intellectual operation aiming to extract the legal solution that stands out at a given moment in time'. ${ }^{229}$ However, interpretation is 'an art, not an exact science', ${ }^{230}$ and 'appeals to the artistic rather than the scientific qualities of a lawyer'. ${ }^{231}$ It is 'a process involving the deployment of analytical and other skills [that] cannot be reduced to a few propositions capable of purely automatic application in all circumstances'. ${ }^{232}$ French observed that the issue of treaty interpretation has remained a 'deeply obscure and subjective process'. ${ }^{233}$ It was the obscurity and subjectivity in treaty interpretation that drove Lord McNair to observe that 'there is no part of the law of treaties which the textwriter approaches with more trepidation than the question of interpretation'. ${ }^{234}$

The principles of treaty interpretation, as reflected in Articles 31 to 33 of the 1969 Vienna Convention, are in many respects considered as a codification of existing customary international law. ${ }^{235}$ In particularly, Article 31 sets out, in four paragraphs, the overall logic of a progression of legal reasoning through concentric circles ${ }^{236}$ characteristic of an interpretative process. The ILC concluded that Draft Article 27 [now Article 31], when read as a whole, could not be 'regarded as laying down a legal

\footnotetext{
${ }^{227}$ Olivier Corten and Pierre Klein (eds.), The Vienna Conventions on the Law of Treaties: A Commentary (Oxford University Press, Oxford, New York, 2011) at p 806.

${ }^{228} \mathrm{~J}$ Romesh Weeramantry, Treaty Interpretation in Investment Arbitration (Oxford University Press, Oxford, 2012) at $\mathrm{p} 1$.

${ }^{229}$ Corten and Klein (eds.), The Vienna Conventions on the Law of Treaties: A Commentary, supra $\mathrm{n} 227$, at $\mathrm{p} 806$.

${ }^{230}$ ILC, 'Draft Articles on the Law of Treaties with Commentaries' (Text as adopted by the ILC at its $18^{\text {th }}$ Session) [1966] II Yearbook of International Law Commission 187 - 274, at p 218, para 4 $<$ http://untreaty.un.org/ilc/texts/instruments/english/commentaries/1_1_1966.pdf > accessed 14 February 2013.

${ }^{231}$ Corten and Klein (eds.), The Vienna Conventions on the Law of Treaties: A Commentary, supra $\mathrm{n} 227$, at pp $806-807$.

${ }^{232}$ Sinclair, The Vienna Convention on the Law of Treaties, supra $\mathrm{n} 272$, at $\mathrm{p} 153$.

${ }^{233}$ French, 'Treaty Interpretation and the Incorporation of Extraneous Legal Rules', supra n 148, at 281.

${ }^{234}$ Ian McNair, The Law of Treaties (Clarendon Press, Oxford 1961) at $\mathrm{p} 364$.

${ }^{235}$ Richard Gardiner, Treaty Interpretation (Oxford University Press, Oxford 2008) at p 14. See also Mark E Villiger, Customary International Law and Treaties: A Study of Their Interactions and Interrelations with Special Consideration of the 1969 Vienna Convention on the Law of Treaties (Martinus Nijhoff, Dordrecht, 1985) especially at pp $342-343$.

${ }^{236}$ Fragmentation Report, supra n 17, at p 233, para 463.
} 
hierarchy of norms for the interpretation of treaties ... [but] considerations of logic'.237 It is a matter of logic to start the process of interpretation with the meaning of the text where -

"'the ordinary meaning to be given to the terms of the treaty in their context and in the light of its object and purpose" should be the first element to be mentioned, followed by elements comprised in the "context" since they form part of or are intimately related to the text'. ${ }^{238}$

Elements extrinsic to the text and the context but obligatory in character, such as subsequent agreement regarding the interpretation; subsequent practice establishing the understanding of the parties on the interpretation; and relevant rules of international law applicable in the relations between the parties; should follow and not precede the text and the context. However, by the very nature of the obligatory character of these norms of interpretation, they could not be considered 'norms of interpretation in any way inferior to those which precede them'. 239

In light of the logical order of arrangement of these interpretative norms by the ILC, the present text sets out the architecture for the process of interpretation in Draft Article 27 [now Article 31] that represents a unity. Provisions of this Article 'form a single, closely integrated rule' where 'all the various elements ... would be thrown into the crucible, and their interaction would give the legally relevant interpretation'. ${ }^{240}$ Article 31(1) provides the interpretation of a treaty in good faith in accordance with the ordinary meaning given to the terms of the treaty in their context, as elaborated in Article 31(2), and in the light of its object and purpose.

Article 31(3) of the 1969 Vienna Convention addresses the insufficiency of the context of a treaty in the interpretation of a treaty provision, where it requires that account shall be taken, together with the context, subsequent interpretative agreements, subsequent practice of parties, and any relevant rules of international law applicable in the relations between the parties. ${ }^{241}$ The insertion of the phrase 'together with the context' in Article

\footnotetext{
${ }^{237}$ ILC, 'Draft Articles on the Law of Treaties with Commentaries', supra n 230, at p 220, para 9.

${ }^{238}$ ILC, 'Draft Articles on the Law of Treaties with Commentaries', supra n 230, at p 220, para 9.

${ }^{239}$ ILC, 'Draft Articles on the Law of Treaties with Commentaries', supra n 230, at p 220, para 9.

${ }^{240}$ ILC, 'Draft Articles on the Law of Treaties with Commentaries', supra n 230, at pp 219-220, para 8.

${ }^{241}$ The ILC observed that 'there is no reason to separate these techniques (of the interpretative process listed in Articles 31 - 32 that represents an effective sequence) too sharply from each other ... as sometimes external sources may usefully clarify the ordinary meaning of treaty words, or their object and
} 
31(3) emphasised that subsequent agreement, subsequent practice, and any relevant rules of international law applicable in the relations between the parties do not form part of the 'context' of a treaty. ${ }^{242}$

An analysis into the subparagraphs of Article 31(3) of the 1969 Vienna Convention reveals that even though subsequent agreement, subsequent practice and relevant rules of international law do not form part of the context as defined under Article 31(2), subparagraphs (a) and (b) of Article 31(3) are more closely related to the treaty as compared to subparagraph (c) of Article 31(3). The phrases of 'any subsequent agreement between the parties regarding the interpretation of the treaty or the application of its provision' in Article 31(3)(a), and 'any subsequent practice in the application of the treaty which establishes the agreement of the parties regarding its interpretation', are more closely related to the context of the treaty if compared to Article 31(3)(c).

Recourse is had to 'subsequent agreement between the parties regarding the interpretation of the treaty or the application of its provision' (author's own emphasis) as stipulated in Article 31(3)(a) for the clarification of the interpretation of a treaty term or provision. The subsequent agreement between the parties is concluded by the same parties to the treaty being interpreted, on the interpretation of the text of the treaty provision. In this situation, the subsequent agreement could be said to be " "quasi context" (context latissimo sensu), ${ }^{243}$ as it seeks to clarify the interpretation of a treaty provision of the treaty that is being interpreted, whereby the text forms part of the context of a treaty as stated in Article 31(2).

purpose'. Fragmentation Report, supra n 17, at p 216, para 248. However, Corten and Klein (eds.), The Vienna Conventions on the Law of Treaties: A Commentary, supra n 227, observed, at p 817 that 'the separation from the means codified in Art 32 implies that the supplementary means are first and foremost subsidiary'. Corten and Klein further observed, at pp 836 - 837 that the absence of hierarchy in the application of the rule of treaty interpretation codified under Articles 31 (and 32) of the Vienna Convention in the complex operation that constitutes treaty interpretation allows the exercise of creativity by interpreters where the ultimate difference is not the manner of interpretation but the competence of the interpreter. The relationship between subpara(c) of Art 31(3) and other subparagraphs of Art 31(3) is further explored in Section 3.2.2 of this thesis.

242 'Context' is limited to the text of a treaty, including its preamble and annexes, and any agreement or instruments accepted by the other parties as an instrument related to the treaty made in connection with the conclusion of the treaty as stated in Article 31(2)(a) and (b) of the 1969 Vienna Convention. A detailed analysis of the 'context' is undertaken in Section 7.2 of the thesis.

${ }^{243}$ This phrase is borrowed from Michael Waibel, 'Demystifying the Art of Interpretation' (2011) 22(2) The European Journal of International Law 571 - 588, at p 577. 
Similarly, 'subsequent practice in the application of the treaty which establishes the agreement of the parties regarding its interpretation' (author's own emphasis) as stated in Article 31(3)(b) could be said to be quasi-contextual. This is because the subsequent practice is executed by the parties in accordance with the agreement established by the parties regarding the interpretation of a treaty provision, in the course of the application of the treaty. ${ }^{244}$ Although subsequent practice undertaken by the parties is deemed quasi-contextual because it does not form part of the 'context' as defined under Article 31(2), it is still closely related to the context. This is due to the reason that the subsequent practice concretises the agreement of the parties regarding the interpretation of a treaty provision (which forms part of the text of a treaty) in practice.

The same could not be said for Article 31(3)(c) of the 1969 Vienna Convention. The phrase 'any relevant rules of international law applicable in the relations between the parties' has no direct or indirect reference to the text of the treaty being interpreted. These relevant rules of international law have their own text, preamble and annexes, as well as agreements or instruments made in connection with the conclusion of these rules of international law. The determination of the normative scope of the provision of these relevant rules of international law through the interpretation these rules requires the performance of all the principles of interpretation codified in Articles $31-32$ of the 1969 Vienna Convention. This is because these relevant rules of international law are completely extrinsic to the treaty being interpreted, as opposed to the quasi-contextual nature of subparagraphs (a) and (b) of Article 31(3). ${ }^{245}$

\footnotetext{
${ }^{244}$ For further discussion on 'subsequent practice', see Section 4.4 .3 of the thesis.

${ }^{245}$ In this regard, the author would like to differ from the position adopted by Isabelle van Damme, Treaty Interpretation by the WTO Appellate Body (Oxford University Press, Oxford, 2009). The author is of the opinion, at p 366 that 'other principles of treaty interpretation might justify the same result' in her comment on the limited value of Article 31(3)(c) of the 1969 Vienna Convention. The author justified her stance by stating, at p 382 that 'Panels and the Appellate Body have interpreted the WTO covered agreements in the light of the wider corpus of international law, with or (mostly) without Article 31(3)(c) VCLT'. On this point, it is earlier raised by the ILC in the Fragmentation Report, supra n 17, at pp $212-$ 213. The ILC, at p 212, para 422, commented that 'if that (other techniques provide sufficiently the need to take into account the normative environment where customary law, general principles of law and general treaty provisions forming the interpretative background for specific treaty provisions) were all article 31(3)(c) covered, it would have been unnecessary [to refer to article 31(3)(c)]'. However, the ILC asserted, at p 212, para 422 that the wording of Art 31(3)(c) 'is not restricted to general international law, but extends to any relevant rules of international law applicable in the relations between the parties'. This implies that Art 31(3)(c) provides for situation where other techniques are insufficient to attain systemic integration. The ILC elaborated, at p 212, para 423 that 'if ... all international law exists in systemic relationship with other law, no such application can take place without situating the relevant jurisdictionendowing instrument in its normative environment. This means that although a tribunal may only have jurisdiction in regard to a particular instrument, it must always interpret and apply that instrument in its
} 
The uniqueness of Article 31(3)(c) of the Vienna Convention that makes it the focus of this study lies in the fact that this Article enables the taking into account of any relevant rules of international law applicable in the relations between the parties, which are extrinsic to a contextual interpretation of a treaty provision. Its systemic integration potential goes beyond a contextual interpretation that could be informed by the quasicontextual elements of subsequent agreement, subsequent practice, or the prescription of a special meaning to a treaty term by the parties. Article 31(3)(c) is the 'clearest formal expression of the systemic nature of international law' where it is suggested that 'the Article operates as a "master key" to the house of international law [i]n the case [of] a systemic problem ... and no other interpretative means provides a resolution' ${ }^{246}$ The systemic integration potential expressed in Article 31(3)(c) provides an aperture through which the difficulties arising from the fragmentation of international law that results in 'a multitude of parallel' could be addressed. ${ }^{247}$ The ILC opined that -

"if the article is merely the expression ... of "systemic integration" - and if that principle, again, expresses a reasonable or even necessary aspect of the practice of legal reasoning, then a discussion of its actual and potential uses would constitute a useful contribution to the study of the alleged fragmentation (or diversification) of international law, ${ }^{248}$

The explicit reference to other rules of international law in Article 31(3)(c) enables the incorporation of treaty obligations beyond the context of a treaty, but relevant and applicable between the parties in the interpretation of a treaty provision. This capacity is crucial for the purpose of this thesis, which seeks to study the role of interpretation as a mechanism that enables a reasoned resolution of the difficulties of the fragmentation of international law. This is so in light of the need to maintain the 'perceived purposes or functions of the legal system as a whole ${ }^{249}$ that strongly favours the presumption against normative conflict. ${ }^{250}$

The actual and latent potential of Article 31(3)(c) have been studied extensively by the ILC due to the 'flowering of case law' that refers to Article 31(3)(c), which initially,

relationship to its normative environment - that is to say "other" international law. This is the principle of systemic integration to which article 31(3)(c) VCLT gives expression'.

${ }^{246}$ Fragmentation Report, supra n 17, at p 211, para 420.

${ }^{247}$ Refer supra n 14.

${ }^{248}$ Fragmentation Report, supra n 16, at p 213, para 423.

${ }^{249}$ Fragmentation Report, supra n 17, at p 25, para 36.

${ }^{250}$ Fragmentation Report, supra n 17, at p 25, para 37. 
was meant to address the issue of inter-temporal law. ${ }^{251}$ However, it has shown to have the capacity to become applicable in a greater variety of circumstances than its origins would suggest, especially amidst the apprehension over the undesirable effect of a fragmented international legal order as a result of the diversification of international law, and the need to manage the fragmentation in a legal-professional way.

Article 31(3)(c) provides that 'there shall be taken into account, together with the context ... any relevant rules of international law applicable in the relations between the parties'. This provision was said to codify, or at least, to reflect the principle of systemic integration. ${ }^{252}$ A textual analysis of the article reveals five aspects of emphasis: ${ }^{253}$

\section{1. 'Relevant'}

The rules all appear to address the same facts, or concerning the subject matter of the treaty term at issue ${ }^{254}$ or 'chains of treaties that grapple with the same type of problem at different levels or from particular (technical, geographical) points of view'. ${ }^{255}$ The existence of rules that address the same facts or grapple with the same type of problem, although the relevance might be obscured by the different level or technical perspective these rules address, ${ }^{256}$ creates what is known as a 'parallelism of treaties ${ }^{, 257}$ where the need to coordinate the reading of these instruments in 'mutually supportive light' is exceedingly important. ${ }^{258}$

\section{2. 'Rules'}

The 'rules' of international law referred to must be rules of law, and not broader principles or considerations which may not be firmly established as rules. Such rules cover all the sources of international law, ${ }^{259}$ including custom, general principles, and

${ }^{251}$ Gardiner, Treaty Interpretation, supra $\mathrm{n} 235$, at $\mathrm{p} 251$.

${ }^{252}$ McLachlan, 'The Principle of Systemic Integration', supra n 162. See also French, 'Treaty Interpretation and the Incorporation of Extraneous Legal Rules', supra n 148.

${ }^{253}$ McLachlan, 'The Principle of Systemic Integration', supra n 162, at p 290. Also Fragmentation Report, supra $\mathrm{n} 17$, at $\mathrm{p} 214$, para 426.

${ }^{254}$ Mark E Villiger, Commentary on the 1969 Vienna Convention on the Law of Treaties (Martinus Nijhoff Publishers, Netherlands, 2009) at p 433, para 24.

${ }^{255}$ See Fragmentation Report, supra n 17, at pp 209 -210, para 416.

${ }^{256}$ Fragmentation Report, supra n 17, at pp 209 -210, para 416.

${ }^{257}$ Bluefin Tuna case, supra $\mathrm{n} 120$, at para 52

${ }^{258}$ Fragmentation Report, supra $\mathrm{n} 17$, at $\mathrm{p} 210$, para 417

${ }^{259}$ Sources of law includes that the sources identified under Art 38(1) of the Statute of the International Court of Justice (1945) 29 American Journal of International Law Supp 215; 3 Bevans 1179; 59 Stat 1031; TS 993. 
where applicable other treaties, and also, subject to Article 59 of the ICJ Statute, judicial decisions and the teaching of the most highly qualified publicists.

\section{3. 'Applicable in the relations between the parties'}

Further research is needed to determine what the context for 'applicable' is and who the parties are. ${ }^{260}$ Preliminary research shows that for the rules to be 'applicable', they must be binding. ${ }^{261}$ McGrady suggested that the 'applicability' of the 'rule of international law applicable in the relations between the parties', by reference to the definition of 'the party' in Article 1(g) of the 1969 Vienna Convention ${ }^{262}$, refers to questions of scope of whether the extraneous rule applies to the circumstance under consideration. ${ }^{263}$ Interpretation of 'the parties' attracted more controversy with the most restrictive view adopted by the panel in the EC-Biotech case. ${ }^{264}$

4. 'Shall be taken into account'

Customary law and general principles external to the treaty exist as lex generalis in relation to any particular agreements. Although they are rarely specifically mentioned, these customary law and general principles are applied alongside particular treaties. ${ }^{265}$ Special reference to the use of Article 31(3)(c) arises in the circumstance whereby recourse to 'rules that exist at the same level of generality and binding force as the treaty to be interpreted ${ }^{266}$ are made in the interpretation of the treaty to be applied. The

\footnotetext{
${ }^{260}$ See Benn McGrady, 'Fragmentation of International Law or "Systemic Integration" of Treaty Regimes: EC-Biotech Products and the Proper Interpretation of Article 31(3)(c) of the Vienna Convention on the Law of Treaties', (2008) 42 Journal of World Trade 589 - 618. See a contrary account by Ulf Linderfalk, 'Who are 'The Parties'? Article 31, Paragraph 3(c) of the 1969 Vienna Convention and the 'Principle of Systemic Integration’ Revisited’, (2008) 55 (3) Netherlands International Law Review 343 - 364.

${ }^{261}$ Villiger, Commentary on the 1969 VCLT, supra n 254, at p 433, para 24.

${ }^{262} 1969$ Vienna Convention, supra n 31, Art 1(g). 'Party' was defined in Art 1(g) to mean 'a State which has consented to be bound by the treaty and for which the treaty is in force'.

${ }^{263}$ McGrady, 'Fragmentation of International Law', supra n 260, at p 612. It is further elaborated in pp 612 - 613 that, 'in adopting this approach (where applicability is a question of scope), the question of applicability is distinct from the question of relevance. Relevance concerns the question of whether an extraneous treaty can influence interpretation, whereas applicability concerns whether the relevant rules extends to the circumstances at hand'.

${ }^{264}$ EC- Biotech, supra n 117, at pp 299-300, paras, 7.68 - 7.70, quoted in the Fragmentation Report, supra n 17, at p 237, para 471. McGrady, 'Fragmentation of International law', supra n 260. McGrady suggested three approaches for the interpretation of 'the parties', and the merits and possible implications of these approaches. The three approaches suggested are, the restrictive approach, the divergent approach and the broad approach. For more on 'restrictive approach', see Joost Pauwelyn, 'The Role of Public International Law in the WTO: How Far Can We Go?' (2001) 95 American Journal of International Law 535 - 578; and McLachlan, 'The Principle of Systemic Integration', supra n 162.

${ }^{265}$ See Fragmentation Report, supra n 17, at p 233, para 462, first limb.

${ }^{266}$ See Fragmentation Report, supra n 17, at p 233, para 462, second limb.
} 
significance of 'taking into account the relevant rules ${ }^{267}$ lies in 'its performance of a systemic function in the international legal order, linking specialized parts to each other and to universal principles'. ${ }^{268}$ Analysis is on the normative weight to be given to a particular right and obligation under the rules applicable in the balancing process of 'taking into account'. However, this question can only be addressed by a 'case-by-case basis', with the aim not to triumph one norm over another, but to seek the accommodation of values. ${ }^{269}$

\section{The element of temporality}

Inter-temporal law made a short-lived appearance at the initial stage in the form of Article 56 of the 1969 Vienna Convention in Sir Waldock's third Special Rapporteur Report, ${ }^{270}$ where extensive reference was made to the inter-temporal law formulated by Judge Huber in the Island Palmas Case. ${ }^{271}$ It was designed originally to address the

2671969 Vienna Convention, supra n 31, Art 31(3)(c).

${ }^{268}$ Fragmentation Report, supra n 17, at pp 239 - 240, para 473.

${ }^{269}$ Adapted from the Fragmentation Report, supra n 17, at p 240, para 474, in reference to the Case Concerning the Arrest Warrant of 11 April 2000 (Democratic Republic of the Congo v. Belgium) [2002] ICJ Reports 3 (hereinafter: 'Arrest Warrant case') <http://www.icj-cij.org/docket/files/121/8126.pdf> accessed 9 April 2012. Joint separate opinion of Judges Higgins, Kooijimans and Burgenthal, at pp 86 87 , para 79.

${ }^{270}$ ILC 'Third Report on the Law of Treaties by Sir Humphrey Waldock, Special Rapporteur' (3 March, 9 June, 12 June and 7 July 1964) UN Doc A/CN.4/167 and Add. 1-3, (1964) II(1) Yearbook of the International Law Commission 5- 65 (hereafter: 'Waldock's $3^{\text {rd }}$ Report') at p 9 <http://untreaty.un.org/ilc/documentation/english/a_cn4_167.pdf> last accessed 26 January 2011. Art 56 provides that:

Art 56 - The Inter-temporal law

1. A treaty is to be interpreted in the light of the law in force at the time when the treaty was drawn up

2. Subject to paragraph 1 , the application of a treaty shall be governed by the rules of international law in force at the time when the treaty is applied.

${ }^{271}$ Island of Palmas Case (Netherlands, USA) (Award of 4 April 1928) (1928) II Reports of International

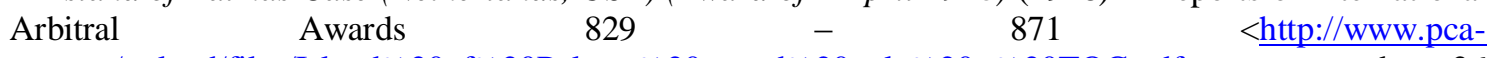
cpa.org/upload/files/Island\%20of\%20Palmas\%20award\%20only\%20+\%20TOC.pdf> $\quad \begin{array}{ll}\text { accessed } & 26\end{array}$ January 2011 (hereinafter: 'Island Palmas case'). The main elements of the inter-temporal law is firstly, the principle of contemporaneity, where 'a juridical fact must be appreciated in the light of the law contemporary with it, and not of the law in force at the time when a dispute in regard to it arises or falls to be settled'. Island Palmas case, $\mathrm{p}$ 845. The principle of contemporaneity is defined in Waldock ${ }^{\text {rd }}$ Report, at p 56, para 12, by reference to Sir Gerald Fitzmaurice's formulation based on the jurisprudence of the World Court, as 'the terms of a treaty must be interpreted according to the meaning which they possessed, or which would have been attributed to them, and in the light of current linguistic usage, at the time when the treaty was originally concluded'. Secondly, the second limb, and also the more controversial limb, is the so-called 'extension' of the doctrine, 'which subjects the act creative of a right arises, demands that the existence of the right, in other words its continued manifestation, shall follow the conditions required by the evolution of the law'. Waldock $3^{\text {rd }}$ Report, at p 9, para 4, quoted Judge Huber in the Island Palmas case, at $\mathrm{p}$ 845. Judge Huber emphasized that "a distinction must be made between the creation of rights and the existence of rights", at $\mathrm{p}$ 845. This extension of the doctrine was criticised on grounds of instability resulting from such extension, for more see Philip C Jessup, 'The Palmas Island Arbitration', (1928) 22 American Journal of International Law 735 - 752; and Anthony D'Amato, 'International Law, Intertemporal Problems' in (1992) Encyclopedia of Public International Law 1234-1236, p 1235 where it is stated that: 'Huber's "extension" of the doctrine of inter-temporal law, therefore, has not been generally 
temporal aspect of treaty interpretation to reflect the general principle that 'a juridical fact must be appreciated in the light of the law contemporary with it'. ${ }^{272}$ However, the Commission decided to omit the phrase 'in force at the time of its conclusion' because it was deemed inadequate to address the problem of the effect of an evolution of the law on the interpretation of legal terms in a treaty. ${ }^{273}$ This provision was subsequently inserted to the current position of paragraph 3 to Article 27 [now Article 31(3)(c)] that is 'extrinsic both to the text and to the "context" as defined in paragraph 2 '. ${ }^{274}$

The debate in the ILC over the issue of inter-temporality has remained inconclusive. ${ }^{275}$ The importance of the inter-temporal aspect to all treaties dealing with projects that impact on the environment is firmly emphasised in the Gabčíkovo-Nagymaros case by Judge Weeramantry, where the Judge lamented the failure of article 31(3)(c) of 1969 Vienna Convention, which 'scarcely covers this aspect with the degree of clarity requisite to so important a matter'. ${ }^{276}$ The lacuna is exceptionally pronounced in the environmental regime where environmental concerns are live and continuing concerns regardless of the date of the treaty is concluded, which necessitates the application of

accepted. If it were not for the prominence of the Palmas Island case, there would probably be no confusion regarding the general principle that, with respect to title and treaty questions arising in the distant past, the rules of international law that are applicable are those contemporaneous with the acts in question'. However, criticism seems to emphasise the need for care in the application of the rule, see Ian Brownlie, Principles of Public International Law $\left(6^{\text {th }}\right.$ edn, Oxford University Press, Oxford, 2003) at $\mathrm{p}$ 125. It is stated that: 'In any case the principle cannot operate in a vacuum: its theoretical extent will in practice be reduced by the effect of recognition, acquiescence, estoppels, prescription, the rule that abandonment is not to be presumed, and the general condition of the pleadings and evidence'.

${ }^{272}$ Ian Sinclair, The Vienna Convention on the Law of Treaties $\left(2^{\text {nd }}\right.$ edn, Manchester University Press, Manchester, 1984) at pp 138 - 139. At p 139, Sir Sinclair elaborated that 'Reference to 'relevant rules of international law' means, 'every treaty provision must be read not only in its context, but in the wider context of general international law, whether conventional or customary'. He commented that 'there is some evidence that the evolution and development of international law may exercise a decisive influence on the meaning to be given to expressions incorporated in a treaty, particularly if these expressions themselves denote relative or evolving notions such as "public policy" or "the protection of morals".

${ }^{273}$ Sir Arthur Watt, The International Law Commission, 1949 - 1998 (vol. II, Oxford University Press, Oxford, 1999) at p 690. Sir Arthur Watts recounted the decision of the ILC to remove the phrase since it considers that 'the relevance of rules of international law for the interpretation of treaties in any given case was dependent on the intentions of the parties, and that to attempt to formulate a rule covering comprehensively the temporal element would present difficulties. It further considered that correct application of the temporal element would normally be indicated by interpretation of the term in good faith'. See also Shabtai Rosenne, Developments in the Law of Treaties, 1945 - 1986 (Cambridge University Press, Cambridge, 1989) at pp $76-79$.

2741994 Draft Articles and Commentaries, supra n 44, at p 220, para 9.

275 McLachlan, 'The Principle of Systemic Integration', supra n 162, at p 293.

${ }^{276}$ Gabčíkovo-Nagymaros case, supra n 1, at p 114. 
relevant environmental standards at the time of interpretation, and 'not limited to the rules of international law applicable at the time the treaty was concluded'. 277

In relation to the issue of temporality, it is recognised that the application of external rules of international law via Article 31(3)(c) is a risky issue, especially in terms of the 'formal legitimacy' of rules. ${ }^{278}$ It is argued that application of an external rule is justified in a situation where the said rule has risen to the level of a 'contemporary concern of the community of nations'; 'a widely recognised principle' or a 'broad-based recognition of a particular need'. ${ }^{279}$

The ICJ renders support for the need to interpret and apply certain provisions of a treaty in the light of international law as it has evolved since the conclusion of the treaty, albeit with caution where limits are carefully prescribed. In the case of Namibia, the Court concluded that the parties to the Covenant must have accepted the evolutionary character of the concepts adopted in the treaty provision. ${ }^{280}$ The Court opined that the provision should then be interpreted and applied within the framework of the entire legal system prevailing at the time of the interpretation, which 'takes into consideration the changes occurred through the subsequent development of law'. ${ }^{281}$

${ }^{277}$ Gabč́́kovo-Nagymaros case, supra n 1, Separate Opinion of the Vice-President Weeramantry, at p 114. Judge Weeramantry substantiated his observation on the inter-temporality aspect by reference to the case of Legal Consequences for States of the Continued Presence of South Africa in Namibia (South West Africa) notwithstanding Security Council Resolution 276 (1970) (Advisory Opinion of 21 June 1971) [1971] ICJ Reports 16, at p 31, para 53 <http://www.icj-cij.org/docket/files/53/5595.pdf> accessed 26 January 2011.

${ }^{278}$ This concern is addressed in Donald K Anton, "Treaty Congestion" in Contemporary International Environmental Law', supra n 107, at p 664. The author noted that 'cross-fertilisation in the international legal system must account for the consensual nature of international law. This makes borrowing and applying rules of decision outside of consent more difficult'.

${ }^{279}$ Malgosia Fitzmaurice, Olufemi Elias, and Panos Merkouris (eds) Treaty Interpretation and the Vienna Convention on the Law of Treaties: 30 Years on (Queen Mary Studies in International Law, Martinus Nijhoff, 2010) at p 237.

${ }^{280}$ Namibia case, supra n 277, at p 31, para 53. The Court is mindful of the primary necessity of interpreting an instrument in accordance with the intentions of the parties at the time of its conclusion, but it is "bound to take into account the fact that the concepts embodied in Art 22 of the Covenant - "the strenuous conditions of the modern world" and "the well-being and development" of the peoples concerned - were not static, but were by definition evolutionary, as also, therefore, was the concept of the "sacred trust"". The parties to the Covenant must consequently be deemed to have accepted them as such. That is why, viewing the institutions of 1919, the Court must take into consideration the changes which have occurred in the supervening half-century, and its interpretation cannot remain unaffected by the subsequent development of law, through the Charter of the United Nations and by way of customary law. Moreover, an international instrument ahs to be interpreted and applied within the framework of the entire legal system prevailing at the time of the interpretation'.

${ }^{281}$ The Court, in the Namibia case, supra n 277, at p 31, para 53, enunciated that 'Mindful as it is of the primary necessity of interpreting an instrument in accordance with the intentions of the parties at the time of its conclusion, the Court is bound to take into account that concepts embodied in Art $22 \ldots$ were not static, but were by definition evolutionary ... The parties must consequently be deemed to have accepted 
Reconciliation between the two assertions, of the application of the principle of contemporaneity and the application of the extension of the principle of contemporaneity that allows evolutionary interpretation of a treaty term at the point of interpretation, is difficult and very much depends on the nature of the treaty interpreted. The nature of the treaty interpreted is indicated by the intention of the parties, which is the determining factor in the application of second limb of the inter-temporal law that allows for evolutionary interpretation. ${ }^{282}$ An evolutionary interpretation is permissible in 'interpreting certain terms in a treaty which are by their very nature expressed in such general terms as to lend themselves to an evolutionary interpretation, ${ }^{283}$ to the extent that such interpretation is not contrary to the intentions and expectations of the parties. ${ }^{284}$ The issue of inter-temporality will be addressed in later chapters in the ascertainment of the common intentions of the parties.

The preliminary review of current scholarship on the interpretations the five salient features of Article 31(3)(c) of the 1969 Vienna Convention demonstrates the potential of this Article as a tool of integration. As illustrated in the foregoing section, the provision is worded in such a way that permits an integrated approach to be adopted in the interpretation of a treaty term or provision in the light of its normative environment. The systemic integration potential of the Article that could assume the role of an integration tool is further discussed in the next section.

them as such. That is why ... the Court must take into consideration the changes which have occurred in the supervening half-century, and its interpretation cannot remain unaffected by the subsequent development of law, through the Charter of the United Nations and by way of customary law. Moreover, an international instrument has to be interpreted and applied within the framework of the entire legal system prevailing at the time of the interpretation'.

${ }^{282}$ This conclusion is arrived by the Court in the Namibia case, supra $\mathrm{n}$ 277, at p 31, para 53: 'the parties must consequently be deemed to have accepted them as such'. This is reiterated in the case of Navigational and Related Rights, supra n 210, at p 242, para 64: 'there are situations in which the parties' intent upon conclusion of the treaty was, or may be presumed to have been to give the terms used - or some of them - a meaning or content capable of evolving, not one fixed once and for all, so as to make allowance for, among other things, developments in international law'; further elaboration found at p 243, para 66: 'where the parties have used generic terms in a treaty, the parties necessarily having been aware that the meaning of the terms was likely to evolve over time, and where the treaty has been entered into for a very long period or is 'of continuing duration', the parties must be presumed, as a general rule, to have intended those terms to have an evolving meaning'.

${ }^{283}$ Sinclair, The Vienna Convention on the Law of Treaties, supra n 272, at p 140.

${ }^{284}$ Hugh Thirlway, 'The Law and Procedure of the International Court of Justice 1960-1989: Part Three' (1991) 62 British Yearbook of International Law 1 - 75, at p 57: 'where it can be established that it was the intention of the parties that the meaning or scope of a term or expression used in the treaty should follow the development of the law, the treaty must be interpreted so as to give effect to that intention'. Thirlway employed the term 'intertemporal renvoi' to describe the situation that arises when the intention of the parties is deemed to have been 'to subject the legal relations created to such law as might from time to time thereafter become effective'. Hugh Thirlway, 'The Law and Procedure of the International Court of Justice: 1960-1989, Part One’ (1989) 60 British Yearbook of International Law 1 - 157, at p 135. 


\subsubsection{The Potential of Article 31(3)(c) as an Integration Tool}

The principle of systemic integration, ${ }^{285}$ said to be codified or reflected in Article 31(3)(c) of the 1969 Vienna Convention, indicates the potential of this provision as an integration tool ${ }^{286}$ that plays a bridging role between a rule and its normative system 'whereby international obligations are interpreted by reference to their normative environment'. ${ }^{287}$ This is reiterated by the Appellate Body (AB) in the recent WTO case of EC - Aircraft where the AB noted that -

'We recognize that a proper interpretation of the term "the parties" must also take account of the fact that Article 31(3)(c) of the 1969 Vienna Convention is considered an expression of the 'principle of systemic integration'. [It] seeks to ensure that 'international obligations are interpreted by reference to their normative environment in a manner that gives 'coherence and meaningfulness' to the process of legal interpretation'.288

In addressing the potential conflict between norms of different specialised regimes, the ILC suggested to take recourse to the interpretative tools provided in the 1969 Vienna

\footnotetext{
${ }^{285}$ Systemic integration is defined to mean 'the integration in the system of principles and presumptions that underlie the idea of an inter-State legal order and provide its argumentative materials'. See Fragmentation Report, supra n 17, at p 234, para 465. The two presumptions mentioned are: (a) Positive. Parties are taken 'to refer to general principles of international law for all questions which [the treaty] does not itself resolve in express terms or in a different way' (Georges Pinson (France v. United Mexican States) (Award of 13 April 1928) (1928) V Reports of International Arbitral Awards 327 - 466) at p 422; and (b) Negative. In entering into treaty obligations, the parties intend not to act inconsistently with generally recognize principles of international law or with previous treaty obligations towards third States. (Case Concerning the Right of Passage over Indian Territory (Portugal v India) (Preliminary Objections Judgment of 26 November 1957) [1957] ICJ Reports 125 (hereinafter: 'Right of Passage case') at p 142, <http://www.icj-cij.org/docket/files/32/2231.pdf> accessed 26 January 2011). See Vassilis P Tzevelekos, 'The Use of Article 31(3)(c) of the VCLT in the Case Law of the ECtHR: An Effective AntiFragmentation Tool or A Selective Loophole for the Reinforcement of Human Rights Teleology? Between Evolution and Systemic Integration' (2010) 31 Michigan Journal of International Law 621 - 690. At $\mathrm{p}$ 633, it is stated: 'Systemic integration has two implications. In addition to implying that special international law is, by means of interpretation, harmonically integrated within the general system, it also suggests that the process of harmonious integration enables the system of international law to become more complete, firm, compact and uniform -or, in a word, integrated'.

286 Interpretation is an important approach in seeking integration of different legal regimes. For interpretation as tools of integration, see Boyle, 'Relationship', supra n 159, at pp 128-132.

${ }^{287}$ Fragmentation Report, supra n 17, paras $410-480$, in particularly para 413. This method of interpretation accords that 'each instrumentum of international law must be interpreted and applied in a manner that safeguards harmony within the broader normative environment - that is, the international legal order'. Tzevelekos, 'The Use of Article 31(3)(c)', supra n 285. At p 280, the author commented that 'Treaties are creatures of international law and despite its diverse subject matter, it should be 'applied and interpreted against the background of the general international law'.

${ }^{288}$ WTO, European Communities and Certain Member States - Measures Affecting Trade in Large Civil Aircraft (Appellate Body Report, 18 May 2011) WT/DS316/AB/R (hereinafter: 'EC - Aircraft'), at p 363, para 845.
} 
Convention, especially Article 31(3)(c), where 'any relevant rules of international law applicable in the relations between the parties' in the adjudication of the dispute. ${ }^{289}$ By taking into account other treaties or legal norms in the interpretation and application of a treaty term or provision, this legal technique will assist in conflict avoidance between agreed norms (prior to the formation of a 'conflict'), or in the event of conflict, in dispute resolution. Properly employed, Article 31(3)(c) will feature greatly as a useful tool for treaty integration, ${ }^{290}$ where a dynamic approach to interpretation that allows the harmonious interpretation of relevant rules enables evolution of rules enshrined in treaties, to change over time and in accordance with new relevant rules of international law' ${ }^{291}$ This enables the reconciliation of the plurality of norms that apply to the same subject matter, and leads to the harmonisation of environmental treaties and enhances the conformity of the international legal system.

In view of the systemic integration potential intrinsic to Article 31(3)(c), this thesis proposes a re-interpretation of salient features of the Article in order to realise its potential, which is currently heatedly contested. The next section lays out the overall structure of this thesis.

\section{$1.7 \quad$ Structure}

Chapter 1 has given a brief overview of the problématique arising from the fragmentation of international law, which forms the context of the research, introduced

\footnotetext{
${ }^{289}$ See Pauwelyn, 'Bridging Fragmentation and Unity', supra n 132, at pp 906 - 907. It is stated that 'when a treaty leaves room for interpretation, an attempt must be made to read it in a way harmonious with other treaties. This is called for explicitly in Art 31(3)(c) of the Vienna Convention on the Law of Treaties: when interpreting a treaty, one must take account of "any relevant rules of international law applicable in the relations between the parties'. ILC 'Conclusions of the Work of the Study Group on the Fragmentation of International Law: Difficulties Arising from the Diversification and Expansion of International Law' (adopted by the International Law Commission at Its Fifty-eighth Session 1 May - 9 June and 3 July - 11 August 2006, Geneva) UNGAOR 61 ${ }^{\text {st }}$ Session Supp No 10 UN Doc A/61/10, at p 1, para 251 〈http://untreaty.un.org/ilc/texts/instruments/english/draft\%20articles/1_9_2006.pdf> accessed 2 November 2012 (hereinafter: 'Conclusion on Fragmentation').

${ }^{290}$ See Tzevelekos, 'The Use of Article 31(3)(c)', supra $\mathrm{n}$ 285. The author stated that: 'Article 31(3)(c) is much more than an apparatus enabling the interpreter of a special instrumentum of international law to read its norms in light of third (that is to say, extraneous) relevant sources - stemming from both general and inter-subjective or special international law. While definitely offering this option, Art 31(3)(c) does so in a broader, inter-temporal frame. Hence, the interpretation of a treaty "cannot remain unaffected by the subsequent development of law" and "has to be interpreted and applied within the framework of the entire legal system prevailing at the time of the interpretation". Again, a treaty "is not static, and is open to adapt to emerging norms of international law"'.

${ }^{291}$ Rüdiger Wolfrum and Nele Matz, Conflicts in International Environmental Law (Max-Planck-Institut für Ausländisches Öffentliches Recht und Völkerrecht, Springer-Verlag Berlin, Heidelberg, New York, 2003) at p 145.
} 
the core elements of the thesis, and set out the methodology, the analytical framework, and the structure of the thesis.

Following the introductory chapter, Chapter 2 illuminates the emergence of the ecosystem approach in international law and policy, where it sets out the criteria for the identification of rules of international law that are 'relevant' for the interpretation of the obligation to preserve ecosystems of international watercourses. The emergence of the ecosystem approach frames the protection of environment in ecosystem language, where the goal of protection is to maintain the integrity of an ecosystem that enables the continuous supply of ecosystem services.

Chapter 3 provides research and discussion of the existing scholarship on how 'applicable in the relations between the parties' is to be interpreted, and concludes that the effective operationalisation of Article 31(3)(c) cannot be attained if the existing construction of the Article is maintained.

Chapter 4 proposes an interpretation of "rules of international law applicable in the relations between the parties" that is informed and guided by the interactional theory of law. The theory posits that law emerges when shared understanding become fused with a 'practice of legality' through a continuous process of mutual engagement and robust interaction, rooted in Lon Fuller's eight criteria of legality and embraced by a community of legal practice that adheres to these criteria in day-to-day decision-making. This chapter concludes that the phrase 'applicable in the relations between the parties' should be interpreted in relation to the 'rules of international law'. The applicability of the rules of international law in the relations between the parties is dependent on the shared legal understanding achieved by the parties in the process of the making of that rule of international law. This approach diverges from the existing interpretation of this Article where scholars defined 'relevant', 'rules of international law', 'applicable' and 'the parties' separately. It re-assesses existing interpretations that the applicability of the rules of international law is contingent on the rules being formally binding on the parties, by pointing out that this reading of 'applicable' is neither supported by the interpretation of 'the parties' nor the context of the 1969 Vienna Convention and the jurisprudence. The theoretical framework developed for the interpretation of 'rules of international law applicable in the relations between the parties' through an interactional understanding of law will be illustrated through the subsequent two chapters. 
Chapters 5 and 6 are the two operative parts that apply the framework developed in Chapter 4, in the case studies of the Ramsar Convention and the Biodiversity Convention. First, the substantive content and the applicability of the relevant rules of international law identified in Chapter 2 in the relations between the parties are ascertained through the prism of an interactional understanding of law. Second, it operationalises the interactional framework of the conceptualisation of international law whereby the shared understanding undertaken in a practice of legality by the parties of both Conventions is assessed against the criteria of legality.

Chapter 7 explores the extent to which relevant rules of international law relevant to the interpretation of the obligation to preserve ecosystems of international watercourses shall be taken into account. This chapter proposes a structure for the systemic integration of relevant rules of international law constructed in reference to the approach undertaken in international court and tribunal.

Chapter 8 focuses on the operationalisation of the analytical framework developed in this research for the interpretation of the obligation to preserve ecosystems of international watercourses provided under Article 20 of the 1997 Watercourses Convention in light of its systemic environment proffered by the Ramsar Convention and the Biodiversity Convention. It provides an abridged compendium of empirical research of existing jurisprudence in the illustration of the normative weight to be given to the external rules in the interpretation of a treaty term or regime in order to identify the extent and scope of 'shall be taken into account'.

Chapter 9 provides a general conclusion and reflection of the analytical framework developed for the interpretation of the obligation to preserve ecosystems of international watercourses in the systemic environment provided by the relevant rules of international law in the form of Ramsar Convention and Biodiversity Convention. It concludes on how Article 31(3)(c) of the 1969 Vienna Convention could be operationalised for the systemic integration of the obligation to preserve under Art 20 through the legal technique of interpretation. 


\section{Chapter 2. Relevant: Preservation of Ecosystems of International Watercourses -}

\section{An Ecosystem Approach}

This chapter interprets the term 'relevant', and identifies the threshold to be satisfied for a rule to be considered 'relevant' to the interpretation of the obligation to preserve ecosystems of international watercourses stipulated under Article 20 of the 1997 Watercourses Convention. The chapter starts firstly with the interpretation of the concept of ecosystem and the emergence of the ecosystem approach in legal scholarship, pivotal in the identification of rules relevant to the interpretation of the obligation to preserve ecosystem under Article 20. Then, the interpretation of 'relevance' is explored through the concepts of doctrine in pari materia; normative parallelism and the parallelism of treaty; and multi-sourced equivalent norms (MSENs). Next, the thesis explores how Articles 2.1 and 4.1 under the Ramsar Convention and Article 8(a) and (d) of the Biodiversity Convention, as informed by the concept of ecosystem and the application of the ecosystem approach is relevant to the obligation to preserve under Article 20. Finally, the thesis discusses the implication of the climate change regime on the obligation to preserve, in particularly on the prima facie incompatibility of the climate change regime with the obligation to preserve under Article 20.

\subsection{The Emergence of an Ecosystem Approach}

An ecosystem is an entirely human-defined construct ${ }^{292}$ developed in scientific literature during the 1930s and 1940s. ${ }^{293}$ The modern definition of 'ecosystem' emphasised its

\footnotetext{
${ }^{292}$ Hugo Tremblay, 'An Analytical Framework for Legal Regimes Applicable to Freshwater Ecosystems' (2010) 20 Journal of Water Law 152 - 164, at p 152, quoting Michael Dobson and Chris Frid, Ecology of Aquatic Systems, (2 $2^{\text {nd }}$ edn, Oxford University Press, Oxford, 2009), at p 277.

${ }^{293}$ McIntyre, 'Ecosystem Approach', supra n 79, at p 1. For example, AG Tansley, 'The Use and Abuse of Vegetational Concepts and Terms' (1935) 16(3) Ecology 284 - 307, at p 299 〈http://karljaspers.org/files/tansley.pdf〉 accessed 22 June 2011 defined an ecosystem as 'the whole system including not only the organism-complex, but also the whole complex of physical factors forming what we call the environment of the biome - the habitat factors in the widest sense'. Raymond Lindeman, in 'The Trophic-Dynamic Aspect of Ecology', (1942) 23(4) Ecology 399 - 417, defined ecosystem, at p 400: "The system may be formally defined as the system composed of physical-chemical-biological processes active within a space-time unit of any magnitude, ie, the biotic community plus its abiotic environment'. Both were quoted in Ved P Nanda, 'The Law of the Non-navigational Uses of International Watercourses: Draft Articles on Protection and Preservation of Ecosystems, Harmful Conditions and Emergency Situations, and Protection of Water Installations' (1992) 3 Colorado Journal of International Environmental Law and Policy 175 - 207, at pp 177 - 178, in the clarification of the term 'ecosystem' used in the 1994 Draft Articles and Commentaries, supra n 44, on the protection and preservation of ecosystems.
} 
position as a functional unit that includes both biotic and abiotic elements. ${ }^{294}$ Science generally defines ecosystem as a biological community of interdependent plants, animals, and microorganisms that occurs in a specific place associated with particular soils, temperatures, and disturbance patterns and the physical and chemical factors that make up that community's abiotic, non-living environment. ${ }^{295}$

Despite the wealth of literature surrounding the concept of ecosystems, it has been proven to be difficult to define the concept in a simple manner, ${ }^{296}$ as the ecosystem is characterised by its composition, structure, and function ${ }^{297}$ whereas the concept, depending on its characterisation is said to be 'dimensionless'. ${ }^{298}$

\subsubsection{The River Basin as an Ecosystem}

The river basin has been proposed as a natural unit, initially for pollution control, and gradually for ecosystem management. ${ }^{299}$ The realisation that there are interactions

${ }^{294}$ Ludwik A Teclaff and Eileen Teclaff, 'International Control of Cross-Media Pollution - An Ecosystem Approach', (1987) 27 Natural Resources Journal 21 - 53. The authors referred to the definition of ecosystem as stated by PR Ehrlich, AH Ehrlich, and JP Holdren, Ecoscience: Population, Resources, Environment (WH Freeman and Company, San Francisco, CA, 1977) at p 97: 'The interdependence that characterizes the physical and biological elements of the environment has led ecologists to coin the term ecosystem (shot for ecological system) for the functional unit that includes both biotic (living) and abiotic (non-living) elements'.

${ }^{295}$ Dan Tarlock, 'Ecosystems', Chapter 24, in Daniel Bodansky, Jutta Brunnée and Ellen Hey (eds), The Oxford Handbook of International Environmental Law, (Oxford University Press, Oxford, 2007) at p 576. Ecosystem was viewed as a subset of nature's global economy, a local or regional system of plants, microorganisms, and animals working together to survive from an ecologist's traditional approach to nature. Nature is understood as a series of overlapping but integrated biological systems or ecosystems, a web of life intricately organized, a world of living things, constantly busy in discernible patterns producing goods and services essential for one another, services upon which life on earth depends, and also vital to human existence. Birnie, Boyle, Redgwell, International Law and the Environment, supra $\mathrm{n}$ 112 , at $\mathrm{p} 585$.

${ }^{296}$ CBD Guidelines, supra $\mathrm{n} 166$, at $\mathrm{p} 3$.

${ }^{297}$ Dale D Goble, 'What are Slugs Good For? Ecosystem Services and the Conservation of Biodiversity' (2007) 22 Journal of Land Use and Environmental Law 411 - 440, at p 419.

298 William A Reiners, 'Complementary Models for Ecosystems', (1986) 127(1) The American Naturalist $59-73$, at p 59. The difficulties of the conceptualisation of the ecosystem are due to: 1 . The enormous range of possible scales due to the positive attribute that lend generality to the properties of ecosystem at all size scales; 2 . the relative intangibility of ecosystems as compared with organelles, cells, and individual organisms, due to the lack of boundary integrity or behavioural cohesion. Henceforth, confusion concerning ecological properties that fall into the ecosystem domain arises. CBD, 'Decision V/6. Ecosystem Approach' (Fifth Ordinary meeting of the Conference of the Parties to the Convention on Biological Diversity, Nairobi, Kenya, $15-26$ May 2000) at Annex, p 104, para 3 <http://www.cbd.int/doc/decisions/cop-05/full/cop-05-dec-en.pdf $>$ accessed 14 November 2012. It is stated in the decision adopted by the COP that the definition of ecosystem 'does not specify any particular spatial unit or scale, and can refer to any functioning unit at any scale. Indeed, the scale of analysis and action should be determined by the problems being addressed. It could be a grain of soil, a pond, a forest, a biome or the entire biosphere'.

${ }^{299}$ See Teclaff and Teclaff, 'Ecosystem Approach', supra n 294, at pp 30 - 33. Initially, the concept of drainage basin was advocated as the best areal unit for national and international water management. Teclaff, 'Ecosystem Approach', supra n 294, at p 30. For the evolution of drainage basin in national and 
between water and its environment within the drainage basin was explicitly expressed in the two articles adopted by the International Law Association in the Belgrade conference in 1980. ${ }^{300}$ The Great Lakes Agreement $1978^{301}$ gave authoritative legal force to the concept of drainage basin as an ecosystem, ${ }^{302}$ which acknowledges the appropriateness of drainage basin as the functional unit for the protection of ecological integrity and sustainability of aquatic environment found expression in the Berlin Rules on Water Resources. ${ }^{303}$ Despite the recognition of an ecosystem approach in the environmental protection of international watercourses in the 1997 Watercourses Convention, a considerably more conservative approach was taken. ${ }^{304}$

international water law, see Ludwik A Teclaff, 'Evolution of the River Basin Concept in National and International Water Law’ (1996) 36 Natural Resources Journal 359 - 391.

${ }^{300}$ ILA, 'Articles on the Relationship between Water, Other Natural Resources and the Environment' (Report of the Committee on International Water Resources Law 17 - 18, Belgrade Conference, 1980). Art 1(a) reiterated the obligation of states to prevent transboundary pollution. It provides for States to ensure that they do not cause substantial injury to the environment of other states, or of areas beyond the limits of national jurisdiction. It made explicit the connections between water resource and its environment by providing, in para 1(b) that the management of states' natural resources (other than water) and other environmental elements located within their own boundaries does not cause substantial injury to the water resources of other states.

${ }^{301}$ Protocol Amending the 1978 Agreement between the United States of America and Canada on Great Lakes Water Quality (as amended on 16 October 1993). Great Lakes Water Quality Agreement of 1978, United States-Canada, 30 UST 1383, TIAS No. 9257 (hereinafter: the 'Great Lakes Agreement'). It is defined in Art 1 of the Great Lakes Agreement that the 'Great Lakes Basin Ecosystem' means the interacting components of air, land, water and living organisms, including humans, within the drainage basin of the St. Lawrence River at or upstream from the point at which this river becomes the international boundary between Canada and the United States.

${ }^{302}$ Art I $(\mathrm{g})$ defined the Great Lakes Ecosystem as 'the interacting components of air, land, water and living organisms, including man, within the drainage basin of the St. Lawrence River at or upstream from the point at which that river becomes the international boundary between Canada and the United States...'.

${ }^{303}$ This gives explicit recognition to the ecosystem approach. ILA, 'Report of the Conference on Water Resources Law' (Berlin, August 2004) (hereinafter: 'Berlin Rules') <http://www.cawaterinfo.net/library/eng/l/berlin_rules.pdf $>$ accessed 24 June 2011. Art 22, Chapter V on the protection of the aquatic environments provides that: 'States shall take all appropriate measures to protect the ecological integrity necessary to sustain ecosystems dependent on particular waters'. Art 1 provides that: 'These (Berlin) Rules express international law applicable to the management of the waters of international drainage basins and applicable to all waters, as appropriate'.

${ }^{304} 1997$ Watercourses Convention, supra n 35, Art 20. The implicit acceptance of application of the ecosystem approach, which means ecosystem-based management approach, is found in the immediate and overall context of Art 20, introduced in Chapter One, and more specifically in the determination of 'relevant' in subsequent section of this chapter; and Chapter Seven. The use of the term 'ecosystems' in Art 20 and the related provisions under Chapter IV indicates the recognition of the ecological dynamics within and beyond the functional unit of an ecological systems of the environment. In addition, the explicit reference to the management of the environment of international watercourses in the preamble and the title of Chapter IV for on the protection, preservation and management of ecosystems support the application of the ecosystem approach in the interpretation and application of the relevant provisions under Chapter IV of the 1997 Watercourses Convention. The concept of ecosystem and the ecosystem approach is elaborated in depth in subsequent sections in this chapter. 


\subsubsection{The Ecosystem Approach in International Policy}

The idea of an ecological and systemic approach to managing natural resources is not new. ${ }^{305}$ An ecosystem approach in the protection of the integrity of the environment was adopted in the 1992 Rio Declaration where the Preamble indicated the Declaration's goal to work towards an international agreement that 'protects the integrity of the environmental and developmental system, ${ }^{306}$ The States are called on to

${ }^{305}$ Richard Haeuber, 'Setting the Environmental Policy Agenda: The Case of Ecosystem Management', (1996) 36 Natural Resources Journal 1 - 28, at pp 3 - 4. Victor E Shelford, 'The Preservation of Natural Biotic Communities', (1933) 14(2) Ecology 240 - 245, at pp 240 - 241 stated that '[Many] believes that such areas [national parks of Canada and the United States] are examples of primeval nature with the animal life essentially complete. The national parks of both countries doubtless represent the least disturbed series of areas .. Yet many have been surprised to learn of the large amount of modification which has gone on in times past within these park areas, both before and in some cases perhaps after they were set aside ... The whole trend of research and education is toward specialisation on particular objects or particular organisms. These are stressed while the assemblage to which they belong is ignored or forgotten, together with the fact that they are to be regarded as integral parts of the system of nature. Perhaps one reason why nature study has been unsuccessful is because too often it is not the study of nature but of single natural objects or groups of objects which constitute a small part of any natural aggregation ... Biologists are beginning to realise that it is dangerous to tamper with nature ... the unmodified assemblage of organisms is commonly more valuable than the isolated rare species. However, because the significance of the unmodified assemblage is popularly ignored, the whole is commonly sacrificed in the supposed interest of the rare species. To the ecologist, it is the entire series of plants and animals which live together in any community which is of primary interest.' At pp $241-245$, Shelford commented that the Ecological Society of America's Committee for the Study of Plant and Animal Communities has recognised the importance of viewing the environment from an ecological perspective in the early 1930s. The Committee factored in and incorporated natural disturbance regimes and the natural area protection with core reserve/buffer zone design approach into management schemes. Harold W Wood, Jr, 'The United Nations World Charter for Nature: The Developing Nations' Initiative to Establish Protections for the Environment', (1985) 12 Ecology Law Quarterly 977 - 996 at p 991. See also Peter Jackson, 'A World Charter for Nature' (1983) 12 AMBIO 133. UNESCO, 'Man and the Biosphere Programme' $<$ http://www.unesco.org/new/en/natural-sciences/environment/ecologicalsciences/man-and-biosphere-programme/> accessed 9 August 2011. Similarly, the biosphere reserves approach of the UNESCO's Man and the Biosphere Programme in the 1970s resembles the inner core reserve/buffer zone approach proposed by the Ecological Society of America Committee on Plant and Animal Communities. UNGA, 'World Charter for Nature' (48 ${ }^{\text {th }}$ Plenary Meeting, 28 October 1982) UN Doc A/RES/37/7 <http://www.un.org/documents/ga/res/37/a37r007.htm> accessed 22 June 2011. Recalling UNGA, 'Draft World Charter for Nature' (Resolution 35/7, 49 ${ }^{\text {th }}$ Plenary Meeting, 30 October 1980) where it stated that the General Assembly is 'conscious that life on earth is part of nature and depends on the uninterrupted functioning of natural systems, and is persuaded that the benefits which can be obtained from nature depend on the maintenance of natural processes and on the diversity of life-forms and that those benefits are jeopardized by the excessive exploitation and the destruction of natural habitats'. See UNGA, 'Draft World Charter for Nature', (41 ${ }^{\text {st }}$ Plenary Meeting, 27 October 1981) UN Doc A/RES/36/6 <http://www.un.org/documents/ga/res/36/a36r006.htm> accessed 22 June 2011. Evidence of the recognition by states of the necessity to protect essential ecological processes can be found in numerous declarations and resolutions concerning the preservation of the environment, as noted by the ILC in 1994 Draft Articles and Commentaries, supra n 44, at pp 120 - 121, para 9. They include Stockholm Declaration; General Assembly Res 37/7 on the World Charter for Nature; 1989 Amazon Declaration; 1989 Draft American Declaration on the Environment; 1988 ECE Declaration on Conservation of Flora, Fauna and Their Habitats; 1990 Bergen Ministerial Declaration on Sustainable Development in the ECE Region; the Hague Declaration on the Environment of 11 March 1989; the work of the World Commission on Environment and Development and its Experts Group on Environmental Law.

$3063^{\text {rd }}$ preambular para of 1992 Rio Declaration, supra n 148. The paragraph reads 'Working towards international agreements which respect the interests of all and protect the integrity of the global 
cooperate to conserve, protect and restore the health and integrity of the Earth's ecosystem, and beware of their responsibilities towards environmental degradation. ${ }^{307}$

Agenda 21 is a comprehensive and dynamic plan of action that reflects a global consensus and political commitment at the highest level on development and environment cooperation ${ }^{308}$. It is replete with references to 'integrated approaches' where the functional unit employed is ecosystem. ${ }^{309}$ A strong endorsement of the ecosystem approach at the global policy level is also found in the Plan of Implementation adopted at the 2002 World Summit on Sustainable Development. ${ }^{310}$

\subsubsection{The Ecosystem Approach in International Law}

It has been commented that there are overlapping, historical, conceptual, and institutional reasons for the amorphous and ultimately marginal legal status of ecosystems in international law, ${ }^{311}$ where the ecosystem approach has so far been confined to non-legally binding instruments. ${ }^{312}$

The extent of ecosystem protection adopted in the Great Lakes Agreement, as specified in Article II, is "to restore and maintain the chemical, physical, and biological integrity of the waters of the Great Lakes Basin Ecosystems". ${ }^{313}$ The preamble to the 1985

environmental and developmental system'. The phrase 'environmental and development system', indicated in the adopted Principles 2 and 11, means the governance system, especially the policy and legislative aspects, of environmental conservation and economic development of a United Nations state.

3071992 Rio Declaration, supra n 148, Principle 7.

${ }^{308}$ Agenda 21, supra n 161, Preamble, at para 1.3.

${ }^{309}$ Agenda 21, supra n 161 was expressed in ecosystem terms, in particularly paras $1.1 ; 9.6 ; 10.1 ; 12.1$; 15.2; 17.86; and 18.8. See Chs 9, 10, 11, 12, 13, 15, 17, 18, 19, 20, 21, and 22 of the Agenda 21.

${ }^{310}$ Arie Trouwborst, 'The Precautionary Principle and the Ecosystem Approach in International Law: Differences, Similarities and Linkages', (2009) 18(1) Review of European Community and International Environmental Law 26 - 37, at p 30. World Summit on Sustainable Development, 'Plan of Implementation of the World Summit on Sustainable Development' (Johannesburg, South Africa, 26 $\begin{array}{lllllll}\text { August } & - & 4 & \text { September } & \text { 2002) UN } & \text { Doc } & \text { A/Conf.199/20 }\end{array}$ <http://www.johannesburgsummit.org/html/documents/documents.html > accessed 14 November 2012. The Plan encourages the application by 2010 of the ecosystem approach in the integrated management of oceans, seas, islands and coastal areas. See paras 30; 44(e) and 70(b).

${ }^{311}$ Tarlock, 'Ecosystems', supra n 295, at p 577. At pp $576-577$, the author elaborated that the reasons include the indistinctive and undifferentiated components of the environment within national territory that generates no distinctive legal status. Apart from that, ecosystem function impairment does not fit well into the traditional conceptualisation of environmental liability where the basic principles of international environmental law, developed prior to the emergence of ecosystem approach, where state responsibility was only triggered by harm and injury that pose immediate threat to human health or life. In addition, the lack of a single national or international conservation regime that enforces the protection of ecosystems leads to the weak legal status of ecosystem.

312 Trouwborst, 'Ecosystem Approach', supra n 310, at p 30.

${ }^{313}$ Great Lakes Agreement, supra n 301, Art II - Purpose. 
Agreement on the Conservation of Nature and Natural Resources ${ }^{314}$ recognises the interdependence of living resources within the ecosystems of which the natural resources are a part. ${ }^{315}$

The Helsinki Convention 1992 stipulated that sustainable water resources management, where the application of an ecosystem approach is intrinsic to such management, should be promoted. ${ }^{316}$ In the 1997 Convention, the specific adoption of the terminology of 'ecosystem' indicates the clear intention to embrace an ecosystem approach in the management of the ecosystems of international watercourses where the functional unit for the protection and preservation of the environment of international watercourses is the ecosystem of these international watercourses. ${ }^{317}$

\subsubsection{The Ecosystem Approach and Its Normative Standard}

The conceptualisation of the ecosystem as a functional unit emphasised the interconnectedness and the interdependence of a biological community with its abiotic environment. Pollution caused by human activities, due to the use of water in rivers, lakes and underground that is in permanent contact with other environmental components, will lead to deterioration of natural ecosystems. ${ }^{318}$ It is now recognised that the uses of watercourses can both affect and be affected by processes related to other natural elements, such as soil degradation and desertification, deforestation and climate change, ${ }^{319}$ where the artificial distinctions between water and associated land

\footnotetext{
${ }^{314}$ The functional unit of protection explicit in the Agreement is the ecosystem and the inter-relationship between ecosystems. See ASEAN Agreement on the Conservation of Nature and Natural Resources (adopted at Kuala Lumpur on 9 July 1985).

3151985 ASEAN Agreement, Arts 4(b) and (d), 6, 7, 8, 9, 10, 11, 12(1), 13, and 14. The conservation and sustainable use of species and ecosystems include maintaining the ecological relationship of living resources within an ecosystem and minimises risk of changes in the ecosystem. Specific attention in the management of ecosystems is drawn to the vegetation and forest cover, soil, water, and air in the functioning of natural ecosystems that indicates the adoption of the ecosystem approach in the conservation of nature and natural resources aimed to conserve the ecological processes. The incorporation of an ecosystem approach is implied in the requirement to integrate environmental conservation into land use planning process, establishment of protected areas, and undertaking assessment and incorporating the result of such assessment in decision making for proposals prior to their adoption.

${ }^{316}$ The 1992 Helsinki Convention, supra n 67, required the Parties to take all appropriate measures to ensure the conservation, and where necessary, restoration of ecosystems, especially in the prevention, control and reduction of transboundary impact. See Arts 2(d) and 3, especially 3.1(i),

3171997 Watercourses Convention, supra n 35, Art 20.

${ }^{318}$ McIntyre, 'Ecosystem Approach', supra n 79, at p 5.

${ }^{319}$ Maurizio Arcari, 'Chapter 1. Theoretical Background and Genesis of the Convention', in Tanzi and Arcari, The United Nations Convention on the Law of International Watercourses: A Framework for Sharing, supra n 48, at pp 8 - 9. See also George Francis, 'Ecosystem Management' (1993) 33 Natural Resources Journal 315 - 345; and Teclaff and Teclaff, 'Ecosystem Approach', supra n 294.
} 
use and water management are eroded. ${ }^{320}$ This induced the scientific community to adopt the ecosystem approach that proposed a less economic-oriented criterion for the management of freshwater resources. ${ }^{321}$

The operationalisation of the ecosystem approach for the attainment of the overall purpose of sustaining ecosystem integrity includes the maintenance of viable populations of all native species in situ that is representative of all native species across their natural range of variation within the protected areas. It involves the maintenance of evolutionary and ecological processes such as the disturbance regimes within the ecosystems, the hydrological processes and the nutrient cycles over a long-term temporal scale, while accommodating human use within these constraints. ${ }^{322}$ The maintenance of ecosystem integrity necessitates the maintenance of (native) diversity at the genetic, population, species and ecosystem levels, as well as the ecological patterns and processes sustaining that diversity within an adaptive framework of management. ${ }^{323}$

The Ecosystem Approach Guideline under the Biodiversity Convention presents the most tangible normative guideline for the application of the ecosystem approach where the core elements of application are stipulated in concrete principles with annotations and guidelines for implementation. The Subsidiary Body on Scientific, Technical and Technological Advice (SBSTTA) of the Biodiversity Convention endorses parameters of the ecosystem approach, comprising its description, the five points of operational guidance, ${ }^{324}$ and 12 principles of application in the attempt to operationalise this concept.

\footnotetext{
${ }^{320}$ Dan Tarlock, 'International Water Law and the Protection of River Ecosystem Integrity' (1996) 10 Brigham Young University Journal of Public Law 181 - 211, at p 208.

${ }^{321}$ McIntyre, 'Ecosystem Approach', supra n 79, at p 2.

${ }^{322}$ R Edward Grumbine, 'What is Ecosystem Management?' (1994) 8(1) Conservation Biology 27 - 38, at $\mathrm{p} 31$ 〈http://www8.nau.edu/envsci/ENV330website/ENV330/downloads/GrumbineEcosystemmngt.pdf > accessed 5 August 2011.

${ }^{323}$ Trouwborst, 'Ecosystem Approach', supra n 310, at p 28.

${ }^{324}$ CBD, Decision V/6, supra n 298. The five points include focus on the functional relationships and processes within ecosystems; enhance benefit sharing; the use of adaptive management practices; undertaking management action at an appropriate scale and to decentralise to the lowest level as appropriate; and to ensure inter-sectoral cooperation. Apart from these five points of guidance, there are three important considerations to be incorporated in the application of the ecosystem approach. The management of living components must be considered alongside economic and social considerations at the ecosystem level of organisation. An integrated management of land, water and living resources in equitable ways within their natural limits of the functioning of ecosystems are needed for it to be sustainable. Ecosystem management is a social process where management decisions should be obtained through efficient and effective structures and processes for decision making and management that involve interested communities. CBD Guidelines, supra n 166, Annex II Further Guidance on the Implementation of the Ecosystem Approach Principle, at p 34, para 3 (a), (b), and (c).
} 
The Ecosystem Approach Guidelines describe the ecosystem approach as 'a strategy for the integrated management of land, water and living resources that promotes conservation and sustainable use in an equitable way, ${ }^{325}$ which is consistent with the definition of ecosystem provided in Article 2 of the Biodiversity Convention. ${ }^{326}$ The Ecosystem Approach Guideline requires an adaptive management approach to deal with the complex and dynamic nature of the ecosystem despite the lack of complete comprehension of the functioning of the ecosystem. ${ }^{327}$

Principle 3 of the ecosystem approach illustrates the need for a broad-based, spatial approach that acknowledges the interconnectedness of the biosphere where effects on the ecosystem functioning on one ecosystem are seldom confined to the point of impact, or only to one system, especially in view of the non-linear outcome compounded by the time-lags effect. ${ }^{328}$ The priority target of the ecosystem approach is the conservation of ecosystem structure and functioning in order to maintain ecosystem services, ${ }^{329}$ where the management of ecosystems must be conducted in consideration of the environmental conditions that limit natural productivity, ecosystem structure, functioning and diversity. ${ }^{330}$

\footnotetext{
${ }^{325}$ CBD Guidelines, supra n 166, at p 6, para 1, extracted from section A of Decision CBD, Decision V/6, supra $\mathrm{n} 298$.

${ }^{326}$ Art 2 of the Biodiversity Convention, supra n 12 defined 'ecosystem' as 'a dynamic complex of plant, animal and microorganism communities and their non-living environment interacting as a functional unit'. ${ }^{327}$ The difficulty in acquiring complete understanding of ecosystem functions and processes is due to the non-linear outcome often caused by time-lags, contributing to the uncertainty and discontinuities in the outcome. See the Ecosystem Approach Guideline, p 6, para 3. Hence, the ecosystem approach necessitates an adaptive management framework in order to factor in the uncertainties and to "learn by doing" that does not preclude other management and conservation approaches in dealing with such complex situations. Other methodologies not precluded are: biosphere reserves, protected areas, and single species conservation programmes, as well as other approaches carried out under existing national policy and legislative frameworks. See the Ecosystem Approach Guideline, supra n 324, at p 6, paras 4 and 5.

${ }^{328}$ This recognition involves spatial connections, such as the adjacent ecosystem or the downstream ecosystems, but extends to other form of connections, such as network connected through migratory species as well. Ecosystem Approach Guideline, supra n 324, at pp 12 - 13.

${ }^{329}$ Principle 5, Ecosystem Approach Guideline, supra n 324, at pp $16-17$. Management focus must be on the maintenance and restoration of the key structures and ecological processes (eg hydrological systems, pollination systems, habitats and food webs) given the complexity of the structure, functioning, resilience and interrelationship among composition of natural ecosystems, in particularly the human interaction, needs and values; conservation management of biodiversity and environmental quality, integrity and vitality. The implementation guideline for this principle advocates for the development and application of instruments that contribute towards the achievement of conservation management goals through a combination of managing protected area networks, ecological networks and areas outside of such networks. . At para 5.8, Principle 5, Ecosystem Approach Guideline, supra n 324, at p 17.

${ }^{330}$ Principle 6, Ecosystem Approach Guideline, supra n 324, at pp 18 - 19. The application of the ecosystem approach is bounded by appropriate spatial and temporal scales depending on the objective of management, with regards to connectivity between areas based on the hierarchical nature of biological diversity characterized by dynamic interaction and integration of genes, species and ecosystems across
} 
The uncertainty in the management of an ecosystem due to its non-linear outcome, time lag characteristics, and the lack of comprehensive understanding of the ecosystem processes, necessitates an adaptive approach to the framework of management. ${ }^{331}$ Conservation and use of ecosystems should be seen as a continuum from strictly protected to human-made ecosystems where the balance between, and integration of, conservation and use can be struck. ${ }^{332}$

The existing approach in the international environmental legal regimes focuses more on the prevention against harm caused by uses, pollution and invasive alien species, ${ }^{333}$ with less consideration of the ecosystem in its entirety, especially the ecological structure, processes, functioning, and the intangible benefits of ecosystem services. The duty to prevent harm and the obligation not to cause harm, especially transboundary harm, are deemed the cornerstones of international environmental law. ${ }^{334}$ States are obliged to take all necessary measures in accordance with the doctrine of sic utere tuo ut alienum non laedas.

space, time and quality. Principle 7, Ecosystem Approach Guideline, supra n 324, pp 20 - 21. In particularly, management objectives should be set at a long-term basis in recognition of the varying temporal scales and lag-effects that characterize ecosystem processes. Principle 8, Ecosystem Approach Guideline, supra $\mathrm{n} 324$, at pp $22-23$.

${ }^{331}$ In view of the dynamics, the management approach should acknowledge that change is inevitable. The adaptive management should anticipate and cater for changes, and consider mitigating measures in order to cope with such changes. Principle 9, Ecosystem Approach Guideline, supra n 324, at pp $24-25$.

332 Principle 10, Ecosystem Approach Guideline, supra n 324, at pp 26 - 27. In this regard, in view of the ultimate objective of attaining ecosystem integrity, the application of ecosystem approach should consider all forms of relevant information, including scientific, indigenous, and local knowledge, innovations and practices and involve all relevant sectors of society and scientific disciplines as appropriate. Principles 11 and 12, Ecosystem Approach Guideline, supra n 324, at pp 28 - 31.

${ }^{333}$ The existing MEAs that adopted a tangible harm-based approach, to name a few: Convention on LongRange Transboundary Air Pollution (concluded 13 November 1979, entered into force 16 March 1983) TIAS 10541, 1302 UNTS 217, (1979) 18 ILM 1442, and its eight Protocols; Convention for the Protection of the Ozone Layer (concluded 22 March 1985, entered into force 22 September 1988) TIAS No11097, 1513 UNTS 323, (1987) 26 ILM 1529, and its Montreal Protocol on Substances that Deplete the Ozone Layer (concluded 16 September 1987, entered into force 1 January 1989) 1522 UNTS 3; (1987) 26 ILM 1550; Stockholm Convention on Persistent Organic Pollutants (concluded 22 May 2001, entered into force 17 May 2004) 2256 UNTS 119, (2001) 40 ILM 532; and Basel Convention on the Control of Transboundary Movements of Hazardous Wastes and Their Disposal (concluded 22 March 1989, entered into force 5 May 1992) 1673 UNTS 126, (1989) 28 ILM 657. See also ILC, 'Draft Articles on Prevention of Transboundary Harm from Hazardous Activities' (Report of the International Law Commission on the Work of its Fifty-third Session) UNGAOR Supp No 10, UN Doc A/56/10.

3341992 Rio Declaration, supra n 148, Principle 21. Barbara Kwiatkowska, 'The Ireland v United Kingdom (Mox Plant) Case: Applying the Doctrine of Treaty Parallelism', (2003) 18 International Journal of Marine and Coastal Law 1 - 58, at pp 41 - 42. Corfu Channel Case (Great Britain v. Albania) (Judgment of 9 April 1949) [1949] ICJ Report 4, at pp 22 - 23 <http://www.icjcij.org/docket/files/1/1645.pdf> accessed 14 November 2012; Nuclear Test Case (New Zealand v. France) (Judgment of 20 December 1974) (1974) ICJ Report 457, at paras 63 - 64 <http://www.icjcij.org/docket/files/59/6159.pdf > accessed 14 November 2012; and reaffirmed in Legality of the Threat or Use of Nuclear Weapons, (Advisory Opinion of 8 July 1996) [1996] ICJ Report 226, at paras 30, 32 and 243 〈http://www.icj-cij.org/docket/files/95/7495.pdf> accessed 14 November 2012. See also Trail Smelter Case, supra n 169. 
The traditional approach to the watercourses' environmental protection addressed in most international watercourses treaties relates mainly to the prevention against harm caused by pollution and invasive species. The increasing tension over the use and regulation of water, driven by a systemic state of water shortages, underscores the fundamental conflict that exists between consumptive use and users in-situ (water as a medium of ecological processes). ${ }^{335}$

Recent developments in international environmental law, in light of the emergence and advancement of the ecosystem approach, raise concerns over the implications of environmental degradation, for example biodiversity lost, and climate change, that influence the extent and scope of 'protection and preservation of freshwater ecosystems of international watercourses' under international watercourses treaties. The decreased availability of freshwater due to the reduction in renewable freshwater runoff on Earth; the expansion of unsustainable pattern of human consumption; ${ }^{336}$ mounting pollution to waterways; ${ }^{337}$ and the degradation of freshwater ecosystems; set the stage for a global water crisis. ${ }^{338}$ This development has prompted the field of international watercourses law to treat the maintenance of ecological integrity as a point of concern in the regulation of uses. ${ }^{339}$

Various factors that lead to biodiversity loss and climate change have been uncovered and identified by scientists, which include, inter alia, land use and land-use change. ${ }^{340}$

\footnotetext{
${ }^{335}$ See Robin Kundis Craig, 'Climate Change, Regulatory Fragmentation, and Water Triage' (2008) 79 University Colorado Law Review 825 - 927.

${ }^{336}$ MA, Ecosystems and Human Well-Being: Synthesis (Island Press, Washington DC, 2005) at pp $106-$ 107.

${ }^{337}$ Charles Vörösmarty et al (Coordinating Lead Authors); Rober Bos et al (Lead Authors); and Frank Rijsberman et al (Review Editors), 'Chapter 7. Fresh Water' in MA, Global Assessment Reports (Vol 1: Current State \& Trends, Island Press, Washington DC, 2005) at pp 165 - 207 $<$ http://www.millenniumassessment.org/documents/document.276.aspx.pdf $>$ accessed 14 November 2012.

${ }^{338}$ David Dudgeon, Angela H Arthington, Mark O Gessner, Zen-Ichiro Kawabata, Duncan J Knowler, Christian Lévêque, Robert J Naiman, Anne-Hélène Prieur-Richard, Doris Soto, Melanie LJ Stiassny, and Caroline A Sullivan, 'Freshwater Biodiversity: Importance, Threats, Status and Conservation Challenges' (2006) 81 Biological Review 163 - 182, at pp $165-167$.

${ }^{339}$ For the emergence of the ecosystem approach in the field of international law concerning water resources, see in general Jutta Brunnée and Stephen J Toope, 'Environmental Security and Freshwater Resources: A Case for International Ecosystem Law', supra n 3; and McIntyre, 'Ecosystem Approach', supra $\mathrm{n} 79$.

${ }^{340}$ See further Richard T Kingsford, 'Conservation Management of Rivers and Wetlands under Climate Change - A Synthesis', (2011) 62 Marine and Freshwater Research 217 - 222 $\langle$ http://www.publish.csiro.au/?act=view file\&file id=MF11029.pdf $>$ accessed 30 March 2011. It is stated, at p 221 that: 'There are many factors degrading rivers and wetlands; however, the most pervasive and deleterious is alteration of flow regimes, primarily driven by appropriation of freshwater for human use, considerably exceeding any effects of climate change on flow regimes'.
} 
The most notable and much debated consequence of the loss of biodiversity and climate change is the impaired provision of ecosystem services, and water scarcity. Apart from the protection of freshwater ecosystems against environmental harm under the rubric of pollution or invasive species, the extent and scope of this protection must necessarily address environmental degradation that is not subsumed under the two categories mentioned above.

In reflection of Brunnée's sentiment that aside from engineering 'a shift in the predominant focus on transboundary pollution to a conceptual framework with much broader [or global] outlook', ${ }^{341}$ the focus of this research seeks to address mainly the aspect of environment protection traditionally neglected in the international watercourses regime. International water treaties substantively address issues regarding the non-navigational uses of water and its allocation. The concern on the quality and quantity of the water is raised only to the extent whether the waters are of such quality and quantity that the intended usage by parties of that particular water treaty is not affected. The environmental needs of the freshwater ecosystems are greatly neglected, and no regard will be paid to the maintenance of the integrity of the freshwater ecosystems until the threshold for self-organisation of these ecosystems has been exceeded to a point of no return, where the damage done is irreversible. ${ }^{342}$

\footnotetext{
${ }^{341}$ Chidi Oguamanam, 'Biological Diversity' in Shawkat Alam, Md Jahid Hossain Bhuiyan, Tareq MR Chowdhury and Erika J Techera (eds) Routledge Handbook of International Environmental Law (Routledge, London and New York, 2013) at p 220. Quoted Jutta Brunnée, 'The Stockholm Declaration and the Structure and Process of International Environmental Law', pp 41 - 62, in Aldo Chircop, Ted L McDorman and Susan J Rolston (eds) The Future of Ocean Regime Building: Essays in Tribute to Douglas M Johnston (Martinus Nijhoff, Leiden, Boston, 2009) at p 44.

${ }^{342}$ Bruce Pardy, 'Changing Nature: The Myth of the Inevitability of Ecosystem Management' (2003) 20 Pace Environmental Law Review 675 - 692, at p 691. Pardy analogises the point of no return in ecosystems to that of a Rubik's Cube. Pardy stated that 'the point of no return is reached when all the colours are hopelessly mixed up, when the cube is so changed that it does not resemble the cube in its original organisation, and it is not possible to put the cube back into its pristine state ... One danger of ecosystem management is that it allows and encourages ecosystems is changed, the closer to the real point of no return it becomes'. Anwar et al raises that the over-exploitation of the common resources can bring the ecosystem to the point of no return. See Sk Morshed Anwar, Cédric A Jeanneret, Lael Parrott, and Danielle J Marceau, 'Conceptualization and Implementation of a Multi-agent Model to Simulate Whalewatching Tours in the St Lawrence Estuary in Quebec, Canada' (2007) 22 Environmental Modelling and Software 1775 - 1787, at $\mathrm{p}$ 1777. There are ample examples that raised deep concern in the global community, and the degradation of the Aral Sea Basin is one of them. Brunnée and Toope, 'Environmental Security, supra n 3, at p 55. The authors further elaborated that: 'an ecosystem's capacity to 'self-organise' allows it to regenerate or to adapt to stresses, that is, to maintain or regain integrity'. The exploration of protection that goes into the level of 'ecosystem integrity' is an incorporation of the ecosystem approach, as employed by the Biodiversity Convention regime, noted by the Ramsar Convention where the concept of wise use in the Ramsar regime is updated in the reflection of the emergence of the ecosystem approach.
} 
There is sufficient scholarship to urge the global community to treat maintenance of ecosystem integrity as the main objective in environmental protection. The minimal management approach they propose to safeguard the ecological structure, processes and functions, as one of the better means ${ }^{343}$ to achieve ecosystem integrity, is reflected in existing legal obligations under international law on the environment, and manifested in legal terminologies such as 'preservation', or even 'conservation', which has a broader connotation.

The subsequent sections will be directed to the identification of rules that impose obligations to preserve freshwater ecosystems of international watercourses. The Ecosystem Approach, which aims to guide the management of ecosystems to achieve integrity of the systems, by ensuring that the ecological structure, processes and functions remain intact, underpins this analysis.

\section{2 'Relevant' Rules}

Relevance relates to the subject matter where the extraneous rule must be related in some way to the treaty being interpreted. ${ }^{344}$ The 'relevancy' of rules suggests that external rules, to be applicable in the interpretation process under Article 31(3)(c), should 'primarily focus on rules in cognate areas'. 345

A recent WTO case at the AB level illustrated the depth of detail needed for an external rule of international law to be considered 'relevant' for the purpose of interpretation under Article 31(3)(c) of the 1969 Vienna Convention. In the EC - Aircraft case, ${ }^{346}$ the European Union argued that Article 4 of the 1992 Agreement $^{347}$ is relevant to the

\footnotetext{
${ }^{343}$ See Joern Fischer, David B Lindenmayer, and Adrian D Manning, 'Biodiversity, Ecosystem Function, and Resilience: Ten Guiding Principles for Commodity Production Landscapes' (2006) 4 Frontiers in Ecology and the Environment 80 - 86; and Adrian Phillips (ed) Economic Values of Protected Areas. Guidelines for Protected Area Managers (Best Practice Protected Area Guidelines Series No 2, IUCN, 1998) <http://data.iucn.org/dbtw-wpd/edocs/PAG-002.pdf> accessed 9 September 2012.

${ }^{344}$ Sands, 'Treaty, Custom and the Cross-fertilization of International Law', supra n 119, at p 102.

${ }^{345}$ Thomas W Wälde, 'Interpreting Investment Treaties: Experiences and Examples' pp 724 - 781 in Christian Binder, Ursula Kriebaum, August Reinisch, and Stephen Wittich (eds) International Investment Law for the $21^{\text {st }}$ Century. Essays in Honour of Christoph Schreuer (Oxford University Press, 2009) at $\mathrm{p}$ 775. Gardiner commented that: "It seems reasonable to take the ordinary meaning of "relevant" rules of international law as referring to those touching on the same subject matter as the treaty provisions being interpreted or which in any way affect that interpretation'. Gardiner, Treaty Interpretation, supra n 235, at $\mathrm{p} 260$.

${ }^{346}$ EC - Aircraft, supra n 288.

${ }^{347}$ The 1992 Agreement between the European Economic Community and the Government of the United States of America Concerning the Application of the GATT Agreement on Trade in Civil Aircraft on Trade in Large Civil Aircraft, was concluded in furtherance of the 1979 Agreement Trade in Civil
} 
interpretation of 'benefit' in two ways. ${ }^{348}$ The $\mathrm{AB}$ observed that the subject matter of the 1992 Agreement might be 'relevant' in the context of Article 31(3)(c) of the 1969 Vienna Convention as it relates closely to issues germane to the dispute especially the measures taken by the European Communities in the area of civil aircraft that the United Sates challenges under the [Subsidies and Countervailing Measures Agreement (SCM Agreement)]. ${ }^{349}$

The first argument proposed by the European Union was, the reference to 'support' and the thresholds applied in Article 4 of the 1992 Agreement 'speak to the existence of "benefit" and thus to the existence of a subsidy and the obligation for the government not to exceed such a ceiling when providing development support'. ${ }^{350}$ The European Union contended that Article 4 of the 1992 Agreement "informs the meaning of "benefit" provided under Article 1.1(b) of the SCM Agreement as well as the benefit analysis under the provision'. ${ }^{351}$ In this regard, the AB considered that Article 4 of the 1992 Agreement is not relevant to the 'specific question that must be examined under Article 1.1(b) of the SCM Agreement'. 352

Alternatively, European Union argued that the 'existence and operation of Article 4 [are] part of the facts to establish the relevant market benchmark ${ }^{353}$ at the time the launch aid or member state financing (known as 'LA/MSF' throughout the AB's decision) was granted'. ${ }^{354}$ The $\mathrm{AB}$ commented that Article 4 has no direct bearing on the specific financial market, ${ }^{355}$ and they were not convinced that the 'existence and operation of

\footnotetext{
Aircraft against a background of differences between the EEC and the US over support measures to their respective large civil aircraft industries.

${ }^{348}$ EC - Aircraft, supra n 288, at p 40, para 83.

${ }^{349} \mathrm{EC}$ - Aircraft, supra n 288, at p 363, para 847.

${ }^{350} \mathrm{EC}$ - Aircraft, supra n 288, at p 366, para 850.

${ }^{351} \mathrm{EC}$ - Aircraft, supra n 288, at p 366, para 850. At para 851, relating to the first argument, the $\mathrm{AB}$ noted that Art 4 addresses the concern of financial contribution component of the definition of subsidy in Art 1.1 of the SCM Agreement. However, it does not distinguish between government support that places the recipient in a more advantageous position inherent in a definition of subsidy that makes the recipient 'better-off', and government support that is neutral where recipient could have obtained similar terms on the market.

${ }^{352}$ EC - Aircraft, supra n 288, at p 366, para 851. The question to be examined is: whether the amount to be paid by the recipient of the government loan is lower than the amount that would be paid for a comparable commercial loan. See Art 1.1 of the SCM Agreement.

${ }^{353}$ The AB has noted that one of the accepted definition of 'market' is 'the area of economic activity in which buyers and sellers come together and the forces of supply and demand affect prices'. See fn 1932, EC - Aircraft, supra n 288, at p 367, para 853.

354 The European Union emphasised that 'the existence of benefit requires an examination of the specific market conditions existing at the time the financial contribution is granted'. EC - Aircraft, supra n 288, at p 367, para 852 .

${ }^{355}$ Financial market is defined by the interaction between the economic agents that are willing to provide funds and those that seek to obtain funds. EC - Aircraft, supra n 288, at p 367, para 853.
} 
Article 4 is relevant as part of the facts to establish the relevant market benchmark for assessing benefit at the time LA/MSF was granted'. 356

For the foregoing reasons, the $\mathrm{AB}$ found that Article 4 does not distinguish between LA/MSF that is advantageous to the recipient and that is not, and that the existence and operation of Article 4 have no bearing on the determination of 'benefit'. It then concluded that Article 4 is not a 'relevant' rule of international law application in the relations between the parties within the meaning of Article 31(3)(c) that informs the interpretation of 'benefit' under Article 1.1(b) of the SCM Agreement. The Article was found not to form part of the facts to establish the relevant market benchmark.

The EC - Aircraft case illustrated that even if the external rule appears to address the same subject matter, it might not be sufficient if the rule of international law addresses or concerns the subject matter of the provision at issue. To be 'relevant', the external rule must be either 'relevant' for the interpretation of the provision of the interpreted treaty, or 'relevant' for the establishment of facts in the interpretative process of an interpreted treaty. ${ }^{357}$

In the interpretation of what 'relevant' means under Article 31(3)(c) of the 1969 Vienna Convention, the general rule is, the rules that are 'relevant' must all appear to address the same facts, or concern the subject matter of the treaty term at issue. ${ }^{358}$ Relevant rules may also be in the form of "chains of treaties that grapple with the same type of problem at different levels or from particular (technical, geographical) points of view'. ${ }^{359}$ The impressive normative development in the international regulation of the environment gives rise to a growing amount of normative equivalence between rules in different

\footnotetext{
${ }^{356}$ The AB is of the opinion that Art 4 of the 1992 Agreement may have influenced the relationship between the member States and Airbus because it determined how much support was provided by the member States, and how Airbus was expected to pay it back. However, Art 4 has no direct bearing on the financial market that is meant to be used as the benchmark to determine benefit. EC - Aircraft, supra $\mathrm{n}$ 288, at p 367, para 853.

${ }^{357}$ Although the Art 4 of the 1992 Agreement prima facie relates to issues germane to the dispute that revolves on the area of the development support of civil aircraft challenged by the United States under Art 1.1(b) of the SCM Agreement, the AB found that it is neither 'relevant' for the determination of 'benefit', nor 'relevant' as part of a fact that establishes the relevant market benchmark for the determination of 'benefit'. EC - Aircraft, supra n 288, at p 368, para 855. See further Villiger, Commentary on the 1969 VCLT, supra $\mathrm{n} 254$, at $\mathrm{p} 433$.

${ }^{358}$ Villiger, Commentary on the 1969 VCLT, supra n 254, at p 433, para 24.

${ }^{359}$ Fragmentation Report, supra n 17, at pp 209-210, para 416.
} 
treaty regimes. Such situation creates 'parallelism of treaties', ${ }^{360}$ and the existence of 'Multi-Sourced Equivalent Norms' (MSENs). ${ }^{361}$

The rules of international law are 'relevant' to the interpretation of a particular treaty because treaties, no matter how wide their subject matter is, are themselves a creature of international law predicated for their existence and operation on being part of the international law system, and as such are limited in scope. ${ }^{362}$ The treaties must be 'applied and interpreted against the background of the general principles of international law' whereby this 'background' and the 'general principles of international law' are deemed relevant for the purpose of Article $31(3)(\mathrm{c}) .{ }^{363}$ In addition to that, the scope of 'relevance' encompasses rules and principles that address questions, which the treaties do not 'resolve expressly and in a different way'. 364

For an external rule to play a role in the interpretative process, certain conditions must be fulfilled. ${ }^{365}$ Rules that are relevant must at least impinge on the same subject matter (in pari materia); rules that form part of a 'chain of treaties' that grapple with the same or similar problems albeit from different perspectives; or rules that are similar but arising in multiple treaties (normative pluralism or parallelism of treaties). Relevant rules also include situation where norms are multi-sourced, but equivalent (MSENs). Furthermore, relevant rules include general international law, the interpretation of which affects the treaty to be interpreted; or law that completes the picture; fills the lacunae; and reflects the subsequent evolution and development of international law that resolves the temporal issues.

\footnotetext{
${ }^{360}$ Bluefin Tuna case, supra n 120, at para 52.

${ }^{361}$ Broude and Shany, Multi-Sourced Equivalent Norms in International Law, supra $\mathrm{n} 98$.

${ }^{362}$ Conclusion on Fragmentation, supra n 289, at para 17.

${ }^{363}$ McNair, The Law of Treaties, supra $\mathrm{n} 234$, at $\mathrm{p} 466$.
}

${ }^{364}$ P Verzij, Georges Pinson Case (1927 - 1928) AD No 292 quoted in McLachlan, 'The Principle of Systemic Integration', supra n 162, at pp 279 - 280. Hence, apart from the logical adoption of the meaning of relevant to be rules directly relevant to the subject matter or the interpretation of rules that affects the treaty being interpreted as iterated above, relevant rules also encompass within their ambit general principles of international law in the background for all questions not addressed by the treaty to be interpreted. In particularly, these 'relevant' rules to be taken into account together with the context as stipulate under Art 31(3)(c) have the functions of: (a)resolving the issue of further or subsequent development in the law (including the application of the inter-temporal law); (b) completing the legal picture, or filling gaps, in a treaty by reference to general international law; (c) deriving guidance from parallel treaty provisions; and (d) resolving conflicting obligations arising under different treaties. See Gardiner, Treaty Interpretation, supra n 235, p 260.

${ }^{365}$ An extrapolation of the outcome of analysis in the WTO regime revealed that these conditions are the interpreted term must be broad and ambiguous in order to justify taking into account of external rules; and the external rules must be of assistance in the determination of the meaning of the interpreted rule. See Fitzmaurice, Elias, and Merkouris (eds) Treaty Interpretation and the VCLT, supra n 279, at p 234. 


\subsubsection{Doctrine In Pari Materia}

'Statutes in pari materia are to be construed together; each legislative act is to be interpreted with reference to other acts relating to the same matter or subject'. ${ }^{366}$ In further deliberation of what are rules that appear to address the 'same' facts, 'similar' facts, or 'concerning the subject matter of the treaty term at issue', the rule on interpretation for statutes in pari materia will be able to provide guidance in such interpretation and analysis. The doctrine of in pari materia is applicable to international law, especially if the subject matter is identical, ${ }^{367}$ despite its origin as a rule of statutory interpretation in the domestic legal sphere. ${ }^{368}$ The idea of uniformity that underpins this doctrine is equally applicable for advising the interpretation of 'relevant' at the international legal sphere. ${ }^{369}$

The rule of interpreting statutes in pari materia necessitates the consideration of all previous acts of legislation relating to the same matters in order to construe the legislative act in hand. ${ }^{370}$ In order for the statute to be in pari materia in aid of

\footnotetext{
${ }^{366}$ Henry Campbell Black, MA, Handbook on the Construction and Interpretation of the Laws (The Lawbook Exchange, New Jersey, 2008) at p 204.

${ }^{367}$ Hans Aufricht, 'Supersession of Treaties in International Law' (1952) 37 Cornell Law Quarterly 655 700, at p 656. Despite recognising that the doctrine of in pari materia is applicable to international law, it does not entailed that the doctrine is 'a necessary corollary to the rule that the later law supersedes the earlier law', as stated by the author.

${ }^{368}$ This doctrine of in pari materia is referred to for multi-sourced norms at the international law in the interpretation investment protection rules at the international level. See Martins Paparinskis, 'Sources of Law and Arbitral Interpretations of Pari Materia Investment Protection Rules' (8 October 2010) in Ole K Fauchald and André Nollkaemper (eds) The Practice of International and National Courts and the (De)Fragmentation of International Law (Hart Publishing, Oxford, 2012) <http://papers.ssrn.com/sol3/papers.cfm?abstract_id=1697835> accessed 7 September 2012.
}

${ }^{369}$ See Hersch Lauterpacht, 'Decisions of Municipal Courts as A Source of International Law' (1929) 10 British Yearbook of International Law $65-95$, at pp 85 - 86. Lauterpacht proposed a thesis that 'decisions of the municipal courts, when forming a link in a chain of concordant decision in pari materia on the part of courts of several states, participate in the creation of a customary rules of international law. When the decision in question originate from courts of a large number of states and relate to a matter which lies within the particular province of those states, they will create customary international law binding also upon such states as had no occasion to signify their adherence to this rule. It is submitted that the true sedes materiae of uniform decisions of municipal courts in their cumulative effect as international custom is in the second paragraph of Article 38'. It is elaborated earlier in p 85 that 'uniform municipal case law on questions of international law may well be regarded as forming part of "international custom as evidence of a general practice accepted as law" referred to in the second paragraph of Article 38 of the Statute of the Permanent Court of International Justice'.

${ }^{370}$ Henry Campbell Black, Interpretation Handbook, supra n 366, at p 205. For example, when a term in a statute is used with a certain meaning, the subsequent uses of the same word in regulations on the same subject matter will be understood as implying the same meaning, unless indicated otherwise. At pp $205-$ 207, it is further elaborated that 'statutes are in pari materia when they relate to the same person or thing, or to the same class of persons or things'. Examples quoted include: 'English laws concerning paupers and their bankrupt acts are to be construed together, as if they were one statute and as forming a united system ... such laws are in pari materia. All the statutes of the same state relating to the property rights and contracts of married women, removing their common law disabilities, authorizing them to manage their separate estates, to engage in business, etc., are to be read and construed together as constituting one 
interpretation, explicit stipulation in the latter to refer to the former is not necessary; nor it is necessary that the former should still continue to be in force. It is emphasised that contemporaneous legislation of a similar nature, although not precisely in pari materia, is within the reason of the rule, and may be referred to for the same purpose. ${ }^{371}$

\subsubsection{Normative Parallelism and the Parallelism of Treaty}

Parallelism of norms commonplace in the national legal system is regarded as attributed to the normative unity and institutional 'integrativity' of domestic legal systems. ${ }^{372}$ However, normative parallelism entails a different effect in the international legal order due to the absence of a central authority and the lack of institutional integration. ${ }^{373}$

The notion of parallelisms of treaty surfaced in Australia and New Zealand's argument against Japan's reliance on the principle of lex posterior and lex specialis in the Bluefin Tuna case that the 1993 Convention for the Conservation of Southern Bluefin Tuna prevailed substantively and procedurally over the 1982 UNCLOS. The Arbitral Award elucidated the doctrine of parallelism in addressing dispute that arises within the framework of the umbrella UNCLOS and many compatible special treaties such as the 1993 Convention. ${ }^{374}$

In the dispute, Australia and New Zealand argued that Japan's interpretation that relies on the principle of lex posterior and lex specialis was misplaced because the principles are applicable only if there are conflicts or actual inconsistencies ${ }^{375}$ between two legal instruments. Furthermore, Article 311 of UNCLOS evidenced its mandate to regulate

system. Though they may have been passed at different times, successively advancing to a standard the opposite of that of the common law, they are all strictly in pari materia, and any doubt or ambiguity in one should be cleared up by reference to the terms, the purpose, and the policy of the rest. An act authorising married women to dispose of their property by will is in pari materia with the general statute relating to the execution and proof of wills. A statute in relation to attachments against steamboats for debt is in pari material with the general attachment law of the state, and hence, in so far as the special law is silent as to the modes of proceeding in the execution and return of writs issued under it, they must be regulated by the general rules prescribed by the general law. [This rules] is especially applicable in the case of revenue laws, though made up of independent enactments, are regarded as one system, in which the construction of any separate act may be aided by the examination of other provisions which compose the system. An act providing for a homestead and exemption for families of minor children is in pari materia with the laws allowing dower to the widow and minor children of a decedent ... All the laws relating to the subject of the regulation of liquor-traffic, are in pari materia.'

${ }^{371}$ Black, Interpretation Handbook, supra n 366, at p 209.

${ }^{372}$ Broude and Shany, 'The International Law and Policy of Multi-Sourced Equivalent Norms', supra $\mathrm{n}$ 99, at $\mathrm{p} 3$.

${ }^{373}$ Fragmentation Report, supra n 17, at p 33, para 52.

374 Barbara Kwiatkowska, 'Southern Bluefin Tuna' (2001) 95 American Journal of International Law 162 - 171, at p 169.

${ }^{375}$ Bluefin Tuna case, supra n 120, at p 35, para 41(k). 
relationships with implementing conventions such as the 1993 Convention, whereby UNCLOS could not be said to be in conflict or inconsistent with the 1993 Convention. ${ }^{376}$ The Tribunal concluded that the dispute between Australia and New Zealand, on the one hand, and Japan on the other, over Japan's role in the management of Bluefin Tuna stocks and particularly its unilateral experimental fishing programme, while centred in the 1993 Convention, also arises under the UNCLOS. ${ }^{377}$

The Tribunal rejected Japan's argument and reaffirmed their recognition that parallelism of treaty, substantively or procedurally, including provision for settlement of dispute, is commonplace, ${ }^{378}$ longstanding and widespread ${ }^{379}$ in international law and State practice. The Tribunal further stated that in the present case, it would be artificial for the Tribunal to find a dispute arising under UNCLOS that is distinct from the 1993 Convention, as the same Parties grapple with not two separate disputes but in fact a single dispute arising under both Conventions. ${ }^{380}$

The award of the Tribunal in the Bluefin Tuna case indicates that the parallelism of treaty means there is 'more than one treaty to bear upon a particular dispute' where a violation of a certain obligation could be found 'under more than one treaty'. ${ }^{381}$ It is noted that increased normative density will necessarily result in the occurrence of parallel legal regimes that regulate the same subject matter. ${ }^{382}$ The arguments of Australia and New Zealand substantiated the content of 'parallelism' by stating that even if the 1993 Convention 'completely covered' all relevant obligations of UNCLOS, it is only a situation of parallelism of obligations, and emphasised that such a situation is not unusual in international practice. ${ }^{383}$

The existing international legal regime is a product of 'a process of accretion and cumulation' where the conclusion of an implementing convention does not necessarily obliterate the obligations imposed by the framework convention (UNCLOS) upon the parties to the implementing convention. ${ }^{384}$ The parallel and overlapping existence of

\footnotetext{
${ }^{376}$ Bluefin Tuna case, supra n 120, at pp $33-34$, para 41(g).

${ }^{377}$ Bluefin Tuna case, supra n 120, at p 41, para 52.

${ }^{378}$ Bluefin Tuna case, supra n 120, at p 40, para 52.

${ }^{379}$ Bluefin Tuna case, supra n 120, Separate Opinion of Justice Sir Kenneth Keith, at p 51, para 11.

${ }^{380}$ Bluefin Tuna case, supra n 120, at p 42 , para 54. See also Barbara Kwiatkowska, 'MOX Plant', supra n 334, at pp 4 and 28.

${ }^{381}$ Bluefin Tuna case, supra n 120, at p 40, para 52.

382 Shany, 'The First MOX Plant Award', supra n 99, at p 823.

${ }^{383}$ Bluefin Tuna case, supra $\mathrm{n} 120$, at $\mathrm{p} 35$, para 41(k).

${ }^{384}$ Bluefin Tuna case, supra n 120, at p 40, para 52.
} 
obligations arising under one treaty has not excluded or in any relevant way prejudiced the other. ${ }^{385}$

A parallelism of laws is said to exist when there may be two distinct sets of rules applicable to a particular situation, such as the possible (simultaneous) applicability of international human rights law and international humanitarian law. ${ }^{386}$ The UN Report on the Situation concerning the Detainees in Guantánamo Bay supports the complementary application of international humanitarian law and international human rights law. ${ }^{387}$

The Court in the Palestine Wall case considered that -

'Protection offered by human rights conventions does not cease in case of armed conflict, save through the effect of provisions for derogation of this kind to be found in Article 4 of the International Covenant on Civil and Political Rights ... The Court will have to take into consideration both these branches of international law, namely human rights law and, as lex specialis, international humanitarian law. 388

In Congo v Uganda, the ICJ had decided that the acts of killing, torture and other forms of inhumane treatment of the civilian population, and other acts contrary to human rights and international humanitarian law committed by the Uganda People's Defence

\footnotetext{
${ }^{385}$ Bluefin Tuna case, supra n 120, Separate Opinion of Justice Sir Kenneth Keith, at p 49, para 1.

${ }^{386}$ European Union Guidelines on Promoting Compliance with International Humanitarian Law [2005] OJ $\mathrm{C} 327 / 04$

lex.europa.eu/LexUriServ/LexUriServ.do?uri=OJ:C:2005:327:0004:0007:EN:PDF>, $\quad$ accessed 16 September 2011, at para 12. It is stated that: 'It is important to distinguish between international human rights law and international humanitarian law. They are distinct bodies of law and, while both are principally aimed at protecting individuals, there are important differences between them. In particularly international humanitarian law is applicable in time of armed conflict and occupation. Conversely, human rights law is applicable to everyone within the jurisdiction of the State concerned in time of peace as well as in time of armed conflict. Thus while distinct, the two sets of rules may both be applicable to a particular situation and it is therefore sometimes necessary to consider the relationship between them'.

${ }^{387}$ The Report reiterated General Comment No. 31 (2004) by the Human Rights Committee, and stated, 'The Covenant [International Covenant on Economic, Social and Cultural Rights (ICESCR)] applies in situations of armed conflict to which the rules of international humanitarian law are applicable.' UN, 'Situation of Detainees at Guantánamo Bay', Report of the Commission on Human Rights, Sixty-second Session, (27 February 2006) UN Doc E/CN.4/2006/120, at p 7, para 15 <http://www.unhcr.org/refworld/country,,UNCHR,,CUB,,45377b0b0,0.html> accessed 11 August 2011.

${ }^{388}$ Legal Consequences of the Construction of A Wall in the Occupied Palestinian Territory (Advisory Opinion of 9 July 2004) [2004] ICJ Reports 136, at p 46, para 106 <http://www.icjcij.org/docket/files/131/1671.pdf> accessed 11 August 2011 (hereinafter: 'Palestine Wall' case).
} 
Force (UPDF) troops in the occupied territories, were attributable to Uganda. ${ }^{389}$ Subsequently, the Court turned to examine whether such conduct constituted a breach of Uganda's international obligations under international human rights law and international humanitarian law relevant for this purpose. ${ }^{390}$ The Court concluded that Uganda is internationally responsible for the violations of their obligations under both international human rights law and international humanitarian law in the occupied territory. $^{391}$

The equal applicability of both international humanitarian law and human rights law in situations of belligerent occupation are recognised by international courts, because these rules as deemed relevant in the given situation, especially when they also outlaw the same conduct. The parallel rules are applicable simultaneously even if the protection in one branch of law is found to be less than the protection in the other branches of law. ${ }^{392}$ The International Criminal Tribunal for Former Yugoslavia (ICTY) expounded the reason for the recourse to international human rights law in the case of Kunarac and stated that 'in certain aspects, international humanitarian law can be said to have fused with human rights law, 393

The parallelism of treaties occurs where parallel norms of similar content are found to be applicable and relevant to a particular context. The norms can said to be relevant due to the similarity of content, dealing with the same matter, outlawing the same matter, or the resemblance between them, in terms of goals, values and terminology. ${ }^{394}$

\footnotetext{
${ }^{389}$ Armed Activities on the Territory of the Congo (Democratic Republic of the Congo v. Uganda) (Judgment of 19 December 2005) [2005] ICJ Reports 168, at pp 241 - 242, paras 211 - 213 (hereinafter: 'Congo v Uganda' case) <http://www.icj-cij.org/docket/files/116/10455.pdf> accessed 12 August 2011.

${ }^{390}$ The Palestinian Wall case, supra $\mathrm{n} 388$ (at p 178, para 106) was quoted in Congo v Uganda, supra $\mathrm{n}$ 389 , at pp 242 - 243, paras 215 - 216 to lend support to the applicability of both branches of law in case of armed conflict, unless there is a proviso for the derogation of such kind to be found in Art 4 of the International Covenant on Civil and Political Rights. The Court commented that in the Palestinian Wall case, it had the occasion to address the issues of the relationship between international humanitarian law and international human rights law. It decided that some rights might be exclusive to the respective regimes of human rights law and humanitarian law, 'yet others may be matters of both of these branches of international law'. This indicates the cognisance of the Court of the existence of the parallelism of laws due to the parallelism of treaty. See Congo v Uganda, supra n 389, at pp 242 - 243, paras 215 - 216.

${ }^{391}$ Congo v. Uganda, supra $\mathrm{n} 389$, at p 245, para220.

392 Orakhelashvili, 'The Interaction between Human Rights and Humanitarian Law', supra n 96, at p 163.

393 ICTY, Prosecutor v. Dragoljub Kunarac, Radomir Kovac and Zoran Vukovic (Judgment of 22 February 2001) (Case No.: IT-96-23-T and IT-96-23/1T) at p 158, para 467 (hereinafter: 'Kunarac' case) <http://www.icty.org/X/cases/kunarac/tjug/en/kun-tj010222e.pdf> accessed 12 August 2011.

${ }^{394}$ Kunarac case, supra n 393, at p 158, para 467. See also Orakhelashvili, 'The Interaction between Human Rights and Humanitarian Law', supra n 96, at p 182.
} 


\subsubsection{Multi-Sourced Equivalent Norms (MSENs)}

The fragmentation of international law produced a growing amount of normative equivalence between rules in different fields of international law, leading to the creation of what has been known as parallel or equivalent international norms that 'point in the same direction'. ${ }^{395}$ Equivalent norms that point in the same direction must necessarily be considered relevant within the purview of Article 31(3)(c) of the 1969 Vienna Convention in the interpretation of a treaty provision.

The background for the discussion of MSENs is the phenomenon of increased legal pluralism that promotes cross-fertilisation of legal concepts fed by two competing forces in pluralism, one towards differentiation and the other towards harmonisation. ${ }^{396}$ The broad definition adopted for MSENs represents the nucleus of equivalence amongst these multi-sourced norms. This definition allows the study group to tease out the conflicting aspects through specific lenses, in order to determine whether there exists a unifying characteristic that cuts across the specific normative systems from which these MSENs are derived. ${ }^{397}$

The Proceeding on the Convention for the Protection of the Marine Environment of the North-East Atlantic (OSPAR), ${ }^{398}$ which forms part of the MOX Plant dispute, is useful as a case study for the identification of the existence of the relevant MSENS relating to

\footnotetext{
${ }^{395}$ Fragmentation Report, supra n 17, at p 52, para 93. Broude and Shany, 'The International Law and Policy of Multi-Sourced Equivalent Norms', supra n 99, at pp 4-5.

${ }^{396}$ Maduro, 'Foreword', supra n 98, at p viii. The study group funded by the Davis Institute for International Relations at the Hebrew University of Jerusalem took up this research project to explore situations where distinct international legal rules direct similar or identical behaviour, where MSENs were defined as: 'Two or more norms which are (1) binding upon the same international legal subjects; (2) similar or identical in their normative content; and (3) have been established through different international instruments or 'legislative' procedures or are applicable in different substantive areas of the law'. Broude and Shany, 'The International Law and Policy of Multi-Sourced Equivalent Norms', supra n 99, at p 5. The result of the research is presented in Broude and Shany, Multi-Sourced Equivalent Norms in International Law, supra $\mathrm{n} 98$.

${ }^{397}$ Broude and Shany, 'The International Law and Policy of Multi-Sourced Equivalent Norms', supra $\mathrm{n}$ 99 , at pp 4-7. The conflictual qualities of norms deemed equivalent are explored through the lens of the various legal sources that give rise to their normative parallelism, which are influenced by the different underlying principles and rules depending on their different institutional framework laid out by the various specific normative regimes. Examples of these MSENs are - the obligation to prevent transboundary pollution; the legal defence of necessity; the general laws of state responsibility; the prohibition of the use of force and the self-defence exception thereto; national treatment obligations that might overlap with non-discrimination norms applicable to foreign labourers under human rights law and certain provisions of international investment law; and the prohibition of torture. Broude and Shany, 'The International Law and Policy of Multi-Sourced Equivalent Norms', supra n 99, at pp 5-6.

${ }^{398}$ OSPAR Proceeding, supra n 118.
} 
the right of access to environmental information. ${ }^{399}$ The OSPAR Convention, the EURATOM, the EC Directives, and the Convention on Access to Information, Public Participation in Decision-Making and Access to Justice in Environmental Matters (Aarhus Convention) formed the relevant MSENs that provided the analytical framework for the right to access to information in this case study. ${ }^{400}$

These instruments were viewed as relevant to the Proceeding because from the facts of the case, it was apparent that the basis of Ireland's claim of the right to access to information could be found in the instruments as mentioned above. Although the right to access to information, as provided under these various instruments, are all binding on the United Kingdom and Ireland, albeit to varying degrees, they were deemed equivalent for the purpose of the study of MSENs only because their normative content met the specified criteria for the qualification of these norms as MSENs. The right to access information as provided under the various sources, with subtle differences, all pointed towards a right to access to the economic information relevant to the protection of the environment, which meets the criteria for a MSEN case study (original emphasis). ${ }^{401}$

The study on MSENs gave a contemporaneous interpretation of 'relevant' in Article 31(3)(c) of the 1969 Vienna Convention on the Law of Treaties, defining the criteria for the qualification of norms as multi-sourced but equivalent. In this instance, apart from having identical or similar facts as a basis for relevance, 'relevant' rules could also be rules that are multi-sourced and equivalent; in other words, rules that have similar or identical normative content, or at least point in the same direction. ${ }^{402}$

In general, there are various approaches employed by interpreters, especially judges and scholars, which enrich the jurisprudence on the interpretation of 'relevant'. The analysis explores how judicial decisions, the doctrine of in pari materia, the phenomenon of normative and treaty parallelism, and the recent study on multi-sourced equivalent norms, inform the process of identification of relevant rules for the purpose of interpretation as provided under Article 31(3)(c) of the 1969 Vienna Convention.

\footnotetext{
${ }^{399}$ Nikolaos Lavranos, 'The OSPAR Convention, the Aarhus Convention and EC Law: Normative and Institutional Fragmentation on the Right of Access to Environmental Information', pp 143 - 169 in Broude and Shany, Multi-Sourced Equivalent Norms in International Law, supra $\mathrm{n} 98$.

${ }^{400}$ Lavranos, 'Right of Access to Environmental Information', supra n 399, at p 148.

${ }^{401}$ Lavranos, 'Right of Access to Environmental Information', supra n 399, at p 158.

402 Lavranos, 'Right of Access to Environmental Information', supra n 399, at p 148.
} 
'Relevant' rules include rules that address the same facts, similar facts or concerning the subject matter of the terminology of the treaty at issue. Rules that are related to the same person or thing, or to the same class of persons or things, or contemporaneous rules of a similar nature, can be considered "relevant". In addition to that, multi-sourced rules that have similar or identical normative content pointing in the same direction are considered as 'relevant' for the purpose of this research.

There is a general scientific consensus that minimal interference with/in the natural state of the environment is the best approach in the maintenance of the integrity of an ecosystem. ${ }^{403}$ The aim of the present research is to seek integration of rules that are relevant to the preservation of freshwater ecosystems via the interpretative framework provided under Article 31(3)(c) of the 1969 Vienna Convention.

The subsequent section of this chapter will seek to identify relevant rules through the assessment criteria established for the interpretation of 'relevant' for an interpretation of the obligation to preserve ecosystems of international watercourses, provided under Article 20 against its normative system.

\subsection{Relevant as Informed by the Ecosystem Approach}

The emergence of the ecosystem approach in international water law is evident in the explicit recognition of 'ecosystems' in Article 20 of the 1997 Watercourses Convention, and in light of the overall context of the protection, preservation and management of the international watercourses undertaken in the Convention. This approach is further supported by the advancement in scientific and technological knowledge and knowhow, ${ }^{404}$ and the expansive interpretation of 'international watercourses' adopted by eminent scholars in the field. ${ }^{405}$

\footnotetext{
${ }^{403}$ This approach has been reflected in the obligations stipulated under multilateral environmental agreements (MEAs) that are instituted in response to the need for a holistic system of ecosystem governance and management, including the use of their services and the regulation of human activities that have impact on ecosystems. W Bradnee Chambers et al., 'Typology of Responses', in Kanchan Chopra et al., eds., Ecosystems and Human Well-being: Policy Responses, (Volume 3 - Findings of the Responses Working Group of the MA, Island Press, Washington, 2005) <http://www.maweb.org/documents/document.307.aspx.pdf> accessed 13 September 2011, at p 41.

${ }^{404}$ Scientific evidence was heavily relied on in Schwebel's $3^{\text {rd }}$ Report, supra $\mathrm{n} 4$. A careful reading of the Commentary to the Convention seems to indicate that the careful choice of the Commission in adopting the specific terminology of 'ecosystem' does not seem to confine the potential scope of the obligation stated in Art 20. The Commission adopted the general definition of ecosystem - believed to have a more precise scientific and legal meaning, which is: 'an ecological unit consisting of living and non-living components that are interdependent and function as a community'. See 1994 Draft Articles and Commentaries, supra n 44, at p 118 para 2. The Commission further elaborated, at p 118 para 2 that '..
} 
The 1997 Watercourses Convention imposes firstly that 'watercourse States shall, individually, protect and preserve the ecosystems of international watercourses' (own emphasis). ${ }^{406}$ Only then, and where appropriate shall these watercourse States 'jointly ... preserve' these ecosystems. ${ }^{407}$

Environmental instruments that cater to the protection of watercourse ecosystems are already in existence even though they do not address international watercourses per $s e{ }^{408}$ In the analysis of the obligation to preserve freshwater ecosystems of international watercourses, all relevant rules applicable to the interpretation of this obligation have to be taken into account.

where in the ecosystem, everything depends on everything else and nothing is really wasted ... Thus, an external impact affecting one component of an ecosystem causes reactions among other components and may disturb the equilibrium of the entire ecosystem'. The interdependencies, the interrelations, and the interactions within the ecosystem inherent and intrinsic to the term 'ecosystem', explicated and clarified by the definition attached to this terminology as adopted by the Commission appear to belie the intention of the Commission to apply an overly restrictive interpretation that negates the land-water nexus.

${ }^{405}$ Korhonen lamented the shortcoming of the ILC where land and water is treated as separate entity where the definition of watercourse 'relies solely on the aquatic element without addressing the interdependencies that riverine systems have with the terrestrial environment'. Korhonen, 'Riverine Ecosystems in International Law', supra n 79, at p 482. The author adopted the definition for 'riverine ecosystem' to include the entire river network, including tributaries, side channels, sloughs, intermittent streams. However, a broad understanding to the term of 'ecosystems' would invariably include 'not only the flora and fauna in and immediately adjacent to a watercourse, but also the natural features within its catchment that have an influence on, or whose degradation could influent, the watercourse'. See McCaffrey, The Law of International Watercourses, supra n 79, at p 459. This sentiment resonated with the view held by Tanzi and Arcari where they pointed out that: '... since the concept of ecosystem encompasses a dynamic interrelationship between flora, fauna and the geographical elements which sustain them, inclusive of land areas, one cannot discard a priori the territorial implications of this concept in relation to the duty of protection of international watercourses ... [I]f the reach of an ecosystem is to be assessed in relation to the physical reactions among its components which are caused by an external factor, it is inevitable that the scope of the ecosystem is to cover also those land areas whose use may affect a watercourse, more or less directly'. See Tanzi and Arcari, The United Nations Convention on the Law of International Watercourses: A Framework for Sharing, supra n 48, at pp $240-$ 241. Sohn eloquently asserted that the attempt of the Commission to exclude territorial implication in a restrictive interpretation of the term 'ecosystem' to confine only to areas that are water-covered is imprudent and should be avoided where he stated that: 'It is important, however, to consider also the adjoining land area, regardless of some purists who would like to confine the idea of watercourse ecosystems to water-covered areas ... Water provides life-support not only to flora and fauna living in the water but also to all on land who need it for drinking or for industries on which the livelihood of many depends. In turn, the ecosystems of the watercourses are affected by activities on land, not only in the immediate vicinity but often far away from the river valleys and neighbouring mountain ranges.' Louis B Sohn, 'Commentary. Articles 20-25 and 29' (1992) 3 Colorado Journal of International Environmental Law and Policy 215 - 223, at p 216.

4061997 Watercourses Convention, supra n 35, Art 20.

4071997 Watercourses Convention, supra n 35, Art 20.

${ }^{408}$ McCaffrey, The Law of International Watercourses, supra $\mathrm{n}$ supra $\mathrm{n}$ 79, at $\mathrm{p} 393$. Other treaty regimes that directly and indirectly affect freshwater ecosystem are identified in The Implementation of Multilateral environment Agreements for Efficient Water Management, a paper prepared by The Foundation for International Environmental Law and Development (FIELD), April 2005 (on file with author). 
The adoption of the term 'preservation' by the Commission reflected the intention of the Commission to impose an obligation to keep the pristine state of the environment. ${ }^{409}$ This is supported further by Schwebel's statement in his Third Special Rapporteur Report that the preservation entails the creation and management of national or international parks where the wildlife and scenery are 'removed from the operation of ordinary legislation and are reserved, under special regimes, for controlled, limited use as preserves'. ${ }^{410}$ The employment of the term 'ecosystems' in the protection, preservation and management of international watercourses 411 under the 1997 Watercourses Convention indicates the recognition of the watercourse states of the concept of ecosystems and the application of the ecosystem approach in the ascertainment of the standard of protection and preservation imposed under Article 20.

Relevant rules must be within cognate areas of the 'ecosystems of international watercourses', which touches on the watercourses' states' obligation to 'preserve'. Thus, a preliminary identification of relevant rules includes rules that impinge on the states' obligations to preserve freshwater ecosystems. ${ }^{412}$ MEAs that may possibly fit the interpretation of 'relevant' are found in the biodiversity conservation cluster. Due to the limitation of a three-year research, the two most robust conventions from the biodiversity cluster, namely the Ramsar Convention and the Biodiversity Convention are selected for analysis. ${ }^{413}$

\footnotetext{
4091994 Draft Articles with Commentaries, para3, p 119.

${ }^{410}$ Schwebel's $3^{\text {rd }}$ Report, , supra n 4, at p 190, para 518.

4111997 Watercourses Convention, supra n 35, Preamble and Chapter IV.

${ }^{412}$ A recent $\mathrm{AB}$ decision in the World Trade Organisation demonstrated the level of detail necessary for an external rule of international law to be considered relevant for the purpose of interpretation under Art 31(3)(c). EC - Aircraft, supra n 288. The AB, at p 363, para 847, observed that the subject matter of the external rules has to be closely related to the issues germane to the dispute, namely measures taken by the European Communities in the area of civil aircraft. Furthermore, at pp $363-367$, paras $847-853$, it must also be relevant to the ascertainment of the interpretation of 'benefit' provided in Art 1.1(b) of the SCM Agreement or relevant as part of a fact that establishes the relevant market benchmark for the determination of 'benefit'.

${ }^{413}$ The biodiversity-related conventions and treaties includes Biodiversity Convention, supra $\mathrm{n}$ 12; CITES, supra n 199 supra n 199; CMS; International Treaty on Plant Genetic Resources for Food and Agriculture (FAO Conference at Its Thirty-first Session) (concluded 3 November 2001, entered into force 29 June 2004) Registered with the UN on 13 December 2006, I-43345 <ftp://ftp.fao.org/docrep/fao/011/i0510e/i0510e.pdf > accessed 15 November 2012; Ramsar Convention, supra $\mathrm{n}$ 13; and the World Heritage Convention, supra n 199. UNEP-World Conservation Monitoring Centre, 'Promoting Synergies within the Cluster of Biodiversity-related Multilateral Environmental Agreements Summary Report' (April 2012) wcmc.org/medialibrary/2012/04/27/ff1a00f0/MEA synergies summary for web cover 27April2012.pd $\underline{f}>$ accessed 27 September 2012. See UNEP-World Conservation Monitoring Centre, 'Report by UNEPWCMC on "Promoting Synergies within the Cluster of Biodiversity-related Multilateral Environmental Agreements' (2012) < http://www.unep-wcmc.org/report-by-unep-wcmc-on-promoting-synergies-within-
} 
Both conventions can be said to be 'grappling with the same type of problem', which is the protection of ecosystems, including the designation of an area that is pristine and near natural for protection, albeit from the different perspectives of wetlands and biodiversity. These conventions presented themselves as appropriate candidates for the identification of rules within these treaty instruments that are relevant for the interpretation of the obligation to preserve under Article 20 of the 1997 Watercourses Convention.

\subsubsection{The 1971 Ramsar Convention on Wetlands}

The Ramsar Convention is an intergovernmental treaty concluded for the maintenance of the ecological functions of wetlands, as regulators of water regimes and as habitats supporting a characteristic flora and fauna, especially waterfowl. ${ }^{414}$ Despite not being affiliated with other MEAs under the United Nations system, it works closely with other treaties and agreements under the biodiversity-cluster. ${ }^{415}$

The recognition of the ecosystem is explicit in the definition of 'wise use', which is the central philosophy of the Ramsar Convention. ${ }^{416}$ Subsequent development in field of international environmental law, such as the introduction of the concepts of 'sustainable development', 417 'ecosystems', 'ecosystem approach' and 'ecosystems services' 418 prompted a revision of the definition. ${ }^{419}$

the-cluster-of-biodiversity-related-multilateral-environmental-agreements_866.html> $>\quad$ accessed 27 September 2012. See also Chidi Oguamanam, 'Biological Diversity', supra n 341, at p 218; and supra n 199.

${ }_{414}$ Birnie, Boyle, and Redgwell, supra n 112, at p 666.

415 See Ramsar Secretariat, 'About the Ramsar Convention' <http://www.ramsar.org/cda/en/ramsarabout-about-ramsar/main/ramsar/1-36\%5E7687_4000_0_> accessed 13 September 2011.

${ }^{416}$ A definition of 'wise use' was first adopted by Contracting Parties at COP 3 in 1987, Ramsar Convention, 'Recommendation 3.3: Wise Use of Wetlands' ( $3{ }^{\text {rd }}$ Meeting of the Conference of the Contracting Parties, Regina, Canada 27 May - 5 June 1987) 〈http://www.ramsar.org/pdf/rec/key_rec_3.03e.pdf> accessed 15 November 2012. The principles of 'wise use' and the maintenance of 'ecological character' of wetlands lie at the very heart of the Ramsar Convention. Maintaining the ecological character of wetlands designated as Wetlands of International Importance (Ramsar sites) and securing, as far as possible, the wise use of the wetlands in their territory, is recognized in the text of the Convention adopted in 1971 as amongst the key outcomes of the implementation of the Convention by its Contracting Parties. Recommendation 3.3 defined 'wise use' as 'the maintenance of their ecological character, achieved through the implementation of ecosystem approaches, within the context of sustainable development' (Definition updated in Resolution IX.1, Annex A, 2005). See Ramsar Convention Secretariat, The Ramsar Convention Manual: A Guide to the Convention on Wetlands (6th edn, Ramsar Convention Secretariat, Gland, Switzerland, 2013) at p 102 $\langle$ http://www.ramsar.org/pdf/lib/manual6-2013-e.pdf> accessed 17 February 2013.

417 Report of the World Commission on Environment and Development: Our Common Future, transmitted to the General Assembly as an Annex to document A/42/427 - Development and International Co-operation: Environment 〈http://www.un-documents.net/wced-ocf.htm> accessed 13 September 2011. 
The important components of the 'wise use' concept are amended in light of subsequent development in the field of environmental governance at the international level. The amendment takes into account the Millennium Ecosystem Assessment's (MA) terminology, ${ }^{420}$ the concepts of the ecosystem approach and sustainable use applied by the Biodiversity Convention, ${ }^{421}$ and the definition of sustainable development adopted by the 1987 Brundtland Commission. The 'wise use' concept is amended, in reflection of such developments, to 'the maintenance of their ecological character, achieved

${ }^{418}$ MA, 'Guide to the Millennium Assessment Reports' (2005) <http://www.maweb.org/en/index.aspx>
accessed 13 September 2011 .
${ }^{419}$ Foreword, Ramsar Convention Secretariat, Ramsar Handbooks for the Wise Use of Wetlands (3rd edn,
Ramsar Convention Secretariat, Gland, Switzerland, 2007) at p 4 $\begin{array}{lllllll}\text { Ramsar Convention Secretariat, Gland, Switzerland, } & \text { 2007) at } & \text { a } & 4 \\ <\text { http://www.ramsar.org/pdf/lib/lib_handbooks2006_e01.pdf> accessed } & 12 & \text { May 2011. An updated }\end{array}$ definition adopted for "ecological character" in view of the terminologies adopted in Biodiversity Convention and MA is 'the combination of the ecosystem components, processes and benefits/services that characterise the wetland at a given point in time'. Consistent with the updated definition of 'ecological character', the updated definition of 'change in ecological character of wetlands', for the purposes of implementation of Art 3.2, is: 'the human-induced adverse alteration of any ecosystem component, process, and/or ecosystem benefit/service'.

${ }^{420}$ Within the MA terminology, 'ecosystems' are described as the complex of living communities (including human communities) and non-living environment (ecosystem components) interacting (through ecological Process) as a functional unit which provides inter alia a variety of benefits to people (ecosystem services). In the context of the Ramsar Convention, ecosystem services refer to products, functions and attributes as defined in Resolution VI.1 and expanded to include both material and nonmaterial cultural values, benefits and functions as outlined in COP 8 DOC.15 'cultural aspects of wetlands', Ramsar Convention, 'Resolution IX.1 Annex A. A Conceptual Framework for the Wise Use of Wetlands and the Maintenance of Their Ecological Character', infra n 422. For further information, see Synthesis Report prepared by the MA for the Ramsar Convention, CM Finlayson, R D'Cruz, NC Davidson, Wetlands and Water: Ecosystem Services and Human Well-Being (World Resources Institute, Washington DC, 2005). Under the MA framework, 'wise use' equates to the maintenance of ecosystem benefits/services to ensure long term maintenance of biodiversity as well as human well-being and poverty alleviation.

${ }_{421}$ 'Ecosystem approach' is defined in CBD, Decision V/6, supra n 298, as 'a strategy for the integrated management of land, water and living resources that promotes conservation and sustainable use in an equitable way. The ecosystem approach is based on the application of appropriate scientific methodologies focused on levels of biological organisation, which encompass the essential structure, processes, functions and interactions among organisms and their environment. It recognises that humans, with their cultural diversity, are an integral component of many ecosystems'. This focus on structure, processes, functions and interactions within the ecosystem as a functional unit, without any specification of any particular spatial unit or scale, is consistent with the definition of 'ecosystem' provided in Art 2 of Biodiversity Convention, supra n 12. It is interesting to note the flexibility of the application of the ecosystem approach. Decision V/6 stated that: 'the ecosystem approach does not preclude other management and conservation approaches, such as biosphere reserves, protected areas, and single-species conservation programmes, as well as other approaches carried out under existing national policy and legislative frameworks, but could, rather, integrate all these approaches and other methodologies to deal with complex situations. There is no single way to implement the ecosystem approach, as it depends on local, provincial, national, regional or global conditions. Indeed, there are many ways in which ecosystem approaches may be used as the framework for delivering the objectives of the Convention (CBD) in practice'. 
through the implementation of ecosystem approaches, within the context of sustainable development'. 422

The obligation to preserve is explicit in the Ramsar Convention. Article 2.1 provides for the designation of wetlands for inclusion in the List of Wetlands of International Importance. ${ }^{423}$ This reinforces the obligation to conserve wetlands situated within the territory of the Contracting Parties, especially concerning designated wetlands of international importance.

The obligation to conserve wetlands is not limited to the designation of Listed sites. Article 4 stipulates that the promotion of the conservation of wetlands and waterfowl shall be undertaken through the establishment of nature reserves on wetlands, regardless of whether these wetlands are to be included in the List. ${ }^{424}$ The obligation to conserve wetlands are treated as an obligation of conduct, whereby the removal of conservation sites entails compensation in the form of the creation of additional natural reserves for waterfowl and for the protection of an adequate portion of the original habitat. ${ }^{425}$

The adoption of an ecosystem approach is explicit in the Ramsar Convention where wetlands have been acknowledged as an ecosystem under the Ramsar Convention. ${ }^{426}$

${ }^{422}$ Ramsar Convention, 'Resolution IX.1 Annex A. A Conceptual Framework for the Wise Use of Wetlands and the Maintenance of Their Ecological Character' $\left(9^{\text {th }}\right.$ Meeting of the Conference of the Parties to the Convention on Wetlands (Ramsar, Iran, 1971) Kampala, Uganda, 8 - 15 November 2005) <http://www.ramsar.org/cda/en/ramsar-documents-resol-resolution-ix-1-annex-a/main/ramsar/1-31107\%5E23536_4000_0_> accessed 14 November 2012. At paras $23-24$, it is agreed that within the context of ecosystem approaches, planning processes for the promotion of wetland ecosystem benefits/services delivery should be formulated and implemented in the view of the maintenance or enhancement (as appropriate), of wetland ecological character at appropriate spatial and temporal scales, in order to attain sustainable development. The phrase 'in the context of sustainable development' as stated in the updated definition of 'wise use' is intended to qualify that - although it is 'recognised that whilst some wetland development is inevitable and that many developments have important benefits to society, developments can be facilitated in sustainable ways by approaches elaborated under the Convention, and it is not appropriate to imply that "development" is an objective for every wetland'.

${ }^{423}$ Ramsar Convention, supra n 13, Art 2.1, 2.6, and 3.1.

${ }^{424}$ Ramsar Convention, supra n 13, Art 4.1.

${ }^{425}$ Ramsar Convention, supra n 13, Art 4.2 provides that in the event of 'urgent national interest' that the Listed wetlands are to be deleted or to have their boundaries restricted, the Contracting Party should endeavour to compensate for any loss of wetland resources. Compensation should be in the form of creating additional natural reserves for waterfowl and for the protection of an adequate portion of the original habitat in either the same area or elsewhere.

${ }^{426}$ The vision for the List of Wetlands of International Importance amended by Resolution IX.1 Annex B, 2005 had explicitly recognised that the development and maintenance of an international network of wetlands for the conservation of global biodiversity and human life sustenance are undertaken through the maintenance of their (ie, the wetlands') ecosystem components, processes and benefits/services. Ramsar Convention, 'Strategic Framework and Guidelines for the Future Development of the List of Wetlands of International Importance of the Convention on Wetlands (Ramsar, Iran, 1971)' (3 ${ }^{\text {rd }}$ edn, as adopted by Resolution VII.11 (COP 7, 1999) and has been amended by Resolutions VII.13 (1999), VIII.11 and VIII.33 (COP8, 2002), IX.1 Annexes A and B (COP 9, 2005), and X.20 (COP10, 2008) 2009) at p 2, para 
The description of wetlands that requires submission of information on ecological processes and services provision reflects the application of the ecosystem approach, as reiterated subsequently in the 2009 Strategic Framework and Guidelines that stressed the importance of wetlands 'as rich centres of biological diversity and productivity and as life support systems for human populations'. ${ }^{427}$

The Ramsar Convention, further refined in the most recent Strategic Framework and Guidelines for the implementation of the twin pillars of the Convention, i.e., conservation and wise use of wetlands, expressly recognises the transboundary nature of wetland ecosystems. The 2009 Strategic Framework and Guidelines gave a broad definition to 'wetland' for an application on a biogeographic region. ${ }^{428}$ The biogeographic regionalisation of the application of the Ramsar Convention, especially in the determination of the regions through scientifically rigorous biological and physical parameters, will entail a transboundary management of biogeographic regions that requires collaboration between countries of the determined biogeographic region. ${ }^{429}$

Despite the different perspective of freshwater ecosystems adopted in the Ramsar Convention (wetlands) and the 1997 Watercourses Convention (watercourses), the obligation to conserve wetlands of international importance under Articles 2.1 and 4.1 of the Ramsar Convention addresses the protection of freshwater ecosystems through designation of reserved sites for protection that maintains the natural condition of the site.

The designation of wetland nature reserves based on the ecological character, functioning and ecosystem services provided by the reserves within a biogeographic

6 <http://www.ramsar.org/pdf/key_guide_list2009_e.pdf> accessed 23 July 2012 (hereinafter: '2009 Strategic Framework and Guidelines'). Most notably is the requirement to descript the general ecological features of the wetlands under the Guidance on information to provide in each numbered section of the Information Sheet on Ramsar Wetlands (RIS) section, where Contracting Parties are required to provide a description of 'the wetland ecosystem with its main habitats, wetland and vegetation types, describing any zonation, seasonal variations, and long-term changes.' See 'Explanatory Note and Guidelines for Completing the Information Sheet on Ramsar Wetlands (RIS)', at pp $50-63$, in 'Appendix A. Information Sheet on Ramsar Wetlands', Ramsar Convention, '2009 Strategic Framework and Guidelines', at p 58, para 20. Information provided should include a brief description of - 'ecological processes which maintain the wetland and the ecosystem services that characterise the wetland and the benefits derived from these services; [and] a brief not on habitats and vegetation types in adjacent areas, and more importantly, information on specific food chains'. See also 'Explanatory Note and Guidelines for Completing the Information Sheet on Ramsar Wetlands (RIS)', p 58, para 20.

${ }^{427}$ Ramsar Convention, '2009 Strategic Framework and Guidelines', supra n 426, at p 5, para 21.

428 'Explanatory Note and Guidelines for Completing the Information Sheet on Ramsar Wetlands (RIS)', Ramsar Convention, '2009 Strategic Framework and Guidelines', supra n 426, at p 7, para 31.

${ }^{429}$ Ramsar Convention, '2009 Strategic Framework and Guidelines', supra n 426, at p 7, para 32. 
region required under Articles 2.1 and 4.1, render the two provisions in pari materia with and equivalent to Article 20 of the 1997 Watercourses Convention. These provisions are parallel in the sense that both impinge on the subject matter of the individual obligation of state parties on the 'preservation' of 'international or transboundary freshwater ecosystems', especially the character, functioning and services provided within a biogeographic region in light of the ecosystem approach.

An assessment of both obligations against the criteria for the ascertainment of rules that are 'relevant' confirmed the relevance of Articles 2.1 and 4.1 in the interpretation of the obligation to preserve freshwater ecosystem of international watercourses under Article 20 of the 1997 Watercourses Convention.

\subsubsection{The 1992 Convention on Biological Diversity}

The Convention on Biological Diversity entered into force on 29 December 1993 after the $30^{\text {th }}$ ratification. ${ }^{430}$ Unlike other treaties, the Biodiversity Convention placed the main decision-making at the national level where provisions are mostly expressed as overall goals and policies rather than precise binding rules. ${ }^{431}$ The adoption and the subsequent coming into force of this Convention reflect the recognition of the need ${ }^{432}$ for an international instrument for the institutionalisation ${ }^{433}$ of effort in the conservation, and sustainable, fair and equitable use, of biodiversity and its components. The intrinsic value and the importance of biodiversity, gradually recognised as a common concern of

\footnotetext{
${ }^{430}$ CBD Secretariat, 'History of the Convention' $<$ http://www.cbd.int/history/> accessed 12 September 2011. The Convention evinced a major breakthrough in the area of biodiversity conservation, while ensuring the sustainable use of biological components and the fair and equitable sharing of benefits arising from the use of genetic resources. The scope of the Convention encompasses diverse issues such as access to technology, including biotechnology that goes beyond conservation of biological diversity per se. See Birnie, Boyle, and Redgwell, International Law and the Environment, supra n 112, at p 612.

431 Biodiversity Convention, supra $\mathrm{n}$ 12, Art 6. It emphasises the common but differentiated responsibilities that differentiate between capabilities of developed and developing country. See Lyle Glowka, Françoise Burhenne-Guilmin, Hugh Synge, A Guide to the Convention on Biological Diversity (IUCN, Gland and Cambridge, 1994) at p 4.

${ }^{432}$ The concern on the dire state of biodiversity was raised in the Preamble of the Biodiversity Convention, supra n 12, using terminologies such as 'Concerned that biological diversity is being significantly reduced by certain human activities ...'; and 'Noting also that where there is a threat of significant reduction or loss of biological diversity ...'.

${ }^{433}$ Biodiversity Convention, supra n 12, Preamble. It states, inter alia, that: 'Stressing the importance of, and the need to promote international, regional and global cooperation among States and intergovernmental organisations and the non-governmental sector for the conservation of biological diversity and the sustainable use of its components' whereby having an institution for a biodiversity conservation and use believed to promote such cooperation. Apart from that, the objective as stated in the Preamble, for the 'provision of new and additional financial resources and appropriate access to relevant technologies' and the 'substantial investments required to conserve biological diversity' will be better achieved with the establishment of a governance architecture.
} 
humankind for the evolution and the maintenance of life sustaining systems of the biosphere - are highlighted in the Preamble of the Convention. ${ }^{434}$

The Biodiversity Convention has three objectives. It aims to conserve biological diversity, the sustainable use of its components and the fair and equitable sharing of the benefits arising out of the utilisation of genetic resources, ${ }^{435}$ and for the benefit of present and future generations. ${ }^{436}$ Biological diversity is defined in Article 2 to mean the variability among living organisms from all sources including, inter alia, terrestrial, marine and other aquatic ecosystems and the ecological complexes of which they are part: this includes diversity within species, between species and of ecosystems. Biodiversity Convention reinforced and reaffirmed the legal status of the conservation of biodiversity as a common concern of mankind, although the Preamble of the Convention conceded an anthropocentric approach to such concern by stating that the intrinsic value of biodiversity lies in its critical importance in meeting food, health and other needs of the growing world population. ${ }^{437}$

Even so, the attention drawn to the importance of the conservation of biodiversity will necessarily lead to the conservation of ecosystems. The all-encompassing definition of biodiversity indeed covers, and necessarily has an impact on, all ecosystems, including the ecosystem of freshwater. Article 8 obligations are framed in policy-oriented goals concerning effective on-site conservation of biodiversity, that Parties may act on in line with their own policies and internal laws. ${ }^{438}$

The Biodiversity Convention reflects the need for Contracting Parties to conserve the natural state of the environment, in order to ensure the integrity of the ecosystem

\footnotetext{
${ }^{434}$ Biodiversity Convention, supra n 12, Preamble, at paras 1 and 2.

${ }^{435}$ Biodiversity Convention, supra n 12, Art 1. It is reaffirmed in CBD, 'Decision II/8. Preliminary Consideration of Components of Biological Diversity Particularly Under Threat and Action which could be Taken under the Convention' (Second Ordinary Meeting of the Conference of the Parties to the Convention on Biological Diversity, Jakarta, Indonesia, $6-17$ November 1995) UN Doc $\mathrm{UNEP} / \mathrm{CBD} / \mathrm{COP} / 2 / 19$, at p 12, para 1 〈http://www.cbd.int/doc/decisions/cop-02/full/cop-02-dec-en.pdf> accessed 23 March 2011. It states: 'The conservation and sustainable use of biological diversity and its components should be addressed in a holistic manner, taking into account the three levels of biological diversity and fully considering socio-economic and cultural factors. However, the ecosystem approach should be the primary framework of action to be taken under the Convention'.

${ }^{436}$ The Preamble of the Biodiversity Convention, supra n 12, states that the Contracting Parties are: "Determined to conserve and sustainably use biological diversity for the benefit of present and future generations".

${ }_{437}$ Birnie, Boyle, and Redgwell, International Law and the Environment, supra n 112, at pp 618 - 619.

${ }^{438}$ Glowka, Burhenne-Guilmin, and Hugh Synge, A Guide to the Convention on Biological Diversity, supra $\mathrm{n} 431$, at $\mathrm{p} 1$.
} 
through the conservation of biodiversity. According to Article 8, the Contracting Parties shall, as far as possible and as appropriate:

(a) Establish a system of protected areas or areas where special measures need to be taken to conserve biological diversity; and

(d) Promote the protection of ecosystems, natural habitats and the maintenance of viable populations of species in natural surroundings.

The emphasis on a 'system of protected areas' implies the intention of the Contracting Parties to designate these protected areas in a logical way to form a network. ${ }^{439}$ The subsequent paragraphs are laid out under Article 8(b) - (l) for the operationalisation of the system of protected areas for the conservation of biodiversity. ${ }^{440}$ In-situ conservation of biodiversity involves a firm legal base where the Contracting Parties are required to develop guidelines for the selection, establishment and management of the protected areas. ${ }^{441}$ The tension between conservation and sustainable use of biodiversity and its components is addressed in Article 8(i). ${ }^{442}$ The conditions for a compromise over present uses and conservation are left to be determined by the Contracting Party.

In drawing out the relevance of the obligation to conserve biodiversity in-situ as provided under the Biodiversity Convention, the definition given to 'conservation' is of particular interest. According to the references to various treaties on the use of 'conservation', it is found that the concept of "conservation' includes both the "cclassic" elements of protection and preservation, including restoration, and the safeguarding of ecological processes and genetic diversity beside management of natural resources, in order to ensure their maintenance by sustainable utilisation'. ${ }^{443}$

The ordinary meaning of 'conservation', or 'to conserve', used prevalently in international environmental law indicates a higher standard of care compared to the

\footnotetext{
${ }^{439}$ Glowka, Burhenne-Guilmin, and Hugh Synge, A Guide to the Convention on Biological Diversity, supra $\mathrm{n} 431$, at $\mathrm{p} 39$.

${ }^{440}$ Art 8(b) - (1), the Biodiversity Convention, supra $\mathrm{n} 12$.

${ }^{441}$ Article 8(b) of the Biodiversity Convention, supra $\mathrm{n} 12$.

${ }^{442}$ Article 8(i) of the Biodiversity Convention, supra n 12. It provides that: 'Each Contracting Party shall, as far as possible and as appropriate ... [e]ndeavour to provide the conditions needed for compatibility between present uses and the conservation of biological diversity and the sustainable use of its components'.

${ }^{443}$ Pieter van Heijnsbergen, International Legal Protection of Wild Fauna and Flora (IOS Press, Amsterdam, the Netherlands, 1997), at pp 45 - 52, at pp 51 - 52.
} 
term 'protection'. ${ }^{444}$ However, it is noteworthy that 'conservation' is consistently used in distinction with the phrase 'sustainable use', which highlights that the Biodiversity Convention intends to differentiate 'conserve' with 'use', and hence, emphasises the protectionist objectives.

Article 8(a) and (d) provides for the conservation of biodiversity-rich areas in their natural state to the extent possible, where establishment of a system of protected areas of national parks, nature reserves, wilderness areas and heritage sites are stipulated. ${ }^{445}$ This approach reflects the initial methodology in the implementation of the ecosystem approach in the 1930s. ${ }^{446}$

The in-situ conservation of freshwater ecosystems is specifically developed in the inland water biodiversity programme of work pursuant to the recommendation of the Subsidiary Body on Scientific, Technical and Technological Advice (SBSTTA). ${ }^{447}$ It is pertinent to note that the definition of 'inland water ecosystems' under the Biodiversity

\footnotetext{
${ }^{444}$ Birnie, Boyle, and Redgwell, International Law and the Environment, supra $\mathrm{n} 112$, at $\mathrm{p} 589$. Quoting the author, the ordinary meaning of 'conservation' includes 'to keep in safety or from harm, decay or loss; to preserve in being; to keep alive' or now, more usually, 'to preserve in its existing state from destruction or change', or from 'destructive influences, decay or waste' or 'in being and health'.

${ }^{445}$ Glowka, Burhenne-Guilmin, and Hugh Synge, A Guide to the Convention on Biological Diversity, supra $\mathrm{n} 431$, at $\mathrm{p} 39$.

${ }^{446}$ See Shelford, 'The Preservation of Natural Biotic Communities', supra $\mathrm{n} 305$.

447 'Annex. Programme of Work on Protected Areas', at p 6, to CBD, 'Decision VII/28 Protected Areas (Articles 8(a) to (e))' (Seventh Meeting of the Conference of the Parties to the Convention on Biological Diversity, Kuala Lumpur, 9 - 20 and 27 February 2004) UNEP/CBD/COP/DEC/VII/28 (13 April 2004) $\langle$ http://www.cbd.int/doc/decisions/cop-07/cop-07-dec-28-en.pdf > accessed 31 July 2012. 'Inland waters' are defined as aquatic-influenced environments located within land boundaries, including those located in coastal areas, adjacent to marine environment. Inland water systems can be fresh, saline or a mix of the two (brackish water). Coastal aquatic habitats are considered as the lower sections of river basins, while estuaries are considered transitional zones between rivers and the sea although in practice, inland waters tend to focus on freshwater. Inland waters include lakes, rivers, ponds, streams, groundwater, springs, cave waters, floodplains, as well as bogs, marshes and swamps traditionally grouped as inland wetlands The adoption of the definition of wetlands of the Ramsar Convention under the aegis of the CBD encompasses all possible kinds of inland water body or ecosystem or components thereof, including groundwater. See CBD, 'Inland Waters Biodiversity - What is It?' (undated) $<$ http://www.cbd.int/waters/inland-waters/> accessed 31 July 2012. CBD, 'Inland Waters Biodiversity Background' (undated) <http://www.cbd.int/waters/background/> accessed 31 July 2012. Recommendation III/1 recognised the importance of inland water ecosystems for global biodiversity and human welfare and their vulnerability to human actions; and proposed to the COP a work plan developed for the SBSTTA be developed in cooperation with relevant organisations that builds on the ongoing efforts in inland water ecosystem conservation. See 'Recommendation III/1' in CBD-SBSTTA, at $p$ 30, in CBD, 'Annex 1. Recommendations of the SBSTTA at Its Third Meeting' (Third Meeting of the SBTTA, $1-5$ September 1997, Montreal, Canada) UNEP/CBD/COP/4/2 <http://www.cbd.int/doc/recommendations/sbstta-03/full/sbstta-03-rec-en.pdf〉 $>$ accessed 31 July 2012.
} 
Convention includes land that is influenced directly by inland aquatic habitats, ${ }^{448}$ which makes explicit the adoption of an ecosystem approach. ${ }^{449}$

The Programme of Work recognises the need for Parties to implement the programme of work on protected areas in the context of their nationally determined priorities, capacities and needs, while at the same time, expressly including transboundary inland waters, and seeks transboundary cooperation for the sustainable management of these inland waters through the appropriate mechanisms. ${ }^{450}$

The obligation imposed onto the state contracting parties of the Biodiversity Convention through Article 8(a) and (d) to conserve biodiversity under the Biodiversity Convention, via the establishment of a network of protected areas on (transboundary) inland waters, is relevant to the interpretation of the obligation to preserve freshwater ecosystems stipulated under Article 20 of the 1997 Watercourses Convention. Article 8(a) and (d) stipulates the individual obligation of state contracting parties to designate areas of protection, whereby ecosystems are conserved to maintain their near-natural conditions, in accordance with the ecosystem approach. Although the Biodiversity Convention does not specifically mention international watercourses, transboundary river basins are within the definition of transboundary inland water ecosystems, the conservation of which is specifically developed in the Programme of Work on Inland Water Biodiversity.

From the preceding, it is affirmed that Article $8(a)$ and (d) is relevant for the interpretation of the obligation to preserve ecosystems of international watercourses

\footnotetext{
${ }^{448} \mathrm{CBD}$, 'Inland Waters Biodiversity - What is It?' (undated) $<$ http://www.cbd.int/waters/inland-waters/> accessed 31 July 2012. It is emphasised that 'from the ecological hydrological, environmental and socioeconomic perspective, all land is an integral part of an inland water ecosystem because fresh water (usually from rain) runs off it into rivers, lakes and wetlands. For example, the vegetation near water bodies (in the riparian zone), even if never submerged, is influenced greatly by proximity to water. The clearest example of land-water interactions is with seasonally flooded areas, eg, river floodplains, which may be dry or submerged depending on flood conditions. Inland water ecosystems are ecologically dynamic. They are not amenable to artificial conceptual boundaries. They are best considered from the landscape or ecosystem perspective'.

${ }^{449}$ CBD, 'Decision VII/11 Ecosystem Approach' (Seventh Meeting of the Conference of the Parties to the Convention on Biological Diversity, Kuala Lumpur, 9-20 and 27 February 2004) UNEP/CBD/COP/DEC/VII/11 (13 April 2004) at p 1, para $2<$ http://www.cbd.int/doc/decisions/cop07/cop-07-dec-11-en.pdf> accessed 31 July 2012.

${ }^{450}$ CBD, 'Decision IV/4 Status and Trends of the Biological Diversity of Inland Water Ecosystems and Options for Conservation and Sustainable Use' (Fourth Ordinary Meeting of the Conference of the Parties to the Convention on Biological Diversity, 4 - 15 May 1998, Bratislava, Slovakia) at p 15, para 7; and pp 21 and 24, paras 9(k) and $18<$ http://www.cbd.int/doc/decisions/cop-04/full/cop-04-dec-en.pdf $>$ accessed 31 July 2012. Also CBD, 'Decision VII/28 Protected Areas (Articles 8(a) to (e))', supra n 447, at para 5 <http://www.cbd.int/doc/decisions/cop-07/cop-07-dec-28-en.pdf> accessed 31 July 2012.
} 
under Article 20 of the 1997 Watercourses Convention, where the criteria laid out for in the determination of 'relevant' is satisfied.

\subsection{A Discussion on the Implication of the Climate Change Regime}

Climate change has been identified and recognised as a 'cross-cutting and persistent crisis [where the] scale and gravity of the impacts of climate change affect all countries and undermine the ability of all countries to achieve sustainable development, the Millennium Development Goals, and threaten the viability and survival of nations'. ${ }^{451}$ The Secretary-General of the United Nations emphasised that 'Climate change is real, and it is accelerating in a dangerous manner. It not only exacerbates threats to international peace and security, it is a threat to international peace and security'. ${ }^{452} \mathrm{~A}$ research conducted by Brazil's environmental protection agency found out that ecosystem of the Amazon will cease to function at a certain point of warming, and this has implication on the "entire hydrological cycles of significant parts of South America that depend on the systems of the Amazon function'. 453

The Rio+20 Outcome Document pronounced the common intention of the international community to combat climate change with urgent and ambitious action 'in accordance with the principles and provisions of the United Nations Framework Convention on Climate Change' (UNFCCC). ${ }^{454}$ Hence, there is a need to comment and reflect on the prevailing climate change regime that dictates current trend of environmental governance.

Climate change is a main concern and features heavily in the effort to conserve land, water, biodiversity and ecosystems, where resilience to climate change to ensure sustainability of natural ecological processes is of the utmost necessity in attaining sustainable development. ${ }^{455}$ In this respect, the climate change regime was underscored as the pivotal vehicle in the protection of the climate system 'for the present and future generations of humankind on the basis of equity and in accordance with their common

\footnotetext{
${ }^{451}$ The Future We Want, supra n 59, at para 25.

${ }^{452}$ UNSC, 'Maintenance of International Peace and Security. Impact of Climate Change' $\left(6587^{\text {th }}\right.$ Meeting, 20 July 2011, New York) S/PV.6587 at p $<$ http://www.un.org/ga/search/view doc.asp?symbol=S/PV.6587> accessed 12 September 2012.

${ }^{453}$ UNSC, 'Maintenance of International Peace and Security. Impact of Climate Change', supra $\mathrm{n}$ 452, at p 5 .

${ }^{454}$ The Future We Want, supra n 451, at p 6, para 25.

455 The Future We Want, supra n 451, at p 23, para 111.
} 
but differentiated responsibilities and respective capabilities'. ${ }^{456}$ The Parties to both the UNFCCC and the Kyoto Protocol were urged to 'fully implement their commitments, as well as decisions adopted under those agreements [and] build upon the progress achieved [in the Conferences of the Parties to the Convention]' ${ }^{457}$

The important influence of the climate change regime in the efforts and initiative in the conservation of biodiversity and ecosystems, especially in the context of this research the preservation of ecosystems of international watercourses - cannot be ignored. More so as the importance of the full implementation of commitments under the climate change regime is recognised and affirmed by the international community as evidenced in the Rio+20 Outcome Document. ${ }^{458}$ In particularly, the complexity of the climate change regulatory regimes encumbers and hinders the coordination between the multilateral environmental treaty regimes, which leads to 'hasty and erroneous interpretations and conclusions as to the relationship between different regulatory systems'. 459

The coordination of the implementation of mitigation measures under the climate change regime with other conventions, such as the Biodiversity Convention, will lead to 'a practically unfeasible and inextricably fragmented regulatory regime for climate change'. ${ }^{460}$ The reality of the fragmentation of international law caused by the proliferation of treaties necessitates 'a careful analysis of their reciprocal relationships in order to avoid erroneous interpretations that might have very relevant practical consequences'. ${ }^{461}$ This realisation paves the way for a cursory review of the climate change regime, and identifies the possible point of compatibility that enables the coordination and synergies between the climate change regime, and the MEAs under the biodiversity-conservation cluster.

\subsubsection{Climate Change Regime - Its Aims, Objectives and Context}

Negotiations on the need for a regime to address the need for the reduction of carbon dioxide and other greenhouse gases were initiated in 1990 by virtue of the UNGA

\footnotetext{
${ }^{456}$ The Future We Want, supra $\mathrm{n}$ 451, at para 191.

${ }^{457}$ The Future We Want, supra n 451, at p 37, para 192.

${ }^{458}$ The Future We Want, supra n 451, at p 3, para 17.

${ }^{459}$ Ottavio Quirico, 'Disentangling Climate Change Governance: A Legal Perspective' (2012) 21(2) Review of European Community and International Environmental Law 92 - 101, at p 100.

${ }^{460}$ Quirico, 'Disentangling Climate Change Governance: A Legal Perspective', supra n 459, at p 101.

${ }^{461}$ Quirico, 'Disentangling Climate Change Governance: A Legal Perspective', supra n 459, at p 101.
} 
Resolution 45/212. ${ }^{462}$ The climate change negotiation was concluded in 1992 with the adoption of a Framework Convention on Climate Change at the 1992 Rio Conference. ${ }^{463}$ The Convention aims to stabilise greenhouse gas concentrations caused by anthropogenic interferences, at a level and within a certain temporal scope that allows ecosystems to adapt naturally to climate change, in order to ensure sustainable food production and economic development. ${ }^{464}$

Article 4 deals principally with the commitments agreed by all parties on matters related to the establishment of national anthropogenic emission inventories. ${ }^{465}$ The Parties are required to provide planning for climate change mitigation and adaptation measures, to cooperate in the preparation for adaptation to climate change impacts, and to develop and elaborate appropriate and integrated plans. ${ }^{466}$ Cooperation is proposed for the development, application and diffusion of technologies, practices and processes that control, reduce, or prevent anthropogenic emissions of greenhouse gases. ${ }^{467}$

\subsubsection{Climate Change Regime and the Obligation to Preserve}

\subsubsection{1992 United Nations Framework Convention on Climate Change}

Article 4(1)(d) of UNFCCC seems to relate to the subject matter of the obligation to preserve. The general commitments in Article 4(1), despite neglecting freshwater ecosystems totally, still reflect the acknowledgment and incorporation of the ecosystem approach where the Parties are obliged to promote and to cooperate in the conservation of all greenhouse gases sinks and reservoirs.

The mention of various types of ecosystems as possible sinks and reservoirs crucial for the stabilisation of carbon dioxide $\left(\mathrm{CO}_{2}\right)$ and other greenhouse gases, indicates the recognition of ecosystem as a unit for the satisfaction of the obligation as stipulated under Article 4(1)(d). This explicit view is supported by the Preamble of the UNFCCC where the Parties made clear their awareness of the role and importance of terrestrial and marine ecosystems as sinks and reservoirs of greenhouse gases.

\footnotetext{
${ }^{462}$ UNGA, 'Protection of Global Climate for Present and Future Generations of Mankind' (Report of the $71^{\text {st }}$ Plenary Meeting, 21 December 1990) UN Doc A/RES/45/212 <http://www.un.org/documents/ga/res/45/a45r212.htm> accessed 14 September 2011. Birnie, Boyle, and Redgwell, International Law and the Environment, supra n 112, at p 356.

${ }^{463}$ UNFCCC, supra n 208.

${ }^{464}$ Art 2, UNFCCC, supra $\mathrm{n} 208$.

${ }^{465}$ UNFCCC, supra $\mathrm{n}$ 208, Art 1(a).

${ }^{466}$ UNFCCC, supra $\mathrm{n} 208$, Art 1(b).

${ }^{467}$ UNFCCC, supra $\mathrm{n} 208$, Art 1(c).
} 
Stricter commitment standards are applied to developed country Parties and other Annex I parties, where these Parties committed themselves to adopt and communicate national policies and corresponding measures on the mitigation of climate change, through limitation of greenhouse gases emissions and the enhancement of greenhouse gas sinks and reservoirs. ${ }^{468}$

The first Intergovernmental Panel on Climate Change (IPCC) report indicated that even with the stabilisation of greenhouse gas emissions at current levels, atmospheric concentrations would continue to rise for the next two centuries. ${ }^{469}$ The obligation to conserve greenhouse gas sinks and reservoirs are further strengthened by a more rigorous regime (i.e., the 1997 Kyoto Protocol) where fixed targets are laid out in order to achieve the objective of the Convention. In the study of the obligation to conserve greenhouse gas sinks and reservoirs as laid out under Article 4(1)(d), and the various steps required from the Annex I Parties for the achievement of emissions target, it is important to look into the Kyoto Protocol.

\subsubsection{1997 Kyoto Protocol to the United Nations Framework Convention on Climate Change}

The objective of the Kyoto Protocol is the pursuit of the ultimate objective of the Convention as stated in Article 2, guided by Article 3 and pursuant to the Berlin

\footnotetext{
${ }^{468}$ Art 4(2)(a) and (b) UNFCCC. The provision strives to modify longer-term trends in anthropogenic emissions by returning the present level of anthropogenic emission of carbon dioxide and other green house gases not controlled by the Montreal Protocol to earlier levels (ie 1990 levels) by the end of the decade (ie year 2000). The indeterminacy of the extent of commitments prevails in language used such as 'taking into account the differences in the Parties' starting points and approaches, economic structures and resource bases'; their 'need to maintain strong and sustainable economic growth', 'available technologies and other individual circumstances'; and the 'need for equitable and appropriate contributions'. However, this shortcoming is somewhat overcome by the power of the COP to review the adequacy of the national policies adopted and communicated by the developed country Parties and other Parties in Annex I as stipulated under Art 4(2)(a) and (b). See Article 4(2)(d) of the UNFCCC, supra $\mathrm{n}$ 208.

${ }^{469}$ The IPCC reported that there is a dire need for the immediate reductions of over $60 \%$ in the net (sources minus sinks) emissions from human activities of long-lived gases would achieve stabilisation of concentration at today's levels'. IPCC, 'First Assessment Report Overview Chapter' (1990) <http://www.ipcc.ch/ipccreports/1992\%20IPCC\%20Supplement/IPCC_1990_and_1992_Assessments/En glish/ipcc_90_92_assessments_far_overview.pdf> accessed 15 September 2011. It is accepted that the commitments stipulated under the UNFCCC are inadequate and the Parties negotiated a new, more rigorous obligation that eventually becomes the 1997 Kyoto Protocol, supra $\mathrm{n}$ 208. It is clear from the outset that the Parties recognised that commitment should be strengthened in light of new scientific information, which necessitates the need for continuous reporting and assessments. The review process will be carried out in the light of the best available scientific information on climate change and its impact, including the reports of the IPCC. See Art 4(1)(j), Art 4(2)(b) and (d), the UNFCCC. Also UNFCCC, 'Report of the Conference of the Parties on Its First Session' (First Session of the Conference of the Parties of the, Berlin, 28 March - 7 April 1995) (16 June 1995) UN Doc FCCC/CP/1995/7/Add.1, at p 6, para 3 <http://unfccc.int/resource/docs/cop1/07a01.pdf> accessed 15 September 2011.
} 
Mandate. ${ }^{470}$ It sets binding targets for 37 industrialised countries and the European Community for the reduction of greenhouse gases to an average of 5 per cent against 1990 levels over a five-year period $(2008-2012) .{ }^{471}$ As opposed to the less stringent obligations laid out under the UNFCCC, the Kyoto Protocol stipulated quantified emission limitation or reduction commitments in plain numerical forms as committed to by Annex I parties. ${ }^{472}$

Article 2 stipulated the obligations to be undertaken by the Annex I parties in achieving their quantified emission limitation and reduction commitments of at least 5 per cent below 1990 levels, in order to promote sustainable development. ${ }^{473}$ Apart from meeting their targets primarily through national measures, the 1997 Kyoto Protocol also established three additional 'flexibility mechanisms' by which the Annex I Parties may employ to achieve their emissions reductions. ${ }^{474}$ These mechanisms are joint implementation (Article 6), clean development mechanism (CDM) (Article 12), and emission trading (known as 'carbon market or carbon trading') (Article 17). ${ }^{475}$

Joint implementation, as explicated in Article 6 allows Annex B Parties to transfer to, or acquire from, any other such party, emission reduction units resulting from projects aimed at reducing anthropogenic emissions by sources or enhancing anthropogenic removals by sinks of greenhouse gases in any sector of the economy. CDM is provided

\footnotetext{
${ }^{470}$ Kyoto Protocol, supra n 208, Preamble. The Berlin Mandate is adopted by Decision 1/CP1 of the Conference of the Parties to the Convention at its first session. UNFCCC, 'Report of the Conference of the Parties on Its First Session', supra $\mathrm{n}$ 469. The Berlin Mandate review the adequacy of Art 4(2)(a) and (b) of the UNFCCC, including proposals related to a protocol (Kyoto Protocol) and decisions on followup.

471 UNFCCC, 'Kyoto Protocol' 〈http://unfccc.int/kyoto_protocol/items/2830.php $>$ accessed 15 September 2011.

${ }^{472}$ Art 3(1), Kyoto Protocol, supra n 208. See also Annex B, Kyoto Protocol, at p 20. The monitoring and review mechanisms in place are stricter, where the methodologies used for the estimation of anthropogenic emissions by sources and removals by sinks, of all greenhouse gases not controlled by the Montreal Protocol, shall be those accepted by the IPCC and agreed upon by the Conference of the parties. The IPCC and the Subsidiary Body for Scientific and Technological Advice will render advice in the review and revision of proposed methodologies of Annex I Parties at the Meeting of the Parties for the Protocol. Article 5(2), Kyoto Protocol, supra n 208.

${ }^{473}$ The obligations include implementation and elaborate policies and measures in accordance with national circumstances; the protection and enhancement of sinks and reservoirs of greenhouse gases, in view of its commitments under relevant international environmental agreements, promotion of sustainable forest management practices, afforestation and reforestation. Kyoto Protocol, supra n 208, Art 2(1)(a)(ii); 2(1)(a)(iii); 2(3); and 3(3).

${ }^{474}$ UNFCCC, 'The Kyoto Protocol', supra n 471. Also Birnie, Boyle, and Redgwell, International Law and the Environment, supra $\mathrm{n} 112$, at $\mathrm{p} 361$.

${ }^{475}$ Annex B Parties in this context are Annex I Parties with quantified emission limitation or reduction commitment stipulated in the Annex B of Kyoto Protocol. See Art 6(1) of Kyoto Protocol, supra n 208.
} 
in Article 12 of the Kyoto Protocol. ${ }^{476}$ Under the CDM, projects implemented in developing countries under the Mechanism entitled Annex B Party to earn saleable certified emission reduction (CER) credits, which can be counted towards meeting Kyoto emission reduction targets committed by the Party. ${ }^{477}$ Article 17 explicated the third mechanism that facilitates Annex I Parties to meet their emission targets. Annex I countries may participate in emissions trading in fulfilment of their commitments under Article 3, which should be supplemental to domestic actions in order to meet the quantified emission limitation and reduction commitments under Article 3. ${ }^{478}$

The meaning of the phrase 'direct human-induced land-use change and forestry activities, limited to afforestation, reforestation and deforestation' is further clarified in the First Meeting of the Parties for Kyoto Protocol in 2005. ${ }^{479}$ The First Meeting of the Parties emphasised that the implementation of land use, land-use change and forestry activities that are eligible to offset emission targets must be 'direct human-induced' afforestation, reforestation and/or deforestation activities that meet the requirements as set forth in the Annex of 16/CMP.1. ${ }^{480}$ From the standpoint of striving towards

${ }^{476}$ According to Art 12(2) of Kyoto Protocol, supra n 208: 'The purpose of the clean development mechanism shall be to assist Parties not included in Annex I in achieving sustainable development and in contributing to the ultimate objective of the Convention, and to assist Parties include in Annex I in achieving compliance with their quantified emission limitation and reduction commitments under Art 3. 477 See 'Clean DNFCC, Development Mechanism (CDM)' <http://unfccc.int/kyoto_protocol/mechanisms/clean_development_mechanism/items/2718.php> accessed 3 March 2011. It is stated that: 'The mechanism is seen by many as a trailblazer. It is the first global, environmental investment and credit scheme of its kind, providing standardised emission offset instruments, CERs. A CDM project activity might involve, for example, a rural electrification project using solar panels or the installation of more energy-efficient boilers. The mechanism stimulates sustainable development and emission reductions, while giving industrialized countries some flexibility in how they meet their emission reduction or limitation targets'. See in general UNFCCC, 'Decisions 2 6/CMP.1' (Report of the Conference of the Parties Serving as the Meeting of the Parties to the Kyoto Protocol on its First Session, Montreal, Canada, 28 November - 10 December 2005, 30 March 2006) FCCC/KP/CMP/2005/8Add.1 〈http://unfccc.int/resource/docs/2005/cmp1/eng/08a01.pdf> accessed 15 November 2012.

${ }^{478}$ Art17 Kyoto Protocol, supra n 208, provides that: 'The Conference of the Parties shall define the relevant principles, modalities, rules and guidelines, in particularly for verification, reporting and accountability for emissions trading. The Parties included in Annex B may participate in emissions trading for the purposes of fulfilling their commitments under Article 3. Any such trading shall be supplemental to domestic actions for the purposes of meeting quantified emission limitation and reduction commitments under that Article'.

${ }^{479}$ Annex to UNFCCC, 'Decision 16/CMP.1 Land Use, Land-use Change and Forestry' (Report of the Conference of the Parties Serving as the Meeting of the Parties to the Kyoto Protocol on its First Session, Montreal, Canada, 28 November - 10 December 2005, 30 March 2006) FCCC/KP/CMP/2005/8/Add.3, at p 5 〈http://unfccc.int/resource/docs/2005/cmp1/eng/08a03.pdf> accessed 15 September 2011.

${ }^{480}$ Annex to UNFCCC, 'Decision 16/CMP.1 Land Use, Land-use Change and Forestry', supra $\mathrm{n}$ 479, at $\mathrm{p}$ 6. The implementations of land use, land-use change and forestry included under the provisions of the Kyoto Protocol shall be consistent with the objectives and principles of, and decisions taken, under the UNFCCC and the Kyoto Protocol. See UNFCCC, 'Decision 16/CMP.1', supra n 479, at p 3. At p 6, other additional land-use, land-use change other than afforestation, reforestation and deforestation as mentioned 
maintaining ecosystem integrity through minimal interference with the environment, and the preservation of pristine environment, the fact that "deforestation" is treated as a means to achieve emissions targets is disconcerting. ${ }^{481}$

This sparks an interesting observation in the further analysis of Articles 2 and 3 of the Kyoto Protocol. The two articles seemed to propose different approaches in achieving the objectives of the UNFCCC to stabilise greenhouse gases concentration in the atmosphere. Article 2 proposed for the implementation and/or further elaboration of policies and measures in accordance with Parties' national circumstances, or to cooperate and coordinate the implementation of such policies and measures as the Conference of Parties deemed fit. ${ }^{482}$ Article 3 laid down an actual standard for emission reduction, which is different from the obligations stipulated under Article 2. Article 2 seemed to aim for a longer-term goal of achieving sustainable development, while Article 3 strived to set out a rule of result to be complied with within a set timeframe.

The two different approaches might be relevant to rationalise the fact that the obligation of the Parties under Article 2 to implement and/or further elaborate policies and measures that promote sustainable forest management practices, afforestation and reforestation did not include deforestation even though Article 3 allowed for deforestation in order for Annex I Parties to meet their reduction targets. ${ }^{483}$ The fact that deforestation is not stipulated in Article 2 must necessarily indicate the consensus of the Parties that deforestation is a mere short-term measure to meet the emission reduction targets.

Based on the assumption that the omission of 'deforestation' in Article 2 is not unintentional, it can be deduced that deforestation is not considered to be a long-term measure to be promoted in the implementation and elaboration of policies and measures for the reduction of greenhouse gases emission. It can be inferred that the omission of 'deforestation' in Article 2 is considered counterproductive in achieving the ultimate

under Art 3(4) of the Framework Convention are suggested. They include revegetation, forest management, cropland management and grazing land management.

${ }^{481}$ Annex, to UNFCCC, 'Decision 16/CMP.1', supra n 479, at p 5, para 1(d). Similar sentiment shared by Harro van Asselt, 'Managing the Fragmentation of International Environmental Law: Forests at the Intersection of the Climate and Biodiversity Regimes', supra n 106, at p 1211. The author noted that 'the emphasis so far has been on conflicts or potential conflicts between the two [climate change and biodiversity] regimes, particularly following decisions on the use of forest carbon sinks in the Kyoto Protocol'.

${ }^{482}$ Art 2(1)(a), (3), and (4), Kyoto Protocol, supra n 208.

${ }^{483}$ Arts 2(1)(a)(ii) and 3(3), Kyoto Protocol, supra n 208. 
objective of the UNFCCC to promote sustainable development. This assertion is further supported by the fact the 'deforestation' is not an eligible activity under Article 12 of the Kyoto Protocol on CDM, which seek to assist non-Annex I Parties to achieve sustainable development. ${ }^{484}$

\subsubsection{Compatibility of the Climate Change Regime with the Obligation to Preserve}

For the purpose of this research on the identification of rules relevant to the interpretation of the obligation to preserve freshwater ecosystems, the most salient features of the UNFCCC and the Kyoto Protocol are the commitment of the Annex I Parties under Article 4(2)(a) of the UNFCCC and Article 2(1)(a)(ii) of Kyoto Protocol. Article 2(1)(a)(ii) of the Kyoto Protocol strengthened the obligation of Annex I Parties to 'protect and enhance greenhouse gas sinks and reservoirs' (Article 4(2)(a)) by imposing a duty onto the Parties to implement and/or further elaborate policies and measures to protect and enhance sinks and reservoirs of greenhouse gases. The implementation of the Annex I parties' commitments under the Kyoto Protocol must take into account their commitments under relevant international environmental agreements, and to promote sustainable forest management practices, afforestation and reforestation. ${ }^{485}$

The reason for the use of 'protection' in the Article 4(2)(a) and subsequently in Article 2(1)(a)(ii) of the Kyoto Protocol instead of "conservation" used in Article 4(1)(d) regarding the same subject matter is unclear. But what is more certain is, the concept of 'protection' has come to have its own meaning and the distinctive meaning this concept of 'protection' commands could be significant for the legal scope of this provision. ${ }^{486}$ 'Protection' is said to be the most neutral term if compared to other similar terms used in international environmental law, namely, 'preservation' and 'conservation'; and often expresses an 'incidental protective action to prevent damage to the protected object, without necessarily implying any duration or clearly developed policy for the future'. ${ }^{487}$

Despite the seemingly more neutral 'protection' concept used in the language of the climate change regime, it does not negate the fact that the regime attempts to protect the

\footnotetext{
${ }^{484}$ Annex, to UNFCCC, 'Decision 16/CMP.1', supra n 479, at p 7.

${ }^{485}$ Art 2(1)(a)(ii), Kyoto Protocol, supra n 208.

${ }^{486}$ Heijnsbergen, International Legal Protection of Wild Fauna and Flora, supra n 443, at p 43.

${ }^{487}$ Heijnsbergen, International Legal Protection of Wild Fauna and Flora, supra $\mathrm{n} 443$, at $\mathrm{p} 43$.
} 
greenhouse gas sinks and reservoirs. In fact, the emphasised and repetitive use of this term in the Preamble of $\mathrm{UNFCCC}^{488}$ and throughout the Framework Convention, declared the commitment and seriousness of the Parties to protect greenhouse gas sinks and reservoirs. This interpretation can be supported by the use of 'protection' in Article 4(2)(a) of the UNFCCC, which is meant for Annex I Parties with more stringent reduction commitments imposed on them. ${ }^{489}$

Article 4(1)(a) of the UNFCCC obliges all Contracting Parties to promote and cooperate in the conservation of sinks and reservoirs of all greenhouse gases not controlled by the Montreal Protocol, including biomass, forests and oceans as well as other terrestrial, coastal and marine ecosystems. ${ }^{490}$

Although greenhouse gas sinks and reservoirs are not separately defined under Article 4(2)(a) of the UNFCCC, and in the subsequent Article 2(1)(a)(ii) of Kyoto Protocol, the common understanding of the term as used in the Preamble and Article 4(1)(d) of the UNFCCC should be adopted. Thus, the greenhouse gas sinks and reservoirs include biomass, forests and oceans as well as other terrestrial, coastal and marine ecosystems. According to the analysis of the above provisions, there exists a general obligation under the climate change regime to protect terrestrial and marine ecosystems by virtue of their importance as greenhouse gas sinks and reservoirs.

In the determination of whether these obligations are inimical to the obligation to preserve freshwater ecosystems, it is important to note the linkages between freshwater resources and other components in the environment, as advocated by the ecosystem approach. ${ }^{491}$ An ecosystem approach focuses on the interaction and interconnectedness between different sub-systems and the responses to stresses resulting from human

\footnotetext{
${ }^{488}$ For example, 'the Parties to this Convention is "determined to protect the climate system for present and future generations"'.

${ }^{489}$ Heijnsbergen, International Legal Protection of Wild Fauna and Flora, supra $\mathrm{n} 443$, at $\mathrm{p} 43$. This seems to support the scholarship that 'protection' may have an ethical connotation that implies the protection of the weak against the strong.

${ }^{490}$ Art 4(2)(a) of the UNFCCC applies more specifically to Annex I Parties where these Parties are obliged to adopt national policies and take corresponding measures on the mitigation of climate change by, inter alia, protecting and enhancing its greenhouse gas sinks and reservoirs. Art 2(1)(a)(ii) of the Kyoto Protocol further the commitments under Art 4(2)(a) of the UNFCCC by requiring Annex I Parties to implement and/or further elaborate policies and measures to protect sinks and reservoirs of greenhouse gases not controlled by the Montreal Protocol, taking into account their commitments under relevant international environmental agreements.

${ }^{491}$ McIntyre, 'Ecosystem Approach', supra n 79, at p 5.
} 
activity. ${ }^{492}$ By conserving and protecting terrestrial and marine ecosystems that are closely connected to wetlands and freshwater ecosystems, by virtue of the physical unity of the environment as greenhouse gas sinks and reservoirs, it can be asserted that such conservation and protection will definitely affect, and hence are relevant to, the preservation of freshwater ecosystems.

In addition to that, scientific evidence had shown that continental hydrologic networks (watercourses systems) themselves play a crucial role as sinks and reservoirs in the carbon cycle where the aquatic systems act as accumulators of sedimentary organic matter, otherwise known as 'carbon storage'. ${ }^{493}$ Freshwater ecosystems, apart from being closely connected to the terrestrial and marine ecosystems that act as greenhouse gas sinks and reservoirs, are themselves active players in the carbon cycle. By virtue of their capacity as greenhouse gas sinks or reservoirs, the obligation under the UNFCCC and the subsequent Kyoto Protocol to protect these sinks and reservoirs must necessarily encompass freshwater ecosystems.

From this perspective, the provisions under the climate change regime are not only pointing towards a similar direction as the preservation of freshwater ecosystems under the 1997 Convention, but actually concern the same subject matter. This strengthens the position that the obligations identified above are not intrinsically incompatible with the preservation/conservation objectives. These obligations share similarities, whereby they not only address similar components in the environment and move in a similar direction towards maintaining the integrity of ecosystems, they are also not in an irreconcilable conflicting relationship with the obligation to preserve freshwater ecosystems.

Although the provisions of the climate change regime might not be 'relevant' for the interpretation of the obligation to preserve or conserve within the meaning of Article 31(3)(c) of the 1969 Vienna Convention, ${ }^{494}$ an interpretation that is compatible for a coordinated implementation of the climate change regime and regimes under the biodiversity cluster is not impossible.

This conclusion can be drawn despite the fact that the UNFCCC and the 1997 Kyoto Protocol establish a distinct regime with its own objective and scope, and does not

\footnotetext{
${ }^{492}$ McIntyre, ' 'Ecosystem Approach', supra n 79, at p 1.

493 JJ Cole et al, 'Plumbing the Global Carbon Cycle: Integrating Inland Waters into the Terrestrial Carbon Budget' (2007) 10 Ecosystems 171 - 184, at pp 178 - 179.

494 'Relevance' as established in Section 2.2.
} 
address freshwater ecosystems specifically. The obligation to conserve greenhouses gases sinks and reservoirs, which include various ecosystems, will directly or indirectly affect freshwater ecosystems.

\subsection{Conclusion}

The emerging ecosystem approach exercises its influences in today's conceptualisation of environmental protection. Environmental protection, apart from the obligation to prevent harm, or the obligation not to cause harm, has now gradually embraced a previously neglected component of preservation. This obligation serves to maintain the environment in its natural state to the extent possible, through the establishment of designated areas of protection or nature reserves.

This approach is seen by the scientific communities to be one of the better means to maintain the ecological structure, processes and functions essential to the provision of ecological services. The maintenance of ecosystem integrity through the preservation of ecosystems and other components of the environment, have been codified in various international instruments on the environment.

The dominion of climate change discourse in international environmental law necessitates the discussion on the possible discordance between the Biodiversity Convention, and the UNFCCC and Kyoto Protocol, in particularly on the use of direct human-induced land-use change and forestry activities as a means to offset carbon emissions. However, the discussion above ${ }^{495}$ shows that the underlying ethos of the regime is not irreconcilably in conflict with the general objective to maintain ecosystem integrity, where the simultaneous application of both regimes is possible.

In the context of the present research, the obligation to preserve the ecosystems of international watercourses is codified under Article 20 of the 1997 Watercourses Convention. Similar expressions of this obligation have been found in other international environmental agreements. The provisions identified to be relevant are Articles 2.1 and 4.1 of the Ramsar Convention and Article 8(a) and (d) of the Biodiversity Convention. The relevant rules deal with the same facts and the same subject matter of preservation of transboundary freshwater ecosystems, where the obligation is placed primarily on individual state parties. All these aspects satisfy the

\footnotetext{
${ }^{495}$ In particular, Section 2 of this thesis.
} 
criteria laid out for rules to be 'relevant' for the purpose of interpreting the obligation to preserve ecosystems of international watercourses as provided under Article 20 of the 1997 Watercourses Convention. It can be concluded that the provisions cited above are rules relevant for the interpretation of Article 20 obligation to preserve the ecosystems of international watercourses of the 1997 Watercourses Convention.

The next chapter will determine whether these rules, identified to be relevant to the interpretation of Article 20, are 'applicable in the relations between the parties' within the meaning of Article 31(3)(c) of the 1969 Vienna Convention. 


\section{Chapter 3. Rules of International Law Applicable in the Relations between the Parties: A Review of Existing Interpretation}

This chapter will proceed firstly to give an extensive review of the existing approach in the interpretation of this pertinent phrase of 'rules of international law applicable in the relations between the parties'. It seeks to discover whether the prevalent structure of interpretation of the Article is capable of elucidating its true potential in the systemic integration of a rule of law through an interpretative mechanism. This chapter intends to show that the term 'applicable' does not requires that rules of international law need be binding on the parties in order to be considered as 'applicable in the relations between the parties'. The reasoning for this proposition is undertaken through a review of existing scholarship on the interpretation of 'applicable' and 'the parties' that constitute the current interpretative landscape of Article 31(3)(c). A critical analysis of the prevailing scholarship of the subject matter is the foundation on which grounds for reinterpretation of the salient features of the Article are proposed.

\section{1 'Rules of International Law'}

It is stated that the external rules referred to in an interpretative process via Article 31(3)(c) 'must be rules of international law, and not to broader principles or considerations which may not be firmly established as rules' ${ }^{496}$ Accordingly, Article $31(3)$ (c) is said to impose the requirement of legality where rules that are applicable in the interpretative process must be rules of international law.

Law is the product of many acts of law-making processes that are 'far from displaying coherent design' over long stretches of time, contributed to by various entities pursuing divergent, even conflicting ends and possibly, only partially aware of each other. ${ }^{497}$ The law, taken as a whole, consists of legal rules, which are obtained through law-making activities, including legislation, and the rendering of judgments that are considered as supplementary sources of international law. ${ }^{498}$

\footnotetext{
${ }^{496}$ Fragmentation Report, supra n 17, at p 214, para 426(a).

497 Joseph Raz, Between Authority and Interpretation. On the Theory of Law and Practical Reason (Oxford University Press 2009) at p 5.

${ }^{498} \mathrm{Raz}$, Between Authority and Interpretation, supra $\mathrm{n}$ 497, at p 5.
} 
International law, 'sometimes referred to as public international law ... is the body of rules which are legally binding on states in their intercourse with each other', and arises from the juxtaposition of states. ${ }^{499}$ It is distinguishable from private international law, or 'conflict of laws ${ }^{500}$ where it 'governs the relations of states and other subjects of international law amongst themselves' instead of 'rules developed by states as part of their domestic law to resolve the problems which involve a foreign element in cases between private persons. ${ }^{501}$ International law has been regarded as 'rules that restrain, or as a common language; or as a normative guidance in the making of decisions. ${ }^{502}$

The unqualified use of international law by the ILC, as a United Nations body, to refer to public international law, is supported by the context of the 1969 Vienna Convention that intended to promote treaty as a source of legal obligations between states in the development of friendly relations and the achievement of cooperation among nations. ${ }^{503}$ The applicability of the 1969 Vienna Convention on 'treaties between states, 504 and the definition of 'treaty' to mean 'an international agreement concluded between states and governed by international law' 505 emphasised that 'international law' means 'public international law' for the purpose of this Convention. In light of the common reference of international law as public international law nowadays, the term 'international law', 'without adjectival qualification, denotes public international law'. ${ }^{506}$

\footnotetext{
${ }^{499}$ Robert Jennings and Arthur Watts (eds), Oppenheim's International Law (Vol I, $9^{\text {th }}$ edn, Longman, Essex, 1992) at pp $4-6$.

${ }_{500}$ Malcolm N Shaw, International Law ( $5^{\text {th }}$ edn, Cambridge University Press, Cambridge, 2003) at p 1.

${ }^{501}$ Jennings and Watts (eds), Oppenheim's International Law, supra n 499, at p 6.

${ }^{502}$ Rosalyn Higgins, 'Reflections from the International Court' pp $1-10$ in Malcolm D Evans (ed) International Law ( $2^{\text {nd }}$ edn, Oxford University Press, Oxford, 2006) at p 5.

${ }^{503}$ Preamble of the 1969 Vienna Convention, supra $\mathrm{n}$ 31. The Preamble speaks of 'Recognising the everincreasing importance of treaties as a source of international law and as a means of developing peaceful cooperation among nations... [and] Believing that the codification and progressive development of the law of treaties achieved in the present convention will promote the purposes of the United Nations set forth in the Charter ...'. The reference of 'international law' as 'public international law' is apparent in the engagement of this term throughout the Convention, eg, Arts 1, 3, 4, 38, 43, 52, 53, 64, and 71. The repetitive reference to 'cooperation among nations', peoples of the United Nations', and 'sovereign equality and independence of all states' supported the contention that 'international law' refers to public international law where the actors are primarily states. This assertion is further supported by the final decision to include the phrase 'governed by international law' in Article 2(1)(a) by the International Law Commission. Some members opined that such reference is not necessary due to the nature of the contracting parties of the Convention (states), which at any rate in the first instance, are subjected to international law. Dietrich Rauschning, The Vienna Convention on the Law of Treaties (Alfred Metzner Verlag, Frankfurt, 1978) at p 77, para 6.

${ }^{504} 1969$ Vienna Convention, supra n 31, Art 1.

5051969 Vienna Convention, supra n 31, Art 2.

${ }^{506}$ Gardiner, Treaty Interpretation, supra n 235, at p 261.
} 
According to the Black's Law Dictionary, 'rule' is generally defined as 'an established and authoritative standard or principle; a general norm mandating or guiding conduct or action in a given type of situation. ${ }^{507}$ The Dictionary of Legal Theory defines rule as 'a standard meant to guide behaviour'. It must necessarily include principles, standards, practices, concepts and procedures considered as legal grounds for the assertion of rights and obligations. ${ }^{508}$ It is found that the terms of 'rule', 'norm', 509 'principle', 'standards' and 'prescription' are frequently used interchangeably. ${ }^{510}$ Scholars comment that a broad approach needs to be adopted in defining 'rules'. A rule - a prescribed guide for conduct or action, includes 'the whole range of rules as there are many sorts of action, many kinds of guidance, and many different ways of prescribing,, ${ }^{511}$ which necessitates a broad conceptualisation.

Twining and Miers developed this definition of rules where they adopted a similar broad formulation of 'rules' to denote general norms mandating or guiding conduct or action in a given type of situation. ${ }^{512}$ They highlighted the particular attention to be drawn to four aspects of a broad formulation of 'rule, 513 and emphasised that a prescriptive definition of rules (such as Dworkin's 'all-or-nothingness' approach) obscures distinctive characteristics and nature of rules, which they termed 'separate ideas of rules', not to mention that the distinction between rules and principles is artificially sharp. $^{514}$

${ }^{507}$ Bryan A Garner (ed) Black's Law Dictionary ( $8^{\text {th }}$ edn, Thomson, USA, 2004) at $\mathrm{p} 1357$.

${ }^{508}$ The broad interpretation of 'rules' is adopted in Oscar Schachter, International Law in Theory and Practice (Vol 13 Developments in International law, Martinus Nijhoff Publishers, Dordrecht, Boston, London, 1991) at $\mathrm{p} 10$.

509 See Abram Chayes and Antonia Handler Chayes, The New Sovereignty. Compliance with International Regulatory Agreement ( $2^{\text {nd }}$ edn, Harvard University Press, Cambridge Massachusetts, London England, 1998) at p 113. Interestingly, scholars defined norms as 'a generic reference to a broad class of generalised prescriptive statements, namely principles, standards, rules, both procedural and substantive where all of them are prescriptions for action in situations of choice, carrying a sense of obligation, a sense that they ought to be followed.' (Original emphasis).

${ }^{510}$ Brian H Bix, A Dictionary of Legal Theory (Oxford University Press, Oxford, 2004) at pp 192 and 193. ${ }^{511}$ Newton Garver, 'Rules', pp 231 - 233, in Paul Edwards (ed), Encyclopedia of Philosophy (vol. 7, Macmillan/Collier Macmillan, New York and London 1967) at p 231.

512 William L Twinning and David Miers, How to Do Things with Rules: A Primer of Interpretation ( $4^{\text {th }}$ edn Butterworths London 1999) at p 123.

${ }^{513}$ The four aspects of a broad formulation of rule are: (a) A rule is normative or prescriptive in relation to behaviour, rather than with factual description of behaviour. (b) A rule is general, concerning types of behaviour in types of situation or circumstances. (c) Rules both guide and serve as standards for human behaviour. (d) Rules provide the justification or reason for decision or action. Twinning and Miers, How to Do Things with Rules, supra n 512, at pp 123 - 126.

${ }^{514}$ The three separate ideas are: the level of generality or particularity of a prescription; its precision or vagueness; and its status or force in dictating, guiding or influencing a result. Twinning and Miers, How to Do Things with Rules, supra n 512, at p 126. See Ronald M Dworkin, Taking Rights Seriously 
As suggested above, some theorists seek to distinguish them in various ways in the course of making points about the nature of law or the nature of practical reasoning. ${ }^{515}$ Most commonly a distinction between 'rules' and 'principles' or other normative considerations are drawn, where theorists confine rules to standards that are conclusive, or that have a canonical formulation, or that are relatively specific. ${ }^{516}$ In particularly, jurists opine that there is normative significance to the distinction between rules and principles, where rules tend to be highly prescriptive whereas principles serves as guidelines and operate at a higher level of generality that does not impose concrete obligations. ${ }^{517}$ However, it is doubtful if there are benefits derivable from attempting a comprehensive taxonomy of types of rules in view of the richness and complexity of material of law that is 'so shot through with fine gradations', 518 especially in the context of the present research. ${ }^{519}$

'Rules', although not specifically defined in the 1969 Vienna Convention, do not merely refer to treaty law and customary international law. The sources of international law stipulated in Article 38(1) of the Statute of International Court of Justice support giving generic scope to the definition of rules. ${ }^{520}$ The sources of international law, from where rules of international law can be derived, include treaty laws, customary laws and also general principles of law. A broad definition of 'rules' that does not distinguish between 'rules', 'standards' or other normative considerations can be seen in the observation and proposal of the Special Rapporteur, where the ILC deemed it desirable

(Duckworth London 1977) especially pp 22 - 25. According to Dworkin, at p 24, 'The difference between legal principles and legal rules is a logical distinction. Both sets of standards point to particular decisions about legal obligation in particular circumstance, but they differ in the character of the direction they give. Rules are applicable in an all-or-nothing fashion. If the facts a rule stipulates are given, then either the rule is valid, in which case the answer it supplies must be accepted, or it is not, in which case it contributes nothing to the decision'.

${ }_{515}$ Bix, A Dictionary of Legal Theory, supra n 510, at pp 192 and 193.

${ }^{516}$ Bix, A Dictionary of Legal Theory, supra n 510, at pp 192 and 193. See also Daniel Bodansky, 'Rules vs Standards in International Environmental Law' (2004) 98 American Society International Law Proceeding 275 - 280. Bodansky raised the importance of the distinction between rules and standards, especially in the design of international regimes, and highlighted the need for further study on the distinctions.

${ }^{517}$ Michael Leir, 'Canadian Practice in International Law, 1998-99' (1999) 37 Canadian Yearbook of International Law 317 - 349, at p 320.

${ }_{518}$ Twinning and Miers, How to Do Things with Rules, supra n 512, at p 127

${ }^{519}$ For a thorough analysis of 'rules', see John Rawls, 'Two Concepts of Rules' (1955) 54(1) The Philosophical Review 3 - 32; Joel Feinberg, 'Supererogation and Rules' (1961) 71 Ethics 276 - 288 ; Joseph Raz, Practical Reason and Norms (Hutchinson London 1975); HLA Hart, The Concept of Law ( $2^{\text {nd }}$ edn Oxford University Press 1994) on Ch 3; and Anthony Dickey, 'The Concept of Rules and the Concept of Law' (1980) 25 American Journal of Jurisprudence 89 - 116;

${ }^{520}$ Supra n 259. 
to formulate "any "principles" found by the Commission to be "rules". 521 The Commission went further to elaborate that "all "rules" of interpretation have the character of "guidelines", ${ }^{522}$ The Commission went on to support the codification of such 'guidelines' due to the importance of the role of treaty interpretation. Where recourse of the international community to adjudication depends on the will of the parties, 'there may be particular value in codifying as rules such basic principles of interpretation as are found to be generally accepted as law'. ${ }^{523}$ It is observed that the Commission treated the codification of rules to include 'guidelines and principles' or any other forms of norms considered as, or equivalent to 'rules'.

The scope of 'rules' is not clearly indicated in the jurisprudence of international courts and tribunals, although a more extensive concept of law can fire the debate on whether non-'binding' international law (in the source-oriented formal sense) 'may legitimately influence interpretation'. ${ }^{524}$ In the Iron Rhine case, it is noted that this debate extends to the concept of 'rules' where the Tribunal considers that -

'There is considerable debate as to what, within the field of environmental law, constitutes "rules" or "principles"; what is "soft law"; and which environmental treaty law or principles have contributed to the development of customary international law. Without entering further into those controversies, the Tribunal notes that in all of these categories, "environment" is broadly referred to as including air water, land, flora and fauna, natural ecosystems and sites, human health and safety, and climate. The emerging principles, whatever their current status, make reference to conservation, management, notions of prevention and of sustainable development, and protection for future generations... ${ }^{525}$

The European Court of Human Rights has invoked a wide range of international instruments in its decisions. This was recognised by the House of Lords in the context

\footnotetext{
${ }^{521}$ Dietrich Rauschining (ed), The Vienna Convention on the Law of Treaties. Travaux Préparatoires (Alfred Metzner Verlag, Frankfurt, 1978), at p 242.

${ }_{522}$ Rauschining (ed), The VCLT, supra $\mathrm{n} 521$, at $\mathrm{p} 242$.

${ }^{523}$ Rauschining (ed), The VCLT, supra n 521, at p 242.

${ }^{524}$ For a brief jurisprudential summary of the concepts of rules, principles, measures, etc see Leir, 'Canadian Practice in International Law, 1998-99', supra n 517, at p 320; and more extensively Twinning and Miers, How to Do Things with Rules, supra n 512, at pp 113 - 204.

${ }^{525}$ Arbitration regarding the Iron Rhine ('Ijzeren Rijn') Railway (Belgium/Netherlands) (Award of 24 May 2005) at para 58 <http://untreaty.un.org/cod/riaa/cases/vol XXVII/35-125.pdf> accessed 15 November 2012. The Arbitral Tribunal did not find it necessary to go far into the meaning of rules because it found that the duty of states to prevent or mitigate harm to the environment had become a principle of international law, at para 59.
} 
of Article 31(3)(c) in the case of A and Others, where examples of the range of instruments used by the Human Rights court are conveniently cited ${ }^{526}$ although 'some of those instruments do not appear to be binding in themselves'. ${ }^{527}$ The WTO Panel in the EC - Biotech case does not consider the precautionary principle as a rule of international law (own emphasis) if it had not become a general principle of international law, which the Panel found that it had not. ${ }^{528}$ What is clear from these cases is that the notion of a 'rule' cannot usefully be taken in isolation from 'international law', and the phrase 'rules of international law' must be read together where 'rules' must be read with 'international law'. 529

Despite the 'anarchic nature of world affairs and the clash of competing sovereignties' that might make ascertainment of rules of international law difficult, nevertheless, these rules are ascertainable from the available sources from which the rules may be extracted and analysed. ${ }^{530}$ In general, it is commented that 'rules of international law' as stated under Article 31(3)(c) of the1969 Vienna Convention refer to rules of international law that originated from all formal sources of international law. ${ }^{531}$ Shaw went on to comment that these sources of law operate within the legal system on a technical level and exclude such 'ultimate sources' such as reason or morality, or functional sources such as libraries and journals, as provided under Article 38(1) of the Statute of

\footnotetext{
${ }^{526}$ Per Lord Bingham, A and Others v Secretary of State for the Home Department (No 2) [2006] 1 All England Law Reports 575 at pp $604-606$, paras $39-41$.

${ }^{527}$ Gardiner, Treaty Interpretation, supra $\mathrm{n} 235$, at p 269. However the author conceded that the position is more complex because the range of instruments conveniently cited by the European Courts of Human Rights may amount to statements of customary international law or have other relevant aspects connecting them with the Vienna rules.

${ }^{528}$ EC- Biotech, supra n 117, at $\mathrm{p} 333$, para 7.67.

${ }^{529}$ Gardiner, Treaty Interpretation, supra $\mathrm{n} 235$, at p 269.

${ }^{530}$ Shaw, International Law, supra n 500, at p 66.

${ }^{531}$ Martin Dixon, Textbook on International Law (6 ${ }^{\text {th }}$ edn, Oxford University Press 2007) at $\mathrm{p} 25$. The author elaborated that 'The procedures or methods by which rules become legally binding are formal sources of law. A formal source of law is a process by which a legal rule comes into existence: it is law creating'. See Linderfalk, 'Who are 'The Parties'?', supra n 260, at p 344. Also, the Fragmentation Report, supra n 17, at para 426; McLachlan, 'The Principle of Systemic Integration', supra n 162, at p 290; Pauwelyn, Conflict of Norms in Public International Law, n 100, at p 254; Mark E Villiger, Customary International Law and Treaties: A Study of their Interactions and Interrelations with Special Consideration of the 1969 Vienna Convention on the Law of Treaties (Martinus Nijhoff, Dordrecht 1985), at p 268; Gabrielle Marceau, 'Conflict of Norms and Conflict of Jurisdictions: The Relationship between the WTO Agreement and MEAs and Other Treaties', (2001) 35 Journal of World Trade 1081 - 1131, at 1087; Gardiner, Treaty Interpretation, supra n 235, at pp 260 - 263; Georges Abi-Saab, 'The Appellate Body and Treaty Interpretation', in Giorgio Sacerdoti, Alan Yanovich and Jan Bohanes (eds) The WTO at Ten: The Contribution of the Dispute Settlement System (Cambridge University Press, Cambridge 2006) at $\mathrm{p} 463$.
} 
International Court of Justice. ${ }^{532}$ Questions are raised on whether the 'rules of international law' as stipulated in the 1969 Vienna Convention include treaty law, if treaties are opined to be 'simply a source of obligation binding pursuant to international law, 533

The records of the ILC support the inclusion of treaties in rules of general international law where Jiménez de Aréchaga welcomed the deletion of 'general' international law that has a narrower connotation. ${ }^{534}$ The qualification imposed in the insertion of the word 'general' in international law would exclude treaty law, and specific or regional rules of international law that might be relevant and applicable for the interpretation of a treaty obligation by providing the background for such interpretation.

Reviewing the fine difference between the notions of 'rules' and 'obligations', where the former indicates an element of imposition whilst the latter expresses voluntariness, ${ }^{535}$ the further specification for the rules of international law to be 'applicable in the relations between the parties' points towards the conclusion that treaty obligations are covered by Article 31(3)(c). It is clear that the Commission intended to include treaty obligation amongst the 'rules of international law applicable in the relations between the parties' because unlike general international law that is deemed 'axiomatically applicable in relations between states ${ }^{\text {'536 }}$ without the need to be explicit, treaty obligations are 'distinctly a matter of relations between the parties'. 537

\footnotetext{
${ }^{532}$ Shaw, International Law, supra n 500, at p 66. The Statute of the International Court of Justice is widely recognised as the most authoritative statement as to the sources of international law. Art 38(1) of the Statute of the International Court of Justice, supra n 259, provides that - the Court, whose function is to decide in accordance with international law such disputes as are submitted to it, shall apply: (a) international conventions, whether general or particular, establishing rules expressly recognised by the contesting states; (b) international custom, as evidence of a general practice accepted as law; (c) the general principles of law recognised by civilised nations; (d) subject to the provisions of Article 59, judicial decisions and the teachings of the most highly qualified publicists of the various nations, as subsidiary means for the determination of rules of law.

${ }^{533}$ Gardiner, Treaty Interpretation, supra n 235, at p 261. By this, the author seems to indicate that treaties are 'simply' a product of international law, and not international law. See Gerard Fitzmaurice, 'Some Problems Regarding the Formal Sources of International Law', pp 153 - 195 in Jan Hendrik Willem Verzijl and F M Van Asbeck, Symbolae Verzijl (Martinus Nijhoff, The Hague, 1958) at p 153.

534 [1966] 1(II) Yearbook of International Law Commission $1-351$, at p 190, para 70 <http://untreaty.un.org/ilc/publications/yearbooks/Ybkvolumes(e)/ILC_1966_v1_p2_e.pdf> accessed 15 November 2012; cited in Gardiner, Treaty Interpretation, supra n 235, at p 262.

${ }^{535}$ Gardiner, Treaty Interpretation, supra n 235, at p 263. The author further elaborated that 'This might suggest a distinction between those treaties which codify rules of customary law and those which simply establish particular commitments which are voluntarily assumed'.

${ }^{536}$ Gardiner, Treaty Interpretation, supra n 235, at p 263.

${ }^{537}$ Gardiner, Treaty Interpretation, supra $\mathrm{n} 235$, at $\mathrm{p} 263$.
} 
The explicit requirement that the rules of international law are 'applicable in the relations between the parties', and the intentional omission of the word 'general' from the earlier draft articles, confirmed the intention of the Commission that treaty obligations are to be included in the scope of 'rules of international law'. The omission of the word 'general' to refer to an unqualified reference to international law, including treaties, is deemed justified because a treaty should be interpreted against the background of all types of international rules applicable, whether or not they are customary rules or rules of written law. ${ }^{538}$ The Panel of WTO in the EC - Biotech case was unanimous in stating that treaties and customary rules of international law are rules of international law within the meaning of Article 31(3)(c). ${ }^{539}$

The scope of the rules of international law applicable for the interpretation of a treaty term shall encompass all the formal sources of law in addition to general international law. The difficulty in considering treaties in a vacuum strengthens the need to interpret treaty against its normative environment, where the normative environment is composed of the various sources of international law that forms the international legal system as a whole. $^{540}$

The adoption of a broad approach in the interpretation of 'rules of international law', which encompasses treaty law, custom, principles or standards "common" to the parties to the treaty ${ }^{541}$ in the interpretative process (whether as the source from which they draw their force of obligation or as facts necessarily relevant to the issue under consideration) is in accordance with the principle of pacta sunt servanda. ${ }^{542}$

\footnotetext{
${ }^{538}$ Gardiner, Treaty Interpretation, supra n 235, at p 262.

${ }^{539}$ EC- Biotech, supra n 117, at p 332, para 7.67.

${ }^{540} \mathrm{Mr}$. Yasseen succinctly summed up this general position by stating that -

'The reference to the rules of international law was indispensable, for just as a term could only be understood in a sentence, a sentence only in an article, and an article only in the treaty as a whole. It was impossible to understand the treaty except within the whole international legal order of which it formed a part, which it influenced and by which it was influenced'. [1966] 1(II) Yearbook of International Law Commission, supra n 534, at p 197 para 51,. It is quoted in Jan Klabbers, 'Reluctant Grundnormen: Articles 31(3)(c) and 42 of the Vienna Convention on the Law of Treaties and the Fragmentation of International Law', pp 141 - 161, in Matthew Craven, Malgosia Fitzmaurice, and Maria Vogiatzi (eds) Time, History and International Law (Martinus Nijhoff, Leiden, 2007), at p 147.

${ }^{541}$ [1966] 1(II) Yearbook of International Law Commission, supra n 534, at p 197, para 52.

${ }^{542}$ Art 26 of the 1969 Vienna Convention, supra n 31. See Gardiner, Treaty Interpretation, supra n 235, at $\mathrm{p} 263$.
} 


\section{2 'Applicable in the Relations between the Parties'}

The general scholarly understanding of a rule that is applicable in the relations between the parties necessarily refers to 'a rule that creates legal relationship between the parties, either at the time of interpretation, or at the time when the treaty was concluded, depending on the particular expression interpreted ${ }^{543}$ The existing interpretation of the phrase 'applicable in the relations between the Parties' is explored through the notions of legality and bindingness where scholars noted that there is a need for a legal relationship to exist for a rule to be applicable. This imposes a legality requirement the rule has to be 'law', ${ }^{444}$ and that the rule must be 'binding'. 545

The research into the binding force of rules of international law considered to be 'applicable in the relations between the parties' are crucial, especially in the context of the interpretation of environmental protection rules. Villiger commented that the 'vague' or 'soft' nature of these rules couched in flexible treaty language, and the open-textured quality of customary international law or general principles of international law on the environment, give rise to imprecise legal force, and affect the rules' ability to bind states. $^{546}$

The interpretation of the term 'the parties' invites much discussion and controversy. ${ }^{547}$ Various scholars have suggested different approaches in the interpretation of 'the parties', broadly categorised as strict or broad interpretations. ${ }^{548}$ The ongoing argument

\footnotetext{
${ }^{543}$ Linderfalk, 'Who are 'The Parties'?', supra n 260, at p 345. Ulf Linderfalk, 'Doing the Right Thing for the Right Reason: Why Dynamic or Static Approaches Should be Taken in the Interpretation of Treaties', (2008) 10 International Community Law Review 109 - 141.

544 OSPAR Proceeding, supra n 118, at p 34 para 103. The Tribunal stated that: 'The reference in the Court's [ICJ in the Gabčíkovo-Nagymaros Project case] dictum and the doctrinal statement in Oppenheim based upon it is to developments in law ... the Court's reference in Gabčíkovo-Nagymaros is to new law "in a great number of instruments" and not material that has not yet become law' (original italics maintained).

${ }^{545}$ Jiménez de Aréchaga's statement on the reason the new text that omitted the requirement of general international law in Article 31(3)(c) demonstrated the underlying understanding of the Commission that the a rule of international law 'had to be interpreted in the light of other treaties binding on the parties'. [1966] I(II) Yearbook of International Law Commission, supra n 534, at para 70.

${ }_{546}$ Villiger, Commentary on the 1969 VCLT, supra n 254, at p 433, para 24.

${ }^{547}$ Pauwelyn, Conflict of Norms in Public International Law, supra n 100, at pp 261 - 262; Mélanie Samson 'High Hopes, Scant Resources: A World of Scepticism about the Anti-Fragmentation Function of Article 31(3)(c) of the Vienna Convention on the Law of Treaties' (2011) 24 Leiden Journal of International Law 701 - 714; Yasuhiro Shigeta, International Judicial Control of Environmental Protection. Standard Setting, Compliance Control and the Development of International Environmental Law by the International Judiciary (Kluwer Law International, The Netherlands, 2010) at p 239.

${ }^{548}$ See McGrady, 'Fragmentation of International Law', supra n 260; Linderfalk, 'Who are 'The Parties'?', supra n 260, at p 344. Isabelle van Damme, 'Jurisdiction, Applicable Law, and Interpretation' pp 298 - 343 in Daniel Bethlehem, Donald McRae, Rodney Neufeld and Isabelle van Damme (eds) The
} 
seems to indicate that the potential of Article $31(3)(\mathrm{c})$ as an anti-fragmentation, systemic integration tool is limited. It also seems to suggest that this potential can only be realised by adopting the appropriate interpretation of 'the parties', either in a restrictive sense or a broader sense.

The following sections will review the prevalent scholarship on the interpretation of the phrase 'applicable in the relations between the parties' from the notion of legality and bindingness raised. The subsequent analysis seeks to explore -

1. What is 'applicable' and whether 'applicability' imposes the requirement of the existence of a legal relationship that is binding. This necessitates clarification of the meaning of 'binding', in answering what applicable means; and

2. Who are the parties?

\subsection{1 'Applicable'}

Mark Villiger stressed in forceful terms that for Article 31(3)(c), the applicability of the relevant rules necessarily means these rules are binding. He asserted that the term "applicable" leaves no room for doubt: non-binding rules cannot be relied upon'. 549 Sands reiterated this position by commenting that the Article's use of the term 'applicable' refers to its legal character, where 'the legal status of a rule (other than qua treaty) must be assessed and determined to be legally binding upon the parties disputing the interpretation prior to the application of the rule. ${ }^{550}$ There seems to be an

Oxford Handbook of International Trade Law (Oxford University Press, Oxford, 2009) at p 332. She quoted the ILC Fragmentation Study Group where she is of the opinion that the narrower interpretation should be referred to, in the interest of pragmatism. She quoted that 'Article 31(3)(c) also requires the interpreter to consider other treaty-based rules so as to arrive at a consistent meaning. Such other rules are of particular relevance where parties to the treaty under interpretation are also parties to the other treaty, where the treaty rule has passed into or expresses customary international law or where they provide evidence of the common understanding of the parties as to the object and purpose of the treaty under interpretation or as to the meaning of a particular term. A better solution is to permit reference to another treaty provided that the parties in dispute are also parties to that other treaty. Although this creates the possibility of eventually divergent interpretations (depending on which States parties are also parties to the dispute), that would simply reflect the need to respect (inherently divergent) party will as elucidated by reference to those other treaties as well as the bilateralist character of most treaties underpinned by the practices regarding reservations, inter se modification and successive treaties'.

${ }^{549}$ Mark E Villiger, 'The Rules on Interpretation: Misgivings, Misunderstandings, Miscarriage? The 'Crucible' Intended by the International Law Commission', in Enzo Cannizzaro (ed), The Law of Treaties Beyond the Vienna Convention, (Oxford University Press, Oxford, 2011).

${ }^{550}$ Sands, 'Treaty, Custom and the Cross-fertilization of International Law', supra n 119, at p 102. See also Lorand Bartels, 'Applicable Law in WTO Dispute Settlement Proceedings' (2001) 35(3) Journal of World Trade $499-519$, at p 501. Bartels added as an afterthought in commenting on the applicability of external instruments in the interpretation of WTO provisions that 'of course, it will be important first to assess the legal status of such instruments before applying them as law'. 
overwhelming work of eminent publicists on the interpretation of the scope of 'applicable' in the context of Article 31(3)(c) indicating that the relevant rules applicable in the relations between the parties have to be 'binding' for the purpose of interpretation.

The ordinary meaning of 'applicable', obtained from a perusal of established dictionaries in accordance with Article 31(1) of the 1969 Vienna Convention, in the context of interpretation of treaties and in light of this purpose, can be summarised to mean -

1. That may be applied or having reference or appropriate; ${ }^{551}$

2. Affecting or relating to a person or thing; relevant or appropriate, suitable, able to applied; fitting; ${ }^{552}$

3. To employ for a limited purpose, as in 'apply payments to a reduction in interest', or to put to use with a particular subject matter, as in 'apply the law to the facts' or 'apply the law only to transactions in interstate commerce'; ${ }^{553}$ or

4. To affect or to touch, as in 'this clause applies only to deals outside the EU; the legal precedent applies to cases where the parents of the child are divorced'. ${ }^{55}$

The term 'applicable' has not been specifically analysed in the context of Article 31(3)(c) despite the crucial role it plays in the determination of whether the relevant rules can be taken into account in interpretation. ${ }^{555}$ Although the meaning of 'applicable' in Article 31(3)(c) is not specifically defined, its discussion was mostly linked to the

\footnotetext{
${ }^{551}$ Joyce M Hawkins and Robert Allen (eds) The Oxford Encyclopedic English Dictionary (Clarendon Press, Oxford, 1991) at p 64.

552 Oxford University Press, 'Oxford Dictionaries' 〈http://oxforddictionaries.com/definition/applicable?view=uk〉 accessed 24 May 2012; Cambridge University Press, 'Cambridge Advanced Learner's Dictionary and Thesaurus' (2011) available at 〈http://dictionary.cambridge.org/dictionary/british/applicable> accessed 24 May 2012; Chambers Publishers, 'Chambers $21^{\text {st }}$ Century Dictionary' (2010) available at 〈http://www.chambersharrapco.uk/chambers/features/chref/chref.py/main?query=applicable\&title=21st $>$ accessed 24 May 2012; Collins, 'The Collins English Dictionary' (2011) available at <http://www.collinsdictionary.com/dictionary/english/applicable> accessed 24 May 2012.

${ }_{553}$ Bryan A Garner, Black's Law Dictionary, supra n 507, at p 109.

${ }^{554}$ PH Collin, Dictionary of Law ( $3^{\text {rd }}$ edn, Peter Collin Publishing, 2000) at p 19.

${ }^{55}$ Panos Merkouris 'Article 31(3)(c) of the VCLT and the Principle of Systemic Integration' (PhD, Queen Mary University of London, 2010) at pp 16-17. Merkouris stated that: 'Despite the scrutiny under which Article 31(3)(c) has been put, an analysis of the term "applicable" in doctrine is almost nonexistent. This may be partially attributed to the fact that even the definitions of the term 'applicable', ie, (adjective): relevant or appropriate; (verb): to put to use with a particular subject matter; seem to connect this term with another one preceding it: "relevant". This would seem a somewhat tautological selfreference ...'.
} 
analysis and discourse of 'relevant'. ${ }^{556}$ If rules of international law determined to be 'relevant' ipso facto means that it is 'applicable in the relations between the parties', then the whole phrase of 'applicable in the relations between the parties' will be considered to be redundant. By virtue of the retention of this phrase in the text of the 1969 Vienna Convention, it is apparent that the phrase prescribes a separate determination from the consideration of whether or not a rule of international law is relevant.

It is a well-settled canon of interpretation in all systems of law that 'a clause must be so interpreted as to give it a meaning rather than so as to deprive it of meaning, ${ }^{557}$ Lord McNair, in his separate opinion in Anglo-Iranian Oil Co case rejected the meaning of a tacit or an implied agreement to be given to the interpretation of 'acceptés par la Perse' because "some meaning must be given to the word "acceptés". 558 The ICJ emphasised the importance of uncovering the real meaning through the interpretation of the Belgian Declaration as it stands, 'having regard to the words actually used' ${ }^{559}$ In addition, the principle that 'a legal text should be interpreted in such a way that a reason and a meaning can be attributed to every word in the text' should be applied in general in the interpretation of the text of a treaty. ${ }^{560}$ It is an unfavourable method of interpretation if such interpretation would 'leave certain words in the air'. 561

Thus, 'applicable in the relations between the parties' should be given its own meaning through the interpretation as it stands of the words actually used. The meaning to be given to this phrase should not be subsumed under a discourse on 'relevant', an approach that would have leave the meaning of 'applicable in the relations between the

\footnotetext{
${ }^{556}$ Merkouris 'Article 31(3)(c) of the VCLT and the Principle of Systemic Integration', supra $\mathrm{n} 555$, at pp $16-17$.

${ }^{557}$ British-American Claims Commission, Cayuga Indians (Great Britain) v United States (22 January 1926, pages 307 - 331) (1926) VI Reports of International Arbitral Awards 173 - 190, at p 184 <http://untreaty.un.org/cod/riaa/cases/vol_VI/173-190_Cayuga.pdf> accessed 16 November 2012.

558 Individual Opinion of President McNair of ICJ, Anglo-Iranian Oil Co. Case (United Kingdom v Iran) (Preliminary Objection, Judgment of 22 July 1952) [1952] ICJ Reports 93, at p 122 <http://www.icjcij.org/docket/files/16/2001.pdf> accessed 7 September 2012. President McNair, from pp $121-122$, elaborated that 'upon the significance of the expression "acceptés par la Perse" ... [t]he words "acceptés par la Perse" would not be apt to describe a tacit or an implied agreement, if any such agreement had arisen. Some meaning must be given to the word "acceptés". This implied that if some meaning is to be given to 'acceptés', a tacit or implicit could not be brought within the formula of 'traités ou conventions acceptés par la Perse'.

${ }^{559}$ ICJ, Anglo-Iranian Oil Co. Case, at p 105.

${ }^{560}$ ICJ, Anglo-Iranian Oil Co. Case, at p 105.

${ }^{561}$ Gerard Fitzmaurice, 'The Law and Procedure of the International Court of Justice, 1951-54' [1957] 33 British Yearbook of International Law 203 - 293, at p 222.
} 
parties' in the air, and rendered redundant, which is against the cardinal canon of interpretation.

Scholars interpreted the requirement of applicability to mean 'binding', ${ }^{562}$ where 'binding' is commonly understood to be formally binding under the prevalent sourceoriented formalistic school of legal theory. ${ }^{563}$ Sands was unequivocal when he commented that 'applicability' refers to its legal character - the extraneous rule must be 'legally binding (other than qua treaty) upon the parties disputing the interpretation to be given to a particular treaty'. 564

Gardiner commented that a rule of international law considered to be 'applicable in the relations between the parties' must necessarily point towards the existence of significant relations between the parties especially when parties have an immediate interest in the issue of interpretation. ${ }^{565}$ However it is doubtful if the need for a significant relationship necessarily implies that 'applicable' gives the connotation that such significant relations must be 'legal' - whereby a legal relationship between the parties is in existence ${ }^{566}$ or that the rules of international law should be 'binding' on the relations between the parties.

A perusal of the existing scholarship that imposes a requirement of 'bindingness' in the interpretation of 'applicable' entails two subsidiary questions in order to answer the first question raised above, of what is applicable -

1. What is the meaning of 'binding'? This is to clarify the reason behind scholars' assertion that 'what is applicable must be binding'; and

2. Is the need for the rules to be binding on the parties in order to be considered as 'applicable in the relations between the parties' an indirect (yet inappropriate) implication of the requirement of legality? This is a further contemplation into the statement by Gardiner to the effect that what is applicable indicates the existence of a significant relationship that is 'legal' ${ }^{567}$.

\footnotetext{
562 Villiger, 'The Rules on Interpretation' supra n 549.

563 Jean D'Aspremont, Formalism and the Sources of International Law (Oxford University Press, Oxford, 2011).

${ }^{564}$ Sands, 'Treaty, Custom and the Cross-fertilization of International Law', supra n 119, at p 102.

${ }^{565}$ Gardiner, Treaty Interpretation, supra n 235, at p 265.

${ }^{566}$ Gardiner, Treaty Interpretation, supra n 235, at $\mathrm{p} 265$.

${ }^{567}$ Gardiner, Treaty Interpretation, supra $\mathrm{n} 235$, at $\mathrm{p} 265$.
} 
An analysis into the concept of bindingness will enable a judgment to be made on whether the assertions that 'applicable' means 'binding' is based on sound foundation.

\subsubsection{Binding}

The tradition of analytic jurisprudence demonstrates a sustained focus on the identification of the constitutive features of law. ${ }^{568}$ Sartor reflected that legal theory has 'a large role to play in providing the theories of the grounds of legal bindingness'. 569 Apart from developing normative theories on the grounds of legal bindingness, legal theorists are engaged in the empirical investigation of the adoption of views in legal communities that provides a description of how (upon which grounds) the members of the relevant communities usually derive a bindingness proposition. ${ }^{570}$

The notion of bindingness is explored to mean 'cognitive necessity to endorse the normative proposition' or the '(cognitive) participability in the collective adoption of a normative proposition'. ${ }^{571}$ Participability in this context, according to Sartor, expresses the collective adoption of a rule, or its 'adoption-worthiness', which means 'a rule is binding to a reasoner exactly when ideal practical cognition would lead that reasoner to

\footnotetext{
${ }^{568}$ Dennis Patterson, 'After Conceptual Analysis: The Rise of Practice Theory', in Jaap C Hage, Dietmar von der Pfordten (eds) Concepts in Law (Law and Philosophy Library 88, Springer, Dordrecht Heidelberg London New York, 2009) at p 117.

${ }^{569}$ Giovanni Sartor, 'The Foundation of Legal Bindingness', pp 357 - 386, in Enrico Pattaro, Hubert Rottleuthner, Roger A Shiner, Aleksander Peczenik, Giovanni Sartor, and Corrado Roversi (ed) A Treaties of Legal Philosophy and General Jurisprudence (Springer, 2005) at pp 359 - 360. The author noted that: 'We must carefully distinguish such a definition of bindingness from a theory of the grounds for bindingness, by which we mean an account of what properties a rule must enjoy in order to be legally binding. A theory of the grounds for legal bindingness, when applied to the appropriate inputs (facts and evaluations) will provide a determination of what rules are legally binding'. In p 260, the author further stated that 'A theory of the grounds for legal bindingness is indeed mainly constituted by a combination of meta-rules about bindingness:

- $\quad$ positive ones, establishing that a rule is binding if it has certain features, and - negative ones, establishing that a rule is not binding if it has certain other features.'

The author opined, in p 361 that 'the definition of legal bindingness as "adoption-worthiness in legal reasoning" is neutral with regard to different theories of the grounds of bindingness (of the conditions making so that a rule is adoption-worthy): This definition constrains neither the content of the meta-rules in these theories, nor the sources they are derived from'. It is noted however that 'neutrality of the definition of legal bindingness does not imply that adopting one or another theory of the grounds of legal bindingness is an irrelevant or arbitrary choice. By determining what rules one view as legally adoptable, it affects the conclusions of one's legal reasoning, and hence the decisions one will impose on the parties of legal disputes and possibly enforce upon them against their will'.

${ }^{570}$ Sartor, 'The Foundation of Legal Bindingness', supra n 569, at pp $344-345$ and 386.

${ }^{571}$ Sartor, 'The Foundation of Legal Bindingness', supra n 569, at p 357.
} 
endorse the rule from the plural perspective, in the attempt to participate in the collective adoption of that rule'. ${ }^{572}$

Accordingly, it is argued that assertion of the legal bindingness of a rule is due to the intention to adopt the rule in legal reasoning, which is, the reasoning that is intended to establish an enforceable normative conclusion. ${ }^{573}$

Bindingness denotes the basis of obligations that command or require compliance of states. ${ }^{574}$ The terminology of 'binding' is commonly taken to mean the authority of law commanded by formal recognition through the doctrine of sources as codified under Article 38 of the Statute of ICJ. ${ }^{575}$ The analysis revealed that a careful distinction needs to be drawn between 'formal bindingness', which is commonly accepted as 'binding' by the majority of international lawyers, and the inquiry into the 'binding' character of a rule of law, where 'bindingness' is not restricted to the formal sources from where a rule is derived. ${ }^{576}$

This approach is reflected in Rosenne's comments on the catalogue of elements of the sources of doctrines, where resolutions of most international organisations, especially organs of the United Nations are considered 'not binding' under 'the terms of the constituent instrument of the organisation in question [with no legislative function]'. 577 The inquiry into the 'binding' character of a rule, or from where its obligatory character arises, is difficult. ${ }^{578}$

\footnotetext{
${ }^{572}$ Sartor, 'The Foundation of Legal Bindingness', supra n 569, at pp $344-345$. It is further summarise in pp 357 - 358 that: 'According to our notion of bindingness as (cognitive) participability in the collective adoption of a normative proposition, what is binding may vary according to the context and the purpose of the bindingness judgment, but also according the specific position of the author of the judgment. In fact, such circumstances impact on two (sub-) reasons supporting the conclusion that a new rule is binding: 1. the extent to which the general adoption of a new rule would contribute to realising (or impairing) legal values, and 2. the chance that one's adoption of the rule would lead to its collective endorsement. These dimensions of legal bindingness adds further contextual specification to the word binding'

${ }^{573}$ Sartor, 'The Foundation of Legal Bindingness', supra n 569, at pp $344-345$.

${ }^{574}$ Rosalyn Higgins, Problems and Process. International Law and How We Use It (Clarendon Press, Oxford, 1994) at $\mathrm{p} 13$.

${ }^{575}$ See Rosenne, Practice and Methods of International Law, supra $\mathrm{n} 221$, at pp $17-19$.

${ }^{576}$ See a discussion on 'form' at pp $9-12$ in Pauwelyn, 'Is it International Law or Not, And Does it Even Matter' (26 February 2010) supra n 209.

${ }^{577}$ Rosenne, Practice and Methods of International Law, supra n 221, at p 18.

${ }^{578}$ Gerard G Fitzmaurice, 'The Foundations of the Authority of International Law and the Problem of Enforcement' (1956) 19(1) Modern Law Review 1 - 13, at p 1. The difficulty lies in, as stated by the author, in $\mathrm{p} 8$ that, 'There is, however, this difference between the national and the international position: in the national society, the individual has, normally, no difficulty in accounting for his feeling that the law is binding on him - for instance, because it has been enacted by the proper authority; whereas it is less easy - in fact it is very difficult - in the international field, to say precisely what it is, in the ultimate and
} 
There is a proposition that the first and most powerful reason an international law is regarded as law is the recognition by the persons whom it controls - the states and other subjects of international law, as such. ${ }^{579}$ A law might be considered a valid law due to the way it is created, whereby the legal subjects whom the law addresses regard the method in which the law is created as authoritative. ${ }^{580}$

It reflects Fitzmaurice's observation that the real foundation of authority of international law 'resides in the fact that the States making up the international society recognise it as binding upon them, and, moreover, as a system that ipso facto binds them as members of that society'. ${ }^{581}$ Higgins explored the notion of 'bindingness' and the basis of obligation of international law and raised two pertinent questions in addressing this issue. Firstly, why should any normative system be regarded as binding? Secondly, why is that states should comply with the norms of international law $?^{582}$

In answering the first question, Higgins commented that a wealth of literature has been generated on the foundation of the binding, obligatory nature of international law, 'ranging from natural law, consent, an infinitely regressive concept ${ }^{583}$ of consent

juridical sense, that makes international law a binding system that States have a duty to conform to, and which, moreover, makes that duty a legal and not merely a moral or social duty'.

${ }^{579}$ Dixon, Textbook on International Law, supra n 531, at p 19. The author commented, at p 6 that analogy can be drawn between national law and international law where, if national law is considered law because it is generally accepted as such by the community to whom it is addressed, then international law is regarded as a system of 'law' if all states are under a legal obligation to abide by its rules. See Fitzmaurice, 'The Foundations of the Authority of International Law and the Problem of Enforcement', supra $\mathrm{n} 578$, at $\mathrm{p} 8$. The author reinforces the analogy from national law where he elaborated that 'Just as in the national society the law would not command the assent of the individual unless it were felt to be binding precisely because, and for no other reason than that it was the law, so equally international law could derive no authority from its acceptance by States as binding, or States would not give that acceptance, unless it were felt by them to be in fact inherently binding'. Also at pp 9-10: 'The problem of the ultimate foundation of the binding character of law is in no way peculiar to international law. It is a general legal problem, and arises just as much with regard to national law as it does for international law'. ${ }^{580}$ Dixon, Textbook on International Law, supra n 531, at p 6.

${ }^{581}$ Fitzmaurice, 'The Foundations of the Authority of International Law and the Problem of Enforcement', supra $\mathrm{n} 578$, at $\mathrm{p} 8$.

${ }^{582}$ Higgins, Problems and Process. International Law and How We Use It, supra n 574, at p 13. Such questions are raised in the light of her definition of what law is in $\mathrm{p} 2$. Her analysis of international law as a process rather than a set of rules are quoted in full: 'When decisions are made by authorised persons or organs, in appropriate forums, within the framework of certain established practices and norms, then what occurs is legal decision-making. In other words, international law is a continuing process of authoritative decisions. This view rejects the notion of law merely as the impartial application of rules. International law is the entire decision-making process, and not just the reference to the trend of past decisions which are termed "rules".

${ }^{583}$ An inquiry into the juridical foundation of the consent of States that makes a rule binding is a question where it is very difficult to give an answer to, as such inquiry will embark on what is 'known to the mathematicians as an infinite regress'. Fitzmaurice, 'The Foundations of the Authority of International Law and the Problem of Enforcement', supra n 578, at p 9. 
anterior to the legal system itself, consensus, ${ }^{584}$ to reciprocity'. ${ }^{585}$ She opined that for international law, it has been accepted that consensus, obtained through the process of decision-making in a normative system, be it explicit or tacit, is the foundation of the obligatory and binding nature of the rules of international law. ${ }^{586}$

As to the second question Higgins raised, on the basis of the obligation generated from law that drives the compliance of states with the norms of international law, she is of the view that the foundation of obligation rests on 'states' perception of reciprocal advantage in cautioning self-restraint'. ${ }^{587}$ It is noted that consent in itself does not create an obligation unless the consent was given within a system of law that recognises that submission of consent is the foundation from which obligation arises. ${ }^{588}$ This is reflected in Fitzmaurice's comment that the basis of obligation and the authority generated by international law - i.e. the law's binding force - resides in the will and recognition of the members of the society. ${ }^{589}$

The giving of consent by states could be motivated by the presumption of reciprocal advantages perceived to be available to them, ${ }^{590}$ but this motivation in itself does not explain the ontology of the authority that law commands. Similar arguments could be extended to tacit consent or consensus where states' recognition of the authority of law could be deduced in the absent of active act of a submission of consent.

\footnotetext{
${ }^{584}$ The concept of consensus is further elaborated where a review of the legality of informal international law is based on the criteria of a thick consensus on both the procedural and substantive quality of the norm. See Pauwelyn, 'Is it International Law or Not, And Does it Even Matter' (26 February 2010) supra n 209, at p 47.

${ }^{585}$ See Higgins, Problems and Process. International Law and How We Use It, supra n 574, at pp 13, 14 and 16.

${ }^{586}$ Higgins, Problems and Process. International Law and How We Use It, supra n 574, at p 16.

${ }^{587}$ Higgins, Problems and Process. International Law and How We Use It, supra n 574, at p 16. The author noted that 'the classic starting-points remains Brierly, The Basis of Obligation in International Law' (James Leslie Brierly, Hersch Lauterpacht, CHM Waldock, The Basis of Obligation in International Law (Clarendon Press, Oxford 1958)). See also Myres S McDougal, Harold D Lasswell and W Michael Reisman, 'Theories about International law: Prologue to a Configurative Jurisprudence' (1968) 8 Virginia Journal of International Law 188 - 194. See Karl Zemanek, 'Is the Term “Soft Law” Convenient?' pp 843 - 881 in Gerhad Hafter (ed) Liber Amicorum Professor Ignaz Seidl-Hohenveldern in Honour of His $80^{\text {th }}$ Birthday (Kluwer Law International, The Hague, 1998), at pp 856 and 885. The author commented that hard law is normally observed and applied because of its 'general acceptance ... the recognition that the existing legal rules reflect the shared values and interests of the members of the international community. Soft law is normally performed when they correspond to carefully balanced reciprocal interests. As long as these interests subsist, the possible political and/or economic consequences of non-performance are often a far stronger deterrent than the consequences of the non-performance of most legal obligations. This suggests that reciprocity as an incentive of performance is independent of the nature of the commitment'.

${ }^{588}$ James Leslie Brierly, The Law of Nations (Oxford University Press, Oxford, 1950) at p 54.

${ }^{589}$ Fitzmaurice, 'The Foundations of the Authority of International Law and the Problem of Enforcement', supra $\mathrm{n} 578$, at pp $6-12$.

${ }^{590}$ Higgins, Problems and Process. International Law and How We Use It, supra n 574, at p 16.
} 
Hence, it seems that there is only one answer for the two questions raised by Higgins. ${ }^{591}$ Normative systems, and the norms created from normative systems, are considered binding on states due to the consent given by states that 'declares that consent duly given, as in a treaty or a contract, shall be binding on the party consenting, ${ }^{592}$ Dixon explored substance and content of legal obligations through the notion of material sources. ${ }^{593}$ Dixon commented that the purpose of these material sources of law is to identify the substance of the obligations which becomes law'. 594

The analysis into the underpinnings of 'bindingness' reveals that the connotation of 'bindingness' is not a notion independent from the conceptualisation of law and legality. The quest to understand the meaning and nature of 'bindingness', the sense of obligation imposed by a rule of law, cannot be disengaged from the understanding of the law, and the legal system in which law is created. ${ }^{595}$ This raises the second subsidiary question of - does the requirement that 'what is applicable must be binding' originates from the imposition of legality required by rules of international law, and not because 'applicable' is defined to mean 'binding'? The next section will address these issues accordingly.

\footnotetext{
${ }^{591}$ Higgins, Problems and Process. International Law and How We Use It, supra $\mathrm{n}$ 574, at $\mathrm{p}$ 13. Such questions are raised in the light of her definition of what law is in $\mathrm{p} 2$. Her analysis of international law as a process rather than a set of rules are quoted in full: 'When decisions are made by authorised persons or organs, in appropriate forums, within the framework of certain established practices and norms, then what occurs is legal decision-making. In other words, international law is a continuing process of authoritative decisions. This view rejects the notion of law merely as the impartial application of rules. International law is the entire decision-making process, and not just the reference to the trend of past decisions which are termed "rules".

${ }^{592}$ Brierly, The Law of Nations, supra n 588, at p 54. The author stated that 'consent cannot of itself create an obligation; it can do so only within a system of law which declares that consent duly given, as in a treaty or a contract, shall be binding on the party consenting'.

${ }^{593}$ Dixon, Textbook on International Law, supra $\mathrm{n} 531$, at $\mathrm{p} 25$.

${ }^{594}$ Dixon, Textbook on International Law, supra n 531, at p 25. The author laid out that 'state practice, the practice of international organisations, the practice of non-state actors, judicial decisions, the writings of jurists and General Assembly resolutions are all material sources for they indicate what a state's obligations actually are, rather than the method by which those obligations became legally binding'. However, the sources of law as codified in Article 38(1) of the Statute of the International Court of Justice do not distinguish between formal sources of law and material sources of law.

${ }^{595}$ According to Pokol, 'the adequate exposition of the concept of law can cover nothing but the concept of the legal system. Once the concept of the legal system has been expounded, it is possible ... to sum up the concept of the less precise "law", which is actually a notionally looser repetition of the concept of the legal system'. Béla Pokol, The Concept of Law. The Mult-Layered Legal System (Rejtjel Edition, Budapest, 2001) at p 9. See also Raz, Between Authority and Interpretation, supra n 497, at p 5. Raz defined law as 'the product of many acts of law-making usually over long stretches of time, through processes which, far from displaying coherent design, are contributed to by many bodies, only partially aware of each other, often pursuing divergent, even conflicting, ends'.
} 


\subsubsection{Bindingness and Legality}

A convergence between the notion of legality and bindingness is apparent in Fitzmaurice's elaboration of law. The notion of 'law' is -

'revealed as something that has no meaning unless it is external to the will of the members of the society in which it functions, as something to which those members are subject, and which derives its obligatory character from sources that do not rest on consent, but rather themselves confer on consent its law-making capacities. And the ultimate source of the validity of this law is and must be extralegal'. 596

A rule of law gained its authority and sense of obligation not as much as the states gave consent to that rule, but consent of states as to the system of law and the process of law making. This consent is what gives law its 'binding' force that commands a sense of obligation, from which law gains its authority. 'Bindingness' in this context, is a quality unique to law and a rule of law developed from the system of law.

This raises the pertinent question of, is it a misconception then, to require that a rule of international law be 'binding' on the parties in order to be applicable? Is the notion of 'bindingness' not a normative quality specific to law, which should not have implications on the interpretation of 'applicable' in the context of Article 31(3)(c)?

An initial perusal of the 1969 Vienna Convention is not capable of addressing these questions raised. But the text of the Convention demonstrated that it could be the intention of the drafters to distinguish the requirement of legality inherent in the explicit reference to 'rules of international law' in the earlier part of Article 31(3)(c), with the subsequent requirement of the rules of international law to be 'applicable in the relations between the parties'. A requirement of 'legal relations' is intentionally omitted, although some 'significant relationship' should exist in the relations between the parties in order to take into account relevant rules of international law in the interpretative process via Article 31(3)(c) of the 1969 Vienna Convention. ${ }^{597}$

\footnotetext{
${ }^{596}$ Fitzmaurice, 'The Foundations of the Authority of International Law and the Problem of Enforcement', supra $\mathrm{n} 578$, at $\mathrm{p} 12$.

${ }^{597}$ In reference to the comment by Gardiner - a rule to be applicable, there must exist a significant relationship between the parties Gardiner, Treaty Interpretation, supra n 235, at p 265.
} 
The omission of the term 'legal' is not silent as the term 'legal' is expressly stipulated in Article 63 of the Convention. Article 63 provides that 'the severance of diplomatic or consular relations between parties to a treaty does not affect the legal relations established between them by the treaty'. ${ }^{598}$ A close reading of Article 72 informs that 'legal relations' mean relations established by treaty by which the states have expressed their consent to be bound. ${ }^{599}$ Legal relations are distinct from other relations and reference to legal relations connotes that the drafters have the intention to refer particularly to the legal relations between the parties in Article 72 instead of other relations, which could be the case in Article 31(3)(c).

If the omission of 'legal' in Article 31(3)(c) is interpreted, it could imply that the requirement of legality, or any legal relation, is not imposed in the phrase 'applicable in the relations between the parties'. This indicates the intention of drafters that Article 31(3)(c) does not requires a legal relationship established by treaty, and strengthens the argument that legality is not a requirement in the interpretation of 'applicable'.

It has been argued previously that bindingness is a unique feature of law, and intrinsic to a conceptualisation of legality. If legality is not imposed in the phrase 'applicable in the relations between the parties' (evidenced in the omission of legal relations in the latter phrase), bindingness would not be presumed to be a criterion to be fulfilled in the interpretation of 'applicable in the relations between the parties'.

The subsequent section seeks to support the assertion that a determination of 'applicability' of a rule of international law stipulated in Article 31(3)(c) should not be implicated in, or be confounded with, a discourse into the bindingness of law, which constitutes a defining feature of legality. A possible suggestion of this disengagement of the idea of 'legality' and 'applicability' is hinted in debates of the ILC, where Mr. Bartoš commented that a treaty could be considered in force, but not applicable, if certain conditions that lead to the severance of diplomatic relations, which precludes the performance of treaties, had occurred. ${ }^{600}$

\footnotetext{
5981969 Vienna Convention, supra n 31, Art 63.

5991969 Vienna Convention, supra n 31, Art 72(1)(b).

${ }^{600}$ ILC, 'Summary Records of the Eighteenth Session. 4 May - 19 July 1966, [1966] 1(II) Yearbook of International Law Commission 1 - 351, supra n 534, at p 213, para 13. Mr. Bartoš stated that 'he would vote for Article 64 [Article 63 in the current text] because he favoured the principle enunciated in the Drafting Committee's text. He wished to point out, however, that the severance of diplomatic relations
} 


\subsubsection{Requirement of 'Bindingness' for 'Applicable' Not Supported by Both Textual Analysis and Jurisprudence}

(a)

\section{Textual Analysis}

The text provisionally adopted in 1964 that subsequently became Article 31(3)(c) stated that 'A treaty shall be interpreted in good faith in accordance with the ordinary meaning to be given to each term ... in the light of the rules of general international law in force at the time of its conclusion. ${ }^{, 601}$ The Commission explained that Article 31(3)(c) [Draft Article 69(1)(b)] was intended to codify the principle of 'inter-temporal' law, reflecting that a juridical fact must be appreciated in the light of the law contemporary with it. ${ }^{602}$

It reiterated the words of Max Huber in the Island of Palmas Arbitration that were applied in the Grisbadarna, North Atlantic Coast Fisheries arbitrations, and the case of Rights of Nations of the USA in Morocco. ${ }^{603} \mathrm{~A}$ majority of the members of the Commission preferred to maintain the words 'in force at the time of its conclusion' despite recognising that the scope of a term may sometimes be altered by a change in the law. ${ }^{604}$ The Commission decided to leave the temporal element to the intentions of the party by subsequently revising the Article to the present wording, and further opined that a correct application of the temporal element will be indicated in the interpretation of a treaty term in good faith. ${ }^{605}$

By reference to the development of the provision, it can be found that it is not the explicit intention of the Commission to impose the obligation that the 'rules of international law' must be 'binding on the parties' in order to be applicable. The requirement that the rules of international law must be 'binding' on the parties for them to be applicable in the relations between the parties has never been envisaged in the

\footnotetext{
sometimes occurred under conditions which precluded the performance of treaties. He considered that in such a case the treaty was in force, but not applicable'.

${ }^{601}$ Art $69(1)(b)$, ILC, 'Report of the ILC on the work of its $16^{\text {th }}$ session, 11 July 1964' (ORGA 19 $9^{\text {th }}$ Session, Supplement) A/5809 (1964) II Yearbook of International Law Commission 173 - 227, at p 199 <http://untreaty.un.org/ilc/documentation/english/a_cn4_173.pdf> accessed 5 April 2012.

${ }^{602}$ ILC, 'Report of the ILC on the work of its $16^{\text {th }}$ session, 11 July 1964', supra n 601, at pp $202-203$, para 11. See also ILC, 'Report of the International Law Commission on the Work of Its Eighteenth Session, 4 May - 19 July 1966' (ORGA, $21^{\text {st }}$ Session Supp No 9) A/6309/Rev.1, [1966] II Yearbook of International Law Commission $169-363$, at $p$ 222, para 16 〈http://untreaty.un.org/ilc/reports/english/a cn4 191.pdf> accessed 16 November 2012.

${ }^{603}$ ILC, 'Report of the ILC on the work of its $16^{\text {th }}$ session, 11 July 1964', supra $\mathrm{n}$ 601, at pp $202-203$, para 11. ILC, 'Report of the International Law Commission on the Work of Its Eighteenth Session, 4 May - 19 July 1966', supra n 602, at p 222, para 16.

${ }^{604}$ ILC, 'Report of the ILC on the work of its $16^{\text {th }}$ session, 11 July 1964', supra $\mathrm{n}$ 601, at $\mathrm{p} 203$, para 1.

${ }^{605}$ ILC, 'Report of the International Law Commission on the Work of Its Eighteenth Session, 4 May - 19 July 1966', supra n 602, at p 222, para 16.
} 
codification of this element of interpretation. This emphasises that the difficulty of comprehensively addressing the temporal issue was due to the consideration that the correct application of the temporal element is an interpretation of good faith, and the intentions of the parties.

Besides, if 'bindingness' is a requirement, the Convention would be explicit in indicating that it is the case, as shown in Article 38 where it provides that a rule set forth in treaty is not precluded from becoming binding on a third state as a customary rule of international law. If 'applicable' means binding, then in the need to maintain uniformity and consistency throughout the convention, this provision should have read 'a rule set forth in a treaty is not precluded from becoming "applicable" on a third state as a rule of customary international law, ${ }^{606}$

Similarly, if 'applicable' means binding, Article 65(4) will not read 'nothing in the foregoing paragraphs shall affect the rights or obligations of the parties under any provisions in force binding the parties with regard to the settlement of disputes' (author's emphasis). Instead, it should read 'nothing in the foregoing paragraphs shall affect the rights or obligations of the parties under any provisions in force "applicable to" the parties with regard to the settlement of disputes' (author's emphasis). The wording of this provision goes further, to illustrate that firstly, provisions in force do not necessarily 'bind' the parties unless it is the intention of the parties to be so bound, or else Article 65(4) will be the 'provision in force [binding the parties] with regard to the settlement of dispute'. Secondly, the Article shows that if rules of international law 'applicable' in the relations between the parties are meant to be 'binding' on the parties, the wording of Article 31(3)(c) will be 'rules of international law binding on the parties' as has been done in Article 38 and Article 65(4).

Moreover, Article 72(1)(b) highlights the fact that the Convention will be explicit in indicating what type of 'relations between the parties' the Commission has envisaged be it 'legal' or 'binding' - in phrasing the text of the Convention. Article 72(1)(b) stipulates that 'the suspension of the operation of a treaty ... does not otherwise affect the legal relations between the parties' (author's emphasis) and gives a clear indication

\footnotetext{
${ }^{606}$ The current text of Art 38 of the 1969 Vienna Convention, supra n 31, reads 'Rules in a treaty becoming binding on third States through international custom. Nothing in articles $34-37$ precludes a rule set forth in a treaty from becoming binding upon a third State as a customary rule of international law, recognised as such'.
} 
that if the intention of the provision is meant to create an obligation that addresses the 'legal relations between the parties', it will be explicit in doing so.

Thus, the current opinion of scholars that - in order for the rules to be 'applicable in the relations between the parties', these rules must be 'binding'; and the relations between the parties must be legal - does not seem to be reflected in a textual analysis of the text of the Convention.

\section{(b) Jurisprudence of International Courts and Tribunals}

It is interesting to note that the approach adopted by Pauwelyn also suggested that a requirement of bindingness in the interpretation of the term 'applicable' is not imposed. He suggested that, apart from the applicability of general international law and the norms binding on all WTO members that are deemed applicable as reference material for the interpretation of WTO covered agreements, norms that 'reflect their [the parties'] common intentions' are equally applicable in the relations between the parties. ${ }^{607}$

The possibility of a non-requirement of 'bindingness' in the determination of whether a rule of law is considered 'applicable in the relations between the parties' has opened a new horizon for the debate on the normative content of 'applicable', and shed new light on the interpretation of 'applicable'. Pauwelyn's argument that favours and supports the notion that the intention of the parties is the ultimate determination of 'applicability', can be observed from decisions taken by international courts and tribunals. It can be observed that the pre-condition of 'bindingness' in the determination of whether the rule is applicable in the relations between the parties has not always been shown in international adjudication.

In reference to the Dissenting Opinion of Judge Griffith in the OSPAR Arbitration, relevant rules, which were not yet binding on the disputing parties, are considered as relevant rules applicable in the relations between the parties. He arrived at this decision based on the consideration that it is the common intention of the parties as to the 'applicability' of the 1999 Aarhus Convention as manifested through the fact that the parties are signatories to the Convention. ${ }^{608}$ Judge Griffith opined that the OSPAR Convention repeatedly and explicitly requires close consideration of international legal

\footnotetext{
${ }^{607}$ Pauwelyn, 'Bridging Fragmentation and Unity', supra n 132, at p 915.

${ }^{608}$ OSPAR Proceeding, supra n 118, Dissenting Opinion of Judge Griffith, at paras $7-19$.
} 
sources. ${ }^{609}$ In particularly, the OSPAR Convention defined 'dumping' to include an operation that takes place in accordance with other relevant international law. ${ }^{610}$

Judge Griffith opined that by defining 'dumping' as not to include '[operations] leaving wholly or partly in place of a disused offshore installation or disused offshore pipeline provided that any such operation takes place in accordance with any relevant provision other relevant international law, ${ }^{611}$ it provides an explicit mandate for the Tribunal to apply the OSPAR Convention as a lex specialis between the Parties. The definition of dumping to exclude the leaving of offshore installation or disused offshore pipeline that is in accordance with other relevant international law indicates an interpretation of Article 9 of the OSPAR Convention that is consistent with 'broadly defined international law, and not confined merely to treaty and conventional law in force binding on the Parties'. ${ }^{612}$

Judge Griffith cross-referred to the majority decision in paragraphs 101 to 105 that rejected the application of Aarhus Convention and also the 'draft proposals for a new EC Directive' in informing the meaning of Article 9(2) of the OSPAR Convention because they are 'evolving international law and practice', and 'material that has not yet become law'. ${ }^{613}$ The main concern of the majority is not because the proposed instruments are not binding, but because these instruments are not yet law, of which Judge Griffith departed from the majority decision. ${ }^{614}$ Judge Griffith concluded that the

'Aarhus Convention falls within the definition of applicable law and Article 31(3)(c) of the 1969 Vienna Convention as a legal source that possesses some normative and evidentiary value to the extent that regard may be had to it to

\footnotetext{
${ }^{609}$ OSPAR Proceeding, supra n 118, Dissenting Opinion of Judge Griffith at p 120, para 4.

${ }^{610}$ Convention for the Protection of the Marine Environment of the North-East Atlantic (concluded 22 September 1992, entered into force 25 March 1998) 2354 UNTS 67; (1993) 32 ILM 1069 <http://www.ospar.org/html_documents/ospar/html/OSPAR Convention_e updated text_2007.pdf> accessed 2 January 2011 (hereinafter: 'OSPAR Convention').

${ }^{611}$ OSPAR Convention, supra n 610, Art 1(g)(iii).

${ }^{612}$ OSPAR Proceeding, supra n 118, Dissenting Opinion of Judge Griffith at p 120, para 5.

${ }^{613}$ OSPAR Proceeding, supra n 118, Dissenting Opinion of Judge Griffith at pp 120 - 121, paras 6-7.

${ }^{614}$ OSPAR Proceeding, supra n 118, Judge Griffith commented, in paras $6-7$ that, the majority rejected the application of the Aarhus Convention and the EC legislative proposal due to, as stated in paras 99 105: 'law in statu nascendi'; and para 180: 'legally unperfected instruments'.
} 
inform and confirm the content of the definition of information contained in Article 9(2) of the OSPAR Convention'. ${ }^{615}$

A similar stance has been taken by the ICJ in the case of Gabčíkovo-Nagymaros Project where the Court explicitly stated that -

'Owing to new scientific insights and to a growing awareness of the risks for mankind - for present and future generations - of pursuit of such interventions at an unconsidered and unabated pace, new norm and standards have been developed ... Such new norms have to be taken into consideration, and such new standards given proper weight. ${ }^{616}$

The Court proceeded to conclude that the obligation to regularise Variant $\mathrm{C}$ through the reestablishment of a join regime as required under Articles 9 and 10 of the 1977 Treaty is in accordance with Article 5(2) of the 1997 Watercourses Convention. ${ }^{617}$ Despite the fact that the 1997 Watercourses Convention has not entered into force during the adjudication of this dispute, the Court recognised and applied this Convention in the interpretation and application of the 1997 Watercourses Convention. The Court opined that 'modern development of international law has strengthened the principle of [the community of interest in a navigable river] for non-navigational uses of international watercourses as evidenced by the adoption of the 1997 Watercourses Convention' ${ }^{618}$

Formal sources of international law do not seem to be a great concern in the Iron Rhine case. ${ }^{619}$ The Tribunal had the opportunity to reflect on the duty to prevent or mitigate significant harm caused by development where the Tribunal opined that this duty had now become a principle of general international law, as reflected in Principle 4 of the 1992 Rio Declaration. ${ }^{620}$ In this context, the Tribunal pronounced that the dictum of 'new norms have to be taken into consideration and new standards given proper weight ${ }^{621}$ is equally applicable in the interpretation of Article XII of the 1839 Treaty of Separation and Article IV of the Iron Rhine Treaty. The pivotal consideration of the Tribunal was that neither party denies the applicability of environmental norms. This

\footnotetext{
${ }^{615}$ OSPAR Proceeding, supra n 118, Dissenting Opinion of Judge Griffith at p 123, para 19.

${ }^{616}$ Gabčíkovo-Nagymaros case, supra n 1, at p 78, para 140.

${ }^{617}$ Gabčíkovo-Nagymaros case, supra n 1, at pp 78 - 80, paras $145-147$.

${ }^{618}$ Gabčíkovo-Nagymaros case, supra n 1, at p 56, para 85.

${ }^{619}$ Iron Rhine case, supra n 525.

${ }^{620}$ Iron Rhine case, supra $\mathrm{n} 525$, at para 59.

${ }^{621}$ Gabčíkovo-Nagymaros case, supra n 1, at p 78, para 140.
} 
prompted the Tribunal to decide that any emerging principles, provisions of European law or general international law referring to the conservation, management, notions of prevention and of sustainable development, and protection for future generation, regardless of their status, are relevant in the relations between the parties. ${ }^{622}$

The International Tribunal of the Law of the Sea (ITLOS) adopted similar approach where Judge Treves, in his separate opinion, considers the 1995 Straddling Fish Stocks Agreement as relevant for the purpose of interpretation despite the fact that it neither had entered into force nor was it ratified by the disputing parties in the case of Bluefin Tuna. The reason it is considered applicable is that the 1995 Agreement is 'significant for evaluating the trends followed by international law'. ${ }^{623}$

These cases confirm that the relevant rules of international law applicable in the relations between the parties for the purpose of interpretation do not necessarily need to be 'binding' on the parties. It could have binding force on the parties due to the nature of the rule of international law identified, but it is not a determinative factor in the ascertainment of whether the rule of international law is 'applicable in the relations between the parties' in the context of Article 31(3)(c).

This assertion is reflected in Pauwelyn's categorisation of types of rules of international law and the purposes for which these rules of international law are used. Pauwelyn categorised and treated similarly the three types of international law - namely general international law; norms binding on all WTO members; or norms reflecting the parties' [WTO parties'] 'common intentions'. ${ }^{624}$ The applicability of general international law and norms binding on all WTO members is due to the reason that these laws or norms reflect the common intentions of the parties'. ${ }^{625}$

In this regard, the requirement of bindingness is not to be considered as a yardstick in the ascertainment of 'applicability in the relations between the parties' of a rule of international law under Article 31(3)(c). The assessment of whether a rule of international law is 'applicable in the relations between the parties' commands the question of whether the rule reflects the common intention of the parties.

\footnotetext{
${ }^{622}$ Iron Rhine case, supra $\mathrm{n} 525$, at paras 58 and 59.

${ }^{623}$ ITLOS, Southern Bluefin Tuna Cases (New Zealand and Australia v Japan) (Provisional Measures, 27 August 1999) <http://www.itlos.org/index.php?id=62\&L=1\%2F> accessed 30 December 2011 (hereinafter: 'Bluefin Tuna Provisional Measure'). Separate Opinion of Judge Treves para 10.

${ }^{624}$ Pauwelyn, 'Bridging Fragmentation and Unity', supra n 132, at p 915.

${ }^{625}$ Pauwelyn, 'Bridging Fragmentation and Unity', supra n 132, at $\mathrm{p} 915$.
} 
The analyses of the text and existing jurisprudence in this section revealed that what is most important for a rule of international law to be considered 'applicable in the relations between the parties' was that the rule possesses some normative and evidentiary value to inform and confirm the content of the provision to be interpreted. ${ }^{626}$ Alternatively, it is 'significant for the evaluation of trends followed by international law' ${ }^{627}$ From this juncture, it could be observed that rules that are considered to be applicable for the reasons stated above could also be said to be 'relevant' for the interpretation of a treaty term or provision.

The method of treaty interpretation adopted by the Panel in the EC - Biotech case that 'bindingness' is not a requirement in the determination of whether the rules of international law are 'applicable in the relations between the parties' was commented to be 'over-inclusive'. ${ }^{628}$ Scholar argued that such approach, where 'bindingness' of the external 'informative' treaty to be taken into account is not a requirement, leads to the 'loosening of the requirement of state consent'. ${ }^{629}$ The criticism posed was based on the need for state consent pursuant to the concept of sovereignty as the 'entrance condition' for an external treaty serving an informative function to be taken into account in treaty interpretation, and not to the fact that these external rules must be legally binding.

This criticism can be addressed by the argument submitted above, that the rules of international law deemed applicable in the relations between the parties should reflect the common intentions of the parties. The common intention of the parties reflects the consent of states as to the interpretation of the external rule, which allows the incorporation of the external treaty in the interpretation of a term or provision of treaty without the need for the external rule to be binding on the parties.

In other words, the crux of Young's argument to impose the requirement of 'bindingness' in the interpretation of 'applicable' under Article 31(3)(c) was due to the importance placed on the need for state consent. However, this concern is not neglected if a requirement of bindingness is not imposed. A rule that is implicitly accepted or tolerated by all parties to the treaty under interpretation in the sense that it can

\footnotetext{
${ }^{626}$ Evidenced in the dissenting opinion of Judge Griffith in the OSPAR Arbitration, and the judgment of the case concerning the Gabčíkovo-Nagymaros Project. See supra n 615 and n 616.

${ }^{627}$ Separate opinion of Judge Treves, See supra n 623 and accompanying text.

${ }^{628}$ Margaret A Young, 'The WTO's Use of Relevant Rules of International Law: An Analysis of the Biotech Case' (2007) 56 International and Comparative Law Quarterly 899 - 930, at p 908.

${ }^{629}$ Young, 'An Analysis of the Biotech Case', supra n 628, at pp 908 and 909.
} 
reasonably be considered to express the common intentions or understanding of all members as to the meaning of the term concerned ${ }^{630}$ (which is how applicable should be defined), does not bypass state consent.

The lack of legal 'bindingness' of an external treaty does not render the external rules inapplicable under Article 31(3)(c) as long as there is consensus from the states. The fact that a rule of international law that is binding on the parties could be, or is de facto applicable in the relations between the parties as the consent of the states is apparent. However, this does not mean that the phrase 'applicable in the relations between the parties' itself as provided under Article 31(3)(c) imposes a criterion of bindingness.

The Panel in EC - Biotech illustrated this point succinctly where it stated that -

'the mere fact that one or more disputing parties are not parties to the convention does not necessarily mean that a convention cannot shed light on the meaning and scope of a treaty term to be interpreted'. ${ }^{631}$

A common understanding could be drawn from relevant scholars that the requirement imposed on the stipulation for the applicability of the relevant rule to be taken into account in an interpretative process is the intention of the parties. The fact that the relevant rules are binding on the parties merely strengthened the common intentions of the parties as to the applicability of the rules in their relations. It does not impose that what is 'applicable' must be binding.

In the context of Article 31(3)(c) where relevant rules of international law are used as 'an aid to the interpretation of a given provision of an agreement', ${ }^{632}$ the interpretation that requires 'applicable' to be binding is demonstrated to be inconsistent with the existing jurisprudence of international courts and tribunals. This induces a revision of the interpretation of the phrase 'applicable in the relations between the parties' where the existing threshold of 'bindingness' is argued in this thesis to be inappropriate.

The rules of international law considered 'applicable in the relations between the parties' are contingent on the common intentions of the parties. The common intention of the parties is informed by the normative content underlying the said rule of international

\footnotetext{
${ }^{630}$ McLachlan, 'The Principle of Systemic Integration', supra n 162, at p 314, para 15(d).

${ }^{631}$ EC- Biotech, supra $\mathrm{n} 117$, at paras 7.94.

${ }^{632}$ Lorand Bartels, ‘Applicable Law in WTO Dispute Settlement Proceedings', supra n 550, at p 510.
} 
law. Such revision prompts a reconstruction of the salient feature of the phrase 'relevant rules of international law applicable in the relations between the parties' where emphases are relocated to -

1. The setting of criteria against which 'relevant' is assessed;

2. The normative scope and content of rules of international law; which informs

3. The common understanding amongst the parties, or the common intention of the parties. $^{633}$

A reconstruction of the salient points for the operationalisation of Article 31(3)(c) will ensue if 'applicable' is appreciated in the light of the argument that Article 31(3)(c) does not require that a rule of international law must be binding on the parties in order to be considered to be 'applicable in the relations between the parties'. This flexibility afforded in this approach of the interpretation of 'applicable in the relations between the parties' supports the four possible constructions of 'the parties' elaborated in the subsequent section in which the "rules of international law applicable in the relations between the parties' are analysed through the interpretation of who 'the parties' are.

\subsubsection{In the Relations between 'the Parties'}

The debate on the correct interpretation of 'the parties' continues to plague the interpretation and application of Article 31(3)(c). ${ }^{634}$ Gardiner's interpretation suggested otherwise. He is of the opinion that 'the immediate context [of Article 31(3)(c)] is slightly different [where] the omission of "all" is combined with the phrase "applicable in the relations between the parties"[, which seems to] import the idea of significant relations' (author's emphasis), ${ }^{\text {,63 }}$

Much controversy has been created by the claims over the correct interpretation of 'the parties' ${ }^{636}$ It is raised that the qualifier of 'applicable in the relations between the parties' suggests the need for scrutiny if the external rule is 'truly applicable to (all) the

\footnotetext{
${ }^{633}$ Pauwelyn, 'Bridging Fragmentation and Unity', supra n 132, at p 915. Pauwelyn, 'The Role of Public International Law in the WTO: How Far Can We Go?', supra n 264, at pp 575 - 576. This notion of common understanding and common intentions of parties are further elaborated in the subsequent section in the study of the four constructions of 'the parties'.

${ }^{634}$ Linderfalk, 'Who are 'The Parties'?', supra n 260, especially pp $362-364$.

${ }^{635}$ Gardiner, Treaty Interpretation, supra $\mathrm{n} 235$, at $\mathrm{p} 265$.

${ }^{636}$ Merkouris 'Article 31(3)(c) of the VCLT and the Principle of Systemic Integration', supra $\mathrm{n}$ 555, at p 17.
} 
parties to a treaty'. ${ }^{637}$ The various interpretative approaches are loosely categorised as strict or broad, whereby the determination of 'the parties' in the stricter approach or the broader approach will influence how Article 31(3)(c) is to be interpreted, that is, whether it should be understood in a narrow sense or in a broader context. ${ }^{638}$ However, questions remain, especially in the case where the treaty to be interpreted and the external treaty relied upon are both multilateral treaties, whether identical membership is required in the application of Article 31(3)(c). ${ }^{639}$

A strict interpretation of 'the parties' refers to 'all parties to the interpreted treaty', that each and every one of the states bound by the interpreted treaty at the time of interpretation must be equally bound by the rule used as a means of interpretation. A more generally held view at present is the broad or divergent approach in interpretation, which suggests that, a correct meaning of 'the parties' should be - two or more parties to a specific dispute (concerning the interpretation or application of the treaty). ${ }^{640}$ The interpreter of that treaty may draw on the existence of a rule of law applicable in the relations between the disputing states, irrespective of whether the said rule can be applied in the relations between other parties to the interpreted treaty. ${ }^{641}$

A careful reading of the 1969 Vienna Convention does not reveal how the Convention meant to interpret 'the parties' because the initial design of this rule was originally to deal with the inter-temporal aspect of interpretation. ${ }^{642}$ Hence, it is inevitable that the scope and limitation of 'the parties' in the application of Article 31(3)(c) are indeterminable by sole reference to the ordinary meaning of this term. ${ }^{643}$ The ordinary meaning and the context of Article 31(3)(c) is unhelpful in seeking the intended meaning of this term. ${ }^{644}$ The controversy over this term has been eloquently summed up by Gardiner -

\footnotetext{
${ }^{637}$ Wälde, 'Interpreting Investment Treaties: Experiences and Examples', supra n 345, at p 775.

${ }^{638}$ Linderfalk, 'Who are 'The Parties'?', supra n 260, at p 345.

639 Anne van Aaken, 'Defragmentation of Public International Law through Interpretation: A Methodological Proposal' (2009) 16(2) Indiana Journal of Global Legal Studies 483 - 512 at p 498.

${ }^{640}$ Van Aaken, 'Defragmentation of Public International Law through Interpretation', supra $\mathrm{n}$ 639, at $\mathrm{p}$ 498.

${ }^{641}$ Linderfalk, 'Who are 'The Parties'?', supra n 260, at p 345.

${ }^{642}$ Sinclair, The Vienna Convention on the Law of Treaties, supra $\mathrm{n} 272$, at $\mathrm{p} 138$.

${ }^{643}$ Gardiner, Treaty Interpretation, supra n 235, at p 263.

${ }^{644}$ Merkouris 'Article 31(3)(c) of the VCLT and the Principle of Systemic Integration', supra $\mathrm{n} 555$, at $\mathrm{p}$ 18.
} 
'The first issue is whether the reference is to the parties to a dispute or difference over the meaning of a treaty, or to parties to the treaty being interpreted. Even if the latter, the question which recurs in the case of a multilateral treaty is whether the meaning is just those of the parties to the treaty who have a dispute or difference over interpretation, or a group of parties who have established some particular international regime among themselves, or whether the reference is to all parties to the treaty which is being invoked to provide applicable rules. ${ }^{645}$

Hence, apart from the possibility that 'the parties' might refer to parties that are not party to the treaty, the controversy also revolves on the situation where even 'the parties' are parties to the treaty. If the treaty happens to be a multilateral treaty, questions arise. First, whether the meaning of the interpreted term in the treaty that takes into consideration the external treaty will apply only to the parties to the dispute. Alternatively, whether it will be equally applied to the parties not party to a dispute, but who are parties to the multilateral treaty to be interpreted.

To complicate the matter, will such meaning be applicable to the parties to the multilateral treaty but not parties to the dispute and the external treaty relied upon for interpretation? The discussion of whether 'the parties' applies only to parties in dispute becomes more convoluted in reference to Article 66(a) of the 1969 Vienna Convention. Article 66(a) provides for procedures for judicial settlement, arbitration and conciliation where it seems to indicate that the drafters will be explicit if 'the parties' are intended only for 'the parties to a dispute' by referring to these parties as 'the parties to a dispute'. ${ }^{646}$ The contextual reading of the term does not clarify the confusion. It merely provides a possibility that 'the parties' in Article 31(3)(c) are not restricted to 'the parties to the dispute'. Whether 'the parties' actually refers to any other parties remained uncertain.

The Commentary to the 1969 Vienna Convention was careful in distinguishing the meanings for four separate categories of states, according to the requirement in a particular context, and stressed that the terminology used must be uniform. ${ }^{647}$ Article

\footnotetext{
${ }^{645}$ Gardiner, Treaty Interpretation, supra n 235, at p 263.

${ }^{646} 1969$ Vienna Convention, supra n 31, Art 66.

${ }^{647}$ ILC, 'Report of the International Law Commission on the Work of Its Eighteenth Session, 4 May - 19 July 1966', supra n 602, at p 190, para 12. The four categories are , namely 'negotiating state', 'contracting state', 'party' and 'states entitled to become parties to the treaty' (which the Commission considered that it did not appear to require definition). The Commission commented that: 'Negotiating
} 
2(1)(g) defines 'party' to mean a state which has consented to be bound by the treaty and for which the treaty is in force. However, it does not mean that the use of this term, 'party' conveys similar meaning throughout the Convention. ${ }^{648}$ This strengthens further the proposition that the plural usage of 'party', be it 'parties' or 'state parties' (as suggested by Gardiner to be the common usage in treaty parlance), or the Commission's abbreviation to "the parties ${ }^{, 649}$ does not necessarily have the same context or meaning of 'party' as defined in Article 2(1)(g).

A variety of the plural form of 'party' is used throughout the Convention and each use of this term has its own meaning in the context of the provision. They do not necessarily refer to the meaning of 'party' as defined in Article $2(1)(\mathrm{g})$, which refers to states that have consented to be bound by a treaty that is in force. It is noted that in Part III of the 1969 Vienna Convention, the plural form of 'all the parties' is used in Article 31(2)(a). It provides that the context for the purpose of the interpretation of a treaty shall include any agreement relating to the treaty made between all the parties (own emphasis) in connection with the conclusion of the treaty. The use of 'all the parties' in this context clearly refers to all the parties of the treaty to be interpreted.

In the immediate context that has closer proximity with Article 31(3)(c), Article 31(3)(a) invokes the term 'the parties' in the context of subsequent agreement between the parties (own emphasis) regarding the interpretation of the treaty or the application of its provisions. 'The parties' in this instance strictly referred to parties for whom the treaty is in force. This strict approach in the particular context of Article 31(3)(a), despite being consistent with the meaning adopted in Article 2(1)(g), is not repeated in Article 31(2)(a) and (b) where the Commission resorted to use different variations of 'party' in the specific context of a particular provision. Article 31(2)(a) employs 'all the parties' if referring to all the parties in connection with the conclusion of the treaty; whereas Article 31(2)(b) uses 'one or more parties in connection with the conclusion of the treaty' or 'the other parties' in reference to the specific situations pertaining to the conclusion of the treaty. In instances of such specificity, different versions of 'parties' are used.

states is required to be distinguished from both 'contracting states' and 'parties' in different context, especially whenever an article speaks of the intention underlying the treaty

${ }^{648}$ ILC, 'Report of the International Law Commission on the Work of Its Eighteenth Session, 4 May - 19 July 1966', supra n 602, at p 190, para 12.

${ }^{649}$ Gardiner, Treaty Interpretation, supra n 235, at p 263. 
This is consistent with the uniform approach adopted by the Commission, whereby when the Commission intended that all the parties to a treaty are involved in the particular provision, the term 'all the parties' are specifically mentioned. ${ }^{650}$ In support of this contention, the use of the term 'the parties' that does not refer to 'all the parties' can be found in Article 30(4). The article provides for the application of successive treaties relating to the same subject matter when not all the parties to the preceding treaties are the parties to the successive treaties (own emphasis). The location of Article 31(3)(c) does not seem to be determinative of how 'the parties' is interpreted. Recourse to the records of the ILC indicates that the provision was moved to the existing position simply because it was 'extrinsic both to the text and to the context as defined in paragraph 2,, ${ }^{651}$ and did not belong anywhere else.

The Commentary further noted that it is considered justifiable to employ the term 'the party' in certain cases - where the validity of a treaty that has purportedly come into force is challenged; ${ }^{652}$ or where a treaty that was in force has been terminated ${ }^{653}$ despite the decision of the Commission to confine the term to states deemed 'party' to a treaty that is in force. ${ }^{654}$ For both Articles 65 and 69(3), although the validity of the treaty is challenged, the term 'the party' is still used even though Article 2(1)(g) defines 'party' to mean 'a state which has consented to be bound by the treaty and for which the treaty is in force'.

The use of 'the party', despite the Commission's intention to confine to states for which the treaty is in force, does deviate from this intention. This observation is pertinent especially in the interpretation of 'parties' as stated in Article 31(2)(a) and (b) that addresses 'parties' in connection with the conclusion of a treaty. If the strict interpretation provided in Article 2(1)(g) is imposed, unless the state ratifies the treaty immediately, and it entered into force straight away (which is not the case normally),

\footnotetext{
${ }^{650}$ Merkouris 'Article 31(3)(c) of the VCLT and the Principle of Systemic Integration', supra $\mathrm{n} 555$, at $\mathrm{p}$ 18. The author further noted in support of his contention that 'party' as defined in Article 2(1)(g) does not mean ipso facto that the term should be understood as meaning only 'parties to the interpreted treaty'. If the provision intended to be understood to mean only 'parties to the interpreted treaty', such intention is explicit in the use of 'all the parties'. Examples include Articles 15(c), 20(2), 30(3), 57(b), and 59(1).

${ }^{651}$ ILC, 'Report of the International Law Commission on the Work of Its Eighteenth Session, 4 May - 19 July 1966', supra n 602, at p 222, para 16.

6521969 Vienna Convention, supra n 31, Art 69(3).

6531969 Vienna Convention, supra n 31, Art 65.

${ }^{654}$ ILC, 'Report of the International Law Commission on the Work of Its Eighteenth Session, 4 May - 19 July 1966', supra n 602, at p 190, para 12.
} 
the application of these provisions would be problematic (but in practice, the application of these provisions has never been an issue). ${ }^{655}$

Furthermore, a careful analysis of Article 72 of the 1969 Vienna Convention shows 'the parties' does not necessarily refer to all parties of the treaty to be interpreted. Article 72 provides that the suspension of the operation of a treaty 'releases the parties between which operation of the treaty is suspended, from the obligation to perform the treaty in their mutual relations during the period of the suspension' (author's emphasis). ${ }^{656}$ Interestingly, it is implicit in the Article that the Convention provides for multilateral treaty where its obligations are owed in a synallagmatic ${ }^{657}$ way (reciprocal) between the parties, as evidenced in the used of the word 'mutual'.

The use of the term 'mutual' connotes that the operation of treaty during the suspended period is terminated only in the mutual relations between paired parties instead of all the parties to the treaty being interpreted (author's emphasis), that is, a bilateral relationship between 'mutual' parties is permissible within a multilateral treaty. This interpretation is supported by the commentary by the Commission where it elaborates that 'the subparagraph speaks of relieving "the parties between which the operation of the treaty is suspended" because in certain cases the suspension may occur between only some of the parties to a multilateral treaty,. ${ }^{658}$

The subsequent subparagraph furthers the same approach whereby it states that the suspension of a treaty 'does not otherwise affect the legal relations between the parties established by the treaty', which the Commission clarified to mean - even though the operation of the treaty provisions are suspended, the legal nexus between the parties established by the treaty remains intact (author's emphasis). ${ }^{659}$ Article 72(2) strengthens the interpretation that 'the parties' in the context of this provision does not refer to all the parties to the treaty, where it provides that 'the parties' shall refrain from acts tending to obstruct the resumption of the operation of the treaty.

\footnotetext{
${ }^{655}$ Gardiner, Treaty Interpretation, supra n 235, at p 264.

6561969 Vienna Convention, supra n 31, Art 72(1)(a)

${ }^{657}$ McLachlan, 'The Principle of Systemic Integration', supra n 162, at p 315.

${ }^{658}$ ILC, 'Report of the International Law Commission on the Work of Its Eighteenth Session, 4 May - 19 July 1966', supra n 602, at p 267, para 2.

${ }^{659}$ ILC, 'Report of the International Law Commission on the Work of Its Eighteenth Session, 4 May - 19 July 1966', supra n 602, at p 267, para 3.
} 
After emphasising that the legal relationships between the parties of the treaty are not otherwise affected, it further requires that 'the parties' (the parties who had invoked the suspension of the treaty) shall not undertake acts that will obstruct the resumption of the operation of the treaty in accordance with the spirit of good faith. ${ }^{660}$ It is apparent that 'the parties' does not have the intended meaning of 'all the parties to the treaty'. However, if the multilateral treaty is an integral treaty that is owed erga omnes or erga omnes partes, where 'the force of the obligation is self-existent, absolute and inherent for each party'; ${ }^{661}$ or 'towards all the world rather than towards particular parties' and must be applied integrally, ${ }^{662}$ the interpretation of 'the parties' might have to be all the parties to the interpreted treaty, depending on the common intentions of 'the parties' to the multilateral treaty being interpreted. ${ }^{663}$

However, in EC - Biotech, the Panel took a different approach by explaining that the use of 'all the parties' in Article 31(2)(a) is necessitated by the existence of Article $31(2)(b)$, which does not rule out the interpretation of the term 'the parties' to mean 'all the parties' in Article 31(3)(c). The Panel stated that -

'the absence of a reference to "all the parties" in Article 31(3)(c) is explained by the fact that Article 31(3) contains no provision like Article 31(2)(b). [This means] Article 31(3) contains no provision which refers to "one or more parties" and hence could render unclear or ambiguous the reference to "the parties" in Article $31(3)(\mathrm{c}){ }^{\prime} .664$

${ }^{660}$ ILC, 'Report of the International Law Commission on the Work of Its Eighteenth Session, 4 May - 19 July 1966', supra n 602, at p 267, para 4.

${ }^{661}$ Gerard Fitzmaurice, 'Third Report on the Law of Treaties by Gerald Fitzmaurice, Special Rapporteur', (18 March 1958) UN Doc A/CN.4/115 and Corr.1 (1958) II Yearbook of International Law Commission $20-46$, Art 19, at pp $27-28$ <http://untreaty.un.org/ilc/documentation/english/a_cn4_115_corr1.pdf> accessed 16 November 2012.

${ }^{662}$ Gerard Fitzmaurice, 'Second Report on the Law of Treaties by Gerald Fitzmaurice, Special Rapporteur' (15 March 1957) UN Doc A/CN.4/107 (1957) II Yearbook of International Law Commission 16 - 70, Art 19, pp 54 and 55, paras $124-128$ <http://untreaty.un.org/ilc/documentation/english/a_cn4_107.pdf> accessed 16 November 2012.

${ }^{663}$ This strengthens the argument that the common intentions of the parties to the interpreted treaty is of paramount importance. Refer to discussion in infra $\mathrm{n} 1513$ on the normative weight is command by an interpretation of multilateral agreement that is integral in nature. For a comprehensive distinction between synallagmatic treaty and integral treaty, see Oliver Dörr and Kirsten Schmalenbach (eds) Vienna Convention on the Law of Treaties. A Commentary (Springer-Verlag, Berlin Heidelberg 2012) at pp 441 445. The Jean Monnet Center for International and Regional Economic Law and Justice, 'WTO Obligations are Bilateral Obligations' (Academy of European law online, undated) $\langle$ http://centers.law.nyu.edu/jeanmonnet/archive/papers/02/020101-01.html\#P49_10903〉 accessed 24 May 2012.

${ }^{664}$ EC- Biotech, supra n 117, at p 333 at para 7.68, fn 242. 
The Panel in the EC - Biotech case decided that 'the parties' under Article 31(3)(c) requires that all WTO parties have to be a party to the external rules applicable in the interpretation of a treaty. ${ }^{665}$

Samson supported the narrow interpretation based on Article 2(1)(g) of the 1969 Vienna Convention taken by the WTO Panel, and defended a direct application of the interpretative regime of the 1969 Vienna Convention that interpreted 'the parties' to refers to all of the parties to the treaty. ${ }^{666}$ She supported her contention with two lines of inquiry: Firstly, she argues that there is no proof in support of the argument that 'the parties' under Article 31(3)(c) is meant to differ from its ordinary meaning in the overall context of the 1969 Vienna Convention.

The second inquiry proposed was consistent with the argument made in this section. She contended that it goes against the desirable outcome of the harmonisation of international legal order to interpret 'the parties' as referring only to the parties in dispute, when harmonisation requires that there is one correct meaning for any treaty provision common to all its parties, as obtained through the application of the rules of interpretation under the 1969 Vienna Convention. ${ }^{667}$ However, unlike the case of Article 66, and despite the availability of Article 31(4) to provide for 'special meaning if the parties so intended', the lack of textual specification does not by itself prove that 'the parties' under Article 31(3)(c) is not intended to have a meaning that differs from Article 2(1)(g).

The European Court of Justice supported the arguments proposed throughout this section that 'the parties' is not narrowly restricted to only 'parties to the treaty' where the Court reiterated that the European Convention on Human Rights -

'must be applied in accordance with the principles of international law, in particularly with those relating to the international protection of human rights where it considers that the positive obligations that Article 8 of the Convention ... must be interpreted in the light of the Hague Convention of 25 October 1980 on

\footnotetext{
${ }^{665}$ EC- Biotech, supra n 117 , at p 333 at para 7.68.

${ }^{666}$ Samson 'A World of Scepticism about the Anti-Fragmentation Function of Article 31(3)(c) of the VCLT', supra n 547, at p 704.

${ }^{667}$ Samson 'A World of Scepticism about the Anti-Fragmentation Function of Article 31(3)(c) of the VCLT', supra n 547, at p 705.
} 
the Civil Aspects of International Child Abduction, all the more so where the respondent state is also a party to that instrument (own emphasis)' ${ }^{668}$

The approach adopted by the European Court of Justice is entirely consistent with Article 31(3)(c) despite not specifically referring to the Article. The Court strongly emphasised the need to apply the European Convention on Human Rights in accordance with principles of international law, especially principles of international law that relate to the international protection of human rights. The Court held that Article 8 of the European Convention on Human Rights must be interpreted in the light of the Hague Convention on the Civil Aspects of International Child Abduction. The reiteration by the Court of the fact that the respondent state 'is also a party to that instrument' is merely a matter of judicial prudence. ${ }^{669}$ The use of the phrase 'all the more so' ${ }^{670}$ by the Court indicates the Court's position that the respondent state, being a party to the Hague Convention, merely strengthens the applicability of the Hague Convention in the interpretation of Article 8 of the European Convention on Human Rights. The use of this phrase, as interpreted in conjunction with the earlier phrase of 'must be interpreted in the light of the Hague Convention of 25 October 1980 on the Civil Aspects of

${ }_{75}^{668}$ European Court of Human Rights, HN v Poland, Application no 77710/01 (13 September 2005) para 75 $<$ http://www.humanrights.is/the-human-rightsproject/humanrightscasesandmaterials/cases/regionalcases/europeancourtofhumanrights/nr/2601> accessed 8 January 2011.

${ }^{669}$ Saint Thomas Aquinas, translated and edited with introduction and glossary by Richard J Regan, Aquinas. The Cardinal Virtues. Prudence, Justice, Fortitude, and Temperance (Hackett Publishing Company, Indianapolis, Indiana, 2005) at $\mathrm{p} 1$. It is stated that 'Prudence involves three acts of reason: deliberating well, judging rightly, and commanding what one should do or not do. Commanding what one should do or not do, since it is closer to the end of practical reason (i.e., proper human action), is the chief act of prudence'. The justification of the Court of its reference to the Hague Convention with the fact that the respondent state is a party to the Hague Convention in para 75 (despite not doing so in para 73) merely indicates the Court's intention to demonstrate that its decision is undertaken in fulfilment of the three acts of reason in its judicial reasoning. See infra $\mathrm{n} 670$.

${ }^{670}$ This phrase is used by the European Court of Human Rights in para 73 of the Judgment, supra $\mathrm{n} 668$. The Court stated that 'In cases of this kind the adequacy of a measure is to be judged by the swiftness of its implementation, as the passage of time can have irremediable consequences for relations between the child and the parent who does not live with him or her. In proceedings under the Hague Convention this is all the more so (author's own emphasis), as Article 11 of the Hague Convention requires the judicial or administrative authorities concerned to act expeditiously in proceedings for the return of children and any inaction lasting more than six weeks may give rise to a request for a statement of reasons for the delay'. The use of the phrase 'all the more so' in para 73 indicates the Court's intention to reinforce the obligation of the national authority to take swift action to facilitate the reunion of a parent with his or her child imposed under Art 8 of the European Convention on Human Rights (para 71) in reference to the proceedings under Art 11 of the Hague Convention. In para 73, the reference of the Court to the Hague Convention is not contingent on the respondent state being a party to the Hague Convention, as the reference was made without explicating that the respondent party is a party to the Hague Convention. This phrase is used again in para 75 to emphasise the position adopted by the Court over the applicability of the Hague Convention in the interpretation of Art 8 of the European Convention on Human Rights, and substantiated the reference with the fact that the respondent state is a party to the Hague Convention, as a matter of judicial prudence. 
International Child Abduction', implies that, even if the respondent state is not a party to the Hague Convention, it does not take away or reduce the competence of the Court in interpreting the European Convention on Human Rights in accordance with it.

Thus, as shown by the preceding arguments, it seems that both limbs of the definition of 'party' under Article 2(1)(g), namely 'consent to be bound' and 'treaty in force', are not generally reflected in the subsequent use of the plural form of this term throughout the Convention. ${ }^{671}$ Apart from that, it can be observed that a more flexible interpretation of 'parties' has been undertaken, where this term has been used lato sensu. ${ }^{672}$ This goes to prove that the ordinary meaning of the term 'the parties' offers no assistance in the identification of its intended meaning. ${ }^{673}$ The interpretation of this term in the context of the Convention is not helpful either in the determination of who are 'the parties' in Article 31(3)(c). Despite the emphasis on the need for consistency by the Commission, the different variations of the term in its plural form used throughout the Convention made it impossible to circumvent the ambiguity posed by the term 'the parties' stated under Article 31(3)(c) by an examination of the context. ${ }^{674}$

Hence, the confusion, succinctly summarised by Gardiner quoted above, remains. ${ }^{675} \mathrm{~A}$ reading based on the ordinary meaning of the term 'the parties', or a contextual reading of the term, goes no further than showing that 'the parties' as stated in Article 31(3)(c) could refer to 'only some of the parties'. ${ }^{676}$ Whether the relations examined are 'relations between all the parties to the treaty' similar to that of subsequent practice (which entails that sufficient number of parties demonstrated concordant practice ${ }^{677}$

${ }^{671}$ Gardiner, Treaty Interpretation, supra n 235, at p 264.

${ }^{672}$ Merkouris 'Article 31(3)(c) of the VCLT and the Principle of Systemic Integration', supra $\mathrm{n} 555$, at $\mathrm{p}$ 18.

${ }^{673}$ Merkouris 'Article 31(3)(c) of the VCLT and the Principle of Systemic Integration', supra n 555, at p 17.

${ }^{674}$ Merkouris 'Article 31(3)(c) of the VCLT and the Principle of Systemic Integration', supra $\mathrm{n} 555$, at $\mathrm{p}$ 18.

${ }^{675}$ See Gardiner, Treaty Interpretation, supra n 235, at p 263.

${ }^{676}$ Gardiner, Treaty Interpretation, supra n 235, at p 265.

${ }^{677}$ Alexander M Feldman, 'Evolving Treaty Obligations: A Proposal for Analysing Subsequent Practice Derived from WTO Dispute Settlement' (2009) 41 International Law and Politics 655 - 706, at p 664. The author commented on the difficulty in applying subsequent practice that has led tribunals to question what kinds of state conduct amount to 'practice' and whether that subsequent practice establishes agreement among the parties as to the interpretation and/or modification of the treaty's terms. The quoted opined that 'In most multilateral treaties, many parties do not engage in the relevant practice or are silent as to whether they believe the practice properly interprets the treaty obligation. In these instances, agreement must be inferred by other parties' reactions to the subsequent practice, but this evidence is rare. If other parties to the treaty do not partake in the practice and are silent, the value and significance of the subsequent practice will depend on the extent to which it is concordant, common, and consistent'. Also relevant are pp $690-695$. 
with acquiescence and imputed concurrence of the rest) or some other interpretation, remains unclear. ${ }^{678}$ The horizon for the quest in search of the correct determination of to whom 'the parties' refers, remains muddled where the ordinary meaning or a contextualised interpretation of this term is not helpful in providing a solution to the problem.

\subsubsection{The Four Possible Constructions of 'the Parties'}

McLachlan attempts to untangle the maze of possible interpretations available to the parties' where he proposes four different ways of possible construction of the term 'the parties' as possible solutions to the problem:

(a) All parties to the treaty under interpretation are also parties to any external treaties relied upon in the process of interpretation. ${ }^{679}$

The argument against a narrow interpretation is that, in light of the objective of Article $31(3)$ (c) to integrate rules of international law and its potential capacity to do so, a narrow interpretation will negate an integration of rules in their systemic environment. ${ }^{680}$ Gardiner commented that the right question to be argued should not be whether all the parties are party to the treaty concerned but whether 'the provisions state rules of international law, ${ }^{681}$

\footnotetext{
${ }^{678}$ Gardiner, Treaty Interpretation, supra $\mathrm{n} 235$, at p 269.

${ }^{679}$ McLachlan, 'The Principle of Systemic Integration', supra n 162, at p 314, referred to the approach adopted by the GATT panel in the Tuna/Dolphin case, WTO, United States - Restrictions on Imports of Tuna - Report of the Panel (16 June 1994) DS29/R, at para 5.19 $<$ http://www.worldtradelaw.net/reports/gattpanels/tunadolphinII.pdf > accessed 16 November 2012. See also Linderfalk, 'Who are 'The Parties'?', supra n 260, at pp 351 and 362. EC- Biotech, supra n 117, at p 333, para 7.68. The Panel noted that the contention that 'the parties' in Article 31(3)(c) should be understood as referring to all the parties to a treaty has been expressed by Mustafa Kamil Yasseen, L'interprétation des Traités d'après la Convention de Vienne sur le Droit des Traités (1976) 151 Recueil des Cours de l'Académie de Droit International at p 63, para 7.

${ }^{680}$ This sentiment is reiterated in McGrady, 'Fragmentation of International Law', supra n 260, at p 599. The author noted that: "if "the parties" refers to all WTO Members, it will be impossible for the provision to have application to extraneous treaties because the WTO admits non-sovereign members that are not capable of becoming parties to an extraneous treaty'. See also Gabrielle Marceau, 'WTO Dispute Settlement and Human Rights' (2002) 14 European Journal of International Law 753 - 814. Due to the very extensive membership of the WTO, the relevant rules of international law that could be applied in the interpretation of WTO agreements will be extremely limited, especially since some of the WTO members are not 'state' member, which make integration of rules virtually impossible.

681 Gardiner, Treaty Interpretation, supra n 235, at p 271.
} 
(b) Reference to the external treaty is permitted provided that the treaty parties in dispute are also parties to the external treaty relied upon. ${ }^{62}$

An overwhelming body of scholarship indicates that this possibility is neither supported nor appropriate in international law. ${ }^{683}$ The lack of support seen is due to concerns regarding consistency in decision making where an interpretation of a treaty can be subjected to different interpretations by relying on the possibility of inter se agreements. ${ }^{684}$ It cannot be said that this approach finds no basis in international law, because the interpretation and the application of a multilateral treaty might diverge between the parties to the same multilateral treaty due to the possibility of inter se agreements between them. ${ }^{685}$

It is detailed further that the type of multilateral treaty affects the application of the divergent approach. A distinction has been drawn between 'ordinary treaties' known as bilateral treaties or 'treaties of the reciprocal benefits and concessions type'; and collective treaties, which are 'treaties that require absolute or integral performance', ${ }^{68}$

${ }^{682}$ Gardiner, Treaty Interpretation, supra n 235, p 272. McGrady labelled this possibility as the 'divergent approach' where such approach interpreted 'the parties' to refer to the parties to a dispute. According to McGrady's interpretation of 'the parties' in its context, he opined that it is plausible, and natural to conclude that 'the parties' refer to parties to a dispute because Article 31 can be applicable in a dispute settlement context. McGrady, 'Fragmentation of International Law', supra n 260, at p 593.

${ }^{683}$ McGrady, 'Fragmentation of International Law', supra n 260; Gardiner, Treaty Interpretation, supra $\mathrm{n}$ 235; Samson 'A World of Scepticism about the Anti-Fragmentation Function of Article 31(30(c) of the VCLT', supra n 547; French, 'Treaty Interpretation and the Incorporation of Extraneous Legal Rules', supra $\mathrm{n} 148$, at $\mathrm{p} 306$.

${ }^{684}$ McGrady, 'Fragmentation of International Law', supra n 260, at pp 609-611. McLachlan noted that this approach would 'run the risk of potentially inconsistent interpretation decisions dependent upon the happenstance of the particular treaty partners in dispute'. McLachlan, 'The Principle of Systemic Integration', supra n 162, at p 314.

${ }^{685}$ McGrady, 'Fragmentation of International Law', supra n 260, at p 601. The concern of consistency in decision-making raised against the divergent approach is not exclusively due to the interpretation of 'the parties' to mean 'parties to a dispute'. Art 21 contemplates situations where reservations that apply to certain parties only are permissible as long as they fall within the limitations imposed by Art 19. Art 41 of the 1969 Vienna Convention provides for the opportunity to conclude an agreement between two or more of the parties to a multilateral treaty to modify the multilateral treaty between themselves if certain conditions as provided under Art 41(1)(a) and (b) are met. In addition to that, Art 30(4) governs the application of successive treaties relating to the same subject matter and foresees the possibility of divergence in multilateral treaties between parties.

${ }^{686}$ ILC, 'Second Report on the Law of Treaties by Mr. G Fitzmaurice, Special Rapporteur', supra $\mathrm{n}$ 662, at p 54, para 124. See also Joost Pauwelyn, 'A Typology of Multilateral Treaty Obligations: Are WTO Obligations Bilateral or Collective in Nature?' (2003) 14(5) European Journal of International Law 907 951. The different typologies of treaties acknowledged are evidenced in the proviso (i) and (ii) of Art 41(1)(b) of the 1969 Vienna Convention. Art 41(1)(b)(i) is apparent that it provides for treaty that have synallagmatic obligations when it provides that inter se agreements can be concluded if the modification is not prohibited by treaty and 'does not affect the enjoyment by the other parties of their rights under the treaty or the performance of their obligation'. See ILC, 'Third Report on the Law of Treaties by Mr. GG Fitzmaurice, Special Rapporteur', supra n 661, p 44, para 91. It is stated that ordinary treaty was defined to mean 'treaty, whether bilateral or multilateral, involving a mutual exchange of benefits between the 
as such a difference was due to the 'make-up of parties to a dispute' ${ }^{687}$ In the case of a treaty with synallagmatic obligations, where obligations are modified through inter se agreement, the interpretation of 'the parties' could adopt the divergent approach to mean parties to the dispute.

Hence, although the adoption of the divergent approach proposed as the second possibility by McLachlan founds little support in jurisprudence, and was deemed to be unappealing, 'it is not necessarily a departure from the norm'. ${ }^{688}$

(c) Insofar as the external treaty is not in force between all members to the treaty under interpretation, the rule contained in that external treaty is treated as being a rule of customary international law. ${ }^{689}$

parties, or a reciprocal course of conduct by each towards each, of such a kind that a default by one party would be a default in that party's relations with some other party, and could be compensated for by a counter default by that party towards the defaulting party.' (Original emphasis). This means that the provision subjected to modification by the inter se agreement is an obligation that involves a mutual exchange of benefits that affects the relations with the other party of the inter se agreement, but not other parties to the multilateral agreements.

${ }^{687}$ McGrady, 'Fragmentation of International Law', supra n 260, at p 602. See also McLachlan, 'The Principle of Systemic Integration', supra n 162, at p 315. McLachlan expounded that interpretation applied to 'any particular parties in dispute ... if (a) a particular obligation in the treaty is owed in a synallagmatic way between pairs of parties, rather than erga omnes partes, then the application of that obligation as between the relevant pair of parties [in dispute] may properly be considered in the light of other obligations applying bilaterally between those parties only'. See in general Pauwelyn, Conflict of Norms in Public International Law, supra n 100, at pp 440 - 486; and Pauwelyn, 'A Typology of Multilateral Treaty Obligations: Are WTO Obligations Bilateral or Collective in Nature?', supra n 686.

${ }^{688}$ McGrady, 'Fragmentation of International Law', supra n 260, at p 603; French, 'Treaty Interpretation and the Incorporation of Extraneous Legal Rules', supra n 148, at p 307; Fragmentation Report, supra $\mathrm{n}$ 17, at p 238, para 472. The possibility of inter se agreements modifying relations between states in a multilateral treaty is most apparent in the international trade regime under the WTO. David Palmeter and Petros C Mavroidis, 'The WTO Legal System: Sources of Law' (1998) 92 American Journal of International Law 398 - 413, at p 410. According to Palmeter, under the trade regime, the WTO Agreement and its annexed covered agreements are among the many international regulatory agreements entered into by governments particularly to address economic, environmental and social problems, which raises the question of to what extent such agreements affect the rights and obligations of WTO members vis-à-vis other WTO members. At p 411, Palmeter opined that, the conclusion of the GATT panel in the Tuna/Dolphin case that those external treaties cited by parties to the dispute, and that were not concluded among the contracting parties to the GATT, did not apply to the interpretation or the application of GATT, is not consistent with the interpretation of Article 31(3)(c) of the 1969 Vienna Convention. It is commented by Palmeter, at p 411 that 'the parties' in Art 31(3)(c) of the 1969 Vienna Convention 'would seem to refer to the parties to the particular dispute, not to the parties to the multilateral agreement'.

${ }^{689}$ McLachlan, 'The Principle of Systemic Integration', supra n 162, at p 303 (fn 97) referred to the emphasis placed in the case of Shrimp/Turtle where although the United States had not ratified UNCLOS, it had accepted during the course of argument that the relevant provisions for the most part reflected international customary law. WTO, United States - Import Prohibition of Certain Shrimp and Shrimp Products - Report of the Appellate Body (12 October 1998) WT/DS58/AB/R, at para 51 〈http://www.wto.org/english/tratop_e/dispu_e/58abr.pdf> accessed 16 November 2012. However, he commented that such an approach could have an inappropriate restrictive effect under two situations: (i) It could preclude reference to treaties which have very wide acceptance in the international community (including by the disputing states) but which are nevertheless not universally ratified and which are not accepted in all respects as stating customary international law (such as UNCLOS); and (ii) It could also 
The merit of adopting this approach where the rule applied in interpretation via Article 31(3)(c) of the 1969 Vienna Convention must be a rule of customary international law is that it has 'the merit of doctrinal rigour'. ${ }^{600}$ As a principle or rule of international customary law, it is applicable to all parties, be it parties to the treaty or parties to the dispute, unless the persistent objector principle applied. ${ }^{691}$ However, McLachlan opined

preclude reference to treaties which represent the most important elaboration of the content of international law on a specialist subject matter, on the basis that they have not been ratified by all the parties to the treaty under interpretation. Such a possibility is not supported by judicial decisions either,

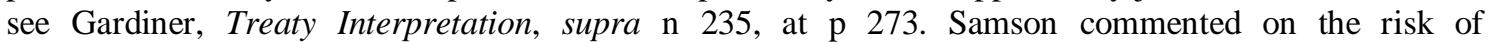
inconsistency in interpreting 'the parties' to mean 'parties to the dispute', especially in the event that 'inter se agreements can be relied upon to modify multilateral treaties between certain of the parties only'. Samson 'A World of Scepticism about the Anti-Fragmentation Function of Article 31(30(c) of the VCLT', supra $\mathrm{n}$ 547, at $\mathrm{p} 705$.

${ }^{690}$ Even if the treaty is not 'applicable in the relations between the parties', if the rule of the extraneous treaty relied upon for interpretation is a rule of international customary law, the rule can be applied by virtue of Article 31(3)(c). See McLachlan, 'The Principle of Systemic Integration', supra n 162, at 314; Palmeter and Mavroidis, 'The WTO Legal System: Sources of Law', supra n 688, at p 409; Gardiner, Treaty Interpretation, supra n 235, at p 271. This requirement was specifically emphasised by the AB in the Shrimp/Turtle case, supra n 689, at p 49, para 130, fn 110. The phrase 'exhaustible natural resources' of Art XX $(\mathrm{g})$ of the GATT are interpreted 'in the light of contemporary concerns of the community of nations about the protection and conservation of the environment'. The AB cited the 1982 UNCLOS in the interpretation and determination of whether living natural resources are 'exhaustible' in the context of Art XX $(\mathrm{g})$. The AB explicitly noted that India, Malaysia and Pakistan have ratified the UNCLOS, and that the United States had agreed that the UNCLOS reflects international customary law for the most part, and hence, justified for its incorporation in the interpretation of GATT. See Gabčíkovo-Nagymaros case, supra $\mathrm{n} \mathrm{1,} \mathrm{at} \mathrm{p} \mathrm{38,} \mathrm{para} \mathrm{46;} \mathrm{p} \mathrm{62,} \mathrm{para} \mathrm{99;} \mathrm{and} \mathrm{pp} 39$ - 41, paras 49 - 52. The ICJ in GabčíkovoNagymaros explained the applicability of rules under the 1969 Vienna Convention; and the criteria laid down by Draft Article 33 of the 2001 Draft Articles on State Responsibility are relevant in assessing whether the conditions for a state of necessity due to their status as customary international law. The IranUS Claims Tribunal has always found customary international law applicable. See Fragmentation Report, supra n 17, at pp 183 - 184, para 434. In the case of Iran-US Claims Tribunal, Amoco International Finance Corporation $v$ The Government of the Islamic Republic of Iran, National Iranina Oil company, National Petrochemical Company and Kharg Chemical Company Limited, 15 Iran-US CTR 189, at p 222 at para $112<$ http://www.trans-lex.org/231900> accessed 19 June 2012. the Tribunal expressly confirmed that customary international law, though superseded by lex specialis, may still be relevant to 'fill in possible lacunae of the Treaty, to ascertain the meaning of undefined terms in its text or, more generally, to aid interpretation and implementation of its provisions'. As a lex specialis in the relations between the two countries, the Treaty supersedes the lex generalis, namely customary international law. This does not mean, however, that the latter is irrelevant in the instant Case. On the contrary, the rules of customary law may be useful in order to fill in possible lacunae of the Treaty, to ascertain the meaning of undefined terms in its text or, more generally, to aid interpretation and implementation of its provisions.

${ }^{691}$ Fisheries Case (United Kingdom v Norway) 18 December 1951 [1951] ICJ Reports 116 <http://www.icj-cij.org/docket/files/5/1809.pdf> accessed 12 January 2011. Due to the intrinsic nature of international law dependent on state consent, several eminent scholars have since maintained that the joint United Kingdom - Norwegian view expressed in the case of Anglo-Norwegian Fisheries represented existing law that a dissenting state is not bound by the rule to which it objected. See Oscar Schachter, International Law in Theory and Practice, supra n 508, at pp 13 - 14. If new principles of customary international law are regarded as fundamental and of major importance, strong argument is in favour for denying the dissenting state the right to avoid the obligation that all other states incur as a consequence of the acceptance of the new principles. The author goes further to assert that the degree of imposition of the new customary rules of fundamental and major importance on recalcitrant states will depend on a set of relevant circumstances, where the issue cannot be decided solely by reference to voluntarist theory. Refer also to Gerard G Fitzmaurice, 'The General Principles of International Law Considered from the Standpoint of the Rule of Law’ (1957) 92-II Recueil des Cours 1 - 228, at pp 99 - 100; Humphrey 
that the adoption of the third possibility, which requires the application of extraneous rules in interpretation, would have an inappropriately restrictive effect. ${ }^{692}$

If McLachlan's third proposition is viewed as, inter alia, a possible means of the application of Article 31(3)(c) and the possible definition for 'the parties' without prejudice to other modes of application, then, such a proposition stands. A rule of customary international law will be considered to have solved the problem of consent plaguing the discussion on who 'the parties' are, where regardless of whether 'the parties' are all the parties to the treaty interpreted; or parties to the dispute, a rule of customary international law are applicable to the two possible interpretation of 'the parties'.

(d) Establish an intermediate test which does not require complete identity of treaty parties, but does require that the external rule relied upon can be said to be implicitly accepted or tolerated by all parties to the treaty under interpretation 'in the sense that it can reasonably be considered to express the common intentions or understanding of all members as to the meaning of the term concerned' ${ }^{693}$

Waldock, 'General Course on Public International Law' (1962) 106-II Recueil des Cours 1 - 252, at pp $49-53$.

${ }^{692}$ McLachlan, 'The Principle of Systemic Integration', supra n 162, at p 314, para 15(c)(ii). See discussion in $\mathrm{n}$ 688. The restrictive effects as mentioned by McLachlan are premised on the fact that a treaty will only state a rule of customary international law if all states are parties to it, and if the treaty as a whole is viewed as reflecting customary law. Although it is difficult to assess and evaluate the limitation suggested to be inherent in the adoption of the third possibility, the instances as mentioned above for both the 1969 Vienna Convention and the 1982 UNCLOS indicated otherwise. The application of certain provisions of the 1969 Vienna Convention, the UNCLOS and legal principles regarding shared natural resources is not contingent upon the whole treaty being reflective of customary international law.

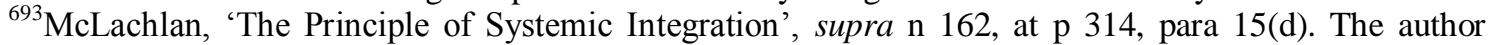
noted that this approach has been adopted in some of the decisions of the WTO AB. This possibility was first proposed by Pauwelyn where he stressed that 'the parties' in Article 31(3)(c) of the 1969 Vienna Convention refers to 'parties to the treaty', and not 'parties to a particular dispute under that treaty', and in the specific context of WTO Agreement that is multilateral in nature. See Pauwelyn, Conflict of Norms in Public International Law, supra n 100, at p 261; and Pauwelyn, 'The Role of Public International Law in the WTO: How Far Can We Go?', supra n 264, at pp 575 - 576: 'As noted, the non-WTO rules must reflect the "common intentions" of the WTO members by being agreed upon or tolerated - be it explicitly, implicitly, or by acquiescence only - by all WTO members ... if the non-WTO rule is legally binding on all WTO members (like a general principle of law or general customary international law), the non-WTO rule must be regarded as an expression of "common understanding"". McLachlan elaborated that the AB in Shrimp/Turtle case referred to rules of international law that were not binding on all WTO members, or on all the parties to the dispute, to the extent that these non-WTO rules gave meaning to Art XX(g) because they reflected 'the contemporary concerns of the community of nations'. See Gabrielle Marceau, 'WTO Dispute Settlement and Human Rights' (2002) 13(4) European Journal of International Law 753 814, at p 782. Marceau posits from a technical perspective in the interpretation of 'the parties' in Art 31(3)(c), reiterating Pauwelyn's suggestion that the interpretation of WTO provisions should only take account rules of international law that 'reflect the "common intention" of the WTO Members' being agreed of tolerated - either explicitly, implicitly or by acquiescence by all WTO Members'. At p 782, Marceau argued that the usage of 'all the parties' in Art 31(2)(a), and 'one or more parties' and accepted 
The $\mathrm{AB}$ in $\mathrm{EC}-$ Computer Equipment ${ }^{694}$ clarified that the purpose of treaty interpretation under Article 31(3) 'is to ascertain the common intentions of the parties' (original emphasis), ${ }^{695}$ even though the rule or the treaty is not legally binding on them. ${ }^{696}$ The establishment of the common intention of the parties to the treaty, as laid out in EC - Computer Equipment by the $\mathrm{AB}$, is reiterated in the recent case of EC Aircraft. ${ }^{697}$ The $\mathrm{AB}$ further elaborated that caution must be exercised in drawing from an international treaty to which not all WTO Members are party, where prima facie common intentions cannot be adduced. However, it does not mean that recourse cannot be had to non-WTO treaties to which not all WTO members are party. ${ }^{698}$

This strengthens the assertion that an interpretation of 'the parties' that reflects the principle of systemic integration must refer to their normative environment. Such reference should be in a manner that gives -

'coherence and meaningfulness to the process of legal interpretation [where] a delicate balance must be struck between individual WTO Members' international obligations and a consistent and harmonious approach to the interpretation of WTO law among all WTO members'. ${ }^{699}$

The Shrimp/Turtle ${ }^{700}$ case illustrates this probability where external rules are invoked in the interpretation of Article $\mathrm{XX}(\mathrm{g})$ of the GATT despite the fact that not all the parties to GATT, nor all the parties to the dispute, are party to the external rules. ${ }^{701}$ The AB supported the incorporation of the UNCLOS, the Biodiversity Convention, CMS and

by 'the other parties' of Art 31(2)(b) without qualifications in 'the parties' of Art 31(3)(c) 'allows consideration of treaties signed by a subset of the WTO Membership that is less than all the parties, but more than one of the parties that is accepted by the other parties'.

${ }^{694}$ WTO, European Communities - Customs Classification of Certain Computer Equipment - Report of the Appellate Body (5 June 1998) WT/DS62/AB/R, WT/DS67/AB/R, WT/DS68/AB/R $\langle$ http://www.worldtradelaw.net/reports/wtoab/ec-lan(ab).pdf> accessed 17 January 2012 (hereinafter: 'EC - Computer Equipment').

${ }^{695} \mathrm{EC}$ - Computer Equipment, supra n 694, at p 31, para 84.

${ }^{696}$ Pauwelyn, 'The Role of Public International Law in the WTO: How Far Can We Go?', supra n 264, at p 576.

${ }^{697} \mathrm{EC}-$ Aircraft, supra n 288, at p 363, para 845.

${ }^{698}$ EC - Aircraft, supra n 288, at p 363, para 845, fn 1916. This is implied in an interesting statement noted by the $\mathrm{AB}$ where the $\mathrm{AB}$ is cognisance of the fact that agreement of the parties regarding a treaty's interpretation may be deduced, not only from the actions of those actually engaged in the relevant practice, but also from the acceptance of other parties to the treaty through their affirmative reactions, or depending on the attendant circumstances, their silence.

${ }^{699} \mathrm{EC}$ - Aircraft, supra $\mathrm{n} 288$, at p 363, para 845.

${ }^{700}$ Shrimp/Turtle case, supra $\mathrm{n} 689$.

${ }^{701}$ Pauwelyn, 'The Role of Public International Law in the WTO: How Far Can We Go?', supra n 264, at p 576. 
CITES, in the interpretation of WTO Agreement. They were of the opinion that the [words of Article XX(g)] "exhaustible natural resources" must be read by a treaty interpreter in the light of contemporary concerns of the community of nations about the protection and conservation of the environment', as informed by the explicit acknowledgement of the objective of sustainable development in the Preamble of the WTO Agreement. ${ }^{702}$ The AB goes further in support of the incorporation that -

'Given the recent acknowledgement by the international community of the importance of concerted bilateral or multilateral action to protect living natural resources, and recalling the explicit recognition by WTO Members of the objective of sustainable development in the preamble of the WTO Agreement, we believe it is too late in the day to suppose that Article XX(g) of the GATT 1994 may be read as referring only to the conservation of exhaustible mineral or other non-living natural resources. ${ }^{, 703}$

The ILC commentary to Article 31(3)(b) is explicit on this point. It explains that the Commission, by omitting the word 'all' from the provisional draft articles adopted in 1964 that speaks of 'establishes the understanding of all the parties' (author's own emphasis), does not mean to change the rule. The Commission considered that the amended phrase 'the understanding of the parties' necessarily means 'the parties as a whole'. The Commission elaborated that the omission of the word 'all' was merely to 'avoid any possible misconception that every party must individually have engaged in the practice where it suffices that it should have accepted the practice' ${ }^{704}$

A similar approach was adopted in the European Court of Human Rights in the Demir Case. ${ }^{705}$ The Court observed that individual ratification of a source of law is not a ground to distinguish between sources of law in the identification of rules relevant to the consideration of the object and purpose of the Convention. ${ }^{706}$ The decision of the

\footnotetext{
${ }^{702}$ Shrimp/Turtle case, supra n 689, at p 48, para 129.

${ }^{703}$ Shrimp/Turtle case, supra n 689, at p 50, para 131.

${ }^{704}$ ILC, 'Report of the International Law Commission on the Work of Its Eighteenth Session, 4 May - 19 July 1966', supra n 602, at p 222, para 15. Reprinted in Rauschining (ed), The VCLT, supra n 521, at $\mathrm{p}$ 254.

${ }^{705}$ European Court of Human Rights, Case of Demir and Baykara v Turkey App No 34503/97 (Grand Chamber, $\quad$ Strasbourg, $\quad 12$ November 2008 ) <http://www.ictu.ie/download/pdf/case of demir_baykara_v turkey_apr_09.pdf $>$ accessed 18 September 2012 (hereinafter: 'Demir').

${ }^{706}$ Demir case, supra $\mathrm{n} 705$, at paras 76, 78, and 79. The Court considered that 'when it considers the object and purpose of the Convention provisions, it also takes into account the international law background to the legal question before it. Being made up of a set of rules and principles that are accepted
} 
Court in the Demir case, where individual ratification was not necessary in the identification of relevant rules, supports the assertion that if 'the parties' in Article 31(3)(b) means 'all the parties' without requiring the explicit agreement of all of them, or their actual engagement in practice, there is no reason to give a different meaning to 'the parties' in Article 31(3)(c). If the phrase 'all the parties' as stipulated under Article 31(3)(b) is not interpreted to require individual ratification by all the parties, the requirement of individual ratification by all the parties in the interpretation of the parties' in Article 31(3)(c) could not be said to have been intended by the 1969 Vienna Convention. ${ }^{707}$

The analysis above, supported by the cases of Shrimp/Turtle and Demir, leads to the conclusion that in the specific context of a multilateral treaty such as the WTO Agreement, the requirement of 'the parties' in Article 31(3)(c) is not that all the parties to the WTO agreement have, one after the other, formally and explicitly agreed with the non-WTO rule, nor even that this rule is otherwise legally binding on all WTO members (author's own emphasis). ${ }^{708}$ It could be submitted that the criterion is rather that -

'the rule can be said to be at least implicitly accepted or tolerated by all WTO members, in the sense that the rule can reasonably be said to express the common intentions or understanding of all members as to what the particular WTO term means (author's own emphasis) ${ }^{709}$

The imposition of 'bindingness' in the interpretation of 'applicable' is the underlying reason that leads to the much debated controversy of who are the parties on whom the rule is binding. This controversy casts into doubt the potential uses and contribution of

by the vast majority of States, the common international or domestic law standards of European States reflect a reality that the Court cannot disregard when it is called upon to clarify the scope of a Convention provision that more conventional means of interpretation have not enabled it to establish with a sufficient degree of certainty'. The Court stated further, in para 78 that 'The Court observes in this connection that in searching for common ground among the norms of international law it has never distinguished between sources of law according to whether or not they have been signed or ratified by the respondent State'. The Court quoted its own decision in the Marckx v Belgium case, in para 79, and emphasised that 'the small number of ratifications of these instruments [concerning legal status of children born out of wedlock] could not be relied on in opposition to the continuing evolution towards full recognition of the maxim "mater simper certa est"'. European Court of Human Rights, Case of Marckx v Belgium App No 6833/74 (Court (Plenary), Strasbourg, 13 June 1979) <http://hudoc.echr.coe.int/sites/eng/pages/search.aspx?i=00157534> accessed 16 November 2012.

${ }^{707}$ Pauwelyn, 'The Role of Public International Law in the WTO: How Far Can We Go?', supra n 264, at p 575, fn 262.

${ }_{708}$ Joost Pauwelyn, Conflict of Norms in Public International Law, supra n 100, at pp $257-263$.

${ }^{709}$ Joost Pauwelyn, Conflict of Norms in Public International Law, supra n 100, at p 261. 
Article 31(3)(c) of the 1969 Vienna Convention as an interpretative mechanism that exhibits the principle of systemic integration in the study of the fragmentation of international law.

Scholars have proposed four constructions of the possible interpretation of to whom 'the parties' refer, in view of the fact that an ordinary interpretation of 'the parties' according to the context of the treaty does not inform an interpreter who 'the parties' are. ${ }^{710}$ The four possibilities are plausible as long as consent of the parties as a whole, be it explicit or implicit, is established. The general observation of the four constructions of 'the parties' is, the common intention and shared understanding as to the interpretation of the external rule are essential in the determination of the applicability of the external in the relations between them.

In the event that consensus or shared understanding of the external rule regarding its interpretation and applicability in the interpretative process is established, there is no need to ensure that each individual party to the interpreted treaty has to be individually engaged with the external treaty. This conclusion is supported by the Commentary to the 1969 Vienna Convention. The Commission removed codification of the temporal element, the so-called inter-temporal law in its application to the interpretation of treaties in Article 31(3)(c). ${ }^{711}$

In view of the proliferation of treaty regimes and the engagement of both state and nonstate members in international instruments, it is no longer practical to require that all parties to the treaty being interpreted are also a party to the external treaty. The general acceptance of consensus, reflected in the common understanding of the parties as a basis for obligation, absolves the stringent requirement for all parties to the treaty being interpreted is also be a party to the external treaty. ${ }^{712}$

\footnotetext{
${ }^{710}$ Gardiner, Treaty Interpretation, supra n 235, at p 265.

${ }^{711}$ Rauschining (ed), The VCLT, supra $\mathrm{n}$ 521, at p 254, para 16. Apart from the difficulty associated with the codification of temporal element, the Commission envisioned that the imposition of an evolutive interpretation onto a treaty depends on the will of the parties, and had decided to remove the temporal element from codification. It is considered that 'in any event, the relevance of rules of international law for the interpretation of treaties in any given case was dependent on the intentions of the parties ... and that the correct application of the temporal element would normally be indicated by interpretation of the term in good faith'.

${ }^{712}$ Some parties might not be able to give express consent 'either because they were not party to the lawmaking agency or because they did not wish to approve the specific proposals'. Higgins, Problems and Process. International Law and How We Use It, supra n 574, at p 16.
} 
Hence, it can be deduced that the most important element in the application of an external rule by virtue of Article 31(3)(c) and also in the application of international law in general, intrinsic to the origin of the international legal order itself, is the expression of consent, ${ }^{713}$ or the notion of 'consensus'. ${ }^{714}$ Such understanding and agreement are the foundation underlying the expression of 'common intention' sought after in the fourth possibility proposed above in the determination of the scope of 'the parties' in Article $31(3)(c)$.

The validity of the four possibilities proposed as the possible interpretation and scope of 'the parties' in Article 31(3)(c) is supported by the ILC where the application of Article $31(3)$ (c) is subtly formulated to provide interpretative guidance in its application to include all four possibilities. ${ }^{715}$

\subsection{Rules of International Law Applicable in the Relations between the Parties: Reflection and Conclusion}

The preceding sections have shown that current and existing interpretations of 'rules of international law applicable in the relations between the parties' of Article 31(3)(c) of 1969 Vienna Convention on the Law of Treaties could be challenged. It is demonstrated that the threshold of 'bindingness' need not be attained in order for a relevant rule of international law to be considered as 'applicable in the relations between the parties'. The analysis and review of existing scholarship sufficiently show that rules of

\footnotetext{
${ }^{713}$ Fitzmaurice, 'The Foundations of the Authority of International Law and the Problem of Enforcement', supra $\mathrm{n}$ 578, at $\mathrm{p}$ 9. The author quoted Verdross, Brierly and others that it is not consent, as such, that creates obligation, though it may be the occasion of it. It is a method of creating rules, but it is not, in the last resort, the element that makes the rules binding, when created. In short consent could not, in itself create obligations unless there were already in existence a rule of law according to which consent had just that effect. Another way of putting it is to say that it is because international law already makes consent a source of obligation that obligations can arise from consent ... the discussion enters what is known to the mathematicians as an infinite regress.'

${ }^{714}$ Higgins, Problems and Process. International Law and How We Use It, supra n 574, at p 16. The author elaborated that 'states have undoubtedly come to regard themselves as bound by norms to which they have not given their express consent, either because they were not party to the law-making agency or because they did not wish to approve the specific proposals. If consensus, often tacit and sometimes unenthusiastic, is the basis of international law, then that consensus comes about because states perceive a reciprocal advantage in cautioning self-restraint'.

${ }^{715}$ Conclusion on Fragmentation, supra $\mathrm{n} 289$, at pp $414-415$, para 21. It is stated that Art31(3)(c) also requires the interpreter to consider other treaty-based rules so as to arrive at a consistent meaning. Such other rules are of particular relevance where parties to the treaty under interpretation are also parties to the other treaty, where the treaty rule has passed into or express customary international law or where they provide evidence of the common understanding of the parties as to the object and purpose of the treaty under interpretation or as to the meaning of a particular term.
} 
international law need not be binding on the parties in order to be considered as 'applicable in the relations between the parties'.

Discussions in the previous sections have demonstrated that the phrase 'applicable in the relations between the parties' in Article 31(3)(c) does not impose the requirement that the identified rules of international law must be binding. The conclusion arrived at is, as long as the rules of international law reflect the common understanding and common intentions of the parties as to the interpretation of that given rule of international law, it should be considered to be 'applicable in the relations between the parties'. This conclusion is strengthened by the four possible constructions of 'the parties' collated by scholars under the perception that the correct interpretation of 'the parties' will provide the master key in the operationalisation of Article 31(3)(c).

However, if 'applicable in the relations between the parties' is not interpreted to mean 'binding', then the whole interpretative landscape on Article 31(3)(c) is reconstructed. The framework of the operationalisation of Article 31(3)(c) developed through a reinterpretation of Article 31(3)(c) relocates the emphasis of interpretation of the Article to -

1. The interpretation of 'relevant', and the identification of rules that are relevant;

2. Whether these rules constitute 'rules of international law', and if so, what is the content and scope of these rules of international law; and

3. Whether these rules are considered to be 'applicable in the relations between the parties'. This determination impels the interpretation of rules of international law to delve not just into the explicit text of the rule of international law, but also the implicit dimension of the explicit text that shows the shared legal understanding of the parties that partake in the making of the law. The common intention of the parties can be evidenced in the practice of legality undertaken by the parties, which exhibits the shared legal understanding attained by the parties.

The General Assembly Resolution 3232 (XXIX) ${ }^{716}$ recognised that 'the development of international law may be reflected, inter alia, by declarations and resolutions of the General Assembly which may to that extent be taken into consideration by the

\footnotetext{
${ }^{716}$ UNGA, 'Resolution 3232 (XXIX) Review of the Role of the International Court of Justice' (12 November 1974).
} 
International Court of Justice'. ${ }^{717}$ The guiding rule to see whether a rule of international law is 'couched in a language [that] imposes a legal obligation of compliance with [the rule] ${ }^{718}$ necessitates a careful analysis of the language of a resolution 'before a conclusion can be made as to its binding effect' ${ }^{719}$

Rosenne is of the opinion that non-formally binding instruments ${ }^{720}-$

'cannot today be ignored entirely [and it would be considered rash if international lawyers] took shelter behind the formal position as a ground for ignoring resolutions of major international organisations operating in a field of concern to him at a given moment'. 721

This is because such instruments are 'brought within the general thesaurus of international law as indicators of a possible direction for the desired evolution of the law ... [and] to that extent, be considered by the International Court of Justice'. ${ }^{722}$ Despite their indeterminate formal position as a rule of international law, their applicability is not negated and should be considered in a court of law.

The cautious expression as to the legal consequence of resolutions of the General Assembly and other international organisations in Resolution 3232 (XXIX) generates two implications. The first implication is, the requirement of 'legality' imposed in Article 31(3)(c) of the 1969 Vienna Convention that specified for rules of international law to be taken into account in the interpretation of a treaty term or provision is not determined by its source-oriented formal form. ${ }^{723}$ The second implication is, it strengthens the proposition that the intention of the parties, demonstrated through the language adopted in the resolution, is the deciding factor in the determination of not

\footnotetext{
${ }^{717}$ Resolution 3232 (XXIX), supra n 716, at p 142.

${ }^{718}$ See Rosenne, Practice and Methods of International Law, supra n 221, at pp 18 and 111.

${ }^{719}$ Namibia case, supra n 277, at p 53, para 114. The Court elaborated that 'In view of the nature of the powers under Article 25, the question whether they have in fact exercised is to be determined in each case, having regard to the terms of the resolution to be interpreted, the discussions leading to it, the Charter provisions invoked and, in general, all circumstances that might assist in determining the legal consequences of the resolution of the Security Council'.

${ }^{720}$ UNGA resolutions and declarations of GA was cited as an example of such instruments. See Rosenne, Practice and Methods of International Law, supra $\mathrm{n} 221$, at $\mathrm{p} 18$.

${ }^{721}$ Rosenne, Practice and Methods of International Law, supra n 221, at $\mathrm{p} 18$.

${ }^{722}$ Rosenne, Practice and Methods of International Law, supra $\mathrm{n} 221$, at pp 18 and 19.

${ }^{723}$ See a discussion of form, or certain formalities or procedural steps as criteria in the ascertainment of legal rules in Pauwelyn, 'Is it International Law or Not, And Does it Even Matter' (26 February 2010) supra $\mathrm{n} 209$.
} 
only the legality or binding effect of a rule, but also the extent to which the rule is applicable in the relations between the state parties.

The second implication greatly supports the proposition of this chapter that the interpretation of the phrase 'applicable in the relations between the parties' in Article 31(3)(c) of the 1969 Vienna Convention does not impose a requirement of 'bindingness'. The ultimate determinant of whether a rule of international law is 'applicable in the relations between the parties' depends on the common intention of the parties as to the interpretation of that particular rule of international law.

In this context, the crux of the analysis in the interpretation of 'applicable', or the applicability of the rules of international law external to the interpreted treaty in the interpretative process, resides in the ascertainment of 'rule of international law' namely its content and its applicability as commonly understood and intended by the parties. This revelation impels the need for a renewed understanding of international law, especially the implicit dimension constituted from the shared legal understanding attained by the parties, and undertaken in a practice of legality, that informs an interpreter as to the common intention and understanding of the parties. The implicit dimension underpinning a rule of international law informs the interpretation of whether the relevant rule of international law is 'applicable in the relations between the parties'.

Drawing from the discussions in the previous sections, this chapter has amply demonstrated that the interpretation of 'applicable in the relations between the parties' should be nuanced and multi-layered. This chapter has sufficiently presented the argument of this thesis that the existing interpretation of 'applicable' and 'the parties' is inadequate to realise the systemic integration potential of Article 31(3)(c).

The next chapter of this thesis proposes to reconceptualise the ascertainment of 'rules of international law', or 'international law', that better reflects the contemporary trend in international law. For this purpose, an interactional understanding of law could provide the content and scope of the relevant rules of international law in which the 'applicability' of the rule 'in the relations between the parties' is revealed. An interactional theory of law viewed law not as just the explicit textual outcome of a lawmaking process, but the entirety of the law-making process that infused the explicit dimension codified in the text, with the implicit dimension, the shared understanding, 
that provides the structure and context of the text developed through legal interactions. $^{724}$

The explicit stipulation of a requirement of legality in Article 31(3)(c) by virtue of the reference to 'rules of international law' can be satisfied through an assessment of a particular rule against the eight criteria of internal morality. The criteria of legality are engaged as a yardstick for the determination of a rule of law and distinguish law from other norms. An interactional understanding of law requires that these shared legal understandings must be undertaken in a practice of legality undertaken by the parties involved in the making of law (the enterprise of law-making) in order to demonstrate their common and collective intention that these rules of (international) law, are 'applicable' on them. The fidelity of law that commands the sense of obligation is the basis of the understanding of the binding force of law.

Instead of being constraint by a formalistic, hierarchical and inherently positivist approach to the determination of sources, the thesis endeavour to look beyond the black letter of law, and attempts to discern the common intentions and understanding of parties regarding the content and applicability of a rule of international law.

\footnotetext{
${ }^{724}$ Jutta Brunnée and Stephen J Toope, Legitimacy and Legality in International Law: An Interactional Account (Cambridge University Press, Cambridge, 2010) at p 66.
} 


\section{Chapter 4. Rules of International Law Applicable in the Relations between the Parties: An Interactional Understanding of Law}

\subsection{Overview}

This chapter will suggest a reinterpretation of 'rules of international law' through the adoption of an interactional theory of law proposed by Fuller, and further developed by Jutta Brunnée, Stephen Toope and Gerard Postema. An interactional understanding of law entails that a rule of international law is interpreted not just at the explicit level, but also the implicit dimension in which the shared understanding of a text is found.

The chapter will analyse and interpret 'rules of international law' through the prism of an interactional theory of law that comprises three main components. These components are shared understandings, the eight criteria of internal morality, and a practice of legality. The shared legal understandings developed through an interactional process and undertaken in a practice of legality will be able to answer the questions of - what is the normative content of the 'rule of international law' that indicates the applicability of the rule as intended by the members of the law-making enterprise? The scrutiny of the interactional process will demonstrate who the members of the enterprise are, and to which 'the parties' the rule is applicable.

The rules of international law identified to be 'relevant' in the previous chapter are analysed through the proposed framework of an interactional conceptualisation of law. The outcome of this process provides the substantive and normative content for the integration of rules of international law, relevant to the obligation to preserve ecosystems of international watercourses.

The conceptualisation of 'law' from an interactional perspective reconstructs the current interpretative methodology underlying the interpretation of Article 31(3)(c), where the salient features of the Article, 'rules of international law applicable in the relations between the parties', are interpreted in relation to each other instead of individually. Moreover, the adoption of an interactional approach to international law raises the need to rethink the formal doctrine of sources, which may potentially be another area for further research. 


\section{Part I: Theory}

\subsection{Introduction}

'Identifying international law-making today is not as easy as it used to be."725

'Law is a process in that it is both the product and the source of a flux of various dynamics ... Law is not only a process. It also constitutes a set of rules which, at times and for multiple purposes, need to be ascertained. ${ }^{726}$

Normativity has been correlatively construed as a continuum where the idea of a penumbra between law and non-law is gradually being accepted. ${ }^{727}$ The retreat from the question of ascertainment was emphasised by the development of the international legal order, where most of the international normative activity and the creation of norms are beyond the remit of traditional understanding of international law.

The emerging participation of non-state actors and the pluralisation of both international law and international law-making processes have 'cast into doubt the relevance of traditional international law-ascertainment, especially the doctrine of formal sources from which international laws were emanated'. ${ }^{728}$ The phenomenon of pluralised normativity in both the norm-making process and the norms produced at the

\footnotetext{
${ }^{725}$ Oscar Schachter, 'Recent Trends in International Law-Making' (1988-1989) 12 Australian Yearbook of International Law $1-15$.

${ }^{726}$ D'Aspremont, Formalism and the Sources of International Law, supra n 563, at p 1.

${ }^{727}$ D'Aspremont, Formalism and the Sources of International Law, supra $\mathrm{n} 563$, at $\mathrm{p} 1$. The ascertainment of law and a formalistic account of legality used to be the central concern of international legal scholarship but has now become "a matter of "more or less"' in contemporary agenda of international legal scholars. Brunnée and Toope, Legitimacy and Legality in International Law, supra n 724, at p 46. The expression in quote is from Martti Koskenniemi, From Apology to Utopia: The Structure of International Legal Argument (Cambridge University Press, Cambridge, 2005) at p 393.

The idea in support of normative continuum, see Richard R Baxter, 'International Law in "Her Infinite Variety" (1980) 29 International and Comparative Law Quarterly 549 - 566, at p 593; Oscar Schachter, 'The Twilight Existence of Non-binding International Agreements' (1977) 71 American Journal of International Law 296 - 304; Boyle, 'Some Reflections on the Relationship of Treaties and Soft Law', supra n 208, at p 913; Christine M Chinkin, 'The Challenge of Soft Law: Development and Change in International Law' (1989) 38 International and Comparative Law Quarterly 850 - 866, at p 866; Alain Pellet, 'Complementarity of International Treaty Law, Customary Law and Non-Contractual Law-Making' pp 409 - 415, in Rüdiger Wolfrum and Volker Röben (eds) Development of International Law in Treaty Making (Springer, Berlin, 2005), at p 415.

${ }^{728}$ D'Aspremont, Formalism and the Sources of International Law, supra n 563, at pp 3-4. Jan Klabbers, 'Constitutionalism and the Making of International Law' (2008) 5 No Foundations 84 - 112, at p 89. Albeit for a different reasons, this finding has also been made by scholars affiliated to deconstructivism and critical legal studies. See Koskenniemi, From Apology to Utopia, supra n 727, at p 393.
} 
international level, necessitates the inquiry into the conceptualisation of norms generated. $^{729}$

A detailed and exhaustive study of the complex phenomenon of the contemporary rejection of formalism in the identification of law is beyond the ambit of this research. ${ }^{730}$ The present research intends to focus on the understanding of international

${ }^{729}$ D'Aspremont, Formalism and the Sources of International Law, supra n 563, at p 221. D'Aspremont observed the gradual change in source-based ascertainment of international law to a recognition of international law based on effect (or impact), which brings back the revival of process-based conceptions of law-identification, and accentuated the current deformalisation of the identification of international legal rules. The gradual shift in the law-ascertainment framework into a 'deformalise' approach is drawn upon the disconnect between the international rules identified by formal law-ascertainment mechanisms and the command actually relied upon by actors. See e.g. Higgins, Problems and Process. International Law and How We Use It, supra $\mathrm{n} 574$, at pp 8 - 10. For another illustration of the contemporary tendency towards process-based law-identification, see Paul Schiff Berman, 'A Pluralist Approach to International Law' (2007) 32 Yale Journal of International Law 301 - 329. For a hybrid law-ascertainment approach based on both effect and processes see Harlan Grant Cohen, 'Finding International Law: Rethinking the Doctrine of Sources' (2007) 93 Iowa Law Review 65 - 129. D’Aspremont, Formalism and the Sources of International Law, supra n 563, at pp 4, and 12 - 13. See José Alvarez, International Organizations as Law-makers (Oxford University Press, Oxford, 2005). Brunnée and Toope's suggested that international law ought to be defined by the sense of obligation among its addressees, which indirectly grounds lawascertainment in the impact of rules on their addressees, Jutta Brunnée and Toope, Legitimacy and Legality in International Law, supra n 724, at p 7 ('The distinctiveness of law lies not in form or in enforcement but in the creation and effects of legal obligation'). A similar use of non-formal lawidentification criteria can be found in the studies about non-state actors. See Anne Peters, Lucy Koechlin, and Gretta Fenner Zinkernagel, 'Non-State Actors as Standard Setters: Framing the Issue in An Interdisciplinary Fashion', pp 1 - 32, in Anne Peters, Lucy Koechlin, Till Förster, and Gretta Fenner Zinkernagel (eds) Non-State Actors as Standard Setters (Cambridge University Press, Cambridge, 2009). The effect-based approaches must be distinguished from the subtle conception defended by Friedrich Kratochwil based on the principled rule-application of a norm which refers to the explicitness and contextual variation in the reasoning process and the application of rules in 'like' situations in the future. Friedrich Kratochwil, Rules Norms and Decisions: On the Conditions of Practical and Legal Reasoning in International Relations and Domestic Affairs (Cambridge University Press, Cambridge, 1989) pp 206 208. See also Friedrich Kratochwil 'Legal Theory and International Law' in David Armstrong (ed) Routledge Handbook of International Law (Routledge, London, 2009) at p 58. Likewise, effects-based conceptions must be distinguished from the conceptions based on expectations and the relative normativity of the Heidelberg project on the international exercise of public authority. See in this respect Matthias Goldmann, 'Inside Relative Normativity: From Sources to Standards Instruments for the Exercise of International Public Authority' (2008) 9 German Law Journal 1865 - 1908; and Armin von Bogdandy, Philipp Dann, and Matthias Goldmann, 'Developing the Publicness of Public International Law: Towards a Legal Framework for Global Governance Activities' (2008) 9 German Law Journal 1375 - 1400. While adhering to non-formal law-identification criteria, these authors have tried to formalise it.

${ }^{730} \mathrm{My}$ thesis is not attempting to define what formalism of law is. Instead, the thesis adopts the implicit understanding of formalism and the formality of law in current legal scholarship to refer narrowly to source-based evaluation of legality. See D'Aspremont, Formalism and the Sources of International Law,

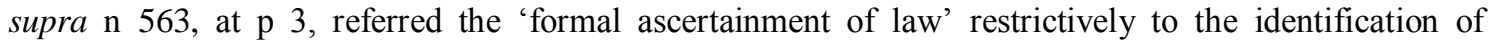
international legal rules by virtue of the 'formal source from which they emanate'. However, it has to be borne in mind that the formal character of law is not limited to identification through the doctrine of sources. See Robert S Summers, 'The Formal Character of Law' (1992) 51(2) The Cambridge Law Journal 242 - 262; Ernest J Weinrib, 'Legal Formalism: On the Immanent Rationality of Law' (1988) 97(6) The Yale Law Journal 949 - 1016, in particularly at pp 953 - 957. The interactional understanding of law adopted in this research in the conceptualisation of international law reflects the contemporary landscape of international law-making where the importance to ascertain both the explicit and implicit dimension of a rule of law has arisen. The ascertainment of the shared legal understanding that provides the normative foundation of an explicit rule necessitates a move away from a narrowly-defined 
law from an interactional perspective, which refers to the transposition of Fuller's procedural natural law ${ }^{731}$ based on the eight criteria of internal morality to the realm of international law. ${ }^{732}$ It is the objective of this chapter to synthesise the application of an interactional understanding of law in interpreting 'rules of international law' under Article 31(3)(c). An interpretation of 'rules of international law' from an interactional perspective is crucial for the operationalisation of this Article in the realisation of its potential as an integration tool.

In light of the interactive nature of multilateral law making ${ }^{733}$ prevalent in the current environment, there is a need for a more 'flexible recognition of changes in patterns of state behaviour and wider methods of determining state consent and evidence of that consent'. ${ }^{734}$ The interactional understanding of law proposed by Brunnée and Toope, which expanded Fuller's theory, rekindled the argument of a 'cooperative international law, ${ }^{735}$ based upon mutual interest and reciprocity in achieving common benefits and shared understanding, especially through common institutional participation and institutional practices. ${ }^{736}$

The broadening of the vertical and horizontal scope of international law, especially in the area of international environmental law, ${ }^{737}$ has changed the landscape of law making, where although states remain a dominant actor of international law, it is no longer apparent that the omnes - the international community - must be identified exclusively

formalistic approach to legal validity, of which this thesis demonstrates through the interactional understanding of relevant rules under the two identified MEAs in Chapters Five and Six.

${ }^{731}$ Fuller opined that 'much of international law, and perhaps the most vital part of it, is essentially customary law ... I shall argue that the phenomenon called customary law can best be described as a language of interaction'. See Lon L Fuller, 'Human Interaction and the Law' (1969) 14 American Journal of Jurisprudence $1-36$, at p 2.

${ }^{732}$ Brunnée and Toope, Legitimacy and Legality in International Law, supra $\mathrm{n} 724$.

${ }^{733}$ Alan E Boyle and Christine M Chinkin, The Making of International Law (Oxford University Press, Oxford, 2007) at p 98. The authors describe 'multilateral lawmaking' as the 'most striking features of modern international making is the interaction of states, intergovernmental organisations and governmental organisations described on various occasions as "epistemic communities" or "transnational networks" of officials, experts and interest groups with quasi-autonomous characters that constitutes the broader international community than the states'.

${ }^{734}$ Boyle and Chinkin, The Making of International Law, supra $\mathrm{n}$ 733, at $\mathrm{p} 12$.

${ }^{735}$ Wolfgang Friedmann, Law in a Changing Society (Stevens and Sons Limited, London, 1959) at p 460. This argument is expanded in Wolfgang Friedmann, The Changing Structure of International Law (Columbia University Press, New York, 1964).

${ }^{736}$ Jutta Brunnée, 'COPing with Consent: Law-Making under Multilateral Environmental Agreements' (2002) 15 Leiden Journal of International Law 1 - 52; Alvarez, International Organizations as LawMakers, supra $\mathrm{n} 729$.

${ }^{737}$ Geoffrey Palmer, 'New Ways to Make International Environmental Law' (1992) 86 American Journal of International Law $259-283$. 
with states. ${ }^{738}$ An interactional understanding of international law acknowledges and recognises the reality of contemporary legal discourse, consisting of the participation of 'a range of non-state actors in productive power', where the interaction and the collaborative effort of actors that shape their identities, and in which shared expectations arise, may ultimately lead to the making of interactional international law. ${ }^{739}$

The transition of social norms to legal norms is studied where the need for relevant, continuous and reciprocal legal communications emphasised by Fuller arise in 'communities of practice'. ${ }^{740}$ An interactional theory in the understanding of international law may not provide a full-fledged doctrine of sources, but it definitely contributes to 'the important enterprise of distinguishing law from the morass of approaches to governance in which it threatens to disappear, ${ }^{741}$ by providing formal and substantive criteria for the identification of legal rules. ${ }^{742}$

\footnotetext{
${ }^{738}$ John Tasioulas has recognised the place of non-state actors in identifying fundamental norms and obligations owed erga omnes. John Tasioulas, 'In Defence of Relative Normativity: Communitarian values and the Nicaragua Case' (1996) 16 Oxford Journal of Legal Studies 85 - 128. Pauwelyn has proposed the test of a thick consensus to be met in the ascertainment of law, especially law obtained through informal international law-making. See Pauwelyn, 'Is it International Law or Not, And Does it Even Matter' (26 February 2010) supra n 209, at p 44.

${ }^{739}$ See also Brunnée and Toope, Legitimacy and Legality in International Law, supra $\mathrm{n} 724$, at $\mathrm{p} 85$. At $\mathrm{p}$ 15 , the authors elaborated that the interactional theory of law articulated a pragmatic view of the creation and maintenance of international law based on a few premises. First, 'legal norms can only arise in the context of social norms based on shared understandings. Second, internal features of law, which are called the criteria of legality, are crucial to law's ability to promote adherence, or to inspire "fidelity". Third, legal norms are built, maintained, and sometimes destroyed through a continuing practice of legality'. At pp $15-16$, the authors explained that the interaction and the collaborative effort of actors in a 'community of practice' where actors' identities are shaped and in which shared expectations arise, may ultimately lead to the making of interactional international law. The concept of 'community', as stated in $\mathrm{p} 80$, is fundamentally different from the notion of community underlying the historical and contemporary universalist claims of international law. A community of practice is constituted by mutual engagement rather than by shared values or goals, membership neither presupposes nor necessarily leads to homogeneity of purposes. In $\mathrm{p} \mathrm{79}$, the authors draw a difference between the assumptions of 'international community' to uphold not just state interest, but community interests, claimed by the Universalist, are misleading and unhelpful. It obfuscates the reality of deep cultural and social diversity across our globe. The values embraced in the Universalist approach obfuscate the reality of deep cultural and social diversity across our globe; the values said to be represented by the community of states are actually culturally western-specific values. The authors envisaged that the concept of 'community' in this context embraces diversity. The joint enterprise of members of a community of practice requires only that they share an understanding of 'what they are doing and why'. A 'thin' community of international legal practice based in very limited shared understandings that there is a need for law in shaping international communication and interaction, can be said to exist.'

${ }^{740}$ Brunnée and Toope, Legitimacy and Legality in International Law, supra n 724, at p 16.

${ }^{741}$ A term quoted from Benedict Kingsbury, 'International Law as Inter-Public Law' pp $167-204$ in Henry S Richardson and Melissa S Williams (eds) Moral Universalism and Pluralism (New York University Press 2009) at p 197.

${ }^{742}$ Klabbers, 'Constitutionalism and the Making of International Law', supra $\mathrm{n}$ 728. This complements the need for 'a formal mechanism that clearly identifies when treaties have been followed by a significant
} 
The multilateral environmental treaty regimes are particularly congenial and useful for an interactional analysis, where the norms within a treaty-based regime over multiple issues (that pose what Fuller called 'polycentric problems') ${ }^{743}$ are constructed by the shared understanding of actors or regime-participants of diverse perspectives and priorities through repeated negotiation. ${ }^{744}$ It is described that 'institutions can "represent frozen configurations of privilege and bias" whereby if the insights provided by an interactional international law are being taken seriously, 'it is possible to build a setting [an institution] that will facilitate a practice of legality and the emergence of communities of practice that could lead to the deepening of social interactions'. ${ }^{745}$

Such a setting allows the recursive process ${ }^{746}$ of the purposive enterprise of law making ${ }^{747}$ that actualises the common interest of society, where the 'dialectic of ideas

number of nations for a sufficient amount of time for its substance to have attained the status of customary law would at least allow for better integration with those well established treaties. An example might be the United Nations Convention on the Law of the Sea'. Meinhard Doelle, 'Integration among Global Environmental Regimes: Lessons Learned from Climate Change Mitigation' pp 63 - 85, in Aldo Chircop, Ted L McDorman and Susan J Rolston (eds) The Future of Ocean Regime Building: Essays in Tribute to Douglas M Johnston (Martinus Nijhoff, Leiden, Boston, 2009) at pp 83 - 84. See also Meinhard Doelle, 'Climate Change and the Use of the Dispute Settlement Regime of the Law of the Sea Convention' (2006) 37 Ocean Development and International Law 319 - 337.

${ }^{743}$ Lon L Fuller, 'Adjudication and the Rule of Law' (1960) 54 American Society of International Law Proceedings $1-7$, at pp 3 - 5. The author clarified polycentric problems in the context of adjudication in order to avoid misunderstanding. It is stated that ' 1 . Polycentricity is not merely a matter of the complexity of the issues present to the deciding tribunal. It is not complexity of issues but of patterns of decision that characterises the polycentric problem ... 2. Polycentricity is not a matter merely of a multiplicity of affected parties. It can arise between two parties. [Multiple parties] would make for a cumbersome hearing, but it would not make the problem polycentric ... 3. Polycentric problems are not problems without rational solution [where entire structure must be deal as a whole at once] ... 4. The fact that adjunctive decision affects and enters into a polycentric relationship does not of itself mean that the adjudicative tribunal is moving out of its proper sphere. On the contrary, [drawing analogy with an economic market], the laying down of rules that will make a market function properly is one for which adjudication is generally well suited ... 5. Polycentricity of any given problem is a matter of degree, though a distinction may be a matter of degree ...'

${ }^{744}$ Brunnée and Toope, Legitimacy and Legality in International Law, supra n 724, at p 17.

${ }^{745}$ Brunnée and Toope, Legitimacy and Legality in International Law, supra n 724, at p 85.

${ }^{746}$ Anthony D'Amato, 'International Law as A Unitary System' (Northwestern University School of Law Public Law and Legal Theory Series No 08-02, SSRN-id1106420) at pp 6 - 10 $<$ http://ssrn.com/abstract $=1106420>$ accessed 29 May 2012. The recursive process undertaken in the selfregulating system will produce rules that both explain the facts and justify them.

${ }^{747}$ Lon L Fuller, The Morality of Law (Revised edn, Yale University Press, New Haven and London, 1969) at pp 106 - 107; Fuller, at p 130, described law as 'a purposive human effort consists in the enterprise of subjecting human conduct to the governance of rules' where law is treated as an activity whereas the legal system is the product of the said activity. and that the legal system is the sustained purposive effort. At pp 194 - 195, Fuller stated that 'the quality and terms of the parties' emergent relationship - its "laws" if you will - constitute an important social reality, but it is a reality brought into being and kept alive by purposive effort and by the way each of the parties interprets the purposes of the other'. At p 129, Fuller stated that 'law is formed and maintained through continuing struggles of social practice'. At p 209, Fuller argued that in a legal system 'the existence of a relatively stable reciprocity of expectations between lawgiver and subject is part of the very idea of a functioning legal order'. Lon L Fuller, 'American Legal Philosophy at Mid-Century', (1954) 6(4) Journal of Legal Education 457 - 485 , at $\mathrm{p}$ 467. Brunnée and Toope, Legitimacy and Legality in International Law, supra $\mathrm{n} 724$, at p 7. Law as 
which is concealed within the dialectic of practice of customary law becomes the dominant form of the dialectic of practice', ${ }^{748}$

This echoed D'Amato's pragmatic observation, from a self-preserving point of view, that the emergence of customary international law over time does not 'depart appreciably from patterns of state behaviour'. ${ }^{749}$ The 'successful norms in the Darwinian struggle taking place in the international arena ${ }^{750}$ will be those that are closest to state behaviour because the international legal system is interested in an orderly and peaceful international environment that is conducive to its own maintenance and self-perpetuation. ${ }^{751}$

\footnotetext{
'a continuing struggle of social practice, the work of its everyday participants, a continuous effort to construct and sustain a common institutional framework to meet the exigencies of social life in accordance with certain ideals' illustrate Fuller's perception of 'law' in terms of 'the activity that sustains it, instead of considering only the formal sources of its authority'. Lon L Fuller, 'American Legal Philosophy at Mid-Century' (1954) 6 Journal of Legal Education 457 at p 467. Fuller emphasised that 'law is not a datum, but an achievement that needs ever to be renewed'. Kenneth I Winston, 'Three Models for the Study of Law', in Willem J Witteveen and Wibren van der Burg (eds), Rediscovering Fuller: Essays on Implicit Law and Institutional Design (Amsterdam University Press, Amsterdam, 1999) at $\mathrm{p}$ 63. The author elaborated that 'it is the work of its everyday participants, a continuous effort to construct and sustain a common institutional framework to meet the exigencies of social life in accordance with certain ideas'). When law is understood as a purposive activity, its existence will now depend 'on effective interaction and cooperation between citizens and law-making and law-applying officials'. In this context, reciprocity is necessary where citizens are interacting agents who create law through 'specific processes of communication' in which the mutually constructed law gained its authority. Gerard J Postema, 'Implicit Law' (1994) 13 Law and Philosophy 361, reproduced in Witteveen and van der Burg (eds) Rediscovering Fuller, n 747, at pp 256 - 275; and Brunnée and Toope, Legitimacy and Legality in International Law, supra n 724, at p 23, 24, and 25. See also See also Fuller, 'Human Interaction and the Law', supra $\mathrm{n}$ 731, at $\mathrm{p} 27$, which Fuller commented that 'law and its social environment stand in a relation of reciprocal influence; any given form of law will not only act upon, but be influenced and shaped by, the established forms of interaction that constitute its social milieu'. See also Lon L Fuller, 'A Reply to Professors Cohen and Dworkin' (1965) 10 Villanova Law Review 655 666, at p 661.

${ }^{748}$ Philip Allot, 'The Concept of International Law' (1999) 10 European Journal of International Law 31 -50 , at $\mathrm{p} 43$. The author, at pp $38-39$, explains that 'Customary law, including customary international law, is the product of a dialectic of practice, as opposed to legislation, including international treaty-law, which is the product of a dialectic of ideas'. It is demonstrated, recently in the case of Nile Basin that 'when states participated in norm creation through open interactional processes, communities of practice are created that allow for the evolution of stronger normative regimes'. Brunnée and Toope, Legitimacy and Legality in International Law, supra $\mathrm{n} 724$, at pp $27-28$.

${ }^{749}$ D'Amato, 'International Law as A Unitary System', supra n 746, at pp $10-11$.

${ }^{750}$ D'Amato, 'International Law as A Unitary System', supra $\mathrm{n}$ 746, at $\mathrm{p} 11$.

${ }^{751}$ D'Amato, 'International Law as A Unitary System', supra n 746, at p 11. 'Law has a self-perpetuating quality. When it is accepted that the principles governing the activities of a society amount to 'law', as is the case with states and international law, the rules of that system assume a validity and force all of their own.' Dixon, Textbook on International Law, supra $\mathrm{n}$ 531, at $\mathrm{p} 11$.
} 


\subsection{Lon L. Fuller's Interactional Theory of Law}

Fuller opined that 'much of international law, and perhaps the most vital part of it, is essentially customary law, which can best be described as a language of interaction ${ }^{, 752}$ (author's emphasis). ${ }^{753}$ Fuller's 'eunomics' models on the 'theory of good order and workable social arrangements, ${ }^{754}$ where customs or social practices are understood broadly as 'the patterns of reciprocal expectations and actions that arise tacitly out of human interaction'. ${ }^{755}$ Social norms constructed through 'struggles of social practice' and the necessary legal communications are distinguishable from other social norms due to the explicit sense of obligation that they generate. ${ }^{756}$

Fuller's interactional conception of law consisted of several claims. First, legal order is constituted by an explicit, namely the formally institutionalised, explicitly articulated and enacted dimension, and an implicit dimension that are interdependent. Second, the implicit dimension must be understood in interactional terms at several levels. ${ }^{757}$ Third,

${ }^{752}$ Fuller, 'Human Interaction and the Law', supra $\mathrm{n} 731$, at $\mathrm{p} 2$.

${ }^{753}$ Helmut Philipp Aust, Complicity and the Law of State Responsibility (Cambridge University Press, Cambridge, 2011) at p 59. The author commented, in reference to Charter of the United Nations (26 June 1945, entered into force 24 October 1945) 59 Stat 1031; TS 993; 3 Bevans 1153, Art 2(1) that 'We have to account for the legal relationships between States as forms of interaction between sovereign equals. It is thus not a relationship of subordination between various actors but one of coordination'.

${ }^{754}$ Gerald J Postema, A Treatise of Legal Philosophy and General Jurisprudence (Springer, 2011), at $\mathrm{p}$ 147. These institutions or practices have a distinctive structure for decision making with a distinctive mode of participation for individuals in that decision making. They are also equipped with a set of background conditions that enable the institution to function well, governed by an 'internal morality or a set of governing principles or ideals appropriate to it'. See also Robert S Summers, Lon L Fuller (Edward Arnold, United States of America, 1984) at p 8. Summers noted Fuller's conception of 'eunomics' as a study of basic processes of social ordering and their corresponding forms of law. Kenneth I Winston (ed) The Principles of Social Order: Selected Essays of Lon L Fuller (Revised Edition, Hart Publishing, 2001) at pp $8-9$ and pp $188-205$. The six primary types of social arrangements or mechanisms of social order are custom or practice, contract, adjudication, mediation, legislation, and administration or 'managerial direction'. The common features these arrangements or mechanisms of social order, known as 'focal points of human striving', share include specificity of purpose that aims to address a range of problems, or to procure certain outcomes. These focal points typically perform the tasks of social ordering whereby legal order is seen as 'a balanced combination of several of these social orders', as stated by Winston in pp $8-9$.

${ }^{755}$ Summers, Lon L Fuller, supra n 754, at p 8. Summers noted Fuller's conception of 'eunomics' as a study of basic processes of social ordering and their corresponding forms of law. The generation of social norms through interaction, and the sense of responsibility that arises only from humans' ability to reason with norms are the two key ideas that inspired the interactional framework. Brunnée and Toope, Legitimacy and Legality in International Law, supra n 724, at p 20.

${ }^{756}$ Brunnée and Toope, Legitimacy and Legality in International Law, supra n 724, at p 26. When law is understood as a purposive activity, its existence will now depend 'on effective interaction and cooperation between citizens and law-making and law-applying officials'.

${ }^{757}$ Fuller eloquently stated that 'Implicit in all is the view that law and its social environment stand in a relation of reciprocal influence; any given form of law will to only act upon, but be influenced and shaped by, the established forms of interaction that constitute its social milieu'. Fuller, 'Human Interaction and the Law', supra n 731, at p 27. Postema postulated that interactional terms are '(a) social behaviour is the product of the intermeshing of anticipations of rational self-directing agents with respect to the reasoning 
the content of laws and the effectiveness and legitimacy of the legal order depends on the cooperation achieved at the vertical level between the governing and the governed. 758

When law is understood as a purposive activity, its existence will now depend 'on effective interaction and cooperation between citizens and law-making and lawapplying officials'. ${ }^{759}$ Reciprocity is necessary where citizens are interacting agents who create law through 'specific processes of communication' in which the mutually constructed law gained its authority. ${ }^{760}$

The moral foundation of legal order, propounded by Fuller, 'is one that promotes human interaction on two planes: horizontally, between individuals pursuing their own ends in society and vertically, in the political relationship between rulers and ruled'. ${ }^{761}$

\subsubsection{The Horizontal Nature of Law}

All systems of normativity, even state systems of law, are constructed through rhetorical activity and social practice, producing increasingly influential mutual expectations or

and actions of others with whom they are locked in networks of interdependence; (b) as the result of more or less explicit mutual accommodations, these intermeshing anticipations congeal into regularities of behaviour and stable points of expectation in the network of conventions or practices; and (c) the content and practical (reason-giving, action-guiding) force of these conventions depends fully on the network of intermeshing expectations out of which they arose.' The levels in which interactions took place are '(a) in citizen-to-citizen relations; (b) in relations among departments of government and individual officials in formal governmental roles; and (c) in relations between officials and departments of government, on the one hand, and individual citizens and non-governmental groups and institutions, on the other.' Postema, $A$ Treatise of Legal Philosophy and General Jurisprudence, supra n 754, at p 153.

${ }^{758}$ In particularly, the legal order is contingent on 'a broad congruence between the explicit directives of the legal order and the implicit conventions and practices that give structure to the social lives of law subjects'. Postema, A Treatise of Legal Philosophy and General Jurisprudence, supra n 754, at p 153.

${ }^{759}$ Gerard J Postema, 'Implicit Law', supra n 747, at p 256. See also Lon L Fuller, The Morality of Law, supra $\mathrm{n}$ 747, at pp 194 - 195, 'The quality and terms of the parties' emergent relationship - its "laws" if you will - constitute an important social reality, but it is a reality brought into being and kept alive by purposive effort and by the way each of the parties interprets the purposes of the other'. And at p 209, arguing that in a legal system 'the existence of a relatively stable reciprocity of expectations between lawgiver and subject is part of the very idea of a functioning legal order'. See Fuller, 'Human Interaction and the Law', supra n 731, at p 27, 'law and its social environment stand in a relation of reciprocal influence; any given form of law will not only act upon, but be influenced and shaped by, the established forms of interaction that constitute its social milieu'; and Fuller, 'A Reply to Professors Cohen and Dworkin', supra n 747, at p 661. Brunnée and Toope, Legitimacy and Legality in International Law, supra $\mathrm{n}$ 724, p 23, fn 16.

${ }^{760}$ Brunnée and Toope, Legitimacy and Legality in International Law, supra n 724, at pp $24-25$.

${ }^{761}$ Dyzenhaus explained that 'the promotion of interaction on the horizontal plane leads to the idea of individual liberty, while on the vertical plane one gets the development of democracy. Each plane will perforce influence the particular ideas developed in the other. One consequence is that the moral foundation of legal order not only constrains what can be done in its name, but also becomes open to question and change from within. However, the author commented that Fuller might not want to tie legal order to a very particular vision of constitutional democracy. David Dyzenhaus, 'Fuller's Novelty', in Witteveen and van der Burg (eds) Rediscovering Fuller, supra n 747, at pp 98 - 99. 
shared understandings of actors that are reinforced through practice of legality that fulfils the eight criteria of internal morality, whereby obligation, or fidelity to law, can be generated. ${ }^{762}$ An interactional view of law explains the central features of the international system, what Georges Scelle termed 'dédoublement fonctionnel', in which the dual role of states as both subjects of international law and lawmakers is highlighted. ${ }^{763}$

It makes 'analytical sense to speak of states as individual agents, and to treat sovereignty as a proxy for autonomy', but having said that states are proxy for autonomy does not go on to show that state sovereignty is indispensable for interactional international law. ${ }^{764}$ In fact, an interactional approach attempts to illustrate how contemporary international law is more receptive to the actions of non-state participants, where norms, although formally sanctioned by states, are greatly influenced by a diversity of actors. ${ }^{765}$ In light of the burgeoning participation of individuals and 'non-state collectivities such as governmental or non-governmental

${ }^{762}$ Brunnée and Toope, Legitimacy and Legality in International Law, supra n 724, at p 34.

${ }^{763}$ For commentary on Scelle's theory of dédoublement fonctionnel, see (1990) 1 European Journal of International Law 193 - 239 <http://207.57.19.226/journal/Vol1/No1/index.html\#TopOfPage> accessed 10 September 2012. In particularly, see Antonio Cassese, 'Remarks on Scelle's Theory of "Role Splitting" (dédoublement fonctionnel) in International Law' (1990) 1 European Journal of International Law 210 231, especially at $\mathrm{p} 227$. The author commented that 'It follows that the new trends emerging in the international community have led (or are leading) to an enhancement of the "dual" role played by state agents under Scelle's doctrine of dédoublement fonctionnel'. Aust, Complicity and the Law of State Responsibility, supra $\mathrm{n} 753$, at pp 59 -60. The author noted that 'States play a double role in international law: they enact the law to which they are then bound. To this scenario, the idea of the so-called dédoublement fonctionnel could apply: Georges Scelle conceptualised this idea with individuals in mind who would fulfil a double role as agents of their home State and of the international community. His considerations have afterwards, mutatis mutandis, been applied to States. This transposition of Scelle's concept makes sense insofar as States may at times act as agents for their own interests and may at other times (also) act for the interests of the international community as a whole ... its basic tenets still hold: international law lacks a general institutional structure which would turn it is not a legal system which no longer needs to rely on States for its practical enforcement. Therefore, States may take up different roles on the international level, depending on the circumstances in which they act. In some situations, they are law-makers, whereas in other situations they are subjected to the law they previously enacted. This double role of States, it needs to be carefully analysed what the rule of law protects States against'. A distinction could be drawn between human agency central to Fuller's account of interactional law, and state sovereignty in interactional international law where state sovereignty can be seen only as an imperfect proxy for human agency. Nonetheless, it is still plausible to relate states' interaction through law to that of individual human beings within a system of law. See Gerald J Postema, 'Custom in International Law: A Normative Practice Account' in Amanda Perreau-Saussine and James Bernard Murphy (eds) The Nature of Customary Law: Legal, Historical and Philosophical Perspectives (Cambridge University Press, 2007) at $\mathrm{p}$ 306. The author contested that 'despite obvious disanalogies, international actors, like individual human agents, can and do engage in discursive, practically concrete normative practices'.

${ }^{764}$ Brunnée and Toope, Legitimacy and Legality in International Law, supra n 724, at p 36.

${ }^{765}$ Brunnée and Toope, Legitimacy and Legality in International Law, supra n 724, at p 36. The authors stated that "A "State" exists only within a normative framework, that is, the framework of international law. Unlike individual human beings, states are entirely creatures of interaction. States are but one manner in which people can organise themselves to pursue their goals.' See also Benedict Kingsbury, 'International Law as Inter-Public Law', supra n 741, at pp 175 - 179. 
organisations or corporations', ${ }^{766}$ the potential for major shifts in the horizon of international legal interaction is imminent.

\subsubsection{The Vertical Nature of Law}

The sense of obligation, the 'added value of law', ${ }^{767}$ is a product of reciprocity. ${ }^{768}$ It is the connection between citizens and government with respect to the observance of rules - the reciprocal fulfilment of duties - on which fidelity of law is founded. ${ }^{769}$ The creation of law at the international level that commands the sense of obligation, the fidelity to law - is contingent on the congruence between the practice of states and the shared legal understandings that embedded Fuller's criteria of legality. ${ }^{770}$

A deeper sense of reciprocity, evidenced in the adherence of practice to a rule of law that is created and maintained collectively, is even more salient in international society because states are both subjects and lawmakers. ${ }^{771}$ An interactional conceptualisation of law where the horizontality of the international society is seen as an asset instead of a defect in international law making, highlights the interactional nature of the international normative order, and better explains the contemporary practice of international law. ${ }^{772}$

\footnotetext{
${ }^{766}$ Brunnée and Toope, Legitimacy and Legality in International Law, supra $\mathrm{n} 724$, at $\mathrm{p} 36$.

${ }^{767}$ Brunnée and Toope, Legitimacy and Legality in International Law, supra n 724, at p 42.

768 Brunnée and Toope, Legitimacy and Legality in International Law, supra n 724, at p 37. The New Haven School dismisses the need to explain obligation because international law 'functions purely on the basis of reciprocal obligations rooted in interests'. Higgins, Problems and Process. International Law and How We Use It, supra n 574, at p 16. See also Michael Byers, Custom, Power and the Power of Rules (Cambridge University Press, 1999) at pp $89-105$.

${ }^{769}$ Brunnée and Toope, Legitimacy and Legality in International Law, supra n 724, at $\mathrm{p} 38$. This version of reciprocity is specifically addressed in Fuller's eighth criterion of legality, which is, law are administered congruently with their language as announced. See Jeremy Waldron, 'Why Law - Efficacy, Freedom, or Fidelity?' (1994) 13(3) Law and Philosophy 259 - 284, at p 277.

${ }^{770}$ Brunnée and Toope, Legitimacy and Legality in International Law, supra n 724, at pp 40 - 41. At p 41, the authors stated that 'Only when the conditions of legality are met, and embraced by a community of practice, can we imagine agents feeling obliged to shape their behaviour in the light of the promulgated rules.' However, this does not mean that each law must be regarded as having moral force on its own. Winston, 'Three Models for the Study of Law', supra n 747, at p 62 stated that 'Actors may well follow a particular law out of calculated self-interest or to avoid governmental coercion'. However, Brunnée and Toope, in $\mathrm{p} 42$, commented that they are looking at a broader point about fidelity to the legal order.

${ }^{771}$ Brunnée and Toope, Legitimacy and Legality in International Law, supra $\mathrm{n} 724$, at $\mathrm{p} 40$.

${ }^{772}$ Brunnée and Toope, Legitimacy and Legality in International Law, supra n 724, at $\mathrm{p} 34$. First, the horizontality is an asset, and not a defect of law. Second, the understanding of law that grounds in social interaction highlighted its ability to shape human behaviour through the generation of fidelity. Third, a procedural conception of the rule of law upholds and supports diversity in moral and political ends while at the same time helping to build a stronger global society through the possibility of deeper normative communities. Fourth, an over-indulgence in a formalistic account of legality misses the opportunity for a richer understanding of customary, treaty and soft law. Fifth, 'legitimacy' has a specific, legal meaning.
} 


\subsection{A Framework for an Interactional Theory of International Law}

An interactional theory of law proposes the acknowledgment of the construction of international actors, both state and non-state actors, in the hard work of international law making that is based in, and derived from, social interaction that is legal. ${ }^{773}$ An interactional theory of international law comprises three elements:

1. The shared understanding of states and international actors on what they want to accomplish through law, and of specific candidate norms, through an interactional process that is legal. ${ }^{774}$

2. The shared understanding must meet specific criteria of legality that establishes the conditions for reasoned dialogue and reciprocity and enables an extension of normative ambition to include the development of a broader base of shared legal understandings. ${ }^{775}$

3. The shared understandings or norms that adhere to the criteria of legality must be reinforced through a continuing practice of legality. ${ }^{776}$

\footnotetext{
${ }^{773}$ For an analogous reference, see Jennifer Nedelsky, 'Communities of Judgment and Human Rights' (2000) 1(2) Theoretical Inquiries in Law 245 - 282 where the author gave a detailed account of the concepts of 'common sense', 'community' and 'other judging subjects' in the elaboration of Hanna Arendt's work on judgment, which was deemed relied on a 'common sense' shared by members of a community of judging subjects. And also, by the same author, Jennifer Nedelsky, 'Judgment, Diversity, and Relational Autonomy', pp 103 - 120, in Ronald Beiner and Jennifer Nedelsky (eds) Judgment, Imagination, and Politics: Themes from Kant and Arendt (Rowman and Littlefield, Lanham, 2001) where the author traces the contradistinctions and the relationship between 'judgment and autonomy' in the context of judiciary diversity'.

${ }^{774}$ Fuller, The Morality of Law, supra n 747, at $\mathrm{p} 186$. Legal interactions are an essential feature of law, precisely because law's central purpose is to 'open up, maintain, and preserve the integrity of the channels through the barriers that separate them'.

${ }^{775}$ Brunnée and Toope, Legitimacy and Legality in International Law, supra $\mathrm{n} 724$, at $\mathrm{p} 72$. The authors noted that shared understanding cannot be enacted as '[t]he form of law will prove a hollow shell unless law-making is understood as an effort to build and sustain legality'.

${ }^{776}$ Brunnée and Toope, Legitimacy and Legality in International Law, supra $\mathrm{n} 724$, at $\mathrm{p} 55$. At $\mathrm{p} 70$, and pp $75-76$, the authors noted that practice is an important component in an account of interactional law, where law is built through a practice that sustains shared understandings of legality, as the vigour of a norm is the 'triumph of constant effort to support it'. The authors cited the demise of the prohibition on the use of force where its inconsistent invocation and application in international practice, and exceptionalism by powerful states all threaten to undermine its legality, and underscore the work of all other international actors - states, citizens, inter-governmental organisations, NGOs, and the media to uphold its legality. The authors elaborated further, in pp $80-81$ that without a robust interaction that facilitates deep engagement in diversity, law cannot emerge nor it can be created in international society. See Etienne Wenger, Communities of Practice: Learning, Meaning, and Identity (Cambridge University Press, 1998) at pp $131-133$, stated that for a community of practice to exist, participants must be engaged in interactions of a certain density and specificity. The communities of practice can exist only in settings that allow for sustained mutual engagement. They must have sustained mutual relationships (harmonious or not), shared approaches to interaction, shared indicators of membership, knowledge of others and their roles in the joint enterprise, shared discourses and shortcuts to communication, and common criteria for the appropriateness of actions and outcomes.
} 
It is an important feature that an interactional law can exist despite a thin set of substantive commitments, which reflects the reality of contemporary international law. Limited shared understanding on substantive values is not an insurmountable obstacle to the creation of law as long as efforts are maintained to build a more resilient community of legal practice that promotes continuous mutual engagement and interactions, which allows for the development of richer substantive rules. ${ }^{777}$

\subsubsection{Shared Understanding}

Brunnée and Toope's conceptualisation of 'shared understanding' is based on what Fuller described as stable interactional expectancies. ${ }^{778}$ These stable interactional expectancies are mutually adjusted in an interactional and reciprocal process, and arise from the "vocabulary of deeds and basic grammar that will organise deeds into meaningful patterns'. ${ }^{779}$ This dynamic process allows the identification of the quality and terms of an emerging shared understanding intended to govern the relationship between the parties ${ }^{780}$ who are rational self-directing agents. ${ }^{781}$ This reflects the classical horizontal relationship, the 'ordre relationnel' (relational order) that exists between equal sovereigns at the international level. ${ }^{782}$

This view is supported by Giovanni Sartor in his discussion of the 'bindingness' of legal rules, where it is proposed that a rule is binding to a reasoner when ideal practical cognition would lead that reasoner to endorse the rule from the plural perspective, that is, the collective participation in the adoption of that rule. ${ }^{783}$ This proposition

\footnotetext{
${ }^{777}$ Brunnée and Toope, Legitimacy and Legality in International Law, supra n 724, at p 87.

${ }^{778}$ Fuller, The Morality of Law, supra n 747, at p 209. The purposive enterprise of law that facilitates social interactions depends on 'a relatively stable reciprocity of expectations between law-giver and subject'. Postema, A Treatise of Legal Philosophy and General Jurisprudence, supra n 754, at p 153.

${ }^{779}$ Fuller, 'Human Interaction and the Law', supra n 731, at p 33. Fuller stated that 'Stable interactional expectancies can arise with reference to roles and functions as well as to specific acts; a language of interaction will contain not only a vocabulary of deeds but also a basic grammar that will organise deeds into meaningful patterns'.

${ }^{780}$ Fuller, The Morality of Law, supra n 747, at p 195. Sartor, 'The Foundation of Legal Bindingness', supra $\mathrm{n} 569$, at $\mathrm{p} 341$.

${ }^{781}$ Postema, A Treatise of Legal Philosophy and General Jurisprudence, supra n 754, at p 151. Fuller, The Morality of Law, supra $\mathrm{n}$ 747, at $\mathrm{p} 209$. Fuller stated that 'for a legal system, the existence of a relatively stable reciprocity of expectations between lawgiver and subject is part of the very idea of a functioning legal order'.

${ }^{782}$ Pierre-Marie Dupuy, 'Evolutionary Interpretation of Treaties: between Memory and Prophecy’ pp 123 - 137, in Enzo Cannizzaro (ed) The Law of Treaties Beyond the Vienna Convention (Oxford University Press, Oxford, 2011) at p 125.

${ }^{783}$ Sartor, 'The Foundation of Legal Bindingness', supra n 569, at pp $344-345$. At pp $331-355$, Sartor explored the two 'schema' of bindingness, which is persistent convergence of shared normative belief dimension, and the present teleological convergence dimension. The reasoning schema entails that there should be a persistent convergence of a shared normative belief in order to ensure that there is a sufficient
} 
exemplifies how the normative notion of legal validity allows a rich construction of the conceptions of law where social facts (or what he stated as legal sources) can be given appropriate recognition as reasons supporting legality. ${ }^{784}$

\subsubsection{The Horizontal Feature of Shared Understanding}

The ability of the subjects of law to rely on law in decision-making, and their commitment to law, are 'fostered by adherence to the requirements of legality'. ${ }^{785}$ Legality is related to social practice in the broader sense, where a common reference point, known as 'implicit rules' embedded in social practice, is shared between subjects and makers of law. ${ }^{786}$ Postema postulated that legal norms 'exist only to the extent that they are accepted and practiced in the community at large', and concluded that law 'reduces to the behaviour of everyone in the community'. ${ }^{787}$ Fuller described the implicit element as 'a language of interaction" ${ }^{, 788}$ where in order to understand the nature,

chance of contributing to the collective adoption of the rule. As to the teleological convergence schema, there should be a belief that adoption of this rule representing a shared normative belief would contribute to legal values. The two schema as analysed in the conceptualisation of 'bindingness' lead to a determination that the rule is 'binding'.

${ }^{784}$ Sartor, 'The Foundation of Legal Bindingness', supra n 569, at p 357.

${ }^{785}$ Brunnée and Toope, Legitimacy and Legality in International Law, supra n 724, at p 66.

${ }^{786}$ See Postema, 'Implicit Law', supra n 747, at pp 259 and 264. Friedrich V Kratochwil, 'How do Norms Matter?' in Michael Byers (ed), The Role of Law in International Politics: Essays in International Relations and International Law (Oxford University Press, 2000), pp 40 - 41 (providing the example of the injunction 'Dogs must be carried on the escalator' and of the social understandings needed to correctly understand that rule). Brunnée and Toope, Legitimacy and Legality in International Law, supra n 724, at p 66.

${ }^{787}$ Postema, A Treatise of Legal Philosophy and General Jurisprudence, supra n 754, at p 143. Law viewed from this lens refocused the conventional attention on the 'superficial facts about the behaviour of state functionaries to deeper facts about the social behaviour and patterns of social interactions that give official behaviour its meaning and force'. At p 147, Postema stated that the concept of 'implicit law' derives from Fuller's 'eunomics' model of legal theory where customs or social practice, 'understood broadly as the patterns of reciprocal expectations and actions that arise tacitly out of human interaction', is accorded a special place in his account of the legal order. This 'pattern of reciprocal expectations and actions that arise tacitly out of human interaction' is the founding blocks for the 'informal and implicit foundation of the formal and explicit institutions, constitutions, and processes of the legal order' that gives meaning, legitimacy and effectiveness to the formal institutions and processes. See also Summers, Lon L Fuller, at p 8. Winston (ed) The Principles of Social Order, supra n 754, at pp 8 - 9 and pp $188-$ 205.

${ }^{788}$ Lon Fuller, 'Human Interaction and the Law', supra n 731, at p 2. Fuller elaborated that 'To interact meaningfully men require a social setting in which the moves of the participating players will fall generally within some predictable pattern. To engage in effective social behaviour men need the support of intermeshing anticipations that will let them know what their opposite numbers will do, or that will at least enable them to gauge the general scope of the repertory from which responses to their actions will be drawn. We sometimes speak of customary law as offering an unwritten "code of conduct"'. At p 33, Fuller proceed to explain that customary law does not limit itself to requiring or prohibiting precisely defined acts, but may also designate roles and functions, and then, when the occasion arises, hold those discharging these roles and functions to an accounting for their performances. 
limits and characteristic modes of functioning of a legal order's more immediately apparent surface phenomena, we must appreciate its social depth. ${ }^{789}$

The implicit dimension of legal order (also known as custom or social practice) is broadly understood as the patterns of reciprocal expectations and actions that arise tacitly out of human interaction, and are sustained through the rational and purposive social interactions of people. ${ }^{790}$ Fuller explained that such is a situation of human interaction, where each participant guides himself by anticipating what the other will do and will expect him to do. ${ }^{791}$ Postema gave a similar account of implicit norms where he summarised that implicit norms emerged from the accommodation and adjustment of expectations and actions of interacting agents. ${ }^{792}$

\subsubsection{The Vertical Feature of Shared Understanding}

The establishment of stable interactional expectancies between lawgiver and subject, of which states play this dual role, ${ }^{793}$ can be analogised to the vertical dimension of interaction between officials of government and ordinary citizens in Fuller's eunomic model. ${ }^{794}$ The congruence between official action and declared rule, one of the criteria of legality, is the "very essence of the rule of law ... where law furnishes a baseline for self-directed action, not a detailed set of instructions for accomplishing specific

\footnotetext{
${ }^{789}$ Postema, A Treatise of Legal Philosophy and General Jurisprudence, supra $\mathrm{n}$ 754, at p 148. At p 151, Postema postulated that explicit rules might structure the coordination of law-making and law-applying, but 'much of it depends on the reciprocal expectations of the agencies and their intermeshing anticipations'. Fuller succinctly stated that 'The effective functioning of the total law-making and lawapplying process, depends, then upon a kind of customary law that lies behind enacted law and enables it to achieve its goals effectively', Winston (ed) The Principles of Social Order, supra n 754, at p 195.

${ }^{790}$ Postema, A Treatise of Legal Philosophy and General Jurisprudence, supra $\mathrm{n} 754$, at p 148.

${ }^{791}$ Lon L Fuller, Anatomy of the Law (Praeger, 1968), at p 73.

${ }^{792}$ Postema, A Treatise of Legal Philosophy and General Jurisprudence, supra n 754, at p 148. Raz reiterated the same point, and explained that man-made rules, whether customary, legislated or social rules are not independent. It is emerged within an institutional structure, and form part of a system of social rules. Joseph Raz, Between Authority and Interpretation (Oxford University Press 2009) at p 5. Raz opined that 'In fact rules made by people (I will refer to all such rules, whether customary, legislated, or others, as social rules) hardly ever stand alone. Typically they emerge within an institutional structure, and form part of a system of social rules'.

${ }^{793}$ Karl Zemanek, 'Is the Term “Soft Law” Convenient?' pp 843 - 881 in Gerhad Hafter (ed) Liber Amicorum Professor Ignaz Seidl-Hohenveldern in Honour of His $80^{\text {th }}$ Birthday (Kluwer Law International, The Hague, 1998), at p 844. 'States are not only the subjects but also the makers of international law and are as such free to invent new processes of lawmaking as it suits their purposes, as long as these processes are accepted by the system partners'. Fuller described law as 'the product of an interplay of purposive orientations between the citizen and his government'. Winston (ed) The Principles of Social Order, supra n 754, at p 254; Gerald J Postema, 'Implicit Law' (1994)13(3) Law and Philosophy $361-387$, at pp $368-373$.

${ }^{794}$ Winston (ed) The Principles of Social Order, supra n 754, at p 254; Gerald J Postema, 'Implicit Law' (1994)13(3) Law and Philosophy 361 - 387, at pp 368 - 373.
} 
objectives'. ${ }^{795}$ An interactive relationship between lawmaker and subject, caught in a web of 'reciprocal interactive expectancies', supports the above propositions that the implicit social dimension is inherent and intrinsic to the very process of making law. ${ }^{796}$

\section{These reciprocal interactive expectancies give rise to a relationship that has a distinctive} normative (or what Fuller called, moral ${ }^{797}$ ) dynamic, and which provides fertile soil for implicit understandings, norms, and conventions to take root. ${ }^{798}$ Vertical congruence of interactions between officials and subjects, 'the establishment of stable interactional expectancies between lawgiver and subject' is pivotal in the understanding of 'law' because it is from such vertical congruence of interactions that law derives its content, effectiveness, and indeed its very existence. ${ }^{799}$

${ }^{795}$ Fuller, The Morality of Law, supra n 747, at $\mathrm{p} 210$, elaborated that law is 'a matter of providing the citizenry with a sound and stable framework for their interactions with one another, the role of government being that of standing as a guardian of the integrity of this system'.

${ }^{796}$ Postema, A Treatise of Legal Philosophy and General Jurisprudence, supra $\mathrm{n} 754$, at p 152. Postema summarised that 'The subjects' understanding of the law enacted depends on their expectations with respect to the way in which other subjects and officials are likely to understand it and the practical force they are likely to accord it; likewise, officials will draft laws and others will interpret them in ways that they anticipate that subjects are likely to understand them .'

${ }^{797}$ Fuller explained that 'certainly there can be no rational grounds for asserting that a man can have a moral obligation to obey a legal rule that does not exist, or is kept secret from him, or that came into existence only after he had acted ...' where he seems to conflate normativity with morality, and labelled his procedural natural law as criteria of internal morality. See Fuller, The Morality of Law, supra $\mathrm{n}$ 747, at p 39. See also Anthony D'Amato, 'Lon Fuller and Substantive Natural Law' (Faculty Working Papers, Northwestern University School of Law Scholarly Commons, 1981) <http://scholarlycommons.law.northwestern.edu/cgi/viewcontent.cgi?article=1130\&context=facultyworki ngpapers > accessed 2 November 2012.

${ }^{798}$ Postema, A Treatise of Legal Philosophy and General Jurisprudence, supra n 754, at p 152. Postema stressed that law can be said to 'exists', or capable of effective governance in its distinctive way only when the implicit rules (which are unwritten, customary commitments) embedded in the legal order, giving structure and stability to the collaborative enterprise of law are acknowledged and honoured.

${ }^{799}$ Postema, A Treatise of Legal Philosophy and General Jurisprudence, supra $\mathrm{n}$ 754, at p 151. See also Winston (ed) The Principles of Social Order, supra n 754, at p 254, and Gerald J Postema, 'Implicit Law' (1994)13(3) Law and Philosophy 361 - 387, at pp 368 - 373. Postema eloquently summarised the two key implications of the Fuller's argument on the importance of vertical interaction and congruence between government and subject, depending on its content, to the effectiveness and existence of law. At $p$ 151, Postema qualified 'effectiveness' to be limited to 'effectiveness given a commitment to govern in a law-like way.' Postema elaborated that 'it is intended as an argument about the extent to which law exists (allowing, as Fuller always does, that this is always a matter of degree)'. At pp $152-153$, he stated that this argument concerns 'conditions under which the meaning or content of the laws (directives regarded as laws) is practically determinate'. More importantly, the vertical dimension of congruence in the interactional relationship between law-maker and subject. The vertical dimension presupposes the horizontal dimension because the reciprocity at the vertical level and the congruence achieved are merely a reflection of the horizontal dimension, the implicit rules engaged and understood. It is asserted that 'law is a projection of the ongoing life of the society it intends to governed, and cannot be cut loose from the developing life into which it is projected'. His arguments are adapted from Lon L Fuller, Anatomy of Law (Frederick A Praeger, New York, Washington, London, 1968) at p 66. Fuller initiated a lengthy discussion on the importance of 'implicit sources' on the interpretation of law where he pointed out that it is 'fallacious to suppose that in interpreting a statute the judge simply draws out of its text a meaning that the legislature has put there.' He cited an example of a hypothetical statute prohibiting vehicles from entering a park in the determination of the effect of the statute. The answer to the question of what are 
Thus, it is demonstrated in the preceding sections that the horizontal feature and the vertical feature of shared understanding, developed through interaction and reciprocity, which result in the congruence between lawmaker and its subjects, are not mutually independent from each other. Reciprocity is possible only if vertical congruence is not disengaged from its horizontal dimension, grounded in the implicit rules where the interactions took place. A separate discussion of the horizontal and the vertical feature is conceptually useful in drawing the nuanced difference between both features in order to enable a more subtle and refined understanding of the intricate complexity involved in the development and the emergence of shared understanding.

The conceptualisation of shared understanding is based on Fuller's interactional theory where the interactional and reciprocal processes of law as a purposive enterprise allow mutual expectations to organise into stable, meaningful patterns, and gradually converge into stable interactional expectancies. The interactional process gradually shapes and develops shared understanding through mutual reciprocity. Congruence between lawmakers and subjects dictates the emergence of shared understanding, where such congruence presupposes a horizontal feature whereby congruence is possible only if it is not disengaged from the expectations of the subjects as embedded in the implicit rules of the societal structure in which such interactions and reciprocity took place.

Shared understandings represent the embedded and implicit dimension of background knowledge, norms and practices that are re-generated and maintained through social interaction. The emergence of shared understanding provides the structure that shapes conduct and behaviour of actors, and their relations and role within the social matrix. ${ }^{800}$

parks for must necessarily be drawn from 'what may be called implicit sources, from the attitudes and practices of the community, and some shared conception of the most beneficial use of park areas. The considerations that make it vain to suppose that a statute can be cut loose from the developing life into which it is projected apply with a vengeance to the interpretation of constitutions'.

${ }^{800}$ See Brunnée and Toope, Legitimacy and Legality in International Law, supra n 724, at pp $64-65$. In this respect, Philip Allot shared similar sentiments where he commented that -

'A treaty is a disagreement reduced to writing ... [It] is not the end of a process, but the beginning of another process ... The making of legislation is a similar dialectical process, by which conflicts of ideas and interest are resolved into a legal form which then re-enters the general social process as a new datum. The treaty and the law become a datum in the general social process, but it is a datum with a life of its own.' Philip Allot, 'The Concept of International Law', supra n 748, at p 43. 


\subsubsection{Internal Morality of Law}

A law which a man cannot obey, nor act according to it, is void and no law: and it is impossible to obey contradictions, or act according to them. ${ }^{801}$

What Fuller had claimed as 'internal morality of law' is rooted in his interactional understanding of law, where the morality of these criteria lies partly in their ability to uphold and promote agency, as 'they enabled citizens to reason with law, to make choices about their own lives and appropriate conduct' ${ }^{802}$ The congruence of law with wider social practice posited by Postema, which is the precondition that exists for legality to evolve, is grounded in social consensus expressed in practice. ${ }^{803}$ This shared understanding generated by social practice evolves and matures through more interactions. ${ }^{804}$ The communications that shape such interactions, be they symbolic or physical, weaves the social fabric. ${ }^{805}$

${ }^{801}$ Vaughan CJ in Edward Thomas v Thomas Sorrell, (1674) Vaugh 330 at p 337, 124 English Reports 1098 - 1113, at p 1102. Quoted by Fuller, The Morality of Law, supra n 747, at p 33.

${ }^{802}$ Brunnée and Toope, Legitimacy and Legality in International Law, supra $\mathrm{n} 724$, at p 30. The autonomy of law, its capability to generate the obligation to obey, the 'fidelity' generated, is 'rooted in a sense of legitimacy gained primarily from upholding the 'internal morality of law'. Brunnée and Toope commented that it is generally agreed that Fuller's eight internal morality of law 'capture the essence of rule of law' where when the law meets these conditions, it is capable of influencing the practical reasoning of citizens and directing the conduct of citizens, in accordance with his categorisation of law as 'the enterprise of subjecting human conduct to the governance of rules'. Colleen Murphy, 'Lon Fuller and the Moral Value of the Rule of Law' (2005) 24 Law and Philosophy 239 - 262, at pp 240 and 241. The author elaborated that 'when lawmakers respect the eight principles of the rule of law, their laws can influence the practical reasoning of citizens. Citizens can take legal requirements and prohibitions into consideration when deliberating about how to act. They can predict how judges will interpret and apply rules, enabling them to form reliable expectation of the treatment different actions are likely to provoke. When the rule of law is realised, their expectations of congruence will not be disappointed. Taken together with the reasonable expectation that fellow citizens will also obey the law, these expectations justify the belief that the law gives citizens reasons to act or refrain from acting in certain ways.' At p 242, the author opined that the rule of law provides 'some normative grounds for thinking that citizens have a moral obligation to obey the law'. See also Vaughan Lowe, 'The Politics of Law-Making: Are the Method and Character of Norm Creation Changing' in Michael Byers (ed) The Role of Law in International Politics (Cambridge University Press, 2000) at p 221. Lowe described international law as 'a system where the plausibility of analogical reasoning and the persuasiveness of topical, rhetorical argument lie at the root of the perception of legitimacy'.

${ }^{803}$ Postema, 'Implicit Law', supra n 747, at p 265.

${ }^{804}$ Brunnée and Toope, Legitimacy and Legality in International Law, supra n 724, at p 33.

${ }^{805}$ Tim Blanning, The Pursuit of Glory: Europe 1648 - 1815 (Allen Lane, London, 2007), at p 3. Fuller argues that 'how and when we accomplish communication with one another can expand or contract the boundaries of life itself ... It is through communication that we inherit the achievements of past human effort'. Fuller, The Morality of Law, supra $\mathrm{n} \mathrm{747,} \mathrm{at} \mathrm{p} 186$. The rhetorical activity involved in communication was claimed to be 'a means of discerning and evaluating the ends available to a given community' where law is constructed through 'everyday practice by all participants in the system'. See Francis J Mootz III, 'Natural Law and the Cultivation of Legal Rhetoric' in Witteveen and van der Burg(eds) Rediscovering Fuller, n 747, at p 444 and Willem J Witteveen, 'Rediscovering Fuller: An Introduction' in Witteveen and van der Burg(eds) Rediscovering Fuller, n 747, at p 37. Brunnée and Toope, Legitimacy and Legality in International Law, supra $\mathrm{n} 724$, at $\mathrm{p} 31$. The authors commented that 
Fuller expounded the eight ways to fail to make law with the example of the benevolent dictator Rex who came to the throne 'filled with the zeal of a reformer' ${ }^{806}$ The internal morality of law, or the eight criteria of legality proposed by Fuller are: $:^{807}$

(1) The generality of law, namely, there must be rules for the creation of a system for subjecting human conduct to the governance of rules; ${ }^{808}$

(2) promulgation of laws; ${ }^{809}$

(3) Non-retroactive laws; ${ }^{810}$

(4) The clarity of law. ${ }^{811}$

The specificity and clarity of law depend on the nature of the problem, and determine the extent to which delegation of its precision to courts or special administrative

'the practice-driven account of the generation of law is, of course, closely allied to Adler's 'community of practice' description of the generation of all social norms.

${ }^{806}$ Fuller, The Morality of Law, supra n 747, at pp 33 - 39. The eight reasons for failure explained by Fuller from the example of the Rex are: a failure to achieve rules where every issue has to be decided on an $a d$ hoc basis; a failure to publicise, and to make available to the affected parties the rules expected for observation; the abuse of retroactive legislation that fails to guide action, and undercuts the integrity of rules prospective in effect since the rules risk retrospective change; a failure to make rules understandable; the enactment of contradictory rules; rules that require conduct beyond the powers of the affected party; introducing such frequent changes in the rules that the subject cannot orient his action by them; and a failure of congruence between the rules as announced and their actual administration.

${ }^{807}$ Fuller, The Morality of Law, supra $\mathrm{n} 747$, at pp $46-91$.

${ }^{808}$ The requirement of generality is interpreted occasionally to mean 'the law must act impersonally, where its rules must apply to general classes and should contain no proper names'. Fuller, The Morality of Law, supra $\mathrm{n} 747$, at pp 47 and 48.

${ }^{809}$ The promulgation of laws simply means the publishing of the law, and to make them generally available, whereby such publication or promulgation is subjected to the principle of marginal utility, depending on how far requirements imposed by the law 'depart from generally shared views of right and wrong'. The more it is at variant with generally shared views the more promulgation is needed. The large coincidence between moral and legal demands entails that the objection of a rule based on difficulty of access will be reduced. Fuller, The Morality of Law, supra n 747, at pp 49, 50 and 51.

${ }^{810}$ Fuller, The Morality of Law, supra n 747, at p 53. At pp 53-54, Fuller commented that there are still occasions where it is essential to resort to retrospective law as a curative measure to advance the cause of legality, especially in the circumstances that such recourse aims to alleviate the effect of a failure to realise other desiderata of legality. The role of judges in deciding disputes invariably creates retrospective law where in the resolution of the dispute through a pronouncement on the issue, the judge invariably engages in an act of retrospective legislation. In this context, retrospective law-making is to be tolerated because it is essential that the parties must have the chance to learn what the rules are, and to be assured that in the event of dispute on their meaning, a dispute resolution mechanism is in place. Fuller, The Morality of Law, supra n 747, at pp 56 - 57. See Richard H Fallon Jr and Daniel J Meltzer, 'New Law, Non-Retroactivity, and Constitutional Remedies' (1991) 104(8) Harvard Law Review 1731 - 1833. Francis X Beytagh, 'Ten Years of Non-Retroactivity: A Critique and A Proposal' (1975) 61(8) Virginia Law Review 1557 - 1625. Jill E Fisch, 'Retroactivity and Legal Change: An Equilibrium Approach' (1997) 110(5) Harvard Law Review 1055 - 1123. For a definition of 'retrospectivity', see 'Chapter 1 Defining Retrospectivity' pp 9 -37, in Charles Sampford, Retrospectivity and the Rule of Law (Oxford University Press, Oxford, 2006). Kenneth J Kress, 'Legal Reasoning and Coherence Theories: Dworkin's Rights Thesis, Retroactivity, and the Linear Order of Decisions' (1984) 72(3) California Law Review 369 $-402$.

${ }^{811}$ Fuller, The Morality of Law, supra n 747, at p 63. 
tribunals is permissible. ${ }^{812}$ Clarity of law does not require that law is to be drafted in such a way that it prescribes the command of the law in absolute terms, and does not negate the incorporation of standards such as 'good faith' and 'due care' into rules. ${ }^{813} \mathrm{~A}$ similar response is offered to the criticism levelled against the improbability of this criterion in the evaluation and assessment of general principles of law. These principles of law are mostly open-textured in nature, serving as a guide to the development, interpretation and application of law or as a benchmark against which rules, standards and behaviour can be evaluated.

Even very clear rules are not meant to prescribe action in absolute terms, as rules are meant only to provide a framework for action. Such misconception is to 'conflate fidelity to law with deference for established authority'. ${ }^{814}$ In fact, it is sometimes more effective to take advantage of, and to incorporate into law 'common sense standards of judgment that have grown up in the ordinary life lived outside legislative halls' since 'a specious clarity can be more damaging than an honest open-ended vagueness' ${ }^{815}$

Many rules of international law evolved from state practice, where rigid obligations or overriding legal rights are not stipulated. It is the nature of the international legal system that "clear and unambiguous substance of a rule" ${ }^{816}$ cannot always be achieved, as international law is not an adversarial system. ${ }^{817}$ This flexible nature of international law, where no objectively 'right' answer allows a premium on compromise and where

\footnotetext{
${ }^{812}$ Fuller elaborated that 'the problems of governmental regulation may safely be assigned to adjudicative decision with a reasonable prospect that fairly clear standards of decision will emerge from a case-by-case treatment of controversies as they arise'. Fuller, The Morality of Law, supra n 747, at $\mathrm{p}$ 65. In the context of the 1992 Framework Convention on Climate Change, Brunnée and Toope illustrated that the clarity requirement of the Convention is satisfied through the subsequent elaboration of subsidiary rules, or the reference to complementary rules. Brunnée and Toope, Legitimacy and Legality in International Law, supra $\mathrm{n} 724$, at $\mathrm{p} 179$.

${ }^{813}$ Hayek caution against the creeping vagueness into law in his eloquent but sweeping condemnation of legal provisions requiring what is 'fair' or 'reasonable'. He stated that - 'One could write a history of the decline of the Rule of Law ... in terms of the progressive introduction of these vague formulas into legislation and [adjudication], and of the increasing arbitrariness and uncertainty of, and the consequent disrespect for, the law and the judicature'. Friedrich von Hayek, The Road to Serfdom (George Routledge and Sons, London, 1944) at $\mathrm{p} 81$.

${ }^{814}$ Fuller, The Morality of Law, supra n 747, at $\mathrm{p}$ 63. See a brilliant discussion of the application of the Fuller's internal morality to the principle of precautionary principle in Jaye Ellis and Alison FitzGerald, 'The Precautionary Principle in International Law: Lessons from Fuller's Internal Morality' (2004) 49 McGill Law Journal 779 - 800 〈http://lawjournal.mcgill.ca/documents/Ellis_and_FitzGerald.pdf> accessed 22 May 2012.

${ }^{815}$ Fuller, The Morality of Law, supra $\mathrm{n} 747$, at $\mathrm{p} 64$.

${ }^{816}$ Dixon, Textbook on International Law, supra n 531, at p $11-12$.

${ }^{817}$ Dixon, Textbook on International Law, supra n 531, at p 11.
} 
states are entitled to choose 'a range of policies, all of which will be legal', is 'a great advantage for a system so bound up with politics and diplomacy'. ${ }^{818}$

(5) Non-contradictions in the laws: ${ }^{819}$

This criterion is especially useful in the current climate of a fragmented legal order ostensibly riven with contradictions. It is interesting that Fuller did not pronounce that laws that contradict are not law, but proceeded to seek reconciliation through recourse to the context. This is aligned with the current approach in the field of international law that seeks to address conciliation of conflicting norms through a variety of techniques, including principles of harmonisation, systemic integration and mutual supportiveness.

(6) Laws not requiring the impossible: ${ }^{820}$

The study on the impossibility of law enquires into the aspirational language of a law that looks into the fine line between extreme difficulty and impossibility. There is a blurred distinction between vigorous exhortation and imposed duty. This is exceptionally true in the current trend of international environmental law making, where provisions are mostly aspirational instead of requiring the impossible.

${ }^{818}$ Dixon, Textbook on International Law, supra $\mathrm{n}$ 531, at p 12.

${ }^{819}$ Fuller, The Morality of Law, supra n 747, at pp $65-69$. The avoidance of contradictions in law is simply one of logic where there cannot be a violation of the law of identity whereby an act is forbidden and commanded at the same time. The first accepted principle of recourse for dealing with apparent contradictions in law is to seek any means in which reconciliation of the seemingly inconsistent provisions is possible through 'effecting a reciprocal adjustment between the two statutes, interpreting each in the light of the other'. Fuller elaborated that in the determination of incompatible rules, other extrinsic considerations beyond the language of the rules must be taken into account, because it encompasses the whole institutional setting of the problem - legal, moral, political, economic, and sociological where the repugnancy might be rendered as merely the consequence of legislative oversight. However, Fuller acknowledged the difficulty in such endeavour where 'one would be to know where to stop, for the courts might easily find themselves embarked on the perilous adventure of attempting to remake the entire body of our statutory law into a more coherent whole. The reinterpretation of old statues in the light of new would also present embarrassing problems of retrospective legislation'.

${ }^{820}$ Fuller, The Morality of Law, supra $\mathrm{n} 747$, at $\mathrm{p} 70$. Fuller distinguished this requirement with other desiderata that make up the internal morality of law, and are ultimately concerned with the possibility of obedience. Although it is reasonable to contend that it is impossible to obey a law that is not created, promulgated, unintelligible, or in contradiction, it is not the purpose of the development of this article. This desiderata rises from the justification that there is a need to develop principles for the guidance purposive human effort, and not to engage in an exercise in logical entailment. At pp $70-71$, Fuller viewed that 'such law serves what Lilburne called a law-less unlimited power' by its very absurdity'. He distinguished this requirement with other desiderata that make up the internal morality of law, and are ultimately concerned with the possibility of obedience. Although it is reasonable to contend that it is impossible to obey a law that is not created, promulgated, unintelligible, or in contradiction, it is not the purpose of the development of this article. Fuller stated in $\mathrm{p} 71$ that 'its brutal pointlessness may let the subject know that there is nothing that may not be demanded of him and that he should keep himself ready to jump in any direction'. 
Ellis and FitzGerald outlined a variety of possible circumstances in which a principle of law might be deemed 'impossible'. ${ }^{821}$ It can be found that there is no hard and fast line to be drawn between a rule that can be achieved with extreme difficulty, and a rule that is impossible ${ }^{822}$ for a harsh and unfair rule need not contradict the basic purpose of a legal order, unlike a rule that demands what is patently impossible. ${ }^{823}$ Despite the need for an inquiry that seeks to exemplify the two ends, alas, the law 'knows no magic that will enable it to transcend this antinomy'. ${ }^{824}$

On this, Fuller observed that 'between the two [extreme difficulty and impossibility] is an indeterminate area in which the internal morality [that requires a law that is not asking the impossible] and external moralities [of what is fair and just] meet' ${ }^{825}$ The determination and assessment of a rule against the criteria of not asking the impossible must be taken on a case-by-case basis, in consideration of the context and all relevant factors surrounding the law.

(7) Constancy of law through time:

Brunnée and Toope adapt the requirement of constancy for its relevance and application to multilateral environmental treaty regimes, ${ }^{826}$ where it is considerably more difficult and costly for developing countries to meet the commitments negotiated than they have

\footnotetext{
${ }^{821}$ Ellis and FitzGerald, 'The Precautionary Principle in International Law', supra n 814, at pp 790 - 791. Such possible circumstances include an exorbitant price and an impossibly onerous duty that rendered an action or the achievement of the rule unviable. Another possible circumstance arises in the case of strict liability where the rule prohibits an activity in order to avoid a particular harm that the actor cannot reasonably know that it will lead to such harm. Concern is not placed on laws that requires patently impossible acts that is absurd, but laws that places a very high burden on the subjects, perhaps in the hope that such aspirational imposition of duty contribute towards the a positive outcome, short of the actual attainment of the desirable goal.

${ }^{822}$ Fuller observed that the notion of impossible is, he stated, 'what is in fact impossible may be determined by presuppositions about the nature of man and the universe, presuppositions that are subject to historical change'. He cited the example of laws purporting to compel religious or political beliefs whereby today's opposition will be grounded on 'unwarranted interference with individual liberty'. However, Jefferson took the view that such laws are compelling the impossible, although he is 'well aware that the opinions and beliefs of men depend not upon their own will, but follow involuntarily the evidence proposed to their minds'. Fuller then raised the question of 'whether there is not in this conception a profounder respect both for truth and for human powers than there is in our own'.

${ }^{823}$ Fuller, The Morality of Law, supra $\mathrm{n} 747$, at $\mathrm{p} 79$.

${ }^{824}$ Fuller, The Morality of Law, supra $\mathrm{n} 747$, at $\mathrm{p} 72$. Fuller commented at $\mathrm{p} 71$, that the application of an objective standard (the standard of a reasonable man), it runs the risk of imposing on him requirements he is incapable of meeting. If contrary course is taken where a subjective inquiry into whether his individual limitations fell short of what he ought to have achieved, the capacity for objective judgment may be lost. He adds further, at p 72 that 'It is therefore condemned to tread an uncertain middle course, tempering the standard of the reasonable man in favour of certain obvious deficiencies, but formalising even its definitions of these'. .

${ }^{825}$ Fuller, The Morality of Law, supra n 747, at p 79.

${ }^{826}$ Brunnée and Toope, Legitimacy and Legality in International Law, supra n 724, at pp $182-183$.
} 
initially envisaged at the time the agreement is concluded. In such instances, although the commitments themselves are predictable, the ramifications may not have been completely so. Moreover, the evolutionary nature of most environmental problems results in a difficulty in maintaining predictability.

In light of this context, it is deemed that this criterion is satisfied as long as at least the decision-making rules and law-making processes are constant and predictable. ${ }^{827}$ It is noted that the adaptation of this criterion against the backdrop of a rapidly changing field of international environmental law has a positive impact on how a rule measures against the previous criterion of not asking the impossible. In the recognition and acknowledgment that predictability and constancy are constantly negotiated for the purpose of ensuring continued feasibility, or in accordance with changing circumstances particularly pertinent in the adaptive management of the environment, the law in question will be increasingly less impossible, or more reasonable.

(8) Congruence between official action and declared rule: ${ }^{828}$

Fuller elaborated that the congruence is prone to be destroyed or impaired through 'mistaken interpretation, inaccessibility to the law, the lack of insight into what is required to maintain the integrity of a legal system, bribery, prejudice, indifference, stupidity and the drive toward personal power'. ${ }^{829}$ There are varieties of procedural devices designed to maintain congruence, where most of them are elements of procedural due processes. ${ }^{830}$

\footnotetext{
${ }^{827}$ Brunnée and Toope, Legitimacy and Legality in International Law, supra n 724, at pp $182-183$.

${ }^{828}$ Fuller pronounced that the legality criterion that requires the congruence between official action and declared rules is the most complex of all the legality criteria. Congruence denotes the consistent application of the law by the officials charged with its administration. It is to be reminded that congruence is exceptionally important in the development and the emergence of shared understanding. The noncongruence, or the non-observation of the rule of law will seriously impair the development and functioning of a legal system, where by a law not observed by its maker cannot be deemed law at all. Fuller, The Morality of Law, supra n 747, at p 81 - 91. See Nico Krisch, 'Review of Legitimacy and Legality in International Law: An Interactional Account by Jutta Brunnée and Stephen J Toope (Cambridge University Press 2010)' (2012) 106(1) American Journal of International Law 203 - 209, at p 206.

${ }^{829}$ Fuller, The Morality of Law, supra $\mathrm{n} 747$, at $\mathrm{p} 81$.

${ }^{830}$ Fuller, The Morality of Law, supra $\mathrm{n} 747$, at $\mathrm{p} 81$. Fuller cited examples relevant to the procedural due processes that maintain congruence, such as right to representation by council, the right to cross-examine adverse witnesses, habeas corpus, right to appeal an adverse decision to a higher tribunal, and even locus standi. Fuller raised the concern that 'a haphazard and fluctuating principles concerning these matters can produce a broken and arbitrary pattern of correspondence between the constitution and its realisation in practice.
} 
Interpretation occupies a sensitive and central position in the maintenance of congruence between law and official action, where the most subtle element in the task of maintaining congruence lies in the problem of interpretation. ${ }^{831}$ Legality requires that the application of law must be executed in accordance with "principles of interpretation appropriate to their position in the whole legal order' ${ }^{832}$ Central to the task of interpretation is the necessity to understand the aim, objective or the context of the law, ${ }^{833}$ although the purpose of a statute, or rather, the 'intention of the statute' is not as easily discerned or defined. ${ }^{834}$

In instances where a situation is not covered by the legislature, or the legislature offers no meaning (to the problem), 'the judges, [in such cases] are professing to declare what the legislature meant, and they are in truth, themselves legislating to fill up casus omissi. ${ }^{835}$ In light of the above, one is driven towards the reinforcement of the

${ }^{831}$ Fuller, The Morality of Law, supra n 747. Closely connected to the problem of interpretation in the determination of the congruence between the law and its administration, is the role of interpreter (Fuller cited the example of judges). Fuller cited, at pp $81-84$, several situations in which interpreter plays a pivotal role. Fuller stated that the chief function of interpretation is said to discover the actual meaning of the legislature. However, even 'when a legislature has had a real intention', there are still various occasions that doubt arises as to the intention. In this respect, judges are sometimes seen as a bulwark against lawless administration of law. In the event of limited financial ability of affected parties to seek redress in courts, the overseeing agency such as the Scandinavian ombudsman will be capable of responding to complaints that are more informal. In instances where a situation is not covered by the legislature, or the legislature offers no meaning (to the problem), 'the judges, [in such cases] are professing to declare what the legislature meant, and they are in truth, themselves legislating to fill up casus omissi'. At p 87, Fuller opined that the time for praise or blame for a creative interpretation by judges 'comes when we [can] survey' what had been accomplished in their inescapably creative role as judges. At $p$ 91. Fuller elaborated that 'If the interpreting agent is to preserve a sense of useful mission the legislature must not impose on him senseless tasks. If the legislative draftsman is to discharge his responsibilities, he in turn, must be able to anticipate rational and relatively stable modes of interpretation. This reciprocal dependence permeates in less immediately obvious ways the whole legal order. No single concentration of intelligence, insight, and good will, however strategically located, can insure the success of the enterprise of subjecting human conduct to the governance of rules.'

${ }^{832}$ Fuller quoted the Barons of the Exchequer in the Heydon's Case in 1584 that the principles are '(1) what was the common law before the making of the Act; (2) What was the mischief and defect for which the common law did not provide'; (3) What remedy the Parliament hath resolved and appointed to cure the disease of the common wealth; (4) The true reason of the remedy; and then the office of all the judges is always to make such construction as shall suppress the mischief, and advance the remedy'. Fuller added a fifth element, which was 'How would those who must guide themselves by its words reasonable understand the intent of the Act for the law must not become a snare for those who cannot know the reasons of it as fully as do the judges'. Fuller, The Morality of Law, supra n 747, at pp $82-83$.

${ }^{833}$ Fuller, The Morality of Law, supra $\mathrm{n} 747$, at $\mathrm{p} 83$.

${ }^{834}$ Fuller, The Morality of Law, supra $\mathrm{n}$ 747, at $\mathrm{p} 87$. Fuller explained, at $\mathrm{p} 85$ that - 'the social mischief it seeks to remedy is often subtle and complex, and perceptible only to those holding certain value judgments'.

${ }_{835}$ Fuller, The Morality of Law, supra n 747, at p 84. Fuller quoted John Chipman Gray and Roland Gray, The Nature and Sources of the Law (The Macmillan Company, New York, 1921) at pp $172-173$. This point is reflected in Jörg Kammerhofer, Uncertainty in International Law: A Kelsenian Perspective (Routledge, Oxon, 2011) at p 102. The author stressed that 'filling the "gap" is creation, not cognition', where 'cognition' is taken to mean interpretation. See Kammerhofer, 'Systemic Integration, Legal Theory and the ILC', supra $\mathrm{n} 104$. 
proclamation that the problem of interpretation occupies a 'sensitive, central position in the internal morality of the law' with all it subtleties, for interpretation reveals the cooperative nature of the task of maintaining legality. ${ }^{836}$

\subsubsection{Internal Morality of Law - A Commentary}

Brunnée and Toope recounted that, for Fuller, the key to the distinction between law and non-law lies in what Fuller termed the internal morality of law - the eight criteria of legality. ${ }^{837}$ The procedural nature of the criteria of legality is rooted in Fuller's belief that 'certain conditions must be in place to allow human beings to pursue their purposes through law and for law to guide their actions and interactions'. ${ }^{838}$

Fuller recognised that legal norms are distinguishable by the explicit responsibilities they impose and, by the specific sense of obligation that they generate. When the conditions are met, the process of law-creation, imbued in a practice of legality embraced by the community of practice, ${ }^{839}$ obtains distinctive legal legitimacy. ${ }^{840}$ Only a complete failure of any of the eight criteria would deny a normative order the

\footnotetext{
${ }^{836}$ Fuller, The Morality of Law, supra $\mathrm{n} 747$, at $\mathrm{p} 91$.

${ }^{837}$ Brunnée and Toope, Legitimacy and Legality in International Law, supra n 724, at p 26. The authors stated that the eight criteria that identify legal norms are general, prohibiting, and requiring or permitting certain conduct. They must also be promulgated and therefore accessible to the public, enabling citizens to know what the law requires. They should not be retroactive, but prospective, enabling citizens to take the law into account in their decision-making. The law must be clear, and should avoid contradiction, not requiring or permitting and prohibiting at the same time. It must be realistic and not demand the impossible. Its requirement of citizens must remain relatively constant. Finally, there should be congruence between legal norms and the actions of officials operating under the law.

${ }^{838}$ Brunnée and Toope, Legitimacy and Legality in International Law, supra n 724, at p 25. Brunnée and Toope, at $\mathrm{p} 28$, reiterated that this 'distinctive form of legitimacy is internal to interactional law and not an external measure of political value or preference'. This rises from Fuller's project to bring morality firmly within the reach of law. Dyzenhaus, 'Fuller's Novelty', supra n 761, at p 97 elaborate that 'the moral foundation of law has to be manifest in the institutions of law so that law can fulfil its moral task the promotion of interaction between individuals subject to the law. [As] "law is not, like management, a matter of directing other persons how to accomplish tasks set by a superior, but is basically a matter of providing the citizenry with a sound and stable framework for their interactions with one another, the role of government being that of standing as a guardian of the integrity of this system"; [and] the judicial role is to see to it that the interpretation of particular laws measures up to the moral foundation which gives law its legitimacy. Wherever law is found, there we will find the phenomenon of "an interplay of purposive orientations between the citizen and his government". But all can be compared and evaluated on a common measure - the promotion of human interaction - and to that extent any legal order promotes an authentic or sound moral order - an internal morality of law'.

${ }^{839}$ The reasoning of rules through interaction in the continual process of mutual engagement by the community of practice brings these criteria to live. Brunnée and Toope, Legitimacy and Legality in International Law, supra $\mathrm{n} 724$, at $\mathrm{p} 86$.

${ }^{840}$ It is further stated that 'morality, at least the part of morality that is both public and legitimately enforceable, is produced through the procedures of legality, procedures which promote such values as publicity, accountability, and participation'. Dyzenhaus, 'Fuller's Novelty', supra n 761, at $\mathrm{p} 97$. The fidelity generated, the obligation felt due to the adherence to the eight criteria of legality (also the 'practice of legality') produces law that is legitimate in the eyes of the addressee. Brunnee and Toope, Legitimacy and Legality in International Law, supra n 724, at pp 25 and 27.
} 
distinctive legal quality, but beneath that, the fulfilment of the criteria is a matter of a morality of aspiration rather than a morality of duty, where the conceptualisation of 'law' is a matter of degree. ${ }^{841}$

Jan Klabbers commented on Fuller's theory and its applicability in the international legal order, drawing several interesting aspects of the applicability and usefulness of Fuller's doctrine in looking at the doctrine of sources in international law. ${ }^{842}$ Some of the criteria might seem to be counterintuitive, where occasions of international law being less than clear, contradictory, or seeming to demand the impossible, are prevalent and expected in international law. ${ }^{843}$ However, it is found that the first point of relevance of Fuller's doctrine at the international level was his perception of law not made by authorities, but emerges between subjects of the law, and the congruence of law with its social substratum known as implicit laws. ${ }^{844}$

At the international level, congruence is seen as congruence amongst the actions of a majority of international actors. ${ }^{845}$ Congruence seems to pose a different set of problems at the international level, where the application of law is more likely to be inconsistent and unpredictable through diverging interpretation (or even blatant violations). It is in this respect that the reformulation of Fuller's criteria of legality to inform the conceptualisation of international law in response to the normative development in international legal order might be useful. ${ }^{846}$

\footnotetext{
${ }^{841}$ Fuller, The Morality of Law, supra n 747, at pp 198 - 200. See also Peter P Nicholson, 'The Internal Morality of Law: Fuller and His Critics' (1974) 84 Ethics 307 - 326, at pp 309 - 311. Nicholson stated, in p 309 that 'the significance of the distinction between the moralities of duty and aspiration is the internal morality of law is "largely a morality of aspiration"".

${ }^{842}$ It is commented that an immediate transposition of Fuller's doctrine is not possible simply because the domestic setting in which the theory arises where a kind of legal vacuum (single society, governed by a benign dictator) is assumed. Klabbers, 'Constitutionalism and the Making of International Law', supra n 728.

${ }^{843}$ It is logical to demand that international law be 'clear' to the extent possible as hiding disagreement behind 'constructive ambiguity' is pointless, despite its prevalence. Likewise, contradictory rules are a concern acknowledged by the international community, of which the discourse of fragmentation seeks to address. Rules that seem to demand the impossible, evidenced in the obligations set out in a majority of international environmental treaties and the ensuing compliance issues that were raised, can merely be seen as an expression of aspiration, rather than legal commitment in a true sense.

${ }^{844}$ Klabbers, 'Constitutionalism and the Making of International Law', supra n 728, at pp 96 - 97.

${ }^{845}$ Brunnée and Toope, Legitimacy and Legality in International Law, supra n 724, at p 35.

${ }^{846}$ A resurgence in the elaboration of Fuller's criteria of internal morality of law in the ascertainment of the legal normativity of international legal order can be found in Thomas Schultz, 'The Concept of Law in Transnational Arbitral Legal Orders and Some of Its Consequences' (2011) 2(1) Journal of International Dispute Settlement 59 - 85; Ralf Michaels, 'A Fuller Concept of Law Beyond the State? Thoughts on Lon Fuller's Contributions to the Jurisprudence of Transnational Dispute Resolution - A Reply to Thomas Schultz' (2011) 2(2) Journal of International Dispute Settlement 417 - 426; and Peer
} 
A basis of international normativity indeed lies in shared understandings, which prompted Brunnée and Toope to propose that rules could be destroyed through the continuing practice of states and other international actors. ${ }^{847}$ However, such a proposal has to be contemplated in light of the need to distinguish normative-legal aspiration and actual behaviour because 'the real demands of justice are not determined by our present understanding of them, ${ }^{848}$ and the potential of law is not limited to what is already widely practiced. ${ }^{849}$

To put the matter into perspective, despite the need to separate normative-legal aspiration and actual behaviour where law should not be reduced to mere state behaviour, if a particular law is commonly disregarded, and does not seem to have impact on guiding state behaviour, the meaningfulness of law must surely be questioned. ${ }^{850}$ Perhaps, as emphatically put by Glennon, 'non-compliance shades into non-law, ${ }^{851}$

An analysis of the demise of Article 2(4) of the United Nations Charter ${ }^{852}$ arrived at the conclusion that a 'rule that has fallen into desuetude is no longer obligatory'. ${ }^{853}$ The

Zumbansen, 'Debating Autonomy and Procedural Justice: The Lex Mercatoria in the Context of Global Governance Debates - A Reply to Thomas Schultz' (2011) 2(2) Journal of International Dispute Settlement $427-433$.

${ }^{847}$ Brunnée and Toope, Legitimacy and Legality in International Law, supra $\mathrm{n} 724$, at p 35. This lead the authors, at p 269 to conclude that that actual practice of many countries does not show respect to the prohibition against torture and thus, 'the absolute prohibition on torture does not meet the standards of interactional international law'. Such startling assessment put into serious doubt the formulation of Fuller's notion of congruence in international law as prohibition against torture is one of the few widely recognised jus cogens norms. This raises the need to consider the question of whether international law is all 'apology', where rules merely mirror state action and lose all critical distance. See Koskenniemi, From Apology to Utopia, Supra n 727, and Krisch, 'Review of Legitimacy and Legality in International Law', supra $\mathrm{n} 828$, at $\mathrm{p} 206$.

${ }^{848}$ Will Kymlicka, Liberalism, Community and Culture (Clarendon Press, Oxford 1989) at p 232.

${ }^{849}$ Krisch, 'Review of Legitimacy and Legality in International Law', supra n 828, at p 206.

${ }^{850}$ Cohen, 'Finding International Law: Rethinking the Doctrine of Sources', supra n 729, at p 960.

${ }^{851}$ Michael J Glennon, 'How International Rules Die' (2005) 93 Georgetown Law Journal 939 - 991, at p 960. Glennon opined, at p 956 that law at the international realm is relentlessly reflexive, 'where the collapse of legal rules through violation feeds upon itself, creating a downward spiral and threatening the contagion of other legal rules'.

${ }^{852}$ Art 2(4) of the United Nations Charter, supra $\mathrm{n}$ 753, provides that 'All Members shall refrain in their international relations from the threat or use of force against the territorial integrity or political independence of any state, or in any other manner inconsistent with the Purposes of the United Nations'.

${ }^{853}$ Glennon, 'How International Rules Die', supra n 851, at pp 958 - 960. At p 960, Glennon stated that 'If a rule is breached by a significant number of states a significant number of times over a significant period of time, I would not call it international law ... It may still exert "compliance pull" as a social norm. It may still be regional law - it is entirely possible that different use-of-force norms hold sway in Europe, say than in Africa. It may be "soft law" whatever that is. But it is not international law. It is not a rule embraced by the international community as a whole. If the community of nations behaves as though rules do not exist, then they do not exist; and if they do not exist, they are not binding ... and no longer capable of moving men to action'. 
change in the underlying social norms, leading to the fall of law into desuetude and reflected in the institution of legal order, ${ }^{854}$ provides an insight in the transposition of Fuller's formulation of congruence into the present context of an international legal order that is constantly in a state of flux.

Fuller's notion of congruence challenges the existing positivist emphasis on consent, where international law is viewed from a perspective that is more attenuated to the dynamics and expansion of the international community. It is beyond dispute that international legal order resides in an international society. Whether a norm is internalised by the international community and treated as law that has binding force is a social fact. Fuller's notion of congruence is plausible, and even welcomed in this respect.

The interaction and the need for reciprocity in striking a stable pattern of expectancies according to Fuller's theory procedural natural law, evidenced in its requirement of congruence brings forth the dynamic process of international law. As already hinted at by Krisch in his commentary of Brunnée and Toope's scholarship, there is indeed a need to distinguish normative-legal aspirations and actual behaviour, and perhaps, there is also a need to distinguish normative-legal aspirations from normative-legal duty. ${ }^{855}$

In terms of the applicability of Fuller's framework in the international setting, the institutionalised multilateral law-making process or the recent activities of the Security Council is not too remote from the legislating exercise practiced at the domestic setting to render a Fullerian analysis futile. ${ }^{856}$ What is most interesting in Fuller's doctrine was the lack of distinction between law made through legislation, and other law-making devices (i.e. custom), where legislation is viewed not as an exercise of authority, but a continuum of law as a social ordering process. ${ }^{857}$

\footnotetext{
${ }^{854}$ Glennon, 'How International Rules Die', supra n 851, at p 983.

${ }^{855}$ Krisch, 'Review of Legitimacy and Legality in International Law', supra n 828, at p 206.

${ }^{856}$ See Jeremy Matam Farrall, United Nations Sanctions and the Rule of Law (Cambridge University Press 2007).

${ }^{857}$ Klabbers, 'Constitutionalism and the Making of International Law', supra n 728, at p 97. On the emergence and normativity of other international law-making devises, see Joost Pauwelyn, Ramses Wessel, and Jan Wouters (eds) Informal International Lawmaking (Oxford University Press, Oxford, 2012).
} 
One of the criticisms posed against Fuller's conceptualisation of law is the lack of consideration of the question of value. ${ }^{858}$ Fuller treats law that satisfies the eight internal moralities as law that is morally responsible and responsive without having to rely on values. ${ }^{859}$ Klabbers argued that it is such value that provides the source of command that separates law from other normative commands. It is such value that differentiates law from other normative systems from which formal validity arises. ${ }^{860}$ In answering this critique, it is important to look at how Fuller has treated substantive principles of external morality more commonly known as values.

Fuller's natural law method principally lies in the attempt to articulate a scholarly framework for the investigation of the natural laws of social dynamics, 'without relapsing to the comforting but misguided quest to develop a comprehensive natural law system of substantive moral principles'. ${ }^{861}$ Fuller regards the internal and external moralities as being connected and insists that there is a natural affinity or continuity of moral status between them, despite the conceptual usefulness in the separation of the two. ${ }^{862}$ The nuanced connections do risk an ultimate collapse of law and morality into each other, but that may be what 'international law is in need of, judging by the clever justifications of torture, refusal of habeas corpus, renditions, and the like in today's international law, ${ }^{863}$

\footnotetext{
${ }^{858}$ The critics, especially Hart, Dworkin, Cohen, and Summers opined that 'the principles of internal morality of law are not moral principles, and following them is not moral action; so there is no necessary connection between law and morality'. See Nicholson, 'The Internal Morality of Law: Fuller and His Critics', supra n 841, at p 312.

${ }^{859}$ Klabbers, 'Constitutionalism and the Making of International Law', supra n 728, at p 100.

${ }^{860}$ Klabbers, 'Constitutionalism and the Making of International Law', supra n 728, at pp $100-104$. Klabbers further commented, in p 106 that Fuller's internal morality of law presupposes formal validity of international law, and merely focused on the evaluation and assessment of the substantive validity of law.

${ }^{861}$ Mootz, 'Natural Law and the Cultivation of Legal Rhetoric', supra n 805, at p 429.

${ }^{862}$ Fuller argued that - ' $[\mathrm{T}] \mathrm{o}$ be in a position to pursue morally praise-worth goals, citizens require a stable, institutionalised social framework within which to act. Consequently, providing such a framework for moral behaviour - which is precisely the work of legislators, judges, and lawyers - is itself a moral undertaking. The internal morality of law is not just a means of distinguishing law from non-law, it also represents the institutional form of law that enables citizens to participate in the external morality of aspiration and excellence. A conceptual distinction between the two moralities is to better-explain their nuanced connections'. Mootz, 'Natural Law and the Cultivation of Legal Rhetoric', supra n 805, at p 431. Fuller, The Morality of Law, supra n 747, at $\mathrm{p}$ 160. On the relationship between law and morality of Fuller's conceptualisation of the moral foundation of legal order, see Dyzenhaus, 'Fuller's Novelty', supra $\mathrm{n} 761$, at pp $98-99$.

${ }^{863}$ Klabbers, 'Constitutionalism and the Making of International Law', supra $\mathrm{n}$ 728, at p 108. See also Philippe Sands, Lawless World. America and the Making and Breaking of Global Rules (Allen Lane, London 2005). In this respect, Brunnée and Toope provide a succinct exposition as to the seemingly independent of any normative values of Fuller's procedural natural law. The legality requirements proposed by Fuller, 'despite its largely autonomous relationship with morality, or normative values, are
} 
Fuller regards that despite the procedural nature of the eight desiderata of internal morality of legality, it is harder if not impossible to inflict injustice through legal means. ${ }^{864}$ Adherence to the legality requirements alone could not possibly bridge a yawning gap between law and social understandings. More importantly, the adherence to these procedural requirements creates conditions in which reasoned communication and decision-making with deeper agreement or fidelity to law, can be nurtured. ${ }^{865}$ The creation of these conditions are crucial especially in the face of disagreement on values or policies characteristic of international law making of today.

We must not lose sight of the most basic assumption of law, that is, law per se is morally good. ${ }^{866}$ It is on this basis that Fuller developed his thesis that the existence of a legal system is found upon a relatively stable reciprocity of expectations between lawmaker and subject, and provides citizens with a sound and stable framework for their interactions with each other. ${ }^{867}$ Law is not just an internal principle of efficiency, as shared by his example of managerial direction, but a principle of efficiency rooted in morality and imposes moral duties. ${ }^{868}$ Fuller's position on law and morality provides a

not completely divorced from the dominant understandings in Brunnée and Toope, Legitimacy and Legality in International Law, supra $\mathrm{n}$ 724, at p 67. Indeed, Fuller, The Morality of Law, supra $\mathrm{n}$ 747, at pp 131 - 132, and pp $145-167$, argued that the 'internal morality' requirements are still connected to the standards of external morality'.

${ }^{864}$ See Nicholson, 'The Internal Morality of Law: Fuller and His Critics', supra n 841, at pp $312-322$. See also Mootz III, 'Natural Law and the Cultivation of Legal Rhetoric', supra n 805, at pp 429 - 431. Mootz explained, at p 430 that 'Fuller consistently emphasised that the two moralities coincide as a practical matter'. It is further elaborated at $\mathrm{p} 431$ 'Fuller regards the two moralities as being connected by more than mere coincidence in history. He insists that there exists a natural affinity, or continuity of moral status, between the two moralities, despite the conceptual usefulness of distinguishing them ... Fuller's argument proceeds as follows: to be in a position to pursue morally praiseworthy goals, citizens require a stable, institutionalised social framework within which to act; consequently, providing such a framework for moral behaviour - which is precisely the work of legislators, judges, and lawyers - is itself a moral undertaking'. See also Fuller, The Morality of Law, supra n 747, at pp 205 - 207. Fuller emphasised, at p 207 that 'to regard as morally indifferent the existence or non-existence of law is to assume that moral precepts retain the same meaning regardless of the social context into which they are projected ... it brings to expression a distaste for phenomena of interaction characteristic of positivistic thought [where] the essential reality of law is perceive as a one-way projection of authority originating with government and imposing itself upon the citizen'.

${ }^{865}$ Brunnée and Toope, Legitimacy and Legality in International Law, supra n 724, at pp $67-68$.

${ }^{866}$ Fuller was quoted at length - 'For men to live together successfully they need rules that will keep peace among them, make them deal justly with one another, and enable them to collaborate effectively. It is the legal system which provides such rules, rules which are the foundation of morality. Law and morality are inseparable. Law is morally good: it brings mutual benefits to those who share in its cooperative enterprise. Therefore the purposes of law makers, who seek to achieve these effects, are morally good'. Nicholson, 'The Internal Morality of Law: Fuller and His Critics', supra n 841, at p 320.

${ }^{867}$ Fuller, The Morality of Law, supra n 747, at p 210.

${ }^{868}$ Nicholson, 'The Internal Morality of Law: Fuller and His Critics', supra n 841, at p 324. 
viable alternative perspective on law and morality to that of legal positivists, which had better reflect social facts, social reality and also social dynamics. ${ }^{869}$

Klabbers commented that although Fuller's doctrine does not qualify as a fully-fledged source doctrine because it lacks a Grundnorm, ${ }^{870}$ Fuller's conception of law as facilitative and allowing for self-directed actions would be recognisable in contemporary international legal language. ${ }^{871}$ If viewed from the perspective of law as a largely social construction that 'mainly serve certain purposes other than, or in addition to, the service of high moral ends, ${ }^{872}$ it becomes plausible to regard Fuller's eight criteria of legality as 'approaching a full-fledged sources theory, combining formal and substantive criteria for the identification of legal rules' ${ }^{873}$

In fact, the thin reference to value in Fuller's doctrine is more befitting in the realm of a pluralised international legal order, where attempts to assert a common good on the international community will be difficult due to the global political diversion constituted by an approximation of 200 independent sovereign entities. ${ }^{874}$ More importantly, the internal morality of law proffers a standard against which international law made could be assessed, and which could inform the constitutionalisation of international law. ${ }^{875}$

The preceding section elaborated on how the eight criteria of morality are positioned in the overall framework of an interactional understanding of law where the criteria of legality shape the generation of shared understandings. It provides a structural framework where shared understandings are guided towards the attainment of legality. ${ }^{876}$ An identification of international law, its obligatory force and its content, through the lenses of law-making as an interactive process where a rule is constantly

\footnotetext{
${ }^{869}$ Nicholson, 'The Internal Morality of Law: Fuller and His Critics', supra n 841, at p 326.

${ }^{870}$ A rule of recognition immediately identified by the two leading $20^{\text {th }}$ century positivists, Hans Kelsen and HLA Hart that establishes law's formal validity. Klabbers, 'Constitutionalism and the Making of International Law', supra n 728, at p 107.

${ }^{871}$ Klabbers, 'Constitutionalism and the Making of International Law', supra n 728, at p 102.

${ }^{872}$ Klabbers, 'Constitutionalism and the Making of International Law', supra n 728, at p 107.

${ }^{873}$ Klabbers, 'Constitutionalism and the Making of International Law', supra $\mathrm{n}$ 728, at pp $107-108$. He stated further that 'not only laying down a substantive set of criteria for the validity of law, but simultaneously embodying also a formal criterion: law that did not meet the eight criteria, to a certain extent, would simply not be law'.

${ }^{874}$ See Benjamin R Barber, 'Conserving Politics: Michael Oakeshott and the Conversation of Political Theory' pp 152 - 176, in Benjamin R Barber, The Conquest of Politics. Liberal Philosophy in Democratic Times (Princeton University Press, 1988) at p 169.

${ }^{875}$ Klabbers, 'Constitutionalism and the Making of International Law', supra n 728, at p 106.

${ }^{876}$ By focussing on the dynamic relationship of the development of a rule embraced by a community of practice that emphasises the interactive process instead of the mere discovery of rules through static sources, Fuller's thesis undermines the formalism of the positivist system. Nicholson, 'The Internal Morality of Law: Fuller and His Critics', supra n 841, at p 326.
} 
shaped in a practice of legality, is more attenuated to the dynamics of the international society and will provide a deeper and more powerful understanding of international law.

Contrary to the relaxed approach adopted by Fuller, recent scholars took the view that it is crucial to maintain the distinction between law and non-law in order to "uphold an admittedly weak rule of law tradition'. ${ }^{878}$ An attempt to clearly demarcate the tipping point where non-law turns to law, or vice versa might risk 'consigning the issue to sterility', especially when the 'law' properly so-called is simply a symbol for an idea that may vary with the person or context in which the word is used. ${ }^{879}$ The controversy surrounding a correct definition of law is merely a logomachy - a 'dispute about words, not things' - and that the answer to the question of 'is there a true international law ... depends upon the definition of law which we choose to adopt' ${ }^{880}$

${ }^{877}$ Despite Fuller's lack of interest in identifying a fixed boundary between law and other forms of social normativity, it is more important that the two essential commitments in law - human autonomy, and communication or interaction - interact with each other, so that Fuller's autonomy' was an autonomy created and supported through communication. The promotion and facilitation of social interaction while supporting autonomy are the moral foundation of the institution of law envisaged by Fuller. Dyzenhaus, 'Fuller's Novelty', supra n 761, at p 97. He noted that 'for Fuller, the moral foundation of law has to be manifest in the institutions of law so that law can fulfil its moral task - the promotion of interaction between individuals subject to the law ...' Brunnee and Toope, Legitimacy and Legality in International

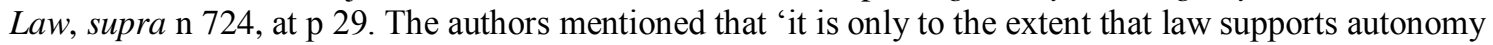
while facilitating social interaction that law pursues "moral" ends'.

${ }^{878}$ Brunnée and Toope, Legitimacy and Legality in International Law, supra n 724, at pp $26-27$. The authors proceed to assess the regimes of climate change, human rights and use of force under the framework of interactional theory of international law it established and instigate a binary determination of whether a rule is a law or not. They believed that the distinction between being legally obliged to follow a rule and being encouraged to do so through social pressure alone is important to the political calculations of international actors. In addition, a theory of legal obligation helps social actors to take strategic decisions about how to act so as to shape, uphold or change norms. The authors extrapolated Fuller's approach toward the relative specificity of law, the obligatory quality of law from Fuller's arguments, where Fuller reiterated that when the eight criteria of legality are met, law will tend to attract its own adherence, as what he called it 'fidelity to law'. The closest Fuller comes to discussing the distinction between law and other forms of social normativity is in the concluding chapter of Lon L Fuller, The Law in Quest of Itself (The Foundation Press, Chicago, 1940). See also, but more opaquely, Lon F Fuller 'Freedom as a Problem of Allocating Choice' (1968) 112 Proceedings of the American Philosophical Society 101 - 106; and Fuller, The Morality of Law, supra n 747, at pp 33 - 38 (on mythical King Rex coming to understand an interactional legal order as relying on internalised conceptions of bindingness). See also Klabbers, 'Constitutionalism and the Making of International Law', supra n 728, at pp 106 - 108 (arguing that Fuller's eight requirements might be seen as approaching a fully fledged sources theory of international law, 'combining formal and substantive criteria for the identification of legal rules'). See also Pauwelyn, 'Is it International Law or Not, And Does it Even Matter' (26 February 2010) supra n 209, at p 44. Pauwelyn opined that 'to have a theoretical bright line which separates law from non-law (as difficult as it may sometimes be to actually draw that line in a particular case) remains conceptually important'.

${ }^{879}$ Glanville L Williams, "International Law and the Controversy Concerning the Word "Law"" (1945) 22 British Yearbook of International Law 146 - 163, at pp 146 and 163.

${ }^{880}$ Williams, 'International Law and the Controversy Concerning the Word "Law", supra n 879, at p 154. 
Glennon, despite arguing that repetitive violations cause the fall of a rule into desuetude, has to concede that the assessment of when a law becomes non-law "will always be a matter of opinion' ${ }^{881}$ To couch his proposition in a term more familiar to lawyers, the dividing line between binding legal rules and non-binding norms, is a matter of interpretation. ${ }^{882}$ This is precisely what Fuller had in mind when he posited that the 'problem of interpretation occupies a sensitive, central position in the internal morality of the law. It reveals, as no other problem can, the cooperative nature of the task of maintaining legality'. 883

In this context, an interactional account that views law as shared understanding rooted in criteria of legality and undertaken by the practice of legality, captures the true normative force of international law that can, and truly does shape state action. ${ }^{884}$

\subsubsection{Practice of Legality and the Community of Practice}

'Law is not a datum, but an achievement that needs ever to be renewed'. ${ }^{885}$

The shared legal understandings generated through robust interactions and reciprocity between lawmakers and subjects, nourished by the implicit rules of the broader background understandings, must be maintained through a practice of legality. ${ }^{886} \mathrm{~A}$ practice of legality is built up through reasoned dialogue (interaction and reasoning through law) and reciprocity (vertical congruence), where a broader base of shared legal understandings is developed via interactions that adhere to the requirements of legality. ${ }^{887}$ The practice of legality is a distinctive type of interaction performed by 'a

\footnotetext{
${ }^{881}$ Glennon, 'How International Rules Die', supra n 851, at p 964.

${ }^{882}$ Pauwelyn, 'Is it International Law or Not, And Does it Even Matter' (26 February 2010) supra n 209, at $\mathrm{p}$ 13. The author commented that 'The conventional view [intent-based criterion to distinguish law from non-law] is that an instrument becomes international law when the parties to it want it to be international law. In many cases, the intent of the makers of informal international law may be unclear. Whether informal international law is international law then becomes a question of interpretation'.

${ }^{883}$ Fuller, The Morality of Law, supra $\mathrm{n}$ 747, at p 91. That might be partly the reason Fuller did not endeavour to clarify when social norms turn to legal norms, but instead, encourage and promote the engagement of interaction and reciprocity by the purposive enterprise, and allowed the development of law to take its own course, in accordance with the demands of the participants. This strengthens the position adopted in this thesis. It is not the purpose of the thesis to give a 'proper' definition to law, but to look beyond a formalistic, positivist imposition of doctrine of sources and seek to unearth the dynamic process of rules of international law, which provides the rules their content, and their basis of obligation.

${ }^{884}$ Cohen, 'Finding International Law: Rethinking the Doctrine of Sources', supra n 729, at p 129.

${ }^{885}$ The vigour of law is upheld through the constant effort to support it. Fuller, 'American Legal Philosophy at Mid-Century', supra n 747, at p 467.

${ }^{886}$ Brunnée and Toope, Legitimacy and Legality in International Law, supra n 724, at pp $80-81$.

${ }^{887}$ Brunnée and Toope, Legitimacy and Legality in International Law, supra n 724, at p 72.
} 
joint enterprise of members that shares collective understandings, directing and rationalising their conducts for them'. 888

The importance of subsequent practice in the interpretation of a treaty is enshrined in Article 31(3)(b) of the 1969 Vienna Convention. The definition of 'practice' in Article 31(3)(b) is useful to elucidate the meaning and scope of 'practice' in a practice of legality. Sinclair emphasised that the requirement of practice necessitates not one isolated fact or act, or even several individual applications. 'Practice' must be constituted by a plurality of acts, or a sequence of facts or acts. ${ }^{889}$ It requires 'an element of constancy which is reinforced by the context in that subsequent practice must be sufficient to reveal the agreement of the parties on interpretation'. ${ }^{890}$ Essentially, what is to be required of practice, must necessarily satisfy three criteria, namely - concordant; common; and consistent. ${ }^{891}$

Thus, in order to qualify as 'subsequent practice', the act or pronouncement subsequent to the declaration of the rule must be consistent and sufficiently distinct to express the interpretation of the parties regarding the pronounced rule. This interpretation is aligned with the definition of 'practice' as adopted in the ICJ where practice is not merely an $a d$ hoc act or pronouncements, but a sequence or a plurality of such acts or pronouncements.

\footnotetext{
${ }^{888}$ Brunnée and Toope, Legitimacy and Legality in International Law, supra n 724, 45.

${ }^{889}$ Sinclair, The Vienna Convention on the Law of Treaties, supra $\mathrm{n} 272$, at $\mathrm{p} 137$.

${ }^{890}$ Gardiner, Treaty Interpretation, supra n 235, at p 230.

${ }^{891}$ Fitzmaurice, Elias, and Merkouris (eds) Treaty Interpretation and the VCLT, supra n 279, at $\mathrm{p} 223$. The criteria that need to be satisfied in order to meet the requirement of 'practice' have been laid out by the ICJ in the case of Kasikili/Sedudu Island (Botswana/Namibia) are firstly, the practice must linked to a belief on the part of the parties or the relevant representative of the parties that the act or conduct is a position taken in the interpretation of the treaty (or a particular rule of international law) as to its application. Second, the other parties to the relevant treaty or the relevant rule of international law in question are fully aware of, and accepted the action or conduct of application as a confirmation of the interpretation of the treaty or rule. Kasikili/Sedudu Island (Botswana/Namibia) (Judgment of 13 December 1999) [1999] ICJ Reports 1045, at p 1094, para 74 <http://www.icjcij.org/docket/files/98/7577.pdf> accessed 17 November 2012. The meaning of 'subsequent practice' is explored in the WTO where the AB in the Chile - Priceband case reiterated the definition of 'subsequent practice' as laid down in the Japan Alcohol case. The AB quoted that '[subsequent practice] is a concordant, common and consistent sequence of acts or pronouncements which is sufficient to establish a discernible pattern implying the agreement of the parties [to a treaty] regarding its interpretation'. WTO, Chile - Price Band System and Safeguard Measures Relating to Certain Agricultural Products - Report of the Appellate Body (23 September 2002) WT/DS207/AB/R $<$ http://www.worldtradelaw.net/reports/wtoab/chile-agproducts(ab).pdf $>$ accessed 17 November 2012, at pp 68 - 69, para 213. WTO, Japan - Taxes on Alcoholic Beverages - Report of the Appellate Body (4 October 1996) WT/DS8/AB/R; WT/DS10/AB/R; $\quad$ WT/DS11/AB/R 〈http://www.mofa.go.jp/policy/economy/wto/cases/WTDS8ABR.pdf〉 accessed 17 November 2012.
} 
In light of the current jurisprudence on the ambit and scope of 'practice', the two dimensions of a practice of legality in the present context, namely -

- a horizontal interaction of reasoned dialogue in the attainment of shared understandings, and a vertical reciprocity in obtaining congruence between law; and

- practice that adheres to the rule of law;

must not be isolated acts, but a plurality and a series of actions or conduct of mutual engagement.

\subsubsection{Practice of Legality}

The interactional account of law emphasises the importance of the practice aspect of an interactional process in law making. Law emerges only when shared legal understandings obtained in social interactions are undertaken in a practice of sufficient specificity and density that satisfies the element of legality. ${ }^{892}$ Brunnée and Toope articulated that an interactional law is a more strengthened version of usus that reflects the opinio or the conviction or belief, but disregard the usefulness of a determination of opinio that largely resides in the abstract. ${ }^{893}$

Postema delved deeper into the subject matter of the notion of normative practice that is akin to a practice of legality in his elaboration and description of custom as a deliberative normative practice, ${ }^{894}$ developed based on the initial conceptualisation by

\footnotetext{
${ }^{892}$ Such assertion is deemed to go beyond mere usus or opinio required in the current determination of customary international law. It is established in international law that customary international law is found 'primarily in the actual practice and opinio juris of states' where the practice must be executed in evidence of a belief that the practice is obligatory by virtue of the existence of a rule of law that impose such obligation. This is implicit in the very notion of opinio juris sive necessitatis. In general, see Brunnée and Toope, Legitimacy and Legality in International Law, supra n 724, at p 47.

${ }^{893}$ Brunnee and Toope noted that 'Interactional law is not dependent upon practice alone, for that would undermine any distinction between social and legal norms. But neither does it require reference to an artifice - opinio juris - that refers to 'belief' on the part of a social construct, thereby upholding the fiction of consent ... thus providing a more objective, less mystical account of how customary legal norms become binding'. Brunnée and Toope, Legitimacy and Legality in International Law, supra $\mathrm{n} 724$, $\mathrm{p}$ 47. On the development of customary international law, see North Sea Continental Shelf Cases (Germany/Denmark; Germany/Netherlands) (Judgment of 20 February 1969 (1969) ICJ Reports 3 <http://www.icj-cij.org/docket/files/52/5561.pdf> accessed 17 November 2012, at p 44, para 77.

${ }^{894}$ Postema 'Custom in International Law: A Normative Practice Account', supra n 763, at pp 279 - 306. Postema, at $\mathrm{p}$ 287, has termed the specific interactional process of a practice of legality as 'normative practice', of which such practice is distinguishable from other 'regularities of behaviour by the mode of engagement or participation of custom-following agents in a normative practice'. He went further to identify the features essential in constituting 'normative practice' that are interrelated, namely mutual commitment, a notion of correct use and common resources.
} 
Robert Brandom. ${ }^{895}$ A normative practice presupposes that the agent undertaking a commitment acknowledges that his actions and judgments will be subjected to an implicit element of correctness. ${ }^{896}$ The reciprocal and mutual recognition of normativity in adherence to the implicit standards of correctness hold these rational agents, participants or parties to the normative practice of their commitments, where the intrinsically interrelated features of normative practice constitute a common resource from which the rational agents draw. ${ }^{897}$

The essential features of 'normative practice' are not dissimilar to the notion of 'interactional law', or the emergence of 'a community of practice'. In fact, an interactional ascertainment of law through the prism of shared understanding (commitment) that satisfies the criteria of legality (standard of correctness), which is then maintained and developed through a practice of legality (common resources), is fundamentally similar.

The notion of a deliberative normative practice supports a requirement of an interactional process that is of a particular specificity and density. ${ }^{898}$ A deliberative normative practice that establishes customary (legal) norms must be deliberate, and is equipped with two defining features - they must be essentially discursive and practically concrete. ${ }^{899}$ A deliberative normative practice requires that the commitments of intentions, shaped by discursive practices that went through a deliberative reasoning process in which thoughtful adjustment of norms are grounded in, are executed through concrete practice. ${ }^{900}$ The satisfaction of two crucial elements of deliberative practice,

\footnotetext{
${ }^{895}$ Robert B Brandom, Making It Explicit (Harvard University Press, Cambridge, 1994) and Robert B Brandom, Articulating Reasons (Harvard University Press, Cambridge, 2000).

${ }^{896}$ Postema 'Custom in International Law: A Normative Practice Account', supra n 763, at p 289. This standard of correctness is a standard in which the agents or participants are rely on in the determination of whether their actions or judgments are 'correct', without which the notion of 'wrong', or 'mistake' is emptied of all content, and so does the notion of normativity.

${ }^{897}$ Postema 'Custom in International Law: A Normative Practice Account', supra n 763, at p 289. The standard of practice, the commitment is not mere belief or opinio 'in the heads of participants', but in the practice. Postema postulated that it is - 'the activity rather than any articulated account of it that is the fundament, the commons from which all the participants drawn and to which they all contribute [whereby] all accounts or formulations are ultimately accountable to this commons'.

${ }^{898}$ Brunnée and Toope, Legitimacy and Legality in International Law, supra n 724, at p 70.

${ }^{899}$ Postema 'Custom in International Law: A Normative Practice Account', supra n 763, at p 290. The discursive element provides the substantive foundations, the underlying network of reasoning and arguments that explore, proffer, or assess the content of norms in actions and judgments.

${ }^{900}$ Postema 'Custom in International Law: A Normative Practice Account', supra n 763, at pp $290-291$. An analogy of the practicality of interactional law formed through a practice of legality can be found in Postema's pronouncement of the distinctive practical concreteness of customary norms that are anchored to discursively articulated but concrete deeds. He enunciated that -
} 
namely discursiveness and practical concreteness, is paramount in the formation of customary (legal) norms.

An analogy can be drawn between deliberative normative practice and the practice of legality propounded by Brunnée and Toope. Deliberative normative practice proposed by Postema is crucial in the formation of customary norms while the interactional theory of law based on Fuller's legal theory involves extensive inquiry into different aspects of law - the quest of law, the anatomy of law, and the morality of law. Where deliberative normative practice progresses into customary law through satisfaction of the elements of commitment subject to an implicit standard of correctness that are deliberately practised, an interactional law is said to exist when a community of practice that performs the shared understanding generated through interactions and reciprocity emerges.

An interactional understanding of law benefits from Postema's thesis on deliberative normative practice. The elements of concretised practicality and discursive articulation fill in the lacuna of what constitutes a practice of legality, and how it is measured, by providing the necessary insights that inform the conceptualisation and assessment of the sufficiency of a practice of legality to satisfy the requirement of interactional law.

\subsubsection{Community of practice}

The idea of a community of practice completes the thesis of an interactional theory of law based on shared legal understandings undertaken in a practice of legality. ${ }^{901}$ It can be analogised to a 'joint enterprise of members of a community of practice that share collective understandings', which direct their conduct and give reasons for them. ${ }^{902} \mathrm{~A}$

\footnotetext{
'Custom-shaping normative practices [akin to the formation of interactional law] require mastery, not of abstract rules, or of tracing presuppositions and implications, but of rules-in-action, of grasping the custom-relevant significance of actions in their concrete circumstances, and of judgment applying the rules'.

${ }^{901}$ Essential constituents of interactional law, described as the emergence of a community of practice on the shared legal understandings achieved through the interactions and reciprocity of the relevant parties (the law-makers and the subjects), are further developed by legal philosophers and legal theorist. The scholars, most notably Brunnée and Toope in the establishment of essential yardsticks of interactions and reciprocity in interactional theory of law; and Postema who detailed the essential elements of important notions such as shared understandings and practice of legality crucial in the ascertainment of international law from an interactional perspective. The concept of community of practice can be said to 'round up' the relationship between law and shared understandings in the sense that the generation of shared legal understandings that are intertwined with a practice of legality creates the emergence of a community of practice, of which interactional law arises. Brunnée and Toope, Legitimacy and Legality in International Law, supra $\mathrm{n} 724$, at $\mathrm{p} 69$.

${ }^{902}$ Brunnée and Toope, Legitimacy and Legality in International Law, supra n 724, at p 45.
} 
community of practice is said to have emerged when a practice of legality built around Fuller's eight criteria of legality and nourished by broader social practices, creates shared legal understandings that leads to the creation of law. ${ }^{903}$

Such interactions or such practice of legality must be of a certain density and specificity where basic shared understandings of legality are sustained, even though they might not share the same goals or values. ${ }^{904}$ The adequacy or sufficiency of a practice of legality that fulfils the threshold of density and specificity required to constitute law is explored through the twin pillars of discursiveness and concrete practice of the notion of deliberative normative practice. In this context, Postema's assertion that 'enacted, pedigree-validated, authoritative norms represent only the surface phenomena of law' can be fully appreciated since 'a full realisation of the rule of law requires the observance of principles of the rule of law beyond those that assist in determining the content of the law'. 905

It can be summarised that an interactional law-making process arises from a community of practice that engages actors in a practice of legality aimed at building and maintain shared legal understandings, where the criteria of legality adhered facilitates interaction on the basis of mutual respect and reciprocity. ${ }^{906}$ Source-oriented formal validity is not the only criteria for the ascertainment of law. It is the adherence to specific criteria of

\footnotetext{
${ }^{903}$ Brunnee and Toope, Legitimacy and Legality in International Law, supra n 724, at pp 69 - 70. The authors opined that 'communities of practice exist not just in domestic settings, but can also operate in transnational or international relations. For example, the world of diplomacy, or the trade, environment or human rights arenas could all be thought of as particular types of communities of practice in which state and non-state actors participate in international law and policy processes'. The authors equate interactional law as a particular type of community of practice where a practice of legality built around shared understandings permeated with Fuller's criteria of internal morality, be they procedural or substantive, modest or ambitious, are undertaken. At p 69, the authors explained that a community of practice exists as long as there is a basic layer of shared understandings of legality where participants in the legal system continued to build and maintain the practice of legality where shared legal understandings may flourish, deepen and become more complex. The authors, at p 65 explored the linkages and divergences between shared understandings, communities of practice and their perspective of an interactional framework of international law. They reiterated the proposition that law guides selfdirected human interaction only if relatively stable patterns of expectation (or shared understandings) that embedded legality emerged in which Fuller theory of law has demonstrated the importance of horizontal and vertical interaction, and reciprocity between law makers and subjects in the creation and sustenance of law.

${ }^{904}$ Brunnée and Toope, Legitimacy and Legality in International Law, supra n 724, at pp 69, 70, 80 and 81.

${ }^{905}$ Postema, 'Implicit Law', supra n 747, at p 268. David Dyzenhaus, The Constitution of Law: Legality in a Time of Emergency (Cambridge University Press, Cambridge, 2006) at p 231 that argues that positivist legal order is but 'a step along a continuum of legality'.

${ }_{906}$ Brunnée and Toope, Legitimacy and Legality in International Law, supra n 724, at p 76.
} 
legality, which promotes fidelity and generates a sense of obligation that creates international law. ${ }^{907}$

Thus, it is amply illustrated that the emergence of shared understandings is characterised by the continuous interaction and reciprocity in a practice of legality by the community of practice where the ultimate aim of that purposive enterprise is to achieve 'substantial congruence between the everyday practices and understandings of citizens and the formal dictates of law' ${ }^{908}$ The congruence is fostered by the adherence to the requirements of legality tethered to a shared basic repertoire of common reference points implicit in the broader social practices. ${ }^{909}$

The vertical aspect of congruence through the interaction and reciprocal relationship between the lawmaker and subject is only possible if it reflects a shared basic repertoire of common reference points implicit in the broader social practices in adherence to the requirements of legality. Such substantive congruence exemplifies two interrelated qualities, namely a respect for systematic structure and an understanding of the social context. ${ }^{910}$

The horizontal and vertical features of Fuller's interactional theory of law are parallel to a classic conceptualisation of the international legal order. The potential for Fuller's interactional account of law to inform the ascertainment of law at the international level seems promising where the 'dédoublement fonctionnel' of states as both law maker and subject in the international legal order fits Fuller's preoccupation with law as a set of non-hierarchical practices that orders human interaction.

Three main components are synthesised in reference to Fuller's interactional theory of law in order to transpose an essentially domestic framework into the international realm. The first requirement of the emergence of shared understanding encapsulates the horizontal dimension of Fuller's interactional understanding of law where the surface phenomenon of explicit law is informed and nourished by its implicit dimension of the broader society. Shared understanding emerges through a continuous process of mutual engagement where shared expectancies converge, in which a substantial congruence

\footnotetext{
${ }^{907}$ Brunnée and Toope, Legitimacy and Legality in International Law, supra n 724, at p 76.

${ }^{908}$ Postema, A Treatise of Legal Philosophy and General Jurisprudence, supra n 754, at p 152. See also Postema, 'Implicit Law' at pp 373 - 379.

${ }^{909}$ Brunnée and Toope, Legitimacy and Legality in International Law, supra n 724, at p 66.

${ }^{910}$ Fuller, The Morality of Law, supra n 747, at p 229.
} 
between the governing and the governed is attained. ${ }^{911}$ The substantial congruence attained derives its distinctive legal quality only if the process of interaction and reciprocity is shaped through a systematic structure rooted in the eight desiderata of internal morality of legality.

The eight criteria of legality that structure the development of shared understanding, and shape the process of interactions, are not an independent yardstick of legality. Their main role is to structure and guide the engagement of interaction and reciprocity of international actors to reach congruence that attains the characteristic of legality, as opposed to other forms of normative interaction. They exhibit their influence only when actors undertake and perform the shared understanding achieved in a practice of legality, where the practice is deemed legal if it is rooted in the criteria of legality.

The notion of a practice of legality is summarised as the engagement of shared legal understanding in concrete practice. It has been analogised to an enriched form of usus where the belief or conviction of opinio in the abstract must be undertaken in practice. Postema's thesis on the notion of deliberative normative practice provides a more in depth insight into the assessment of the specificity and density of a practice of legality. A normative practice is considered deliberate only if the twin pillars of articulated discursiveness and concretised practice is fulfilled. Such specifications complement and support the requirement of sufficiency of specificity and density of a practice of legality to qualify as an emergence of a community of practice.

A particular concern is whether the tipping point of social norms to legal norms is contingent on the satisfaction of all criteria of legality, in view of the positioning of the criteria of legality as a systematic structure that guides interaction and reciprocity. Unless any of the criteria is blatantly disregarded or breached, the satisfaction of these criteria is a matter of a morality of aspiration. ${ }^{912}$

\footnotetext{
${ }^{911}$ Brunnée and Toope, Legitimacy and Legality in International Law, supra n 724, at p 86. For the elaboration of a community of practice, see supra $\mathrm{n} 903$ and accompanying text.

912 'Law is a not a datum, but an achievement that needs ever to be renewed'. Fuller, 'American Legal Philosophy at Mid-Century', supra n 747, at p 467. Brunnée and Toope, Legitimacy and Legality in International Law, supra n 724, at pp $43-44$. The very process of interaction, 'the reasoning through law' that society is gradually built up, of what Fuller had called 'the enterprise of law-making', is aspirational where the goal of fidelity to law, is not presumed to be fully achieved. Similar observation can be made of the ascertainment of law at the international level where a study of international law in general revealed that despite the existence of formal, positivistic doctrine of sources, the distinction between law and nonlaw is shrouded in shades of grey. See Jan Klabbers, Anne Peters, and Geir Ulfstein, The Constitutionalization of International Law (Oxford University Press, Oxford, 2009) at p 97.
} 
According to an understanding of international law as a purposive effort that is interactional, law is said to have emerged when there exists a community of practice that practices the shared legal understandings developed through reciprocal interactions between the maker and the subject. This perspective allows for the lifting of the veil of formal sources of law to reveal the content of the law and its binding force limited by (or frustrated by, due to a lack of) the veil of positivist, source-oriented formality.

\subsection{Discussions and a Suggestion for Reinterpretation}

In reference to the previous chapters, a separate interpretation of terminologies, namely 'relevant', 'rules of international law', 'applicable', and 'the parties' in the interpretation of the phrase 'relevant rules of international law applicable in the relations between the parties' is incapable of clarifying the interpretation of the whole phrase. It has been illustrated that although scholars have insisted that what is applicable must be binding, it is not supported by jurisprudence of international courts and tribunals. In addition to that, the imposition that the rules must be binding for them to be applicable is neither supported by a literal reading of the convention text, nor the travaux preparatoire of the 1969 Vienna Convention. Apart from that, various scholarships on the possible meaning and scope of 'the parties', be it the narrow approach, or the broad approach, have caused more confusion than solutions.

This research endeavours to show that the existing interpretation of 'applicable in the relations between the parties' is incapable of clarifying the actual meaning of the Article. It proposes to reconstruct Article 31(3)(c) through the re-interpretation of salient points and seeks to identify how relevant rules of international law shall be incorporated into the interpretation of a treaty term or provision through the application of Article $31(3)(c)$.

A reconstruction of 'rules of international law applicable in the relations between the parties' imposes that 'applicable in the relations between the parties' cannot be interpreted in isolation from the rest of Article 31(3)(c). What is 'applicable in the relations between the parties' is qualified and conditioned by 'rules of international law' that are 'relevant'. In this context, 'applicable in the relations between the parties' must be interpreted in relation to 'relevant rules of international law', as opposed to the existing scholarships that interprets each salient point, 'rules of international law', 'relevant', 'applicable' and 'the parties' independently. 
This research proposes a reconstruction of the interpretation of Article 31(3)(c) that is capable of operationalising the Article in the quest to realise the potential of the Article as an integration tool in reflection of the principle of systemic integration. It challenges the existing interpretation that argues that 'what is applicable must be binding', as understood in the formally binding context. The thesis argues that the requirement of 'bindingness' contended by scholars as explained in Chapter Three originates not from the word 'applicable', but from the explicit requirement of legality entrenched in the phrase of 'rules of international law' in Article 31(3)(c).

'Applicable' should be given its ordinary meaning, through an interpretation in accordance with its context to mean, inter alia, may be applied, having reference, relevant or appropriate, or to employ for a limited purpose, for the purpose of interpretation. The applicability of the rule is dependent on the shared understanding achieved by the parties in the making of the rule that reflects the common intention of the parties as to the content and scope of the parties, and the extent of its applicability that denotes the binding force of the rule.

The determination of the applicability of a rule in the relations between the parties derives solely from the development of the rule of law by the enterprise of law making. This strengthens the argument that all the elements of the phrase of 'rules of international law applicable in the relations between the parties' need to be interpreted in relation to each other, where the implicit dimension of the rules of international law informs the applicability of the rules in the relations between the parties. Full understanding of the provision could not be realised in an isolated interpretation of 'relevant', 'rules of international law', 'applicable' and 'the parties' as done in existing literature.

The important question to be asked is then, what is a rule of international law? As it has been established that 'rules' cannot be interpreted in isolation from international law, the next question to consider will be, 'what is international law'? An answer found in the formal doctrine of sources will not be able to inform the interpretation and the subsequent operationalisation of the phrase 'rule of international law applicable in the relations between the parties'. Even if a source-oriented determination of legal validity confirms that the relevant rule is a rule of international law, it does not provide the content and the extent of the applicability of the rules of international law commonly intended and understood by the parties, for their application in the interpretative process. 
Chapter Three shows that the legality, or the bindingness, of a rule of international law is independent from the sources from which it is derived. That a rule is found in treaty, custom, and general principles of law, or even soft law does not, per se, delimit or expand its legality and its binding force. An ascertainment of what is binding demands a foray beyond its sources. ${ }^{913}$ This thesis proposes a framework of analysis for the purpose of identifying the content and scope of a rule of law, and seeks to explore the bindingness of the rule - the shared legal understanding of a rule that is commonly intended by the parties in the enterprise of law-making - which informs the interpretation of the 'applicability' of the rule.

An interactional understanding of rules of international law enables the ascertainment of the legality of the rule, its content and the fidelity it generates, unconstrained by whether these rules came from one of the formal sources of law. An interactional understanding of rules of international law supports the prevailing interpretation adopted by scholars (where 'the parties' are interpreted broadly to include non-parties to the external rules of international law), whereby the external rules of international are taken into account in the interpretation of a treaty, as long as it is the common understanding of the parties. A review of the jurisprudence of international courts and tribunals reveals that as long as the 'relevant rule of international law' reflect the common understanding of 'the parties', whether or not the relevant rule originates from one of the sources of law codified in Article 38(1) of the Statute of ICJ is immaterial.

According to an interactional understanding of international law, the content and applicability of the rules of international law that is commonly intended and understood by the parties for its application in the interpretative process could be found from an analysis of the rule through the three components of shared understanding, criteria of legality, and a practice of legality. Shared understanding consists of the horizontal aspect of the reciprocal expectations sustained through rational and purposive social interactions of people and the vertical congruence of lawmaker to the rule of law. It is an extension of the notion of implicit rules that forms the broader context from which legal norms are derived.

\footnotetext{
${ }^{913}$ Pauwelyn, 'Is it International Law or Not, And Does it Even Matter' (26 February 2010) supra n 209, at $\mathrm{p}$ 47. The author commented that in order to alleviate the tension between formal international law arising from thin State consent; and informal international law based on thick consensus in both the procedural and substantive quality of the norm, 'a fundamental reassessment not so much of informal international law but of traditional international law would be called for'.
} 
Legal order is to be understood as comprising both the explicit dimension that is formally institutionalised, enacted and articulated; and the implicit dimension that is interdependent where there is a broad congruence between explicit directives and the implicit conventions and practices. The implicit dimension is the product of the interactions and the intermeshing of networks of interdependent anticipations and reasoning of actions. These anticipations and reasoning of actions are mutually accommodating and congeal into regularities of behaviour and stable points of expectation in the network of conventions or practices. The content and practical (reason-giving, action-guiding) force of these conventions or practices is derived from the congruence of the networks of intermeshing anticipations and reasoning of actions.

The shared understanding obtained has the potential to develop into legal norms only if it is intertwined with, and in satisfaction of, the eight criteria of legality known as the eight morality of law developed by Fuller. The shared understandings identified from social interactions have the potential to develop into 'law' only if such shared understandings are 'legal'. This means, the shared understandings must satisfy the requirements of generality; promulgation; non-retroactivity; clarity; non-contradiction; reasonable; constant through time; and in compliance with the rule of law; in order to be considered as 'law'.

Only if the criteria of legality are satisfied will the social understandings achieved from social interactions and mutual reciprocity command the autonomy of law that is capable of generating fidelity to law and imposes the obligation to obey. The force of law is rooted in the sense of legal legitimacy gained through upholding the internal morality of law, which gives a rule of law its binding character.

However, a shared legal understanding is not 'law' unless it has been put into a continuous engagement of a practice of legality. A practice of legality is understood as a robust interactional process of continuing practice of shared understanding that adheres to the eight criteria of internal morality. The idea of a practice of legality is further substantiated by the notion of deliberative normative practice that consists of three elements, i.e., commitment, standard of correctness and common resources.

It is emphasised that a practice of legality must be of certain specificity and density before an interactional law is said to emerge. Furthermore, the normative practice is deliberate whereby its discursiveness aspect that provides the reasoning and arguments 
on the actions and judgments tending to be law, is concretised in practice. A rule of international law, or an interactional international law, is said to have been created when a community of practice emerges that continuously engages with and develops the shared legal understandings.

Thus, through the framework established in the ascertainment of 'rules of international law' from an interactional perspective, the conceptualisation of international law is revitalised to correspond to the dynamic changes in the law making of the international legal order. The doctrine of sources where international law is found is revisited in order to incorporate modern ways of making law that produce a variety of legal instruments, not all of which fit comfortably into the sources of international law enshrined in the traditional, formal doctrine of sources.

An interpretation of 'rules of international law' through an interactional account places less emphasis on the sources from which rules of international law are derived. Instead, the interactional framework focuses on whether these rules are rules of international law obtained through shared legal understanding of the participating actors where these actors are committed to the development of its legal normativity through continuous engagement in a practice of legality.

This interpretation of 'rules of international law' complements and supports scholars' construction of 'the parties' where consent or consensus of parties are considered to be more important than whether the parties are party to the treaty in the assessment of whether an external rule shall be taken into account in the interpretation of a treaty term or provision. The identification of the intention of the parties through an interactional construction is important in addressing the inter-temporal issues raised with respect to Article 31(3)(c), where emphasis is placed on the intentions of the parties in the application of the second limb of the inter-temporal law that supports an evolutionary interpretation. $^{914}$

If the rule reflects the shared legal understanding achieved by the social enterprise that has been undertaken in a practice of legality, it necessarily reflects the common understanding of the parties. Since these rules are the 'triumph' achieved from the hard work of society, these rules will be considered 'applicable in the relations between the

\footnotetext{
${ }^{914}$ The issue of inter-temporality is addressed in Section 1.6.1 of Chapter One of this thesis.
} 
parties' and shall be taken into account in the process of interpretation as long as the criterion of relevance is satisfied.

More importantly, the research purports to highlight that in light of recent developments in the contemporary international law-making process, there is a need to rethink the traditional, formal doctrine of sources in order to incorporate the recent phenomena of multilateral, pluralised actors ${ }^{915}$ in the scene of the international legal order that revolutionised the law-making environment of the international legal order. The potential of Article 31(3)(c) as an integration tool can be extended if the ascertainment of what is international law is re-established in view of the expansion of international law. ${ }^{916}$

The multilateralisation ${ }^{917}$ of international law making as encapsulated in the conclusion of multilateral agreements that establish a common pattern of institutional arrangements,

915 In fact, the most striking feature of contemporary international law-making processes is the participation of non-state actors, namely inter-governmental organisations and non-governmental organisations, recently described as 'epistemic communities' or 'transnational networks' of officials, experts and interest groups equipped with quasi autonomous power, in the making of international law. In Alan Boyle and Christine Chinkin, 'UNCLOS III and the Process of International Law-Making' pp 371 388 in Tafsir Malick Ndiaye and Rüdiger Wolfrum (eds) Law of the Sea, Environmental Law and Settlement of Disputes. Liber Amicorum Judge Thomas A Mensah (Martinus Nijhoff Publishers, Leiden, 2007) at pp 371 - 372. Pauwelyn, 'Is it International Law or Not, And Does it Even Matter' (26 February 2010) supra n 209, at p 25. The author commented that 'the fact that informal international law-making processes include non-State actors (the actor informality of IN-LAW) does not preclude IN-LAW from being international law'.

916 Arnold N Pronto, 'Some Thoughts on the Making of International Law' (2008) 19(3) European Journal of International Law $601-616$.

917 'Multilateralism' is traditionally understood as 'a dialogue among government representatives who "hope to work out common approaches to common concerns", quoted in Michael G Schechter, 'Systemic Change, International Organizations, and the Evolution of Multilateralism' pp 23 - 41, at p 23, in James P Muldoon, Jr, JoAnn Fagot Aviel, Richard Reitano, and Earl Sullivan (eds) The New Dynamics of Multilateralism. Diplomacy, International Organizations, and Global Governance (Westview Press Boulder 2011). Keohane has defined it as 'the practice of coordinating national policies in groups of three or more states, through ad hoc arrangements or by means of institutions" where as he limited his connotation of 'multilateralism' to arraignments involving states', or more specifically, intergovernmental arrangements despite acknowledging that transnational relations are important. See Robert O Keohane, 'Multilateralism: An Agenda for Research' (1990) 45(4) Multilateralism: Old and New 731 - 764, at p 732. Recent international relations scholars have accommodated the increased interactions among and between non-state actors including non-governmental organisations (NGOs), transnational advocacy and transnational social movements, and intergovernmental organisation due to the erosion of the pillars of state sovereignty by democracy and globalisation. Scholars have advocated the redefinition of 'multilateralism' to encompass interactions between multilateral economic institutions and global social movements in an 'incrementally pluralised governing structures' that captures the complexity, substantive, and qualitative dimensions this phenomenon, which makes it distinct. For the purpose of this research, multilateralism, multilateralisation and multilateral law-making are understood in the context of this research as "interactions of states, intergovernmental organisations (IGOs) and non-governmental organisations (NGOs) commonly described as "epistemic communities" or "transnational network" of officials, experts and interest groups with quasi-autonomous character' that constitute a broader international community. In Boyle and Chinkin, The Making of International Law, supra $\mathrm{n}$ 733, at pp 98 -99 . 
is a recent phenomenon of modern international law. The emergence of international consensus is strengthened by the multilateralisation of international law making in contemporary international legal order, especially in the context of international organisations such as MEAs. ${ }^{918}$

A general summary of the suggestion of the re-interpretation of the salient features of Article 31(3)(c) is presented. The phrase of 'rules of international law' is interpreted through an interactional account of international law to refer to shared legal understandings maintained by a continuous practice of legality in a community of practice. These rules generate a sense of obligation, the fidelity of law that commands compliance (bindingness) from the parties. In light of a reinterpretation of 'rules of international law' in accordance with an interactional understanding of law, Article $31(3)(c)$ is reconstructed and re-interpreted where -

1. Determination of whether the rule is a rule of international law. These rules are ascertained through the prism of an interactional theory of law, where the existence of law is contingent on whether a community of practice has emerged.

2. The rules of international law are considered to be 'applicable' in the interpretative process between the parties if the shared legal understanding of the parties reflects their common intention and collective agreement as to the interpretation of both the explicit and implicit dimension of the rule, and has demonstrated this shared legal understanding in their practice of legality. This is a de facto demonstration of their collective understanding of the bindingness of the rule or the obligation commanded by the rule, which generates their fidelity to the rule of law.

\footnotetext{
${ }^{918}$ In the contemporary law-making process, the institutional framework established by virtue of a treaty instrument, guided by the mandate of its constituent instrument that codifies shared legally understandings, can 'represent frozen configurations of privilege and bias' and contributes toward the emergence of the community of practice necessary for the generation of law. Jutta Brunnée and Stephen J Toope, 'International Law and Constructivism: Elements of an Interactional Theory of International Law' (2000) 39 Columbia Journal of Transnational Law 19 - 74, at pp 29 - 3. The authors follow Alexander Wendt's definition of institution to mean 'relatively stable set or "structure" of identities and interests'. See also Michael Barnett and Raymond Duvall, 'Power in International Politics' (2005) 59(1) International Organization $39-75$, at p 52. In fact, the institutional arrangement created is meant to develop the norms contained in the treaty, and may serve as a catalyst, or provide the necessary platform for the generation of new international law. See Robin R Churchill and Geir Ulfstein, 'Autonomous Institutional Arrangements in Multilateral Environmental Agreements' (2000) 94 American Journal of International Law 623 - 659, at p 636 and 642; and Boyle and Chinkin, The Making of International Law, supra $\mathrm{n} 733$, at $\mathrm{p} 161$.
} 
3. 'The parties' are members to the joint enterprise of law-making where shared legal understandings are attained and practiced.

'Rules of international law applicable in the relations between the parties' should be interpreted as a whole where the extent and scope of what is 'applicable in the relations between the parties' depends on the force and the autonomy of law commonly understood by the parties to be applicable on them. Who the parties are is no longer a separate determination from the parties who had participated in the making of the rule of international law. In this regard, the determination of who 'the parties' are and the debate of whether a narrow or broad approach should be taken in the interpretation of 'the parties' is no longer crucial to the interpretation of Article 31(3)(c).

By identifying 'the parties' as members to the joint enterprise of law-making, it is not necessary to show who each individual party is, and whether they are formally bound (through ratification) by the rule of law. As long as the parties to the interpreted treaty are engaged in the development of the rule of law (and satisfy other conditions provided under the Article 31(3)(c) of the 1969 Vienna Convention), the rule will be considered to be applicable in the relations between them. The extent of applicability will then depend on the content of the shared legal understanding attained in the interactional process.

This interpretation of 'the parties' corresponds to the multilateralisation of treaty making in an institutionalised setting such as the Conference of the Parties (COP) of multilateral environmental treaty regimes. The collective understanding developed within and beyond a treaty regime through cross-referencing between treaty regimes strengthens the international shared understandings of a relevant rule of international law, and enhances the universality of the rule. This confirms the emergence and establishment of a common international understanding on this subject matter. It is noted by Dupuy that -

'cross-references from one institution to another, the recalling of guidelines adopted by other apparently concurrent international authorities, recurrent invocation of the same rules formulated in one way or another at the universal, 
regional and more restricted levels, all tend progressively to develop and establish a common international understanding, ${ }^{919}$

If the 'rule of international law' is created through an interactional process that involves the parties as a whole (majority of states), these parties will be assumed to share the common understanding that the rule of international law is intended to be applicable to them in an interpretative process. This applies even though the parties, on an individual basis, might not be party to the external international law taken into account.

This approach adopted in dealing with 'the parties' is deemed more appropriate in light of the prevailing multilateral setting of international law-making, where the normative development of international law on the environment is conducted through multilateral settings that involve the majority of states. Under such settings, an ascertainment of law that embraces diversity in the face of pluralised interests with thin commonalities, and promotes legitimacy that facilitates achievement of shared understandings, is very much in need.

It is not only a matter of theoretical importance in looking at law from an interactional perspective. It is also a matter of practicality and pragmatism. Looking at a rule of (international) law through an interactional perspective enables the operationalisation of Article 31(3)(c) for the interpretation of a rule of law in its systemic environment in light of the principle of systemic integration.

\subsection{Conclusion}

The re-interpretation of the phrase 'rules of international law applicable in the relations between the parties' in light of an interactional understanding of law enables the revelation of the implicit dimension of the shared legal understanding that provides the normative foundation to an explicit rule. The normative content and scope of a relevant rule of international law, brought to the forefront through an interactional ascertainment of international law via the three-component framework inform the interpretation of a treaty term or provision by virtue of Article 31(3)(c).

The next two chapters (Chapters Five and Six) proceed to illustrate the application of this architecture of interpretation constructed from an understanding of international law

\footnotetext{
${ }^{919}$ Pierre-Marie Dupuy, 'Soft Law and the International Law of the Environment' (1991) 12 Michigan Journal of International Law 420 - 435, at p 424.
} 
from an interactional perspective. The rules that are considered relevant are assessed through the three-tier interactional framework of shared understanding; satisfaction of legality; and a practice of legality in the determination of whether these rules are rules of international law applicable in the relations between the parties. The assessment of a rule through the interactional framework developed in this chapter identifies the normative content and to what extent these rules are applicable in the relations between the parties for the purpose of interpretation in accordance with Article 31(3)(c) of the 1969 Vienna Convention. 
5

\section{Chapter 5. Rules of International Law Applicable in the Relations between the Parties: An Interactional Understanding of Law}

\section{Part II: Operation - 1971 Ramsar Convention on Wetlands}

\subsection{Overview}

A review of existing interpretation of Article 31(3)(c) of the 1969 Vienna Convention in Chapter 4 of this thesis revealed that a separate interpretation of selected terminologies of the Article, such as 'applicable' and 'the parties', is incapable of operationalising the Article to reflect the principle of systemic integration. A reconstruction of the interpretation for 'rules of international law applicable in the relations in the relations between the parties' is necessary where what is 'applicable in the relations between the parties' has been shown to be qualified and conditioned by the nature and content of 'rules of international law'. What is 'applicable in the relations between the parties' depends on the external rule of international law sought to be taken into account in the interpretative process. The nature of the 'relevant rule of international law' determines whether it is applicable in the relations between the parties.

This realisation highlights the importance of exploring and identifying the content and status of the external rule of international law. The ascertainment of the content and fidelity of the rule of international law through an interactional understanding of law clarifies the interpretation of the 'rule of international law that is applicable in the relations between the parties'. The ascertainment of the extent of the relevant rule of international law is undertaken through an interactional perspective of law. A rule of international law is understood as a shared legal understanding undertaken in a practice of legality by the purposive enterprise of law. The emergence of a rule of international law is characterised by the attainment of a practice of legality of a certain specificity and density along the continuum of social norms at one end, and legal norms at the other end.

The conceptualisation of a rule of international law through an interactional understanding of law reflects scholars' interpretation of 'the parties', where 'the parties' need not be a party to the external rule as long as the rule reflects the common understanding of the parties. This common understanding can be deduced from the 
shared legal understanding developed through the interactional and reciprocal process of law making.

The 'rules of international law applicable in the relations between the parties' that shall be taken into account in the interpretation of the obligation to preserve ecosystems of international watercourses in Article 20 of the 1997 Watercourses Convention will be determined through an interactional framework. This framework consists of three components, namely shared understanding; criteria of legality; and practice of legality. An interactional understanding of law looks beyond the legal formality of the formation of law limited through formal sources of law. It identifies, through the interactional and reciprocal process of the formation of law, the normative content, and the legality of rules. The subsequent section will look into the rules of international law through the prism of the three components in order to uncover the content of the rules of international law that determines whether it is 'applicable in the relations between the parties'.

This chapter will first determine the shared understandings implicit to Articles 2.1 and 4.1 of the Ramsar Convention, identified to be relevant for the interpretation in Chapter Two for the interpretation of Article 20 of the 1997 Watercourses Convention. Secondly, it will assess the shared understanding against the eight criteria of internal morality in the determination of its legal validity. Thirdly, the chapter proceeds to ascertain whether the parties to the COP of Ramsar Convention performed the shared legal understanding attained at the institutionalised law-making platform of COP in a practice of legality.

This is necessary to confirm that these rules are 'rules of international law' within Article 31(3)(c) from the perspective of an interactional understanding of international law. In addition, the assessment of these rules through the interactional framework enables the ascertainment of their normative content, and allows the identification, from the shared legal understanding undertaken in a practice of legality, whether these rules of international law are 'applicable in the relations between the parties'.

\subsection{Rules of International Law - Shared Understanding}

Chapter Two established that Articles 2.1 and 4.1 of the Ramsar Convention are relevant for the interpretation of the obligation to preserve the freshwater ecosystems of 
international watercourses. ${ }^{920}$ This section will explore the shared legal understanding undertaken in a practice of legality of these rules in order to determine what is the content of the rules that are 'applicable in the relations between the parties'.

The 2002 Guidelines for management planning for Ramsar sites and other wetlands adopted by Resolution VIII.14 (2002) were specifically developed to address the requirements of Articles 3 and 4.1 of the Ramsar Convention. ${ }^{921}$ Articles 3 and 4.1 seek to promote the conservation of wetlands and waterfowl through the establishment of nature reserves on wetlands, and provide for their management thereof. The interpretation and application of these Articles are furnished by the 2002 Guidelines, where requirements concerning the conservation of wetlands in Listed and non-Listed wetlands are specified, with particular focus on site-based management planning. ${ }^{922}$

The 2002 Guidelines for the management of Listed and non-Listed Ramsar sites are complemented by the 2009 Strategic Framework and Guidelines for the Future Development of the List of Wetlands of International Importance of the Convention on Wetlands (Ramsar, Iran, 1971). ${ }^{923}$ The 2009 Strategic Framework guides the implementation for the future development of Listed wetlands, and its objective is to develop and maintain an international network of wetlands 'important for the

\footnotetext{
${ }^{920}$ Art 2(1) provides that 'Each Contracting Parties shall designate suitable wetlands within its territory for inclusion in a List of Wetlands of International Importance'. Art 3.1 provides that 'The contracting Parties shall formulate and implement their planning so as to promote the conservation of the wetlands included in the List, and as far as possible the wise use of wetlands in their territory'. Article 4(1) provides that 'each Contracting Party shall promote the conservation of wetlands and waterfowl by establishing nature reserves on wetlands, whether they are included in the List or not, and provide adequately for their wardening'.

${ }^{921}$ Ramsar Convention, 'New Guidelines for Management Planning for Ramsar Sites and Other Wetlands' (adopted by Resolution VIII.14 (2002) of the Ramsar Convention), para 2. See Ramsar Convention, 'Resolution VIII.14: New Guidelines for Management Planning for Ramsar Sites and Other Wetlands' (Valencia, Spain, 18 - 26 November 2002) <http://www.ramsar.org/cda/en/ramsar-documents-resolresolution-viii-14-new/main/ramsar/1-31-107\%5E21393_4000_0_> accessed 18 July 2012 (hereinafter: 'New Guidelines for Management Planning for Ramsar Sites and Other Wetlands') . It is noted that 'Resolutions are what the Contracting Parties commit themselves to do'. Agenda Item 16.7 Conference Decisions, para 257, Ramsar Convention, 'Minutes of the $20^{\text {th }}$ Meeting of the Standing Committee, Fourth Day, 3 October 1997' (Minutes of the 20 ${ }^{\text {th }}$ Meeting of the Standing Committee, 29 September -3 October 1997, Gland, Switzerland, 17 October 1997) <http://www.ramsar.org/cda/es/ramsar-documentsstanding-minutes-of-20th/main/ramsar/1-31-41\%5E21668_4000_2_> accessed 20 July 2012.

922 Ramsar Convention, 'New Guidelines for Management Planning for Ramsar Sites and Other Wetlands', supra n 921, at para 3.

${ }^{923}$ Ramsar Convention, '2009 Strategic Framework and Guidelines', supra n 426.
} 
conservation of global biological diversity and for sustaining human life through the maintenance of their ecosystem components, processes and benefits/services'. ${ }^{924}$

Due to the permanent presence, or presence for some significant period of time, of water in wetlands, the wetland ecosystems are adapted to the hydrological regime that is influenced by the quantity and quality of freshwater flowing into these wetlands. ${ }^{925}$ The successful management of wetlands sites thus requires maintenance of sources of water inter-connected through the hydrological cycle, and puts the river basin as the fundamental functional unit for water management. ${ }^{926}$ It is clarified that the ecosystem approach, although focused on the maintenance of ecosystem structure and functioning, is broadly similar to the concept of Integrated Water Resources Management (IWRM) where the river basin, synonymous with the ecosystem boundary, is deemed the most appropriate physical entity for the planning and management of water. ${ }^{927}$

The 2002 Guidelines emphasise the role of management plans and a continuous, longterm management process in satisfaction of the obligations stipulated under Articles 3 and $4 .{ }^{928}$ The initial stage of management planning begins with a minimal management plan that meets the minimal requirement and equipped with an organisation responsible for its management. This establishes an adaptable and dynamic framework, which

${ }^{924}$ Ramsar Convention, '2009 Strategic Framework and Guidelines', supra n 426, at p 2, para 6. The amendment made in 2005 was to take into account subsequent development in ecosystems sciences whereby 'ecosystem benefits' is defined in accordance with the MA definition of ecosystem services as 'the benefits that people receive from ecosystems'.

925 Ramsar Convention, 'New Guidelines for Management Planning for Ramsar Sites and Other Wetlands', supra n 921, para 14.

${ }_{926}$ Ramsar Convention, 'New Guidelines for Management Planning for Ramsar Sites and Other Wetlands', supra n 921, at paras 15 and 16. In para 17, it is stated that 'when groundwater plays a significant role in supplying water to a wetland, and since the underlying aquifer does not always coincide with the surface river basin, more than one basin overlying the aquifer may constitute the appropriate unit of water resource management'. See Ramsar Convention, 'Resolution VII.18: Guidelines for Integrating Wetland Conservation and Wise Use into River Basin Management' (San José, Costa Rica, 10 - 18 May 1999) <http://www.ramsar.org/cda/en/ramsar-documents-resol-resolution-vii-18/main/ramsar/1-31107\%5E20586_4000_0_> accessed 18 July 2012.

927 Ramsar Convention, 'New Guidelines for Management Planning for Ramsar Sites and Other Wetlands', supra n 921, at para 19. Resolution X.19, COP10 confirms that the Consolidated Guidance for Integrating Wetland Conservation and Wise Use into River Basin Management annexed to this Resolution updates and wholly supersedes earlier guidance on the matter. The COP invites Contracting Parties to make good use of it as appropriate, adapting it as necessary to suit national conditions and circumstances within the frameworks of existing regional initiatives and commitments, in the context of sustainable development consistent with national institutions and legal frameworks. See Ramsar Convention, 'Resolution X.19. Wetlands and River Basin Management: Consolidated Scientific and Technical Guidance', $\left(10^{\text {th }}\right.$ Meeting of the Conference of the Parties to the Ramsar Convention, Changwon, 28 October - 4 November 2008) at paras 5 and 6 <http://www.ramsar.org/pdf/res/key_res_x_19 e.pdf> accessed 19 July 2012.

928 Ramsar Convention, 'New Guidelines for Management Planning for Ramsar Sites and Other Wetlands', supra n 921, at paras 6 and 41. 
enables gradual evolution and development in the management process as information becomes available. ${ }^{929}$ The management process involves the identification and designation of wetlands; the assessment and monitoring of wetlands; and the in situ and ex situ management of wetlands, where a flexible approach that allows appropriate response and adaptation to take place is adopted. ${ }^{930}$

The conservation objective and the recognition of the ecosystem approach are apparent in the 2002 Guidelines. The 2002 Guidelines stipulate, as part of the management planning process, the designation of a whole river basin into several types of zonation around the core wetland area if it does not include the surrounding area of influence. ${ }^{931}$ The 2002 Guidelines stress the importance of a buffer zone that surrounds the core wetland area in recognition of the influence the surrounding area might have on the ecological character of the wetland itself. ${ }^{932}$

The 2002 Guidelines recommend the application of an ecosystem approach that considers the functioning of the ecosystems in the designation of management site. ${ }^{933}$ Due to the dependence of wetlands on water supply from outside the wetland, the river basin or catchment area should be viewed as a buffer zone for the wetland, especially when water and land-use in these extended areas indirectly affect the ecological

\footnotetext{
929 Ramsar Convention, 'New Guidelines for Management Planning for Ramsar Sites and Other Wetlands', supra $\mathrm{n} 921$, at paras $41-44$.

${ }^{930}$ Ramsar Convention, 'New Guidelines for Management Planning for Ramsar Sites and Other Wetlands', supra n 921, at paras 44 - 48. The flexible approach adopted in the management of wetlands is known as 'adaptable management, see 'Part IX. Adaptable Management' in Ramsar Convention, 'New Guidelines for Management Planning for Ramsar Sites and Other Wetlands', supra n 921, at paras 48 52.

931 Ramsar Convention, 'New Guidelines for Management Planning for Ramsar Sites and Other Wetlands', supra n 921, at paras 53 - 57. In Para 56, it is stated that 'when the Ramsar site itself does not include a buffer zone, it is generally appropriate for management planning purposes to identify and establish such buffer zone around the core wetland area defined within a Ramsar site or other wetland'. It is further stated that 'when a wetland site is composed of discrete sub-sites, a buffer zone should be defined for each, including, where appropriate, all the area between the sub-sites'. In Para 57, it is stated that 'the location of a buffer zone in relation to the core wetland area of a designated Ramsar site will vary depending upon what ecosystems are included within the site boundaries. Where the designated site is only the wetland itself, then for management purposes a buffer zone should be defined in the surrounding area outside the designated site. In contrast, where the site encompasses the wetland and its surroundings, the buffer zone should extend to the boundaries of the designated site, and then a 'core area', perhaps the wetland ecosystem itself, defined within the site'.

${ }^{932}$ It stated that - ' $[\mathrm{t}]$ he buffer zone should be that area surrounding the wetland within which land use activities may directly affect the ecological character of the wetland itself. [T] he objective for land use within the buffer zone should be one of sustainable use through ecosystem management, consistent with the maintenance of the ecological character of the wetland.' Ramsar Convention, 'New Guidelines for Management Planning for Ramsar Sites and Other Wetlands', supra n 921, at para 56.

${ }^{933}$ Ramsar Convention, 'New Guidelines for Management Planning for Ramsar Sites and Other Wetlands', supra n 921, at p 4, para 19.
} 
character of the wetland. ${ }^{934}$ The Biosphere Reserve is an example of the zonation concept. It divides a site up to three zones - core zone, buffer zone (for research and training) and transition zone (for sustainable use). ${ }^{935}$

The 2002 Guidelines reveal that many Ramsar sites are mostly multiple use sites similar to Biosphere Reserves, even though some sites are designated within protected areas. ${ }^{936}$ The management objectives for multiple use sites differ from protected area sites, where the use of the core wetland is broadly to ensure that the ecological character of the wetland is maintained or enhanced in order to ensure the continuity of provision of ecosystem services and functions. ${ }^{937}$

The permission, according to the 2002 Guidelines, to allow for a designation of Ramsar site or a nature reserve as a multiple use site, indicates that the obligation to conserve wetlands under Articles 3 and 4 includes the core/buffer zonation approach for multiple uses and also the establishment of zonation for a particular use. ${ }^{938}$ The salient aspect for such designation is the establishment of zonation and management objectives for each zone. Full stakeholder participation from the earliest stage in the demarcation of zones

934 Ramsar Convention, 'New Guidelines for Management Planning for Ramsar Sites and Other Wetlands', supra n 921, para 58. It is further noted that 'if a particular case of wetland is situated within a very large river basin, basin-scale or coastal zone management may be seen as a third, outer zone for management purposes. A more limited buffer zone immediately surrounding the wetland may still be a necessary management planning tool'.

${ }^{935}$ Ramsar Convention, 'New Guidelines for Management Planning for Ramsar Sites and Other Wetlands', supra n 921, para 59. The Biosphere Reserve concept is potentially applicable to all reservation sites under Ramsar convention, especially when the site is designated as both a Ramsar site and Biosphere Reserve where the boundary for Ramsar site and the zonation established for the Biosphere Reserve should be clearly demarcated. Ramsar Convention, 'New Guidelines for Management Planning for Ramsar Sites and Other Wetlands', supra n 921, at para 59. It is stated that '[t]he Biosphere Reserve zonation concept, in which the site may include up to three zones - core zone, buffer zone (for research and training) and transition zone (for sustainable use) - is potentially applicable to all Ramsar sites, and should be applied whenever feasible and appropriate. Its application is particularly important where a site is designated as both a Ramsar site and Biosphere Reserve, and here the relationship between the Ramsar site boundary and the zonation established for the Biosphere Reserve should be clearly established'.

${ }^{936}$ Ramsar Convention, 'New Guidelines for Management Planning for Ramsar Sites and Other Wetlands', supra n 921, para 60. In para 61, it is elaborated that 'any zonation scheme should recognise the existing multiple uses of Ramsar sites and their surroundings, and ensure that management objectives for the core zone are designed primarily to maintain the ecological character of the wetland, as well as that those for any form of surrounding buffer zone are consistent with this maintenance of the ecological character. Clear, separate but complementary and mutually supportive management objectives should be established for each zone'.

937 Ramsar Convention, 'New Guidelines for Management Planning for Ramsar Sites and Other Wetlands', supra n 921, at para 60.

${ }^{938}$ Ramsar Convention, 'New Guidelines for Management Planning for Ramsar Sites and Other Wetlands', supra n 921, at para 62. The Man and the Biosphere Programme is an example of the core/buffer zonation approach for multiple uses. The zonation established for a particular use that is under discussion is ecotourism. 
and setting of objectives is involved in order to minimise user conflicts. ${ }^{939}$ This aspect is an important element in the ecosystem approach, where Principles 2 and 12 of the Ecosystem Approach Guidelines 2004 developed by the Biodiversity Convention impose that management should be decentralised to the lowest appropriate level in which all relevant sectors of society and scientific disciplines should be involved. ${ }^{940}$

At this point, it is observed that the scope of 'conservation' is informed by the recognition of the ecosystem and the ecosystem approach. The conservation process, which encompasses the initial identification of a natural or near natural site, and its designation and its continuous management, does not stop at the stage where the pristine or unspoilt site is designated and set aside for protection. It goes beyond an abstract understanding of preservation by ensuring, through continuous management, the safeguarding and even improvement of the ecological character of a reserve site ${ }^{941}$ to ensure sustainability of ecosystem functioning and values to maintain people's livelihood and the conservation of biodiversity. ${ }^{942}$ However, the expansive scope of the definition of conservation includes preservation, and is thus important in informing the interpretation of the term. ${ }^{943}$

The short-term target set by the Contracting Parties for the Ramsar List to the year 2010 to contain at least 2,500 sites covering 250 million hectares, reflects their concern over the continuing loss and degradation of wetlands in many parts of the world. ${ }^{944}$ The long-

\footnotetext{
939 Ramsar Convention, 'New Guidelines for Management Planning for Ramsar Sites and Other Wetlands', supra $\mathrm{n} 921$, at paras $63-64$.

940 Biodiversity Convention, Decision V/6, supra n 12, para 7(B)

941 Ramsar Convention, 'New Guidelines for Management Planning for Ramsar Sites and Other Wetlands', supra n 921, at para 60. The updated definition of 'ecological character', informed by the ecosystem approach is 'the combination of the ecosystem components, processes and benefits/services that characterise the wetland at a given point in time'. Benefits is defined in accordance with the MA's definition of ecosystem services as 'the benefits that people receive from ecosystems'. In Ramsar Convention, 'Resolution IX.1 Annex A. A Conceptual Framework for the Wise Use of Wetlands and the Maintenance of Their Ecological Character', supra n 422.

942 Ramsar Convention, 'New Guidelines for Management Planning for Ramsar Sites and Other Wetlands', supra $\mathrm{n} 921$, at para 60.

943 The present concept of 'conservation', as developed by the IUCN and in the World Conservation Strategy, includes both the 'classic' elements of protection and preservation, including restoration, and the safeguarding of ecological processes and genetic diversity besides management of natural resources in order to ensure their maintenance by sustainable utilisation. See Heijnsbergen, International Legal Protection of Wild Fauna and Flora, supra n 443, at pp 51 - 52. The need for an evolutionary interpretation of the term preservation is necessary, in the light of the advent of the ecosystem approach, and the intrinsic limitation of the definition of 'preservation' that constraints implementation. Van Heijnsbergen, at p 44 noted that the term preservation implies the intention of a durable guarantee against the loss of the damage to the object by defending it against external threats ... but it tells us little about the norms of management and the strategies necessary'.

${ }_{944}$ Ramsar Convention, '2009 Strategic Framework and Guidelines', supra n 426, at p 5, para 21.
} 
term target for the Convention is to include in the Ramsar List 'at least one suitable representative of each wetland type, according to the Ramsar classification system found within each biogeographic region' ${ }^{945}$

The 2009 Strategic Framework and Guidelines tighten the efforts ${ }^{946}$ of realising the vision of the Ramsar Convention. ${ }^{947}$ It refines the obligation to conserve wetlands, in particularly through the designation of Listed wetland sites under Article 2.1, while emphasising the importance for the natural or near natural national networks of Ramsar sites in each contracting party to be fully representative of the diversity of wetlands and their ecological and hydrological functions. ${ }^{948}$

${ }_{945}$ Ramsar Convention, ‘2009 Strategic Framework and Guidelines', supra n 426, at p 17, para 65.

${ }^{946}$ Ramsar Convention, '2009 Strategic Framework and Guidelines', supra n 426, p 2, para 4. It is commented that the strategic direction given to the development of the Listed Wetlands has previously been rather limited. The $6^{\text {th }}$ COP urged Parties through the Convention's Strategic Plan $1997-2002$, to 'increase the area of wetland designated for the List of Wetlands of International Importance particularly for wetland types that are under-represented either at the global or national levels' (Operational Objective 6.2). The 2009 Strategic Framework and Guidelines, supra n 426, reiterated the purpose of the adoption and subsequent amendment of the Guidelines, which is - 'to provide a clearer view, or vision, of the longterm targets or outcomes which the Convention is seeking to achieve through the Ramsar List; [and] to assist Contracting Parties in taking a systematic approach to identifying their priorities for future designations, in order to create comprehensive national networks of Ramsar sites, which, when considered at the global level, fulfil the stated vision for the Ramsar List'. See also Ramsar Convention, '2009 Strategic Framework and Guidelines', supra n 426, p 2, para 5.

${ }^{947}$ The visions are - to 'develop and maintain international network of wetlands important for the conservation of global biological diversity and for sustaining human life' where the international network of wetlands sites are 'built from coherent and comprehensive networks of Ramsar Listed wetlands established within the territory of each Contracting Party to the Convention'. See Ramsar Convention, '2009 Strategic Framework and Guidelines', supra n 426, pp 2 and 3, paras 6 and 7.

${ }^{948}$ Objective 1, Ramsar Convention, '2009 Strategic Framework and Guidelines', supra n 426, at p 3. In para 9, it is stated that 'the criteria for designation should be 'suitable' (ie internationally important) and representative of every natural or near-natural wetland type present in each 'biogeographic region', as defined globally, supranationally/regionally or nationally'. Para 10 stated that, 'suitable site' is determined in relation to those wetlands that "play a substantial ecological or hydrological role in the natural functioning of a major river basin, lake, or coastal system'. Objective 2, Ramsar Convention, '2009 Strategic Framework and Guidelines', p 3. Para 11 stated that development of the Ramsar List should be reviewed where Criteria for identification and selection of Ramsar sites should be further refined as appropriate to best promote conservation of biodiversity and wise use of wetlands at the local, subnational, national, supranational/regional, and international levels. In the context of the conservation of global biodiversity, the second objective explicitly takes on the inclusion of wetlands into the Ramsar List wetlands that consist of threatened ecological communities critical to the survival of vulnerable, endangered or critically endangered endemic species; wetlands that are critical to the conservation of biodiversity in each biogeographic region; wetlands that provide important habitat for plant and animal species at critical stages in their life cycle or during adverse conditions; or wetlands that are of direct significance for waterbird and fish species or stocks, as well as other taxa determined by the relevant Ramsar site selection criteria. See Objective 2, Ramsar Convention, '2009 Strategic Framework and Guidelines', supra n 426, at pp $3-4$, paras 12 - 15. Para 12 stated that threatened ecological communities or ecological communities critical to the survival of endemic species identified as vulnerable, endangered or critically endangered under national, international or intergovernmental endangered species legislation or programmes. Biogeographic region is define as 'a scientifically rigorous determination of regions as established using biological and physical parameters such as climate, soil type, vegetation cover, etc. See also p 7, para 32, For many contracting parties, biogeographic regions will be 
The criteria of representativeness, rarity or uniqueness of wetlands that are in a natural or near natural state for the designation of wetland sites within a biogeographic region ${ }^{949}$ have particular emphasis on their ecological character. The designation of wetlands requires that the ecological character of the site should play a substantial role in the natural functioning of a major river basin or coastal system, especially the hydrological functions provided by wetland ecosystems. ${ }^{950}$ A wetland is considered important, which warrants designation for conservation, if it is critical to the sustenance of species, ecological communities, and populations of flora and/or fauna. ${ }^{951}$

These objectives and the subsequently developed criteria have greatly enhanced the scope of the obligation to conserve wetlands - not just the conservation of wetlands as habitats for waterfowls, but also the extension of the conservation objectives to include biodiversity conservation, in recognition of wetlands as a rich source of biodiversity of international importance. ${ }^{952}$

The 2009 Strategic Conservation Framework and Guidelines elaborate the processes and procedural mechanisms required for the conservation of wetlands in accordance with Article 4.1 of the Ramsar Convention. Conservation starts with the designation of wetlands according to specific criteria, guided by the 2009 Strategic Framework and Guidelines on the identification and designation of specific wetland types; ${ }^{953}$ temporary pools $;{ }^{954}$ and artificial wetlands, ${ }^{955}$ as Ramsar Wetlands of International Importance. The designation of sites is followed by the presentation of information on the sites for the Ramsar database, including the reasons for their inclusion into the Ramsar List

transboundary in nature and will require collaboration between countries to define those wetland types which are representative, unique, etc. In some regions and countries, the term 'bioregion' is used as a synonym for 'biogeographic region'.

${ }_{949}$ Criterion 1, Ramsar Convention, '2009 Strategic Framework and Guidelines', supra n 426, at p 17.

${ }^{950}$ Ramsar Convention, '2009 Strategic Framework and Guidelines', supra n 426, at p 17, para 68. The hydrological attributes may include, as stated in para 69: (i) a major role in the natural control, amelioration or prevention of flooding; (ii) importance for seasonal water retention for wetlands or other areas of conservation importance downstream; (iii) important for the recharge of aquifers; (iv) form part of karst or underground hydrological or spring systems that supply major surface wetlands; (v) major natural floodplain system; (vi) having major hydrological influence in the context of at least regional climate regulation or stability (eg certain areas of cloudforest or rainforest, wetlands or wetland complexes in semi-arid, arid or desert areas, tundra or peatland systems acting as sinks or carbon, etc); and (vii) having a major role in maintaining high water quality standards.

${ }^{951}$ For detail elaboration, refer to Criteria 2, - 9 of Objective 2, pp 18 - 25, Ramsar Convention, '2009 Strategic Framework and Guidelines', supra n 426.

${ }_{952}$ Ramsar Convention, '2009 Strategic Framework and Guidelines', supra n 426, at p 5, para 21.

953 Ramsar Convention, '2009 Strategic Framework and Guidelines', supra n 426, at pp $26-39$.

${ }^{954}$ Ramsar Convention, '2009 Strategic Framework and Guidelines', supra n 426, at pp $39-44$.

955 Ramsar Convention, '2009 Strategic Framework and Guidelines', supra n 426, at p 44. 
according to the criteria set out, and the Ramsar classification system for wetland types. $^{956}$

The presentation of information for sites on the Ramsar database are in the form of the Information Sheet on Ramsar Wetlands (RIS), which is completed and supplied to the Ramsar Secretariat after designation of sites by a contracting party, and updated at least every six years. ${ }^{957}$ Submission of information is important where the initial submission defines the ecological character of Ramsar sites as the basis for monitoring and management of wetlands for their continual maintenance. The information provided in the RIS should be consistent with the description of the ecological character, features, values and functions of the wetland, the factors affecting or likely to affect its character, values and functions, and the management planning process, including monitoring in the management plan prepared for the designated site. ${ }^{958}$

Apart from the initial submission of information of designated wetlands that requires to be updated periodically, the ongoing reporting and monitoring of the implementation of the obligation to conserve are an important element of the procedural mechanism imposed under the obligation to conserve. The Contracting Parties are required to submit the relevant information on the conservation undertaken in Ramsar sites in accordance with Item 27 of the RIS. ${ }^{959}$ The Contracting Parties need to provide details on nationally relevant protected area status, international conservation designations (in addition to Ramsar site status), and the bilateral or multilateral conservation measures on transboundary wetlands, as appropriate. ${ }^{960}$ If a reserve has been established, information such as the date of establishment, size of the protected area, or the part of

\footnotetext{
${ }^{956}$ Ramsar Convention, '2009 Strategic Framework and Guidelines', supra n 426, at p 50. In p 57, para 19 , it is noted that the Classification System for Wetland Type provides the description of what types of wetland are covered by each of the wetland type codes, grouped in three major categories: marine-coastal, inland, and human-made wetlands, and that wetland types under two or more of these categories may be present within a Ramsar site. See also 'Annex B Ramsar Classification System for Wetland Type' pp 64 66, in Ramsar Convention, '2009 Strategic Framework and Guidelines', supra n 426.

${ }^{957}$ Ramsar Convention, '2009 Strategic Framework and Guidelines', supra n 426, at p 50.

958 Ramsar Convention, '2009 Strategic Framework and Guidelines', supra n 426, at p 51. A comprehensive guide on the information to be provided in each numbered section of the RIS is found at pp $52-63$.

959 'Appendix A, Information Sheet on Ramsar Wetlands', at p 49 in Ramsar Convention, '2009 Strategic Framework and Guidelines', supra n 426, at pp $45-49$.

${ }^{960}$ 'Explanatory Note and Guidelines for Completing the Information Sheet on Ramsar Wetlands (RIS)' in 'Appendix A, Information Sheet on Ramsar Wetlands', supra n 426, at p 60.
} 
wetland included within a protected area where the area of protected wetland habitat is noted, is to be submitted. ${ }^{961}$

The RIS submission requirements recommend that the IUCN management categories for protected areas ${ }^{962}$ be applied to the designated Ramsar sites. ${ }^{963}$ The categories of a particular Ramsar site will indicate the extent of the commitment to conserve by the contracting parties on that particular site. The 2009 Strategic Framework and Guidelines illustrate the common understanding of the contracting parties to adopt IUCN's categorisation method in the designation of wetlands for the purpose of conservation. The recommendation of the adoption of the IUCN categorisation indicates the more expansive interpretation of 'conservation', although preservation is still an important element of conservation.

The categorisation of protected areas under the IUCN approach can be broadly classified into two types - preservation and sustainable use. Categories Ia, Ib and III share a similar trait, that is, their protection motivation is not to supply benefits or services to sustain human livelihoods, but to protect the outstanding representativeness of their natural condition and their aesthetic qualities or cultural significance. ${ }^{964}$

The 'preservation-cluster' of the IUCN categorisation corresponds with the Group A criteria laid out in the 2009 Strategic Framework and Guidelines, which stipulates that a wetland should be considered internationally important if it contains a 'representative, rare, or unique example of a natural or near-natural wetland type found within the appropriate biogeographic region'. ${ }^{965}$ This criterion develops into the conservation of

\footnotetext{
${ }^{961}$ Item 27 of the RIS, see Para 27(a), 'Explanatory Note and Guidelines for Completing the Information Sheet on Ramsar Wetlands (RIS)', supra n 426, at p 60.

962 Para 27(b), 'Explanatory Note and Guidelines for Completing the Information Sheet on Ramsar Wetlands (RIS)', supra n 426, at p 61. It is elaborated that IUCN defines a 'protected area' as : 'An area of land and/or sea especially dedicated to the protection and maintenance of biological diversity, and of natural and associated cultural resources, and managed through legal or other effective means'.

963 Para 27(b), 'Explanatory Note and Guidelines for Completing the Information Sheet on Ramsar Wetlands (RIS)', supra n 426, at pp 60 - 61.

${ }^{964}$ See 'Explanatory Note and Guidelines for Completing the Information Sheet on Ramsar Wetlands (RIS)', supra n 426, at p 61, para 27(b). Category Ia Strict Nature Reserve, categorises area of land and/or sea 'possessing some outstanding or representative ecosystem, geological or physiological features and/or species that is available primarily for scientific research and/or environmental monitoring purpose. Category Ib Wilderness Area, refers to a large area of unmodified or slightly modified land and/or sea that is protected to preserve its natural condition. Category III Natural Monument, categorises reserve area containing one, or more specific natural or natural/cultural feature which is of outstanding or unique value because of its inherent rarity, representative or aesthetic qualities or cultural significance.

${ }^{965}$ Criterion 1, 'Annex C. Criteria for Identifying Wetlands of International Importance and Guidelines for Their Application' in Ramsar Convention, '2009 Strategic Framework and Guidelines', supra n 426, at $\mathrm{p} 67$.
} 
natural reserves that protects for sustainability and not development, ${ }^{966}$ whereby the objective of conservation is not benefits/services oriented. These areas are protected because they 'possess outstanding or representative ecosystems, geological or physiological features and/or species, ${ }^{967}$ in a near-natural or natural condition; ${ }^{968}$ or contain outstanding or unique value due to their inherent rarity, representative or aesthetic qualities or cultural significance. ${ }^{969}$

Category II is located on the sustainable use cluster of the IUCN categorisation, where designation as protected area served mainly to protect the ecosystem integrity of the area in order to ensure continuous enjoyment of the present and future generation for spiritual, scientific, educational, recreational uses, on the condition of that these uses are environmentally and culturally compatible. ${ }^{970}$ Protection of pristine or natural conditions is not imposed, as long as modifications to the protected areas due to usage are not inimical or adversely affect the ecosystem integrity of these areas.

Similarly, Category VI establishes areas of protection focused on the long-term protection and maintenance of biological diversity which at the same time ensure the provision of a sustainable flow of natural products and services for the satisfaction of the needs of communities. ${ }^{971}$ The protection of areas that consist of predominantly unmodified natural systems is to ensure the safeguard of the integrity of the ecosystems through the protection of its biodiversity for the benefits of continual sustenance of human livelihood. Although the protection of the area is benefits- or services-oriented, the outcome is the maintenance of the areas of protection in its predominantly unmodified form satisfies the restricted scope of preservation.

\footnotetext{
${ }^{966}$ Ramsar Convention, 'Resolution IX.1 Annex A. A Conceptual Framework for the Wise Use of Wetlands and the Maintenance of Their Ecological Character', supra n 422, at p 7, fn 3.

${ }^{967}$ Category Ia, Para 27(b), 'Explanatory Note and Guidelines for Completing the Information Sheet on Ramsar Wetlands (RIS)', supra n 426, at p 61.

${ }_{968}$ Category Ib, Para 27(b), 'Explanatory Note and Guidelines for Completing the Information Sheet on Ramsar Wetlands (RIS)', supra n 426, at p 61.

${ }^{969}$ Category III Natural Monument, Para 27(b), 'Explanatory Note and Guidelines for Completing the Information Sheet on Ramsar Wetlands (RIS)', supra $\mathrm{n} 426$, at $\mathrm{p} 61$.

${ }^{970}$ The conservation for the services and benefits a wetland ecosystem can provide can be found mainly in Category II of the IUCN categorisation. Category II established areas of protection that - 'protect the ecological integrity of one or more ecosystems for the present and future generations; exclude exploitation or occupation inimical to the purpose of designation; and provide a foundation for spiritual, scientific, educational, recreational and visitor opportunities that are environmentally and culturally compatible'. Category II National Park, Para 27(b), 'Explanatory Note and Guidelines for Completing the Information Sheet on Ramsar Wetlands (RIS)', supra n 426, at p 61.

${ }^{971}$ Category VI Managed Resource Protected Area, Para 27(b), 'Explanatory Note and Guidelines for Completing the Information Sheet on Ramsar Wetlands (RIS)', supra n 426, at p 61.
} 
Categories II and VI correspond loosely to the Group B Criteria ${ }^{972}$ for designation of wetlands sites for the conservation of biodiversity. The importance of the designated site is not due to the protection of vulnerable or endangered species. Instead, it is deemed important to ensure the conservation of biodiversity crucial to the maintenance of ecosystem integrity for the production and provisioning services, aesthetic, spiritual, scientific, educational, recreational and touristic enjoyment of human beings.

Category IV is not established specifically for human livelihoods, and allows intervention to ensure maintenance of habitats. ${ }^{973}$ This Category reflects the initial motivation for the establishment of the Ramsar Convention, which is the protection of wetlands important as habitat for waterfowl. Apart from the inclusion of fishes and other non-avian taxa, Category IV of protected areas for habitat/species management provides for active management intervention to ensure the maintenance of habitats to meet the requirements of specific species. This category corresponds largely with several criteria established for the designation of wetlands, especially criteria established based on specific species, such as Criteria 5 and 6 on waterbirds; Criteria 7 and 8 on fish, and Criterion 9 that provides generally to other non-avian taxa that is wetland-dependent. ${ }^{974}$

A broad approach is envisioned in Category $\mathrm{V}$ where the protection areas span across a landscape and/or a seascape that covers a vast area of land, with coast and sea as appropriate. ${ }^{975}$ The protection protects evolution of interaction between humans and their environment that results in 'an area of distinct character with significant aesthetic, ecological and/or cultural value, and often with high biological diversity. ${ }^{976}$ The protection of the landscape or seascape aims to safeguard the integrity of the traditional interaction between people and nature over time, which is vital to the maintenance and evolution of such an area. ${ }^{977}$

\footnotetext{
972 'Annex C. Criteria for Identifying Wetlands of International Importance and Guidelines for Their Application' in Ramsar Convention, '2009 Strategic Framework and Guidelines', supra n 426, at p 67.

973 Category VI Habitat/Species Management Area, Para 27(b), 'Explanatory Note and Guidelines for Completing the Information Sheet on Ramsar Wetlands (RIS)', supra $\mathrm{n}$ 426, at p 61.

974 'Annex C. Criteria for Identifying Wetlands of International Importance and Guidelines for Their Application' in Ramsar Convention, 'Strategic Framework and Guidelines', supra n 426, at pp 67 and 68.

${ }^{975}$ Category V Protected Landscape/Seascape, Para 27(b), 'Explanatory Note and Guidelines for Completing the Information Sheet on Ramsar Wetlands (RIS)', supra n 426, at p 61.

976 Category V Protected Landscape/Seascape, Para 27(b), 'Explanatory Note and Guidelines for Completing the Information Sheet on Ramsar Wetlands (RIS)', supra n 426, at p 61.

977 Category V Protected Landscape/Seascape, Para 27(b), 'Explanatory Note and Guidelines for Completing the Information Sheet on Ramsar Wetlands (RIS)', supra n 426, at p 61.
} 
In sum, the shared understanding of the contracting parties is evidenced in the adoption of the 2009 Strategic Framework and Guidelines that enumerate specific content of the Parties' obligation to conserve. The Contracting Parties agreed to categorise protected areas management according to the list of categories proposed by IUCN whenever appropriate $;{ }^{978}$ provide a description of the management planning process; $;{ }^{979}$ and submit a copy of management plan developed or approved for the site as supplementary information to the RIS, if available. ${ }^{980}$ The 2009 Strategic Framework and Guidelines provide further direction, elaboration and clarification in the implementation of the vision, objectives and targets of the Ramsar Convention, especially for Listed Wetlands. These are done through the adoption of a systematic approach in the identification of priority wetlands for designation, and enhance the RIS as a comprehensive tool in the satisfaction of the reporting and monitoring procedural obligations stipulated under the Ramsar Convention.

The 2002 Guidelines are relevant as general management guidance for Listed and nonListed Wetlands, especially in terms of the methodology of management, the drafting of management plan, and the integration of the management of designated wetlands within the broader management scale under the integrated water resources management and integrated coastal zone management frameworks.

The implementation of the Ramsar Convention is assisted through a series of Ramsar Strategic Plans, the most current in operation being the third Ramsar Strategic Plan 2009 - 2015, ${ }^{981}$ where the Strategic Plan that aims to contribute towards the implementation of the Ramsar Convention is further strengthened the shared legal understanding enshrined in the Ramsar Convention. In particularly, it specifies that the Strategic Plan aim to contribute to -

\footnotetext{
${ }^{978}$ Para 27(b), 'Explanatory Note and Guidelines for Completing the Information Sheet on Ramsar Wetlands (RIS)', supra n 426, at p 60.

${ }^{979}$ Para 27(c), 'Explanatory Note and Guidelines for Completing the Information Sheet on Ramsar Wetlands (RIS)', supra n 426, at p 61.

${ }^{980}$ Para 27(c), 'Explanatory Note and Guidelines for Completing the Information Sheet on Ramsar Wetlands (RIS)', supra n 426, at p 61.

${ }^{981}$ Ramsar Convention, 'The Ramsar Strategic Plan 2009 - 2015' (adopted by Resolution X.1) (Ramsar Convention, Changwon 2008) <http://www.ramsar.org/pdf/key_strat_plan_2009_e.pdf> accessed 19 July 2012, para 24. See Ramsar Convention, 'Resolution X.1. The Ramsar Strategic Plan $2009-2015^{\prime}$ (10 ${ }^{\text {th }}$ Meeting of the Conference of the Parties to the Convention on Wetlands, Changwon, Republic of Korea, 28 October -4 November 2008) <http://www.ramsar.org/pdf/res/key res_x_01_e.pdf > accessed 19 July 2012.
} 
'a common understanding at global, national and subnational levels of the Convention's purposes and principles, ... [and] progress at all levels in the conservation and wise use of wetlands and the related benefits for biodiversity and human well-being, ${ }^{982}$

The Strategic Plan is devised to achieve the goals of the Ramsar Convention where strategies are developed towards identified and targeted key result areas. The first goal in the implementation of the Ramsar Convention is the wise use of wetlands where the necessary, appropriate instruments and measures are developed, adopted and used. ${ }^{983}$ The wise use of wetlands means, inter alia, more participative management of wetlands, where conservation decisions are made with an awareness of the importance of the ecosystem services provided by wetlands. ${ }^{984}$

The obligation to conserve wetlands as nature reserves is developed further under Goal 2 of the Strategic Plan 2009 - 2015. ${ }^{985}$ Goal 2 seeks to 'develop and maintain an international network of wetlands that are important for the conservation of global biological diversity, including waterbird flyways and fish populations and for sustaining human life'. ${ }^{986}$ The common understanding of the contracting parties of the Ramsar Convention as to the conservation of wetlands is carefully laid out in the strategies develop to achieve this goal. The strategies develop to achieve Goal 2 adopt a step-wise approach.

Strategy 2.1 provides the first step in the designation of a Ramsar site. ${ }^{987}$ The purpose of the designation of the Ramsar site is to facilitate the preparation of national plan and management priorities for these sites and increase the covering of Ramsar sites worldwide, especially the designation of Ramsar sites from under-represented wetlands types. ${ }^{988}$ Strategy 2.2 reflects the Ramsar Guidelines that management is a continuous, long-term process that is adaptable and dynamic, where a management plan will grow

\footnotetext{
982 Ramsar Convention, 'The Ramsar Strategic Plan 2009 - 2015', supra n 981, at p 4, para 24.

${ }^{983}$ Ramsar Convention, 'The Ramsar Strategic Plan 2009 - 2015', supra n 981, at p 6.

${ }^{984}$ Ramsar Convention, 'The Ramsar Strategic Plan 2009 - 2015', supra n 981, at p 6.

${ }^{985}$ Ramsar Convention, 'The Ramsar Strategic Plan 2009-2015', supra n 981, at pp 10 - 12.

${ }^{986}$ Ramsar Convention, 'The Ramsar Strategic Plan 2009 - 2015', supra n 981, at p 10.

987 Ramsar Convention, 'The Ramsar Strategic Plan 2009 - 2015', supra n 981, at p 10. Ramsar Convention, Handbook 14. Data and Information Needs. A Framework for Ramsar Data and Information Needs $\left(4^{\text {th }}\right.$ edn, Ramsar Handbooks, Ramsar Convention, 2010) < http://www.ramsar.org/pdf/lib/hbk414.pdf> accessed 19 July 2012.

${ }^{988}$ Strategy 2.1.i - 2.1.iv, Ramsar Convention, 'The Ramsar Strategic Plan 2009-2015', supra n 981, at $\mathrm{p} 10$.
} 
as information becomes available. ${ }^{989}$ It ensures that the Ramsar Sites Information Service is available and enhanced as a tool for guiding further designation of wetlands under the List, and for the purpose of research and assessment. ${ }^{990}$ Strategy 2.3 recommends that new Ramsar sites should have effective management planning prior to designation, as well as resources for the implementation of the management plan. ${ }^{991}$ The objective of the planning and management of all designated Ramsar sites is to maintain the ecological character of these sites through several measures, including zoning measures for larger Ramsar sites, wetland reserves and other wetlands, and strict protection measures in certain wetlands of particular sensitivity. ${ }^{992}$ A dynamic and adaptable management process necessitates a review of all existing Ramsar sites to determine the effectiveness of management arrangements. ${ }^{993}$

The obligation under Article 3.1 of the Ramsar Convention is specifically addressed in Strategy 2.6, where the condition of these sites are monitored and negative changes in their ecological character are addressed and reported to the Secretariat. Where appropriate, tools such as the Montreux Record and the Ramsar Advisory Mission can be applied to address problems. ${ }^{994}$ For non-Listed sites, Strategy 2.7 requires that the appropriate management and wise use of wetlands provided under Ramsar's 2002 Guidelines for the management and planning of Ramsar sites and other wetlands should be applied, with priority on recognised internationally important wetlands not yet designated as Ramsar sites. ${ }^{995}$

The Ramsar Strategic Plan 2009 - 2015 is intended to provide guidance to all relevant parties on how they should focus their efforts in the implementation of the Ramsar Convention over the next two triennia. ${ }^{996}$ It was adopted by the $10^{\text {th }}$ Meeting of the COP to the Ramsar Convention in Resolution X.1 where the Strategic Plan 2009 - 2015 was approved as the basis for the future implementation of the Convention. ${ }^{997}$ The approval of the Strategic Plan by the contracting parties is based on the recognition that each contracting party is free to choose the extent to which it will implement the Strategic

\footnotetext{
989 Ramsar Convention, 'New Guidelines for Management Planning for Ramsar Sites and Other Wetlands', supra $\mathrm{n} 921$, at paras 41 and 43.

${ }^{990}$ Strategy 2.2, Ramsar Convention, 'The Ramsar Strategic Plan 2009 - 2015', supra n 981, at p 10.

${ }_{991}$ Ramsar Convention, 'The Ramsar Strategic Plan 2009 - 2015', supra n 981, at p 11.

992 Strategy 2.4, Ramsar Convention, 'The Ramsar Strategic Plan 2009 - 2015', supra n 981, at p 11.

${ }_{993}$ Strategy 2.5, Ramsar Convention, 'The Ramsar Strategic Plan 2009 - 2015', supra n 981, at p 11.

994 Strategy 2.6, Ramsar Convention, 'The Ramsar Strategic Plan 2009 - 2015', supra n 981, at p 12.

995 Strategy 2.7, Ramsar Convention, 'The Ramsar Strategic Plan 2009-2015', supra n 981, at p 12.

${ }_{996}$ Ramsar Convention, 'The Ramsar Strategic Plan 2009-2015', supra n 981, at p 1, para 1.

${ }^{997}$ Ramsar Convention, 'The Ramsar Strategic Plan 2009-2015', supra n 981, at para 8.
} 
Plan, the resource allocated for its implementation and the timeframes used in the implementation. ${ }^{998}$ The approval of the Strategic Plan, despite being couched in the softer language of implementation to the extent deemed fit by each Contracting party, still contributes towards a common understanding of the contracting parties as to the purposes and principles of the Convention. It strengthens the commitments of the parties to an improved implementation and progress at all levels in the conservation and wise use of wetlands. ${ }^{999}$

The shared commitment as exhibited in the adoption of the Ramsar Strategic Plan 2009 - 2015 is further strengthened in the recent adjustments made to the Strategic Plan for the 2013 - 2015 triennium adopted in Resolution XI.3. ${ }^{1000}$ The preambular language of Resolution XI.3 recalls the request of the COP for the Standing Committee to assess progress and difficulties in the implementation of the Strategic Plan and to propose adjustments if necessary. ${ }^{1001}$ Apart from the review by the Standing Committee, the contracting parties provide information in their National Reports to the COP 11 on their implementation progress and difficulties, and their proposal for adjustments. ${ }^{1002}$

Indication of the contracting parties' commitments, and that the 28 strategies developed under the Strategic Plan 2009 - 2015 'represent a general consensus of the most important priorities for most parties'. ${ }^{1003}$ The consensus is demonstrated through the willingness of the contracting parties to report the results of the actions undertaken and achievements attained under the Strategic Plan at the global level and the national level to the Conference of the Parties. ${ }^{1004}$

\footnotetext{
${ }^{998}$ Ramsar Convention, 'The Ramsar Strategic Plan 2009 - 2015', supra n 981, at para 6.

${ }^{999}$ Ramsar Convention, 'The Ramsar Strategic Plan 2009 - 2015', supra n 981, at p 4.

${ }^{1000}$ Ramsar Convention, 'Resolution XI.3. Adjustment to the Strategic Plan 2009 - 2015 for the $2013-$ 2015 Triennium' (11 ${ }^{\text {th }}$ Meeting of the Conference of the Parties to the Convention on Wetlands (Ramsar, Iran, 1971) Bucharest, Romania, 6 - 13 July 2012) <http://www.ramsar.org/pdf/cop11/res/cop11-res03e.pdf> accessed 20 July 2012.

${ }^{1001}$ Ramsar Convention, 'Resolution XI.3. Adjustment to the Strategic Plan 2009 - 2015 for the 2013 2015 Triennium', supra n 1000, at p 1, para 2.

1002 Ramsar Convention, 'Resolution XI.3. Adjustment to the Strategic Plan 2009 - 2015 for the 2013 2015 Triennium', supra n 1000, at p 1, para 3.

${ }^{1003}$ Ramsar Convention, 'The Ramsar Strategic Plan 2009 - 2015', supra n 981, at p 2, para 7.

${ }^{1004}$ Results are reported through regional and global synthesis reports prepared by the Secretariat for outcomes at the global level; and through Contracting Parties' National Reports where the National Wetland Committees, where they exist, will have an important role in the evaluation and follow up of these results. See Annex of Ramsar Convention, 'Resolution XI.3. Adjustment to the Strategic Plan 2009 -2015 for the $2013-2015$ Triennium', supra n 1000, at p 2, paras 1 and 2. The reporting of the result by contracting parties is through regional and global synthesis reports prepared by the Secretariat for outcomes at the global level; and through contracting parties' National Reports where the National Wetland Committees will have an important role in the evaluation and follow up of these results.
} 


\subsection{Satisfaction of the Criteria of Legality}

Brunnée and Toope emphasised that it is important to distinguish between law and nonlaw, and imposed that it is important for the internal morality of law, the features of legality crucial to the generation of a distinctive legal legitimacy and a sense of commitment 'among those to whom law is addressed', to be fulfilled. ${ }^{1005}$ The fidelity of law amongst the subject of law derives from the satisfaction of the criteria of morality in the process of law making. Brunnée and Toope stated that -

'What distinguishes law from other types of social ordering is not form, but adherence to specific criteria of legality: generality, promulgation, nonretroactivity, clarity, non-contradiction, reasonableness, constancy and congruence between rules and official action'. ${ }^{1006}$

The eight criteria of morality proposed by Fuller ${ }^{1007}$ provide a structural framework where shared understandings achieved through a process of interaction and reciprocity are guided towards the attainment of legality. It is against these criteria of morality that shared understandings of the contracting parties of the Ramsar Convention on the obligation to conserve wetlands under Articles 2.1 and 4.1 are assessed and measured in the determination whether these rules, and their implicit shared understandings, are 'rules of international law' in accordance with the interactional framework.

\subsubsection{Generality}

The requirement of generality is occasionally interpreted to mean 'the law must act impersonally where its rules must apply to general classes and should contain no proper names'. ${ }^{1008}$ A requirement of generality requires that the participation in the making of the agreement is universal, especially if the obligation tackles a global, or at least a transboundary problem. Brunnée and Toope stated that -

'it is to ensure that all states are subject to the requirements of the convention and participate in the effort to develop an effective and appropriate response, even if

\footnotetext{
${ }^{1005}$ Brunnée and Toope, Legitimacy and Legality in International Law, supra n 724, at p 25.

${ }^{1006}$ Fuller, The Morality of Law, supra n 747, at pp 39 and $46-90$.

${ }^{1007}$ Fuller, The Morality of Law, supra n 747, at pp $46-91$.

${ }^{1008}$ Fuller, The Morality of Law, supra n 747, at p 47.
} 
the commitment of states under the convention is differentiated, the differentiation is based upon generally applicable criteria'. ${ }^{1009}$

The Secretary-General, Mr Ban Ki-moon gave a strong assertion of the need for the conservation of biodiversity, and the protection of ecosystems, in order to safeguard this natural infrastructure that sustainably and continuously produces ecosystem services essential to the existence of life on Earth. ${ }^{1010}$ He remarked that -

'Many still think the Earth is ours to use as we like. This argument betrays a woeful ignorance of the importance of ecosystems to our well-being as a species, to climate regulation, to water supplies, to food security... conserving the planet's species and habitats - and the goods and services they provide - is central to sustainable development and the Millennium Development Goals'. ${ }^{1011}$

The emphasis that the protection of ecosystems enables the international community to achieve the Millennium Development Goals makes the issue of conservation of wetland ecosystems and biodiversity a global issue. This is supported by the outcome of the MA that problems affecting key ecological systems affect the well-being of hundreds of millions of people. ${ }^{1012}$ One of the affected ecosystems is wetlands, which include rivers, lakes, and salt and saltwater marshes; arid land; coastal systems and tropical forests. ${ }^{1013}$

In particularly, the impairment of wetland-related ecosystems function and the degradation of biodiversity in most major drainage basins are due to water abstraction, habitat loss and fragmentation, and pollution by nutrients, sediments, salts, and toxins. ${ }^{1014}$ Wetlands, a source and user of water forming part of a river basin and intricately connected to the freshwater ecosystems, are vital in the production of

\footnotetext{
${ }^{1009}$ Brunnée and Toope, Legitimacy and Legality in International Law, supra n 724, at p 178.

${ }^{1010}$ United Nations Secretary-General Ban Ki-moon, 'Remarks at the High-level Event on Biodiversity' (High-level Event on Biodiversity, New York, 22 September 2010) <http://www.un.org/apps/sg/sgstats.asp?nid=4791> accessed 20 July 2012.

${ }^{1011}$ UN Secretary-General Ban Ki-moon, 'Remarks at the High-level Event on Biodiversity', supra $\mathrm{n}$ 1010.

1012 'Chapter 1. MA Conceptual Framework' in Rashid Hassan, Robert Scholes, and Neville Ash (eds) Ecosystems and Human Well-being: Current State and Trends: Findings of the Condition and Trends Working Group (Island Press, Washington, 2005) pp $1-25$, at $\mathrm{p} 14$ $<$ http://www.maweb.org/documents/document.765.aspx.pdf > accessed 20 July 2012.

${ }^{1013}$ Robert Scholes, Rashid Hassan, and Neville J Ash, 'Summary: Ecosystems and Their Services around the Year 2000', in Hassan, Scholes, and Ash (eds) Ecosystems and Human Well-being: Current State and Trends: Findings of the Condition and Trends Working Group, supra $\mathrm{n} 1012$, at $\mathrm{p} 14$ $<$ http://www.millenniumassessment.org/documents/document.766.aspx.pdf $>$ accessed 17 November 2012 .

${ }^{1014}$ Scholes, Hassan, and Ash 'Summary: Ecosystems and Their Services around the Year 2000', supra n 1013, at $\mathrm{p} 14$.
} 
ecosystem services that contribute towards the 'protection, purification, retention and provision of water resources for water and food supplies, and played a vital role in groundwater recharge and flood control on which the well-being of people and their livelihoods depend on'. 1015

The alarming trends of degradation and deterioration of ecosystems around the globe exposed by the MA threaten to impair human well-being and propelled governments and the international community to move towards strengthening the safeguarding of ecosystems, in order to ensure that these ecosystems continuously and sustainably provide the flow of ecosystem services crucial to sustain life. This makes the conservation of wetlands a global issue that requires global or universal participation 'in the effort to develop an effective and appropriate response even if the commitments of states might be differentiated'. ${ }^{1016}$

In the determination of whether Articles 2.1 and 4.1 of the Ramsar Convention satisfy the criterion of generality, it is necessary to look at the membership of the contracting parties to ensure that almost all states, if not all states, are entitled to participate in decision-making, especially as the conservation of wetlands is a global concern. ${ }^{1017}$ Looking at the membership of the Ramsar Convention, which stands at 163 Contracting Parties at present, the criteria of generality can be said to be satisfied as long as all these contracting parties are entitled to participate in the decision-making process on matters related to Articles 2.1 and 4.1.

Participation of all contracting parties to the COP established under Article 6 of the Ramsar Convention is stipulated in Article 7.2. It is provided that 'each of the contracting parties represented at a Conference shall have one vote, recommendations, resolutions and decisions being adopted by a simple majority of the Contracting Parties present and voting'. The COP consists of voting members of -

'government representatives from each Contracting Parties to receive national reports on the preceding triennium, approve the work programme and budgetary arrangements for the next three years, and consider guidance for the Parties on a

\footnotetext{
1015 Ramsar Convention, 'Resolution IX.3 Engagement of the Ramsar Convention on Wetlands in Ongoing Multilateral Processes Dealing with Water' $\left(9^{\text {th }}\right.$ Meeting of the Conference of the Parties to the Convention on Wetlands (Ramsar, Iran, 1971) Kampala, Uganda, 8 - 15 November 2005) at p 1 paras 3 and 13 <http://www.ramsar.org/pdf/res/key_res_ix_03_e.pdf $>$ accessed 17 November 2012.

${ }^{1016}$ Brunnée and Toope, Legitimacy and Legality in International Law, supra n 724, at p 178.

${ }^{1017}$ Brunnée and Toope, Legitimacy and Legality in International Law, supra $\mathrm{n}$ 724, at p 178.
} 
range of ongoing and emerging environmental issues; and non-voting observers consist of representatives of non-member States, intergovernmental institutions, and national and international non-governmental organisation'. ${ }^{1018}$

In view of the participation of all contracting parties in the decision-making process regarding the obligation to conserve wetlands as supported in the Ramsar Convention, it can be said that this obligation satisfies the criterion of generality. Since this obligation echoes a global commitment of the international community to tackle the problem of biodiversity degradation and the impingement of ecosystem integrity that threatens the sustainability of ecosystem services provisioning, the quasi-universal participation of states parties in the Convention can be said to have satisfied the criterion of generality required in the assessment of the legal legitimacy of these rules.

\subsubsection{Promulgation}

Promulgation means the publishing of the law to make it generally available, but subjected to the principle of marginal utility. ${ }^{1019}$ Fuller envisioned promulgation as the education of citizens in the meaning of the law that might be applied to them, conditioned by the principle of marginal utility. ${ }^{1020}$ It is important that the law is adequately published ${ }^{1021}$ because the citizen is entitled to know the laws that are applicable to 'the practice of his calling', ${ }^{1022}$ including rules governing internal procedures of the Convention. ${ }^{1023}$ This criterion is clearly met by the Ramsar

1018 Ramsar Convention, 'The Conference of the Contracting Parties' (8 December 2010) $<$ http://www.ramsar.org/cda/en/ramsar-about-bodies-conf-conference-of-the-7690/main/ramsar/1-36-7172\%5E7690_4000_0_> accessed 20 July 2012. See Rules 16 and 17, Ramsar Convention, 'Rules of Procedure for Meetings of the Conference of the Contracting Parties to the Convention on Wetlands of International Importance especially as Waterfowl Habitat (Ramsar, Iran, 1971)' $\left(10^{\text {th }}\right.$ Meetings of the Conference of the Contracting Parties, Changwon, Republic of Korea, 29 October 2009) <http://www.ramsar.org/cda/en/ramsar-documents-rules-rules-of-procedure-of-21056/main/ramsar/1-31114\%5E21056_4000_0_> accessed 20 July 2012.

${ }^{1019}$ Fuller, The Morality of Law, supra $\mathrm{n}$ 747, at pp 49 and 51. Fuller stated, at p 51 that 'The requirement that laws be published does not rest on any such absurdity as an expectation that the dutiful citizen will sit down and read them all.'

${ }^{1020}$ Fuller, The Morality of Law, supra n 747, at p 49.

1021 'Adequately published' in this context implies that the promulgation of the law has at least induces one man in a hundred takes the pains to inform himself concerning the laws applicable to the practice of his calling'. It is said to be adequate also if the law is known by a few, and these few man who 'take the pains' of informing himself of the law set a pattern to be followed by others, and indirectly influences the action of many. The publication of the law is also deemed adequate if the public is able to offer criticisms. See Fuller, The Morality of Law, supra $\mathrm{n} 747$, at $\mathrm{p} 51$.

1022 Fuller, The Morality of Law, supra n 747, at p 51.

${ }^{1023}$ Refer supra n 1018. 
Convention as the Convention text is published in various mediums, and widely circulated. $^{1024}$

\subsubsection{Non-Retroactivity}

The criterion of non-retroactivity is clearly met by the Ramsar Convention where the obligation to conserve wetlands has no retroactive effect. Although a reservation as to the possible retroactive effect is raised in one of the Meetings of the Standing Committee, ${ }^{1025}$ the Convention, be it the recommendations, resolutions or decisions, has not been challenged on this ground. Moreover, the Ramsar Convention is still subject to the 1969 Vienna Convention, Article 28 of which stipulates that the provisions of a treaty 'do not bind a party in relation to any act or fact which took place or any situation which ceased to exist before the date of the entry into force of the treaty with respect to that party', unless a different intention appears from the treaty established. ${ }^{1026}$

Non-retroactivity of the Convention's resolutions is evidenced in the recent adjustment to the Strategic Plan 2009 - 2015 for the 2013 - 2015 trienniums. The COP adopts the adjustments made to the Strategic Plan 2009 - 2015 and instructs the Secretariat to make these adjustments available to contracting parties and all others who are concerned with its implementation. ${ }^{1027}$ Furthermore, the resolution of the COP to urge the contracting parties to consider the adjustments in planning their implementation of the Strategic Plan 2009 - 2015 in the coming triennium of $2013-2015^{1028}$ indicates that the adjustments do not affect previous implementation of the Strategic Plan.

\subsubsection{Clarity}

Fuller opined that the most essential ingredient of legality is the clarity of law, where obscure and incoherent legislation can make legality unattainable by anyone. ${ }^{1029}$ The specificity and the clarity of law depend on the nature of the problem. ${ }^{1030}$ The Ramsar Guidelines recognised that wetlands are dynamic areas, open to influence from natural

\footnotetext{
${ }^{1024}$ The Ramsar Convention website makes available all information relating to the Convention in its website, Ramsar Convention on Wetlands (undated) < http://www.ramsar.org/cda/en/ramsarhome/main/ramsar/1 4000_0_> accessed 17 November 2012.

${ }_{1025}$ Agenda Item 16.7 Conference Decisions, para 257, see supra $\mathrm{n} 921$.

1026 Art 28, 1969 Vienna Convention, supra n 31.

${ }^{1027}$ Ramsar Convention, 'Resolution XI.3. Adjustment to the Strategic Plan 2009 - 2015 for the 2013 2015 Triennium', supra n 1000, at p 2, para 8.

${ }^{1028}$ Ramsar Convention, 'Resolution XI.3. Adjustment to the Strategic Plan 2009 - 2015 for the 2013 2015 Triennium', supra n 1000, at p 2, para 8.

${ }^{1029}$ Fuller, The Morality of Law, supra $\mathrm{n} 747$, at $\mathrm{p} 63$.

${ }^{1030}$ Fuller, The Morality of Law, supra n 747, at p 63.
} 
and human factors that necessitate a dynamic and continuous management planning process. ${ }^{1031}$ Thus, the assessment of clarity for this obligation to preserve wetland ecosystems applies notably to the procedural provisions of the obligations, especially when the nature of the obligation is contingent on the availability of information, and relies heavily on scientific information. ${ }^{1032}$

Brunnée and Toope take a similar approach in the assessment of the clarity of the 'rules' of the 1992 Convention on Climate Change, where the clarity requirement of the Convention is said to be satisfied through the subsequent elaboration of subsidiary rules, or the reference to complementary rules. ${ }^{1033}$

Under the Ramsar Convention, the obligation to conserve wetlands through their designation as natural reserves under Articles 2.1 and 4.1 of the Ramsar Convention is further supplemented by the 2002 New Guidelines for Management Planning for Ramsar Sites and Other Wetlands and guided by the Ramsar Strategic Plan 2009 - 2015. The 2002 Guidelines lay out in detail the management and planning for Ramsar sites and other wetlands, in satisfaction of the obligations relating to the conservation of wetlands and the wise use of wetlands as stipulated under Article 3 and Article 4.1 of the Convention, ${ }^{1034}$ which would inform Article 2.1 as well.

The 2002 Guidelines provides comprehensive management guidance. The guidance includes general guidelines; ${ }^{1035}$ management approach and principles, such as the concept of Integrated Water Resources Management (IWRM), Integrated River Basin Management (IRBM), and the integration of wetland site management within broadscale environmental management planning; ${ }^{1036}$ the recommendation of the participatory

\footnotetext{
1031 Ramsar Convention, 'New Guidelines for Management Planning for Ramsar Sites and Other Wetlands', supra n 921, paras 7 and 9.

1032 The Ramsar Guidelines commented that 'the management plan itself should be a technical document, though it may be appropriate for it to be supported by legislation and in some circumstances to be adopted as a legal document'. Ramsar Convention, 'New Guidelines for Management Planning for Ramsar Sites and Other Wetlands', supra $\mathrm{n}$ 921, at para 8.

${ }^{1033}$ Brunnée and Toope, Legitimacy and Legality in International Law, supra n 724, at p 179.

1034 Ramsar Convention, 'New Guidelines for Management Planning for Ramsar Sites and Other Wetlands', supra $\mathrm{n}$ 921, at para 2.

${ }^{1035}$ Ramsar Convention, 'New Guidelines for Management Planning for Ramsar Sites and Other Wetlands', supra n 921, at Part II, paras 7 - 13.

${ }^{1036}$ Ramsar Convention, 'New Guidelines for Management Planning for Ramsar Sites and Other Wetlands', supra n 921, at Part III, paras 14 - 27.
} 
approach in the planning process $;{ }^{1037}$ and the application of the precautionary approach in the management of the environment. ${ }^{1038}$

The management process is fully elaborated whereby pivotal stages of the management planning process are identified. ${ }^{1039}$ The assessment benchmark for the output of management is also explained in the 2002 Guidelines. ${ }^{1040}$ The 2002 Guidelines further recommend the framework for an adaptable management process in the planning of the management of wetlands; ${ }^{1041}$ and suggest the management units, zonation and buffer zones of designated wetlands. ${ }^{1042}$ The 2002 Guidelines even go to the extent of recommending a structure and content of a management plan for a Ramsar site or other wetland. This will assist the contracting parties to satisfy the obligations stipulated under Article 2.1, 3 and 4.1 of the Ramsar Convention, which are, the conservation of wetlands through a designation of wetlands as Ramsar sites, or the establishment of natural reserves. The 2002 Guidelines set out the contents to be included in the management plan, such as the preamble; the description of the site; the evaluation process and the evaluation criteria; the three-step preparation of measureable objectives of the management; the development of action plan for the management project, and its review procedures. ${ }^{1043}$

Furthermore, the operationalisation of the 2002 Guidelines is guided by the Ramsar Strategic Plan 2009 - 2015, which is adjusted for the 2013 - 2015 trienniums. Five goals are targeted in the Strategic Plan in order to attain the mission of the Ramsar Convention, which is the "conservation and wise use of all wetlands through local and

\footnotetext{
1037 Ramsar Convention, 'New Guidelines for Management Planning for Ramsar Sites and Other Wetlands', supra n 921, at Part V, paras 29-38.

1038 Ramsar Convention, 'New Guidelines for Management Planning for Ramsar Sites and Other Wetlands', supra n 921, at Part VI, paras 39 - 40.

1039 Ramsar Convention, 'New Guidelines for Management Planning for Ramsar Sites and Other Wetlands', supra n 921, at para 44. The stages include: (1) Identification and designation of wetlands; (2) Wetland assessment; (3) Wetland monitoring; (4) In situ wetland management; and (5) Ex situ wetland management.

1040 Ramsar Convention, 'New Guidelines for Management Planning for Ramsar Sites and Other Wetlands', supra n 921, at paras 45 - 47. Para 47 commented that 'the only means of judging whether or not inputs and outputs are adequate is by considering the outcomes of management. When this has been done, and only then, it will be possible to determine whether the management is appropriate'.

1041 Ramsar Convention, 'New Guidelines for Management Planning for Ramsar Sites and Other Wetlands', supra n 921, at Part IX, paras 48 - 52.

1042 Ramsar Convention, 'New Guidelines for Management Planning for Ramsar Sites and Other Wetlands', supra n 921, at Part X, paras 53-65.

1043 Ramsar Convention, 'New Guidelines for Management Planning for Ramsar Sites and Other Wetlands', supra n 921, at pp $16-34$.
} 
national actions and international cooperation, as a contribution towards achieving sustainable development throughout the world'. ${ }^{1044}$

With such specificity and clarity in the procedural aspect of the conservation of wetlands, that highlights the pivotal role of the framework for the planning and management of wetland sites, the obligation to conserve under Articles 2.1 and 4.1 satisfies the clarity criterion imposed under Fuller's legality criteria. Moreover, 'clarity is more of a work that is in progress with respect to the convention's substantive provisions ${ }^{1045}$ where the open textured principles or provisions 'serve as guideposts for this continuous law-making enterprise'. ${ }^{1046}$ Thus, the progressive clarification of the rules on the conservation of wetlands necessary to attain legality is forged and promoted over time through a structured procedural framework.

\subsubsection{Non-Contradiction}

The avoidance of contradictions in law is simply one of logic ${ }^{1047}$ but interestingly, Fuller's approach is not to pronounce that contradictory law is not law, but to seek reconciliation through recourse to the context and the reciprocal adjustment between the two contradictory laws. ${ }^{1048}$

The preamble of the Ramsar Convention indicated the desire of the contracting parties to stem the progressive encroachment and the loss of wetlands through the conservation of wetlands. ${ }^{1049}$ Despite indicating the desire to conserve wetlands, the economic potential of wetlands is also acknowledged in the preamble. ${ }^{1050}$

The concepts of 'wise use' and 'conservation' seem to be contradictory from the outset. The preamble recognised the interdependence of humans on their environment and in consideration of the fundamental ecological functions wetlands possess, which lead the contracting parties to be desirous of stemming the progressive encroachment on, and the

\footnotetext{
1044 The five goals are: (1) Wise use; (2) Wetlands of International Importance; (3) International cooperation; (4) Institutional capacity and effectiveness; and (5) Membership Ramsar Convention, 'The Ramsar Strategic Plan 2009 - 2015', supra n 981, at pp 5 and 6. Separate strategies are developed under each goal that itemised, and detailed the steps to be undertaken in the attainment of these Goals.

${ }^{1045}$ Brunnée and Toope, Legitimacy and Legality in International Law, supra n 724, p 180.

${ }^{1046}$ Brunnée and Toope, Legitimacy and Legality in International Law, supra n 724, p 181.

${ }^{1047}$ Fuller, The Morality of Law, supra $\mathrm{n} 747$, at pp $65-66$.

${ }^{1048}$ Fuller, The Morality of Law, supra n 747, at pp $68-69$.

${ }^{1049}$ Preambular Paragraphs 4 and 5, Preamble, Ramsar Convention, supra n 13.

${ }^{1050}$ Preambular Paragraph 3, Preamble, Ramsar Convention, supra n 13.
} 
loss of wetlands through conservation in order to prevent the irreparable loss of a resource of great economic, cultural, scientific and recreational value.

In recognition of the apparently inconsistent rules, the Convention makes some reciprocal adjustment in reference to the context representative of the institutional setting of the contradiction. The interpretation of 'wise use' is updated, taking into account the Convention's mission statement, the MA's terminology, the concept of the ecosystem approach and sustainable use applied by the Biological Convention, and the definition of sustainable development adopted by the 1987 Brundtland Commission. ${ }^{1051}$ The 'wise use' concept indicates that the utilisation of the 'natural productivity and biodiversity at a site' is permitted 'as long as the basic ecological functioning of the wetland is not disturbed'. ${ }^{1052}$ The updated definition is 'wise use of wetlands is the maintenance of their ecological character, achieved through the implementation of ecosystem approaches, within the context of sustainable development'. ${ }^{1053}$

The adjustment made to the concept of 'conservation' is more subtle, where the Ramsar Convention decided that in order to maintain the biodiversity and productivity of the wetlands (i.e., their 'ecological character' as defined by the Convention) while permitting the wise use of their resources, 'an overall agreement is essential between the various managers, occupiers and other stakeholders'. ${ }^{1054}$ However, conservation still lies at the heart of the Convention, where Strategy 2.1.iii stipulated that, in order to attain Goal 2 laid out in the $3^{\text {rd }}$ Strategic Plan of developing and maintaining an international network of wetlands, at least 2500 Ramsar sites covering at least 250 million hectares is targeted to be designated by $2015 .{ }^{1055}$ It is noted by the COP, in the elaboration of the phrase 'in the context of sustainable development' in the updated definition of 'wise use', there is a qualification that -

\footnotetext{
${ }^{1051}$ Ramsar Convention, 'Resolution IX.1 Annex A. A Conceptual Framework for the Wise Use of Wetlands and the Maintenance of Their Ecological Character', supra n 422, at para 22.

${ }^{1052}$ Michael Smart, 'Chapter 2 The Ramsar Convention: Its Role in Conservation and Wise Use of Wetland Biodiversity' in AJ Hails (ed) Wetlands, Biodiversity and Ramsar Convention: The Role of the Convention on Wetlands in the conservation and Wise Use of Biodiversity (Ramsar Convention Bureau, Gland Switzerland, 1997) <http://www.ramsar.org/cda/en/ramsar-documents-cops-cop8-wetlandsbiodiversity-21181/main/ramsar/1-31-58-128\%5E21181 4000_0 \#c2> accessed 11 August 2012.

${ }^{1053}$ Ramsar Convention, 'Resolution IX.1 Annex A. A Conceptual Framework for the Wise Use of Wetlands and the Maintenance of Their Ecological Character', supra n 422, at para 22.

1054 Ramsar Convention, 'New Guidelines for Management Planning for Ramsar Sites and Other Wetlands', supra $\mathrm{n}$ 921, at para 7.

${ }^{1055}$ Ramsar Convention, 'The Ramsar Strategic Plan 2009 - 2015', supra n 981, at p 10.
} 
'although it is recognized that whilst some wetland development is inevitable and that many developments have important benefits to society, developments can be facilitated in sustainable ways by approaches elaborated under the Convention, and it is not appropriate to imply that "development" is an objective for every wetland'. 1056

Potential contradictions between the Ramsar Convention and other MEAs that relate to biodiversity or other ecosystems, are addressed through mutually supportive collaboration as affirmed in Ramsar resolutions, ${ }^{1057}$ and supported through Goal 3 of the $3^{\text {rd }}$ Strategic Plan. The $3^{\text {rd }}$ Strategic Plan aims to enhance the conservation and wise use of wetlands using effective international cooperation. Strategy 3.1 promotes the forging of synergies and partnerships with international and regional MEAs and other intergovernmental agencies, especially through the harmonisation of information management and reporting systems. ${ }^{1058}$

In the current climate of the fragmentation of international law on the environment, the possibility of contradictions on the obligation to conserve biodiversity and ecosystems is high. However, these laws should not be pronounced non-law, ${ }^{1059}$ but should be read in light of each other to seek conciliation through a variety of legal techniques, including principles of harmonisation, systemic integration and mutual supportiveness.

\subsubsection{Law Not Requiring the Impossible - Reasonableness}

A law that is 'impossible' is limited by its own absurdity where the subject is expected to brace himself to jump in any direction, since the 'pointlessness' of an absurd law

\footnotetext{
${ }^{1056}$ Ramsar Convention, 'Resolution IX.1 Annex A. A Conceptual Framework for the Wise Use of Wetlands and the Maintenance of their Ecological Character', supra $\mathrm{n} 422$, at p 7, fn 3.

${ }^{1057}$ These resolutions are Resolutions VII.4 (1999), VIII.5 (2002), IX.5 (2005) and X.11 (2008). Ramsar Convention, 'Resolution XI.6. Partnerships and Synergies with Multilateral Environmental Agreements and other Institutions' $\left(11^{\text {th }}\right.$ Meeting of the Conference of the Parties to the Convention on Wetlands (Ramsar, Iran, 1971) Bucharest, Romania, 6 - 13 July 2012) <http://www.ramsar.org/pdf/cop11/res/cop11-res06-e.pdf> accessed 31 July 2012, at p 1, para 1.

${ }^{1058}$ Such collaborations, however, is conservative, as they are still subjected to the independence of the mandates embodied in each convention. Ramsar Convention, 'Resolution XI.6. Partnerships and Synergies with Multilateral Environmental Agreements and other Institutions', supra n 1057, at p 1, para 1.

${ }^{1059}$ Fuller, The Morality of Law, supra n 747, at pp $68-69$. However, Fuller acknowledged the difficulty in such endeavour where 'one would be to know where to stop, for the courts might easily find themselves embarked on the perilous adventure of attempting to remake the entire body of our statutory law into a more coherent whole. The reinterpretation of old statues in the light of new would also present embarrassing problems of retrospective legislation'. See also Brunnée and Toope, Legitimacy and Legality in International Law, supra $\mathrm{n}$ 724, at p 182.
} 
commands 'nothing that may not be demanded of him' ${ }^{1060}$ The criterion that law should not command the impossible rises from the justification that there is a need to guide the purposive human effort away from an exercise in logical entailment. ${ }^{1061}$

As discussed in Chapter 4, the study into the impossibility of law is two-pronged: firstly, the inquiry into the difference between aspirational language of a law; and secondly, the fine line between extreme difficulty and impossibility. There is a blurred distinction between vigorous exhortation and imposed duty. This is exceptionally true in the current trend of international environmental law making, where provisions are mostly aspirational instead of requiring the impossible. ${ }^{1062}$

In the context of the obligation to conserve wetlands under the Ramsar Convention, the status of sites in the Ramsar List of Wetlands of International Importance is an illustration of whether the obligation placed under Articles 2.1 and 4.1 are 'impossible'. The issue of reasonableness is raised in Resolution X.13 where the COP discusses the reasons for the failure to achieve the quantitative and qualitative target set in Resolution VII.11 (1999). ${ }^{1063}$

According to Resolution X.13, there is an increase of more than $25 \%$ in the total area designated since COP 9, with a total of 1,822 sites designated as of 4 November 2008 (for COP in 2009), although the increase falls below the targeted 2,000 sites set in Resolution VII.11 (1999); and 2,500 set by the year 2010. ${ }^{1064}$

It is noted that there remain significant gaps in the comprehensiveness and representativeness of the global network of sites, where concerns are expressed for the

\footnotetext{
${ }^{1060}$ Fuller, The Morality of Law, supra $\mathrm{n} 747$, at $\mathrm{p} 71$.

${ }^{1061}$ Fuller, The Morality of Law, supra $\mathrm{n} 747$, at $\mathrm{p} 70$.

${ }^{1062}$ Ellis and FitzGerald, 'The Precautionary Principle in International Law', supra n 814, at p 790. In pp $790-791$, Ellis and FitzGerald outlined a variety of possible circumstances where the precautionary principle might be deemed 'impossible'. Concern is not placed on laws that require patently impossible acts that are absurd, but laws that place a very high burden on the subjects, perhaps in the hope that such aspirational imposition of duty contribute towards a positive outcome, short of the actual attainment of the desirable goal. Such possible circumstances include an exorbitant price and an impossibly onerous duty that rendered an action or the achievement of the rule unviable. Another possible circumstance arises in the case of strict liability where the rule prohibits an activity in order to avoid a particular harm that the actor cannot reasonably know that it will lead to such harm.

${ }^{1063}$ Ramsar Convention. 'Resolution X.13. The Status of Sites in the Ramsar List of Wetlands of International Importance' $\left(10^{\text {th }}\right.$ Meeting of the Conference of the Parties to the Convention on Wetlands (Ramsar, Iran, 1971) Changwon, Republic of Korea, 28 October - 4 November 2008) at para 4 <http://www.ramsar.org/pdf/res/key res x 13 e.pdf> accessed 21 July 2012.

${ }^{1064}$ Ramsar Convention. 'Resolution X.13. The Status of Sites in the Ramsar List of Wetlands of International Importance', supra n 1063, at para 4. As it currently stands in 2012, the total sites designated for the List of Wetlands is 2,062, which falls below the targeted 2,500 sites established in the Ramsar Strategic Framework and Guidelines for the Development of the Ramsar List (2005).
} 
lack of RIS and the lack of adequate maps that are supplied to the Secretariat so that information on the current status of $58 \%$ of the Ramsar sites are not available. ${ }^{1065}$ Furthermore, of all the 56 Ramsar sites included in the Montreux Record, only three sites have been removed from the Record since COP 9, excluding the application for removal of six sites from five contracting parties that is currently under review by the Scientific and Technical Review Panel (STRP). ${ }^{1066}$

However, this does not mean that the obligation to conserve wetlands is impossible and that the obligation does not attain legality. There is no hard and fast line to be drawn between a rule that can be achieved with extreme difficulty and a rule that is impossible. ${ }^{1067}$ Some rules, especially in the field of the environment, are set in the hope that such aspirational imposition of duty contributes towards a positive outcome, short of the actual attainment of the desirable goal. ${ }^{1068}$ Fuller's observation in this matter was that 'between the two (extreme difficulty and impossibility) is an indeterminate area in which the internal morality that requires a law that is not asking the impossible and external moralities of what is fair and just', ${ }^{1069}$ which necessitates an assessment on a case-by-case basis.

In the present context, the assessment of the obligation to conserve under the Ramsar Convention against the reasonableness criterion is similar to the assessment against the criterion of clarity in which the clarity requirement of the Convention can be satisfied through the subsequent elaboration of subsidiary rules, the reference to complementary rules, and the progressive clarification through a procedural structure.

For the obligation to conserve wetlands under the Ramsar Convention, despite not meeting the targets laid down in year 2005 by Resolution VII.11 (1999), which is a designation of 2,500 sites by year 2010, various efforts have been undertaken by contracting parties by undertaking the necessary procedural means in their bid to fulfil their obligation to conserve wetlands. ${ }^{1070}$ The COP, in recognising that the pressure on

\footnotetext{
${ }^{1065}$ Ramsar Convention. 'Resolution X.13. The Status of Sites in the Ramsar List of Wetlands of International Importance', supra n 1063, at paras 4 and 5.

${ }^{1066}$ Ramsar Convention. 'Resolution X.13. The Status of Sites in the Ramsar List of Wetlands of International Importance', supra n 1063, at para 9.

${ }^{1067}$ Fuller, The Morality of Law, supra $\mathrm{n} 747$, at p 79.

1068 Ellis and FitzGerald, 'The Precautionary Principle in International Law', supra n 814, at p 790.

${ }^{1069}$ Fuller, The Morality of Law, supra $\mathrm{n} 747$, at $\mathrm{p} 79$.

${ }^{1070}$ Ramsar Convention. 'Resolution X.13. The Status of Sites in the Ramsar List of Wetlands of International Importance', supra n 1063, at paras10. For example, in paras 20 and 21, it is mentioned that 18 Contracting Parties have provided reports fully in accordance with Art 3.2 of the Convention, and
} 
Ramsar wetland sites will be likely to increase (where many sites have undergone or are undergoing change in their ecological character, or are likely to undergo such change), reaffirms the commitment made in Resolution VIII.8 to implement fully the terms of Article 3.2 of the Convention. It continues to encourage the adoption and application of a suitable monitoring and assessment regime as part of the management planning for Ramsar sites and other wetlands. ${ }^{1071}$

The non-satisfaction of the obligation might potentially be due to a lack of capacity, where gradual capacity building will resolve the issue. ${ }^{1072}$ The need to strengthen capacity building is remarked in the Standing Committee where it is stated that 'there is an urgent need to strengthen capacity for the Convention's implementation by the contracting parties at all levels'. ${ }^{1073}$ As capacity improves, and the procedural obligations necessary to attain the ultimate goal of the designation of wetlands as natural reserves for conservation purposes are closely observed, the rule that requires the conservation of wetlands will become less aspirational, less impossible, and more inclined towards the legal-norms end of the social norms-legal norms continuum.

\subsubsection{Constancy}

The adverse impact of a continuous global rise of greenhouse gases emissions has caused persistent drought and extreme weather events, sea-level rise, coastal erosion, and ocean acidification that further threaten food security. ${ }^{1074}$ The uncertainty of the impacts of climate change, where the 'contours and urgency' ${ }^{1075}$ of the problem is not fully understood, makes it difficult or even impossible to predict commitments that stay constant. Brunnée and Toope adapt the criterion of constancy by suggesting that in light of such uncertainty, the satisfaction of the requirement of constancy must necessarily

another 21 Contracting Parties have provided information in their National Reports where human-induced changes in ecological character have occurred, are occurring or may occur. In para 30, the COP mentioned that there are Contracting Parties who have brought their Information Sheets for Ramsar Wetlands (RISs) up to date for all Ramsar sites within their territory.

${ }^{1071}$ Ramsar Convention. 'Resolution X.13. The Status of Sites in the Ramsar List of Wetlands of International Importance', supra n 1063, at paras 17 and 18.

${ }^{1072}$ See Ramsar Convention. 'Resolution X.13. The Status of Sites in the Ramsar List of Wetlands of International Importance', supra $\mathrm{n}$ 1063, at para 8. It is recalled, at $\mathrm{p} 2$, para 8 that the Contracting Parties expressed their concern in Resolution VIII.8 (2002) that many of the Parties do not have in place the mechanisms to fulfil Article 3.2.

${ }^{1073}$ Ramsar Convention, 'Report of the Chairperson of the Standing Committee' (11 ${ }^{\text {th }}$ Meeting of the Conference of the Parties to the Convention on Wetlands (Ramsar, Iran, 1971) Bucharest, Romania, 6 13 July 2012) at p 9, para 56 <http://www.ramsar.org/pdf/cop11/doc/cop11-doc05-e-sc.pdf> accessed 22 July 2012.

${ }^{1074}$ The Future We Want, supra n 59, at para 190.

1075 Brunnée and Toope, Legitimacy and Legality in International Law, supra n 724, at p 183. 
ensure that at least the decision-making rules and the law-making processes are transparent and predictable. ${ }^{1076}$

Article 3.1 imposes the obligation to formulate and implement management planning that promotes the conservation of wetlands included in the List, whereas for non-Listed wetland natural reserves, Article 4.1 requires that conservation of wetlands is to be promoted by establishing nature reserves and provide adequately for their wardening. The 2002 Guidelines provides that the safeguarding and management of wetland sites and their ecological character adopt a flexible approach that allows managers to 'respond to the legitimate interest of stakeholders, and permits adaptation to the changing political climate, uncertain and variable resources, and survive the vagaries of the natural world'. ${ }^{1077}$

The adaptive management plan recommended by the 2002 Guidelines encapsulates a management planning process that provides a mechanism to achieve an overall agreement between various managers, owners, occupiers and other stakeholders in the maintenance of ecological character and wise use of wetland's resources by people. ${ }^{1078}$ At the same time, the management plan enables the management planning process to learn through experience; to take account of and respond to changing factors that affect the features; to continuously develop and refine the management processes; and to demonstrate that management is appropriate and effective. ${ }^{1079}$

The 2002 Guidelines recommend the format of the management plan - an essentially technical document that may be appropriate to be supported by legislation or to be adopted as a legal document. ${ }^{1080}$ The management plan forms part of a dynamic and continuous management planning process, where the plan will be kept under review and will be adjusted where appropriate in order to take into account the monitoring process, changing priorities, and emerging issues. ${ }^{1081}$

\footnotetext{
1076 Brunnée and Toope, Legitimacy and Legality in International Law, supra n 724, at p 183.

1077 Ramsar Convention, 'New Guidelines for Management Planning for Ramsar Sites and Other Wetlands', supra n 921, at para 48.

1078 Ramsar Convention, 'New Guidelines for Management Planning for Ramsar Sites and Other Wetlands', supra n 921, at p 2, para 7.

1079 Ramsar Convention, 'New Guidelines for Management Planning for Ramsar Sites and Other Wetlands', supra n 921, at p 2, at p 13, para 52.

1080 Ramsar Convention, 'New Guidelines for Management Planning for Ramsar Sites and Other Wetlands', supra n 921, at p 2, para 8.

1081 Ramsar Convention, 'New Guidelines for Management Planning for Ramsar Sites and Other Wetlands', supra n 921, at p 2, para 9.
} 
The 2002 Guidelines and the recommended management plan, guided by the $3^{\text {rd }}$ Strategic Plan where 17 strategies are developed to guide the achievement of the $2^{\text {nd }}$ Goal of developing and maintaining an international network of wetlands, and to ensure transparency and predictability in decision-making and law-making processes. Against the background of a rapidly changing environment, where feasibility can only be ensured if commitments are constantly negotiated in respond to changes, the procedural framework (as exhibited in the 2002 Guidelines) and the $3^{\text {rd }}$ Strategic Plan, which are adopted and applied by the contracting parties in their fulfilment of their obligation to conserve under Articles 2.1 and 4.1, go as far as they can to satisfy the criterion of constancy.

\subsubsection{Congruence between Official Action and Declared Rules - the Observation of the Rule of Law}

Congruence denotes the consistent application of the law by the officials charged with its administration. ${ }^{1082}$ In the context of the Ramsar Convention, the 'officials charged with its administration' are primarily, the state parties who are party to these treaties. Other states and non-state actors, not party to the Convention but who nonetheless observe and apply the provisions of the treaties, participate in the making of law and by virtue of their implementation continued to develop the law, should also be considered to be 'officials charged with its administration' for the assessment of the criterion of congruence. ${ }^{1083}$ This is because the conservation of wetlands and the safeguarding of biodiversity, are global concerns. ${ }^{1084}$

The 2012 Report of the Secretary General on the implementation of the Convention at the global level shows the progress and achievements of the parties since COP 10 on key challenges and implementation priorities. The progress and achievements include increased of membership from 158 Contracting Parties to 160; from 1,758 Ramsar Sites to 2,006; from 161.3 million hectares of Ramsar Sites to 192.8 million hectares; and

\footnotetext{
${ }^{1082}$ Fuller, The Morality of Law, supra n 747, at p $81-91$. See Krisch, 'Review of Legitimacy and Legality in International Law', supra n 828, at p 206.

${ }^{1083}$ This is reflected in the multilateralisation of international law-making in environmental treaty regimes, as discussed in Section 4.5 of this thesis. It is explicit in the Ramsar Convention that the COP provides a multilateral platform for the deliberation of all matters concerning the review and the implementation of the Convention where it the representation in $\mathrm{COP}$ of persons who are experts on wetlands or waterfowl in scientific, administrative or other appropriate capacities, are permissible. See Ramsar Convention, Art 7.1.

${ }^{1084}$ Refer to Chapter 4, Section 4.5 on the implications of the multilateralisation of law-making in the international legal order in strengthening international consensus.
} 
increased worldwide recognition of the role of wetlands in conservation and sustainable development, with particular emphasis on the provisioning, supporting, and regulating ecosystem services provided by wetlands. ${ }^{1085}$

It is emphasised repeatedly that the satisfaction of procedural obligations that gear the contracting parties towards their satisfaction of substantive obligations indicates the commitments of the contracting parties in the satisfaction of their obligations under the Convention. For COP 11, there were 127 reports submitted on time, another 11 reports received after the deadline, for a return rate of $86 \% .{ }^{1086}$ Ninety contracting parties have fully met their reporting obligation since COP 8, where annual reports of the Regional Initiatives and the Ramsar Sites Information Service database are the other sources of data used in their report. ${ }^{1087}$ The reporting procedure is important in fulfilling the obligation to conserve wetlands, as outlined in Goal 2 of the $3^{\text {rd }}$ Strategic Plan, where the contracting parties are required to complete and update as appropriate, RIS that were submitted for all Ramsar sites. ${ }^{1088}$ It is reiterated in the Secretary General's report that accurate information is helpful to track the progress made, the difficulties encountered, and possible areas of improvement. ${ }^{1089}$

The Secretary General's report deals more specifically with the achievements attained for Goal 2 of the $3^{\text {rd }}$ Strategic Plan. ${ }^{1090}$ All contracting parties have together designated 248 additional sites covering 31.5 millions of hectares since COP $10 .{ }^{1091}$ According to the data provided in the National Reports, Ramsar sites are in a better condition than wetlands in general, where deterioration in the condition is reported compared to the condition of other wetlands. ${ }^{1092}$

\footnotetext{
${ }^{1085}$ Ramsar Convention, 'Report of the Secretary General on the Implementation of the Convention at the Global Level' (Ramsar COP 11 DOC.7, $11^{\text {th }}$ Meeting of the Conference of the Parties to the Convention on Wetlands (Ramsar, Iran, 1971) Bucharest, Romania, 6 - 13 July 2012) at p 2, para 5 〈http://www.ramsar.org/pdf/cop11/doc/cop11-doc07-e-sg.pdf> accessed 22 July 2012.

${ }^{1086}$ Ramsar Convention, 'Report of the Secretary General on the Implementation of the Convention at the Global Level', supra n 1085, at p 2, para 5

${ }^{1087}$ Ramsar Convention, 'Report of the Secretary General on the Implementation of the Convention at the Global Level', supra n 1085, at p 7, para 52.

${ }^{1088}$ Strategy 2.1.ii, Ramsar Convention, 'The Ramsar Strategic Plan 2009 - 2015', supra n 981, at p 10.

${ }^{1089}$ Ramsar Convention, 'Report of the Secretary General on the Implementation of the Convention at the Global Level', supra n 1085, at p 7, para 52.

${ }^{1090}$ Ramsar Convention, 'Report of the Secretary General on the Implementation of the Convention at the Global Level', supra n 1085, at pp $17-20$.

${ }^{1091}$ Ramsar Convention, 'Report of the Secretary General on the Implementation of the Convention at the Global Level', supra n 1085, at p 17, para 63.

${ }^{1092}$ Ramsar Convention, 'Report of the Secretary General on the Implementation of the Convention at the Global Level', supra n 1085, at p17 and 18, para 64.
} 
Effective management planning in place is crucial for the conservation of wetlands. The number of sites with management is increasing. However, much effort needs to be undertaken as only $59 \%$ of the contracting parties who have a management plan in place, and even then only $92 \%$ of these are being implemented, and $32 \%$ of them being revised or updated. ${ }^{1093}$ However, it is further stated that there is a need for more support in terms of management plan, especially in the Africa region. ${ }^{1094}$

An assessment of the actions undertaken by the contracting parties reveals that in general, there is congruence between the obligation to conserve wetlands and the application of the obligation. Designation of sites has largely increased, whereby the condition of designated sites has showed less deterioration, more stability, and in some cases, improvements. Moreover, the commitment of the contracting parties to fulfil their obligations to conserve under the Convention is apparent in the adoption of the Guidelines and Strategic Plans that direct the implementation of their obligations under the Convention. The procedural requirements to report, monitor, and establish management plans for Ramsar sites are strongly encouraged by the Convention and upheld by the treaty practice of a substantial majority of contracting parties, indicating a general congruence of the administration of the obligation to conserve, with the obligation itself. ${ }^{1095}$

The efforts undertaken by the contracting parties in the fulfilment of the obligation to conserve, which forms one of the two main pillars of the Ramsar Convention, shows that there is a strong congruence between official action and declared rules where the rule of law is observed.

In summary, the eight criteria of morality provide a structural framework positioned in the overall framework of an interactional understanding of law, where shared understandings are guided towards the attainment of legality and shape the generation of

\footnotetext{
${ }^{1093}$ Ramsar Convention, 'Report of the Secretary General on the Implementation of the Convention at the Global Level', supra n 1085, at p17 and 18, para 66.

${ }^{1094}$ Ramsar Convention, 'Report of the Secretary General on the Implementation of the Convention at the Global Level', supra n 1085, at p17 and 18, para 66.

1095 The commitments of the Contracting Parties to improved compliance of their obligation under the Ramsar Convention is affirmed in Resolution VIII.24 where challenges that hinders compliance are raised and addressed. Ramsar Convention, 'Resolution VIII.24. UNEP's Guidelines for Enhancing Compliance with Multilateral Environmental Agreements, and Guidelines for National Enforcement, and International Cooperation in Combating Violations, of Laws Implementing Multilateral Environmental Agreements' ( $8^{\text {th }}$ Meeting of the Conference of the Contracting Parties to the Convention on Wetlands (Ramsar, Iran, 1971) Valencia, Spain, 18 - 26 November 2002) 〈http://www.ramsar.org/pdf/res/key_res_viii_24_e.pdf> 23 July 2012.
} 
shared legal understanding. Shared legal understandings emerge through the dynamic relationship of an interactive process instead of the mere discovery of rules through static sources.

The obligation to conserve wetlands provided under Articles 2.1 and 4.1, supported by the Convention's procedural requirements for the achievement of this substantive obligations measures up to the requirements of legality. The clarity of the obligation and the congruence of practice with the rule are constantly developed as the capacity of the contracting parties improves, and when the underlying normative understandings flourish through continuous practice.

\subsection{A Practice of Legality (Norm Application)}

The vigour of law is upheld through the constant effort to support it. The shared legal understandings generated through robust interactions and reciprocity between lawmakers and subjects, nourished by the implicit rules of the broader background understandings, must be maintained through a practice of legality. ${ }^{1096}$ A practice of legality is built up through reasoned dialogue (the horizontal congruence through interaction and reasoning through law) and reciprocity (vertical congruence), where a broader base of shared legal understandings is developed via interactions that adhere to the requirements of legality. ${ }^{1097}$ It is a distinctive type of interaction performed by 'a joint enterprise of members that shares collective understandings, directing and rationalising their conducts for them'. ${ }^{1098}$

A practice of legality is said to exist when norm creation meets the criteria of legality and is matched with norm applications that also satisfy the legality requirements. It must not be an isolated act, but a plurality or a series of actions or conduct of mutual engagement. The present assessment in the context of this research is whether the obligation to conserve wetlands has developed into a practice of legality.

It is shown in the discussion of the criteria of legality that the membership of the Ramsar Convention stands at 163 Contracting Parties, with a designation of 2,062 Ramsar sites under the List of Wetlands of International Importance that covers a total

\footnotetext{
1096 Brunnée and Toope, Legitimacy and Legality in International Law, supra n 724, at pp 80 - 81.

${ }^{1097}$ Brunnée and Toope, Legitimacy and Legality in International Law, supra n 724, at p 72.

${ }^{1098}$ Brunnée and Toope, Legitimacy and Legality in International Law, supra n 724, p 45.
} 
surface area of 197,258,568 hectares. ${ }^{1099}$ The recent COP 11 reveals that 55 contracting parties have designated a total of 217 Ramsar sites, an increase of $10 \%$ covering a total of 14,679,990 hectares as of 13 July 2012 since the close of COP 10 (4 November 2008). ${ }^{1100}$

It is noted that the satisfaction of the procedural requirements of the Ramsar Convention is important in the fulfilment of its substantive obligations. Apart from the measurement of whether there is an increase in the designation of wetlands as Ramsar sites by the contracting parties, whether the contracting parties satisfy the relevant procedural requirements will be the yardstick in the assessment of whether there is an existence of a practice of legality for the obligation to conserve wetlands. The practice of the contracting parties is commented on in the most recent Resolution for COP 11. The Resolution noted that there still remain significant gaps in the comprehensiveness and representativeness of the global network of Ramsar sites. In addition, the total of 2,026 sites falls below the target of 2,500 sites by the year 2010 that the contracting parties had established in the Strategic Framework and Guidelines for the Development of the Ramsar List (2005). ${ }^{1101}$ Concern was raised for 1,385 Ramsar sites in 149 countries, where their status of their Ramsar sites are not available. ${ }^{1102}$

Many contracting parties do not have in place the mechanisms to fulfil Article 3.2. In many instances, the reports first received by the Secretariat of Ramsar sites facing human-induced change or likely change in their ecological character come from third parties under Article 8.2(d). ${ }^{1103}$ Twelve contracting parties provided information only in their National Reports to COP 11, rather than reporting the matter immediately in

1099 Ramsar Convention, 'The Ramsar Convention on Wetlands' (undated) <http://www.ramsar.org/cda/en/ramsar-home/main/ramsar/1_4000_0_> accessed 7 November 2012.

${ }^{1100}$ Ramsar Convention, 'Resolution XI.4. The Status of Sites on the List of Wetlands of International Importance' ( $11^{\text {th }}$ Meeting of the Conference of the Parties to the Convention on Wetlands (Ramsar, Iran, 1971) Bucharest, Romania, $6-13$ July 2012) at p 1, para 3. <http://www.ramsar.org/pdf/cop11/res/cop11-res04-e.pdf> accessed 31 October 2012. The statistics might differ from the statistics stated in Ramsar Convention, 'Report of the Secretary General on the Implementation of the Convention at the Global Level', supra n 1085, at p 2, para 5. However, in order to remain faithful to the different sources cited, the slight variations of statistics are maintained.

${ }^{1101}$ Ramsar Convention, 'Resolution XI.4. The Status of Sites on the List of Wetlands of International Importance', supra n 1100, at p 2, para 4..

${ }^{1102}$ Ramsar Convention, 'Resolution XI.4. The Status of Sites on the List of Wetlands of International Importance', supra n 1100, at p 2, para 5. The non-availability of current status arises where RIS or adequate maps have not been provided or updated for more than six years.

${ }^{1103}$ Ramsar Convention, 'Resolution XI.4. The Status of Sites on the List of Wetlands of International Importance', supra n 1100, at p 2, paras 8 and 10. 
accordance with Article 3.2 of the Convention, which indicates that the obligation under Article 3.2 is not satisfactory. ${ }^{1104}$

The Resolution on the status of Ramsar sites reaffirmed the commitment made by the parties to implement the terms of Article 3.2 fully and continue to adopt and apply suitable monitoring regimes as part of their management planning for Ramsar sites. ${ }^{1105}$ Various efforts are undertaken under the Ramsar Convention to assist the contracting parties in performing their obligations. The Ramsar Secretariat and the STRP are asked to set up criteria for the streamlining of the procedure for reporting cases of humaninduced negative changes in the ecological character of a Ramsar site in accordance with Article 3.2, and to streamline and combine the lists of Article 3.2 cases with the Montreux Record. ${ }^{1106}$ Apart from that, the Ramsar Convention continues to strengthen the capacity of the contracting parties, where the STRP was requested to display specific examples of the efforts by contracting parties to develop and implement a strategic approach to Ramsar site nomination. ${ }^{1107}$

It can be shown that a community of practice that undertakes the practice of legality on the shared legal understanding to conserve wetlands in accordance with Articles 2.1 and 4.1 of the Ramsar Convention has emerged, where there is a gradual increase of the designation of wetlands for the purpose of conservation. The practice of legality for this rule is rooted in the satisfaction of the procedural obligations provided under the Convention, as informed by the $3^{\text {rd }}$ Strategic Plan. The $3^{\text {rd }}$ Strategic Plan outlined key strategies to guide the contracting parties in achieving their obligation to conserve wetlands of international importance, ${ }^{1108}$ which has gradually yielded tangible results, evidenced in the increase of total areas of wetlands conserved, and the decreased deterioration and increased stabilisation of these wetlands. ${ }^{1109}$

\footnotetext{
${ }^{1104}$ Ramsar Convention, 'Resolution XI.4. The Status of Sites on the List of Wetlands of International Importance', supra n 1100, at p 2, para 9.

${ }^{1105}$ Ramsar Convention, 'Resolution XI.4. The Status of Sites on the List of Wetlands of International Importance', supra n 1100, at p 3, paras 14 and 15.

${ }^{1106}$ Ramsar Convention, 'Resolution XI.4. The Status of Sites on the List of Wetlands of International Importance', supra n 1100, at p 4, paras 21 and 22.

${ }^{1107}$ Ramsar Convention, 'Resolution XI.4. The Status of Sites on the List of Wetlands of International Importance', supra n 1100, at p 4, para 23.

${ }_{1108}$ Ramsar Convention, 'The Ramsar Strategic Plan 2009 - 2015', supra n 981, at pp $10-12$.

${ }^{1109}$ Ramsar Convention, 'Report of the Secretary General on the Implementation of the Convention at the Global Level', supra n 1085, pp 17 - 18, para 64.
} 
In general, the shared understanding arrived at by the contracting parties of the Ramsar Convention pertaining to the obligation to conserve is evidenced in Articles 2.1 and 4.1 of the Convention. That is, the contracting parties shall designate suitable wetlands in their territory in a List of Wetlands of International Importance, and shall formulate and implement their planning in order to promote the conservation and wise use of the Listed wetlands. Even if wetlands are not listed, the Contracting Parties undertake to promote the conservation of these wetlands through the establishment of nature reserves.

The shared understanding on the interpretation of the obligation to conserve wetlands is summarised in the Ramsar Convention Manual. ${ }^{1110}$ The detailed content for the obligation to conserve, via the commitments to designate and formulate plans for the conservation of wetlands within the territory of the contracting parties in the List, and the establishment of nature reserves on non-Listed wetlands are elaborated through guidelines and strategic plans adopted by the contracting parties in its triennium COP.

The recent 2009 - 2015 Strategic Plan expressly confirmed that the strategies developed in the Strategic Plan are representative of the general consensus of the most priorities for most parties. This general consensus arrived at by the contracting parties demonstrates the applicability of the rule of international law on the obligation to conserve enshrined in the Ramsar Convention on its 162 Contracting Parties. ${ }^{111}$

The COP recommended and adopted various procedural means to achieve the short term and long-term target of the Convention. The short-term target is to conserve at least 2,500 sites covering 250 million hectares that suitably represents each wetland type found within each biogeographic region. ${ }^{112}$ The target itself, which could be said to be a morality of aspiration (as opposed to a morality of aspiration), might not form part of the normative content of Articles 2.1 and 4.1, but the procedural mechanisms impose on

\footnotetext{
${ }^{1110}$ The conservation of wetlands necessitates the use of Ramsar criteria for the identification of wetlands of international importance; the making of national wetland inventories that will identify major sites for wetland biodiversity; the designation of wetlands in the List of Wetlands of International Importance; the formulation and implementation of planning that promotes the conservation of Listed sites; the use of Ramsar datasheet and classification and description system; and the establishment of nature reserves on wetlands and the provision of adequate wardening. Ramsar Convention Secretariat, The Ramsar Convention Manual: A Guide to the Convention on Wetlands, supra n 416 at $\mathrm{p} 15$. The shared understanding can be found in the interpretation of the responsibilities of the Contracting Parties in Resolution 5.1 of the Conference of the Parties (1993) that adopts the Framework for the implementation of the Ramsar Convention.

${ }^{1111}$ Ramsar Convention, 'The Ramsar Strategic Plan 2009 - 2015', supra n 981, at p 2, para 7. For the current statistics on the number of contracting parties and Listed sites, see supra $\mathrm{n} 1099$.

${ }_{1112}$ Ramsar Convention, '2009 Strategic Framework and Guidelines', supra n 426, at pp 5 and 17, paras 21 and 65.
} 
the contracting parties in assisting their effort to fulfil their conservation obligation forms part of the normative content of Articles 2.1 and 4.1.

The satisfaction and compliance of their obligation to conserve are measured against whether the contracting parties submit their national reports on time; or whether the contracting parties have fully meet their reporting obligations, especially in updating their Regional Initiatives and the Ramsar Site Information Service database through submission of RIS. ${ }^{113}$ Moreover, assessment of compliance is measured against the satisfaction of strategies under the $3^{\text {rd }}$ Strategic Plan, especially in the designation of Ramsar sites and the formulation of management plans for designated sites. ${ }^{1114}$

The 2002 and 2009 Guidelines, and guided by the constantly revised strategic plans, provide extremely comprehensive instructions in assisting the contracting parties in their implementation of their obligation under the Convention to conserve wetlands. The active furnishing of implementation guidance illustrates the intention of the contracting parties to strengthen the implementation of their obligations under the Convention, which evidenced the commitments of the contracting parties that the shared understandings arrived at are intended to be legal. The obligation to conserve itself is general, promulgated, non-retroactive, non-contradictory, and not unreasonable. The clarity of these rules will be gradually developed through an adaptive, cyclical management process resulted from the application of clear procedural rules. The constancy of both the substantive and procedural rules (output) will evolve in response to the feedback (outcomes) resulting from the act of management intervention (input) executed. ${ }^{115}$ The congruence between the contracting parties and the declared rules is dependent on the capacity of the contracting parties, which the Convention has been striving to assist and support. ${ }^{1116}$

\footnotetext{
${ }^{1113}$ Ramsar Convention, 'Report of the Secretary General on the Implementation of the Convention at the Global Level', supra n 1085, at pp 2 and 7, paras 5 and 52,

1114 Ramsar Convention, 'Report of the Secretary General on the Implementation of the Convention at the Global Level', supra n 1085, at p17 and 18, paras 64 and 66.

${ }^{1115}$ For an elaboration of the definition of input and output, and the subsequent outcomes, see Ramsar Convention, 'New Guidelines for Management Planning for Ramsar Sites and Other Wetlands', supra $\mathrm{n}$ 921 , at pp $11-12$.

${ }^{116}$ Ramsar Convention, 'Report of the Secretary General on the Implementation of the Convention at the Global Level', supra n 1085, at p17 and 18, para 66. See also Ramsar Convention, 'Resolution XI.4. The Status of Sites on the List of Wetlands of International Importance', supra n 1100, at pp 3 and 4, paras 14, 15 and 21, 22 and 23. The Resolution on the status of Ramsar sites reaffirmed the commitment made by the parties to implement the terms of Article 3.2 fully (para 14) and continue to adopt and apply suitable monitoring regime as part of their management planning for Ramsar sites (para 15). Various efforts are
} 
As presented in the explanation in the foregoing sections, it is clearly shown that the shared understandings of the parties on their commitments to conserve wetlands are supported by the practice of legality. ${ }^{1117}$ The contracting parties are relatively steadfast in the undertaking of a practice of legality on their obligation to conserve under the Convention. ${ }^{1118}$ As capacity grows, the practice of legality will be more robust. ${ }^{1119}$

\section{5 'Applicable in the Relations between the Parties'}

In the interpretation that incorporates external rules of international law that are relevant, it is important to identify the content of the rules that is to be taken into account in the interpretative process. It has been established that what is applicable in the relations between the parties' depends on the particular rules of international law. An interactional perspective in the analysis of the rule reveals not only the content of the rule, but also the 'applicability' of the rule on 'the parties', as the 'applicability' of the rule constitutes part of the shared legal understanding arrived at by the parties. The shared legal understandings attained through the interactional process by the members engaged in the practice of legality determine whether the rules are applicable to them. This approach is supported by the context of the text of the 1969 Vienna Convention and the writing of eminent scholars that the phrase 'the parties' in Article 31(3)(c) does not require that the parties to the interpreted treaty must be a party to the external treaty as long as the external rule -

'can be said to be implicitly accepted or tolerated by all parties to the treaty under interpretation in the sense that it can reasonably be considered to express the

undertaken by the Convention to assist the Contracting Parties in performing their obligations. The Ramsar Secretariat and the Scientific and Technical Review Panel (STRP) are asked to set up criteria for the streamlining of the procedure for reporting cases of human-induced negative changes in the ecological character of a Ramsar site in accordance with Art 3.2 (para 21), and to streamline and combine the lists of Art 3.2 cases with the Montreux Record (para 22). Apart from that, the Convention continued to strengthen the capacity of the Contracting Parties where the STRP was requested to showcase specific examples of the efforts by Contracting Parties to develop and implement a strategic approach to Ramsar site designation (para 23).

1117 The Ramsar Convention has 163 Contracting Parties with a designation of 2,062 Ramsar sites covering a total surface area of 197,259,908 hectares. See Ramsar Convention, 'The Ramsar Convention on Wetlands' (undated) <http://www.ramsar.org/cda/en/ramsar-home/main/ramsar/1_4000_0_> accessed 17 November 2012.

${ }^{1118}$ COP 11 indicates an upward trend in the conservation of wetlands under the List where there is an increase of $10 \%$ of designated Ramsar sites in the List since the close of COP 10 (4 November 2008) with a total area of 14,679,990 hectares. Ramsar Convention, 'Resolution XI.4. The Status of Sites on the List of Wetlands of International Importance', supra n 1100, at pp 1 and 2, paras 3 and 4.

1119 This is demonstrated through an $86 \%$ return rate of national reports, with 90 Parties fully meeting their reporting obligation. See Ramsar Convention, 'Report of the Secretary General on the Implementation of the Convention at the Global Level', supra n 1085, at pp 2 and 7, paras 5 and 52. 
common intentions or understanding of all members as to the meaning of the term concerned'. ${ }^{1120}$

The meaning that is 'implicitly accepted or tolerated by all parties that can be considered to express common intentions or understandings of all members ${ }^{1121}$ is reflected in the shared understanding of the parties involved in the enterprise of lawmaking. The members who participate in the interactional process will be 'the parties' within the meaning of Article 31(3)(c).

The parties refer to the 163 contracting parties of the Ramsar Convention. The rules relevant to the preservation of ecosystems of international watercourses are the obligation to conserve as provided under Articles 2.1 and 4.1. The shared legal understandings of the Contracting Parties pertaining to the rule, and undertaken in their practice of legality, are to implement all necessary procedural obligations to achieve the short-term and long-term target of the Convention to designate 2,500 Ramsar sites that are representative of the wetland type of the biogeographic region. The procedural obligations required to achieve their shared legal understandings are -

(1) the identification and designation of wetlands;

(2) the assessment of wetlands;

(3) the monitoring of wetlands;

(4) the management of wetlands. ${ }^{1122}$

What is 'applicable in the relations between the parties' is not just a general stipulation to conserve, but the satisfaction of the procedural obligations intrinsic to the obligation to conserve, which are enumerated above. The accepted meaning of the rules that impose the obligation to conserve and are reasonably considered to express the common intentions or understanding of the Contracting Parties are the duty to identify and designate future wetlands into the List, to ensure the continuous assessment and monitoring of these wetlands, and to provide the appropriate management planning

\footnotetext{
${ }^{1120}$ McLachlan, 'The Principle of Systemic Integration', supra n 162, at pp $314-315$. Pauwelyn, Conflict of Norms in Public International Law, supra n 100, at pp 257 - 263.

${ }^{1121}$ McLachlan, 'The Principle of Systemic Integration', supra n 162, at pp $314-315$.

1122 Ramsar Convention, 'New Guidelines for Management Planning for Ramsar Sites and Other Wetlands', supra n 921, at p 11. The 2002 Guidelines and the $3^{\text {rd }}$ edition of the 2009 Strategic Framework and Guidelines elaborates in detail the structural framework for the future development of Listed wetlands, and the management and planning of Listed wetlands and other wetlands.
} 
process for these wetlands. These shared legal understandings are hence considered as 'applicable in the relations between the parties'.

\subsection{Conclusion}

This chapter undertakes the assessment of Articles 2.1 and 4.1 of the Ramsar Convention, which are identified to be relevant in Chapter Two through an interactional framework developed in Chapter Four for the ascertainment of these rules through the three components of shared understanding; criteria of legality; and the practice of legality.

The conceptualisation of international law through an interactional perspective enables the revelation of the implicit dimension of a rule of international law that informs the interpretation of these rules. Furthermore, the shared legal understanding confirmed in practice provides the normative content and scope that informs the interpretation of Article 20. More importantly, this shared legal understanding indicates the applicability of these rules in the relations between the parties, which is crucial for the interpretation of Article 31(3)(c), and the subsequent operationalisation of this Article in reflection of its systemic integration potential.

This chapter illustrates the operationalisation of the second stage of the analytical framework proposed in Chapter Four of this thesis that interprets the phrase 'rules of international law applicable in the relations between the parties' in Article 31(3)(c). In the context of the Ramsar Convention, Articles 2.1 and 4.1 are rules of international law within the meaning of Article 31(3)(c). The extent of applicability of these rules in the relations between the parties could be derived from the scope of the shared legal understanding practised by the parties, as arrived at in Section 5 of this thesis.

The subsequent Chapter Six presents the operation of the analytical framework developed in Chapter Four in the context of the relevant provisions identified in the Biodiversity Convention. 
6

\section{Chapter 6. Rules of International Law Applicable in the Relations between the Parties: An Interactional Understanding of Law}

\section{Part II: Operation - 1992 Convention on Biological Diversity}

\subsection{Overview}

The previous Chapter Five illustrates the operation of the second stage of the analytical framework that interprets the phrase 'rules of international law applicable in the relations between the parties' stipulate in Article 31(3)(c) of the 1969 Vienna Convention through the prism of an interactional understanding of international law. The interactional framework, developed in Chapter Four, proposes the ascertainment of a rule of international law through three components, namely shared understanding; satisfaction of the eight internal morality of law; and a practice of legality.

The assessment of the Ramsar Convention provisions identified to be relevant for the interpretation of Article 20 of the 1997 Watercourses Convention through the interactional framework in the previous chapter enables the ascertainment of the shared legal understanding undertaken in a practice of legality implicit to Articles 2.1 and 4.1 of the Ramsar Convention. The implicit rules provide the normative content that informs the interpretation of Article 20, and indicates the applicability of these rules in the relations between the parties, which informs the interpretation of the phrase 'applicable in the relations between the parties'.

This chapter undertakes similar operation where Article 8(a) and (d) of the Biodiversity Convention is assessed through the interactional framework in the determination of whether these rules are 'rules of international law' under an interactional understanding of international law. The assessment enables identification of the implicit dimension of the rule that informs the interpretation of 'applicable in the relations between the parties'.

\subsection{Rules of International Law - Shared Understanding}

Chapter Two identifies that the relevant rules for the interpretation of Article 20 in the Biodiversity Convention are the obligation to undertake in-situ conservation stipulated in Article 8, which is defined to include conservation of ecosystems and natural habitats 
and the maintenance of viable populations of species in their natural surroundings. ${ }^{1123}$ Article 8 sets out a clear framework of the necessary elements for in situ conservation $^{1124}$ where Article $8(a)$ and (d) specifically provides that the contracting parties shall, as far as possible and as appropriate, establish a system of protected areas to promote the protection of ecosystems, natural habitats and the maintenance of viable populations of species in natural surroundings. It is relevant to the obligation to preserve freshwater ecosystems stipulated under Article 20 of the 1997 Watercourses Convention in the context that both provisions are geared towards maintaining the ecosystem integrity of ecosystems through the conservation of ecosystems and natural habitats.

Protected areas are designated and set aside to protect and safeguard the natural functioning and ecological processes of ecosystems that cannot be maintained in most intensely-managed landscapes and seascapes, ${ }^{1125}$ and contribute towards the conservation of biodiversity, especially in the face of major threats such as conversion of land for agriculture and other production activities. ${ }^{1126}$ Protected areas are defined as 'a geographically defined area which is designated or regulated and managed to achieve specific conservation objectives ${ }^{, 1127}$ where a system of six management categories for protected areas are developed by international guidelines on the categorisation of protected areas through the World Commission on Protected Areas (WCPA). ${ }^{1128}$

The importance of the obligation to conserve under Article 8 in the fulfilment of the objectives of the Convention is reaffirmed in Decision II/7 of COP 2 (1995). The initial understanding in the implementation of the obligation is to request the Executive Secretary for further information relevant to its implementation, especially in the compilation and dissemination of the information, and a suggestion of how collection

\footnotetext{
${ }^{1123}$ Biodiversity Convention, supra $\mathrm{n}$ 12, Art 2.

${ }^{1124}$ CBD, 'Decision III/9 Implementation of Articles 6 and 8 of the Convention' (Third Ordinary Meeting of the Conference of the Parties to the Convention on Biological Diversity, Buenos Aires, Argentina, 4 15 November 1996) UNEP/CBD/COP/3/38, at p 68 <http://www.cbd.int/doc/decisions/cop-03/full/cop03-dec-en.pdf> accessed 31 July 2012.

${ }_{1125}$ Nigel Dudley, Guidelines for Applying Protected Area Management Categories (IUCN, Gland Switzerland 2008) at p $2<$ http://data.iucn.org/dbtw-wpd/edocs/PAPS-016.pdf> accessed 30 July 2012.

${ }^{1126}$ UNEP-WCMC, Review of the Biodiversity Requirements of Standards and Certification Schemes. A Snapshot of Current Practice (CBD Technical Series No 63, Secretariat of the Convention on Biological Diversity, 2011) at p $16<$ http://www.cbd.int/doc/publications/cbd-ts-63-en.pdf $>$ accessed 30 July 2012.

${ }^{1127}$ Biodiversity Convention, supra $\mathrm{n} 12$, Art 2.

${ }^{1128}$ CBD, 'Protected Areas. Introduction' (undated) <http://www.cbd.int/protected-old/intro.shtml $>$ accessed 30 July 2012. The six management categories can be found at UNEP-WCMC, 'IUCN Management Categories' (2012) <http://www.unep-wcmc.org/iucn-protected-area-managementcategories 591.html $>$ accessed 30 July 2012; and IUCN, 'IUCN Protected Area Management Categories' (16 January 2012) 〈http://www.iucn.org/about/work/programmes/pa/pa_products/wcpa categories/> accessed 30 July 2012.
} 
and sharing of relevant information and experience might be enhanced. ${ }^{1129}$ The subsequent COP 3 (1996) emphasised the need for the sharing of experience and the dissemination of information and requested the Parties not only to submit their first national reports on time, but also to include in their national plans or strategies and legislation, measures for the conservation of biodiversity. ${ }^{1130}$ COP 3 (1996) recommended the development of a thematic approach in the compilation and dissemination of information on the implementation of Articles 6 and 8, including protected areas within this approach. ${ }^{1131}$ Among the efforts undertaken to promote the establishment and management of protected areas, the fourth COP encouraged the Executive Secretary to develop relationships with other processes in the fostering of good management practices pertaining to the comprehensive management of protected areas, ${ }^{1132}$ and the collaboration with other initiatives. ${ }^{1133}$

A concrete shared understanding arrived at for the obligation to conserve via the establishment of a system of protected areas, which is still in operation, is published in

${ }^{1129}$ CBD, 'COP 2 Decision II/7 Consideration of Articles 6 and 8 of the Convention' (Second Meeting of the Conference of the Parties to the Convention on Biological Diversity, Jakarta, Indonesia, $6-17$ November 1995) UNEP/CBD/COP/2/19, at p 11, paras 3 and $4<$ http://www.cbd.int/doc/decisions/cop02/full/cop-02-dec-en.pdf> accessed 30 July 2012.

${ }^{1130} \mathrm{CBD}$, 'Decision III/9 Implementation of Articles 6 and 8 of the Convention', supra n 1124, at pp 68 and 69.

${ }^{1131} \mathrm{CBD}$, 'Decision III/9 Implementation of Articles 6 and 8 of the Convention', supra n 1124, at pp 69 and 70 .

1132 CBD, 'Decision IV/15 The Relationship of the Convention on Biological Diversity with the Commission on Sustainable Development and Biodiversity-related Conventions, Other International Agreements, Institutions and Processes of Relevance' (Fourth Ordinary Meeting of the Conference of the Parties to the Convention on Biological Diversity, Bratislava, Slovakia, $4-15$ May 1998) at p 75 - 78, at para $6<$ http://www.cbd.int/doc/decisions/cop-04/full/cop-04-dec-en.pdf> accessed 31 July 2012. The areas of management includes methods and approaches to deal with protected areas; ecosystem and bioregional approaches to protected area management and sustainable use of biological diversity; mechanisms to enhance stakeholder involvement; methods for developing systems plans and integrating biological diversity considerations into sectoral strategies and planes; and transboundary protected areas.

${ }^{1133}$ The collaborations include - the Commission on Sustainable Development in its implementation of Agenda 21; the endorsement of the Joint Work Plan with the Convention on Wetlands of International Importance; the endorsement of the memoranda of cooperation entered into by the Executive Secretary with the Intergovernmental Oceanographic Commission, the World Bank, the Food and Agriculture Organisation of the United Nations, the World Conservation Union, the Cartagena Convention, the United Nations Educational, Scientific and Cultural Organisation, and the United Nations Conference on Trade and Development; ensuring consistency in the implementation of the Convention on Biological Diversity and the World Trade Organisation agreements, including the Agreement on Trade-Related Aspects of Intellectual Property Rights; and the strengthening of relationship with the United Nations Framework Convention on Climate Change and its Kyoto Protocol, and the United Nations Convention to Combat Desertification in those Countries Experiencing Serious Drought and/or Desertification. See CBD, 'Decision IV/15 The Relationship of the Convention on Biological Diversity with the Commission on Sustainable Development and Biodiversity-related Conventions, Other International Agreements, Institutions and Processes of Relevance' at pp 75 and 76, paras 1, 3, 7, and 8. 
Decision VII/28 of the seventh COP (2004). ${ }^{1134}$ Decision VII/28 (2004) confirms that the establishment and maintenance of systems of protected areas and special measures areas under Article 8 are essential for achieving and implementing the ecosystem approach, and ultimately achieving the three objectives of the Convention. ${ }^{1135}$ It endorses the contributions of the outputs of the Vth IUCN World Parks Congress to the programme of work on protected areas. ${ }^{1136}$

The Vth Congress calls on the COP of the Biodiversity Convention to strengthen the Convention's effort regarding protected areas. ${ }^{1137}$ The global system of protected areas needs to comprise an ecologically representative and coherent ecological network of national and regional protected areas, corridors, buffer zones and transboundary protected areas. ${ }^{1138}$ This system is characterised by interconnectivity with the landscape and existing socio-economic structures and institutions, linked to, supported by, and integrated with efforts to conserve and sustainably use biodiversity across the broader landscape/seascape in accordance with the principles embodied in the Ecosystem Approach. $^{1139}$

The Vth Congress recommends the COP to adopt specific targets and timetables for the in situ conservation of all globally critically endangered and endangered species confined to a single site; the habitats, or viable representations of every terrestrial, freshwater and marine ecosystem within protected areas; and the protection of all natural ecological processes that generate and maintain biodiversity and provide

\footnotetext{
${ }^{1134}$ CBD, 'Decision VII/28 Protected Areas (Articles 8(a) to (e))', supra n 447.

${ }^{1135}$ CBD, 'Decision VII/28 Protected Areas (Articles 8(a) to (e))', supra n 447, at para 1.

${ }^{1136} \mathrm{CBD}$, 'Decision VII/28 Protected Areas (Articles 8(a) to (e))', supra n 447, at para 3. The IUCN Vth World Parks Congress is a 10 yearly event that provides the major global forum for setting the agenda for protected areas. The Vth IUCN World Parks Congress was held in Duran, South Africa, from $8-17$ September 2003. See IUCN, 'World Parks Congress' (29 January 2010) <http://www.iucn.org/about/work/programmes/pa/pa_event/wcpa_wpc/> accessed 31 July 2012.

${ }^{1137}$ IUCN, 'Message of the $\mathrm{V}^{\text {th }}$ IUCN World Parks Congress to the Convention on Biological Diversity' ( $\mathrm{V}^{\text {th }}$ IUCN World Parks Congress, Durban, South Africa, 8 - 17 September) <http://cmsdata.iucn.org/downloads/cbdmessageen.pdf> accessed 17 November 2012. Also in CBD, 'Protected Areas. Message of the Fifth World Parks Congress to the Convention on Biological Diversity. Note by the Executive' (Seventh Meeting of the Conference of the Parties to the convention on Biological Diversity, $9-20$ and 27 February 2004) UNEP/CBD/COP/7/INF/36 (9 February 2004) <http://www.cbd.int/doc/meetings/cop/cop-07/information/cop-07-inf-36-en.pdf > accessed 16 October 2012.

${ }^{1138}$ It is elaborated that the global system of protected areas needs to safeguard all globally and nationally important areas for biodiversity, based on sound science. CBD, 'Protected Areas. Message of the Fifth World Parks Congress to the Convention on Biological Diversity. Note by the Executive', supra n 1137, at $\mathrm{p} 2$.

${ }^{1139}$ IUCN, 'Message of the $\mathrm{V}^{\text {th }}$ IUCN World Parks Congress to the Convention on Biological Diversity', supra $\mathrm{n} 1137$, at pp 1 and 2 .
} 
humanity with vital ecosystem services. ${ }^{1140}$ The Congress considers that a more comprehensive, representative and effectively managed system of protected areas necessitates the maximisation of the representation and persistence of biodiversity in protected area networks through the establishment of enabling environment ${ }^{1141}$ and the implementation of national and individual site biodiversity strategic plans. ${ }^{1142}$

The recommendations of the Vth World Congress laid out the foundation for the conservation of biodiversity through the establishment of protected areas. These recommendations are subsequently adopted thematic programmes of work on protected areas. ${ }^{1143}$ Decision VII/28 (2004) confirms the need to adopt specific targets to be incorporated into the framework of the programme of work, ${ }^{1144}$ and reiterates the importance of capacity building and financial resources for the implementation of the programme of work. ${ }^{1145}$ COP 7 (2004) explicitly recognised the importance of the integration of biodiversity conservation into sectoral policies and programmes, where approaches such as ecological networks, ecological corridors and buffer zones options are considered in the implementation of programme of work on protected areas. ${ }^{1146} \mathrm{An}$ ad hoc open-ended working group on protected areas established in COP 7(2004) will support and review of the implementation of the programme of work on protected areas, are conducted by an ad hoc open-ended working group on protected areas established in COP 7 (2004). ${ }^{1147}$

\footnotetext{
${ }^{1140}$ IUCN, 'Message of the $\mathrm{V}^{\text {th }}$ IUCN World Parks Congress to the Convention on Biological Diversity', supra $\mathrm{n} 1137$, at $\mathrm{p} 2$.

${ }^{1141}$ IUCN, 'Message of the $\mathrm{V}^{\text {th }}$ IUCN World Parks Congress to the Convention on Biological Diversity', supra n 1137, at pp $3-5$. Enabling environment is created through the creation of enabling conditions and the empowerment of a broad range of sectors, communities and interests through capacity building, financial support, well-functioning governance structure and sound policies, and the mechanisms for assessment, monitoring and reporting.

${ }^{1142}$ IUCN, 'Message of the $\mathrm{V}^{\text {th }}$ IUCN World Parks Congress to the Convention on Biological Diversity', supra $\mathrm{n} 1137$, at $\mathrm{p} 2$. In particularly, actions need to be taken to address the severe under representation of freshwater ecosystems and marine ecosystems in the global protected area system, and the creation and expansion of marine protected area networks, including the marine biodiversity and ecosystem processes in the world oceans beyond national jurisdiction.

${ }^{1143}$ CBD, 'Decision VII/28 Protected Areas (Articles 8(a) to (e))', supra n 447, at pp 1 and 4, paras 3 and 31.

${ }^{1144}$ CBD, 'Decision VII/28 Protected Areas (Articles 8(a) to (e))', supra n 447, at paras 6 and 7.

${ }^{1145}$ CBD, 'Decision VII/28 Protected Areas (Articles 8(a) to (e))', supra $\mathrm{n} 447$, at paras 8 and 9.

${ }^{1146} \mathrm{CBD}$, 'Decision VII/28 Protected Areas (Articles 8(a) to (e))', supra n 447, at paras 12 and 13. It is elaborated in fns 2 and 3 of Decision VII/28 that ecological networks "encompass the application of the ecosystem approach that integrates protected areas into the broader land- and/or seascapes for effective conservation of biodiversity and sustainable use'; and that 'ecological corridors may not be applicable to all Parties'.

${ }^{1147}$ CBD, 'Decision VII/28 Protected Areas (Articles 8(a) to (e))', supra n 447, at p 4, para 25.
} 
Decision VII/28 (2004) adopted the Programme of Work on Protected Areas that reaffirmed the importance of protected areas as instruments for meeting the Convention's target to reduce biodiversity loss, especially in the provision of a range of goods and ecological services while preserving natural and cultural heritage, and contribute towards poverty alleviation, research, education, recreation and tourism. ${ }^{1148}$ The aim of the Programme of Work is to support the establishment and maintenance of terrestrial and marine areas that collectively form a global network targeted to reduce the current rate of biodiversity loss at all levels. Apart from that, the Programme of Work aims to achieve the attainment of sustainable development in accordance with the objectives of the Strategic Plan of the Convention, the World Summit on Sustainable Development Plan of Implementation and the Millennium Development Goals. ${ }^{1149}$

The Programme of Work provides guidance for the implementation of the Biodiversity Convention in order to achieve the three objectives of the Convention, namely in situ conservation, sustainable use of biodiversity and the fair and equitable sharing of benefits arising from the use of genetic resources. ${ }^{150}$ For the obligation to undertake in situ conservation, Programme Element 1 of the Programme on Protected Areas, stipulates the step-wise direct actions for the planning, selecting, establishing, strengthening, and managing protected area systems and sites. ${ }^{1151}$ Programme Element 1 provides firstly, the establishment and strengthening of an integrated global network of national and regional systems of protected areas to establish a global network of comprehensive, representative and effectively managed national and regional protected area systems. $^{1152}$

\footnotetext{
1148 'Annex. Programme of Work on Protected Areas' in CBD, 'Decision VII/28 Protected Areas (Articles 8(a) to (e))', supra n 447, at p 6 (hereinafter 'Programme of Work on Protected Areas, Decision VII/28'). ${ }^{1149}$ Programme of Work on Protected Areas, Decision VII/28, supra n 1148, at $\mathrm{p} 7$.

${ }^{1150}$ Programme of Work on Protected Areas, Decision VII/28, supra n 1148, at pp 6 and 8.

${ }^{1151}$ Programme of Work on Protected Areas, Decision VII/28, supra $\mathrm{n} 1148$, at $\mathrm{p} 8$.

1152 Target, Goal 1.1, in Programme of Work on Protected Areas, Decision VII/28, supra n 1148, at p 8. The parties are suggested to establish suitable time-bound and measurable national and regional level protected area targets and indicators, and take action to establish or expand protected areas, especially under-represented marine and inland water ecosystems in national, regional and transboundary systems of inland water protected areas, and the consideration of the conservation needs of migratory species, within a certain timeframe. In addition, to achieve the target, the Parties are advised to conduct effective participation of indigenous and local communities, and the relevant stakeholders in the review of existing and potential forms of conservation and their suitability, and to complete a system gap analyses on the protected area at national and regional levels, taking into account Annex I of the Biodiversity Convention and other relevant criteria. The outcome of the national or regional gap analysis will provide the necessary input for the identification of protected areas for designation that is comprehensive and ecologically representative of the national and regional systems of protected areas, including protected
} 
In order to facilitate Parties in the implementation of their obligation to conserve through the establishment of protected areas, Goal 1.2 recommends the integration of protected areas into the broader land- and seascapes for the maintenance of ecological structure and function. ${ }^{1153}$ The Programme of Work highlights the importance of and the need to develop ${ }^{1154}$ effective site-based planning and management of protected areas that is participatory ${ }^{1155}$ and uses science-based site planning processes in achieving the target set out for the conservation of biodiversity. ${ }^{1156}$ Collaboration in the establishment of transboundary protected areas between neighbouring protected areas across national boundaries is necessary to strengthen regional networks. ${ }^{1157}$ Moreover, the obligation to conserve necessarily implies the need to prevent and to mitigate the negative impacts of key threats to the protected areas. ${ }^{1158}$

areas that benefit indigenous and local communities. See Activities (1.1.1) - (1.1.7), Goal 1.1, Programme of Work on Protected Areas, Decision VII/28, supra n 1148, at pp 8 - 9.

${ }^{1153}$ Programme of Work on Protected Areas, Decision VII/28, supra n 1148, at pp $9-10$. The Parties are suggested to undertake activities such as (1.2.1) evaluation of existing efforts in the integration of protected areas into the broader context, and sectoral plans and strategies; (1.2.2) Identification and implementation measures, including policy, legal, and planning to improve integration of protected areas into broader context; (1.2.3) Integration of protected areas system through establishment and management of ecological networks, ecological corridors and/or buffer zones, and the maintenance of ecological processes where appropriate, in consideration of the needs of migratory species; (1.2.4) Development of tools of ecological connectivity where necessary or beneficial as determined by national priorities for the conservation of biodiversity; (1.2.5) and the rehabilitation and restoration of habitats and degraded ecosystems, as appropriate.

1154 Activity 1.4.4, Goal 1.4, Programme of Work on Protected Areas, Decision VII/28, supran 1148, at p 12. These plans should integrate climate change adaptation measures in the planning, management and design of protected area system (Activity 1.4.5).

1155 Activity 1.4.1, Goal 1.4, in Programme of Work on Protected Areas, Decision VII/28, supra n 1148, at $\mathrm{p} 11$.

${ }^{1156}$ Goal 1.4, in Programme of Work on Protected Areas, Decision VII/28, supra n 1148, at pp $11-12$. The activities suggested for the site management of protected areas include the creation of a highly participatory process that incorporates relevant ecological and socio-economic data in accordance with the ecosystems approach (Activity 1.3.1); the identification of appropriate measurable conservation targets based on the criteria laid out in Annex I of the CBD and other relevant criteria (Activity 1.4.2); the conduct of analysis on opportunities of the protected are to contribute towards conservation and sustainable use of biodiversity at the local and regional scales, as well as an analysis of threats and means of addressing them (Activity 1.4.3). It is important that the management should be conducted through well-trained and skilled personnel who are properly and appropriately equipped and supported (Activity 1.4.6).

${ }^{1157}$ Goal 1.3, in Programme of Work on Protected Areas, Decision VII/28, supra n 1148, at pp $10-11$. The Parties targeted to establish and strengthen transboundary protected areas to enhance the conservation and sustainable use of biodiversity through the implementation of the ecosystem approach, and improving international cooperation (see Activities 1.3.3 and 1.3.4). Collaborative actions include the establishment of effective regional networks of protected areas in areas identified as common conservation priorities, and the establishment of multi-country coordination mechanisms to support long term management of networks (Activity 1.3.1). For marine areas protected areas that lie beyond the limits of national jurisdiction, collaboration can be struck in accordance with international law with other parties through the relevant partners, based on scientific information (Activity 1.3.2).

${ }^{1158}$ Goal 1.5, Programme of Work on Protected Areas, Decision VII/28, supra n 1148, at pp $12-13$. 
The Programme of Work on Protected Areas furnishes the much-needed detail to clarify the obligation imposed by the Biodiversity Convention on the Parties to conserve onsite biodiversity through the establishment of protected areas. The establishment of protected areas, as noted from the detailed elaboration of the Programme of Work, necessitates the parties to take a step-wise procedural approach in the implementation of this obligation under Article 8. The procedural mechanism starts with information procurement, designation of national, regional and transboundary protected areas, the integration of these areas via ecological networks, corridors and/or buffer zones in accordance with the ecosystem approach, and the management of such protected areas, including the provision of mechanisms to address negative impacts of key threats to the protected areas. It is evident in Decision VII/28 (2004) that a clear timeline is stipulated, although its implementation might vary in view of differences in capacity and circumstances. What is clear was the intention of the contracting parties of Biodiversity Convention in achieving their shared understanding of the conservation of biodiversity through the establishment of a system of protected areas in order to reduce biodiversity loss.

The biodiversity of inland water ecosystems are given particular attention in Decision IV/4 (1998) in reference to Recommendation III/1 ${ }^{1159}$ of the Subsidiary Body on Scientific, Technical and Technological Advice (SBSTTA), ${ }^{1160}$ where the importance of inland water ecosystems for global biodiversity and human welfare, and their vulnerability to human actions are recognised. ${ }^{1161}$ The COP welcomed the strategic approaches to the management of freshwater recommended by the Commission on Sustainable Development, and urged parties to include inland water biodiversity considerations in participatory and collaborative work with institutions ${ }^{1162}$ on work related to inland water resources, including the Joint Work Plan with the Ramsar Convention. ${ }^{1163}$

The initial shared understanding on the obligation to conserve freshwater ecosystems under the Biodiversity Convention is demonstrated in the adoption of Recommendation

\footnotetext{
1159 Annex I of CBD, Decision IV/4, supra n 450.

${ }^{1160} \mathrm{CBD}$, Decision IV/4, supra $\mathrm{n}$ 450, at p 14, para 1.

${ }^{1161}$ Annex I of CBD, Decision IV/4, supra n 450, at p 17. Recommendation III/1 was adopted as Annex I to Decision IV/4 as a work programme under the CBD, on the biodiversity of inland water ecosystems and the associated matters of identification and monitoring, assessment methodology and taxonomy 1162 Institution here includes organisation and conventional bodies.

${ }^{1163} \mathrm{CBD}$, Decision IV/4, supra n 450, at pp 3 and 4, paras 2, 3, and 4.
} 
III/1 annexed to Decision IV/4 (1998) as a work programme on inland water ecosystems. ${ }^{1164}$ The elements highlighted in the work programme need to be integrated in the national and sectoral plans of parties and to be implemented as soon as possible. ${ }^{1165}$ Applications for financial support by state parties are advised to prioritise the identification of inland water ecosystems; the preparation and implementation of integrated watershed, catchment and river basin, or inland water ecosystems management plans; and the investigation of processes that leads to the loss of biodiversity of inland water ecosystems. ${ }^{1166}$

The Programme of Work adopted by COP 4 (1998) focused on several salient elements in the conservation of inland water biodiversity, including the assessment of the status and trends of the biodiversity of inland water ecosystems and the identification of options for conservation and sustainable use. ${ }^{1167}$ The COP recommends several actions areas to the parties for the implementation of Element A, including integrated watershed management; research on the ecosystem approach; monitoring and assessment; and environmental impact assessment of projects. ${ }^{1168}$ The parties are advised to prepare indicative lists of inland water ecosystems based on the criteria set out in Annex I of the Biodiversity Convention, and the work of the IUCN. ${ }^{1169}$ Moreover, the Parties are urged to adopt an integrated approach in the assessment, management and where possible

\footnotetext{
${ }^{1164} \mathrm{CBD}$, Decision IV/4, supra $\mathrm{n} 450$, at $\mathrm{p} 14$, para 1.

$1165 \mathrm{CBD}$, Decision IV/4, supra n 450, at p 15, para 5.

$1166 \mathrm{CBD}$, Decision IV/4, supra $\mathrm{n} 450$, at $\mathrm{p} 15$, para 7.

${ }^{1167}$ Element A, CBD, Decision IV/4, supra n 450, at pp 17 - 22. A work plan for the SBSTTA for the assessment inland water biodiversity should include the status and trends, and the conservation and sustainable use of inland water biodiversity including the valuation of ecosystem goods and services of inland water ecosystems, at pp $18-19$, para 8. Apart from the continued collaborations of the Executive Secretary with other relevant institutions, and the development of a list of experts on the conservation and sustainable use of biodiversity of inland waters, COP 4 suggested the clearing-house mechanism be used to promote and facilitate exchange of information. The Executive Secretary and the SBSTTA are requested to assist small island states in the development of rapid-assessment methodologies in light of immediate threats to their inland water ecosystems; or the development of rapid assessment methodologies on disaster and mitigating activities in states that suffer ecological disaster within their territory (pp $18-19$, paras $1-7$ ). In addition, the Executive Secretary is tasked to take decision action to advance the Global Taxonomy Initiative that should be implemented as soon as possible. See Element D, Element A, CBD, Decision IV/4, supra n 450, at p 24.

1168 Element A, CBD, Decision IV/4, supra n 450, at pp $19-22$, para 9(a) - (m).

${ }^{1169}$ Element B, CBD, Decision IV/4, supra n 450, at $\mathrm{p} 23$. The three criteria set out for identification and monitoring in Annex I of the Convention text are - (1) ecosystems and habitats containing high diversity, large numbers of endemic or threatened species, or wilderness; required by migratory species; of social, economic, cultural or scientific importance; or, which are representative, unique or associated with key evolutionary or other biological processes; (2) Species and communities which are threatened; wild relatives of domesticated or cultivated species; or medicinal, agricultural or other economic value; or social, scientific or cultural importance; or important for research into the conservation and sustainable use of biological diversity, such as indicator species; and (3) Described genomes and genes of social, scientific or economic importance.
} 
remedial action on inland water ecosystems and adjacent ecosystems, both within the boundaries of the parties, or transboundary in nature. ${ }^{1170}$

The Programme of Work on Inland Water Biodiversity adopted in Decision IV/4 provides the foundation for the further elaboration and clarification of the obligation to conserve biodiversity of freshwater ecosystems, within an overarching umbrella of the protected area approach. ${ }^{1171}$ The initial shared understanding on the obligation to conserve focuses more on the assessment of status and trends of the biodiversity of inland water ecosystems and identification of options for their conservation and sustainable use. ${ }^{1172}$ COP 4 (1998) recognised the importance of inland water ecosystems for global biodiversity and human welfare, and at the same time, their vulnerability to human action due to the link between human communities, inland waters and their biodiversity that necessitates the participation and awareness of local community in their conservation and sustainable use. ${ }^{1173}$

The need to adopt an ecosystem approach that integrates conservation and sustainable use of biodiversity and the fair and equitable sharing of benefits of inland waters are confirmed in the Preamble of Annex I to Decision IV/4 (1998). ${ }^{1174}$ A work plan was developed for the SBSTTA to build upon the ongoing efforts in inland water ecosystems conservation. ${ }^{1175}$

The SBSTTA initially undertakes the assessment of status and trends using existing information, and the development of guidelines for the rapid assessment of inland water biodiversity for different types of inland water ecosystems. ${ }^{1176}$ The SBSTTA will then compile case-studies of watershed, catchment and river basin management experiences and best practices, in which lessons emerging from these case studies are synthesised. These lessons are mostly from areas such as watershed management that incorporates the ecosystem approach, and the use of protected areas and their management strategies in the conservation and sustainable use of inland water ecosystems. ${ }^{1177}$ In addition, the SBSTTA was tasked to develop methods and techniques for the valuation of goods and

\footnotetext{
${ }^{1170}$ Element C, CBD, Decision IV/4, supra n 450, at pp 23 and 24.

${ }^{1171} \mathrm{CBD}$, Decision IV/4, supra $\mathrm{n}$ 450, at p19, para 8(c)(vii).

1172 Section A, Annex I of CBD, Decision IV/4, supra n 450, at pp $17-22$.

1173 Annex I of CBD, Decision IV/4, supra n 450, at p 17.

${ }^{1174}$ Annex I of CBD, Decision IV/4, supra $\mathrm{n} 450$, at $\mathrm{p} 17$.

1175 Annex I of CBD, Decision IV/4, supra n 450, at $\mathrm{p} 18$, para 8.

${ }^{1176}$ Annex I of CBD, Decision IV/4, supra n 450, at p 18, para 8(a) and (b).

1177 Annex I of CBD, Decision IV/4, supra n 450, at pp 18-19, para 8(c)(i) and (vii).
} 
services of inland water ecosystems, incentives and policy reform, and the understanding of ecosystem function. ${ }^{1178}$

The parties, as recommended by the COP, are encouraged to adopt integrated land and watershed management based on the catchment/watershed/basin approach in the protection, use, planning and management of inland water ecosystems. In particular, integrated watershed/catchment/basin management strategies are adopted to maintain, restore or improve the quality and supply of inland water resources, and the economic, social, hydrological, biological diversity and other functions and values of inland water ecosystems. ${ }^{1179}$ In furtherance of the objective of the conservation and sustainable use of biodiversity through an integrated basin-wide management framework, the Parties are encouraged to explore the appropriate technological means, including technology transfer; and to conduct research on the application of the ecosystem approach. ${ }^{1180}$

In addition, the Parties are required to conduct monitoring and assessment of the status, trends and threats of inland waters ecosystems, to evaluate inland water biodiversity and to promote the sustainable use thereof. ${ }^{1181}$ The importance of environmental impact assessments of water development projects are recognised in Decision IV/4 (1998) adopted by the COP. ${ }^{1182}$ Other areas that were given attention were alien species, genotypes and genetically modified organisms; education and public awareness; collaboration with broader water resource community; transboundary cooperation; local and indigenous communities' participation; economic and legal instruments; and financing of projects. ${ }^{1183}$

It is pertinent to note that the interactional process undertaken by the law making enterprise and the development of the rules relating to the conservation of in situ biodiversity involves the participation of various organisations, institutions and conventions, most notably the Ramsar Convention. ${ }^{1184}$ This is where the international consensus on the need for an integrated approach to river basin management that

\footnotetext{
1178 Annex I of CBD, Decision IV/4, supra n 450, at p 19, para 8(d).

${ }^{1179}$ Annex I of CBD, Decision IV/4, supra n 450, at p 19, para 9(a) and (b).

${ }^{1180}$ Annex I of CBD, Decision IV/4, supra $\mathrm{n}$ 450, at p 20, para 9(b), (c) and (d).

${ }_{1181}$ Annex I of CBD, Decision IV/4, supra $\mathrm{n} 450$, at $\mathrm{p} 20$, para 9(f).

${ }_{1182}$ Annex I of CBD, Decision IV/4, supra $\mathrm{n} 450$, at $\mathrm{p} 21$, para 9(g).

1183 Annex I of CBD, Decision IV/4, supra n 450, at pp $21-22$, para 9(h) - (m) and para 10.

${ }^{1184}$ The outcome of the collaboration with Ramsar includes the River Basin Initiative on the integration of biodiversity, wetland and river basin management. Ramsar Convention, 'Brief Description of the River Basin Initiative' (28 February 2001) <http://www.ramsar.org/cda/en/ramsar-news-archives-2001-briefdescription-of-the/main/ramsar/1-26-45-88\%5E21059_4000_0_> accessed 3 August 2012.
} 
incorporates ecosystem functions and values is made explicit. ${ }^{1185}$ The collaborations with other programmes, organisations, institutions, conventions and stakeholders working on the research, management and conservation of inland water biodiversity contribute towards the clarification and development of the shared understanding of the obligation to conserve biodiversity of inland water ecosystems. This leads to the enhancement of the content and normativity of the rules to conserve as codified under Article 8 of the Biodiversity Convention.

At its seventh meeting in Kuala Lumpur, Malaysia, the COP 7 (2004) adopted a revised and elaborated Programme of Work on the Biodiversity of Inland Water Ecosystems that updates the Programme of Work adopted in Decision IV/4 (1998). ${ }^{1186}$ Decision VII/4 (2004) highlights the collaboration with other organisations, institutions and conventions, or the streamlining of many of its activities, to promote synergies and avoid duplications. ${ }^{1187}$ The aim of the revised programme of work on inland water ecosystems is to enhance the implementation of the Biodiversity Convention at the catchment/watershed/river basin levels and to fulfil its leadership role in international biodiversity issues relating to inland water ecosystems. ${ }^{1188}$ Decision VII/4 (2004) specifically provides that the generic term of 'ecosystem' refers to genomes and genes, species and communities, ecosystems and habitats, unless otherwise specified. ${ }^{1189}$ This confirms the shared understanding of the contracting parties that conservation of

\footnotetext{
${ }^{1185}$ The River Basin Initiative was endorsed by Decision V/2 (2000) (see infra n 1207) of the Biodiversity Convention, and its importance is reiterated in Decision VI/2 of COP 6. Cooperation with the Ramsar Convention continued with the $3^{\text {rd }}$ Joint Work Plan with the Ramsar Convention $(2002-2006)$ as endorsed by the COP in Decision VI/20. See CBD, 'Inland Waters Biodiversity - Background' (undated) <http://www.cbd.int/waters/background/> accessed 3 August 2012. See CBD, 'The Joint Work Programme (JWP) between the CBD and the Ramsar Convention on Wetlands (Ramsar, Iran, 1971): Progress with Implementation and Development of the Fifth Joint Work Programme (2011 Onwards)' (Tenth Meeting of the Conference of the Parties to the Convention on Biological Diversity, Nagoya, 18 29 October 2010) UNEP/CBD/COP/10/INF/38 (19 October 2010) <http://www.cbd.int/doc/meetings/cop/cop-10/information/cop-10-inf-38-en.pdf> accessed 17 August 2012.

${ }^{1186}$ CBD, Decision VII/4, supra $\mathrm{n}$ 158. The adoption of a Revised Programme of Work on Inland Water Biodiversity was considered necessary in Decision VI/2 of the CBD where the COP emphasised 'the importance of review and elaboration of the programme of work on biodiversity of inland water ecosystems'. CBD, 'Decision VI/2 Biological Diversity of Inland Waters' (incorporated as Annex to the Sixth Ordinary Meeting of the Conference of the Parties to the Convention on Biological Diversity, The Hague, Netherlands, 7 - 19 April 2002) UNEP/CBD/COP/6/20 <http://www.cbd.int/doc/decisions/cop06/full/cop-06-dec-en.pdf > accessed 3 August 2012.

${ }^{1187} \mathrm{CBD}$, Decision VII/4, supra n 158, at $\mathrm{p} 1$ para 4. At $\mathrm{p} 6$, para 3 . The activities include the assessment of status and trends and rapid assessment, pp $3-5$, paras 15 - 26; classification systems and criteria for the identification of important inland water biodiversity, pp 5-6, paras $27-30$.

1188 'Annex. Revised Programme of Work on Inland Water Biological Diversity' (hereinafter: 'Revised Programme of Work on Inland Water Biological Diversity'), in CBD, 'Decision VII/4 Biological Diversity of Inland Water Ecosystems', supra n 158, at p 7, para 5.

${ }^{1189}$ Revised Programme of Work on Inland Water Biological Diversity, supran 1188, at p 7, para 8.
} 
biodiversity does not exclude conservation of ecosystems or habitat, as biodiversity is defined to include all the components of the environment. ${ }^{190}$

The implementation of the programme of work is guided by several principles that operate as guiding principles. ${ }^{1191}$ Apart from the transposition of the three pillars of the Biodiversity Convention in the context of inland water biodiversity, namely the promotion of the conservation, sustainable use of inland water biodiversity and the fair and equitable sharing of benefits gained from the use of inland water genetic resources, ${ }^{1192}$ the ecosystem approach must be applied in the management of inland water ecosystems. ${ }^{1193}$

Apart from that, the Programme of Work must not only involve the participation of indigenous and local communities and relevant stakeholders, where their scientific, technical and technological knowledge are used and drawn upon. ${ }^{1194}$ It must also support indigenous and local communities in the re-establishment, development and implementation of traditional approaches and/or adaptive management approaches to conserve and sustain the use of the biodiversity of inland water ecosystems ${ }^{1195}$. In order to promote conservation and sustainable use of inland water biodiversity, appropriate transfer and development of technologies, with appropriate funding, must be made available for the implementation of the Programme of Work. ${ }^{1196}$

Decision VII/4 (2004) has emphasised the need for clarification and elaboration of the programme of work on inland water biodiversity. More specifically for the obligation to conserve inland water ecosystems, Goal 1.2 of Programme Element I on the conservation, sustainable use and benefit sharing of biodiversity is most relevant in furnishing the normative content of this obligation under Article 8. Goal 1.2 of the Revised Programme of Work aims to establish and maintain comprehensive, adequate and representative systems of protected inland water ecosystems ${ }^{1197}$ within the

\footnotetext{
1190 The conceptual variations in the definition of biodiversity are recognised by Oguamanam. See Oguamanam, 'Biological Diversity', supra n 341, at pp $210-212$.

1191 Revised Programme of Work on Inland Water Biological Diversity, supra n 1188, at p 7, para 9(a)(e).

1192 Revised Programme of Work on Inland Water Biological Diversity, supra n 1188, at p 7, para 9(a) and (d).

${ }_{1193}$ Revised Programme of Work on Inland Water Biological Diversity, supra n 1188, at p 7, para 9(b).

${ }^{1194}$ Revised Programme of Work on Inland Water Biological Diversity, supra $\mathrm{n}$ 1188, at p 7, para 9(e).

1195 Revised Programme of Work on Inland Water Biological Diversity, supra n 1188, at p 7, para 9(c).

${ }_{1196}^{119}$ Revised Programme of Work on Inland Water Biological Diversity, supra n 1188, at p 7, para 9(a).

${ }^{1197}$ Protected inland water ecosystems includes all IUCN protected area categories, as appropriate, at Revised Programme of Work on Inland Water Biological Diversity, supra n 1188, at p 11, para (b).
} 
framework of integrated catchment/watershed/river-basin management. It specifically addresses the obligation to conserve inland water biodiversity under Article 8, in particularly paragraphs (a) to (e). ${ }^{1198}$ Goal 1.2 aims to provide a comprehensive, adequate and representative development and maintenance of a system of protected inland water ecosystems within the framework of integrated catchment/watershed/river basin management that involves transboundary collaboration between neighbouring Parties where appropriate. ${ }^{1199}$

In order to achieve Goal 1.2 of establishing and maintaining a comprehensive, adequate and representative systems of protected inland water ecosystems, the parties are required to provide examples of protected-area establishment and management strategies that support the conservation and sustainable use of inland water ecosystems. They are also required to undertake the assessment and identification of priority sites to be included in the system of protected inland ecosystems. ${ }^{1200}$ The Revised Programme of Work suggested the incremental development of the availability of resources and national priorities that contribute to the systematic ${ }^{1201}$ conservation and sustainable use of biodiversity, which maintains the overall ecosystem function, productivity and health within each drainage basin as part of an integrated management approach. ${ }^{1202}$ Where necessary, collaborations must be undertaken with neighbouring parties for the identification, recognition and management of transboundary protected inland water ecosystems. ${ }^{1203}$

The contracting parties of the Biodiversity Convention opined that the Revised Programme of Work is not intended to be prescriptive for parties, given their varying

\footnotetext{
${ }^{1198}$ Goal 1.2, under 'context and linkages, Articles of the Convention on Biological Diversity' in Revised Programme of Work on Inland Water Biological Diversity, supra $\mathrm{n} 1188$, at $\mathrm{p} 11$.

${ }^{1199}$ Revised Programme of Work on Inland Water Biological Diversity, supra n 1188, at $\mathrm{p} 11$.

${ }^{1200}$ It is suggested that assessment can apply the guidance on operationalising Annex I of the Biodiversity Convention and its harmonised application with the criteria for identifying Wetlands of International Importance under the Ramsar Convention, especially sites important for migratory species dependent on inland water ecosystems. See Activities 1.2.1, 1.2.2 and 1.2.3, Revised Programme of Work on Inland Water Biological Diversity, supra n 1188, at p 11.

${ }^{1201}$ A systematic approach necessitates that parties to both the Biodiversity Convention and Ramsar Convention should harmonise their work, in particularly activity 1.2.4 with the development of national networks of wetlands of international importance that are comprehensive and coherent in line with the Ramsar strategic framework for the future development of the List of Wetlands of International Importance and taking into account ecological connectivity and the concept of ecological networks. Activity 1.2.6, Revised Programme of Work on Inland Water Biological Diversity, supra n 1188, at p 12.

${ }^{1202}$ Activity 1.2.4, Revised Programme of Work on Inland Water Biological Diversity, supra n 1188, at p 11.

${ }^{1203}$ Activity 1.2.6, Revised Programme of Work on Inland Water Biological Diversity, supra $\mathrm{n} 1188$, at $\mathrm{p}$ 12.
} 
national circumstances, capacities, and priorities. ${ }^{1204}$ It is viewed as providing a comprehensive and integrated framework of activities where nationally appropriate responses ${ }^{1205}$ can be formulated by each of the contracting parties within the context of their national biodiversity and sustainable development strategies and action plans. ${ }^{1206}$ Limitations in the implementation of the Programme of Work on Inland Water Biodiversity are noted, especially in terms of the lack of information on inland water biodiversity, and the need for improved data and information on the status and trends of, including threats to, the biological diversity of inland water ecosystems. ${ }^{1207}$ In addition, the capacity of states to develop and implement national and sectoral plans to conserve and to use the inland water ecosystems in a sustainable manner necessitates the implementation of capacity-building measures ${ }^{1208}$.

The tenth COP (2010) concluded that the Revised Programme of Work on Inland Waters Biodiversity remains 'a good framework for implementation of relevant

\footnotetext{
${ }^{1204}$ Financial resources are sourced to increase the capacity of the Parties where in Decision VII/24, the COP urges Parties, other Governments and multilateral funding bodies to 'provide the necessary financial support to developing countries, in particularly the least developed and small island developing States, as well as countries with economies in transition, taking into account Art 20 and Article 8 (m) of the Biodiversity Convention to enable them to build capacity and implement the programme of work and undertake the reporting required, including national reports under the Biodiversity Convention, to enable the review of implementation of the programme of work on protected areas in line with goal 2.2 of the programme of work'. CBD, 'Decision VIII/24. Protected Areas' (Eighth Meeting of the Conference of the Parties to the Convention on Biological Diversity, Curitiba, Brazil, 20 - 31 March 2006) at p 2, para 4 <http://www.cbd.int/doc/decisions/cop-08/cop-08-dec-24-en.pdf> accessed 17 November 2012. For mobilisation of financial resources for the implementation of the programme of work by developing countries, see CBD, 'Decision VIII/24. Protected Areas', at pp $3-7$, paras $17-28$. For development of capacity for the identification, designation, management, monitoring and evaluation of national and regional systems of protected areas, see CBD, 'Decision VIII/24. Protected Areas', at p 7, paras 29 - 34.

${ }^{1205}$ These responses are in accordance with the fundamental guiding principles as stated in Revised Programme of Work on Inland Water Biological Diversity, supra n 1188, at p 7, para 9: (a) promotion of the conservation and sustainable use of inland water biodiversity; (b) application of the ecosystem approach to the management of inland water ecosystems; (c) the support of indigenous and local communities to re-establish, develop and implement traditional approaches and/or adaptive management approaches to conserve and sustain the use of the biodiversity of inland water ecosystems; (d) promotion of the fair and equitable sharing of benefits gained from the use of inland water genetic resources and associated traditional knowledge based on prior informed consent in accordance with national laws; and (d) the use of scientific, technical and technological knowledge of indigenous and local communities and relevant stakeholders, with their participation and prior informed consent in accordance with national law, in the implementation of all programme elements.

${ }^{1206}$ Revised Programme of Work on Inland Water Biological Diversity, supra n 1188, at p 7, para 6.

1207 See CBD, 'Decision V/2. Progress Report on the Implementation of the Programme of Work on the Biological Diversity of Inland Water Ecosystems' (Annex III to the Decisions Adopted by the Conference of the Parties to the Convention on Biological Diversity at Its Fifth Meeting, Nairobi, 15 - 26 May 2000) $\mathrm{UNEP} / \mathrm{CBD} / \mathrm{COP} / 5 / 23$, at p 72, para 3 <http://www.cbd.int/doc/decisions/cop-05/full/cop-05-dec-en.pdf> accessed 3 August 2012; and CBD, Decision VII/4, supra n 158, at p 3, para 16.

${ }^{1208}$ CBD, 'Decision V/2. Progress Report on the Implementation of the Programme of Work on the Biological Diversity of Inland Water Ecosystems', supra n 1207, at p 73, para 8.
} 
activities'. ${ }^{1209}$ This conclusion strengthened the shared understanding of the parties of their obligation to conserve the inland waters biodiversity, which furthers the common understanding on the Article 8 obligation to conserve in situ biodiversity through establishment of protected areas.

In addition to the Programmes of Work stated above, the tenth COP (2010) adopted a revised Strategic Plan for Biodiversity $2011-2020^{1210}$ pursuant to its Decision IX/9. ${ }^{1211}$ COP 10 (2010) recognises that the Strategic Plan represents 'a useful flexible framework that is relevant to all biodiversity-related conventions', ${ }^{1212}$ especially when the Strategic Plan is the outcome of submissions made by parties, observers, partners, and the participation of various bodies of the UN system convened through the Environmental Management Group, and of the scientific community. ${ }^{1213}$

The nature of a flexible framework presented in the form of the revised Strategic Plan indicates that the development of national and regional targets imposed in the Plan depends on national priorities and capacities. Its implementation takes into account both the global targets and the status and trends of biodiversity in the country, and the resources provided through the resource mobilisation strategy. ${ }^{1214}$ Noting the financial, human and technical resources that constrain parties' implementation of the Convention, ${ }^{1215}$ the Strategic Plan aims to promote effective implementation of the

\footnotetext{
${ }^{1209}$ CBD, 'X/28 Inland Waters Biodiversity' (Decision Adopted by the Conference of the Parties to the Convention on Biological Diversity at Its Tenth Meeting, Nagoya, Japan, 18 - 29 October 2010) $\mathrm{UNEP} / \mathrm{CBD} / \mathrm{COP} / \mathrm{DEC} / \mathrm{X} / 28$ (29 October 2010) at pp 1 - 2, para 6 <http://www.cbd.int/doc/decisions/cop-10/cop-10-dec-28-en.pdf> accessed 11 August 2012.

${ }^{1210}$ CBD, 'Decision X/2. The Strategic Plan for Biodiversity $2011-2020$ and the Aichi Biodiversity Targets' (Decision Adopted by the Conference of the Parties to the Convention on Biological Diversity at Its Tenth Meeting, Nagoya, Japan 18 - 29 October 2010) UNEP/CBD/COP/DEC/X/2 (29 October 2010) at p 1 para $1<$ http://www.cbd.int/doc/decisions/cop-10/cop-10-dec-02-en.pdf $>$ accessed 4 August 2012.

1211 Decision IX/9 called on the need for the revision and update of the Strategic Plan adopted in Decision VI/26 and the associated framework of goals, targets and indicators stipulated in Decision VIII/15, including the adoption of paragraph 2 of Decision VIII/8 and Paragraph 10 of Decision VIII/9. CBD, 'Decision IX/9 Process for the Revision of the Strategic Plan' (Decision Adopted by the Conference of the Parties to the Convention on Biological Diversity at Its Ninth Meeting, Bonn, 19 - 30 May 2008) UNEP/CBD/COP/DEC/IX/9 (9 October 2008) at p 1 <http://www.cbd.int/doc/decisions/cop-09/cop-09dec-09-en.pdf $>$ accessed 4 August 2012.

$\frac{1212}{121 \text { th }}$ preambular paragraph, CBD, 'Decision X/2. The Strategic Plan for Biodiversity $2011-2020$ and the Aichi Biodiversity Targets', supra n 1210, at $\mathrm{p} 1$.

$12132^{\text {nd }}$ and $4^{\text {th }}$ preambular paragraphs, CBD, 'Decision X/2. The Strategic Plan for Biodiversity $2011-$ 2020 and the Aichi Biodiversity Targets', supra n 1210, at p 1.

${ }^{1214}$ CBD, 'Decision X/2. The Strategic Plan for Biodiversity $2011-2020$ and the Aichi Biodiversity Targets', supra n 1210, at p 2, para 3(b).

1215 'Strategic Plan for Biodiversity 2011 - 2020 and the Aichi Biodiversity Targets' annexed to CBD, 'Decision X/2. The Strategic Plan for Biodiversity 2011 - 2020 and the Aichi Biodiversity Targets', supra n 1210, at p 6, para 6 (hereinafter: 'Strategic Plan for Biodiversity 2011 - 2020 and the Aichi Biodiversity Targets').
} 
Convention that inspires broad-based action by all parties and stakeholders, and to enhance the coherence in the implementation of the provisions of the Convention and the decisions of the COP. ${ }^{1216}$

The Strategic Plan confirms an important shared understanding of the parties on the obligation to conserve biodiversity, which is the recognition of the ecosystem approach, whereby the rationale for the protection of biodiversity is its importance as the underpinning of ecosystem functioning and the provision of ecosystem services essential for human well-being. ${ }^{1217}$ The Strategic Plan outlines multiple entry points to achieve the vision of the Strategic Plan, ${ }^{1218}$ and to take effective and urgent action to halt biodiversity loss to ensure resilience of ecosystems that continuously provide essential services. ${ }^{1219}$ The entry points include addressing the underlying causes of biodiversity loss; decreasing direct pressures on biodiversity; safeguarding and restoring where necessary biodiversity and ecosystem services; ensuring continued provision of ecosystem services and accessing to these services; and enhancing support mechanisms for capacity building. ${ }^{1220}$

The Strategic Plan is organised under five strategic goals and 20 headline Aichi targets that comprise both aspirations for achievement at the global level, and a flexible framework for the establishment of national or regional targets, taking into account national needs and priorities, and their contributions to the achievement of the global targets. ${ }^{1221}$ More specifically, the Strategic Plan outlines the shared understanding of the COP on the conservation of biodiversity in Strategic Goal C, where the aspiration to be achieved at the global level is to improve the status of biodiversity by safeguarding ecosystems, species and genetic diversity. ${ }^{1222}$

\footnotetext{
${ }^{1216}$ Strategic Plan for Biodiversity $2011-2020$ and the Aichi Biodiversity Targets, supra n 1215, at p 6, para 1.

${ }^{1217}$ Strategic Plan for Biodiversity $2011-2020$ and the Aichi Biodiversity Targets, supra n 1215, at p 6, para 3.

${ }^{1218}$ Strategic Plan for Biodiversity 2011 - 2020 and the Aichi Biodiversity Targets, supra n 1215, at p 7, para 11. The vision of the Strategic Plan is a world of 'Living in harmony with nature' where 'by 2050, biodiversity is valued, conserved, restored and wisely used, maintaining ecosystem services, sustaining a healthy planet and delivering benefits essential for all people'.

${ }^{1219}$ Strategic Plan for Biodiversity $2011-2020$ and the Aichi Biodiversity Targets, supra n 1215, at p 8, paras 12.

${ }^{1220}$ Strategic Plan for Biodiversity $2011-2020$ and the Aichi Biodiversity Targets, supra n 1215, at p 7, para 10.

${ }_{1221}$ Strategic Plan for Biodiversity $2011-2020$ and the Aichi Biodiversity Targets, supra n 1215, at p 8, para 13.

${ }_{1222}$ Strategic Plan for Biodiversity 2011 - 2020 and the Aichi Biodiversity Targets, supra n 1215, at p 9.
} 
Targets 11 - 13 provide a flexible framework to achieve the global goal of improved state of biodiversity, where the manifestation of their implementation is contingent on national needs and priorities. A Specific target of at least $17 \%$ of terrestrial and inland water areas and $10 \%$ of coastal and marine areas by 2020, especially areas of particular importance for biodiversity and ecosystem services, are conserved through systems of protected areas and other area-based conservation measures that are effectively and equitably managed, ecologically representative and well connected. ${ }^{1223}$ Ecologically representative and effectiveness of management are the two pivotal qualitative aspects to Target $11 .^{1224}$ Target 12 further develops the obligation to conserve to include to the prevention of the extinction of known threatened species, with their declining conservation status improved and sustained. ${ }^{1225}$ The obligation extends to the conservation and maintenance of genetic diversity and the minimisation of genetic erosion. $^{1226}$

The implementation of the strategic goals and targets are primarily conducted through activities at the national or subnational level, with supporting action at the regional and global levels that adopts a participatory approach at each level of implementation. ${ }^{1227}$ National biodiversity strategies, action plans and national targets are key instruments for translating the Strategic Plan to national circumstances and for the integration of biodiversity across all sectors of government and society. ${ }^{1228}$ The programme of work

\footnotetext{
1223 Target 11, Strategic Plan for Biodiversity 2011 - 2020 and the Aichi Biodiversity Targets, supra n 1215 , at $\mathrm{p} 9$.

1224 CBD, 'Review of Progress in Achieving Aichi Biodiversity Target 11 and Capacity-Building Initiatives under the Programme of Work on Protected Areas. Note by the Executive Secretary' (Fourth Meeting of the Ad Hoc Open-Ended Working Group on Review of Implementation of the Convention, Montreal, 7 - 11 May 2012) UNEP/CBD/WG-RI/4/INF/5 (23 April 2012) at pp 6 - 14 <http://www.cbd.int/doc/meetings/wgri/wgri-04/information/wgri-04-inf-05-en.pdf > accessed 13 August 2012. The Ad Hoc Technical Expert Group on Indicators for the Strategic Plan for Biodiversity 2011 2020 identified three categories of operational indicators that provides support to the parties to improve their monitoring and reporting systems. See the Annex of $\mathrm{CBD}$, ' $\mathrm{XI} / 3$. Monitoring Progress in Implementation of the Strategic Plan for Biodiversity 2011 - 2020 and the Aichi Biodiversity Targets' in CBD, 'Advance Unedited Copy of COP-11 Decision' (Eleventh Meeting of the Conference of the Parties to the Convention on Biological Diversity, 8 - 19 October 2012, Hyderabad, India) at p 29 <http://www.cbd.int/cop/cop-11/doc/2012-10-24-advanced-unedited-cop-11-decisions-en.pdf > accessed 7 November 2012. The list of indicators for achieving Target 11 addresses trends in coverage, condition, representativeness and effectiveness of protected areas and other area-based approaches.

${ }^{1225}$ Target 12, Strategic Plan for Biodiversity 2011 - 2020 and the Aichi Biodiversity Targets, supra $\mathrm{n}$ 1215 , at $\mathrm{p} 9$.

${ }^{1226}$ Target 13, Strategic Plan for Biodiversity 2011 - 2020 and the Aichi Biodiversity Targets, supra $\mathrm{n}$ 1215 , at $\mathrm{p} 9$.

${ }^{1227}$ Strategic Plan for Biodiversity 2011 - 2020 and the Aichi Biodiversity Targets, supra n 1215, at p 10, para 14.

${ }^{1228}$ Strategic Plan for Biodiversity 2011 - 2020 and the Aichi Biodiversity Targets, supra n 1215, at p 10, para 14 .
} 
on different thematic programmes of work under the Convention, together with the various crosscutting programmes and initiatives, are key tools in the updating of national biodiversity strategies and actions plans. ${ }^{1229}$

An effective implementation of the Strategic Plan in the attainment of objectives of the Convention necessitates the broadening of political support from the Heads of State and Government, and the parliamentarians of all Parties who understand the value of biodiversity and ecosystem services. ${ }^{1230}$ In addition, partnerships at all levels, including partnerships with programmes, funds and specialised agencies of the United Nations systems, or other MEAs, are required for effective implementation. ${ }^{1231}$ The assessment and evaluation of implementation involve two important steps. First, the reporting by parties to the COP of their national targets or commitments and policy instruments they have adopted for the implementation of the Strategic Plan. ${ }^{1232}$ Second, the review by the COP, in particularly the Ad Hoc Open-ended Working Group on Review of Implementation of the Convention. ${ }^{1233}$

Parties advocate other supportive mechanisms under the Strategic Plans in light of the various limitations that hamper implementation. Global and regional capacity-building programmes could provide technical support and facilitate peer-to-peer exchange that complements national activities. It could also provide capacity building on mainstreaming of gender, indigenous and local communities' concerns into the implementation of the Strategic Plan at national and subnational levels. ${ }^{1234}$ Apart from

\footnotetext{
${ }^{1229}$ Strategic Plan for Biodiversity 2011 - 2020 and the Aichi Biodiversity Targets, supra n 1215, at p 10, para 15.

${ }^{1230}$ Strategic Plan for Biodiversity 2011 - 2020 and the Aichi Biodiversity Targets, supra n 1215, at p 10, para 16.

${ }^{1231}$ Strategic Plan for Biodiversity 2011 - 2020 and the Aichi Biodiversity Targets, supra n 1215, at p 10, para 17.

${ }^{1232}$ Strategic Plan for Biodiversity 2011 - 2020 and the Aichi Biodiversity Targets, supra n 1215, at p 11, para 18. Reporting shall include milestones achieved for the targets set, and the report on progress towards these targets and milestones.

${ }^{1233}$ Strategic Plan for Biodiversity 2011 - 2020 and the Aichi Biodiversity Targets, supra n 1215, at p 11, para 19. The Ad Hoc Working Group will keep under review implementation of the strategic Plan, and support effective implementation by Parties in ensuring that new guidance is informed by the experience of Parties, in line with the principle of adaptive management through active learning. The COP will review the progress towards the Aichi Biodiversity Targets as set out in the Strategic Plan and make recommendations to overcome any obstacles encountered in meeting those targets. The SBSTTA will facilitate the review process by developing a common set of biodiversity metrics to be used to assess the status of biodiversity and its values. It is stated in pp 12 - 13, para 25 that supportive mechanisms for the monitoring and assessment in global monitoring of biodiversity; and the regular assessment of the state of biodiversity and ecosystems services, future scenarios and effectiveness of responses.

${ }^{1234}$ Strategic Plan for Biodiversity 2011 - 2020 and the Aichi Biodiversity Targets, supra n 1215, at p 11, para 20.
} 
that, supportive mechanisms are available through the clearing-house mechanism and technological transfer to overcome technical incapacity, ${ }^{1235}$ and strategies for the mobilisation of resource to counter financial limitation. ${ }^{1236}$ Ongoing research on biodiversity-ecosystem function and services-human being linkages are needed to ensure effective implementation of the Strategic Plan, not excluding the contributions of knowledge, innovations and practices of indigenous and local communities relevant to the conservation and sustainable use of biodiversity. ${ }^{1237}$

The shared understanding of the parties to the Biodiversity Convention on the obligation to conserve biodiversity is demonstrated through the commitments continuously developed in the COPs since the first COP held in 1994. ${ }^{1238}$ The current shared understanding of parties, after decades of hard work in developing the rule of law in this area, culminated in the adoption of the Strategic Plan by the tenth COP. The most relevant aspect of the Convention for the interpretation of the obligation to preserve ecosystems of international watercourses is the conservation of biodiversity through the establishment of protected areas as stated under Article 8 of the Convention, especially paragraphs (a) and (d).

The obligation imposed by Article 8 requiring the parties to conserve biodiversity and protect their natural surroundings and habitats is incrementally developed through the adoption and implementation of the Programme of Work on Protected Areas. In particularly, the thematic programme on inland water biodiversity fully demonstrates the application of the ecosystem approach within the framework of integrated catchment/watershed/river-basin management where the drainage basin approach is employed. ${ }^{1239}$ The Revised Programme of Work on Inland Water Biodiversity adopted in Decision VII/4 of the seventh COP (2004) guides national, regional and global efforts to reduce inland water biodiversity loss through the

\footnotetext{
${ }^{1235}$ Strategic Plan for Biodiversity 2011 - 2020 and the Aichi Biodiversity Targets, supra n 1215, at p 12, para 22.

${ }^{1236}$ Strategic Plan for Biodiversity $2011-2020$ and the Aichi Biodiversity Targets, supra n 1215, at p 12, para 23. It is reiterated that capacity-building and timely, adequate, predictable and sustainable financial and technical resources are essential to facilitate the implementation of the Strategic Plan. Strategic Plan for Biodiversity 2011 - 2020 and the Aichi Biodiversity Targets, supra n 1215, at p 13, para 25(e).

${ }^{1237}$ Strategic Plan for Biodiversity $2011-2020$ and the Aichi Biodiversity Targets, supra n 1215, at p 13, para 25(c) and (d).

${ }_{1238}$ CBD, 'Conference of the Parties' (undated) $<$ http://www.cbd.int/cop/> accessed 5 August 2012.

${ }^{1239}$ Goal 1.2, especially Activity 1.2 .4 where drainage basin is specifically stated as the functioning unit for the systematic conservation and sustainable use of biodiversity, and the maintenance of overall ecosystem function, productivity and 'health'. Revised Programme of Work on Inland Water Biological Diversity, supra n 1188, at p 11.
} 
protection of inland water ecosystems. The national, regional and global efforts undertaken to reduce inland water biodiversity loss are further supported by the Strategic Plan for Biodiversity 2011 - 2020 adopted in Decision X/2 of COP 10 (2010).

COP 10 (2010) crystallises the common intention of the Parties and their commitments in the implementation of the Strategic Plan. The tenth COP, in assertive language, decides that future meetings of the COP shall review progress in the implementation of the Strategic Plan for Biodiversity 2011 - 2020, shall share experiences relevant for implementation and shall provide guidance on means to address obstacles encountered'. ${ }^{1240}$ The concerted effort of the parties are indicated in the decision of the COP to consider the need for, and possible development of, additional mechanisms that enhance existing mechanisms of the Convention to enable the parties to implement the Strategic Plan, and ultimately meet their commitments under the Convention. ${ }^{1241}$

\subsection{Satisfaction of the Criteria of Legality}

The explicit requirement that the rules that shall be taken into account in the interpretation of a treaty term or provision in Article 31(3)(c) necessitates a determination of whether Article 8(a) and (d) of the Biodiversity Convention satisfies the legality threshold for the interpretation of Article 20 of the 1997 Watercourses Convention. The remainder of this chapter will assess the legality of the shared understanding achieved on the obligation to undertake in situ conservation of biodiversity under Article 8(a) and (d) through the structural framework provided by the eight criteria of morality for the determination of whether these shared understandings attained the status of 'rules of international law'.

\footnotetext{
${ }^{1240}$ CBD, 'Decision X/2. The Strategic Plan for Biodiversity 2011 - 2020 and the Aichi Biodiversity Targets', supra n 1210, at p 4, para 14. This commitment is reaffirmed in the recent COP 11 (2012) through Decisions XI/2; XI/3; XI/23 and XI/24 in CBD, 'Advance Unedited Copy of COP-11 Decision', supra $\mathrm{n} 1224$.

${ }^{1241}$ CBD, 'Decision X/2. The Strategic Plan for Biodiversity 2011 - 2020 and the Aichi Biodiversity Targets', supra n 1210, at p 4, para 15. The commitment to achieve the Aichi Biodiversity Targets through the Strategic Plan for Biodiversity 2011 - 2020 is reaffirmed in the most recent COP 11 (2012). See CBD, 'XI/2. Review of Progress in Implementation of National Biodiversity Strategies and Action Plans and Related Capacity-building Support to Parties' in CBD, 'Advance Unedited Copy of COP-11 Decision', supra n 1204, at preambular paragraph 1. Decision XI/2 (2012), at p 18, para 1, emphasises the need of parties and other governments to review, as appropriate, update and revise their national biodiversity strategies and action plans in line with the Strategic Plan for Biodiversity $2011-2020$, including national plans related to biodiversity.
} 
A conceptualisation of a rule of international law through an interactional framework requires that rules developed through interactions, as established in Chapter Four of this thesis, are differentiated from other social norms by virtue of their satisfaction of the criteria of legality. The confirmation that Article 8(a) and (d) and the shared understanding that underpins these rules are 'rules of international law' is crucial for their incorporation in the interpretation of Article 20 in accordance with Article 31(3)(c) of the 1969 Vienna Convention. ${ }^{1242}$

\subsubsection{Generality}

As noted in Chapter Four and exemplified in Chapter Five, the requirement of generality is sometimes interpreted to mean 'the law must act impersonally, that its rules must apply to general classes and should contain no proper names'. ${ }^{1243}$ This is interpreted to require a generality in the participation of states in the enterprise of international law making, especially in the context of a global concern. The universality of the conservation of biodiversity is evident in Decision $\mathrm{X} / 2$, where the COP invites the UNGA to consider the adoption of relevant elements of the Strategic Plan for Biodiversity 2011 - 2020 and its Aichi Targets as integral elements of the Millennium Development Goal, especially Goal 7 that addresses environmental sustainability. ${ }^{1244}$ Its generality is strengthened by the participation of various bodies of the UN systems in the development of implementation guidelines and the reporting, monitoring and assessment of the progress of implementation. ${ }^{1245}$

The first assessment of the obligation to conserve stipulated under Article 8 against the criterion of generality is the participation of the parties in the making of this rule. The membership for the Biodiversity Convention currently stands at 193 parties. ${ }^{1246}$ Each party $^{1247}$ is entitled to one vote in the COP. ${ }^{1248}$ The COP is the plenary organ and the

\footnotetext{
${ }^{1242}$ Similar operations are undertaken for Article 2.1 and 4.1 of the Ramsar Convention in Section 5.3 of this thesis.

${ }^{1243}$ Fuller, The Morality of Law, supra $\mathrm{n} 747$, at 47.

${ }^{1244}$ CBD, 'Decision X/2. The Strategic Plan for Biodiversity 2011 - 2020 and the Aichi Biodiversity Targets', supra n 1210, at p 4, para 16(e).

${ }^{1245}$ CBD, 'Decision X/2. The Strategic Plan for Biodiversity 2011 - 2020 and the Aichi Biodiversity Targets', supra $\mathrm{n} 1210$, at $4^{\text {th }}$ preambular paragraph at $\mathrm{p} 1$; and $\mathrm{p} 4$, para $16(\mathrm{e})$.

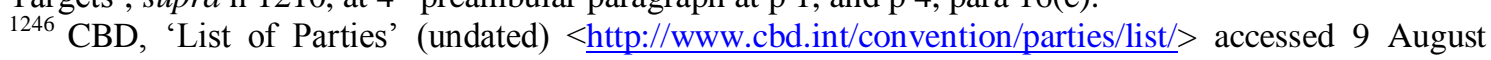
2012.

${ }^{1247}$ Rule 16, CBD, 'Rules of Procedure for Meetings of the Conference of the Parties to the Convention on Biological Diversity' (Annexed to Decision I/1 and Decision V/20) <http://www.cbd.int/doc/legal/cbd-rules-procedure.pdf $>$ accessed 10 August 2012. Each party is
} 
forum in which decisions relating to the implementation of the Convention are undertaken, including the development and operationalisation of obligations under the Convention. ${ }^{1249}$ In this context, the obligations and the subsequent decisions adopted by the COP in the development and operationalisation of the obligations of the Convention have general application, as all parties in an interactional process participate in the enterprise of the making and development of the rule. The satisfaction of the desideratum of generality applies equally to Article 8(a) and (d) where the mechanisms proposed and adopted in the COP decisions to facilitate implementation of the Convention, especially the Programme of Work on Protected Areas on Inland Water Biodiversity, are arrived at through the participation of all Parties.

Moreover, the mechanisms and rules developed in satisfaction of the obligation to conserve inland water ecosystems and their biodiversity applies equally to both the convention bodies and the parties to the Convention. For example, the implementation of Goal 1.2 of the Revised Programme of Work on Inland Water Biodiversity adopted in Decision VII/4 (2004) ${ }^{1250}$ for the establishment and maintenance of a comprehensive, adequate and representative system of protected inland water ecosystems within the framework of integrated catchment/watershed/river-basin management is applicable not only to the contracting parties. It also imposes a duty on the Executive Secretary of the

represented by a delegation consisting of a head of delegation and such other accredited representatives, alternate representatives and advisers as it may require.

${ }^{1248}$ Art 31, Biodiversity Convention, supra n 12. Rule 39(1), CBD, 'Rules of Procedure for Meetings of the Conference of the Parties to the Convention on Biological Diversity', supra $\mathrm{n} 1247$.

1249 Jutta Brunnée, 'COPing with Consent: Law-Making under Multilateral Environmental Agreements',

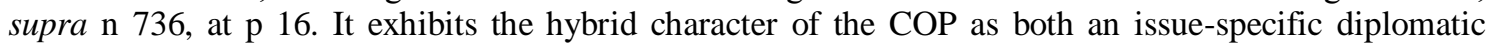
conferences and the permanent plenary bodies of international organisations 'that exercise their functions at the interface of the law of treaties and international institutional law'. The CBD Secretariat explained that the COP is the governing body of the Convention, and 'shall keep under review the implementation of the Convention'. See Art 23, Biodiversity Convention, supra $\mathrm{n}$ 12. It is the supreme decision-making body of the Convention where its main functions are 'to monitor progress and to agree on programmes of work' for the implementation of the convention. CBD, 'Traditional Knowledge, Innovations and Practices. Introduction' (undated) 〈http://www.cbd.int/traditional/intro.shtml> accessed 9 August 2012. In its capacity to review the implementation of the Convention, the COP has the power to 'consider and undertake any additional action that may be required for the achievement of the purposes of this Convention in the light of experience gained in its operation'. Art 23(4)(i), Biodiversity Convention, supra $\mathrm{n}$ 12. The decisions adopted at the COPs are part of the process in which implementation of the Convention is reviewed and undertaken, where the obligations under the Convention is developed and operationalised. See CBD, 'Decision V/20 Operations of the Convention' (Decisions adopted by the Conference of the Parties to the Convention on Biological Diversity at Its Fifth Meeting, Nairobi, 15 - 26 May 2000) UNED/CBD/COP/5/23, para 37 - 41 <http://www.cbd.int/doc/decisions/cop-05/full/cop-05dec-en.pdf $>$ accessed 10 August 2012. The COP, in para 38, decides on the mechanisms to enhance the review and facilitation of implementation of the Convention, including the preparation of strategic plan for the Convention, the second national reports and means to support implementation.

${ }^{1250}$ Goal 1.2, Revised Programme of Work on Inland Water Biological Diversity, supra n 1188, at p 11. 
Convention to support the efforts undertaken by the parties to achieve Goal 1.2 laid out in the Revised Programme of Work. ${ }^{1251}$

The obligation to conserve inland water biodiversity is a global concern and the effort in reaching a solution for its conservation is crystallised in Article 8 of the Convention, where continuous effort in promoting and enhancing its implementation has been undertaken in the interactional process of the COP. The quasi-universal participation of the international community in the COP process evidences the generality of the obligation to conserve, and further supports the assertion that Article 8 on in situ conservation, especially paragraphs (a) and (d), satisfies the criterion of generality.

\subsubsection{Promulgation}

As noted, in reference to the theoretical framework laid out in Chapter Four, Fuller envisioned promulgation as the education of citizens the meaning of the law that might be applied to him, conditioned by the principle of marginal utility. ${ }^{1252}$ It is important that the law be adequately published ${ }^{1253}$ because the citizen is entitled to know the laws that are applicable to 'the practice of his calling'. ${ }^{1254}$ The text of the Convention is published in both hardcopy ${ }^{1255}$ and electronic copy ${ }^{1256}$, which clearly satisfies the promulgation requirement.

In addition, the promulgation of what Fuller labelled as 'rules and practices governing their internal procedures' has also been undertaken by the Convention. The Secretariat of the Biodiversity Convention published the rules of procedures of $\mathrm{COP}^{1257}$ and the decisions adopted by $\mathrm{COP}^{1258}$ concerning the implementation of the obligations under the Convention online, where public access is readily available. Moreover, the

\footnotetext{
${ }^{1251}$ Goal 1.2, Revised Programme of Work on Inland Water Biological Diversity, supra n 1188, at p 12.

1252 Fuller, The Morality of Law, supra n 747, at p 49.

1253 'Adequately published' in this context implies that the promulgation of the law has at least induces one man in a hundred takes the pains to inform himself concerning the laws applicable to the practice of his calling'. It is said to be adequate also if the law is known by a few, and these few man who 'take the pains' of informing himself of the law set a pattern to be followed by others, and indirectly influences the action of many. The publication of the law is also deemed adequate if the public is able to offer criticisms.

See Fuller, The Morality of Law, supra $\mathrm{n} 747$, at $\mathrm{p} 51$.

${ }^{1254}$ Fuller, The Morality of Law, supra $\mathrm{n} 747$, at $\mathrm{p} 51$.

${ }^{1255}$ CBD, supra $\mathrm{n} 12$.

1256 The text of the Convention, and all the subsequent resolutions adopted in furtherance of the objective of the Convention are available at the Biodiversity Convention website $\langle$ http://www.cbd.int $>$ accessed 17 November 2012.

${ }^{1257}$ CBD, 'Rules of Procedure for Meetings of the Conference of the Parties to the Convention on Biological Diversity', supra n 1247.

${ }^{1258}$ CBD, 'Conference of the Parties (undated) < http://www.cbd.int/cop/> accessed 10 August 2012.
} 
mechanisms and guidelines for the implementation of the Convention, ${ }^{1259}$ and the progress of the implementation ${ }^{1260}$ of the obligation on in situ conservation through the establishment of protected areas under Article 8, are traceable online.

It is apparent that the promulgation criterion for the obligation to conserve biodiversity under Article 8, both its external rule and its internal rule, is satisfied.

\subsubsection{Non-Retroactivity}

The principle of non-retroactivity is incorporated in the Biodiversity Convention where Article 22 stipulated that the provisions of the Biodiversity Convention 'shall not affect the rights and obligations of any contracting parties deriving from any existing international agreement, except where the exercise of those rights and obligations would cause a serious damage or threat to biological diversity'. ${ }^{1261}$ As a creature of international law, the Biodiversity Convention is 'limited in scope and are predicated for its existence and operation on being part of the international law system'. ${ }^{1262}$ The principle of non-retroactivity, codified in the 1969 Vienna Convention and forming part of general international law, is intrinsic to the interpretation and application of the obligations under the Convention. ${ }^{1263}$

The non-retroactivity of the provisions of the Biodiversity Convention, especially in the decisions and recommendations arrived at for the implementation of the Convention, and the guidelines ${ }^{1264}$ that provides the content of the obligation to conserve biodiversity are constantly updated and revised subsequent to the assessment and review of progress of the implementation of the contracting parties. These revisions do not have retrospective effect where previous implementation is not rendered inconsistent

\footnotetext{
${ }^{1259}$ For the Programme of Work on Protected Areas, see CBD, 'Programme of Work' (undated) <http://www.cbd.int/protected/pow/learnmore/intro/> accessed 11 August 2012. For tools and guidelines for the conservation of inland waters biodiversity, see CBD, 'Inland Waters Biodiversity - Tool and

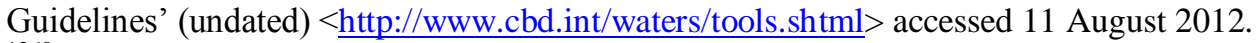

${ }^{1260}$ For the progress in the global implementation of the Programme of Work on Protected Areas, see

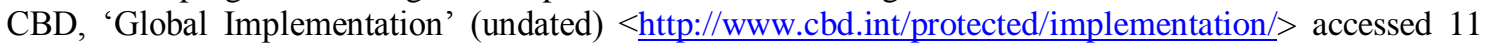
August 2012.

${ }^{1261}$ Art 22(1), CBD, supra $\mathrm{n} 12$.

${ }^{1262}$ McLachlan, 'The Principle of Systemic Integration', supra n 162, at p 280. See Allot, 'The Concept of International Law', supra n 748, at pp 43 - 44. The author elaborated that 'They [Treaties] are an integral part of a society's legal self-constituting, its self-ordering through law. Treaties are a subdelegation of law-making power. The parties may make law for themselves, their legal capacity to do so deriving from international constitutional law, which may set formal and substantial limitations on the capacity'.

12631969 Vienna Convention, supra n 31, Art 28,.

1264 These guidelines are adopted as the Strategic Plan for Biodiversity and the Programme of Work on Protected Areas.
} 
with subsequent amendments and revision. The 'non-retroactivity' of these revisions and amendments is evidenced by the adoption of the Strategic Plan for Biodiversity 2011 - 2020, with its Aichi Targets by the COP of the Biodiversity Convention. ${ }^{1265}$ Furthermore, the COP urges parties and other Governments to develop national and regional targets in accordance with the flexible framework provided by the Strategic Plan; review, update and revise as appropriate their national biodiversity strategies and action plans; and use the revised and updated national biodiversity strategies and action plans as effective instruments for the integration of biodiversity targets into national development and poverty reduction policies. ${ }^{1266}$

This is not contrary to the requirement of non-retroactivity, as previous implementation standards and guidelines provide the basis for further actions to be undertaken in the facilitation of the Parties' implementation of their obligation to conserve. ${ }^{1267}$

\subsubsection{Clarity}

The clarity of law is viewed as the most essential ingredients of legality, where the specificity and the need for clarity of law depend on the nature of the problem. ${ }^{1268}$ The state of global biodiversity is in a continuous state of decline, where the most rapid declines are found in the tropics, in freshwater habitats and marine species utilised by humans. ${ }^{1269}$ Efforts have been undertaken to respond to the degradation of biodiversity, including the increase in the designation of protected areas. ${ }^{1270}$

The adoption of the Strategic Plan for Biodiversity 2011 - 2020 including the Aichi Biodiversity Targets ${ }^{1271}$ clarifies the obligation to conserve biodiversity through in situ conservation laid down in Article 8 of the Biodiversity Convention. The Strategic Plan proposed a flexible framework to address degradation and loss of biodiversity and to

\footnotetext{
${ }^{1265}$ CBD, 'Decision X/2. The Strategic Plan for Biodiversity 2011 - 2020 and the Aichi Biodiversity Targets', supra n 1210 , at p 1, para 1.

${ }^{1266}$ CBD, 'Decision X/2. The Strategic Plan for Biodiversity $2011-2020$ and the Aichi Biodiversity Targets', supra n 1210, at p 2, para 3(b), (c), (d).

${ }^{1267}$ Similar conclusion has been arrived upon regarding the pegging of the UNFCCC's stabilisation commitments to a 1990 reference year. Brunnée and Toope, Legitimacy and Legality in International Law, supra $\mathrm{n} 724$, at pp $185-186$.

${ }^{1268}$ Fuller, The Morality of Law, supra $\mathrm{n} 747$, at $\mathrm{p} 63$.

${ }^{1269}$ Dolors Armenteras and C Max Finlayson (Coordinating Lead Authors) 'Chapter 5. Biodiversity' in UNEP, Global Environmental Outlook 5 (UNEP, 2012) at p 134 <http://www.unep.org/geo/pdfs/geo5/GEO5 report_C5.pdf> accessed 11 August 2012 (hereinafter: 'GEO 5'). ${ }^{1270}$ GEO 5, supra n 1269, at p 134.

1271 Strategic Plan for Biodiversity 2011 - 2020 and the Aichi Biodiversity Targets, supra n 1210, supra n 1215 , at $\mathrm{p} 9$.
} 
improve the state of biodiversity through multiple entry points. These entry points include tackling underlying causes of biodiversity loss; reducing direct pressures on biodiversity; safeguarding and restoring biodiversity and ecosystems; ensuring continued provision of ecosystem services and their accesses; and enhancing the support mechanisms for capacity building. ${ }^{1272}$ Directly pertinent to the obligation to conserve is stipulated in Strategic Goal C of the Aichi Biodiversity Targets and the accompanying Targets $11-13$ that aim to improve the status of biodiversity through the safeguard of ecosystems, species and genetic diversity. In this respect, the obligation to conserve ecosystems aims to achieve a designation of $17 \%$ of terrestrial inland water as protected areas conserved through 'effectively and equitably managed, ecologically representative and well-connected systems of protected areas and other effective area-based conservation measures, and the integration into the wider landscapes and seascapes'. ${ }^{1273}$

The Programme of Work on Protected Areas adopted in Decision VII/28 clarifies the obligation imposed under Article 8 by providing the actions to be taken in the establishment of protected areas. ${ }^{1274}$ It provides procedural guidance in the establishment of protected areas, from information collection, designation of areas of protection informed by the categorisation of IUCN, the management of the protected areas, and the integration of these areas into the overarching ecological networks, corridors and/or buffer zones in accordance with the ecosystem approach within a stipulated time frame.

A more refined level of specificity was undertaken for the conservation of inland water biodiversity, where a work programme on inland water ecosystems, with a scheduled timeframe, was adopted in Decision IV/4. ${ }^{1275}$ The programme of work prescribed actions for the assessment of status and trends, and stipulated the development of work plan for the SBSTTA on matters relating to, inter alia, the assessment of status and trends of inland water biodiversity and their conservation and sustainable use. ${ }^{1276}$ Several salient features for the conservation of inland water biodiversity are highlighted

\footnotetext{
${ }^{1272}$ Strategic Plan for Biodiversity 2011 - 2020 and the Aichi Biodiversity Targets supra n 1215, at p 7, para 10 .

${ }^{1273}$ Target 11, Strategic Plan for Biodiversity 2011 - 2020 and the Aichi Biodiversity Targets, supra $\mathrm{n}$ 1215 , at $\mathrm{p} 9$.

${ }^{1274}$ See Activities (1.1.1) - (1.1.7), Goal 1.1, Programme of Work on Protected Areas, Decision VII/28, supra $\mathrm{n} 1148$, at pp $8-9$.

${ }^{1275}$ Annex I and Annex II of CBD, 'Decision IV/4. Status and Trends of the Biological Diversity of Inland Water Ecosystems and Options for Conservation and Sustainable Use', supra $\mathrm{n} 450$.

${ }^{1276}$ Annex I of CBD, 'Decision IV/4. Status and Trends of the Biological Diversity of Inland Water Ecosystems and Options for Conservation and Sustainable Use', supra n 450, at pp $17-19$, paras $1-8$.
} 
in COP 4 (1998). Several action areas such as the development of integrated land and watershed/catchment/basin management plans; the use of appropriate technology the transfer of technology; the research on the application of ecosystem approach; monitoring and assessment of sites; the evaluation of biodiversity and development of measures for its sustainable use; and etc are recommended by the COP to the Parties. ${ }^{1277}$

The Programme of Work on Inland Water Ecosystems is updated and revised at the seventh COP to enhance implementation of the parties at the catchment/watershed/river basin level, and highlights Biodiversity Convention's leadership role in striving for the collaboration with other organisations, institutions and convention to streamline and to synergise the Convention's activities to avoid duplications. ${ }^{1278}$ In order to achieve the goal of establishing and maintaining comprehensive, adequate and representative systems of protected inland water ecosystems within the framework of integrated catchment/watershed/river-basin management, the parties are required to undertake several activities. These activities include the provision of examples of protected area establishment and management strategies that support the conservation and sustainable use of inland water ecosystems; the assessment and identification of priority sites for inclusion into the system of protected inland water ecosystems using criteria such as sites important for water ecosystem-dependent migratory species as laid out in the Ramsar Convention. ${ }^{1279}$

Apart from that, the Revised Programme of Work prescribes for the development of protected area systems that can contribute in a systematic way to the conservation and sustainable use of biological diversity and to maintain overall ecosystem function, productivity and 'health' of each drainage basin. ${ }^{1280}$ In the attainment of this Goal, the parties are encouraged to collaborate with neighbouring parties for the management and protection of inland water ecosystems. ${ }^{1281}$ Parties to both the Biodiversity Convention and the Ramsar Convention are required to harmonise their activities undertaken in the implementation of the Revised Programme of Work with the Ramsar Strategic

\footnotetext{
${ }^{1277}$ Supra n 1276, at pp $19-22$.

${ }^{1278}$ CBD, Decision VII/4, supra n 158, at p 1 para 4. Revised Programme of Work on Inland Water Biological Diversity, supra $\mathrm{n} 1188$.

1279 Activities 1.2.1 - 1.2.3, Revised Programme of Work on Inland Water Biological Diversity, supra $\mathrm{n}$ 1188 , at $\mathrm{p} 11$.

${ }^{1280}$ Activity 1.2.4, Revised Programme of Work on Inland Water Biological Diversity, supra n 1188, at $\mathrm{p}$ 11.

${ }^{1281}$ Activity 1.2.5, Revised Programme of Work on Inland Water Biological Diversity, supra n 1188, at p 12.
} 
Framework. ${ }^{1282}$ This framework remains relevant as concluded in Decision X/28 of the tenth COP. ${ }^{1283}$

The Revised Programme of Work on Inland Water Biodiversity (Decision VII/4) is supplemented by the Programme of Work on Protected Areas (Decision VII/28) that provides guidance in the establishment of protected areas in accordance with Article 8. Procedural mechanisms, from the identification of sites and their management, to the integration of these sites into an integrated global network of national and regional systems, are provided in the Programme of Work on Protected Areas adopted in Decision VII/28. ${ }^{1284}$ The parties are encouraged to establish suitable time-bound and measurable national and regional protected area targets and indicators, and take action to establish or expand protected areas, especially under-represented marine and inland water ecosystems in national, regional and transboundary systems of inland water protected areas. The parties also need to take into consideration the conservation needs of migratory species within a certain timeframe. ${ }^{1285}$

The Programme of Work on Protected Areas, in particularly the specific thematic programme on inland waters biodiversity, and the recently adopted Strategic Plan and Aichi Targets revised for application to the 2011 - 2020 period, contribute toward the clarification of Article 8 paragraphs (a) and (d). The obligation stipulated under the provision that commands the parties to conserve biodiversity and the protection of ecosystems, natural habitats and the natural surroundings of viable populations of species through the establishment of protected areas, can be said to satisfy the clarity criterion. The persistent and continuous efforts undertaken by the parties in applying the framework, guidelines and technical and/or capacity-building tools available for the implementation of Article 8 provide the foundation for further development of relevant rules, both procedural and substantive, to facilitate the parties' implementation of their obligation to conserve biodiversity stipulated under Article 8. This will progressively develop the substantive and normative clarity of the provision.

\footnotetext{
${ }^{1282}$ Activity 1.2.6, Revised Programme of Work on Inland Water Biological Diversity, supra n 1188, at p 12.

${ }^{1283}$ CBD, ‘X/28 Inland Waters Biodiversity', supra n 1209, at pp $1-2$, para 6.

${ }^{1284}$ Programme of Work on Protected Areas, Decision VII/28, supra n 1148, at p 8.

${ }^{1285}$ See Activities (1.1.1) - (1.1.7), Goal 1.1, 'Programme of Work on Protected Areas, Decision VII/28, supra $\mathrm{n} 1148$, at pp $8-9$.
} 


\subsubsection{Non-Contradiction}

The criterion of non-contradiction seeks not the pronouncement of non-law in the face of contradictions, but instead, to seek reconciliation through recourse to the context and the reciprocal adjustment between the two contradictory laws. ${ }^{1286}$ Similar to the Ramsar Convention, there seems to be an apparent contradiction with the desire to conserve biodiversity, which is a common concern of humankind, while at the same time, reaffirming the use of biological resources, albeit in a sustainable manner. ${ }^{1287}$

The purpose of conservation is to address and resolve the driver of biodiversity loss, and notes the fundamental requirement of conservation through in situ conservation of ecosystems, natural habitats, and the recovery of viable populations of species in their natural surroundings. ${ }^{1288}$ This determination to conserve and sustainably use biodiversity led to the conclusion of the Convention where the objectives of the Convention are 'the conservation of biological diversity, the sustainable use of its components and the fair and equitable sharing of the benefits arising out of the utilisation of genetic resources'. ${ }^{1289}$

'Sustainable use' is defined to mean 'the use of components of biodiversity in a way and at a rate that does not lead to the long-term decline of biodiversity, thereby maintaining its potential to meet the needs and aspirations of present and future generations'. ${ }^{1290}$ It is noteworthy that although sustainable use is defined, there is no such definition for 'conservation' in Article 2. However, in light of Articles 8 and 9 that elaborate steps to be taken in the in situ and ex situ conservation of biodiversity, it can be implied that the concept and scope of 'conservation' could not be substantively defined. Instead, a range of procedural mechanisms is listed out in order to furnish the necessary details that amount to the obligation to conserve biodiversity.

The Preamble is indicative that the preferable method for the conservation of biodiversity is the 'in situ conservation of ecosystems, natural habitats, and the recovery of viable populations of species in their natural surroundings'. This preference is crystallised in Article 8(a) and (d) where it is stipulated that, 'the contracting parties

\footnotetext{
${ }^{1286}$ Fuller, The Morality of Law, supra n 747, at pp $68-69$.

12873 rd and $5^{\text {th }}$ preambular paragraphs, Preamble, CBD, supra $\mathrm{n} 12$.

$12888^{\text {th }}$ and $10^{\text {th }}$ preambular paragraphs, Preamble, CBD, supra $\mathrm{n} 12$.

1289 Art 1, CBD, supra n 12.

${ }^{1290}$ Art 2, CBD, supra $\mathrm{n} 12$.
} 
shall, as far as possible and as appropriate, establish a system of protected areas with special measures taken for the conservation of biodiversity; and to promote the protection of ecosystems, natural habitats and the maintenance of viable populations of species in natural surroundings'. ${ }^{1291}$

The contradiction between conservation and sustainable use is reconciled and harmonised in the implementation of conservation measures. The reconciliation is guided by the flexible framework developed for the period of 2011 - 2020 in the Strategic Plan adopted in Decision X/2 by the COP. ${ }^{1292}$ The Strategic Plan endeavours to take effective and urgent actions to halt the loss of biodiversity, and to increase ecosystem resilience for the continued supply of essential services that sustain human well-being. ${ }^{1293}$

The five Strategic Goals developed to achieve the vision of the Strategic Plan demonstrate the reconciliation between conservation and sustainable use through the prism of an ecosystem approach, where conservation and use are couched in the languages of ecosystem functioning and services provided by its biotic components (biodiversity). The conservation and sustainable use of biodiversity both aim to reduce biodiversity loss through, inter alia, reducing the direct pressure on biodiversity by promoting for sustainable use; and improving the status of biodiversity through the safeguarding of ecosystems, species and genetic diversity. ${ }^{1294}$

The sustainable use of biodiversity under the Strategic Plan implies that the use of biodiversity, be it the harvest of fish and invertebrate stocks; or the management of agriculture, aquaculture and forestry areas; must be within safe ecological limits that avoid over-exploitation and ensure conservation of biodiversity in accordance with the

\footnotetext{
1291 Art 8(a) and (d), Biodiversity Convention, supra $\mathrm{n} 12$.

1292 Strategic Plan for Biodiversity 2011 - 2020 and the Aichi Biodiversity Targets, supra n 1215, annexed to CBD, 'Decision X/2. The Strategic Plan for Biodiversity 2011 - 2020 and the Aichi Biodiversity Targets', supra $\mathrm{n} 1210$.

${ }^{1293}$ Mission, CBD, 'Decision X/2. The Strategic Plan for Biodiversity $2011-2020$ and the Aichi Biodiversity Targets', supra n 1210, at p 8, para 12. The ultimate goal of the Strategic Plan is to achieve the vision of living in harmony with nature by 2050 . Living in harmony with nature means 'biodiversity is valued, conserved restored and wisely used', and ecosystem services are maintained to sustain a healthy planet by delivering essential benefits to all people Vision, CBD, 'Decision X/2. The Strategic Plan for Biodiversity 2011 - 2020 and the Aichi Biodiversity Targets', supra n 1210, at p 7, para 11.

${ }^{1294}$ Strategic Goals B and C, CBD, 'Decision X/2. The Strategic Plan for Biodiversity $2011-2020$ and the Aichi Biodiversity Targets', supra n 1210, at pp $8-9$.
} 
ecosystem approach. ${ }^{1295}$ This indicates that the obligation for the sustainable use of biodiversity is applied in adherence to, and not inconsistent with, the conservation of biodiversity to the minimum extent that it is within the safe limits of the ecological systems.

The aim of conservation is expansive where its objective is not just the preservation of pristine natural environment, but also the safeguarding of representative systems of protected inland water ecosystems, ${ }^{1296}$ ultimately for human well-being and poverty alleviation. ${ }^{1297}$ The Revised Programme of Work on Inland Waters Biodiversity acknowledged and reconciled the tension between conservation and sustainable use where the sustainable use of inland water ecosystems are implicit, or at least not impermissible, in the establishment of protected areas and the design of their management strategies under Goal 1.2. ${ }^{1298}$ This is strengthened by the fact that the systems of protected inland water ecosystems includes all IUCN protected area categories, where the Category VI Protected Areas allows the allocation of a proportion of the area for the low-level, non-industrial use of sustainable natural resources that is mutually beneficial to both conservation and sustainable use. ${ }^{1299}$

This is clear that within the Convention, although the obligation to conserve and to use sustainably seem to be contradictory, reconciliation is struck not only in the treaty instrument, but also the instruments that facilitate the implementation of the Convention and were subsequently developed by the parties through the COP processes. In light of the multiplication of treaty regimes on the environment, the potential conflict of biodiversity-related conventions are foreseen and addressed in the Strategic Plan and Programme of Work on Protected Areas, and the more specific Revised Programme of Work on Inland Water Biodiversity.

\footnotetext{
1295 Targets 5, 6 and 7, Strategic Goal B, CBD, 'Decision X/2. The Strategic Plan for Biodiversity $2011-$ 2020 and the Aichi Biodiversity Targets', supra n 1210, at p 8.

1296 Objective (a), Revised Programme of Work on Inland Water Biological Diversity, supra $\mathrm{n} 1188$, at $\mathrm{p}$ 11.

${ }^{1297}$ Vision, CBD, 'Decision X/2. The Strategic Plan for Biodiversity 2011 - 2020 and the Aichi Biodiversity Targets', supra n 1210, at p 7, para 11.

${ }^{1298}$ Activity 1.2.1, Revised Programme of Work on Inland Water Biological Diversity, supra n 1188, at p 11.

${ }^{1299}$ IUCN, 'Category VI - Protected Area with Sustainable Use of Natural Resources' (10 September 2009) <http://www.iucn.org/about/work/programmes/pa/pa_products/wcpa_categories/pa_categoryvi/> accessed 12 August 2012. For its application, see Dudley (ed) Guidelines for Applying Protected Area Management Categories, supra n 1125, at p 22.
} 
The Strategic Plan recounts the importance of partnerships and synergies at both the national and international levels in order to ensure that the Convention, through its Strategic Plan, contributes not only to its three main objectives but also towards sustainable development and to other Millennium Development Goals, ${ }^{1300}$ and proposes initiatives that enhance cooperation. ${ }^{1301}$ More specifically, the Parties are required to harmonise the work undertaken under the Programme of Work on Inland Water Biodiversity with the Ramsar Convention if the Party is party to both Conventions. ${ }^{1302}$ The collaboration and harmonisation undertaken at the Convention level and the contracting party level ensures that contradictions within and beyond the Convention are reconciled.

Despite the possibility of contradictions between the two concepts of conservation and sustainable use, and the potential conflicts between the Biodiversity Convention and other Conventions, efforts for their reconciliation have been undertaken. Thus, the obligation to conserve through establishment of protected areas, and the safeguarding of ecosystems and habitats stipulated under Article 8, satisfies the non-contradiction criterion.

\subsubsection{Law Not Requiring the Impossible - Reasonableness}

The fine line between law requiring the impossible and law that is not impossible, but is extremely difficult is exceptionally true in the current climate of international

\footnotetext{
${ }^{1300}$ CBD, 'Decision X/2. The Strategic Plan for Biodiversity 2011 - 2020 and the Aichi Biodiversity Targets', supra n 1210, at pp $10-11$, para 17.

${ }^{1301}$ CBD, 'Decision X/2. The Strategic Plan for Biodiversity 2011 - 2020 and the Aichi Biodiversity Targets', supra n 1210, at p 12, para 23. The Programme of Work on Protected Areas adopted in Decision VII/28 listed the partnering institutions for its implementation, which paves the way for further cooperation and creation of synergy and avoids duplication of work. See Programme of Work on Protected Areas, Decision VII/28, supra n 1148, at p 6. The attached Appendix gave an indicative list of partners and other collaborators for the implementation of this Programme of Work, at $\mathrm{p} 23$.

1302 Activity 1.2.6, 'Revised Programme of Work on Inland Water Biological Diversity, supra n 1188, at p 12. Collaborations for the conservation of inland water biodiversity, especially through the expansion of protected areas and ecological networks for inland water biodiversity through designation of coherent and comprehensive networks of wetlands areas within river basins for the Ramsar List of Wetlands of International Importance are reinforced. CBD, 'Decision X/28 Inland Waters Biodiversity', supra n 1209, at p 2, para 10(c). See also p 6, paras 35, 36 and 39. The collaboration between the Biodiversity Convention and the Ramsar Convention is affirmed where the fifth Joint Work Plan (2011 - 2020 between the Biodiversity Convention and the Ramsar Convention are adopted in COP 11(2012). See CBD, 'XI/23. Biological Diversity of Inland Water Ecosystems' Eleventh Meeting of the Conference of the Parties to the Convention on Biological Diversity, 8 - 19 October 2012, Hyderabad, India) in CBD, 'Advance Unedited Copy of COP-11 Decision', supra n 1224, at pp 145 and 146, paras 4 and 8.
} 
environmental law where provisions are mostly aspirational, bordering on, but not to the extent of requiring the impossible. ${ }^{1303}$

The status and progress of implementation of this obligation provides a good starting point for the determination of whether the obligation to conserve biodiversity through the establishment of systems of protected areas and the safeguard of inland water ecosystems is 'impossible'. According to the data presented on the overall global progress in the implementation of the Programme of Work on Protected Areas as reported by the World Database on Protected Areas, $12.9 \%$ of terrestrial area, including inland waters, is designated as protected areas. ${ }^{1304}$

The Ad hoc Working Group on Review and Implementation reported that there is an increase of $1,297,578.52 \mathrm{~km}^{2}$ in cumulative terrestrial protected area from 2004 to 2011. ${ }^{1305}$ Forty-nine parties or $23 \%$ of the parties had achieved Target 11 of the Strategic Plan, which aimed for the designation of at least $17 \%$ of terrestrial and inland water as protected areas. ${ }^{1306}$ Another 40 Parties are close to achieve this Target where between $10-16.99 \%$ of their terrestrial surface area are protected. ${ }^{1307}$

The data used by the Working Group reveals that developing regions are the closest to attain the $17 \%$ target where $13.3 \%$ of their areas were protected in $2010 .{ }^{1308}$ Developed regions and land-locked developing countries follow closely with 11.6 and $11.3 \%$ protected areas respectively. Latin America has over $20.4 \%$ of its terrestrial area protected in 2010, which surpassed the target set down in Target 11 of the Strategic

\footnotetext{
${ }^{1303}$ See Ellis and FitzGerald, 'The Precautionary Principle in International Law', supra n 814, at p 790.

${ }^{1304}$ CBD, 'Global Implementation' (undated) < http://www.cbd.int/protected/implementation/> accessed 13 August 2012. The information was based on best available information from over 100 countries. Data sources included the $4^{\text {th }}$ national reports, as well as a series of CBD regional workshops, in which countries provided detailed status reports on their implementation of the Programme of Work

${ }^{1305} \mathrm{CBD}$, 'Review of Progress in Achieving Aichi Biodiversity Target 11 and Capacity-Building Initiatives under the Programme of Work on Protected Areas. Note by the Executive Secretary', supra n 1224, at p 3, para 11. Figure sourced from UNEP-WCMC, 'The World Database on Protected Areas' (Cambridge, UK, January 2011).

${ }^{1306} \mathrm{CBD}$, 'Review of Progress in Achieving Aichi Biodiversity Target 11 and Capacity-Building Initiatives under the Programme of Work on Protected Areas. Note by the Executive Secretary', supra n 1224 , at $\mathrm{p} 3$, para 11.

1307 CBD, 'Review of Progress in Achieving Aichi Biodiversity Target 11 and Capacity-Building Initiatives under the Programme of Work on Protected Areas. Note by the Executive Secretary', supra n 1224 , at $\mathrm{p} 3$, para 11.

1308 CBD, 'Review of Progress in Achieving Aichi Biodiversity Target 11 and Capacity-Building Initiatives under the Programme of Work on Protected Areas. Note by the Executive Secretary', supra $\mathrm{n}$ 1224 , at $\mathrm{p} 3$, para 12.
} 
Plan. ${ }^{1309}$ The Asian region follows closely with $15.9 \%$ in Eastern Asia, and $15.4 \%$ in Western Asia. ${ }^{1310}$

Although there has been an incremental expansion in the coverage of protected areas, where $23 \%$ of the Parties have managed to achieve the target laid out in the Strategic Plan, management effectiveness remains a lingering issue where $13 \%$ of the assessed 4,100 protected areas have 'clearly inadequate' management. Only $24 \%$ of these protected areas have in place 'sound management' for their protected areas, and the other 62\% have 'basic management'. ${ }^{1311}$ Despite the gap in the qualitative implementation of Target 11, where the lack of effective management remains unsatisfactory, preliminary information gathered in the course of a series of regional and sub-regional capacity-building workshops suggested that 'the world community is making good progress towards Aichi Biodiversity Target 11'. ${ }^{1312}$ Some countries have even surpassed the global target, which goes a long way to indicate that the obligation to conserve biodiversity under Article 8 , and the shared understanding to designate at least $17 \%$ of terrestrial area as a protected area, is not impossible.

The obligation to conserve, from an interactional perspective, continues to be developed and enhanced where after the achievement of the quantitative aspect of the rule, which is the attainment of the $17 \%$ target, efforts are channelled towards improving the management effectiveness of the protected areas, with an increased focus on the representativeness and the connectivity of the protected areas. ${ }^{1313}$ Furthermore, as part of the Programme of Work on Protected Areas, several tools and initiatives have been developed to facilitate and assist the Parties to continue to develop and improve the size

\footnotetext{
1309 CBD, 'Review of Progress in Achieving Aichi Biodiversity Target 11 and Capacity-Building Initiatives under the Programme of Work on Protected Areas. Note by the Executive Secretary', supra n 1224 , at $\mathrm{p} 3$, para 12.

1310 CBD, 'Review of Progress in Achieving Aichi Biodiversity Target 11 and Capacity-Building Initiatives under the Programme of Work on Protected Areas. Note by the Executive Secretary', supra n 1224, at p 3, para 12.

1311 CBD, 'Review of Progress in Achieving Aichi Biodiversity Target 11 and Capacity-Building Initiatives under the Programme of Work on Protected Areas. Note by the Executive Secretary', supra n 1224, at pp $1-2$, para 4 .

1312 CBD, 'Review of Progress in Achieving Aichi Biodiversity Target 11 and Capacity-Building Initiatives under the Programme of Work on Protected Areas. Note by the Executive Secretary', supra $\mathrm{n}$ 1224, at $\mathrm{p} 2$, para 5.

1313 CBD, 'Review of Progress in Achieving Aichi Biodiversity Target 11 and Capacity-Building Initiatives under the Programme of Work on Protected Areas. Note by the Executive Secretary', supra n 1224, at p 2, para 6.
} 
and effectiveness of their protected areas network. ${ }^{1314}$ From this respect, the criterion of reasonableness is satisfied, whereby as capacity grows, the rule becomes less impossible, less aspirational, and less difficult, which draws the rule closer towards the legal-norms end of the social norms-legal norms continuum.

\subsubsection{Constancy}

The uncertainty of the impact of climate change leads to a difficulty in maintaining constancy in the imposition of commitments. ${ }^{1315}$ The criterion of constancy must necessarily be modified in light of the nature of the problem, where adaptation and mitigation in response to changes are pivotal to the relevance of the commitments. The criterion of constancy is deemed satisfied if the decision-making rules and the lawmaking processes are transparent and predictable. ${ }^{1316}$

For Article 8 that imposes the obligation to conserve through the establishment of protected areas that protects ecosystems and natural habitats, the Programme of Work on Protected Areas adopted in Decision VII/28 prescribed activities that serve to contribute toward the achievement of the three objectives of the Convention. ${ }^{1317}$ These activities provide a systematic procedural guidance to assist the parties in their observation of their obligation to conserve under the Convention.

The Programme of Work on Protected Areas proposed for direct actions to be taken for the planning, selecting, establishing, strengthening, and managing protected area systems and sites. ${ }^{1318}$ The Programme of Work requires, firstly, the establishment and strengthening of an integrated system of national and regional protected areas ${ }^{1319}$ that is subsequently integrated into broader land- and seascapes via the application of the

\footnotetext{
1314 CBD, 'Review of Progress in Achieving Aichi Biodiversity Target 11 and Capacity-Building Initiatives under the Programme of Work on Protected Areas. Note by the Executive Secretary', supra n 1224 , at p 2, para 7.

${ }^{1315}$ Brunnée and Toope, Legitimacy and Legality in International Law, supra n 724, at p 183.

${ }^{1316}$ Brunnée and Toope, Legitimacy and Legality in International Law, supra n 724, at p 183.

${ }^{1317}$ Programme of Work on Protected Areas, Decision VII/28, supra n 1148, at p 8.

1318 Programme of Work on Protected Areas, Decision VII/28, supra n 1148, at $\mathrm{p} 8$.

${ }^{1319}$ Goal 1.1, Programme of Work on Protected Areas, Decision VII/28, supra n 1148, at p 8. The Parties are required to establish, by 2006, time-bound and measurable national and regional level protected area targets and indicators, and take urgent steps to establish or expand protected areas in unfragmented, highly irreplaceable natural or highly vulnerable areas; or under-represented marine and inland water ecosystems. See Activity 1.1.1 - 1.1.3, and 1.1.6 at pp 8 and 9. Activity 1.1.6 requires the designation of protected areas identified through the national or regional gap analysis by 2009 and complete the establishment of comprehensive and ecologically representative national and regional systems of protected areas by 2010 for terrestrial environments and 2012 for marine environment.
} 
ecosystem approach to maintain ecological structure and function. ${ }^{1320}$ The designation of protected area systems necessitates the substantial improvement of site-based protected area planning and management ${ }^{1321}$ that integrates climate change adaptation measures in the planning, management strategies, and the design of protected area systems. $^{1322}$

Programme Element 4 is crucial in the parties' effort to implement Programme Element 1 where the continuous management of a protected site and its integration into broader land- or seascape framework necessitate the setting of standards, assessment criteria and monitoring baselines and methodology. ${ }^{1323}$ It develops the substance for an effective management of protected areas that lays out the qualitative aspect of the obligation to conserve biodiversity through the establishment of protected areas. The parties are required to develop standards and best practices where efficient, long-term monitoring of outcomes is implemented. ${ }^{1324}$ The monitoring results provide the input for the adaptation and improvement on the management of protected area. ${ }^{1325}$ Viewed in this context, the obligation of Article 8 is not constant as the subjects of management are constantly modified in response to the results of monitoring, where future management actions are outcome-oriented in accordance with the ecosystem approach. ${ }^{1326}$

${ }^{1320}$ Goal 1.2, Programme of Work on Protected Areas, Decision VII/28, supra n 1148, at pp $9-11$. Activity 1.2.4 requires parties to develop tools of ecological connectivity, such as ecological corridors that link the protected areas together where necessary or beneficial as determined by national priorities for the conservation of biodiversity. Goal 1.3 specifically provides for the establishment and strengthening of regional networks, transboundary protected areas and collaboration between neighbouring protected areas across national boundaries.

${ }^{1321}$ Goal 1.4, Programme of Work on Protected Areas, Decision VII/28, supra n 1148, at pp $11-12$. The plan creates a highly participatory process that involves indigenous and local communities and relevant stakeholders as part of site-based planning. Appropriate measurable biodiversity conservation targets for sites are identified, drawing upon the criteria laid out in Annex I to the Biodiversity Convention. The siteplanning process must include an analysis of opportunities for the protected area to contribute towards the conservation and sustainable use of biodiversity at different scale; as well as the analysis of threats, and their solution. See Activity 1.4.1 - 1.4.4, pp $11-12$.

${ }^{1322}$ Activity 1.4.5, Programme of Work on Protected Areas, Decision VII/28, supra n 1148, at p 12.

${ }^{1323}$ Programme Element 4: Standards, Assessment, and Monitoring, Programme of Work on Protected Areas, Decision VII/28, supra n 1148, at pp 20 - 23. This entails the obligation of parties to - develop and adopt minimum standards and best practices for protected area systems (Goal 4.1); evaluate and improve the effectiveness of protected areas management (Goal 4.2); assess and monitor protected area and trends (Goal 4.3); and to ensure that scientific knowledge contributes to the establishment and effectiveness of protected areas and protected area systems Goal 4.4).

${ }^{1324}$ Activities 4.1.1 an 4.1.2, Goal 4.1, Programme Element 4: Standards, Assessment and Monitoring, Programme of Work on Protected Areas, Decision VII/28, supra n 1148, at p 20.

${ }^{1325}$ Activity 4.1.3, Goal 4.1, Programme Element 4: Standards, Assessment and Monitoring, 'Annex. Programme of Work on Protected Areas' in CBD, 'Decision VII/28 Protected Areas (Articles 8(a) to (e))', supra $\mathrm{n} 447$, at $\mathrm{p} 20$.

${ }^{1326}$ Activity 4.1.3, Goal 4.1, Programme Element 4: Standards, Assessment and Monitoring, Programme of Work on Protected Areas, Decision VII/28, supra n 1148, at p 20. The evaluation of effectiveness of 
Apart from that, the Programme of Work prescribes supportive mechanisms for the equitable sharing of both costs and benefits arising from the establishment and management of protected areas, ${ }^{1327}$ where the rights and responsibilities of indigenous and local communities and other relevant stakeholders in decision-making are accounted for ${ }^{1328}$ through the creation of an enabling environment. ${ }^{1329}$

The Revised Programme of Work on Inland Water Biodiversity acknowledged the general requirements for the conservation and sustainable use of biodiversity in accordance with the ecosystem approach, and the importance of enabling activities and monitoring and assessment in the overall management framework. ${ }^{1330}$ Furthermore, it provides more specificity on the conservation of inland water biodiversity where in this thematic programme, more focus is given to the assessment status, trends and threats to the biodiversity of inland waters that advocates a work plan with defined timeframes, ways, means and capacity needs for the assessment of extent, distribution and characteristics of inland water ecosystems. ${ }^{1331}$

Corresponding to the Programme of Work on Protected Areas adopted in Decision VII/28 for the designation of protected areas, the Revised Programme of Work on Inland Water Biodiversity provides the criteria and systems of classification for the identification of important inland water biodiversity. ${ }^{1332}$ For this purpose, the parties are requested to adopt the Ramsar classification of wetlands as an interim classification system and the framework for the initial inventorying of inland water ecosystems. ${ }^{1333}$

The Revised Programme of Work on Inland Water Biodiversity furthers the conservation objectives under the Programme of Work on Protected Areas where the

management; the assessment of status and trends in accordance with scientific knowledge are further elaborated under Goals $4.2-4.4$.

${ }^{1327}$ Goal 2.1, Programme Element 2: Governance, Participation, Equity and Benefit Sharing, Programme of Work on Protected Areas, Decision VII/28, supra n 1148, at p 13.

${ }_{1328}$ Goal 2.2, Programme of Work on Protected Areas, Decision VII/28, supra n 1148, at p 14.

${ }^{1329}$ Programme Element 3: Enabling Environment, Programme of Work on Protected Areas, Decision VII/28, supra n 1148, at pp 15 - 20. An enabling environment includes the provision of an enabling policy, institutional and socio-economic environment for protected areas (Goal 3.1); capacity building for the planning, establishment and management of protected areas (Goal 3.2); the application and transfer of appropriate technologies for protected areas (Goal 3.3); the guarantee of financial sustainability of protected areas (Goal 3.4); and the strengthening of communication, education and public awareness (Goal 3.5); at pp $15-20$.

${ }^{1330}$ CBD, Decision VII/4, supra n 158, at p 2, para 7(a) - (c). For details, see Programme Elements $1-3$, Programme of Work on Protected Areas, Decision VII/28, supra n 1148, at pp $8-31$.

${ }_{1331} \mathrm{CBD}$, Decision VII/4, supra n 158, at p 3, paras 15 and 16.

$1332 \mathrm{CBD}$, Decision VII/4, supra n 158, at pp 5-6, paras $27-30$.

${ }^{1333} \mathrm{CBD}$, Decision VII/4, supra n 158, at p 5, para 27. Further elaboration on the guidelines on existing criteria is needed, especially for a set of features. See CBD, Decision VII/4, supra n 158, at p 5, para 29. 
management of inland water ecosystems through comprehensive, adequate and representative systems of protected areas requires the adoption of a basin approach that incorporates the ecosystem approach. ${ }^{1334}$ The management of inland water ecosystems must take into account guidelines laid out in the Ramsar Convention for Wetlands and where appropriate, harmonises the implementation under the Programme of Work with Ramsar's Strategic Framework. ${ }^{1335}$

Through the provision of a detailed decision-making processes, from the selection of sites for protection to their management, the obligation to conserve under Article 8 is deemed to satisfy the criterion of constancy.

\subsubsection{Congruence between Official Action and Declared Rules - the Observation of the Rule of Law}

Congruence denotes the consistent application of the law by the officials charged with its administration. ${ }^{1336}$ In the Biodiversity Convention, the 'officials charged with its administration' are the state contracting parties who are party to the Convention. Nonetheless, non-party states and non-state actors, despite not being a party to the Convention, may still observe the provisions of the Convention, and partake in the enterprise of law making in the development of the obligations set forth in the Convention. ${ }^{1337}$ The collaborations and cooperation struck between the contracting

\footnotetext{
1334 Objective (a), Goal 1.1, CBD, Decision VII/4, supra $\mathrm{n} 158$, at $\mathrm{p}$ 8. An integrated watershed/catchment/river basin management strategies are incorporated not only in the conservation and sustainable use of inland water ecosystems and transboundary catchments, watersheds and river basins, but also in the maintenance, restoration, improvement of the quality and supply of inland water resources and other functions and values of inland water ecosystems where adaptive management and mitigation responses are an intrinsic component. Objectives (b) and (c), Goal 1.1, CBD, Decision VII/4, supra n 158, at $\mathrm{p}$ 8. See also Activity 1.2.4, Goal 1.2, CBD, Decision VII/4, supra n 158, at p 11.

${ }^{1335}$ Activities 1.2.2, 1.2.3, 1.2.4, and 1.2.6, Goal 1.2, CBD, Decision VII/4, supra n 158, at pp $11-12$. The recent COP 11 (2012) welcomed the fifth Joint Work Plan (2011 - 2020) between the Biodiversity Convention and the Ramsar Convention. See CBD, 'XI/23. Biological Diversity of Inland Water Ecosystems' (Eleventh Meeting of the Conference of the Parties to the Convention on Biological Diversity, 8 - 19 October 2012, Hyderabad, India) in CBD, 'Advance Unedited Copy of COP-11 Decision', supra n 1224, at p 146, para 8.

${ }^{1336}$ Fuller, The Morality of Law, supra n 747, at p 81 - 91. See Krisch, 'Review of Legitimacy and Legality in International Law', supra n 828, at p 206.

1337 One of the supporting mechanisms proposed to facilitate contracting parties in the implementation of their obligation under the Convention was the enhancement of cooperation between various institutions. They include programmes, funds, and specialised agencies of the United Nations system as well as conventions and other multilateral and bilateral agencies, foundations and non-governmental organisations including UNEP, UNDP, the World Bank, FAO and IUCN, and the indigenous and local communities. CBD, 'Decision X/2. The Strategic Plan for Biodiversity $2011-2020$ and the Aichi Biodiversity Targets', supra n 1210, at p 12, para 24. Deeper normative activity is promoted where the COP is empowered to forge collaborations and cooperation with other conventional bodies in relevant matters. See Biodiversity Convention, supra n 12, Art 23(4)(h). See CBD, 'The Joint Work Programme
} 
parties as the 'officials charged with its administration' and the non-party entities ${ }^{1338}$ form part of the enterprise of law-making that contribute towards the emergence of legal normativity of the obligations crystallised in the Convention, which serve as a yardstick for the assessment against the criterion of congruence. Moreover, the concerted hard work by all parties in the development of the rules demonstrates the universality of the safeguarding of biodiversity as a global concern. ${ }^{1339}$

According to the Review of progress in the implementation of the Strategic Plan for Biodiversity 2011 - 2020 by the Executive Secretary, ${ }^{1340}$ it is re-affirmed that 'wellgoverned and effectively managed protected areas are a proven method for safeguarding both habitats and populations of species and for delivering important ecosystem services'. ${ }^{1341}$ At the global level, some $13 \%$ of the world's terrestrial area is protected where the 2011 data from the World Database on Protected Areas revealed that at the regional level, 20.4\% of Latin America, more than 15\% of Eastern and Western Asia,

(JWO) between the CBD and the Ramsar Convention on Wetlands (Ramsar, Iran, 1971): Progress with Implementation and Development of the $5^{\text {th }}$ JWP (2011 Onwards)', supra $\mathrm{n} 1185$. For more cooperation and partnerships, see CBD, 'Cooperation and Partnership' (CBD, undated) <http://www.cbd.int/cooperation/artsdecs.shtml> accessed 28 March 2012.

$13 \overline{3}$ The phenomenon of the multilateralisation of law-making in the institutionalised setting of MEAs as discussed in Section 4.5 of this thesis strengthens the role that non-state actors play in the normative development of environmental rules. The Biodiversity Convention allows the participation of non-parties to the Convention, such as the United Nations and its specialised agencies, the International Atomic Energy Agency, non-party states, and also 'any other body or agency, whether governmental or nongovernmental qualified in fields relating to conservation and sustainable use of biological diversity' to be involved in the COP as observers. However, this is subject to the condition that such intention to present as observer has been submitted to the secretariat, and not objected by not more than one third of the parties presented at the COP. Biodiversity Convention, supra n 12, Art 24(5). Refer to 'Rules of Procedure for Meetings of the Conference of the Parties to the Convention on Biological Diversity', supra $\mathrm{n}$ 1247, Rules 6 and 7. See Biodiversity Convention, supra n 12, Art 23(5). For example, COP 10 (2010) allowed a list of qualified bodies or agencies which has informed the secretariat their intention to be represented as observers to be presented at the $10^{\text {th }}$ COP, see CBD, 'Qualified Bodies or Agencies, whether Governmental or Non-Governmental, which have Informed the Secretariat of Their Wish to be Represented as Observers at the $10^{\text {th }}$ Meeting of the COP to the CBD' (19 October 2010) (Tenth Meeting of the Conference of the Parties to the Convention on Biological Diversity, Nagoya, 18 - 29 October 2010) UNEP/CBD/COP/10/INF/41 <http://www.cbd.int/doc/meetings/cop/cop-10/information/cop-10inf-41-en.pdf $>$ accessed 28 March 2012.

${ }^{1339}$ See Brunnée and Toope, Legitimacy and Legality in International Law, supra n 724, at p 178. See The Future We Want, supra n 59, at paras 61, 111, and 197 - 204.

${ }^{1340} \mathrm{CBD}$, 'Review of Progress in Implementation of the Strategic Plan for Biodiversity $2011-2020$, Including the Establishment of National Targets and the Updating of National Biodiversity Strategies and Action Plans' (20 July 2012) (Eleventh Meeting of the Conference of the Parties to the Convention on Biological Diversity, Hyderabad, India, 8 - 19 October 2012) UNEP/CBD/COP/11/12 <http://www.cbd.int/doc/meetings/cop/cop-11/official/cop-11-12-en.pdf> accessed 16 August 2012 (hereinafter: 'Review of Progress by Executive Secretary').

${ }^{1341}$ Review of Progress by Executive Secretary, supra n 1340, at p 12 para 21. 
$11.8 \%$ of Sub-Saharan Africa, $4.9 \%$ of Oceania and $4 \%$ of Northern Africa are protected. $^{1342}$

Furthermore, the current data for year 2011 revealed that 42 countries have designated more than $17 \%$ of their territories as protected areas subjected to the Convention, with another 65 countries setting aside $5-15 \%$ of their territories as protected areas. ${ }^{1343}$ Two hundred seventy three out of 823 ecoregions have more than $17 \%$ of their area designated as protected areas. ${ }^{1344}$ Five out of the 14 terrestrial biomes, which are tundra, flooded grasslands and savannas, tropical and sub-tropical moist broadleaf forests, mangroves and montane grasslands and shrublands, have more than $17 \%$ of their area under protection. $^{1345}$

The data reveals that the contracting parties are gradually achieving the shared understanding of the conservation of biodiversity through the establishment of protected areas as evidenced in the adoption of the 17\% target in the Strategic Plan 2011 2020. ${ }^{1346}$ The protected area networks in some developed countries like Australia, Finland, Canada, and Germany and some developing countries such as Brazil, Bhutan, and Costa Rica are 'near comprehensive and ecologically representative, covering major biomes (forests, pastures, deserts, grasslands, mountains, and wetlands) and includes public, private and community protected areas' ${ }^{1347}$ The Secretariat is of the opinion that 'given the current progress in protected areas, it is likely that the target of at least $17 \%$ of terrestrial areas protected will be achieved by $2020{ }^{\prime}{ }^{1348}$

The assessment of the Executive Secretary as to the progress in the implementation of Target 11 intimated the qualitative requirements necessary in the achievement of the Target. The qualitative requirements include the completion of a comprehensive ecological gap analysis as required under the Convention's Programme of Work on Protected Areas; and the implementation of the outcome of the analysis, including the

\footnotetext{
${ }^{1342}$ Review of Progress by Executive Secretary, supra n 1340, at p 12 para 21.

${ }^{1343}$ Review of Progress by Executive Secretary, supra n 1340, at p 12 para 21.

${ }^{1344}$ Review of Progress by Executive Secretary, supra n 1340, at p 12 para 21.

${ }^{1345}$ Review of Progress by Executive Secretary, supra n 1340, at p 12 para 21.

${ }^{1346}$ Target 11, Strategic Plan for Biodiversity 2011 - 2020 and the Aichi Biodiversity Targets, supra $\mathrm{n}$ 1215 , at $\mathrm{p} 9$.

${ }^{1347}$ Review of Progress by Executive Secretary, supra n 1340, at p 13, para 24.

${ }^{1348}$ Review of Progress by Executive Secretary, supra n 1340, at p 13, para 26.
} 
establishment of new protected areas and/or the extension of existing protected areas. $^{1349}$

On this aspect, the data collected showed that more than 40 countries have satisfied the requirement to complete a comprehensive ecological gap analysis as required by the Programme of Work on Protected Areas and are in the process of implementing its results. ${ }^{1350}$ Attempts have been undertaken to conduct comprehensive gap analyses in 20 countries, ${ }^{1351}$ which drive the number of countries who put into practice the qualitative aspect of the shared understanding achieved on the safeguard of biodiversity to 63 parties. This demonstrates the actions undertaken by the contracting parties, as the 'officials charged with administration' that are congruent with the declared rules codified in the Convention, where the shared understanding on these rules are developed in subsequent COP decisions, including the Strategic Plans adopted in Decision $\mathrm{X} / 2$.

Another salient qualitative requirement in the obligation to conserve biodiversity is the issue of effectiveness in the management of protected areas. It is in this aspect that major gaps occurred where a 2010 global assessment of the effectiveness of the management of protected areas revealed that only $62 \%$ of protected areas satisfied basic effectiveness standards, while $13 \%$ of the assessed protected areas have 'clearly inadequate' management. ${ }^{1352}$ Moreover, there are gaps in the representativeness in the current networks of protected areas, where more emphasis is needed to protect critical ecosystems. ${ }^{1353}$

The note by the Executive Secretary for COP 11 painted an inspiring picture of an observation of the rule of law. It demonstrates at least a procedural, quantitative congruence between the declared rule of the obligation to conserve biodiversity through establishment of protected areas and safeguarding of ecosystems, habitats and natural surroundings of viable populations of species under Article 8(a) and (d) of the

\footnotetext{
${ }^{1349}$ Review of Progress by Executive Secretary, supra n 1340, at p 13, para 24.

${ }^{1350}$ Review of Progress by Executive Secretary, supra n 1340, at p 13, para 24.

${ }^{1351}$ Review of Progress by Executive Secretary, supra $\mathrm{n} 1340$, at p 13, para 24.

${ }^{1352}$ Review of Progress by Executive Secretary, supra $\mathrm{n} 1340$, at p 13, para 25.

${ }^{1353}$ Under-represented ecosystems include coastal areas, oases, cave systems, karsts, grasslands, rivers and river canyons, marshes, tropical coral reefs, sea-grass beds, deepwater cold coral reefs, seamounts, tropical forests, peat lands, freshwater ecosystems and coastal wetlands. Review of Progress by Executive Secretary, supra n 1340, at p 13, para 23.
} 
Convention and actions of contracting parties 'charged with the administration of the rule'.

The world community shared the common aim to make good progress towards the achievement of the quantitative component of Target 11 that requires an at least $17 \%$ designation of terrestrial and inland water ecosystems as protected areas. ${ }^{1354}$ At the level of sub-regions, the Central and Eastern Europe and Central Asia achieved significant progress for nine goals laid out in the Programme of Work on Protected Areas, followed by eight goals for the Pacific, two goals for West Africa, and one goal for South, East and South East Asia. ${ }^{1355}$ Eighty-six parties, representing almost half of the world's terrestrial area, have proposed protection targets that would amount to a combined protected area of $16 \%$ of the total terrestrial area of the Earth, which is 'well on the way to achieving the global target of protecting $17 \%$ of terrestrial areas'. ${ }^{1356}$

The Executive Secretary noted that global data collected on the progress status in the implementation of the Programme of Work on Protected Areas, especially in the implementation of Programme Element 1 that is most pertinent to the obligation to conserve biodiversity, showed that there are significant progress in the establishment and strengthening of national and regional systems of protected areas. ${ }^{1357}$ Over 200 priority actions were identified by countries as part of their national action plans for the implementation of the Goal 1.1, in establishing and strengthening national and regional systems of protected areas integrated into a global network as a contribution towards globally agreed goals. ${ }^{1358}$

\footnotetext{
${ }^{1354}$ CBD, 'Protected Areas: Progress in the Implementation of the Programme of Work and Achievement of Aichi Biodiversity Target 11' (Eleventh Meeting of the Conference of the Parties to the Convention on Biological Diversity, Hyderabad, India 8 - 19 October 2012) UNEP/CBD/COP/11/26 (23 July 2012) at p 5, para $16<$ http://www.cbd.int/doc/meetings/cop/cop-11/official/cop-11-26-en.pdf > accessed 16 August 2012 (hereinafter: 'Progress in the Implementation of the Programme of Work and Achievement of Aichi Biodiversity Target 11 ').

${ }^{1355}$ Progress in the Implementation of the Programme of Work and Achievement of Aichi Biodiversity Target 11, supra n 1354, at p 3, para 12. In fn 3: Sample size for the sub-regions used in the analysis are as follows: Central, South and East Africa, 16; Latin America, 14; Central and Eastern Europe and Central Asia, 12; West Asia and North Africa, 12; South, East and South East Asia, 10; Pacific, 10; and West Africa, 10.

${ }^{1356}$ Progress in the Implementation of the Programme of Work and Achievement of Aichi Biodiversity Target 11, supra $\mathrm{n} 1354$, at $\mathrm{p} 5$, para 16.

${ }^{1357}$ Progress in the Implementation of the Programme of Work and Achievement of Aichi Biodiversity Target 11, supra n 1354, at p 3, para 10. See Goal 1.1, Programme Element 1, 'Programme of Work on Protected Areas, Decision VII/28, supra n 1148, at p 8.

${ }^{1358}$ Progress in the Implementation of the Programme of Work and Achievement of Aichi Biodiversity Target 11, supra n 1354, at p 8, para 18.
} 
Some progress is noted in the integration of protected areas into broader landscape and seascapes and sectors to maintain ecological structure and function. Over 100 actions that correspond to Goal 1.2 of the Programme of Work on Protected Areas in achieving Target 11 of Strategic Plan are identified by country parties. ${ }^{1359}$ Improvements of progress in the effort to integrate protected areas into broader landscapes, seascapes and sectors in order to maintain ecological structure and function are attempted through the identification of 115 priority actions by 58 countries. ${ }^{1360}$

For the goal to establish and to strengthen regional networks, transboundary protected areas and collaborations between neighbouring protected areas across national boundaries, nine out of 15 countries in Central, South and East Africa reported significant progress. ${ }^{1361}$ Some parties have identified 13 priority actions in the establishment and the strengthening of regional networks, transboundary protected areas and collaboration between neighbouring protected areas across national boundaries. ${ }^{1362}$ The Executive Secretary interprets the status of progress as an opening up of possibility to build upon existing cooperation within the sub-regions. The deepening of cooperation and collaborations potentially provides greater opportunities for sub-regional transboundary protected area projects and to improve on the establishment and the strengthening of national and regional systems of protected areas advocated in Goal 1.1 of the Programme of Work on Protected Areas. ${ }^{1363}$

Two hundred and seven priority actions identified by countries that correspond to Goal 1.4 are revealed in the Progress Report stated in the Note by the Executive Secretary. ${ }^{1364}$

\footnotetext{
${ }^{1359}$ Progress in the Implementation of the Programme of Work and Achievement of Aichi Biodiversity Target 11, supra n 1354, at pp 3 and 8, paras 11 and 18. See Goal 1.2, Programme Element 1, Programme of Work on Protected Areas, Decision VII/28, supra n 1148, at p 9.

${ }^{1360}$ Progress in the Implementation of the Programme of Work and Achievement of Aichi Biodiversity Target 11, supra $\mathrm{n} 1354$, at $\mathrm{p} 9$, para 19.

${ }^{1361}$ Progress in the Implementation of the Programme of Work and Achievement of Aichi Biodiversity Target 11, supra $\mathrm{n} 1354$, at $\mathrm{p} 4$, para 14 .

${ }^{1362}$ Progress in the Implementation of the Programme of Work and Achievement of Aichi Biodiversity Target 11, supra $\mathrm{n} 1354$, at $\mathrm{p} 8$, para 18.

${ }^{1363}$ Progress in the Implementation of the Programme of Work and Achievement of Aichi Biodiversity Target 11, supra n 1354, at $\mathrm{p}$ 4, para 14. Programme Element 1 concerns the direct actions for the planning, selecting, establishing, strengthening, and managing protected area systems and sites, see Programme of Work on Protected Areas, Decision VII/28, supra n 1148, at pp $8-13$. Target 11 aimed to designate at least $17 \%$ of terrestrial and inland water areas, especially areas of particular importance for biodiversity and ecosystem services by 2020, and to have it conserved through effective and equitable management measures that in a well-connected systems of protected areas that are integrated into the wider landscapes and seascapes. Strategic Plan for Biodiversity 2011 - 2020 and the Aichi Biodiversity Targets, supra n 1215 , at $\mathrm{p} 9$.

${ }^{1364}$ Progress in the Implementation of the Programme of Work and Achievement of Aichi Biodiversity Target 11, supra n 1354, at p 8, para 18 . Goal 1.4 seeks to substantially improve site-based protected area
} 
This Goal forms and important element in achieving Target 11 where the content of the planning and management of site-based protected area provides the much-needed qualitative aspects of Target 11, which is separated into elements based on key terms.

The quantitative aspect of the area target of 'at least $17 \%$ of terrestrial and inland water areas' is qualified by phrases such as 'areas of particular importance for biodiversity and ecosystem services' that can be translated to mean the protection of areas of particular importance for biodiversity and ecosystem services; 'integrated into wider landscapes and seascapes and sectors'; 'ecologically representative'; 'effectively managed', 'equitably managed'; 'other area-based conservation measures' and 'wellconnected systems'. ${ }^{1365}$ The status of progress reported by the Executive Secretary enumerated the actions identified by countries that correspond to the quantitative and qualitative elements of Target 11, the most common priority actions being management effectiveness; protected areas connectivity; area-based conservation measures; and ecological representation. ${ }^{1366}$

In the case of the qualitative element of 'ecological representativeness' in Target 11, ${ }^{1367}$ it is shown that ' $50 \%$ or 414 out of the 823 terrestrial eco-regions meet this target and a further 149 eco-regions are close to it with between $5-10 \%$ of their area under protection'. ${ }^{1368}$ Performance is less satisfactory for terrestrial eco-regions where less than $1 \%$ of the area is protected, suggesting that efforts towards the proactive identification of gaps at the country and area levels in order to resolve the issue are

planning and management. See Programme of Work on Protected Areas, Decision VII/28, supra n 1148, at $\mathrm{p} 11$.

${ }^{1365}$ Progress in the Implementation of the Programme of Work and Achievement of Aichi Biodiversity Target 11, supra $\mathrm{n} 1354$, at pp $9-10$, para 20.

${ }^{1366}$ Progress in the Implementation of the Programme of Work and Achievement of Aichi Biodiversity Target 11, supra n 1354, at p 10, para 21. There are 532 priority actions identified by the contracting parties that relate to the implementation of Target 11 of the Aichi Biodiversity Targets. See Progress in the Implementation of the Programme of Work and Achievement of Aichi Biodiversity Target 11, supra $\mathrm{n}$ 1354, at $\mathrm{p} \mathrm{10}$. There are 73 countries that identified priority actions to improve management effectiveness that has an average implementation timeframe of 2013 to 2016. Other priority actions relating to protected areas connectivity, area-based conservation measures and ecological representation are to be completed within the timeframes ranging from 2015 to 2017 . 16 countries identified priority actions for increasing the connectivity of protected areas; 23 countries identified area-based conservation measures for their designated protected areas; where 27 countries identified priority actions for the designation of protected areas that are ecologically representative.

${ }^{1367}$ Target 11 adopted in Decision VII/28, supra $\mathrm{n} 447$, is to have $10 \%$ of each of the world's ecological regions effectively conserved.

${ }^{1368}$ Progress in the Implementation of the Programme of Work and Achievement of Aichi Biodiversity Target 11, supra $\mathrm{n} 1354$, at $\mathrm{p} 13$, para 33. 
urgently required. ${ }^{1369}$ In a 2010 study where 4,151 assessments were undertaken, less than $30 \%$ of the world's protected areas have a management plan and only $24 \%$ of protected areas have sound management in place. ${ }^{1370}$ Thirteen percent of the 4,151 assessments have clearly inadequate management, whereas $27 \%$ of the assessments 'recorded basic management with major deficiencies'. ${ }^{1371}$

The preliminary information laid out in the Progress Report prepared for COP 11 indicates that 'the world community is on track to meet the terrestrial area component of Target 11' and well on their way to reach the global target of protecting $17 \%$ of terrestrial areas. ${ }^{1372}$ The more capacity-intensive, technically-driven qualitative aspects of Target 11, including ecological representativeness, management effectiveness, connectivity and integration into wider land- and seascapes, and equitable management including other effective area-based conservation, will be continuously developed and enhanced in order to achieve Target $11 .^{1373}$ At this juncture, the careful monitoring and reporting of these priority actions can contribute toward the assessment of progress of the Aichi Biodiversity Target 11 as well as other Aichi Targets. ${ }^{1374}$

In short, there is substantial congruence between the actions undertaken and practised by the contracting parties as the officials in charge of the administration of the rule to conserve biodiversity, both quantitatively and to a lesser degree, qualitatively, as declared under Article 8. The congruence between the actions undertaken and practised by the contracting parties on the rule to conserve biodiversity is continuously developed through decisions adopted by the COP. The efforts undertaken by the contracting parties in their endeavour to perform actions that are congruent with the declared rule on the obligation to conserve biodiversity evidence Article 8's satisfaction of the eighth criterion of internal morality of law.

\footnotetext{
${ }^{1369}$ Progress in the Implementation of the Programme of Work and Achievement of Aichi Biodiversity Target 11, supra $\mathrm{n} 1354$, at $\mathrm{p} 13$, para 33.

${ }^{1370}$ Progress in the Implementation of the Programme of Work and Achievement of Aichi Biodiversity Target 11, supra n 1354, at p 13, para 34. Quoted Fiona Leverington et al, Management Effectiveness Evaluation in Protected Areas - A Global Study ( $2^{\text {nd }}$ edn, University of Queensland, Brisbane Australia, 2010).

${ }^{1371}$ Progress in the Implementation of the Programme of Work and Achievement of Aichi Biodiversity Target 11, supra $\mathrm{n} 1354$, at $\mathrm{p} 13$, para 34.

${ }^{1372}$ Progress in the Implementation of the Programme of Work and Achievement of Aichi Biodiversity Target 11, supra $\mathrm{n} 1354$, at $\mathrm{p} 14$, paras 36 and 37.

${ }^{1373}$ Progress in the Implementation of the Programme of Work and Achievement of Aichi Biodiversity Target 11, supra $\mathrm{n} 1354$, at $\mathrm{p} 14$, para 37.

${ }^{1374}$ Progress in the Implementation of the Programme of Work and Achievement of Aichi Biodiversity Target 11, supra $\mathrm{n} 1354$, at p 11, para 26.
} 
The eight criteria of morality provide a structural framework positioned in the overall framework of an interactional understanding of law, where shared understandings are guided towards the attainment of legality and shape the generation of shared legal understanding. Shared legal understandings emerge through the dynamic relationship of an interactive process instead of the mere discovery of rules through static sources.

The obligation to conserve biodiversity through the establishment of protected areas and the safeguarding of ecosystems, habitats, and the natural surroundings of viable populations of species, are declared in the form of Article 8(a) and (d). As elaborated and analysed in the previous sections, this obligation has clearly satisfied the requirements imposed by the criteria of generality, promulgation and non-retroactivity. The clarity of the obligation and the congruence of practice with the rule will be constantly developed when the underlying normative understandings continue to flourish through the persistent practice of the enterprise of law making. ${ }^{1375}$ The (seemingly) extreme difficulty in the implementation of the requirement of the rule will decrease and will appear to be increasingly reasonable when the capacity of the contracting parties improves through participatory planning, knowledge management, capacity-building, and other supporting mechanisms and enhancement of enabling factors that facilitate the implementation of the obligation. ${ }^{1376}$

Non-contradictions of law have been actively addressed by the Convention where internal tensions inherent between conservation and use are reconciled through interpretation, whereas external contradictions resulting from the fragmentation of international law on the environment are reconciled through collaborative partnerships and cooperation that promote linkages and synergies. Due to the nature of biodiversity conservation that is highly vulnerable to changes, constancy of law through time is not possible, especially when effective management necessitates the employment of adaptive management approach. However, the criterion of constancy should be deemed satisfied as long as the decision-making rules and the law-making processes are transparent and predictable.

\footnotetext{
${ }^{1375}$ This obligation is elaborated and developed by the programmes of work on protected areas in various thematic areas of implementation and other guidelines and instruments where its implementation was guided by the 2011 - 2020 Strategic Plan adopted in Decision X/2, supra n 1215.

${ }_{1376}$ Progress in the Implementation of the Programme of Work and Achievement of Aichi Biodiversity Target 11, supra n 1354, at pp $14-15$, para 39.
} 
To conclude, the assessment of the obligation to conserve under Article 8(a) and (d) against the eight criteria of internal morality of law confirms the position of the obligation at the legal end on the normativity continuum that traverses from social normativity to legal normativity.

\subsection{A Practice of Legality (Norm Application)}

The shared legal understandings generated through robust interactions and reciprocity between lawmakers and subjects, nourished by the implicit rules of the broader background understandings, must be maintained through a practice of legality. ${ }^{1377}$ The vigour of law is upheld through the constant effort to support it where the law is seen as a distinctive interaction performed by 'a joint enterprise of members that shares collective understandings' - the shared understandings of which direct and rationalise the conduct of members in the enterprise. A practice of legality is built up through reasoned dialogue (interaction and reasoning through law) and reciprocity (vertical congruence) where a broader base of shared legal understandings is developed via interactions that adhere to the requirements of legality. ${ }^{1378}$ A practice of legality is said to have emerged when the reasoned dialogue of norms created through shared understanding is 'communicated' and applied through a plurality or a series of actions or conduct of mutual engagement that satisfy the criteria of legality.

In the present research, a practice of legality on the obligation to conserve biodiversity is said to have existed when Article 8(a) and (d), and its substantive content achieved through the interactional COP processes and continuously developed by implementation by state contracting parties, are applied in practices that meet the criteria of legality. For this purpose, there is a need to identify whether the conduct of states, undertaken in satisfaction of the obligation to conserve, satisfy both the quantitative and qualitative elements of the obligation, which forms the substantive content of Article 8(a) and (d) as a whole.

The quantitative element is an obligation of result where Target 11 aimed to increase the global terrestrial protected area, which includes inland water ecosystems, to $17 \%$. The Programme of Work on Protected Areas and the Revised Programme of Work on Inland Water Biodiversity prescribed the necessary procedural mechanisms in achieving the

\footnotetext{
${ }^{1377}$ Brunnée and Toope, Legitimacy and Legality in International Law, supra n 724, at pp 80 - 81 .

${ }^{1378}$ Brunnée and Toope, Legitimacy and Legality in International Law, supra n 724, at p 72.
} 
quantitative element of the Target. Apart from that, the obligation to conserve is qualified by complementary terms such as 'areas of particular importance for biodiversity and ecosystem services'; 'integrated into wider landscapes and seascapes and sectors'; 'ecologically representative'; 'effectively managed', 'equitably managed'; 'other area-based conservation measures' and 'well-connected systems'. ${ }^{1379}$ In the satisfaction of the qualitative elements, the Convention prescribes and recommends the appropriate procedural means in achieving the qualitative elements.

The membership of the Biodiversity Convention currently stands at 193 contracting parties ${ }^{1380}$ with a designation of over 150,000 protected areas covering $756,102 \mathrm{~km}^{2}$, with $12.9 \%$ of the world's terrestrial surface protected. ${ }^{1381}$ The state of a practice of legality can be studied from the analysis of national reports submitted by contracting parties, where the national reports submitted for scrutiny evidence actions undertaken by the parties in satisfaction of their obligations under the Convention. A hundred and twenty six contracting parties submitted the fourth national reports for COP $10 .{ }^{1382}$ The Executive Secretary noted that according to the analysis conducted, 'nearly all countries report on having developed and adopted national biodiversity strategies and action plans, where $18 \%$ of parties went further to revise their strategies and plans in respond to new challenges and guidance from the COP'. ${ }^{1383}$

The implementation of national biodiversity strategies and action plans advocated by the Convention has promoted substantial activities for the conservation and sustainable use of biodiversity. In the progress towards achieving Target 1.1 of the 2010 Biodiversity Target, the national reports revealed that $58 \%$ of the Parties had reported that they managed to achieve Target 1.1 of having a protected area that covers at least

\footnotetext{
${ }^{1379}$ Progress in the Implementation of the Programme of Work and Achievement of Aichi Biodiversity Target 11, supra $\mathrm{n} 1354$, at pp $9-10$, para 20.

${ }^{1380} \mathrm{CBD}$, 'List of Parties' (undated) < http://www.cbd.int/convention/parties/list/> accessed 17 August 2012.

${ }^{1381}$ Progress in the Implementation of the Programme of Work and Achievement of Aichi Biodiversity Target 11, supra n 1354, at p 13, para 32. UNEP-WCMC, 'Biodiversity Indicators Partnership' (2012) $<$ http://www.bipindicators.net/pacoverage> accessed 17 August 2012.

$1382 \mathrm{CBD}$, 'Updated Analysis of Information in the Fourth National Reports' (Tenth Meeting of the Conference of the Parties of the Convention on Biological Diversity, Nagoya, Japan 18 - 29 October 2010) UNEP/CBD/COP/10/INF/2 (22 September 2010) at p 1 , para 1 <http://www.cbd.int/doc/meetings/cop/cop-10/information/cop-10-inf-02-en.pdf> accessed 17 August 2012. The analysis was based on a review of 126 reports received by the middle of July 2010. For the 162 countries, see Annex I, p 10.

${ }^{1383}$ CBD, 'Updated Analysis of Information in the Fourth National Reports', supra n 1382, at p 5, para 7.
} 
$10 \%$ or more, of their terrestrial area. ${ }^{1384}$ Interestingly, $66 \%$ of the contracting parties reported that the ecosystem approach is applied in some manner, either in the management of certain type of ecosystems, or in an integrated management across the country. ${ }^{1385}$ Most parties (81\%) participated in transboundary management of protected areas or shared ecosystems or resources where cooperation, is initiated through transboundary agreements. ${ }^{1386}$

Nearly all Parties undertake programmes or projects relating to the monitoring, research and/or the creation of a database, although it is conceded that much has to be done on the monitoring of implementation of national biodiversity strategies and action plans, and the methodology of monitoring. ${ }^{1387}$ Not many contracting parties undertake detailed quantitative assessments of the implementation of their National Biodiversity Strategies and Action Plans (NBSAP), or the outcomes achieved. ${ }^{1388}$ However, the few quantitative assessments revealed that despite the generally low level of implementation ranging from $30-50 \%$, the NBSAP is not insignificant where some countries do provide cases or success stories in this regard. ${ }^{1389}$ The national reports intimated that challenges are encountered in their effort to implement NBSAP, and in the implementation of the Convention as a whole, ${ }^{1390}$ particularly for many developing countries where financial support for the implementation of NBSAP is clearly lacking. ${ }^{1391}$

\footnotetext{
${ }^{1384}$ CBD, 'Updated Analysis of Information in the Fourth National Reports', supra n 1382, at p 5, para 8(a). See Annex III, 'Examples of National Level Actions towards the 2010 Biodiversity Target', in CBD, 'Updated Analysis of Information in the Fourth National Reports', supra n 1382, at p 15. For the 2010 Biodiversity Target, on the focal area of the protection of the components of biodiversity, Goal 1 seeks to promote the conservation of the biological diversity of ecosystems, habitats and biomes where Target 1.1 aims to achieve at least $10 \%$ of each of the world's ecological regions effectively conserved.

${ }^{1385}$ CBD, 'Updated Analysis of Information in the Fourth National Reports', supra n 1382, at p 5, para 8(e).

${ }^{1386} \mathrm{CBD}$, 'Updated Analysis of Information in the Fourth National Reports', supra n 1382, at pp $5-6$, para $8(\mathrm{o})$

${ }^{1387}$ CBD, 'Updated Analysis of Information in the Fourth National Reports', supra n 1382, at p 6, para $8(\mathrm{~g})$.

${ }^{1388}$ CBD, 'Updated Analysis of Information in the Fourth National Reports', supra n 1382, at p 7, para 9. contracting parties who undertook assessment of the NBSAP includes Djibouti; France; Kyrgyzstan; Togo; Turkmenistan; Namibia; St. Lucia; and Samoa.

${ }^{1389}$ CBD, 'Updated Analysis of Information in the Fourth National Reports', supra n 1382, at p 7, paras 10 and 11.

${ }^{1390}$ CBD, 'Updated Analysis of Information in the Fourth National Reports', supra n 1382, at p 7, para 12. The main obstacles include limited financial, technical and human resources and capacities, limited information, lack of political will, lack of coordination between ministries, poverty, low level of awareness of biodiversity issues, and limited incentives for biodiversity conservation and sustainable use.

${ }^{1391}$ CBD, 'Updated Analysis of Information in the Fourth National Reports', supra n 1382, at p 8, para 14.
} 
The contracting parties of the Strategic Plan noted the substantial progress towards the 2010 biodiversity targets in Decision X/5 (2010), in particularly the development of national biodiversity strategies and action plans, the engagement of stakeholders, and the widespread recognition of the 2010 biodiversity target. ${ }^{1392}$ The COP further requested the Executive Secretary to prepare an analysis/synthesis of national, regional and other actions in order to enable the Working Group on Review of Implementation and the COP to assess the contribution of national and regional targets towards the global targets. ${ }^{1393}$ The fulfilment of the Aichi Targets are assessed in terms of the commitments made by Parties as well as the amount of progress made in reaching the Targets, and this is the benchmark on which a practice of legality is measured.

Reiterating the general review of progress in the implementation of the Strategic Plan for Biodiversity 2011 - 2020 in the previous section, ${ }^{1394}$ the Executive Secretary concluded that, given the current progress in the establishment and expansion of protected areas, the $17 \%$ target by 2020 is likely to be achieved. ${ }^{1395}$ An assessment of the application of the shared legal understandings established above entails the fulfilment of two components: the quantitative 17\% target; and the qualitative aspect, the most important being the ecological representativeness of the areas protected, and the effectiveness of the management of protected areas.

The assessment of whether there is a practice of legality of both the qualitative and quantitative components of the shared legal understanding developed by the contracting parties is conducted through the analysis of the implementation status of the Programme of Work on Protected Areas and the achievement of the Aichi Biodiversity Target 11. ${ }^{1396}$ The Executive Secretary noted that in terms of the quantitative component, the proposed terrestrial protected area by 86 parties that would amount to over $16 \%$ of their combined area being protected is "well on the way to achieving the global target of

\footnotetext{
${ }^{1392}$ CBD, 'Decision X/5 Implementation of the Convention and the Strategic Plan' (Tenth Meeting of the Conference of the Parties to the Convention on Biological Diversity, Nagoya, Japan 18 - 29 October 201) $\mathrm{UNEP} / \mathrm{CBD} / \mathrm{COP} / \mathrm{DEC} / \mathrm{X} / 5$ (29 October 2010) at p 1 <http://www.cbd.int/doc/decisions/cop-10/cop-10dec-05-en.pdf > accessed 17 August 2012.

${ }^{1393} \mathrm{CBD}$, 'X/2 The Strategic Plan for Biodiversity 2011 - 2020 and the Aichi Biodiversity Targets', supra $\mathrm{n} 1210$, at $\mathrm{p} 4$, para 17 (b).

${ }^{1394}$ Review of Progress by Executive Secretary, supra $\mathrm{n} 1340$

${ }^{1395}$ Review of Progress by Executive Secretary, supra n 1340, at p 13, para 26.

${ }^{1396}$ Progress in the Implementation of the Programme of Work and Achievement of Aichi Biodiversity Target 11, supra $\mathrm{n} 1354$.
} 
protecting $17 \%$ of terrestrial areas'. ${ }^{1397}$ This indicates the compliance by the contracting parties of the shared legal understanding established on the obligation to conserve through protected areas, where their commitments are undertaken in practice. ${ }^{1398}$

In terms of the qualitative aspect of conservation, it has been identified that the global quantitative target will be attained, but gaps remain in the representativeness and management effectiveness of these protected areas, where particular focus is needed to improve representativeness of ecosystems protected, and the effectiveness of management. ${ }^{1399}$ The Review of Implementation shows that only 50\%, (414 out of the 823) terrestrial ecoregions meet the target of having $10 \%$ of each of the world's ecological regions effectively conserved, ${ }^{1400}$ while less than $30 \%$ of the world's protected areas have a management plan, where only $24 \%$ of them are sound. ${ }^{1401}$

These short comings are addressed through the Programme of Work on Protected Areas action plans in the contracting parties' effort to achieve Target $11 .{ }^{1402}$ In light of the progress and challenges faced, the Ad Hoc Working Group on Review of Implementation recommends COP 11 to adopt decisions that reaffirm the need for enhanced cooperation and support in all aspects, including scientific and technical capacity; financial resources; information sharing; and capacity-building among Parties for the implementation of the Strategic Plan $2011-2020 .{ }^{1403}$

\footnotetext{
${ }^{1397}$ Progress in the Implementation of the Programme of Work and Achievement of Aichi Biodiversity Target 11, supra $\mathrm{n} 1354$, at p 5 para 16; and p 14, para 36.

${ }^{1398}$ Progress in the Implementation of the Programme of Work and Achievement of Aichi Biodiversity Target 11, supra n 1354, at p 5, para 15. Seventy parties identified quantitative protected area targets ranging from 10 - 30 per cent, with 46 parties setting goals at or above the Target 11 terrestrial goal of $17 \%$ protected coverage. At p 5, para 16, the Executive Secretary stated that the information provided above suggests that the world community is aiming to make good progress towards the quantitative components of Target 11 .

${ }^{1399}$ Progress in the Implementation of the Programme of Work and Achievement of Aichi Biodiversity Target 11, supra $\mathrm{n} 1354$, at p 14, para 37.

${ }^{1400}$ Progress in the Implementation of the Programme of Work and Achievement of Aichi Biodiversity Target 11, supra $\mathrm{n} 1354$, at $\mathrm{p} 13$, para 33.

${ }^{1401}$ Progress in the Implementation of the Programme of Work and Achievement of Aichi Biodiversity Target 11, supra $\mathrm{n} 1354$, at $\mathrm{p} 13$, para 34.

${ }^{1402}$ Progress in the Implementation of the Programme of Work and Achievement of Aichi Biodiversity Target 11, supra n 1354, at p 14, para 37. The Executive Secretary, at p 3, para 10, noted that three goals, namely, Goals 1.1, 3.5 and 3.2, of the Programme of Work on Protected Areas have seen significant progress. The Executive Secretary identifies, in p 14, para 39, that the Strategic Goal E of the Strategic Plan for Biodiversity 2011 - 2020, supra n 1215, that calls for enhancing implementation through participatory planning, knowledge management and capacity-building, including the enhancement of cooperation partnerships, are required to facilitate the implementation of the action plans.

${ }^{1403}$ CBD, 'Recommendation 4/1 Implementation of the Strategic Plan for Biodiversity $2011-2020$ and Progress towards the Aichi Biodiversity Targets' (Fourth Meeting of the Ad Hoc Open-Ended Working Group on Review of Implementation of the Convention , Montreal 7 - 11 May 2012) UNEP/CBD/WF-
} 
It can be concluded that a practice of legality existed for the obligation to conserve biodiversity through systems of protected areas declared under Article 8(a) and (d) where the enterprise of law-making, i.e. the contracting parties, have been shown to undertake practices of legality in the fulfilment of both the qualitative and the quantitative requirements of the rule.

It is demonstrated above that the shared understanding arrived by the contracting parties on the obligation to conserve biodiversity is that the obligation is interpreted as including, and implemented through, the establishment of protected areas to promote protection of ecosystems, habitats and also maintenance of the natural surroundings of viable population of species. The system of protected areas is designated to protect and safeguard the natural functioning and ecological processes of ecosystems in accordance with the ecosystem approach. This initial understanding is codified in Article 8(a) and (d) of the Biodiversity Convention.

In the fulfilment of this obligation, the Vth IUCN World Park Congress recommends for the need to establish a global system of coherent ecological network of protected areas that are ecologically representative. ${ }^{1404}$ This provides the qualitative dimension to the obligation to conserve under Article 8. In order to achieve this aim, the Vth Congress recommends the COP to adopt specific targets and timetables for the in situ conservation of all globally critically endangered species, and the sites to which these critically endangered species are confined. ${ }^{1405}$

COP 7 had taken up this challenge, and adopted the Programme of Work on Protected Areas in its Decision VII/28. ${ }^{1406}$ Its Programme Element 1 prescribed the necessary procedures and actions relating to the conservation of biodiversity through the planning, selecting, establishing, strengthening, and managing of protected area systems and sites within a prescribed timeframe. ${ }^{1407}$ The content of the obligation to conserve through protected areas includes firstly, the establishment and the strengthening of national and regional systems of protected areas integrated into a global network as a contribution to

RI/REC/4/1 (21 June 2012) at pp 2 - 5, para 7 <http://www.cbd.int/doc/recommendations/WGRI04/wgri-04-rec-01-en.pdf $>$ accessed 18 August 2012.

${ }^{1404}$ IUCN, 'Message of the $V^{\text {th }}$ IUCN World Parks Congress to the Convention on Biological Diversity', supra $\mathrm{n} 1137$, at pp 1 and 2.

${ }^{1405}$ IUCN, 'Message of the $\mathrm{V}^{\text {th }}$ IUCN World Parks Congress to the Convention on Biological Diversity', supra $\mathrm{n} 1137$, at $\mathrm{p} 2$.

${ }^{1406}$ CBD, 'Decision VII/28 Protected Areas (Articles 8(a) to (e))', supra n 447, at paras 6 and 7.

${ }^{1407}$ Programme Element 1, Programme of Work on Protected Areas, Decision VII/28, supra n 1148, at $\mathrm{p}$ 8. 
globally agreed goals. ${ }^{1408}$ Secondly the established protected areas are integrated into broader land- and seascapes and sectors so as to main their ecological structure and function. ${ }^{1409}$ All these steps undertaken for the conservation of protected areas apply similarly to the establishment and strengthening of regional networks and transboundary protected areas, where collaboration between neighbouring protected areas across national boundaries is needed. ${ }^{1410}$ The obligation to conserve does not end after the establishment of protected sites, but includes the substantial improvement of the planning and management of site-based protected areas; ${ }^{1411}$ and the prevention and mitigation of negative impacts of key threats to protected areas. ${ }^{1412}$

COP 7 (2004) specifically adopted a Revised Programme of Work on Inland Water Biodiversity for the establishment and maintenance of a comprehensive, adequate and representative system of protected inland water ecosystems within the framework of integrated catchment/watershed/river-basin management. ${ }^{1413}$ The Revised Programme of Work requires the contracting parties to - provide establishment and management strategies for protected areas; identify priority sites that are harmonised with criteria established under the Ramsar Convention; establish collaboration with neighbouring parties in the joint management of transboundary protected inland water ecosystems; and to develop, as part of an integrated catchment/watershed/river basin management approach, protected area systems that contribute towards the conservation of biodiversity, maintenance of overall ecosystem function, productivity and health of each drainage basin. ${ }^{1414}$

The Strategic Plan 2011 - 2020 provides a flexible framework for the implementation of the global goal of an improved state of biodiversity, especially Target 11 that aims to set aside an effectively and equitably managed areas of protection of at least $17 \%$ of terrestrial and inland water areas, especially areas of particular importance for

\footnotetext{
1408 Goal 1.1, Programme Element 1, Programme of Work on Protected Areas, Decision VII/28, supra $\mathrm{n}$ 1148 , at $\mathrm{p} 8$.

${ }^{1409}$ Goal 1.2, Programme Element 1, Programme of Work on Protected Areas, Decision VII/28, supra $\mathrm{n}$ 1148 , at $\mathrm{p} 9$.

${ }^{1410}$ Goal 1.3, Programme Element 1, Programme of Work on Protected Areas, Decision VII/28, supra $\mathrm{n}$ 1148 , at $\mathrm{p} 10$.

${ }^{1411}$ Goal 1.4, Programme Element 1, Programme of Work on Protected Areas, Decision VII/28, supra $\mathrm{n}$ 1148 , at $\mathrm{p} 11$.

1412 Goal 1.5, Programme Element 1, Programme of Work on Protected Areas, Decision VII/28, supra $\mathrm{n}$ 1148 , at $\mathrm{p} 12$.

${ }_{1413}$ Revised Programme of Work on Inland Water Biological Diversity, supra n 1188, at p 11.

${ }^{1414}$ Revised Programme of Work on Inland Water Biological Diversity, supra n 1188, at pp $11-12$.
} 
biodiversity and ecosystem services that are ecologically representative and wellconnected by $2020 .{ }^{1415}$ The Strategic Plan further develops the substantive normativity for the obligation to conserve, namely the quantitative aspect of $17 \%$ of terrestrial protected areas, including inland waters; and the qualitative aspects of effective management and ecological representativeness of the protected areas. These two aspects are equally crucial in the satisfaction of the obligation to conserve under Article 8(a) and (d). ${ }^{1416}$

The shared understandings developed by the contracting parties through the COP forum are continuously developed by the implementation of parties of the shared understandings, of which are periodically scrutinised by the Convention Bodies, such as the Ad Hoc Working Group on Review of Implementation and also the COP. Various mechanisms are make available by the Convention in order to facilitate the implementation by Parties of their obligations that are commonly understood as to their content and scope, which are clearly promulgated in the Programmes of Work and Strategic Plan adopted by the Decisions of the COP. The continuous hard work of the contracting parties in the clarification and observation of the rule of law promulgated in the form of Decisions adopted by the COP are deemed a practice of legality. The efforts undertaken by the contracting parties in the institutionalised interactional process in the development of law propels and pushes the rules attained through this system towards the legal end of the social-legal normative continuum as the criteria of legality are increasingly satisfied.

The shared legal understandings undertaken in a practice of legality through an institutionalised interactional process of legal development, constitute an emergence of a community of practice on the obligation to conserve biodiversity through the establishment and management of protected areas codified in Article 8(a) and (d). This is evidenced in the attainment of an almost $13 \%$ of the world's terrestrial area is protected as of 2011, where the global target of $17 \%$ by 2020 is likely to be achieved. ${ }^{1417}$ The contracting parties are relatively steadfast in the undertaking of a practice of legality on their obligation to conserve under the Convention as

\footnotetext{
${ }^{1415}$ Target 11, 'Strategic Plan for Biodiversity 2011 - 2020 and the Aichi Biodiversity Targets', supra n 1215 , at $\mathrm{p} 9$.

${ }^{1416}$ Progress in the Implementation of the Programme of Work and Achievement of Aichi Biodiversity Target 11, supra $\mathrm{n} 1354$, at pp $9-10$, para 20.

${ }^{1417}$ Review of Progress by Executive Secretary, supra n 1340, at p 13, para 26. Refer supra n 1348 and n 1397.
} 
demonstrated through the submission of their Fourth National Reports by 126 Parties for review of implementation by the Conventional Bodies. ${ }^{1418}$ The gaps that remain in terms of the satisfaction of the qualitative aspects of ecological representativeness and effectiveness of management will be addressed gradually as capacity grows.

\subsection{Applicable in the Relations between the Parties}

In the interpretation that incorporates external rules of international law that are relevant, it is important to identify the content of the rules that is to be taken into account in the interpretative process. It has been established that what is 'applicable in the relations between the parties' depends on the particular rule of international law. An interactional perspective in the analysis of the rule reveals not only the content of the rule, but also the 'applicability' of the rule on 'the parties', as the 'applicability' of the rule constitutes part of the shared legal understanding arrived at by the parties. The shared legal understandings attained through the interactional process by the members engaged in the practice of legality determine whether the rules are applicable to them. This approach is supported by the context of the text of the 1969 Vienna Convention and the writing of eminent scholars that the phrase 'the parties' in Article 31(3)(c) does not require that the parties to the interpreted treaty must be a party to the external treaty as long as the external rule -

'can be said to be implicitly accepted or tolerated by all parties to the treaty under interpretation in the sense that it can reasonably be considered to express the common intentions or understanding of all members as to the meaning of the term concerned'. ${ }^{1419}$

The meaning that is 'implicitly accepted or tolerated by all parties that can be considered to express common intentions or understandings of all members, ${ }^{1420}$ is reflected in the shared understanding of the parties involved in the enterprise of lawmaking. The members who participate in the interactional process will be 'the parties' within the meaning of Article 31(3)(c).

\footnotetext{
${ }^{1418}$ CBD, 'Updated Analysis of Information in the Fourth National Reports', supra n 1382, at p 1, para 1 ${ }^{1419}$ McLachlan, 'The Principle of Systemic Integration', supra n 162, at pp $314-315$. Pauwelyn, Conflict of Norms in Public International Law, supra n 100, at pp 257 - 263.

${ }^{1420}$ McLachlan, 'The Principle of Systemic Integration', supra n 162, at pp $314-315$.
} 
In the context of the 193 contracting parties to the Biodiversity Convention, the rules relevant to the preservation of ecosystems of international watercourses are the obligation to conserve in situ biodiversity through the establishment of protected areas that promotes the protection of ecosystems, habitats, and viable populations of species in their natural surroundings as codified in Article 8(a) and (d). The shared legal understanding of the contracting parties pertaining to the rules, and undertaken in their practice of legality is the achievement of the quantitative and qualitative aspect of their obligation to conserve biodiversity through protected areas. The quantitative target is the designation of $17 \%$ of terrestrial as protected areas, where the qualitative aspect imposes that these areas of protection must be ecologically representative and effectively managed.

The procedural mechanisms impose in the Programmes of Work for the implementation and achievement of these shared understandings include the need for constant reporting, monitoring and assessment; the fulfilment of criteria assigned for the identification and assessment of areas of protection; and the need for collaboration with neighbouring countries in the case of transboundary protected areas. Apart from the imposition of the ecosystem approach in all aspects of identification, designation, and management, the Revised Programme of Work on Inland Water Biodiversity specifically stipulates the application of a drainage basin approach in the implementation of the contracting parties' obligation to conserve through the establishment and management of protected inland water ecosystems.

The relevant rules of international law in the form of Article 8(a) and (d) that are 'applicable in the relations between the parties', as commonly agreed to be applicable in the interpretation of the Article 20 obligation to preserve ecosystems of international watercourses by the parties, is not just a general stipulation to conserve. The shared understandings by the parties, due to the quasi-universal parties to the Biodiversity Convention, are reflected in the subsequent development of this rule in the COP, which had been lengthily discussed in the previous sections. The accepted and reasonably considered to express the common intentions or understanding of the contracting parties as to the content and scope of the obligation to conserve under Article 8(a) and (d) must necessarily be both the quantitative and qualitative requirements for the establishment of protected areas. This includes the necessary procedural mechanisms provided to 
facilitate the parties in achieving the target jointly attained by the contracting parties through the interactional process of COP.

\subsection{Conclusion}

This chapter undertakes the assessment of Article 8(a) and (d) of the Biodiversity Convention, identified as relevant to the interpretation of Article 20 of the 1997 Watercourses Convention in Chapter Two of this thesis, through the interactional framework developed in Chapter Four. The ascertainment of whether these provisions satisfy the legality threshold required by Article 31(3)(c) of the 1969 Vienna Convention through an interactional perspective reveals the shared legal understanding of the parties, confirmed in their practice of legality, informs the interpretation of the salient phrase of 'rules of international law applicable in the relations between the parties'.

As previously demonstrated in Chapter Five of this thesis in the context of the Ramsar Convention, an interactional account of international law, of which Article 8(a) and (d) of the Biodiversity Convention is assessed against provides the normative content and scope for the interpretation of the obligation to preserve under Article 20. The outcome of the analysis as demonstrated in this chapter confirms that Article 8(a) and (d) are 'rules of international law applicable in the relations between the parties' within the definition of Article 31(3)(c), and shall be taken into account together with the context in the interpretation of Article 20.

The next chapter will proceed to develop an architecture in which these rules 'shall be taken into account', and the condition imposes by 'the context' that qualifies the incorporation of these relevant rules as identified in Chapters Five and Six into the interpretation of Article 20. 


\section{Chapter 7. Shall Take into Account, Together with the Context - Systemic Integration: An Architecture}

\section{Part I: Theory}

\subsection{Overview}

This chapter develops a structure for the interpretation of the phrase 'shall be taken into account, together with the context', which forms the last stage of analysis in the framework of operationalisation established for Article 31(3)(c). The Chapter will firstly define the term 'context' and 'shall be taken into account'. Secondly, this Chapter conducts an analysis of selected cases in the determination of normative weight that is given to the external relevant rules in judicial decisions of international court and tribunals. Finally, this Chapter establishes the architecture that guides the systemic integration of relevant rules permissible under the interpretative mechanism of Article 31(3)(c) in reference to the methodology employed in these judicial decisions in the determination of the normative weight of external rules.

It is a key point to note that the normative environment cannot be ignored in the interpretation of treaties where the principle of systemic integration should be borne in mind. ${ }^{1421}$ The order of the operation of Article 31(3)(c) was briefly referred to by Sands where it was mentioned in passing that - 'it is only after the existence, relevance and applicability of a customary norm has been recognised by an adjudicatory body that its precise impact upon the interpretation of a treaty comes to be determined in the application of Article 31(3)(c)'. ${ }^{1422}$

The order enunciated indicated that first the existence of a rule of international law has to be established. Second, the rule needs to be relevant to the subject matter of the treaty norm being interpreted. Next, it must be determined that the relevant rule of international law is applicable in interpretation. Only then can the precise impact be determined of 'shall be taken into account, together with the context', in other words how much normative weight should be given to the "relevant rule of international law applicable on the parties'.

\footnotetext{
${ }^{1421}$ Fragmentation Report, supra n 17, at p 211, para 419; p 216, para 430.

1422 Sands, 'Treaty, Custom and the Cross-fertilization of International Law', supra n 119, at p 102.
} 


\section{2 'Context'}

Christian Wolff introduces the modern international law doctrine regarding the recourse to 'context' ('interpretation in the contexte ${ }^{1423}$ ) in the event of obscurity where it is quoted that -

'Theologi dicunt, sensum erui ex contextu, si corum quae obscurius dicta sunt, sensus inventigatur ex collation cum antecedentibus et consequentibus aut ex locis parallelis, siquae in uno loco obscurius dicta videntur, explicantur, per ea, quae alio loco conspicue de eadem material dicunter'. ${ }^{1424}$

The use of 'context' in interpretation is always in relation to conventional language (the ordinary meaning), and always the second step in the interpretation process. ${ }^{1425}$ The process of interpretation is not just a grammatical exercise. The general rule laid out in Article 31 of the 1969 Vienna Convention does not allow an abstract ordinary meaning that is divorced from the place which that phrase occupies in the text to be given to a phrase. ${ }^{1426}$ It is emphasised that 'the systematic structure of a treaty is of equal importance to the ordinary linguistic meaning of the words used' ${ }^{1427}$

The broad reference to the context as an aid to elucidate the meaning of a treaty term provides the basis for a foray into the scope of 'context'. The meaning of 'context' has been examined by Lord Hoffman in his judgment in the Kirin-Amgen case. ${ }^{1428} \mathrm{He}$ enunciated that 'a judge's construction could not possibly be described as acontextual. It

\footnotetext{
${ }^{1423}$ A phrase coined by Béla Vitányi, 'Treaty Interpretation in the Legal Theory of Grotius and Its Influence on Modern Doctrine' (1983) 14 Netherlands Yearbook of International Law 41 - 67.

${ }^{1424}$ A reference to 'the context', encompassing 'the previous', 'the following', 'the parallels', or if obscurity still persisted, 'other materials that address the same subject matter', are suggested by Wolff, recounted by Vitányi, 'Treaty Interpretation in the Legal Theory of Grotius and Its Influence on Modern

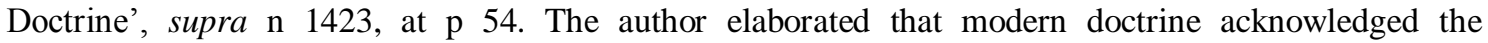
particularly effective means to determine the intention of the parties through a recourse to the context, especially in a determination of the meaning of a treaty term 'whose words lend themselves to different interpretation'.

${ }^{1425}$ Ulf Linderfalk, On the Interpretation of Treaties. The Modern International Law as Expressed in the 1969 Vienna Convention on the Law of Treaties (Springer, 2007) at p 102.

${ }^{1426}$ Dörr and Schmalenbach (eds) Vienna Convention on the Law of Treaties. A Commentary, supra $\mathrm{n} 663$, at p 543.

${ }^{1427}$ Dörr and Schmalenbach (eds) Vienna Convention on the Law of Treaties. A Commentary, supra $\mathrm{n} 663$, at $\mathrm{p} 543$.

${ }^{1428}$ Kirin-Amgen Inc and Others (Appellants) v Hoechst Marion Roussel Ltd and Others (Respondents). Kirin-Amgen Inc and Others (Respondents) v Hoechst Marion Roussel Limited and Others (Appellants) $\begin{array}{llllll}\text { (Conjoined } & \text { Appeals) } & \text { (21 } & \text { October } & \text { 2004) [2004] }\end{array}$ <http://www.bailii.org/uk/cases/UKHL/2004/46.html> accessed 16 April 2012.
} 
was entirely dependent on context and reflected the evidence of how the claim would have been understood by men skilled in the art'. ${ }^{1429}$

The observation made by Judge Learned Hand that 'words are chameleons, which reflect the colour of their environment ${ }^{1430}$ throws doubt on whether a term consisting of words may be given an acontextual meaning, or adopt strict compliance with the conventional meaning approach in the interpretation of the term. It was decided in the Commissioner of Internal Revenue case that a 'corporation' which was organised only to serve as a means of transfer, used once and only for that purpose, and was dissolved as soon as it had done so, cannot be a 'corporation' within the meaning of that term as the Congress were understood to have used it. The Congress must have adopted the meaning of 'corporation' employed in common speech, that means 'a jural person created to conduct industry, commerce, charity, or some other commonly practised activity'. ${ }^{1431}$

According to Gardiner, there are two main roles for the references to context in the Vienna rules. Firstly, context acts as an immediate qualifier of the ordinary meaning of terms used in the treaty, where it aids the selection of the ordinary meaning and avoids an overly strict compliance with its literal or conventional meaning. Secondly, it identifies the material elements, such as the whole text of the treaty, its preamble and any annexes forming the context that need to be taken into account. ${ }^{1432}$

\footnotetext{
${ }^{1429}$ Kirin-Amgen, supra n 1428, at para 63. At para 64, His Honour went on further to expound that - 'No one has ever made an acontextual statement. There is always some context to any utterance, however meagre. "Acontextual meaning" can refer only to the conventional rules for the use of language, such as one finds in a dictionary or grammar. Acontextual meaning refers to a general rule about how words or syntax should be used and contextual meaning refer to the fact of what on a specific occasion the language was used to mean.' Lord Hoffman noted that how the phrase 'an endogenous DNA sequence coding for EPO' should be interpreted depends on 'whether the person skilled in the art would understand the invention as operating at a level of generality which makes it irrelevant whether the DNA which codes for EPO is exogenous or not'. It can be inferred that the interpretation of 'invention' forms the context in the determination of the question of scope encompassed in the phrase of 'an endogenous DNA sequence coding for EPO' as put forth to the House of Lords.

${ }^{1430}$ Judge Learned Hand in Commissioner of Internal Revenue v National Carbide Corp 167 F 2d 304 at 306 (US Court of Appeals, $2^{\text {nd }}$ Circuit) (31 March 1948) (hereinafter: 'Commissioner of Internal Revenue').

${ }^{1431}$ Commissioner of Internal Revenue, supra n 1430, at p 306.

${ }^{1432}$ Gardiner, Treaty Interpretation, supra n 235, at pp 177 - 178. Gardiner elaborated that 'if a word forms part of a phrase, that is the obvious initial contextual assessment that must be made. The second aspects of use of context is in application of the wider definition. This directs the interpreter to look to many factors ranging from those that are fairly immediate, such as the wording of surrounding provisions, headings of articles and punctuation, to more remote elements such as comparisons with other provisions on similar matters or using similar wording, extending to the function of the context as a bridge to the
} 


\subsection{1 'Context' in the 1969 Vienna Convention on the Law of Treaties}

The 'context', for the purpose of interpretation of a treaty is defined in Article 31(2). The context comprises, in addition to the text, including its preamble and annexes:

(a) any agreement relating to the treaty ${ }^{1433}$ which was made between all the parties in connection with the conclusion of the treaty; and

(b) any instrument ${ }^{1434}$ which was made by one or more parties in connection with the conclusion of the treaty and accepted by the other parties as an instrument related to the treaty.

The Commentary to the Draft Articles of the 1969 Vienna Convention further elaborated that these classes of instruments, "made in connexion with the conclusion of the treaty and its relation to the treaty was accepted in the same manner by the other parties' are recognised to form the context of the treaty. ${ }^{1435}$ They should be treated as

further element in the first paragraph of the general rule, that is "the object and purpose"'. Reiterated infra n 1448.

${ }^{1433}$ Dörr and Schmalenbach (eds) Vienna Convention on the Law of Treaties. A Commentary, supra $\mathrm{n}$ 663, at $\mathrm{p}$ 551. The term 'agreement' goes beyond the notion of 'treaty' and imply the inclusion of unwritten consensus although it is common in contemporary treaty practice that these 'agreements' assume the form of final acts, protocols of signature, understandings, commentaries or explanatory reports agreed upon by the drafters of the treaty text and are adopted simultaneously with the text. Such 'agreement' might also come in the forms of resolutions of an international organisation, or an explicit guidance on the interpretation on the interpretation of the treaty. For example, the 1973 Protocol on the Interpretation of Art 69 of the European Patent Convention (revised 29 November 2000), adopted simultaneously with the Convention <http://www.epo.org/law-practice/legal-texts/html/epc/2010/e/ma2a.html> accessed 7 May 2012. See Explanatory Report adopted by the Committee of Ministers of the Council of Europe when it agreed on the text of the Criminal Law Convention on Corruption, ETS No 173 <http://conventions.coe.int/treaty/en/Reports/Html/173.htm> accessed 7 May 2012.

${ }^{1434}$ The reference to 'any instruments made by one or more parties in connection with the conclusion of the treaty and accepted by all the other parties' in Art 31(2)(b) can be taken to mean statements made by individual parties before the conclusion of the treaty or accompanying their expression of consent to be bound. It can also include unilateral interpretative declarations which a state presents at the time the treaty is being agreed upon, which 'regularly share the outer characteristics of reservations to the treaty'. The acceptance however, must be proven by the parties asserting that the instruments advanced are accepted by the other parties. Dörr and Schmalenbach (eds) Vienna Convention on the Law of Treaties. A Commentary, supra n 663, at p 552. At pp 550 - 551, the authors stated that the general design of Article 31, which deals with acts and agreements subsequent to the conclusion of the treaty in Art 31(3) would seem to imply that 'agreement' and 'acceptance' within the meaning of Article 32(2) refer to a consensus established in a certain temporal proximity to the process of conclusion. Usually, agreements of this sort are made at the occasion of adopting the text of the treaty. Individual parties, when signing or ratifying a treaty may very well present unilateral documents and, therefore, require a reaction by the other parties at that later date.

${ }^{1435}$ ILC, 'Draft Articles on the Law of Treaties: Text as Finally Adopted by the Commission on 18 July 1966 (Reproduced at Para 38 of Document A/6309/Rev 1)' Doc A/CN.4/190 (1966) II Yearbook of International Law Commission $177 \quad-\quad 274, \quad$ at $p \quad 46$, para 13 <http://untreaty.un.org/ilc/documentation/english/a_cn4_190.pdf> accessed 17 November 2012 (hereinafter: 'Draft Articles 1966'). The 1964 version [Art 69(2)] reads: 'The context of the treaty, for the purposes of its interpretation, shall be understood as comprising in addition to the treaty, including its 
part of the context for the purpose of arriving at the ordinary meaning of the terms of the treaty, and not merely recourse to resolve an ambiguity or obscurity. ${ }^{1436}$ It is apparent that the context of the treaty comprises the agreements or related documents at the conclusion of the treaty that are made by all the parties, or made by one or two of the parties, but accepted by all the parties to be in connection with or related to the treaty. ${ }^{1437}$

Pertinent to Article 31(2) is the issue of to what extent the instruments made annexes to the treaty form part of the context for the purpose of interpretation, or how much weight the elements that count as relevant context should be given in determining the object and purpose of a treaty. ${ }^{1438}$ Enshrined in Article 31(2) was the principle of both common sense and good faith, where the ordinary meaning of a term is not to be

preamble and annexes, any agreement or instrument related to the treaty and reached or drawn up in connexion with its conclusion'. ILC, 'Report of the International Law Commission on the Work of Its $16^{\text {th }}$ Session, 11 July 1964, Official Records of the General Assembly, $19^{\text {th }}$ Session, Supplement (A/5809)' Doc A/CN.4/173 (1964) II Yearbook of International Law Commission 173 - 227, at p 199 <http://untreaty.un.org/ilc/reports/english/a_cn4_173.pdf> accessed 17 November 2012 (hereinafter: 'Draft Articles 1964). It is also important to note that these documents must be distinguished from mere travaux préparatoires. The documents referred to in Art 31(2) forms the context that is part of the general rule of interpretation where distinction between them was found in the phrase in connexion with the conclusion of the treaty' that leaves the preparatory stage behind and refers instead to the actual existence of consensus on the treaty. Dörr and Schmalenbach (eds) Vienna Convention on the Law of Treaties. A Commentary, supra n 663, at pp 549 - 550. At p 550, the authors noted that a distinction between 'preparation' and 'connection' was drawn by 'taking objective factors (eg the time taken in making the document) and the intention of the actors into account'.

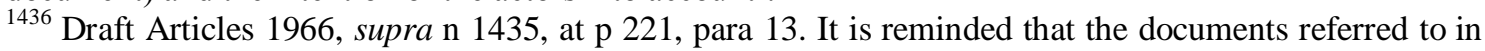
Article 31(2)(a) and (b) are documents that are extrinsic to the treaty, and do not form an integral parts of it.

${ }^{1437}$ The ILC elaborated that the preamble and documents specifically made annexes to the treaty forms part of a treaty for the purposes of interpretation is 'too well settled to require comment'. Draft Articles 1964, supra n 1435, at p 203. However, it is emphasised that whether or not such documents constitutes an actual part of the treaty is contingent on the intention of the parties in each individual case. Dörr and Schmalenbach (eds) Vienna Convention on the Law of Treaties. A Commentary, supra n 663, at p 549. The conditions in which extrinsic materials can be taken to form the context of a treaty according to Art 31(2) are: (1) The object of the document in question must be of a general consensus of all parties; (2) That consensus must be borne by all parties; and (3) The material must relate to the substance of the treaty, either by specifying or clarifying certain concepts used therein, or limiting its field of application. That relation must be one of substance, but it must also be encompassed by the parties' consensus. The ILC commented further that even though these documents may form part of the context, it does not necessarily mean that it is an integral part of the treaty. Draft Articles 1966, supra n 1435, at p 221, para 13. The question of whether the instruments or agreements are an actual part of the treaty was addressed in the Ambatielos case where the Court opined that it depends on the intention of the parties in each case to decide whether such instruments forms an integral part of the treaty. Ambatielos Case (Jurisdiction) (Greece v United Kingdom) (Preliminary Objection) (1 July 1952) (1952) ICJ Reports 28, at p 43 <http://www.icj-cij.org/docket/files/15/1965.pdf> accessed 17 November 2012.

${ }^{1438}$ George Letsas, 'Strasbourg's Interpretive Ethic: Lessons for the International Lawyer' (2010) 21(3) European Journal of International Law 509 - 541, at p 533. 
determined in abstract but in the context of the treaty' ${ }^{1439}$ in which the 'context' is elaborated.

\subsection{2 'Context' in Judicial Practice}

The ILC emphasised that the context is not just the article or the section of the treaty in which the term occurs, but the treaty as a whole. ${ }^{1440}$ The World Court has, on various occasions, recourse to the statement of the object and purposes of the treaty, and the preamble, which forms part of the context, in the interpretation of a specific provision.

The Permanent Court of International Justice in the Advisory Opinion on the Competence of the International Labour Organisation affirmed that treaty must be read in a whole in its context. ${ }^{1441}$ The importance of an interpretation in light of the context of the treaty is confirmed in the United States Nationals in Morocco case where the Court rejected an interpretation of consular jurisdiction that would imply fundamental change in the existing treaty rights. ${ }^{1442}$

The principle that the ordinary meaning of a term is to be determined not in the abstract but in the context of the treaty, in light of its objects and purposes, is affirmed in the Advisory Opinion of the ICJ on the Competence of the General Assembly for the Admission of a State to the United Nations. ${ }^{1443}$ The Court found it necessary to state

\footnotetext{
${ }^{1439}$ Draft Articles 1964, supra n 1435, at p 202, para 10. Reiterated in Draft Articles 1966, supra $\mathrm{n} 1435$, at $\mathrm{p} 221$, para 12.

${ }_{1440}$ Draft Articles 1964, supra n 1435, at p 202.

${ }^{1441}$ The Court enunciated that 'In considering the question before the Court upon the language of the Treaty, it is obvious that the Treaty must be read as a whole, and that its meaning is not to be determined merely upon particular phrases which, if detached from the context, may be interpreted in more than one sense'. PCIJ, Competence of the International Labour Organisation in Regard to International Regulation of the Conditions of Labour of Persons Employed in Agriculture (Advisory Opinion) 12 August $1922 \quad$ (PCIJ, Series B, Nos 2 and 3) $<$ http://www.worldcourts.com/pcij/eng/decisions/1922.08.12_ILC_competence1.htm> accessed 10 April 2012.

${ }^{1442}$ The Court pronounced that 'The interpretation of the provisions of the Act [of Algeciras] must take into account its purposes, which are set forth in the Preamble ... The question therefore is whether the establishment or confirmation of such jurisdiction or privileges can be based upon the implied intentions of the parties to the Act as indicated by its provisions ... Neither the preparatory work nor the Preambles gives the least indication of any such intention [to establish consular jurisdiction or to confirm the rights or privileges of the regime of Capitulations which were then in existence]'. Case Concerning Rights of Nationals of the United States of America in Morocco (France $v$ United States of America) (Judgment of 28 August 1952) [1952] ICJ Reports 176, at p 197 〈http://www.icj-cij.org/docket/files/11/1927.pdf〉 accessed 10 April 2012.

${ }^{1443}$ Competence of Assembly Regarding Admission to the United Nations (Advisory Opinion of 3 March 1950) [1950] ICJ Reports 4 <http://www.icj-cij.org/docket/files/9/1883.pdf> accessed 10 April 2012.
} 
that 'the first duty of a tribunal is to endeavour to give effect to provisions of a treaty in their natural and ordinary meaning in the context in which they occur'. ${ }^{1444}$

A similar approach is adopted in the case of Constitution of the Maritime Safety Committee of the Inter-Governmental Maritime Consultative Organisation. ${ }^{1445}$ The ICJ laid down that the meaning for the expression 'elected' 'cannot be determined in isolation by recourse to its usual or common meaning and attaching that meaning to the word where used in the Article [28(a) of the Convention of 6 March 1948 for the Establishment of the Inter-Governmental Maritime Consultative Organisation]'. ${ }^{1446}$

The recognition of a more expansive scope of context generates the effect of extending the function of the context as a bridge to the 'object and purpose'. ${ }^{1447}$ Gardiner suggested that a wider application of the context necessitates recourse to many factors -

'ranging from the fairly immediate, to the wording of surrounding provisions, headings of articles and punctuation, to more remote elements such as comparisons with other provisions on similar matters or using similar working'. ${ }^{1448}$

\subsubsection{Preamble as Part of Context}

The preamble, which usually comprises a set of recitals that spell out the motivation, aims and considerations that underlined the conclusion of the treaty, is specifically enshrined in Article 31(2) as an element of context, which recognises its textual and teleological significance. ${ }^{1449}$ Textual significance is translated into a role that partly influences the selection and modification of the ordinary meaning of terms used.

\footnotetext{
1444 Competence of Assembly Regarding Admission to the United Nations case, supra n 1443, at $\mathrm{p}$ 8. The Court reiterated the statement of the PCIJ in the case concerning the Polish Postal Service in Danzig that pronounced 'it is a cardinal principle of interpretation that words must be interpreted in the sense which they would normally have in their context, unless such interpretation would lead to something unreasonable or absurd'. Polish Postal Service in Danzig (Advisory Opinion) 16 May 1925, PCIJ Series B, No 11, at p 39

〈http://www.icj-cij.org/pcij/serie_B/B_11/01_Service_postal_polonais_a_Danzig_Avis_consultatif.pdf $>$ accessed 10 April 2012.

${ }^{1445}$ Constitution of the Maritime Safety Committee of the Inter-Governmental Maritime Consultative Organisation (Advisory Opinion of 8 June 1960) [1960] ICJ Reports 150 <http://www.icjcij.org/docket/files/43/2419.pdf> accessed 17 November 2012.

${ }^{1446}$ Constitution of the Maritime Safety Committee of the Inter-Governmental Maritime Consultative Organisation, supra $\mathrm{n} 1445$, at p 158.

${ }^{1447}$ Gardiner, Treaty Interpretation, supra n 235, at p 178.

1448 Gardiner, Treaty Interpretation, supra n 235, at pp 177 - 178.

${ }^{1449}$ Gardiner, Treaty Interpretation, supra n 235, at p 186.
} 
The ICJ in the Border and Transborder Armed Actions case took note of the Preamble to the revised draft Contadora Act of 7 September 1984 and similar wording of the preambular paragraph 35 of the Final Act of 6 June 1986, to clarify that dispute settlement procedures adopted under the treaty were not intended to exclude the right of recourse to other competent international forums. ${ }^{1450}$ Under certain circumstances, the preamble that lays out the object and purpose of the treaty might reject an interpretation that is inconsistent with it, as seen in the case of Canada - Patent. ${ }^{1451}$

In such instance, the preamble of a treaty plays a significant textual role in the interpretation of treaty provision. Although the recitals of the preamble are not a place suitable to place obligations, which should normally be in the operative articles of the treaty or in annexes, it may impose interpretative commitments where a choice of interpretation that runs contrary to its preamble would be excluded. ${ }^{1452}$ By stating the object and purpose, a preamble can thus 'be of both contextual and teleological significance ${ }^{1453}$ where recourse was had on numerous occasions by international courts and tribunals to elucidate the meaning of a particular provision. ${ }^{1454}$

${ }^{1450}$ Border and Transborder Armed Actions (Nicaragua $v$ Honduras) (Jurisdiction and Admissibility, Judgement of 20 December 1988) [1988] ICJ Reports 69, at p 106, para 97 <http://www.icjcij.org/docket/files/74/6591.pdf> accessed 17 November 2012. The Preamble stated that 'The Governments of the Republics of Costa Rica, El Salvador, Guatemala, Honduras and Nicaragua ... Reaffirming without prejudice to the right to resort to competent international forums, their willingness to settle their disputes in the framework of the negotiation process sponsored by the Contadora Group ...'

${ }^{1451}$ WTO, Canada - Term of Patent Protection (Report of the Appellate Body) (18 September 2000) WT/DS170/AB/R <http://www.wto.org/english/tratop_e/dispu_e/170abr_e.pdf> accessed 17 November 2012. At p 18, para 59, the AB pronounced that - If the phrase 'acts which occurred' were interpreted to cover all continuing situations involving patents which were granted before the date of application of the TRIPS Agreement for a Member, including such rights as those under Old Act patents, then Article 70.1 would preclude the application of virtually the whole of the TRIPS Agreement to rights conferred by the patents arising from such 'acts'. This is not consistent with the object and purpose of the TRIPS Agreement, as reflected in the preamble of the Agreement. At para 60, the AB went on to conclude that Art 70.1 of the TRIPS Agreement cannot be interpreted to exclude existing rights, such as patent rights under the Old Act patents, even if such rights arose through acts which occurred before the date of application of the TRIPS Agreement for Canada.

${ }^{1452}$ Gardiner, Treaty Interpretation, supra $\mathrm{n} 235$, at p 186. The author had loosely paraphrased Suy that 'the substantive provisions will usually have greater clarity and precision than the preamble; but where there is doubt over the meaning of a substantive provision, the preamble may justify a wider interpretation, or at least rejection of a restrictive one'. E Suy, 'Le Préambule' in E Yakpo and T Boumedra (eds) Liber Amicorum Judge Mohammed Bedjaoui (Kluwer, The Hague, 1999) at p 262: 'De façon générale, le dispositive offrira, en raison de sa plus grande précision, plus de claret, de sorte qu'un recours à l'interprétation au moyen du prémbule peut en justifier une interpretation extensive - ou au moins justifier le rejet d'une interpretation restrictive'. It is suggested that the preamble of a treaty consisting of a set of recitals, where it is the usual place where parties would enshrine an explicit statement of its object and purpose, may assist the determination of the object and purpose of the treaty.

${ }^{1453}$ Dörr and Schmalenbach (eds) Vienna Convention on the Law of Treaties. A Commentary, supra $\mathrm{n} 663$, at $\mathrm{p}$ 544. In the Golder case, at p 34, it is apparent how the preamble provides a teleological role in the determination of the interpretation of a treaty term. The profound belief in the rule of law by the signatory Governments as shown in the context and the object and purpose of the Convention prompted the Court 


\subsubsection{Annexes as Part of Context}

Article 31(2) expressly spells out that annexes form part of the context of a treaty. In the Chile - Price Band case, the AB found contextual support in Annex 5 and its Attachment to Annex 5, the Guidelines for the Calculation of Tariff Equivalents for the Specific Purpose Specified in Paragraphs 6 and 10 of this Annex, of the Agreement on Agriculture in the interpretation of the term 'ordinary custom duties'. The Annex and its Attachment contemplates the calculation of 'tariff equivalents' in a way that would result in ordinary customs duties to be expressed as ad valorem or specific rates. ${ }^{1455}$ This provides the contextual foundation where the AB held that Members (of the World

to interpret that the right of access constitutes an element inherent in the right stated by Art 6(1) of the Human Rights Convention. The Court went further and proclaimed that 'one can scarcely conceive of the rule of law without there being a possibility of having access to the courts'. European Court of Human Rights, Golder v United Kingdom, Application No 4451/70 (Strasbourg, 21 February 1975) <http://hudoc.echr.coe.int/sites/eng/pages/search.aspx?i=001-57496> accessed 17 November 2012

${ }^{1454}$ For example, Asylum Case (Columbia v Peru) (Judgment of 20 November 1950) [1950] ICJ Reports 266 <http://www.icj-cij.org/docket/files/7/1849.pdf> accessed 17 November 2012. The Court, at p 282, in consideration of the meaning of 'common crimes' within Art 1(1) of the Havana Convention, referred to the object of the Havana Convention as indicated in the preamble. The Convention, as stated in the preamble, intended to fix the rules which the signatory States must observe for the granting of asylum in their mutual relations and to put an end to the abuses which had arisen in the practice of asylum. Sovereignty over Pulau Ligitan and Pulau Sipadan (Indonesia v Malaysia) (Judgment of 17 December 2002) [2002] ICJ Reports 625 <http://www.icj-cij.org/docket/files/102/7698.pdf> accessed 17 November 2012. The ICJ referred to the wording of the preamble, which were 'the parties were desirous of defining the boundaries between the Netherland possessions in the Island of Borneo and the States in that island which are under British protection' and decided that the Convention did not suggest that the parties intended to delimit the boundary between their possessions to the east of the islands of Borneo and Sebatik or to attribute sovereignty over any other islands 'as these islands were little known at that time, and were not the subject of any dispute between Great Britain and the Netherlands', at p 652, para 51. In the Golder case, supra n 1453, at p 12, at para 34, opined that the passage in the preamble that laid out the declaration of the Signatory Governments, 'as Governments of European Countries that are like-minded and have a common heritage of political traditions, ideals, freedom and the rule of law' to resolve the interpretation of 'to take the first steps for the collective enforcement of certain of the Rights stated in the Universal Declaration'. The Court emphasised that the rule of law is one of the features of the common spiritual heritage of the member States of the Council of Europe, and it would be a mistake to treat this reference in the preamble as a merely 'more or less rhetorical reference devoid of relevance' in the interpretation of the Convention. Shrimp/Turtle case, supra n 689, at paras 129 and 131. The AB in the Shrimp/Turtle case referred to the Preamble to the WTO Agreement to infer that the signatories to the WTO Agreement are fully aware of the importance and legitimacy of environmental protection as a goal of national and international policy where the objective of sustainable development is acknowledged. The $\mathrm{AB}$ noted that the perspective embodied in the preamble gave an evolutionary definition to the generic term of 'natural resources' in Art XX(g). The explicit recognition of the WTO Members of the objective of sustainable development in the preamble of the WTO Agreement supports the interpretation of Art $\mathrm{XX}(\mathrm{g})$ to hold that measures to conserve exhaustible natural resources, whether living or non-living, may fall within Art XX(g). In the Chile - Price Band case, supra n 891, the AB made explicit reference to Recital 2 of the Preamble that laid out the objective of the Agreement. The AB acknowledged that the determination of whether Chile's price band system is consistent with the Agreement on Agriculture must bear in mind the objective of the Agreement as stated in its Preamble. In addition, certain special and differential treatment for developing country Members relating to the treatment of agricultural products is recognised in the Preamble, although the parties had both conceded that the fact that both are developing countries has no relevance in the present dispute.

${ }^{1455}$ Chile - Price Band case, supra n 891, at para 277. 
Trade Organisation) are not required to refrain from basing their duties on 'exogenous factors', as long as the ordinary customs duties are to be expressed in the form of ad valorem or specific rates, and reversed the Panel's finding in paragraph 7.52 of the Panel Report. ${ }^{1456}$

\subsubsection{Text as Part of Context}

The various aspects of 'the text' could be elaborated through the categories of grammar and syntax; title, headings, and chapeaux; structure or scheme underlying a provision or the treaty as a whole; related and contrasting provisions; or even the punctuation and syntax. ${ }^{1457}$

A distinction between immediate context and the context in the sense of the entire text of the treaty is carefully drawn in the La Bretagne arbitration. ${ }^{1458}$ The Tribunal, prior to the determination of the scope of the principle of non-discrimination as stipulated in Article $6^{1459}$ needs to examine the content of the term 'fishery regulations' ${ }^{1460}$

The Tribunal first refers to the immediate context, which is Article 6 itself, of 'which the phrase "fishing regulations" forms part'. ${ }^{1461}$ The Tribunal identified the parallel rules that apply reciprocally to Canadian and French fishing vessels and does not refer solely to the internal law of one or another of the Parties in defining the notion of 'fishing regulations'. Therefore, the immediate context of Article 6 prompted the Tribunal to adopt a definition of 'fishing regulations' that is common to both Parties, and involves elements taken from the internal law of each of the two States. ${ }^{1462}$

\footnotetext{
${ }^{1456}$ Chile - Price Band case, supra n 891, at para 278.

${ }^{1457}$ Gardiner, Treaty Interpretation, supra n 235, at pp $178-189$.

1458 Dispute Concerning Filleting within the Gulf of St Lawrence ('La Bretagne') (Canada/French) (1986) 82 ILR 591.

${ }^{1459}$ Art 6 provides that 'Canadian fishery regulations shall be applied without discrimination in fact or in law to the French fishing vessels'

${ }^{1460}$ La Bretagne, supra n 1458, at pp $618-619$, para 37.

${ }^{1461}$ La Bretagne, supra n 1458, at p 620, para 38. Art 6 of the 1972 Agreement between Canada and France on Their Mutual Fishing Relations provides that: '1. Canadian fishery regulations shall be applied without discrimination in fact or in law to the French fishing vessels covered by Articles 3 and 4, including regulations concerning the dimensions of vessels authorized to fish less than 12 miles from the Atlantic coast of Canada. 2. French fishery regulations shall be applied under the same conditions to the Canadian fishing vessels covered by Article 4. 3. Before promulgating new regulations applicable to these vessels, the authorities of each of the parties shall give three months prior notice to the authorities of the other party.'

${ }^{1462}$ La Bretagne, supra n 1458, at p 620, para 38. The Tribunal referred to the statement arrived at the ICJ in the Barcelona Traction case, at p 37, para 50. The ICJ, at p 211, elaborated that 'It is to rules generally accepted by municipal legal systems .. and not to the municipal law of a particular State'. At para 38, in the reference to the immediate context of 'fishing regulations', the Tribunal is of the view that the natural
} 
Apart from the immediate context in which the meaning of 'fishing regulations' is ascertained, the Tribunal proceeded to enunciate that the context in terms of the entire text of the Agreement should also be applied. In this sense, the Tribunal carefully drew out the difference between the immediate context - which is the whole of the Article in which the term is found, and the context in the entire treaty. The Tribunal then continued to refer to the entire text of the Agreement to confirm that the phrase 'fishing regulations' is not to be deprived of its ordinary sense, as the entire Agreement relates to reciprocal relations between the Parties 'in fisheries matters'. ${ }^{1463}$ Hence, the Tribunal decided that the authorities of one of the Parties might not use fishing regulations to subject the other Party's vessels to regulations unconnected with the purpose of fishing. ${ }^{1464}$

\subsubsection{Heading and Title}

Gardiner proposed further guidance in the determination of the 'wider' context that is not provided under the 1969 Vienna Convention, but still intrinsically essential in the determination of 'context' as titles or descriptive headings should clearly form part of the context for the purposes of interpretation. He commented that the obvious starting point for the construction and identification of the scope and ambit of a treaty, or a section or provision of a treaty is the title, headings or the chapeaux. ${ }^{1465}$ In addition, The WTO used the terminology of 'chapeau' to mean the preamble or the preambular language of Article XX. ${ }^{1466}$

and ordinary sense of 'fishing regulations' - consists in designating the legislative or regulatory prescriptions contained in the various systems of internal law, which fix the conditions to which all fishcatching activities are subject and are generally designed to maintain order of fishing grounds as well as to protect and preserve resources'. Case Concerning the Barcelona Traction, Light and Power Company, Limited (Belgium v Spain) (Judgment of 5 February 1970) [1970] ICJ Reports 3; (1970) 46 ILR 178 <http://www.icj-cij.org/docket/files/50/5387.pdf> accessed 17 November 2012.

${ }^{1463}$ La Bretagne, supra n 1458, at pp 620-621, para 38.

${ }^{1464}$ La Bretagne, supra $\mathrm{n} 1458$, at p 621, para 39.

${ }^{1465}$ See Gardiner, Treaty Interpretation, supra n 235, at pp 180 - 181. At p 181, According to Gardiner, titles or descriptive headings clearly form part of the context for the purposes of interpretation. Chapeau is used mainly to describe 'the opening words [or the opening clause] of a provision which consists of a set of terms', at pp 158 and 181. Chapeau is not defined in the Vienna Convention. However, the use of this terminology to refer to the opening clause is 'in vogue', especially in the WTO regime where careful treatment of the chapeau of Article XX of the GATT is undertaken in the interpretation and application of the provisions that permit exceptions listed in GATT.

${ }_{1466}$ See WTO, 'XXI. Article XX' (WTO Analytical Index: GATT 1994) <http://www.wto.org/english/res e/booksp_e/analytic index_e/gatt1994 07_e.htm> accessed 21 April 2012. In Shrimp/Turtle case, supra n 689, at paras 158 - 159, the AB stated that - 'The chapeau of Article XX is, in fact, but one expression of the principle of good faith. This principle, at once a general principle of law and a general principle of international law, controls the exercise of rights by states. One application of this general principle, the application widely known as the doctrine of abus de droit, 
As the chapeau relates to the application of the measure in dispute and not the measure itself, its relation to the interpretation of the obligations and terms of Article XX exceptions is slightly different from the role of title or headings in informing or confirming the ordinary meaning of a treaty term as elaborated above. The chapeau asserts influence on the extent to which a treaty provision under Article XX is applied whereby after ascertaining that the alleged measure falls under the provisions of Article $\mathrm{XX}$, the manner in which the measure is applied must be in accordance with the conditions stipulated in the chapeau.

A very good example illustrates the importance of title in providing the necessary context for the interpretation of a term can be found in the careful adoption of the title of Article 31 of the 1969 Vienna Convention that provides for 'General Rule of Interpretation'. 1467

prohibits the abusive exercise of a state's rights and enjoins that whenever the assertion of a right "impinges on the field covered by [a] treaty obligation, it must be exercised bona fide, that is to say, reasonably". Having said this, our task here is to interpret the language of the chapeau, seeking addition interpretative guidance, as appropriate, from the general principles of international law. The task of interpreting and applying the chapeau is, hence, essentially the delicate one of locating and marking out a line of equilibrium between the right of a Member to invoke an exception under Art XX and the rights of the other Members under varying substantive provisions of the GATT 1994'. Gardiner, Treaty Interpretation, supra $\mathrm{n} 235$, at $\mathrm{p} 159$. The importance of the chapeau in the interpretation and application of Article XX of the GATT is explicitly stated by the WTO in numerous occasions. In US - Gasoline, supra $\mathrm{n} 118$, at pp 20 and 21. The AB stated that - 'In order that the justifying protection of Art XX may be extended to it [Gasoline Rule], the measure at issue must not only come under one or another of the particular exceptions - paragraphs (a) to (j) - listed under Art XX; it must also satisfy the requirements imposed by the opening clauses of Art XX. The analysis is two-tiered: first, provisional justification by reason of characterisation of the measure under $\operatorname{Art} \mathrm{XX}(\mathrm{g})$; second, further appraisal of the same measure under the introductory clauses of Article XX'. At $\mathrm{p} 21$, the $\mathrm{AB}$ went on further to state the importance of the chapeau in the interpretation of the exceptions under Art XX, and the role it plays on the provisions under Art XX, where it is stipulated that - 'The chapeau, by its express terms addresses, not so much the questioned measure or its specific contents as such, but rather the manner in which that measure is applied. It is, accordingly, important to underscore that the purpose and object of the introductory clauses of Art XX is generally the prevention of "abuse of the exceptions of Art XX". The importance of the chapeau in the interpretation and application of exceptions allowed under Art XX relates to whether an alleged measure that infringe other provisions of the GATT but falls under the exceptions permissible under Art XX, are 'applied in such a manner which would constitute ... a disguised restriction on trade'. See WTO, United States - Imports of Certain Automotive Spring Assemblies - Report of the Panel L/5333 - $\quad 30 \mathrm{~S} / 107 \quad$ (26 May 1983) at para 56 <http://www.worldtradelaw.net/reports/gattpanels/usspringassemblies.pdf > accessed 21 April 2012.

${ }^{1467}$ Draft Articles 1966, supra $\mathrm{n} 1435$, at pp $219-220$, para 8. The ILC explicated that - 'by heading the article "General Rule of Interpretation" in the singular and by underlining the connexion between paras 1 and 2 and again between para 3 and the two previous paragraphs, intended to indicate that the application of the means of interpretation in the article would be a single combined operation ... because the Commission desired to emphasise that the process of interpretation is a unity and that the provisions of the article form a single, closely integrated rule. It is shown that the title of the provision in which a term is to be interpreted forms part of the context of the interpretation of that term, where recourse should be had in an interpretation of a treaty term. At p 223, para 18, it is stated that the title of Art 32 of 'Supplementary Means of Interpretation' in the subsequent provision of the Vienna Convention indicated that these supplementary means are applied only in the event that primary rule of interpretation failed to 
An interesting observation can be made in the case of Oil Platforms where the Court decided that 'commerce' in Article X(1) is not confined to maritime commerce where reference was made to the immediate grammar and syntax of 'the rest of the Article', ${ }^{1468}$ and the other aspects of a treaty, in the determination of the scope of 'commerce'. The context in which the term 'commerce' is embedded included the 'recital in Article XXII of the Treaty that stated that the Treaty (of 1955) relates to trade and commerce, and not one restricted purely to maritime commerce. ${ }^{1469}$ The Court went further to impose that the entire range of activities provided in the Treaty, such as the stipulations under Article IV of the freedom, control and power of companies in the effective conduct of their affairs, should be considered. ${ }^{1470}$

In furtherance of the determination of the scope of 'commerce', and whether the ambit of the term should be taken in its ordinary sense and its legal meaning, particular attention was paid regarding the title of the Treaty of 1955. The title refers not just 'Commerce' but 'Economic Relations' besides 'Amity' and 'Consular Rights' to justify that 'commerce' in Article X(1) of the Treaty of 1955 also includes commercial activities that deals with a wide variety of matters ancillary to trade and commerce. ${ }^{1471}$

Thus, a title or heading is not only relevant as a point of reference for an interpretation of a treaty term, its content will be useful as an aid to interpretation as seen in the case of Plama v Bulgaria. ${ }^{1472}$ The Tribunal opined that the Respondent's contention on a case on jurisdictional grounds on the effect of Articles 17(1) and 26 of the Energy Charter Treaty. ${ }^{1473}$ The Tribunal was of the view that the express terms of Article 17 refer to a

disclose clear or reasonable meaning or to confirm the meaning generated by the application of the general rule of interpretation under Art 31. At p 223, para 18, the ILC emphasised that the titling of 'supplementary means' in Art 32 stipulated that the Commission intended for these means to act as an aid to interpretation governed by principles under Art 31 in situation whereby application of Art 31 produces ambiguity or gives a meaning that is manifestly absurd or unreasonable.

${ }^{1468}$ Case Concerning Oil Platforms (Islamic Republic of Iran v United States of America) (Preliminary Objection, Judgment of 12 December 1996) (1996) ICJ Reports 803, at p 817, para 41 <http://www.icjcij.org/docket/files/90/7287.pdf> accessed 17 November 2012.

${ }^{1469}$ Oil Platforms, supra n 1468 , at p 817, para 41.

1470 Oil Platforms, supra n 1468, at p 817, para 42.

1471 Oil Platforms, supra n 1468, at pp 818 - 819, paras 46, 47 and 49.

${ }^{1472}$ Plama $v$ Bulgaria, (Decision on Jurisdiction, 8 February 2005) ICSID Case No ARB/03/24, 〈http://italaw.com/documents/plamavbulgaria.pdf $>$ accessed 17 April 2012. Gardiner, Treaty

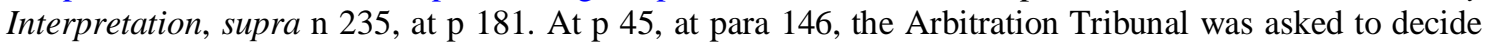
on the question whether any issue raised under Art 17(1) by Bulgaria can deprive the Tribunal of all jurisdiction to decide the merits of the parties' dispute.

${ }^{1473}$ Plama v Bulgaria, supra n 1472, at p 43, para 141. Art 26 of the Energy Charter Treaty (ECT) provides an almost unprecedented remedy to a covered investor for its claim against a host state, , albeit limited to the state's obligations under Part III of the ECT. The relevant part of Art 26, at p 36, para 121 provides that - 'Disputes between a Contracting Party and an Investor of another Contracting Party 
denial of the advantage 'of this Part', which refers to the substantive advantages conferred upon an investor by Part III of the ECT. This reading is confirmed by the title to Article 17, which stated 'Non-Application of Part III in Certain Circumstances' (original emphasis). ${ }^{1474}$

Hence, the denial of protection under Article 17, interpreted in good faith and in accordance with their ordinary contextual meaning, would only exclude the advantages of Part III and would not preclude it exercising jurisdiction under Article 26, Part V of the Treaty to determine whether on the facts Article 17 had been properly invoked. ${ }^{1475}$ It has been shown in this Tribunal decision that the title of Article 17 has aided in the interpretation of Article 17, and confirmed the conclusion arrived at by the Tribunal that the denial of advantages is merely limited to advantages accorded under Part III of the Treaty, and does not extend to include a denial to invoke Article 26 for the resolution of dispute under Article 17(1). ${ }^{1476}$

\subsubsection{The structure and scheme underlying the provision and the treaty as a whole}

The context of a treaty term includes the structure or scheme underlying a provision or the treaty as a whole. ${ }^{1477}$ The reference to 'structure' of a provision in a contextual reading of a treaty term is illustrated in the WTO case of Canada - Measures Affecting

relating to an Investment of the latter in the Area of the former, which concern an alleged breach of an obligation of the former under Part III ... may choose to submit it for resolution to ... international arbitration under the ICSID convention'. At p 8, para 22, Art 17 is situated within Part III of the Treaty that laid out the obligations undertaken by the Contracting States to accord to the Investments of Investors of other Contracting States 'fair and equitable treatment' and 'the most constant protection and security'. Art 17 specifically stipulated that - Contracting States reserve the right to deny the advantages of Part III (ie the substantive protection for investors under Part III) to a legal entity if citizens or nationals of a third state own or control that entity and if that entity has no substantial business activities in the Area of the Contracting Party in which it is organised.

${ }^{1474}$ Plama v Bulgaria, supra n 1472, at p 45, para 147.

${ }^{1475}$ Plama v Bulgaria, supra $\mathrm{n}$ 1472, at pp $45-46$, paras 147 and 149. The Tribunal elaborated that - 'The language is unambiguous [that Art 17 refer to a denial of the advantages of this Part (Part III)]; but it is confirmed by the title to Art 17 ... [T] he denial applies only to advantages under Part III [and does not operate as a denial of all benefits to a covered investor under the Treaty but is expressly limited to a denial of the advantages of Part III of the ECT] ... It would therefore require a gross manipulation of the language to make it refer to Art 26 in Part V of the ECT. Nonetheless, the Tribunal has considered whether any such manipulation is permissible in the light of the ECT's object and purpose'.

${ }^{1476}$ However, if indicated otherwise, the title has limited implication on the context of a treaty, as found in the UNFCCC. A note to the title of Art 1 which stated that 'Titles of articles are included solely to assist the reader', such express limitation might be taken as a specific restraint for its incorporation into the context for the interpretation of a particular provision in the treaty.

${ }^{1477}$ Gardiner, Treaty Interpretation, supra n 235, at p 182. See paras 155 - 156. 
the Export of Civilian Aircraft. ${ }^{1478}$ The AB, after acknowledging that the guidelines for calculating the amount of a subsidy in terms of 'the benefit to the recipient' in Article 14 relates to 'countervailing measures', still decided that it constituted relevant context for the interpretation of 'benefit'. The similar context in which 'benefit' is used in both Articles 14 and 1.1 where Article 14 explicitly referred to Article 1.1 in the calculation of 'benefit' supports the reading of 'benefit' of Article 1.1(b) that 'benefit' concerns the 'benefit to the recipient' and not 'cost to government', contrary to the contention of Canada. ${ }^{1479}$

The role of the 'underlying scheme' of the treaty, as part of the context in 'buttressing an emerging interpretation' can be shown in the judgment of the House of Lords in R v Secretary of State for the Home Department, ex parte Read. The application requires the House of Lords to determine whether the Secretary of State had any power, and if so, to what extent, to provide for a shorter term to be served or to fix an earlier release date in this application for transfer to the United Kingdom under the Repatriation of Prisoners

${ }^{1478}$ WTO, Canada - Measures Affecting the Export of Civilian Aircraft - Report of the Appellate Body (AB-1999-2) (2 August 1999) WT/DS70/AB/R <http://www.worldtradelaw.net/reports/wtoab/canadaaircraft(ab).pdf> accessed 15 November 2012 (hereinafter: 'Canada - Aircraft'). The AB, in the determination of whether the Panel has erred in the interpretation of 'benefit' in Art 1.1(b) of the Subsidy and Countervailing Measures (SCM) Agreement by excluding the cost to the government, rejecting Annex IV as relevant context, and instead focus the interpretation of 'benefit' on the commercial benchmarks in Art 14. At p 38, para 151, the AB referred to the provision of Article 1.1 of the SCM Agreement in para 152, whereby it stated that, 'under the heading of 'Definition of A Subsidy', Art 1.1 provides, in relevant part: ... [A] subsidy shall be deemed to exist if ... (a)(1) there is a financial contribution by a government or any public body within the territory of a Member (referred to in this Agreement as "government") ... and (b) a benefit is thereby conferred.' At para 153, the AB started the interpretation of the ordinary meaning of 'benefit' by looking at the dictionary definition of 'benefit', of which confirmed the Panel's statement that 'the ordinary meaning of "benefit" clearly encompasses some form of advantage'. At pp 38 - 39, para 154, The AB goes further to state that - 'A benefit does not exist in the abstract, but must be received and enjoyed by a beneficiary or a recipient ... The term 'benefit' implies that there must be a recipient. This provides textual support for the view that the focus of the inquiry under Art 1.1(b) of the SCM Agreement should be on the recipient and not on the granting authority. Reference to the ordinary meaning of the word 'confer' used in Art 1.1(b) 'bears this out'. The use of the past participle 'conferred' in the passive form, in conjunction with the word 'thereby' naturally calls for an inquiry into what was conferred on the recipient (emphasis original)'. Following from such argument, the AB decided that Canada's contention that 'cost to government' is one way of conceiving of 'benefit' is at odds with the ordinary meaning of Art 1.1(b) that focuses on the recipient and to on the government providing the financial contribution'. The AB emphasised, at p 39, para 156 that 'the structure of Art 1.1 as a whole confirms our view that Art 1.1(b) is concerned with the "benefit" to the recipient and not with the "cost to government"'. The 'structure' of Art 1.1, in the definition of 'subsidy' as meant by the $\mathrm{AB}$ consists of two elements: first, the action of the government in making the financial contribution; and logically, the second element must necessarily concerns the 'benefit conferred on the recipient by that governmental action'. The structure of Art 1.1 clearly exhibits that 'subsidy' is meant to be determined from whether an action of contribution is taken by the government, and whether such contribution is conferred on the recipient. Nothing in the 'structure' hinted that 'cost incurred to the government' as contended by Canada is relevant to the determination of whether there is a benefit to the recipient. The AB held that such a contention by Canada disregards the overall structure of Art 1.1.

${ }^{1479}$ See Canada - Aircraft, supra n 1478, at paras $155-156$. 
Act 1984 and the International Convention on the Transfer of Sentenced Persons 1983. ${ }^{1480}$ The Secretary of State argued that his task is merely to compare the foreign sentence against the maximum sentence laid down by Parliament, whereby if the foreign sentence is less than the maximum sentence provided by Parliament, he will simply provide for the sentence to be served in full. ${ }^{1481}$

Lord Parker LJ opined that this would produce surprising consequences, where following a foreign court's conviction of two defendants, one with the minimum sentence of 12 years and the other, the maximum sentence of 20 years, both sentences would be reduced to 10 years of continued enforcement in a transfer of prisoner by virtue of the Act of 1984. Lord Parker LJ, on behalf of the Lords, pronounced that it is unacceptable for the Lords of the contention that 'so long as the sentence to be served does not exceed that maximum (of 10 years under Section 15(1) of the Forgery and Counterfeiting Act 1981 of imprisonment not exceeding 10 years)'. ${ }^{1482}$ The Lords are 'unable to ... accept that the parties to the Convention, or Parliament when enacting the Act of 1984, intended to produce any such results.' ${ }^{1483}$

The House of Lords made reference to the underlying scheme of Article 10, where the starting point for Article 10 is always the original sentence. ${ }^{1484}$ The administrating state is bound by the continuation of enforcement determined by the sentencing state. However, it is qualified by paragraph two (Article 10.2) that the enforcement of such sentence, if found incompatible, must be adapted by the administrating state to a

\footnotetext{
${ }^{1480} R$ v Secretary of State for the Home Department, Ex parte Read [1989] Appeal Cases 1014, at p 1025. See pp 1023 - 1025. The Convention provides in Art 9 the procedures the administering state may use in the case of a transferred person. It may either continue the enforcement of the original sentence under Art 10 or it may convert the sentence into a sentence of its own under Art 11. Art 10 concerning the continuation of enforcement is the only applicable provision as the United Kingdom has indicated that it intends to exclude the conversion procedure under Art 11. Art 10, on continued enforcement, provides that - ' 1 . In the case of continued enforcement, the administering sate shall be bound by the legal nature and duration of the sentence as determined by the sentencing state. 2. If, however, this sentence is by its nature or duration incompatible with the law of the administering state, or its law so requires, that state may, by a court or administrative order, adapt the sanction to the punishment or measure prescribed by its own law for a similar offence. As to its nature, the punishment or measure shall, as far as possible, correspond with that imposed by the sentence to be enforced. It shall not aggravate, by its nature or duration, the sanction imposed in the sentencing state, nor exceed the maximum prescribed by the law of the administering state'. Convention on the Transfer of Sentenced Persons (concluded 21 March 1983, $\begin{array}{llllllll}\text { entered into force } 1 & \text { July } & \text { 1985) } & \text { CETS } & \text { No } & 112\end{array}$ <http://conventions.coe.int/Treaty/en/Treaties/Html/112.htm> accessed 18 November 2012. Gardiner, Treaty Interpretation, supra $\mathrm{n} 235$, at $\mathrm{p} 184$.

${ }^{1481} \mathrm{R} v$ Secretary of State for the Home Department, supra n 1480, at $\mathrm{p} 1025$.

${ }^{1482} \mathrm{R} v$ Secretary of State for the Home Department, supra n 1480, at p 1026.

${ }^{1483} \mathrm{R}$ v Secretary of State for the Home Department, supra n 1480, at $\mathrm{p} 1025$.

${ }^{1484} \mathrm{R} v$ Secretary of State for the Home Department, supra n 1480, at p 1021.
} 
punishment or measure prescribed by its own law for a similar offence, and as far as possible correspond with the sentence to be enforced. ${ }^{1485}$

Hence, the underlying scheme on the continuation of enforcement under Article 10 played the role in buttressing the interpretation of this provision, especially in the light of the contrasting scheme underlying Article 11 that is explicitly excluded by the UK government. In the confirmation of this interpretation, reference was made to the 'Explanatory Report', adopted at the time of conclusion of the Convention and thus forming part of the context as stipulated under Article 31(2)(a) of the 1969 Vienna Convention. ${ }^{1486}$

Similarly, the ICJ, in the case of Navigational and Related Rights illustrated the reference to the whole of the treaty in order to infer a necessary consequence or implication in the reading of a disputed provision, implicit in the structure of the treaty as a whole. ${ }^{1487}$ The ICJ decided that the particular aspect of navigational rights for private vessels in order to meet the essential requirements of the population living on

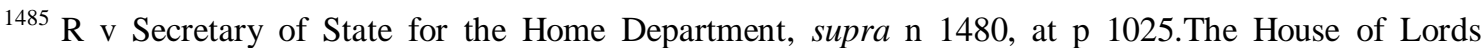
interpreted that Art 10.2 clearly shows that 'the terms of para 1 are qualified by paragraph two which confers the power of the administering state to depart from para 1 if the foreign sentence is by its nature or duration incompatible with the law of the administering state'. The Lords further elaborated that - If there is incompatibility, Art 10 empowers the administering state to 'adapt the sanction to the punishment or measure prescribed by its own law for a similar offence'. It then provides that 'as to its nature' the adaptation shall so 'far as possible, correspond with that imposed by the sentence to be enforced' and is not to 'aggravate, by its nature or duration, the sanction imposed in the sentencing state, nor exceed the maximum prescribed by the law of the administering state'. A similar offence prescribed under Section 15 of the Forgery and Counterfeiting Act 1981 has a maximum sentence of imprisonment not exceeding 10 years. And such sentence is 'to be reserved for the gravest offence' of which the House of Lords opined that the Spanish offence before them 'was far from the gravest' that the Secretary of State, by fixing the term to be served on a 10 year sentence, has 'infringed the final prohibition'. The Lords emphasised that 'compatibility' is not preserved by merely continuing a sentence served that does not exceed the maximum sentence imposed in the administering state. It is held that 'it cannot have been the intention of Parliament to have required the Secretary of State to enforce a sentence considered to be manifestly excessive by the courts in this country', let alone a sentence that is considered manifestly excessive by the sentencing state.

${ }^{1486} \mathrm{R}$ v Secretary of State for the Home Department, supra n 1480, at p 1052. See also Gardiner, Treaty Interpretation, supra $\mathrm{n} 235$, at $\mathrm{p} 185$.

${ }^{1487}$ See also Dörr and Schmalenbach (eds) Vienna Convention on the Law of Treaties. A Commentary, supra $\mathrm{n}$ 663, at $\mathrm{p} 544$. The Court in the case of Navigational and Related Rights, supra $\mathrm{n} 210$, at pp 245 and 246, paras 74 and 77 stated that - '[T]here is reason to take into account the provisions of the Treaty as a whole, especially those fixing the boundary between the two States, in order to draw, if need be, certain necessary implications'. The question raised was whether the navigation of vessels belonging to the inhabitants of the villages on the Costa Rican bank of the river in order to meet the basic requirements of everyday life was protected by the right of free navigation when it is carried out free of charge. Navigational and Related Rights, supra n 210, at p 246, para 77.
} 
the river bank in their daily lives, is inferred from the provisions of the Treaty as a whole, in particularly from the fixing of the boundary along the river bank. ${ }^{1488}$

A similar observation of a relevant provision of the treaty that shows an underlying structure or scheme that might assist in the interpretation of another treaty term or provision is briefly alluded to in the case of Oil Platform. The Court, by its Judgment on Preliminary objection noted that the objective of Article I of the 1955 Treaty is 'to throw light on the interpretation of the other Treaty provisions and thus not without legal significance for such an interpretation'. ${ }^{1489}$ The Court in the Judgment on the merits of the same case further stated that Article $\mathrm{I}$ is relevant in so far that it might affect the interpretation or application of the text of Article X(1). ${ }^{1490}$

\subsubsection{Related and Contrasting Provisions}

Provisions that are related or contrasting offer necessary insights in the interpretation of a treaty provision or its terms, by providing a context for such interpretation. ${ }^{1491}$ The Border and Transborder Armed Actions case shows that a related provision that is dissimilar in its content can be useful in illustrating the interpretation of a term. ${ }^{1492}$ The Court, in the determination of jurisdiction, compared the two contrasted provisions, and noted the different mode of how it may be conferred jurisdiction in accordance with the Statute, where the two provisions provide for 'two distinct ways by which access may be had to the Court'. 1493

The Court confirmed that Article XXXI relates to cases that the Court can be seised directly, whereas Article XXXII confers jurisdiction when parties failed to reach a solution although conciliation is resorted to initially. Thus, the two contrasting

\footnotetext{
1488 Navigational and Related Rights, supra n 210, at p 248, para 84.

1489 Oil Platforms, supra n 1468, at p 815, para 31.

1490 Oil Platforms, supra n 1468, at p 178, para 31.

${ }^{1491}$ Gardiner, Treaty Interpretation, supra n 235, at pp $185-186$.

1492 Case Concerning Border and Transborder Armed Actions (Nicaragua v Honduras) (Jurisdiction of the Court and Admissibility of the Application) Judgment of 20 December 1988, ([1988] ICJ Reports 69. At pp 84 and 88, paras 32 and 43, Honduras contended that jurisdiction is based on Article XXXII of the Pact of Bogotá, and that Article XXXI and XXXII must be read together. It contended that the Court could only be seised under Article XXXI if there had been a prior recourse to conciliation and lack of agreement to arbitrate since Article XXXI establishes jurisdiction of the Court and the subsequent Article XXXII sets out the prerequisites for the reference of a particular dispute. Article XXXI provides for the recognition of the parties of the ICJ's jurisdiction as compulsory ipso facto in accordance with Article 36(2) of the Statute of ICJ. Article XXXII provides for the recourse of either of the parties to the International Court of Justice in accordance with Article 40 of the Statute of ICJ in the event that the conciliation procedure previously established in the Pact or by agreement of the parties does not lead to a solution, or parties have not agreed upon an arbitral procedure.

${ }^{1493}$ Border and Transborder Armed Actions, supra n 1450, at pp 88-89, at paras $42-45$.
} 
provisions, addressing the same subject matter (jurisdiction), forms part of the context in the interpretation, clarification, and confirmation of a treaty provision (jurisdiction of court under Article XXXI). This led the Court to conclude that Article XXXI of the Pact of Bogotá confers jurisdiction upon the Court to entertain the dispute submitted to it regardless of whether there are any declarations of acceptance of compulsory jurisdiction by Nicaragua and Honduras; or whether prior conciliation had been initiated.

\subsubsection{Punctuation and Syntax}

Considerations of punctuations and syntax are needed in uncovering the essential link between the meaning of a single word and its immediate context. ${ }^{1494}$ Together with other elements of treaty interpretation, they constitute part of the whole of treaty interpretation. ${ }^{1495}$ The pivotal role of punctuation was shown in the Protocol Rectifying Discrepancy in the Charter of the International Military Tribunal, where the parties to the Charter viewed it desirable to rectify a discrepancy on punctuation found to exist between the originals of Article 6(c) of the Charter in the Russian language on the one hand, and the originals in the English and French languages on the other. ${ }^{1496}$

\footnotetext{
${ }^{1494}$ Gardiner, Treaty Interpretation, supra n 235, at p 187.

1495 Gardiner, Treaty Interpretation, supra $\mathrm{n} 235$, at $\mathrm{p} 188$.

1496 Yale Law School Lillian Goldman Law Library, 'Charter of the International Military Tribunal' (Nuremberg Trial Proceedings Vol I, The Avalon Project. Documents in Law, History and Diplomacy 2008) <http://avalon.law.yale.edu/imt/imtconst.asp> accessed 3 May 2012. The original Art 6(c) is quote as below: Crimes against humanity: namely, murder, extermination, enslavement, deportation, and other inhumane acts committed against any civilian population, before or during the war; or persecutions on political, racial or religious grounds in execution of or in connection with any crime within the jurisdiction of the Tribunal, whether or not in violation of the domestic law of the country where perpetrated. The London Agreement of 8 August 1945 drew up between the four Governments was executed in triplicate, English, French and Russian, each text having equal authenticity. See Art 7, London Agreement of 8 August 1945. Yale Law School Lillian Goldman Law Library, 'London Agreement of August $8^{\text {th }} 1945^{\prime}$ (Nuremberg Trial Proceedings Vol I, The Avalon Project. Documents in Law, History and Diplomacy 2008) < http://avalon.law.yale.edu/imt/imtchart.asp> accessed 3 May 2012. It was found that in the English and French text, Art 6(c) was found to be divided into two parts by a semicolon between 'war' and 'persecutions' with a semicolon between them. The semicolon is not found in the Russian text, which is equally authentic, where instead of a semicolon dividing the paragraph, a comma had been placed between the corresponding word for 'war' and the corresponding word for 'or persecutions' in Russian. The Rectifying Protocol declared that the respective parties to the London Agreement have duly authorised, and have agreed that Art 6(c) of the Charter in the Russian text is correct, and that the meaning and intention of the Agreement and charter require that the said semicolon in the English text should be changed to a comma. It is commented that the original English and French text that contained the division in Art 6(c) by a semicolon would led to a somewhat absurd results where it could be said that the provision applied only to the words after the semicolon, ie to persecutions on political, racial, or religious grounds. If the semicolon has effectively separated Art 6(c), it means that the crimes of the murder type, committed against any civilian population at any time, are crimes against humanity subject to the Tribunal's jurisdiction. See Egon Schwelb, 'Crimes Against Humanity' (1946) 23 British Yearbook of International Law 178 - 226, at pp 192 and 193. The simple grammatical interpretation of the original English text would read that the requirement of "connection with any crime within the jurisdiction of the Tribunal' and the clarification that 'violation of the domestic law of the
} 
The rectification of the punctuation in the original text of both English and French through the conclusion of the Protocol indicated the clear intention of the parties to alter the law in a significant manner, where barriers that appeared to exist between the first and the second limb of the paragraph by virtue of the semicolon are to be removed. ${ }^{1497}$ As the texts now stand after the rectification, it is beyond doubt that the requirement imposed by 'in execution of or in connection with any crime within the jurisdiction of the Tribunal' applies to the 'whole context of the paragraph and constitutes a very important restriction on the scope of the concept of crimes against humanity'. ${ }^{1498}$

However, it should be kept in perspective that punctuation and syntax proffer assistance, and form only part of the whole picture of treaty interpretation. ${ }^{1499}$

country where perpetrated' is irrelevant, only apply to 'persecutions on political, racial or religious grounds' instead of to both groups of crimes against humanity. See Gardiner, Treaty Interpretation, supra n 235, at p 187.

${ }^{1497}$ Egon Schwelb, 'Crimes Against Humanity', supra n 1496, at p 194.

${ }^{1498}$ Egon Schwelb, 'Crimes Against Humanity', supra n 1496, at p 195. At p 194, It is mentioned earlier that punctuation and syntax is an aid to interpretation, but they merely forms part of the whole of treaty interpretation. In the present case, a comma that is followed by 'or' would in normal circumstances suffice to divide the paragraph of the original English text into two parts where 'in execution of or in connection with any crime within the jurisdiction of the Tribunal' would only relate to 'persecutions and not to the crimes of the inhumane type'. It is recognised that the change of semicolon to comma itself 'would not bring about a fundamental alteration in the law if regard were not had to the circumstances attending this alteration. In consideration of the length the contracting parties went to conclude the Protocol in order to rectify the discrepancy in punctuation between the text, the intention of the parties to impose a significant implication is unambiguous. In this regard, punctuation and syntax is an important part in the context of the treaty provision.

${ }^{1499}$ This is illustrated in the case of Aegean Sea Continental Shelf where the Court found that 'grammatical arguments do not appear to the Court to be so compelling as has been suggested'. Greek's grammatical argument hinged upon the interpretation of the words 'et, notamment' (in particularly) that precede the reference to 'les différends ayant trait au statut territorial de la Grèce' (disputes relating to the territorial status of Greece). It was stated that the reference to 'disputes relating to the territorial status of Greece' was not intended to 'designate an autonomous category of disputes additional to the category of disputes concerning matters solely within domestic jurisdiction' but are mentioned merely as 'a particular example of such disputes which it was desired to emphasise'. Greek Government stressed that the use of the word notamment, in the majority of which the word is preceded by the word et, but still denoted merely a particular instance of a wider genus of category. It is submitted that on the basis of this linguistic evidence, it maintained that - 'the natural, ordinary and current meaning of this expression absolutely precluded the Greek reservation from being read as covering disputes regarding territorial status in addition to, and quite separately from, disputes regarding matters of domestic jurisdiction'. The Court opined that the grammatical interpretation advanced by Greece will lead to a result that is legally surprising. Disputes concerning matters of domestic jurisdiction, and disputes relating to territorial status are two separate concepts that have always been kept distinct, but if Greece's advancement is accepted, it will lead to an integration of these concepts that deprives the concept of disputes relating to territorial status 'of any significance'. Besides, the Court raised that the grammatical argument advanced by Greece overlooks the commas placed both before and after 'notamment', where ' $e t$ ' was intended to be a true conjunctive that introduced a category of disputes in addition to the one that has already been specified. In addition, the meaning attributed to 'et, notamment' by Greece is grammatically not the only, albeit most frequent use of the expression. Whether it has the meaning attributed to it by Greece depends on the context in which those words were used in Greece's instrument of accession and is not a matter simply of their preponderant linguistic usage. The Court emphasised that 'in any event, the Court cannot base itself on a purely grammatical interpretation of the text (Anglo-Iranian Oil Co)', especially when 'a number of 
In summary, the whole of the treaty, including its texts, preamble and annexes; and agreements or instruments concluded or accepted by all the parties in connection with the conclusion of the treaty, are considered to be forming the 'context' for the purpose of interpretation. The context, comprising all the stated, and the extent to which the parties intended for them to form an integral part of the treaty, enables the interpreter to arrive at the ordinary meaning of the terms of the treaty in accordance with Article 31(1) of the 1969 Vienna Convention.

\section{3 'Shall be Taken into Account'}

'The obligatory character of Article 31(3)(c) is the same as that of the provision which immediately precede (sic) it', ${ }^{1500}$ where if the occasion calls for its application, the provision must be applied in that particular instance. Sands supported this approach in the interpretation of Article 31(3)(c) whereby 'shall be taken into account' restricts the exercise of discretion by the interpreter where he "must "take account" of the [extraneous] norm'. ${ }^{1501}$

The obligatory character of Article 31(3)(c) was confirmed by the Commentary of the Draft Articles of the 1969 Vienna Convention. The ILC noted that although elements in Article 31(3) are extrinsic to the text, they are 'all of an obligatory character and by their very nature could not be considered to be norms of interpretation in any way inferior to those which precede them'. ${ }^{1502}$ Furthermore, the obligatory nature of 'shall be taken into account' is reiterated in the elaboration of Article 31(3)(a) [Draft Article

\footnotetext{
considerations of a substantive character point decisively to the conclusion that reservation $(b)$ in fact contained two separate and autonomous reservations'. The preceding discussion laid out that grammar and syntax are essential in understanding the essential link between the meaning of a single word and its immediate context, but it is not the whole of treaty interpretation where sole considerations are given. It forms part of treaty interpretation with other elements of interpretation in arriving at a correct interpretation. The Court in Aegean Sea indicated that purely grammatical analysis that might produce legally surprising result that is contrary to other substantial considerations of the context will not be convincing, and has to be ignored. See Aegean Sea Continental Shelf (Greece v Turkey)(Judgment on the Merits) [1978] ICJ Reports 3, at pp 21, and 22, paras 50, 52, 53, and 54 <http://www.icjcij.org/docket/files/62/6245.pdf> accessed 18 November 2012. The ICJ quoted the Anglo-Iranian Co case, at p 104. Anglo-Iranian Oil Co Case (United Kingdom v Iran) (Preliminary Objection, Judgment of 22 July 1952) [1952] ICJ Reports 93 〈http://www.icj-cij.org/docket/files/16/1997.pdf> accessed 18 November 2012.

${ }^{1500}$ Gardiner, Treaty Interpretation, supra n 235, at p 259.

${ }^{1501}$ Sands, 'Treaty, Custom and the Cross-fertilization of International Law', supra n 119, at p 102.

${ }^{1502}$ Draft Articles 1966, supra n 1435, at p 220, para 9.
} 
27(3)(a)] where the Commission emphasised that the Article 'must be read into the treaty for purpose of its interpretation'. ${ }^{1503}$

However, it is unclear that the obligatory nature stems from the principle of authentic interpretation underlying Article 31(3)(a), or from the opening words of 'shall be taken into account', as a general definition for 'take into account' is not available in international law. The ordinary meaning of the term indicates a range of possible approaches and results. According to the consistent reference by the Commission of Article 31(3) as a whole, it should be taken that a logical interpretation will reveal that the obligatory nature of 'taken into account' is extended to the Article 31(3)(c).

Sands commented that the ordinary usage of the term suggested that this formulation is "stronger than "take into consideration" but weaker than "apply". 1504 Sands demonstrates that the right approach in the application of 'take into account' is to seek a consistent interpretation of the treaty interpreted with general international law (or the applicable relevant rules of international law) in order to 'take into account'. The rule is to be applied unless it is shown that the application will undermine the object and purpose of the interpreted treaty. ${ }^{1505}$ Wälde adopts a similar approach as to the normative weight of 'shall be taken into account', where it is emphasised that the rules of international law 'shall be taken into account' means 'international law shall only be taken into account rather than to be applied'. ${ }^{1506}$

A double presumption seems to be intrinsic in the proposed approach, where the extraneous treaty is presumed to be consistent with the interpreted treaty, and the treaty is presumed to be applied, unless the party that opposes such application succeeds in shifting the onus of proof to show why the extraneous rule should not be applied. It is argued that the proposed 'correct approach' in the interpretation of 'take into account' is broadly consistent with the approach adopted by many municipal courts where in the interpretation of domestic legislation, they will assume that the legislators adopted laws that are 'intended to be consistent with international obligations'. 1507

\footnotetext{
${ }^{1503}$ Draft Articles 1966, supra n 1435, at p 221, para 14.

${ }^{1504}$ Sands, 'Treaty, Custom and the Cross-fertilization of International Law', supra $\mathrm{n}$ 119, at p 103.

1505 Sands, 'Treaty, Custom and the Cross-fertilization of International Law', supra n 119, at pp 103-104.

1506 Wälde, 'Interpreting Investment Treaties: Experiences and Examples', supra n 345, at pp 774 - 775.

1507 Sands, 'Treaty, Custom and the Cross-fertilization of International Law', supra n 119, at p 105, referred to Solomon v Commissioners of Customs and Excise [1967] 2 Queen's Bench 116 at p 141. The Court held that 'in the interests of international comity, the Customs and Excise Act of 1952 must
} 
The approach that assumes consistency between rules, or a presumption of compatibility as known in a domestic jurisdiction, provides a guiding element in the ascertainment of what is to be considered 'take into account'. Moreover, an inclination towards reading all rules as compatible or consistent with each other endorses the quest for coherency in the international legal order that 'tend to unify rather than fragment'. ${ }^{1508}$

The question of how widely relevant rules of international law shall be taken into account under Article 31(3)(c) is considered and answered in the question of the weight to be given to these rules of international law. It is emphasised that the importance of these rules 'does not reside in their overriding character', where such function is reserved to international law of jus cogens character. ${ }^{1509}$ The significance of the need to 'take into account' lies in its performance of a systemic function in the international legal order that connects specialised parts not only to each other, but also to universal principles. ${ }^{1510}$ Thus, no excessive weight should be given to rules of international law extraneous to the treaty interpreted, as it will amount to the precedence of lex generalis over lex specialis that will stifle treaty-making. ${ }^{1511}$

It is observed by the jurisprudence of the international court that the extent to which 'take into account' should be given normative weight in the interpretation of a treaty in light of extraneous rules of international law that are relevant by virtue of Article 31(3)(c) should be decided upon on a case-by-case basis. ${ }^{1512}$ The sentiment that the "strength of the need to "take into account" can only be determined on a case by case basis' was reiterated in a discussion of the possibility of attributing stronger normative weight on treaty rules of 'integral' character, where obligations erga omnes partes shall be taken into account when interpreting a 'reciprocal' treaty. ${ }^{1513}$

conform to the European Convention on the valuation of Goods for Customs Purposes'. A presumption of compatibility is recognised where the Parliament does not intend to act in breach of the United Kingdom's obligations in international law. See John Howell QC and Shaheed Fatima, 'Using International Law in Domestic Courts' (Presented by Blackstone Chambers in Association with Liberty "Focus on Public Law and Human Rights" 18 November 2005) at paras $16-20$.

1508 Sands, 'Treaty, Custom and the Cross-fertilization of International Law', supra n 119, at p 105.

${ }^{1509}$ Fragmentation Report, supra n 17, at p 201, para 473.

${ }^{1510}$ Fragmentation Report, supra n 17, at pp 239-240, para 473.

${ }^{1511}$ Fragmentation Report, supra n 17, at p 239, para 473.

1512 Fragmentation Report, supra n 17, at p 240, para 474.

${ }^{1513}$ Christina Voigt, Sustainable Development as A Principle of International Law: Resolving Conflicts between Climate Measures and WTO Law (Martinus Nijhoff Publishers, The Netherlands, 2009) at p 282. 
The need for the balancing of considerations to be taken into account was raised in the North Sea cases. ${ }^{1514}$ After stating that there is "no legal limit to the considerations that the States may take account of for the purpose of making sure that they apply equitable procedures', ${ }^{1515}$ the ICJ went further to pronounce that -

' $\ldots$ it is the balancing-up of all such considerations that will produce this result rather than reliance on one to the exclusion of all others. The problem of the relative weight to be accorded to different considerations [that was taken into account] naturally varies with the circumstances of the case'. 1516

The issue of how other external rules 'shall be taken into account' is expounded by Judges Higgins, Kooijmans and Buergenthal in the Arrest Warrant case. Their Separate Opinion stated that "immunity", or rather "immunity from jurisdiction" is inextricably linked to jurisdiction. ${ }^{1517}$ It is not a 'free-standing topic of international law' where it is desirable and necessary for the Court to state its position on the issue of jurisdiction. ${ }^{1518}$ In this instance, the external relevant rules of international law on jurisdiction, according to the Separate Opinion, are taken into account to the extent that the assessment of immunity is found upon a decision on the issue of jurisdiction. ${ }^{1519}$ The ILC Study Group on Fragmentation had succinctly restated that -

\footnotetext{
1514 North Sea Continental Shelf, supran 893, at p 50 para 93.

1515 North Sea Continental Shelf, supra n 893, at p 50, para 93.

${ }^{1516}$ North Sea Continental Shelf, supra $\mathrm{n} 893$, at p 50, para 93.

${ }^{1517}$ Separate Opinion of Judges Higgins, Kooijmans and Buergenthal in Arrest Warrant case, supra n 269, at $\mathrm{p} 63$, para 3.

${ }^{1518}$ Separate Opinion of Judges Higgins, Kooijmans and Buergenthal in Arrest Warrant, supra n 269, p 63 at para 3. At p 64, para 5, the Judges opined that ICJ will only be able to fulfil its function of resolving dispute if the two distinct norms of international law in play (though immunity can arise only if jurisdiction exists) are fully appreciated.

${ }^{1519}$ The Judges opined that only when the Court affirmed that the Belgian authorities could legitimately have invoked universal jurisdiction in the issuance and circulation of the arrest warrant for a person outside the territorial jurisdiction at the moment of the issue of the warrant would the question of whether Mr Yerodia is immune from such exercise of jurisdiction would arise. Separate Opinion of Judges Higgins, Kooijmans and Buergenthal in Arrest Warrant case, supra n 269, at p 67 at para 16. Further, the Judges, at p 87 at para 79, opined that caution need to be exercised in the analysis of whether immunities under customary international law are due to high State officials '[i]n view of the worldwide aversion to these crimes, such immunities have to be recognised with restraint, in particularly when there is reason to believe that crimes have been committed which have been universally condemned in international conventions'. On the existence of two distinct norms that appears to be in competition, a contrary conclusion was arrived at by Judge Koroma, see Separate Opinion of Judge Koroma in Arrest Warrant case, supra n 269, at p 60, paras 4 and 5. Judge Koroma, at p 79, para 52, argued that universal jurisdiction can be invoked in the context of heinous international crimes or crimes against humanity is committed. See Robert Jennings and Arthur Watts KCMG QC (eds), Oppenheim's International Law (9 ${ }^{\text {th }}$ edn, Oxford University Press, Oxford, 2008) at $\mathrm{p}$ 998. 'While there is no general rule of positive international law can as yet be asserted which gives to states the right to punish foreign nationals for crimes against humanity in the same way as they are, for instance, entitled to punish acts of piracy, there
} 
'International law seeks the accommodation of this value with the fight against impunity, and not the triumph of one norm over the other. A state may exercise the criminal jurisdiction which it has under international law, but in doing so it is subject to other legal obligations, whether they pertain to the non-exercise of power in the territory of another State or to the required respect of the law of diplomatic relations or, as in the present case, to the procedural immunities of State officials'. ${ }^{1520}$

The decisions of the ICJ elaborated above do not specifically address the normative weight that 'shall be taken into account' for 'relevant rules of international law applicable in the relationship between the parties' for the purpose of interpretation provided under Article 31(3)(c). However, it gave an insightful perspective to the problem of how much weight to be accorded in considerations (including rules of international law) that shall be taken into account, and how such relative weight to be accorded differs on a case-by-case basis.

At this juncture, it seems crucial to determine the relationship between 'rules of international law' in order to establish the normative weight to be given to rules that are to be taken into account. The Institut de Droit International concluded, while considering problems arising from a succession of codification conventions on a particular subject, that the distinct but also interrelated sources of law - treaty and custom - may influence each other as to their respective content and interpretation. ${ }^{1521}$

Although there is no a priori hierarchy between the difference sources of law, the norms deriving from a treaty will prevail between the parties over norms deriving from customary law in the application of international law in the event of conflict. ${ }^{1522}$ The ILC Study Group on Fragmentation commented that the rules that shall be 'taken into account' normally address a situation where the external rules existed at the same level of generality with the treaty to be interpreted, and 'seems to conflict with it or put forward considerations that otherwise seem unorthodox in the context'. ${ }^{1523}$ Customary

are clear indications pointing to the gradual evolution of a significant principle of international law to that effect.

${ }^{1520}$ Fragmentation Report, supra n 17, at p 240, para 474.

${ }^{1521}$ Conclusion 10, Institut de Droit International, 'Problems Arising from a Succession of Codification Conventions on a Particular Subject' (Lisbonne 1995)

<http://www.idi-iil.org/idiE/resolutionsE/1995 lis_01_en.pdf > accessed 9 April 2012.

$15 \overline{22}$ Conclusion 11, supra $\mathrm{n} 1521$.

${ }^{1523}$ Fragmentation Report, supra n 17, at p 196, para 462. 
international law and general principles of law 'exist as lex generalis in relation to any particular agreements, are fully applicable and often applied alongside particular treaties'. 1524

The above sections delve in-depth the normative content and scope of the salient phrase 'shall be taken into account, together with the context' stipulated in Article 31(3)(c) of the 1969 Vienna Convention to inform the development of an architecture for the operationalisation of the third stage of this framework. In light of the principle of systemic integration said to be reflected in Article 31(3)(c) of the 1969 Vienna Convention, it is sufficiently shown that the phrase 'shall take into account' has an obligatory nature. If all circumstances necessitating its application are triggered, i.e., rules of international law are relevant and applicable in the relations between the parties, these rules shall be taken into account. The normative weight to be given to the incorporation of these relevant rules in the interpretative process is circumscribed by the context of the treaty term or provision.

The 'context' referred to in the present research is the colour of the environment that words, like chameleons, change to. ${ }^{1525}$ The 1969 Vienna Convention defined the 'context' to comprise of any agreements made between all the parties; and an instrument made by one or more parties, and accepted by other parties that are in connection with or related to the conclusion of the treaty. In addition, the text, including its preamble and annexes, forms part of the context as well.

'A treaty text is not necessarily the same thing as a set of words and sentences' ${ }^{1526}$ A careful reading of the text requires the careful perusal and construction of the various aspects of 'the text and its preamble'. As noted, the various aspects can be categorised to include grammar and syntax; title, headings, and chapeaux; structure or scheme underlying a provision or the treaty as a whole; related and contrasting provisions; or even the punctuation and syntax. A distinction between immediate context and the context in the sense of the entire text of the treaty should also be carefully drawn. ${ }^{1527}$

Subject to the context, the external rules of international law that satisfied the requirements imposed in Article 31(3)(c) shall be taken into account in the

\footnotetext{
${ }^{1524}$ Fragmentation Report, supra n 17, at p 196, para 462.

1525 Judge Learned Hand in Commissioner of Internal Revenue, supra n 1430.

${ }^{1526}$ Ulf Linderfalk, On the Interpretation of Treaties, at p 103.

${ }^{1527}$ La Bretagne, supra n 1458.
} 
interpretation of a treaty term or provision, where the normative weight to be given to these rules will depend on the circumstances of each individual case.

\section{4 'Shall be Taken into Account, Together with the Context' - Case Analyses}

The debate between the ICJ judges in the Oil Platform case on the interpretation and the application of Article 31(3)(c) provide an insightful perspective in directing how an external rule that is relevant, but not explicit in a treaty provision, is to be taken into account in accordance with this Article. The Esphahanian case illustrates how an external rule of international law is taken into account in the interpretation of the term of 'national' explicit in the treaty provision. These two cases furnish the foundation from which the architecture for the operationalisation of the principle of systemic integration enshrined in Article 31(3)(c) is developed.

\subsubsection{The Case of Oil Platforms in the International Court of Justice}

The Court was presented an opportunity to apply Article 31(3)(c) in the interpretation of Article XX(1)(d) of the 1955 Treaty of Amity, Economic Relations and Consular Rights between Iran and the United Sates. The Court was called upon to determine whether Iran's allegedly neutral commercial shipping during the Iran/Iraq war, and the subsequent act of United States of Navy in destroying three Iranian oil platforms in the Persian Gulf, were in breach of the Treaty. ${ }^{1528}$ The Court decided that the issue at hand is a matter of interpretation of the 1955 Treaty, in particularly Article $\mathrm{XX}(1)(\mathrm{d})$ where the question is -

'[W]hether the parties to the 1955 Treaty, when providing therein that it should "not preclude the application of measures ... necessary to protect [the] essential security interests" of either party, intended that such should be the effect of the Treaty even where those measures involved a use of armed force. [I]f so, whether they contemplated, or assumed, a limitation that such use would have to comply with the conditions laid down by international law'. ${ }^{1529}$

\footnotetext{
${ }^{1528}$ Oil Platforms, supran 1468 , at p 173, at para 21.

${ }^{1529}$ Oil Platforms, supra n 1468, at pp $180-181$, para 40. Art XX(1)(d) provides that 'The present Treaty shall not preclude the application of measures: ... (d) necessary to fulfil the obligations of a High Contracting Party for the maintenance or restoration of international peace and security, or necessary to protect its essential security interests'.
} 
The Court in the present case cited the Nicaragua case where it took the view that 'action taken in self-defence, individual or collective, might be considered as part of the wider category or measures qualified in Article XXI', the text of which corresponds to the text of Article XX of the 1955 Treaty. ${ }^{1530}$ The Court in the Oil Platform case laid out that the approach adopted in the Nicaragua case is consistent with the view that -

'when Article $\mathrm{XX}(1)(\mathrm{d})$ is invoked to justify actions involving the use of armed force, allegedly in self-defence, the interpretation and application of that Article will necessarily entail an assessment of the conditions of legitimate self-defence under international law'. ${ }^{1531}$

The Court held that the jurisdiction conferred to the Court under Article XXI(2) of the 1955 Treaty ${ }^{1532}$ allows reference to international law ${ }^{1533}$ applicable to the determination of whether the action alleged to be justified under the said paragraph was, or was not, an unlawful use of force. ${ }^{1534}$ The Court enunciated that it is not consistent with Article I of the 1955 Treaty "to interpret Article $\mathrm{XX}(1)(\mathrm{d})$ to the effect that the "measures" there contemplated could include even an unlawful use of force by one party against the other'. 1535

Furthermore, Article 31(3)(c) of the 1969 Vienna Convention requires for interpretation to take into account any relevant rules of international law applicable in the relations between the parties. The application of the relevant rules of international law relating to the present question forms an integral part of the interpretation entrusted to the Court under Article XXI(2). This drove the Court to decide that Article XX(1)(d) was -

'not intended to operate wholly independently of the relevant rules of international law on the use of force, so as to be capable of being successfully

\footnotetext{
${ }^{1530}$ Oil Platforms, supra n 1468, at p 182, para 40.

${ }^{1531}$ Oil Platforms, supra n 1468, at p 182, para 40.

${ }^{1532}$ Article XXI(2) of the 1955 Treaty provided that 'Any dispute between the High Contracting Parties as to the interpretation or application of the present Treaty, not satisfactorily adjusted by diplomacy, shall be submitted to the International court of Justice, unless the High Contacting Parties agree to settlement by some other pacific means'. This provision permits the Court to decide any question of interpretation or application of Article XX(1)(d).

${ }^{1533}$ including the Charter of the United Nations and customary international law

${ }^{1534}$ Oil Platforms, supra n 1468, at pp 182 - 183, para 42.

1535 Oil Platforms, supra n 1468, at p 182, para 41.
} 
invoked, even in the limited context of a claim for breach of the Treaty, in relation to an unlawful use of force'. 1536

Thus, in light of the foregoing, the Court was tasked to examine first the application of Article $\mathrm{XX}(1)(\mathrm{d})$, which involves the principle of the prohibition in international law of the use of force, and the qualification to it constituted by the right of self-defence. Under the provision, measures taken by party to the Treaty 'necessary' for the protection of its essential security interest may be justified. However, 'necessary is not purely a question for the subjective judgment of the party'. The question called to be answered is whether the measures taken were 'necessary' overlaps with the question of their validity as acts of self-defence, where criteria of necessity and proportionality must be observed. ${ }^{1537}$ In this regard, the details of the attacks by the United States against the Iranian platforms may be pertinent to the assessment of the lawfulness of those actions, and whether the attacks on two successive occasions each meet the conditions of Article $\mathrm{XX}(1)(\mathrm{d})$ as interpreted by reference to the relevant rules of international law. ${ }^{1538}$

The preceding paragraph indicated that the direction of the Court to itself in the consideration of the normative weight to be given to 'shall be taken into account, together with the context' is - the interpretation of the conditions imposed by Article $\mathrm{XX}(1)(\mathrm{d})$ must be made by reference to the relevant rules of international law in. However, it is unclear how such reference is made, and how it dictates the interpretation of the conditions of Article $\mathrm{XX}(1)(\mathrm{d})$.

Article $\mathrm{XX}(1)(\mathrm{d})$ provides that ' $[\mathrm{t}]$ he present Treaty shall not preclude the application of measures ... necessary to fulfil the obligations of a High Contracting Party for the maintenance or restoration of international peace and security, or necessary to protect its essential security interests'. The Court stated in finer detail that the present case involved a question of whether the action is 'necessary' that arises both as an element of international law relating to self-defence, and also on the basis of the actual terms of Article $\mathrm{XX}(1)(\mathrm{d}){ }^{1539}$

The United States submitted that the interpretation of Article $\mathrm{XX}(1)(\mathrm{d})$ should consider that the attacks on the oil platforms were considered in good faith to be necessary in

\footnotetext{
${ }^{1536}$ Oil Platforms, supra n 1468, at p 182, para 41.

1537 Oil Platforms, supra n 1468, at p 183, para 43.

1538 Oil Platforms, supra n 1468, at p 184, para 45.

${ }^{1539}$ Oil Platforms, supra n 1468, at p 196, para 73.
} 
order to protect its essential security interest. They suggested that 'a measure of discretion should be afforded to a party's good faith application of measure to protect its essential security interests' under this Article. ${ }^{1540}$ In the present case, international law is required to be referred in the interpretation Article $\mathrm{XX}(1)(\mathrm{d})$. The Court held that it is unnecessary to decide whether the interpretation submitted by United States on Article $\mathrm{XX}(1)(\mathrm{d})$ on this point is correct 'since the requirement of international law that measures taken avowedly in self-defence must have been necessary for that purpose is strict and objective, leaving no room for any "measure of discretion". 1541

Regarding the determination of the legality of the alleged attacks on the Iranian oil platforms, the Court reverted directly to the criteria of necessity and proportionality in the context of international law on self-defence, in the determination of whether the alleged actions are 'necessary' without determining the interpretation of Article $\mathrm{XX}(1)(\mathrm{d})$. It concluded that the actions carried out by United States forces against Iranian oil installations on two occasions cannot be justified under Article $\mathrm{XX}(1)(\mathrm{d})$. Most importantly, the rationale for the decision was that these actions 'constituted recourse to armed force not qualifying, under international law on the question, as acts of self-defence, and thus did not fall within the category of measures contemplated, upon its correct interpretation, by that provision (Article XX(1)(d)) of the Treaty' ${ }^{1542}$

It can be observed that from the Oil Platforms case, the majority of the Court seems to favour the approach that substitutes requirements of Article $\mathrm{XX}(1)(\mathrm{d})$ with the test of necessity and proportionality in the context of self-defence under international law. When the Court identified that the international law on self-defence has been identified as relevant rule of international law, and that Article I of the Treaty allowed for the reference to this, the relevant international law of self-defence is 'applied' as 'applicable' law in this case. Interestingly, the final reasons for the decision stated at the end of the majority judgment was -

'The Court finds that the actions of the United States of America against Iranian oil platforms on 19 October 1987 and 18 April 1988 cannot be justified as measures necessary to protect the essential security interests of the United States of America under Article $\mathrm{XX}(1)(\mathrm{d})$ of the 1955 Treaty of Amity, Economic

\footnotetext{
${ }^{1540}$ Oil Platforms, supra n 1468, at p 196, para 73.

1541 Oil Platforms, supra n 1468, at p 196, para 73.

1542 Oil Platforms, supra n 1468, at p 199, para 78.
} 
Relations and Consular Rights between the United States of America and Iran, as interpreted in the light of international law on the use of force'. ${ }^{1543}$

The majority of the Court concluded, in reliance of Article 31(3)(c), that violation of Article $\mathrm{XX}(1)(\mathrm{d})$ of the Treaty will be determined according to international law on the use of force. The Court held that actions of the United States would be inconsistent with Article $\mathrm{XX}(1)(\mathrm{d})$ if they are found to be contrary to international law on the use of force. It can be deduced from the present case that the normative weight given to the relevant rules of international law, which is the rule on self-defence, seems to have the effect of substituting or replacing the provision to be interpreted.

The majority decision in this respect was heavily criticised by Judge Buergenthal in his separate opinion because the majority had placed erroneous reliance on international law on the use of force in the present dispute. Judge Buergenthal expressed that 'even if one were to accept the Court's view that it had jurisdiction to make a specific ruling on Article $\mathrm{XX}(1)(\mathrm{d})$, it would still have to be emphasised that its interpretation of that provision in the light of international law on the use of force exceeded its jurisdiction'. ${ }^{1544}$ In furtherance of this assertion, Judge Buergenthal elaborated that although the rule as stated under Article 31(3)(c) is undisputed, 'it cannot have the effect of allowing the Court to take account of the relevant rules of international law applicable between the parties that the parties had not submitted to the court's jurisdiction'. 1545

External rules of international law, such as the principles of customary international law and "whatever other treaties the parties to a dispute before the Court may have concluded' do not become subjected to the Court's jurisdiction by virtue of Article 31(3)(c) of the 1969 Vienna Convention. Even though it might found to be relevant 'in the abstract' to the interpretation of a treaty that the Court has jurisdiction, as such it would conflict with the consensual basis of the Court's jurisdiction that adversely affect states' willingness to accept the Court's jurisdiction for adjudication of disputes. ${ }^{1546}$ Judge Buergenthal further elaborated that unless parties in the dispute had accepted the

\footnotetext{
1543 Oil Platforms, supra n 1468, at p 218, para 125(1).

1544 Oil Platforms, supra n 1468, Separate Opinion of Judge Buergenthal, p 278, para 20.

${ }^{1545}$ Separate Opinion of Judge Buergenthal, supra n 1544, at pp 278 - 279, para 22.

${ }^{1546}$ Separate Opinion of Judge Buergenthal, supra n 1544, at p 279, para 22.
} 
Court's jurisdiction to rely on such relevant rules of international law, the Court will still lack the power to 'rely on such rules'. ${ }^{1547}$

Whether a use of force can be justified by a treaty provision, the operative provisions should be the treaty provision submitted for the adjudication by the Court, and of which the mandate and jurisdiction of the Court is seised. The alleged use of force cannot be judged against an external relevant rule of international law, even if it is the United Nations Charter, unless agreed by the parties, and conferred jurisdiction on the Court to interpret and apply the Charter in a dispute between them. ${ }^{1548}$

Judge Buergenthal commented that The Court erred in asserting that Article $\mathrm{XX}(1)(\mathrm{d})$ may be interpreted in light of international law on the use of force or any other international law rules with regard to which the United States has not accepted the Court's jurisdiction. ${ }^{1549}$ It is further stated that it is irrelevant if the external provision from the UN Charter in question might also be deemed to be a jus cogens rule. ${ }^{1550}$ The critical question posed under Article $\mathrm{XX}(1)(\mathrm{d})$ of whether the actions are necessary to protect a State's 'essential security interests' may not be answered by the Court 'in light of international law on the use of force', to which the jurisdiction of the Court has not been extended. ${ }^{1551}$

Judge Higgins shared similar sentiments where it is commented that the court has gone beyond what has been decided in the case of Nicaragua in 1986. The Court, Judge Higgins insisted, has no jurisdiction to determine in respect of Article $\mathrm{XX}(1)(\mathrm{d})$ whether a measure is 'an unlawful use of force'. ${ }^{1552}$ She enunciated that -

'the Judgment slides from that verity [that action taken in self-defence, individual or collective, might be considered as part of the wider category of measures qualified in Article $\mathrm{XXI}^{1553}$ that corresponds to Article XX of the 1955 Treaty in

\footnotetext{
${ }^{1547}$ Separate Opinion of Judge Buergenthal, supra n 1544, at p 279, para 23.

1548 Separate Opinion of Judge Buergenthal, supra n 1544, at p 279, para 23.

1549 Separate Opinion of Judge Buergenthal, supra n 1544, at p 280, para 24.

1550 Separate Opinion of Judge Buergenthal, supra n 1544, at p 279, para 23.

1551 Separate Opinion of Judge Buergenthal, supra n 1544, at p 280, para 25.

1552 Oil Platforms, supra n 1468, Separate Opinion of Judge Higgins, at p 237, para 44.

${ }^{1553}$ See Case Concerning Military and Paramilitary Activities In and Against Nicaragua (Nicaragua $v$ United States of America) (Judgment on the Merits 27 June 1986) [1986] ICJ Reports 14, at p 117, para 224 <http://www.icj-cij.org/docket/files/70/6503.pdf> accessed 18 November 2012. The ICJ, in that case, decided that 'action taken in self-defence, individual or collective, might be considered as part of the wider category of measures qualified in Article XXI as "necessary to protect" the "essential security interests" of a party.'
} 
the present case] to the proposition that the Court has in 1986 found that the only permitted military action that might justify what otherwise might be a breach of an obligation of the Treaty is an exercise of self-defence in response to an armed attack'. ${ }^{1554}$

Although Article 31(3)(c) of the 1969 Vienna Convention reflects the common position that treaties are to be interpreted by reference to relevant rules, it does not imply that such reference incorporates the totality of the substantive international law on the use of force beyond the topic provided in the clause, especially without sufficient explanation. ${ }^{1555}$ The Court should have paid more attention to the qualifier of 'context' in Article 31(3)(c) requiring that interpretation of Article $\mathrm{XX}(1)(\mathrm{d})$ will be illuminated by recalling the type of a treaty Article $\mathrm{XX}(1)(\mathrm{d})$ and in light of any other 'relevant rules' governing Iran-United States relations. ${ }^{1556}$ It is not meant for the incorporation of the entire substance of international law on a subject matter not mentioned in the provision.

The Majority of the Court reformulated the present matter as one of self-defence. The justification of defence sought by the parties - whether it is "necessary action for the protection of essential security interests' within the terms of Article $\mathrm{XX}(1)(\mathrm{d})$ of the 1955 Treaty, was displaced by an examination of the legality of self-defence under general international law. Judge Buergenthal and Judge Higgins both shared similar views that the majority has exceeded their jurisdiction in the application of a rule of interpretation under the 1969 Vienna Convention by incorporating the UN Charter into an 'interpretation' of a provision that does not otherwise provide for the subject matter.

The Separate Opinions of both judges are illuminating in one important aspect - the limits of interpretation. An interpretation of a treaty provision, and its treaty terms, does not extend to displace the applicable law, or in any way modify or reformulate the jurisdiction of the court as mandated by the parties. This point is reiterated by the Dissenting Opinion of Judge Khasawneh. Judge Khasawneh stated that 'devoting a large part of the Judgment to a discussion of the concept of non-use of force is inappropriate and unnecessary for disposing of the case besides the risk this runs of going beyond the limits of the Court's jurisdiction'. ${ }^{1557}$

\footnotetext{
${ }^{1554}$ Separate Opinion of Judge Higgins, supra n 1552, at p 236, para 42.

1555 Separate Opinion of Judge Higgins, supra n 1552, at p 237, para 46.

1556 Separate Opinion of Judge Higgins, supra n 1552, at p 237, para 46.

${ }^{1557}$ Oil Platform, supra n 1468, Dissenting Opinion of Judge Al-Khasawneh, at pp 268 - 269, para 8.
} 
Despite the differing opinions as to the normative weight of the relevant rules of international law that shall be taken into account in the interpretation, the Oil Platform case confirmed the relevance and importance of the interpretation of a treaty in its systemic environment and in reference to the general international law. Judge Koroma emphasised that Article $\mathrm{XX}(1)(\mathrm{d})$ 'is not intended to operate wholly independently of general international law on the use of force so as to be capable of justifying, even in the limited context of a claim for breach of the Treaty, the unlawful use of force'. ${ }^{1558}$

The Oil Platform case provides a useful insight into the operationalisation of Article 31(3)(c) of the 1969 Vienna Convention, especially concerning the normative weight to be given to 'shall take into account, together with the context'. First, Judge Koroma had unequivocally pronounced that 'Article $\mathrm{XX}(1)(\mathrm{d})$ was not intended to operate wholly independently of general international law on the use of force, so as to be capable of justifying, even in the limited context of a claim for breach of the Treaty, the unlawful use of force'. ${ }^{1559}$ The normative weight of 'shall be taken into account' entails that general international law relevant on the question is applicable on the question and forms part of the interpretation process which is entrusted to the Court to carry out. ${ }^{1560}$

However, the separate opinions of Judge Buergenthal, Judge Higgins, Judge AlKhasawneh, Judge Owada and Judge Kooijmans did not differ on the point that relevant rules of international law shall be taken into account in the interpretative process. Their separate opinions pointed out two aspects that diverge from the approach adopted by the majority - the methodology of the incorporation and the normative weight of the relevant rules. There is no question raised as to the relevance of the UN Charter on the use of force, and the general international law on self-defence.

The Separate Opinions suggested, in their respective eloquent ways, that the majority should have approached the disputed issues in accordance with the jurisdiction

\footnotetext{
${ }^{1558}$ Oil Platform, supra n 1468, Declaration of Judge Koroma, at p 223. Judge Koroma supported the approach of the Majority of the Court that a determination of whether an act sought to be justified under Article $\mathrm{XX}(1)(\mathrm{d})$ has to be assessed against the criteria of the United Nations Charter and general international law.

1559 Declaration of Judge Koroma, supra n 1558, at p 223.

${ }^{1560}$ Declaration of Judge Koroma, supra n 1558, at $\mathrm{p}$ 223. The criteria provided under the United Nations Charter and general international law on use of force and self defence enabled the Court to reach the conclusion that actions carried out against the oil installations by the United Sates were not lawful under Article $\mathrm{XX}(1)(\mathrm{d})$ of the 1955 Treaty as measures necessary to protect the essential security interests of the United States. The actions constituted recourse to armed force does not qualify, under the United Nations Charter and general international law, as acts of self-defence and thus, did not fall within the category of measures contemplated by $\operatorname{Art} \mathrm{XX}(1)(\mathrm{d})$ of the 1955 Treaty.
} 
submitted by the Court, which is the determination of Article X(1) of the Treaty. The determination of whether actions taken by United States are justified under Article $\mathrm{XX}(1)(\mathrm{d})$ will be undertaken, as a matter of 'economy of judgment', if Article $\mathrm{X}(1)$ is found to be breached. ${ }^{1561}$

The Court could then proceed to an examination of the provision of Article $X X(1)(d)$, in the context of its relevance to Article $\mathrm{X}(1)$ to see if this provision, interpreted in light of the relevant rules of international law, offered a possible defence for justifying the actions of the United States under the Treaty. ${ }^{1562}$ However, if the Court finds it necessary based on jurisdictional reasons to get into an examination of the scope and the relevance of the rules of general international law relating to the use of force, ${ }^{1563}$ it should not form part of the dispositif, which is a decision on the Applicant's claim. ${ }^{1564}$

Considering that the "principles of the law of the United Nations as well as customary international law (that are of the nature of jus cogens) on the use of force in a context and at a time when such a reconfirmation is called for with the greatest urgency', the Court was able, within jurisdictional bounds, to 'restate the backbone of the Charter law on use of force by way of strong, unequivocal obiter dicta'. ${ }^{1565}$ In view of the jurisdictional limitation posed in the present case, the relevant rules incorporated in the interpretation of Article $\mathrm{XX}(1)(\mathrm{d})$ shall be taken into account only through the prism of the interpretation of Article $\mathrm{XX}(1)(\mathrm{d})$ in the context of the Treaty.

In this case, the 'context' is clearly that of an economic and commercial treaty. ${ }^{1566}$ The normative weight to be given to the relevant rules permissible under Article 31(3)(c) is, the rules ${ }^{1567}$ shall provide the criteria in which the provision and its terms of the dispute treaty (Article $\mathrm{XX}(1)(\mathrm{d}))$ are to be assessed against, or to be incorporated in the interpretation. However, the incorporation into the provision shall not envisage an importation of the entire substance of international law on a topic not mentioned in the clause that has the effect of displacing the actual applicable law (Article XX(1)(d)). ${ }^{1568}$

\footnotetext{
1561 Oil Platform, supra n 1468, Separate Opinion of Judge Kooijmans, at p 256, para 32.

1562 Oil Platform, supra n 1468, Separate Opinion of Judge Owada, p 311, para 16.

${ }^{1563}$ Separate Opinion of Judge Owada, supra n 1562, at p 310, para 14.

${ }_{1564}$ Separate Opinion of Judge Kooijmans, supra n 1561, at p 256, para 32.

1565 Oil Platform, supra n 1468, Separate Opinion of Judge Simma, at p 327, para 6.

1566 Separate Opinion of Judge Higgins, supra n 1552, at p 237, para 46.

${ }^{1567}$ United Nations Charter on use of force and the principle of self-defence

${ }^{1568}$ Separate Opinion of Judge Higgins, supra n 1552, at p 237, para 46.
} 
The normative weight to be given to the relevant rules depends on the significance, importance and urgency of the matter, the circumstances of which are apparent in the present case of the Oil Platforms. The Court could go to the extent of stating that the attacks are not found necessary to protect the essential security interests of the United States within the meaning of Article $\mathrm{XX}(1)(\mathrm{d})$ of the Treaty, as they cannot be justified as self defence, and in breach of Article 2(4) of the UN Charter. All the Court could not do is to state that in the dispositif of the Judgment.

The Oil Platform case outlined a coherent architecture for the operationalisation of the last limb of Article 31(3)(c), after the identification of the treaty term and provision of the treaty that has to be interpreted, and the relevant rules of international law that should be referred. These relevant rules shall be incorporated in the interpretation of pivotal terms in the provision, such as 'necessary' to protect essential security interests of the states provided under Article $\mathrm{XX}(1)(\mathrm{d})$. The act of attacks will be judged against the criteria provided by the relevant rules that informs the interpretation of Article $\mathrm{XX}(1)(\mathrm{d})$. However, a determination of whether these attacks are justified will be arrived at only through an adjudication of whether the provision of Article $X X(1)(d)$ has been satisfied, in the context of the economic and commercial nature of the 1955 Treaty.

It is clear that an economic and commercial treaty cannot be said to be capable of contracting out from general international law on the use of force so as to be capable of justifying the unlawful use of force in the limited context of a breach of the Treaty. In a situation where the jurisdiction of the Court is restricted, Article 31(3)(c) cannot be used in such a way to have the effect of bypassing the restrictive jurisdiction conferred by displacing the applicable law through the backdoor of interpretation.

\subsubsection{The Case of Esphahanian's Claims in the Iran-US Claims Tribunal}

A proceeding in the Iran-Us Claims Tribunal was initiated by Esphahanian for the recovery of the face value of the check exchanged from the Rial certificates of deposit held by him at Iranians' Bank, plus interest, and costs of arbitration. Article II(1) of the Claims Settlement Declaration provides that 'an International Arbitral Tribunal (the Iran-US Claims Tribunal) is hereby established for the purpose of deciding claims of 
nationals of the United States against Iran and claims of nationals of Iran against the United States ...' 1569

The Tribunal was tasked to determine whether Esphahanian's claim is within its jurisdiction as a claim of a national of the United States within the meaning of the article. ${ }^{1570}$ A national is defined in Article VII(1) of the Claims Settlement Declaration to mean a natural person who is a citizen of Iran or the United States. ${ }^{1571}$ The question that has arisen was whether it is within the Tribunal's jurisdiction to adjudicate the claim initiated by Nasser Esphahanian, a national of both Iran and the United States under the respective domestic laws of each country.

Prior to the determination of Esphahanian's claim, it is incumbent for the Tribunal to determine whether Esphahanian is a 'national' within the meaning of Article II(1), and whether the claim is a claim by national of the United States against Iran; or a claim of a national of Iran against the United States. The pertinent issues to be resolved are the nationality of Esphahanian, and whether a person with dual nationality is entitled to initiate a claim in the Iran-US Tribunal. Due to the absence of any specific provision in the Claims Settlement Declaration on whether dual nationals are permitted to make claims before the Tribunal against either Government, ${ }^{1572}$ the Tribunal decided to refer to international law of dominant and effective nationality, identified through a variety of sources of international law, including convention, jurisprudence of international courts and tribunals (precedents) and writings of eminent publicist (legal literature) ${ }^{1573}$ as enabled by Article 31(3)(c) of the 1969 Vienna Convention.

In the present case, the external rules of international law application in the relations between the parties to be taken into account for the interpretation of Article II(1) in accordance of Article 31(3)(c) are rules relevant to the determination of the national of Esphahanian. The rules are relevant because these rules are capable of clarifying whether Esphahanian is a 'national', and with which nationality the claim is based on. These rules are relevant for the determination of whether Esphahanian's claim is within the jurisdiction of the Iran-US Tribunal, where the Tribunal had recourse to a variety of

\footnotetext{
${ }^{1569}$ Iran-US Claims Tribunal, Nasser Esphahanian, Claimant v. Bank Tejarat, Respondent (Case No. 157) Chamber Two, 29 March 1983 [2] AWARD NO. 31-157-2 2 Iran-US Claims Tribunal Reports 157.

${ }^{1570}$ Esphahanian v Bank Tejarat, supra n 1569, at p 160.

${ }^{1571}$ Esphahanian v Bank Tejarat, supra n 1569, at p 160.

1572 Esphahanian v Bank Tejarat, supra n 1569, at p 161.

${ }^{1573}$ Esphahanian v Bank Tejarat, supra n 1569, at pp $161-164$.
} 
sources of international law, including convention, the jurisprudence of international courts and tribunals (precedents) and writings of eminent publicists (legal literature). ${ }^{1574}$ In the present case, the external rules identified were relevant in filling the lacunae in light of the absence of the Algiers Claims Settlement Declaration on whether dual nationals are permitted to initiate claims in the Tribunal against either Government where the Claimant possesses both nationalities.

First, the Tribunal referred to Articles $4^{1575}$ and $5^{1576}$ of 1930 The Hague Convention Concerning Certain Questions Relating to the Conflict of Nationality Laws. ${ }^{1577}$ The Tribunal noted that Article 4 of the Hague Convention that prevents provision of diplomatic protection of a nation against another nation if such person also possesses the nationality of the other state, does not extend to claims-related cases brought by a person with dual nationalities, as supported by its negotiation history. ${ }^{1578}$ However, the concept of diplomatic protection has been expanded in which the process of transformation still continues. Thus, Article 4 has to be interpreted cautiously and in an evolutionary manner due to the great changes that have occurred. ${ }^{1579}$

The Tribunal is of the opinion that the present situation is akin to the circumstances posed in Article 5. ${ }^{1580}$ By construing Articles 4 and 5 together, the Tribunal found that it is led to adoption of the notion of effective or dominant nationality in the interpretation of the Claims Settlement Declaration. ${ }^{1581}$ For this purpose, Articles 4 and 5 are considered rules of international law applicable in the relations between the parties that are relevant for the interpretation of the said Declaration.

\footnotetext{
${ }^{1574}$ Esphahanian v Bank Tejarat, supra n 1569, at pp $161-164$.

${ }^{1575}$ Art 4 of The Hague Convention provides that 'A state may not afford diplomatic protection to one of its nationals against a State whose nationality such person also possesses'.

${ }^{1576}$ Art 5 of The Hague Convention provides that 'Within a third State, a person having more than one nationality shall be treated as if he had only one. Without prejudice to the application of its law in matters of personal status and of any conventions in force, a third State shall, of the nationalities which any such person possesses, recognise exclusively in its territory either the nationality of the country in which he is habitually and principally resident, or the nationality of the country with which in the circumstances he appears to be in fact most closely connected'.

${ }^{1577}$ League of Nations, Convention on Certain Questions Relating to the Conflict of Nationality Law (13 April 1930) League of Nations, Treaty Series, vol 179, p 89, No 4137 <http://www.unhcr.org/refworld/docid/3ae6b3b00.html> accessed 18 November 2012.

${ }^{1578}$ Esphahanian v Bank Tejarat, supra n 1569, at p 161. A proposal to extend Article 4 to a case where dual national, by himself, brings before an international tribunal his own claim against one of the Sates whose nationality he possesses was rejected. This means, a distinction has been drawn between diplomatic or consular protection and claims-related litigation brought by himself before the international tribunal.

${ }^{1579}$ Esphahanian v Bank Tejarat, supra n 1569, at p 161

${ }^{1580}$ Esphahanian v Bank Tejarat, supra n 1569, at p 162.

${ }^{1581}$ Esphahanian v Bank Tejarat, supra n 1569, at p 162.
} 
The adoption of the notion of effective or dominant nationality is supported by the jurisprudence of international courts and tribunals, where the Tribunal found that the applicability of the principle of non-responsibility (Article 4) is increasingly limited by the principle of effective nationality as expressed by Article 5 of the Hague Convention. ${ }^{1582}$ The Tribunal noted that eminent scholars, in recent legal literatures, drew the conclusion that the effective or dominant nationality principle has to be read in conjunction with the non-responsibility doctrine as laid out in Article 4 of the Hague Convention. ${ }^{1583}$ It commented that -

'The non-responsibility doctrine has its most common application today not in cases of espousal of claims, but in instances of diplomatic or consular protection of dual nationals physically present in a State which considers them as its own nationals. It is in the latter cases that formal protection will be denied, despite the closeness of other factual connections with the would-be protector State'. ${ }^{1584}$

After the Tribunal established that the principle of dominant and effective nationality is supported by the general structure of the Algiers Declarations and the circumstances in which they were concluded, ${ }^{1585}$ the Tribunal concluded that it has jurisdiction -

(a) over claims against Iran by dual Iran-United States nationals when the dominant and effective nationality of the claimant is that of the United States; and

\footnotetext{
${ }^{1582}$ On the issue that the principle of dominant or effective nationality that tempers the principle of nonresponsibility, the Tribunal had referred to -

(a) The arbitration cases of Miliani Case (Italy and Venezuela) 10 RIAA 58 (France and Venezuela) at p 159; Stevenson Case (Great Britain and Venezuela) 9 RIAA at p 385. Esphahanian v Bank Tejarat, at $\mathrm{p} 162$

(b) PCA, Canevaro Case (Italy and Peru) (1912) Hague Court Reports 284;

(c) The awards of different Mixed Arbitral Tribunals in Hein Case (Great Britain and Germany) (1922) 2 Trib. Arb. Mixtes 71; Barthez de Montfort Case (France and Germany) (1926) 6 Trib. Arb. Mixtes 806; Born Case (Serbo-Croato-Slovene Commission) (1926) 6 Trib. Arb. Mixtes 499;

(d) Nottebohm Case Second Phase (Liechtenstein v Guatemala) (Judgment of 6 April 1955) [1955) ICJ Reports 4;

(e) Italian-United States Conciliation Commission, Mergé Case (United States v Italy) (1955) 14 RIAA 236, 247.

${ }^{1583}$ Esphahanian v Bank Tejarat, supra n 1569, at p 164.

${ }^{1584}$ Esphahanian v Bank Tejarat, supra n 1569, at p 164.

${ }^{1585}$ Esphahanian v Bank Tejarat, supra $\mathrm{n} 1569$, at p 165.
} 
(b) over claims against the United States by dual Iran-United States nationals when the dominant and effective nationality of the Claimant is that of Iran. $^{1586}$

In the present case, the principle of dominant and effective nationality, deemed relevant for the interpretation of Article II(1), laid out the jurisdiction of the Tribunal to decide claims of nationals of the United States against Iran and claims of nationals of Iran against the United States. Most importantly, it is crucial in the interpretation of the nationality of the dual-nationality claimant, which is determinative in the establishment of jurisdiction of the Tribunal (author's own emphasis).

Based on the juridical facts as presented in the case, the Tribunal came to the conclusion that 'Esphahanian's dominant and effective nationality at all relevant times had been that of the United States ${ }^{1587}$ and held that Esphahanian was a national of the United States within the meaning of Article II(1) of the Claims Settlement Declaration. ${ }^{1588}$ Article 31(3)(c) of the 1969 Vienna Convention enables the reference to external rules of international law applicable in the relations between the parties, which is the principle of dominant and effective nationality in the interpretation and clarification of Article II(1) where the content and meaning of whose nationality the claimant belongs to, is in question.

Due to the absence in the Algiers Declarations of provisions for dual nationals, the prevailing international law of dominant and effective nationality in the interpretation of 'nationality' in Article II(1) of the Claims Settlement Declaration was taken into account in its totality in the interpretation of the term 'nationals'. The application of this principle determines which nationality the claimant belongs to in order to establish the jurisdiction of the Tribunal under Article II(1).

The high normative weight given to the relevant rules of international law taken into account was due to the enabling environment provided by the context of the Algiers Declarations. ${ }^{1589}$ The Tribunal elaborated that the general structure of the Algiers Declarations and the circumstances in which the Declarations were concluded are supportive of the application of the principle of dominant and effective nationality.

\footnotetext{
${ }^{1586}$ Esphahanian v Bank Tejarat, supra n 1569, at p 166.

${ }^{1587}$ Esphahanian v Bank Tejarat, supra n 1569, at p 168.

${ }^{1588}$ Esphahanian v Bank Tejarat, supra n 1569, at p 168.

${ }^{1589}$ Esphahanian v Bank Tejarat, supra n 1569, at p 165.
} 
Three important conclusions were drawn in support of its contention that the Tribunal has jurisdiction over dual-state nationals if the dominant and effective nationality of claimant is that of either Iran, or the United States. ${ }^{1590}$

However, it is pertinent to note that, similar to the approach taken by the ICJ in the cases analysed above, the Tribunal takes into account the external relevant rule of international law in the interpretation of a treaty text or the provision without having the external rule replacing the applicable law in question. Jurisdiction of the Tribunal for the adjudication of Esphahanian's claim was not derived from the principle of dominant and effective nationality. Its jurisdiction still originates from Article II(1) where the applicable law that determines the jurisdiction of the Tribunal is still Article II(1) of the Claims Settlement Declaration.

\subsection{Systemic Integration: An Architecture}

The Oil Platform case and the Esphahanian case outline a coherent architecture for the operationalisation of the last limb of Article 31(3)(c). In the incorporation of external rules in the interpretation of a treaty term or provision, the treaty term and provision of the treaty that have to be interpreted must be identified. The rules of international law identified need to be relevant for the interpretation of these terms or provisions, and are applicable in the relations between the parties before the external rules can be incorporated and applied in the interpretative process.

This approach has been classified as an 'evolutionary interpretation supported by memory ${ }^{1591}$ to the extent that it is 'based on the will of the parties, often expressed in the very terms of the treaty, and reflects the common desire of the parties, taking into account the circumstances that have since evolved'. ${ }^{1592}$ The terms of the treaty will be the context in which the treaty has to be read, in the midst of the wider general international law where circumstances that have since evolved, expressed in the development of the rules of international law relevant to the subject matter, shall be taken into account.

\footnotetext{
${ }^{1590}$ Esphahanian v Bank Tejarat, supra n 1569, at pp $165-166$.

${ }^{1591}$ Dupuy, 'Evolutionary Interpretation of Treaties: between Memory and Prophecy', supra n 782, at pp $126-131$.

1592 Dupuy, 'Evolutionary Interpretation of Treaties: between Memory and Prophecy', supra n 782, at $\mathrm{p}$ 126.
} 
This link between an evolutionary interpretation, and the supporting memory, as shown in the Namibia case, is the clarification of the will of the parties in the process of interpretation, where a dynamic and evolutionary interpretation are taken into account together with the context, in which the intention of the parties is crystallised. An evolutionary interpretation of the concept of 'sacred trust' was undertaken because the Court, in interpreting the Covenant in reference to the context, came to the conclusion that the Parties must have accepted that the concept of 'sacred trust' was not 'static, but were by definition evolutionary'. ${ }^{1593}$ The Court took it upon itself that a faithful discharge of its function imposed that it could not ignore the enrichment of the corpus iuris gentium by subsequent developments of law to interpret and apply Article 22 within the framework of the entire legal system prevailing at the time of the interpretation. $^{1594}$

This was the approach adopted by the ICJ in the case of Gabčíkovo-Nagymaros where the evolving obligation on the parties to maintain the quality of the water of the Danube and the protection of nature must take into consideration the current standard of environmental protection. ${ }^{1595} \mathrm{~A}$ link is created between the evolving standards and the formulation of the terms of the treaty of the treaty and its provision where the underlying scheme and structure of Articles 15, 19 and 20 accommodate changes that enable a dynamic and evolutionary interpretation to be adopted. The intention of the parties to allow for an evolutionary interpretation can be deduced from the adoption of a generic terms in a treaty 'of continuing duration', with the parties 'necessarily having been aware that the meaning of the terms was likely to evolve over time'. 1596

Such an evolutionary interpretation, supported by memory, was intended to mean the clarification of the will of the parties, and not the substitution of the will of the parties with the interpreter's own will. ${ }^{1597}$ The normative weight for the subsequent development of law that 'shall be taken into account, together with the context' can be said to be reflected in Dupuy's evolutionary interpretation supported by memory -

\footnotetext{
${ }^{1593}$ Namibia case, supra n 277, at p 31, para 53.

${ }^{1594}$ Namibia, supra n 277, at p p31 - 32, para 53.

1595 Gabčíkovo-Nagymaros, supra n 1, at p 78, para 140.

1596 Navigational and Related Rights, supra n 210, at p 243, para 66.

${ }^{1597}$ Dupuy, 'Evolutionary Interpretation of Treaties: between Memory and Prophecy', supra n 782, at $\mathrm{p}$ 130 .
} 
'A dynamic interpretation of a treaty where justified by notions and concepts in the terms of the treaty from which it may be inferred that the text is open to considerations of factual or legal evolution after the conclusion of the treaty'. ${ }^{1598}$

Subsequent development in law, through rules of international law relevant to the subject matter and applicable in the relations between the parties, shall be taken into account to the extent that it is permissible by the context of the treaty being interpreted.

An operationalisation of 'shall be taken into account, together with the context' entails that the identified relevant rules of international law are to be incorporated (to the extent possible, depending on the context, on a case-by-case basis ${ }^{1599}$ ) in the interpretation of a treaty term of provision. The extent of incorporation excludes a total replacement of the treaty provision to be interpreted to the extent that there is no legal reference at all to the text of the provision, or all the sight of the text of the interpreted treaty provision is lost. ${ }^{1600}$

The systemic integration of an external rule of international law, identified as 'relevant' to the treaty term or provision to be interpreted, and 'applicable in the relations between the parties', is obligatorily incorporated in its interpretation, albeit qualified by the context of the treaty term or provision. The immediate context of Article 31(3)(c) requires that the external rule assumes an interpretative role, where the fine line between interpretation and applicable law is drawn.

An external rule of international law taken into account in the interpretation of a treaty term or provision in accordance with Article 31(3)(c) furnishes the normative content for the treaty term or provision. However, the external rule is not applied instead of it. This fine distinction determines the normative weight that is to be given to an external rule, and illuminates the significance of an interactional understanding of a rule of international law. An interactional theory of law compels the identification of the shared legal understandings, confirmed in a practice of legality that underpin a rule of law, which furnish the normative content upon which an interpretation of a treaty term or provision can be undertaken.

\footnotetext{
${ }^{1598}$ Dupuy, 'Evolutionary Interpretation of Treaties: between Memory and Prophecy', supra $\mathrm{n}$ 782, at $\mathrm{p}$ 131.

${ }^{1599}$ North Sea Continental Shelf, supra n 893, at p 50, para 93. This is discussed in supra $\mathrm{n} 1513$ - 1516 , and Section 7.2.5.4 of this thesis.

${ }^{1600}$ Separate Opinion of Judge Higgins, supra n 1552, at p 238, paras 47 and 48.
} 
The cautious approach exercised in order to prevent a total displacement of the applicable law is only relevant in an adjudicatory setting where jurisdiction of the court is determined by the mandate given by the Parties. In the ordinary interpretation of treaties by country governments and their foreign affairs ministers or other relevant officials, the issue of jurisdiction and applicable law is not of the utmost concern. In an administration setting aiming at the implementation of a country's obligation under international law, the interpretation of a rule of international law, uninhibited by question of jurisdiction and applicability, should place more importance in the systemic integration of rules.

In this context, the application of Article 31(3)(c) in the interpretation of a treaty provision will be able to manifest its fullest potential as an integration tool that contributes towards the systemic integration of relevant rules of international law in light of the increasingly fragmented international legal order.

\subsection{Conclusion}

This chapter provides the theoretical foundation for the third and final stage of the framework of operationalisation developed for Article 31(3)(c). It establishes an architecture for the incorporation of relevant external rules of international applicable in the relations between the parties in the interpretation of a treaty term or provision in an attempt to realise the systemic integration potential expressed in the Article. The architecture guides the incorporation process by providing a structured methodology in the determination of how much normative weight should be given to the external rules in accordance with the stipulations of Article 31(3)(c).

The extent to which the relevant rules (identified in Chapter Two of this thesis) that are applicable in the relations between the parties as presented in Chapters Five and Six are incorporated in the interpretation of Article 20 of the 1997 Watercourses Convention will be considered through the architecture developed in this chapter.

The full execution of the analytical framework established for the operationalisation of Article 31(3)(c) to enable the systemic integration of rules relevant to the obligation to preserve ecosystems of international watercourses will be undertaken in the next chapter of this thesis. 
8

\section{Chapter 8. Systemic Integration: An Operationalisation}

\section{Part II: Operation}

\subsection{Overview}

This chapter will undertake the application of the three-tiered framework of operationalisation developed for Article 31(3)(c) through a re-interpretation of the salient elements of the Article. Article 31(3)(c) provides that 'there shall be taken into account, together with the context, any relevant rules of international applicable in the relations between the parties'. A framework for the operationalisation of this Article has been developed in the previous chapters.

The first tier of the framework of operationalisation is the identification of relevant rules. The second tier of the operationalisation looks into the content and scope of the rules of international law 'applicable in the relations between the parties'. For this purpose, the research undertakes an analysis of 'rules of international law' through an interactional perspective in order to reveal the shared legal understanding of the parties undertaken in a practice of legality, which indicates the common understanding of the parties, including their intentions as to its applicability.

The interactional understanding of the ascertained rules of international law necessitates the identification of 'the parties', who are the members of the enterprise of law-making who partake in the interactional and reciprocal process of the making of law. Subsequently, the 'common intention' of the parties as to the applicability of the rules of international law will be discovered through the analysis of the rules of international law via the prism of an interactional understanding of law.

The final stage of the operationalisation, after the identification of relevant rules of international law applicable in the relations between the parties, is the systemic integration of these rules in accordance with the direction stipulated in the Article. This is undertaken in the third tier of the framework where the normative weight to be accorded to the relevant rules in the interpretative process shall amount to 'take into 
account together with the context' of the interpreted treaty. ${ }^{1601}$ The obligatory nature of 'shall be taken into account ${ }^{, 1602}$ restricts the discretion exercisable by the interpreter. The context ${ }^{1603}$ assumes the role of an immediate qualifier of the ordinary meaning of terms used in the treaty, and together with the phrase 'take into account', the context conditions the extent to which the relevant rules of international law should be taken into account in the interpretation of a treaty term or provision. ${ }^{1604}$

The subsequent sections undertake the execution of each stage of the operationalisation of the analytical framework developed for Article 31(3)(c) through the interpretation of the obligation to preserve ecosystems of international watercourses in light of its systemic environment presented in Articles 2.1 and 4.1 of the Ramsar Convention and Article 8(a) and (d) of the Biodiversity Convention. The integration of rules relevant to the obligation to preserve via the legal technique of interpretation codified under Article 31(3)(c) demonstrates the systemic integration potential of this Article.

\subsection{Stage I: Relevant}

An integrated interpretation of Article 20 of the 1997 Watercourses Convention necessitates taking into account contemporary concerns of the community of nations on the preservation of the environment, ${ }^{1605}$ where an analytical framework is proposed in this thesis through the operationalisation of Article 31(3)(c) of the 1969 Vienna Convention. Contemporary concerns of the community of nations on the preservation of the environment are found in various MEAs that are conservation-centric. This research has identified two most relevant ${ }^{1606}$ Agreements, namely the Biodiversity Convention and the Ramsar Convention.

As illustrated in Chapter Two of this thesis, these rules are relevant as both of them deal with or are closely germane to the subject matter ${ }^{1607}$ of the ecosystem and the

\footnotetext{
${ }^{1601}$ Refer to Chapter Seven of this thesis on a detailed analysis on the interpretation of the phrase 'shall take into account together with the context', where the chapter proposes an architecture that guides the deliberation process undertaken for the incorporation of relevant external rules in accordance with Art 31(3)(c) of the 1969 Vienna Convention.

${ }_{1602}$ Draft Articles 1966, supra n 1435, at p 222, para 18.

${ }^{1603}$ Refer in particularly to Section 7.2 of this thesis.

${ }^{1604}$ Refer to Section 7.3 for a detailed discussion on the normative weight accorded to 'shall be taken into account'.

${ }^{1605}$ Fitzmaurice, Elias, and Merkouris (eds) Treaty Interpretation and the VCLT, supra n 279, at pp 236 237.

${ }^{1606}$ Refer to Chapter Two for justification of how the two MEAs are relevant for the interpretation of Art 20 of the 1997 Watercourses Convention, supra $\mathrm{n} 35$.

${ }^{1607}$ Refer to Section 2.2 on the threshold developed for the interpretation of 'relevant'.
} 
application of an ecosystem approach in the management of such ecosystems. ${ }^{1608}$ The use of the term 'ecosystems' in Article 20 indicates the explicit recognition of the ecosystem approach where the primary target of the ecosystem approach is the maintenance of the ecological integrity, and the safeguarding and protection of the ecological structure and functioning of the environment. ${ }^{1609}$ In addition, the preservation of freshwater ecosystem in its 'pristine and unspoilt condition" ${ }^{1610}$ is one means of such protection. ${ }^{1611}$

Moreover, the Conventions place the onus of the protection of the environment on each contracting party, where implementation of the obligations of the Conventions focuses firstly on the national boundaries of the parties in strengthening the protected areas, and where appropriate, establishes collaboration and cooperation with neighbouring countries to protect transboundary ecosystems or protected areas. ${ }^{1612}$ As explained in Section 2.3, this is aligned with the structure and punctuation of Article 20, where it places the individual obligation on the watercourse states to preserve its ecosystems of international watercourses before the obligation on the Watercourses States to establish joint effort in the preservation of such ecosystems.

Articles 2.1 and 4.1 of the Ramsar Convention address the same concern where the contracting parties are required to designate suitable wetlands in its territory for inclusion in the List of Wetlands of International Importance. The contracting parties shall promote the conservation of wetlands and waterfowls through establishment of nature reserves on wetlands, where preservation is one of its conservation targets regardless of whether these wetlands are included in the List or not. ${ }^{1613}$

Similarly, Article 8(a) and (d) of the CBD requires the Contracting Parties to establish a system of protected areas with special measures taken to conserve biodiversity for the protection of ecosystems, natural habitats and the maintenance of viable populations of

\footnotetext{
${ }^{1608}$ Refer to Section 2.1 on the conceptualisation of 'ecosystems' and the emergence of the ecosystem approach in international policy and international law. Refer in particularly to Section 2.1.4 on the application of the ecosystem approach and its normative standard in international law.

${ }^{1609}$ Principle 5, CBD Guidelines, supra n 166, at p 16.

16101994 Draft Articles with Commentaries, supra n 44, para 3, p 119

${ }^{1611}$ Refer to Section 1.1.1 for discussion on the obligation to preserve.

${ }^{1612}$ Refer to Section 2.3 on the primary obligation imposes by Art 20 on the obligation to preserve ecosystems of international watercourses within national territory.

${ }^{1613}$ Refer to Chapter Five for an elaboration of the shared legal understanding arrived at by Ramsar Convention's contracting parties on the obligation to conserve, where the conservation objective includes the preservation of wetlands. This will be further elaborated in subsequent section of this chapter.
} 
species in natural surroundings. Since it has been established that these rules are rules of international law applicable in the relations between the parties, as both rules are closely related and highly germane to the obligation to preserve under Article 20, they shall be taken into account in the interpretation of the Article 20 and its terms.

In this regard, the provisions in the Ramsar Convention and the Biodiversity Convention are relevant for the interpretation of the obligation to preserve ecosystems of international watercourses where the ecosystem approach is developed in depth within the treaty body. ${ }^{1614}$ Furthermore, these Conventions provide for the designation of areas protected in their pristine and unspoilt condition as a means to achieve the protection and safeguarding of ecosystem integrity, especially its structure and functioning. ${ }^{1615}$

The foregoing discussion re-affirmed that these rules are relevant for the interpretation of the term 'preserve' and 'ecosystems of international watercourses', which has been extensively developed by the law-making enterprise institutionalised under the conventional regime of the Ramsar and Biodiversity Conventions.

The satisfaction of these rules against the threshold of 'relevant' entails the engagement of the next stage of operationalisation, which operationalises the salient phrase of 'rules of international law applicable in the relations between the parties'. ${ }^{1616}$ These 'rules' are assessed against an interactional framework developed from an understanding of international law as an interactional process in the determination of whether these rules achieve the legality threshold to be labelled as 'international law'. ${ }^{1617}$ More importantly, the next stage ascertains the normative content and the scope of these rules, which inform the interpretation of 'applicable in the relations between the parties'.

\footnotetext{
${ }^{1614}$ Refer to Section 2.3 of this thesis.

${ }^{1615}$ Refer to Section 2.1.4 of this thesis on the application of the ecosystem approach that aims to safeguard and maintain ecosystem integrity, as informed by the concept of 'ecosystem'.

${ }^{1616}$ A thorough discussion on the prevailing interpretation of scholars of the terms 'applicable' and 'the parties' are addressed in Chapter Three, where this thesis advocates to reconstruct the prevailing interpretation and suggests a re-interpretation.

${ }^{1617}$ Refer to Chapter Four for the theoretical foundation to the interactional framework, and the proposed interactional framework in the interpretation and the operationalisation of 'rules of international law applicable in the relations between the parties'.
} 


\subsection{Stage II: Rules of International Law Applicable in the Relations between the Parties}

In the present context, 'the Parties' of Article 31(3)(c) of the 1969 Vienna Convention is interpreted to include all watercourse state parties to the 1997 Watercourses Convention. However, Schwebel's Third Report alluded to a general reference of the international community at large by stating that the preservation of the environment, and in particularly the ecosystem of international watercourses, is a licit concern of mankind. 1618 When the Draft Resolution (which is the Convention) was put to vote where all state parties, including 103 for the Convention, 27 abstentions and the three against, shared the common recognition regarding the obligation of states to preserve ecosystems of international watercourses. ${ }^{1619}$ The voting records support the assertion that the parties to the 1997 Watercourses Convention shared the common international understanding that there is an obligation to preserve the ecosystems of international watercourses.

The common international consensus to preserve freshwater ecosystems is strengthened by the multilateralisation of international law-making, especially in the institutionalised law-making of the Ramsar Convention and the Biodiversity Convention, as elaborated in Chapter Four of this thesis. The interactions between law-makers and the reciprocity observed between the law-makers and their subjects, in which states play a dual role at the COP level, reinforce the common understanding of the state parties. The quasiuniversal membership of the Ramsar Convention and the Biodiversity Convention fortifies the common recognition that the preservation of the environment is a licit concern of mankind. ${ }^{1620}$

Furthermore, the ascertainment of the normative content of the external relevant rules under the two concurrent Conventions from an interactional perspective, where in the development of rules the Biodiversity Convention refers to the Ramsar Convention on matters specific to inland water ecosystems, reveals the close interactions between the two treaty regimes in addressing the preservation of freshwater ecosystems. ${ }^{1621}$

\footnotetext{
1618 Schwebel's $3^{\text {rd }}$ Report, , supra n 4, at p 123, para 247.

${ }^{1619}$ UNGA, '99 ${ }^{\text {th }}$ Plenary Meeting', supra $\mathrm{n} 41$. All the parties do not opposed to the wordings or content of Art 20 of the 1997 Watercourses Convention, supra n 35, as it stood at the time of adoption.

${ }^{1620}$ Refer to Section 4.5 of this thesis.

${ }^{1621}$ On the cross-referencing between the Ramsar Convention and the Biodiversity Convention, refer to Section 6.3 .8 of this thesis. Refer to Section 4.5 of this thesis for the emergence of international consensus on a rule of law through cross-referencing between treaty regimes.
} 
The prevention against environmental degradation through preservative means is created, developed and enriched through multilateral institutions such as the plenary organs of environmental treaty regimes known as COP. ${ }^{1622}$ The common understanding attained through legal and institutional interactions ${ }^{1623}$ satisfies the legal threshold required for the external relevant rules to be considered 'applicable in the relations between the parties'.

Thus, the shared legal understanding undertaken in a practice of legality by an almost universal membership of 163 Contracting Parties in the Ramsar Convention should be deemed as to be 'applicable in the relations of the Parties' for the interpretation of the obligation of Watercourse States to individually, and, where appropriate, jointly, preserve the ecosystems of international watercourses. This shared understanding arrived at by the Contracting Parties in the COP processes interprets the obligation to conserve wetlands to include implementation of all necessary procedural obligations. These procedural obligations include the identification and designation of wetlands; the assessment of wetlands; the monitoring of wetlands; and the management of wetlands, ${ }^{1624}$ in achieving the short-term and long-term target of the Convention to designate 2,500 Ramsar sites that are representative of the wetland type of the biogeographic region. ${ }^{1625}$

Similarly, the shared legal understanding undertaken in a practice of legality by the quasi universal membership of 193 Contracting Parties in the Biodiversity Convention should be deemed 'applicable in the relations of the Parties' for the interpretation of the obligation of Watercourse States to individually, and, where appropriate, jointly, preserve the ecosystems of international watercourses.

The common intentions or understanding arrived at by the Contracting Parties of their obligation to conserve under Article 8(a) and (d) must necessarily be both the quantitative and qualitative requirements for the establishment of protected areas. This includes the necessary procedural mechanisms, such as the monitoring and reporting

\footnotetext{
${ }^{1622}$ Refer to Chapter Five and Six, in particularly Sections 5.2 and 6.2 on the development of shared legal understanding on the obligation to preserve within the institutional body of the Ramsar Convention and the Biodiversity Convention.

${ }^{1623}$ Refer to Sections 5.3.8 and 6.3.8 on the role of COP in strengthening international consensus that emerges as a consequence of the multilateralisation of international environmental law-making in institutionalised treaty regimes.

${ }_{1624}$ Ramsar Convention, 'New Guidelines for Management Planning for Ramsar Sites and Other Wetlands', supra $\mathrm{n} 921$, at $\mathrm{p} 11$.

${ }^{1625}$ Refer to Section 6.5 of this thesis.
} 
procedures, provided to facilitate the Parties in achieving the target jointly attained by the Contracting Parties through the interactional process of COP. The qualitative aspect of the obligation to conserve is achieved when the targeted areas of protection (which are $17 \%$ of terrestrial area of which inland water ecosystems form part) are ecologically representative and effectively managed protected areas. ${ }^{1626}$

The implementation of this shared understanding is guided by the Programmes of Work on Protected Areas and Inland Water Biodiversity, and the Strategic Plan for Biodiversity 2011 - 2020. The Programme of Work imposes the obligation to establish and strengthen national and regional systems of protected areas that are integrated within a broader landscape, seascape and sectors for the maintenance of their ecological structure and function. ${ }^{1627}$ The management of the site-based protected areas must be undertaken within the framework of an integrated catchment/watershed/river-basin approach. $^{1628}$

These shared legal understandings are undertaken in a practice of legality implicit to Articles 2.1 and 4.1 of the Ramsar Convention; and Article 8(a) and (d) of the Biodiversity Convention should be regarded as an expression of common understanding, which gives meaning to Article 20 of the 1997 Watercourses Convention, especially when they reflect the contemporary concerns of the community of nations. ${ }^{1629}$ Hence, these rules, both the explicit and the implicit dimensions, are 'relevant rules of international law applicable in the relations between the Parties'. In light of the context of Article 20, these relevant rules of international law application in the relations between the parties 'shall be taken into account'.

The 'relevant rules of international law applicable in the relations between the parties', assessed through an interactional framework that ascertains the implicit dimension of an explicit rules and identifies the normative content and the extent of applicability to the parties participating in the law-making process, enables the operationalisation of the third stage of the analytical framework proposed in this thesis.

\footnotetext{
${ }^{1626}$ Refer to Section 6.5 of this thesis.

${ }^{1627}$ Programme Element 1, Programme of Work on Protected Areas, Decision VII/28, supra n 1148, from p 8 onwards.

${ }^{1628}$ Revised Programme of Work on Inland Water Biological Diversity, supra n 1188, at p 11. Refer to Section 6.2 of this thesis.

${ }^{1629}$ Refer to Section 3.2.2.1 of this thesis.
} 


\subsection{Stage III: A Systemic Integration}

Article 20 provides that 'Watercourse States shall, individually and, where appropriate, jointly, ... preserve the ecosystems of international watercourses'. An interpretation of Article 20 in its systemic environment shall take into account, rules of international law relevant to it, and applicable in the relations between the parties of the 1997 Watercourses Convention (namely Articles 2.1 and 4.1 of the Ramsar Convention; and Article $8(\mathrm{a})$ and (d) of the Biodiversity Convention) to the extent permissible by its context. $^{1630}$

It is explained that 'shall take into account' is obligatory in nature, ${ }^{1631}$ and if the situation that necessitates its invocation is triggered, whereby, these rules are 'rules of international law', 'relevant' and 'applicable in the relations between the parties' - they shall be taken into account. 'Taken into account' for the purpose of interpretation is interpreted to mean providing the criteria against which the terms of the provision, including 'individually', 'preserve' and 'ecosystems' are to be assessed, and to be incorporated in their interpretation. ${ }^{1632}$ Bearing in mind that the systemic integration of relevant rules shall be qualified and delimited by the context of the provision, the context of the obligation to preserve ecosystems of international watercourses is clarified in the subsequent section.

\subsubsection{The Context}

This section will briefly recount the context of Article 20 addressed in general in Section 1.1.1 of this thesis, and in the discussion on 'relevant' address in this chapter and in Chapter Two of this thesis. The specific adoption of the term 'preserve', and the careful distinction drawn between protection and preservation, emphasises the intention of the Commission to protect the pristine and unspoilt state of freshwater ecosystem against harm and damage in order to keep them in their natural state.

\footnotetext{
${ }^{1630}$ The architecture for the incorporation of external rules in accordance with Article $31(3)(\mathrm{c})$ is developed in Chapter Seven, in particularly Section 7.5 of this thesis.

${ }^{1631}$ Refer to Section 7.3 of this thesis.

${ }^{1632}$ The normative weight commanded by the phrase 'take into account' is discussed in Section 7.3 of this thesis.
} 
The obligation to preserve is imposed first and foremost on the state parties to implement protection and preservation measures within their own territory, ${ }^{1633}$ where arguably, environmental damage occurred within the territory of a system state may fall under international regulations.

The Preamble of the 1997 Watercourses Convention express the conviction of the framework convention in ensuring the conservation, management and protection of international watercourses ${ }^{1634}$ whereby in Chapter IV, it provides for the protection, preservation and management aspect of the non-navigational uses of international watercourses. The 'context' of Article 20, as revealed through a perusal of the text of the Convention, indicates that preservation of international watercourses forms part of the objective of the Convention, as evidenced in the Preamble. ${ }^{1635}$

This intention is strengthened by the explicit stipulation in the heading of both Article 20 and the title of Chapter IV in which Article 20 is located. ${ }^{1636}$ The title of Article 20, which is the protection and preservation of ecosystems, and the heading of Part IV of 'Protection, Preservation and Management', provide the context of Article 20 in which the ecosystem approach is acknowledged in the interpretation of the obligations to protect and preserve, and whereby management-oriented procedures and processes are included. ${ }^{1637}$

\footnotetext{
${ }^{1633} 1994$ Draft Articles with Commentaries, supra n 44, pp 120 - 121, para 8. Refer to Section 1.1.1on the ubiquity of the obligation to preserve the environment. As expounded in the said section, the Special Rapporteur implied that there is an emerging normative principle making protection of the environment a universal duty.

${ }^{1634} 5^{\text {th }}$ preambular paragraph, 1997 Watercourses Convention, supra $\mathrm{n} 35$.

1635 The 5th preambular paragraph stated that 'The Parties to the present Convention ... Expressing the conviction that a framework convention will ensure the utilisation, development, conservation, management and protection of international watercourses and the promotion of the optimal and sustainable utilisation thereof for present and future generations'. See Section 7.2.3 of this thesis for a detailed elaboration of preamble as part of context.

${ }^{1636}$ Gardiner proposed further guidance in the determination of the 'wider' context that is not provided under the Vienna Convention, but still intrinsically essential in the determination of 'context' as titles or descriptive headings should clearly form part of the context for the purposes of interpretation. He commented that the obvious starting point for the construction and identification of the scope and ambit of a treaty, or a section or provision of a treaty is the title, headings or the chapeaux. See Gardiner, Treaty Interpretation, supra n 235, at pp 180 - 181. At p 181, According to Gardiner, titles or descriptive headings clearly form part of the context for the purposes of interpretation. Chapeau is used mainly to describe 'the opening words [or the opening clause] of a provision which consists of a set of terms', at pp 158 and 181.

${ }^{1637}$ This supports Schwebel's proposal of a 'special regime' for the preservation of the ecosystems of international watercourses. See Schwebel $3^{\text {rd }}$ Report, supra n 4, at p 190, para 518, and the discussion at supra $\mathrm{n} 57$,.
} 
The identification of the context is more specifically dealt with in the next subsections, in the recognition of the fine distinction between immediate context and context in the entire treaty. ${ }^{1638}$

\subsubsection{Immediate Context}

In reference to the discussion on 'Context' in Chapter Seven, the underlying structure or scheme of a treaty, which might be explicit or implicit, forms part of the context for a contextual interpretation of treaty terms or provisions. ${ }^{1639}$ The underlying structure and scheme underlying Article 20, and the 1997 Watercourses Convention as a whole, support the incorporation of the ecosystem approach. The individual responsibility of states to preserve ecosystems of international watercourses is shown through the explicit reference to ecosystems, and phrasing the obligation as 'Watercourse States shall, individually and, where appropriate, jointly'.

In addition, Articles 21 to 24 of the same Chapter IV, that are related, albeit dissimilar in their contents, support the application of an ecosystem approach as adopted in article 20 and the individual duty of watercourse States to preserve ecosystems of international watercourses. ${ }^{1640}$

This is supported by the context as reflected in the punctuation and syntax of Article 20 . The comma inserted after 'shall,'; 'individually and,'; 'and,'; 'where appropriate,'; and 'jointly,' emphasises the licit concern of all nations of the obligation to protect and preserve of ecosystem of watercourses regardless of its transboundary impacts.

The grammatical analysis adopted in the argument elaborated above in reference to Chapter Seven ${ }^{1641}$ does not produce legally surprising results, nor is it contrary to the other substantial considerations of the context. What the punctuation inserted after these

\footnotetext{
${ }^{1638}$ Refer to Section 7.2.5 of this thesis on the fine distinction between immediate context and context in the entire treaty highlighted in the case of La Bretagne, supra $\mathrm{n} 1458$, .

${ }^{1639}$ Refer to Section 7.2.5.2 of this thesis.

${ }^{1640}$ An expansive inclusion of territorial area beyond the watercourse system is implicit in Arts 21 to 24 . For example, Art 21(2) stipulated that 'Watercourse States shall, individually and, where appropriate, jointly, prevent, reduce and control the pollution of an international watercourse that may cause significant harm to other watercourse States or to their environment' (Author's own emphasis); Article 22 where the use of the term 'ecosystem' is repeated, despite the dissimilar content of prevention against introduction of alien or new species; Art 23, where the interface of watercourses and the marine environment, brought into the limelight through the understanding of the interactions between ecosystems is acknowledged, supports an expansive interpretation of ecosystems.

${ }^{1641}$ The grammatical analysis are conducted in the analysis of context as presented in the punctuation and syntax of the text of the treaty, as explicated in Section 7.2.5.4 of this thesis.
} 
terms or phrases did is strengthen the individual obligation of all states to preserve ecosystems of international watercourses independent of the trigger of transboundary pollution, in reflection of the international consensus that the preservation of ecosystems is a licit concern of mankind.

In summary, the immediate context of the obligation to preserve ecosystems of international watercourses, found in the structure and underlying scheme of the provision, as supported by its heading and title in Part IV, must be read with the overall context, or the context in the sense of the entire text of the treaty. ${ }^{1642}$

\subsubsection{Context in the entire treaty}

The overarching pillar governing the regime of the non-navigational uses of international watercourses - expressed in Article 5, which is then strengthened by Article 7 which confirms its prevailing status as expressly referred to in the Preamble is the principle of equitable and reasonable utilisation. ${ }^{1643}$

The transformation of the obligation to prevent harm set out in Article 7(1) to an obligation of result, due to the adjustment of balance between the equitable utilisation principle and the prevention against harm principle, amounted to a mitigation of the obligation not to cause harm. ${ }^{1644}$ This has direct implications for Article 20 as the substantive obligation of ecosystem protection is changed into an obligation of conduct to which a standard of due diligence is applied. ${ }^{1645}$

\footnotetext{
${ }^{1642}$ Refer to Section 7.2.5 of this thesis on the distinction between the immediate context and the context in the entire treaty, carefully distinguished in the La Bretagne arbitration, supra $\mathrm{n} 1458$.

${ }^{1643}$ Salman, 'The Helsinki Rules, the UN Watercourses Convention and the Berlin Rules: Perspectives on International Water Law', supra n 141. At p 633, the author commented that 'the prevailing view is that the Convention has ... subordinated the obligation not to cause significant harm to the principle of equitable and reasonable utilisation. This conclusion is based on a close reading of Articles 5, 6 and 7 of the Convention'. See Owen McIntyre, 'Case Law Analysis. Environmental Protection of International Rivers' (1998) 10(1) Journal of Environmental Law 79 - 91. McIntyre noted, at p 87 that 'that significant harm to the environment is a special category of injury that automatically transforms a harmful utilisation into an inequitable use of the watercourse'. See also André Nollkaemper, The Legal Regime for Transboundary Water Pollution: Between Discretion and Constraint (Martinus Nijhoff/Graham and Trotman, Dordrecht, 1993) at pp 68 - 69, and Ximena Fuentes, 'The Criteria for the Equitable Utilization of International Rivers' (1996) 67(1) British Yearbook of International Law 337 - 412, at pp $408-411$. On the principle of equitable utilisation in general, see Patricia K Wouters, 'An Assessment of Recent Developments in International Watercourse Law through the Prism of the Substantive Rules Governing Use Allocation' (1996) 36(2) Natural Resources Journal 417 - 439.

1644 Tanzi and Arcari, The United Nations Convention on the Law of International Watercourses. A Framework for Sharing, supra n 48, at pp 151 - 152.

1645 Tanzi and Arcari, The United Nations Convention on the Law of International Watercourses. A Framework for Sharing, supra n 48, at pp 152, 154 and 246. The due diligence standard applied to substantive provision of environmental protection is confirmed in the recent Pulp Mills' case in the
} 
The Preamble of the 1997 Watercourses Convention is explicit in stating that the conservation, management and protection of international watercourses go towards 'the promotion of the optimal and sustainable utilisation thereof (international watercourses) for present and future generations'. Moreover, Article 6(1) of the Convention supports the subservience of the obligation to preserve where it provides that the utilisation of an international watercourse in an equitable and reasonable manner requires taking into account all relevant factors and circumstances. These factors and circumstances include - (a) geographic, hydrographic, hydrology, climatic, ecological and other factors of a natural character; and (f) conservation, protection, development and economy of use of the water resources of the watercourse and the costs of measures taken to that effect.

The conservation, management and protection of the watercourses, or in particular, the preservation of the watercourses, is only one of the factors to be considered in striking the balance of an equitable and reasonable utilisation. Although the obligation to preserve ecosystems of international watercourses forms part of the substantive obligations under the Convention, the satisfaction of this obligation must be in accordance with the equitable and reasonable utilisation of the watercourses. ${ }^{1646}$

An elaborated determination of the context of Article 20, through the perspective of its immediate context and the context of its entire treaty, clarifies the condition in which the incorporation of external rules in the interpretation of Article 20 can be taken into account. The operationalisation of Article 31(3)(c) in the interpretation of Article 20, in light of the context clarified, will be executed in the next section.

interpretation of Art 41 of the 1975 River Uruguay Statute, at p 79, para 197. See also McIntyre, 'The Proceduralisation and Growing Maturity of International Water Law', supra $\mathrm{n}$ 83. This is referred to in the discussion on the current trend of environmental protection in international water law in Section 1.1.2. ${ }^{1646}$ It has been argued that ecosystem protection is closely related to the equitable utilisation principle embodied in Article 5 of the Convention. See Tanzi and Arcari, The United Nations Convention on the Law of International Watercourses. A Framework for Sharing, supra n 48, at p 244. The author further stated that 'the equitable utilisation of an international watercourse must be geared towards sustainable water management, riparian States cannot fail to address the problem of the ecosystem protection of shared watercourses for the purposes of establishing an equitable regime of water utilisation'. At $\mathrm{p} 245$, Arcari concluded that under the Convention, ecosystem protection is conceived as inherent in the idea of equitable use'. See also Jutta Brunnée and Stephen J Toope, 'Environmental Security and Freshwater Resources: A Case for International Ecosystem Law’, supra n 3, at p 65. 


\subsubsection{Article 31(3) There shall be Taken into Account, Together with the Context ... (c) Any Relevant Rules of International Law Applicable in the Relations between the Parties}

In view of the context presented in the process of integration of rules relevant to the preservation of ecosystems of international watercourses in their systemic environment, the Oil Platform case ${ }^{1647}$ and the Esphahanian case ${ }^{1648}$ outline a coherent architecture for the operationalisation of the last limb of Article 31(3)(c). ${ }^{1649}$ The treaty term and provision of the treaty that have to be interpreted must be identified, and only then could the rules of international law relevant for the interpretation of these terms or provisions be incorporated and applied in the interpretative process.

Hence, an operationalisation of 'shall be taken into account, together with the context' entails that the identified relevant rules of international law are to be incorporated (to the extent possible, depending on the context, on a case-by-case basis) in the interpretation of a treaty term of provision. The extent of incorporation excludes a total replacement of the treaty provision to be interpreted, to the extent that there is no legal reference at all to the text of the provision, or all the sight of the text of the interpreted treaty provision is lost. ${ }^{1650}$

The subsequent sections will apply this architecture in the determination of the normative weight of the phrase 'shall be taken into account, together with the context' as stipulated in Article 31(3)(c). The shared legal understanding that is implicit to Articles 2.1 and 4.1 of Ramsar Convention, and Article 8(a) and (d) of the Biodiversity Convention, shall be taken into account, together with the context, in the interpretation of the obligation to preserve stipulated under Article 20 of the 1997 Watercourses Convention. The shared legal understanding does not only provide the normative

\footnotetext{
${ }^{1647}$ In the Oil Platform case, supra n 1468, whether the act of attacks are 'necessary' will be judged against the criteria provided by the relevant rules that informs the interpretation Article $\mathrm{XX}(1)(\mathrm{d})$. However, a determination of whether these attacks are justified will be arrived at only through an adjudication of whether the provision of Article $\mathrm{XX}(1)(\mathrm{d})$ has been satisfied, in the context of the economic and commercial nature of the 1955 Treaty. Refer to Section 7.4.1 of this thesis.

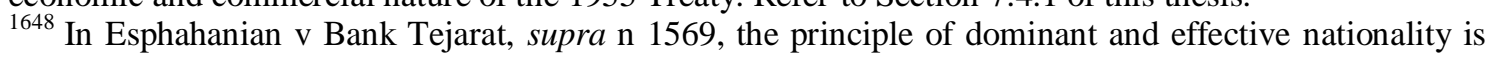
relevant to the interpretation of the term 'national' within the meaning of Article VII(1) prior to the determination whether the Iran-US Tribunal is seised with the jurisdiction to hear Esphahanian's claim under Article II(1). The principle of dominant and effective nationality serves merely to provide the criteria for the determination of whether dual nationals are 'national', and if so, which nationality he possessed for the adjudication of his claims in the Iran-US Tribunal. Refer to Section 7.4.2 of this thesis. ${ }^{1649}$ Refer to Sections 7.4 and 7.5 of this thesis.

${ }^{1650}$ Refer to Section 7.5 of this thesis on the normative weight commands by the phrase 'shall take into account, together with the context' of Art 31 (3)(c).
} 
content to these explicit rules of international law, but also indicates the applicability of these rules in the relations between the parties.

The subsequent sections ${ }^{1651}$ reiterate the summarised shared legal understanding practised by the parties of the two Conventions, that provides the normative content and scope that informs the interpretation of the phrase 'relevant rules of international law applicable in the relations between the parties'.

\subsubsection{Ramsar Convention}

River basins are the fundamental functional unit for water management, where an ecosystems approach is incorporated within the framework of integrated water resources management. ${ }^{1652}$ The ecosystem boundary of the river basin is to be designated into several types of zonation around the core wetland areas if a buffer zone is not incorporated in the designation of the wetland. ${ }^{1653}$ This is important to protect the structure and functioning of the wetlands, intrinsic to an ecosystem approach, where the water and land-use in the surrounding areas directly affect the ecological character of a designation site due to the inter-connected hydrological regime. ${ }^{1654}$

The shared understanding reached in the Ramsar Convention seeks to maintain or even improve the ecological character of a reserve site, where the conservation purpose is to ensure sustainability of ecosystem functioning and values to maintain people's livelihood and biodiversity conservation. ${ }^{1655}$ The 2009 Strategic Framework and Guidelines were adopted to guide the short-term target set by the Contracting Parties to increase Ramsar sites to at least 2,500 sites covering 250 million hectares, including at least one suitable representative of each wetland types. ${ }^{1656}$

\footnotetext{
${ }^{1651}$ Refer to Chapters Five and Six for an elaborate analysis of the shared legal understanding undertaken in a practice of legality that provides the implicit dimension for the interpretation of the phrase 'applicable in the relations between the parties'.

${ }_{1652}$ Ramsar Convention, 'New Guidelines for Management Planning for Ramsar Sites and Other Wetlands', supra $\mathrm{n}$ 921, at para 19.

${ }^{1653}$ Ramsar Convention, 'New Guidelines for Management Planning for Ramsar Sites and Other Wetlands', supra $\mathrm{n} 921$, at paras $53-57$.

${ }^{1654}$ Ramsar Convention, 'New Guidelines for Management Planning for Ramsar Sites and Other Wetlands', supra $\mathrm{n}$ 921, at para 58.

${ }_{1655}$ Ramsar Convention, 'New Guidelines for Management Planning for Ramsar Sites and Other Wetlands', supra $\mathrm{n}$ 921, at para 60.

${ }^{1656}$ Ramsar Convention, '2009 Strategic Framework and Guidelines', supra n 426, pp 5 and 17, paras 21 and 65. See Objectives 1 and 2, Ramsar Convention, '2009 Strategic Framework and Guidelines', supra $\mathrm{n}$ 426 , pp $3-4$, paras $9-15$.
} 
The qualitative component of this requirement is further illustrated in the criteria suggested in 2009 Strategic Framework and Guidelines. The designated sites must be representative, rare or unique, of a natural or near-natural wetland type, within the appropriate biogeographic region ${ }^{1657}$ where its ecological character plays a substantial role in the natural functioning of a major river basin or coastal system; ${ }^{1658}$ or provides supportive functions for vulnerable, threatened, or endangered species and ecological communities and the maintenance of biodiversity. ${ }^{1659}$

The management plan plays a central role in the continuous, long-term management process that started with minimal requirement and minimal organisation within an adaptable and dynamic framework. ${ }^{1660}$ The management plan involves the identification and designation of wetlands; the assessment and monitoring of wetlands; and the in situ and ex situ management of wetlands where a flexible approach that allows appropriate response and adaptation is adopted. ${ }^{1661}$ The 2009 Strategic Framework and Guidelines adopt the IUCN's management categorisation method in the designation of wetlands, which corresponds to, and complements, the criteria laid out in the 2009 Strategic Framework and Guidelines for Ramsar site designation. ${ }^{1662}$

The implementation of the Convention is further guided by the Ramsar Strategic Plan 2009 - 2015 adopted by COP 10 in Resolution X.1 where 28 strategies represent 'a general consensus of the most important priorities for most parties, ${ }^{1663}$ in their implementation of their obligations under the Convention within a stipulated timeframe. ${ }^{1664}$ In particular, Goal 2 of the Strategic Plan seeks to 'develop and maintain an international network of wetlands that are important for the conservation of global biological diversity, including waterbird flyways and fish populations and for sustaining

\footnotetext{
1657 Criterion 1, Ramsar Convention, '2009 Strategic Framework and Guidelines', supra n 426, at p 17.

1658 Ramsar Convention, '2009 Strategic Framework and Guidelines', supra n 426, at p 17, para 68..

${ }^{1659}$ Objective 2, Ramsar Convention, '2009 Strategic Framework and Guidelines', supra n 426, at pp 3 4.

${ }^{1660}$ Ramsar Convention, 'New Guidelines for Management Planning for Ramsar Sites and Other Wetlands', supra $\mathrm{n} 921$, at paras $41-44$.

1661 Ramsar Convention, 'New Guidelines for Management Planning for Ramsar Sites and Other Wetlands', supra n 921, at paras 44 - 48. The flexible approach adopted in the management of wetlands is known as 'adaptable management, see 'Part IX. Adaptable Management' in Ramsar Convention, 'New Guidelines for Management Planning for Ramsar Sites and Other Wetlands', supra n 921, at paras 48 52.

${ }^{1662}$ Para 27(b), 'Explanatory Note and Guidelines for Completing the Information Sheet on Ramsar Wetlands (RIS)', supra n 426, at pp 60-61.

${ }^{1663}$ Ramsar Convention, 'The Ramsar Strategic Plan 2009 - 2015', supra n 981, at p 2, para 7.

${ }^{1664}$ Ramsar Convention, 'Resolution X.1. The Ramsar Strategic Plan 2009 - 2015', supra n 981, at para 6.
} 
human life' through a step-wise approach. ${ }^{1665}$ The steps recommended start with the designation of wetlands; the long-term, continuous and adaptive process of management; putting in place an effective management plan; implementation of different conservation measures, including zonation; and the review of all existing Ramsar sites to determine the effectiveness of management arrangements. ${ }^{1666}$

The shared understanding arrived at by the Contracting Parties of the Ramsar Convention demonstrates the scope and content of Articles 2.1 and 4.1, which are relevant for the interpretation of the obligation to preserve under Article 20. The incorporation of an ecosystem approach has modified the concept of preservation to allow management measures, inherent in the parlance of conservation, to encroach on the concept of preservation that seems to imply that human intervention is impermissible. Conservation of wetlands via the establishment of natural reserves, included or not included in the Ramsar List, is no longer restricted to pure preservation, but has allowed for the use of sites to the extent that it does not adversely affect the sustainability of ecosystem functioning, or lead to change in its ecological character. ${ }^{1667}$

The interpretation of Article 20, in light of the development of the obligation to conserve wetlands through establishment of Listed or non-Listed sites, must be defined to take into account the shared understandings arrived by the Contracting Parties evidenced through the framework and guidelines adopted by the COP. The obligation to preserve ecosystems of international watercourses must necessarily adopt an integrated water resources management approach that strives to maintain and safeguard ecological functions and structures in accordance with the Ecosystem Approach within the river basin ecosystem boundary. An act of preservation is not said to be satisfied unless the Watercourse States have individually undertaken steps to designate ecosystems of international watercourses in accordance with the criteria and categorisation methods recommended, and implemented all procedural measures necessary for the management, monitoring, and assessment of the designated ecosystems.

\footnotetext{
${ }^{1665}$ Ramsar Convention, 'The Ramsar Strategic Plan 2009 - 2015', supra n 981, at p 10. See Strategies 2.1 - 2.7, Ramsar Convention, 'The Ramsar Strategic Plan 2009 - 2015', supra n 981, at pp 10 - 12.

${ }^{1666}$ Ramsar Convention, 'The Ramsar Strategic Plan 2009-2015', supra n 981, at pp 10 - 12, Strategies $2.1-2.7$.

1667 Ramsar Convention, 'New Guidelines for Management Planning for Ramsar Sites and Other Wetlands', supra n 921, at paras 60, and $63-64$.
} 


\subsubsection{Biodiversity Convention}

In the context of the Biodiversity Convention, Article 8(a) and (d) promotes the conservation of biodiversity through the establishment of protected areas where special measures are undertaken in the geographically defined area to conserve biodiversity, and to protect the ecosystems, natural habitats and the maintenance of viable populations of species in their natural surroundings. The Programme of Work on Protected Areas adopted in Decision VII/28 of COP 7 provides a guideline in the implementation of in situ conservation as required under Article 8 of the Convention. It recommends direct actions for the planning, selecting, establishing, strengthening, and managing of protected area systems and sites. ${ }^{1668}$

The conservation of biodiversity through protected areas includes the establishment and strengthening of national and regional systems of protected areas that are integrated into a global network, and the integration of the protected areas into broader land- and seascapes and sectors to maintain ecological structure and functioning. ${ }^{1669}$ This includes the establishment and strengthening of regional networks, where collaborations between neighbouring protected areas are initiated across national boundaries. ${ }^{1670}$ Conservation of biodiversity, apart from the designation of protected areas, must necessarily include the improvement of site-based protected area planning and management, where highly participatory and effective planning processes that incorporate climate change adaptation measures, are in place. ${ }^{1671}$

More specifically for the thematic area of inland water biodiversity, the Revised Programme of Work on Inland Water biodiversity emphasised the need of parties to adopt an integrated catchment/watershed/river-basin framework in the conservation of inland water biodiversity through a comprehensive, adequate and representative system of protected areas. ${ }^{1672}$ Due to the natural characteristic of inland waters, harmonisation

\footnotetext{
${ }^{1668}$ Programme Element 1, Programme of Work on Protected Areas, Decision VII/28, supra n 1148, at $\mathrm{p}$ 8.

${ }^{1669}$ Goals 1.1 and 1.2, Revised Programme of Work on Inland Water Biological Diversity, supra n 1188, at pp $8-10$.

${ }^{1670}$ Goals 1.2.3, Revised Programme of Work on Inland Water Biological Diversity, supra n 1188, at pp 10 - 11. Activity 1.2.5, Revised Programme of Work on Inland Water Biological Diversity, supra $\mathrm{n} 1188$, at $\mathrm{p} 12$.

${ }^{1671}$ Activities 1.4.1, 1.4.2, 1.4.4, and 1.4.5, Revised Programme of Work on Inland Water Biological Diversity, supra n 1188, at pp $11-12$.

${ }^{1672}$ Revised Programme of Work on Inland Water Biological Diversity, supra n 1188, at pp $11-12$.
} 
and collaboration with the Ramsar Convention are arrived at in the implementation of the obligations under both Conventions. ${ }^{1673}$

The normative content of Article 8(a) and (d) are further provided by the Strategic Plan 2011 - 2020. Target 11 aimed to set aside an effectively and equitably managed areas of protection of at least $17 \%$ of terrestrial and inland water areas, especially areas of particular importance for biodiversity and ecosystem services that are ecologically representative and well-connected, by 2020. ${ }^{1674}$ The quantitative requirement of a designation of $17 \%$ of terrestrial area as protected areas is qualified by the qualitative requirements of ecological representativeness, and the effectiveness of management plan.

In this context, the obligation to conserve in situ biodiversity through the establishment of protected areas under Article 8(a) and (d) involves the designation of inland waters as protected areas within an integrated water resources management framework where the catchment/watershed/river-basin serves as the ecosystem boundary for such delimitation. An integrated and effective management plan must be in place, where the implementation of the management process must be harmonised with the Ramsar Strategic Framework for the Future Development of the List of Wetlands of International Importance. The Programme of Work on Protected Areas adopted in Decision VII/28 imposes management planning that is in line with the IUCN management categories for protected areas, ${ }^{1675}$ which takes into account the concept of ecological connectivity and ecological networks stipulated in the Programme of Work on Protected Areas adopted in Decision VII/28. ${ }^{1676}$

In sum, the obligation to conserve inland water biodiversity through the mechanism of protected areas is subject to the quantitative target of at least $17 \%$ coverage of terrestrial protected areas that are ecologically representative and effectively managed. The effective management of these protected areas includes the establishment and maintenance of comprehensive, adequate and representative systems of protected inland

\footnotetext{
${ }^{1673}$ Activities 1.2.2, 1.2.3, 1.2.4 and 1.2.6, Revised Programme of Work on Inland Water Biological Diversity, supra n 1188, at pp $11-12$.

${ }^{1674}$ Target 11, 'Strategic Plan for Biodiversity 2011 - 2020 and the Aichi Biodiversity Targets' annexed to CBD, 'Decision X/2. The Strategic Plan for Biodiversity 2011 - 2020 and the Aichi Biodiversity Targets', supra n 1210, at p 9.

${ }^{1675}$ CBD, 'Decision VII/28 Protected Areas (Articles 8(a) to (e))', supra n 447, at pp 1 and 4, paras 3 and 31.

${ }^{1676}$ Activity 1.2.6, Revised Programme of Work on Inland Water Biological Diversity, supra n 1188, at p 12.
} 
water ecosystems within the framework of integrated catchment/watershed/river-basin management that are harmonised with the implementation of Ramsar Convention. ${ }^{1677}$

\subsubsection{Outcome of Operationalisation}

The obligation to preserve ecosystems of international watercourses in light of Article 8(a) and (d) of the Biodiversity Convention, and Articles 2.1 and 4.1 of the Ramsar Convention, requires Watercourse States to, individually, establish systems of protected areas on inland water ecosystems that are ecologically representative. ${ }^{1678}$ The effectiveness of management forms part of the yardstick of the implementation of the obligation to preserve, where both Conventions require the establishment of a management planning process that is adaptive and effective.

Due to the recognition of the ecosystem approach in the 1997 Watercourses Convention, the development in both Conventions of the implementation of the ecosystem approach orientated the preservation motivation towards the safeguarding and protection of natural functioning and ecological processes in ecosystems, where the conceptualisation of preservation is modified to adopt a more 'conservation' perspective. In this respect, the management process, including the monitoring and reviewing aspects, forms a crucial link in the obligation to preserve.

The Preamble of the 1997 Watercourses Convention stipulated that the Convention intended to ensure, inter alia, the conservation, management and protection of international watercourses. In reference to the context, the modification of the scope of preservation in light of the understanding of the environment from an ecosystem perspective does not seem to be inconsistent with the context of the Convention. Although preservation is intended to mean protection of the pristine and unspoilt condition of watercourses ecosystems, an interpretation that allows the preservation of ecosystems to incorporate conservation concepts, which involve some uses that are not inimical to the ecosystem integrity of a pristine site, is not inconsistent with the context of the Convention.

To summarise, the obligation to preserve ecosystems of international watercourses in Article 20, is interpreted in accordance with Article 31(3)(c) that reflects the principle of

\footnotetext{
1677 Goal 1.2, Revised Programme of Work on Inland Water Biological Diversity, supra n 1188, at p 11.

1678 Activity 1.2.2, Revised Programme of Work on Inland Water Biological Diversity, supra n 1188, at p 11; and Objective 1, Ramsar Convention, '2009 Strategic Framework and Guidelines', supra n 426, at p 3.
} 
systemic integration. The relevant rules of Articles 2.1 and 4.1 of the Ramsar Convention; and Article 8(a) and (d) of the Biodiversity Convention that are applicable in the relations between the parties, are taken into account, together with the context of the 1997 Watercourses Convention. The content and scope of the obligation to preserve must necessarily include both the substantive components of targeted areas of designation and coverage of Ramsar Listed sites or areas of inland waters under protection, and the procedural mechanisms involved in the implementation of the substantive components. In addition, the two Conventions have developed both qualitative and quantitative criteria for the satisfaction of the substantive obligation to preserve. They include the achievement of a quantified number or percentage of targeted area of Ramsar reserve or protected areas; and the attainment of the qualitative aspect of ecological representativeness of the area of protection or reserve, and the effectiveness of their management. ${ }^{1679}$

Only when these substantive and procedural aspects, formed by the shared legal understandings developed by the two Conventions, are undertaken by the Watercourse States, can these States be said to have satisfied their obligation to preserve ecosystems of international watercourses under Article 20. ${ }^{1680}$ The procedural aspects of the normative content that inform the interpretation of Article 20 are of particular importance in light of the imposition of a standard of due diligence in the application of Article 20.

These procedural requirements developed under the Ramsar Convention and the Biodiversity Convention establish the threshold for the application of the standard of due diligence inherent in Article 20, which is a specific application of the requirement contained in Article 5. ${ }^{1681}$ They could be useful in the determination of whether a watercourses state has satisfied the obligation of conduct to preserve ecosystems of international watercourses under Article 20, as assessed against a standard of due diligence.

In reference to the stipulation of Article 31(3)(c), rules of international law applicable in the relations between the parties shall be taken into account together with the context. In

\footnotetext{
1679 These issues are separately discussed in Chapter Five and Six of this thesis.

1680 This outcome is fully consistent with the 'special regime' envisioned by Special Rapporteur Schwebel in his conceptualisation of the obligation to preserve ecosystems of international watercourses under Article 20. Refer to discussion in supra $\mathrm{n} 57$.

${ }^{1681}$ This is discussed as part of the context of the entire treaty in Section 8.4.1.2 of this chapter.
} 
response to this, it is explained in Section 8.4.1 of this chapter that the conservation, management, and protection of watercourses serve to promote the equitable and reasonable utilisation of watercourses, which forms the context of Article 20. The ecological character and other environmental considerations merely form part of the factors and circumstances to be considered in the assessment of whether a nonnavigational use of water is equitable and reasonable. Hence, the relevant rules of international law shall be taken into account in the interpretation of the obligation to preserve under Article 20 only to the extent that their incorporation does not render the non-navigational uses of the international watercourse to cease to be equitable and reasonable. ${ }^{1682}$

Despite the emerging ecosystem approach to the protection of environment, and the increasing importance placed on environmental preservation and protection, it is in no way meant to acquire an overriding precedence over other factors in the balancing of 'equitable and reasonable' utilisation of water. Therefore, an integration of economic, social and environmental needs is the balance strived for under international water law in the deliberation of 'equitable and reasonable utilisation of water'. ${ }^{163}$ This approach was clearly illustrated in the famous quote of 'the need to reconcile economic development with protection of the environment' enunciated by the ICJ in the landmark decision of the Gabčíkovo-Nagymaros case.

However, the multi-faceted development of a rule of international law under the two Conventions identified for this research on the conservation and preservation of environment, be it the wetland component, or the biodiversity component, is not irreconcilably conflicted with the non-navigational uses of a shared watercourse. The underpinnings of the safeguard of the ecological structure and functioning of an ecosystem and the maintenance of ecosystem integrity, strengthen the treaty regime on the non-navigational uses of water resources in ensuring the sustainability of that resource for future uses. ${ }^{1684}$

\footnotetext{
1682 This conclusion was alluded to by Tarlock, 'International Water Law and the Protection of River System Ecosystem Integrity', supra n 320, at p 198. The author commented that 'the fact remains that the protection of a river system's ecological integrity remains secondary to the promotion of development'. ${ }_{1683}$ See Birnie, Boyle, and Redgwell, International Law and the Environment, supra n 112, at p 560.

${ }^{1684}$ Refer to discussion on equitable and reasonable use in Section 8.4.1.2.
} 


\subsection{Conclusion}

This chapter illustrates the operationalisation of the analytical framework developed for the interpretation of Article 31(3)(c) in light of the principle of systemic integration deemed to be expressed in this Article. ${ }^{1685}$ It compiles the outcome of analysis undertaken in the three-tiered analysis undertaken in Chapters Two to Seven, in the operationalisation of how Article 20 of the 1997 Watercourses Convention is to be interpreted in its normative environment through the legal technique codified under Article 31(3)(c) of the 1969 Vienna Convention.

The tiered analysis comprises Chapter Two on the interpretation of 'relevant' and the identification of rules that are 'relevant'; and Chapters Three, Four, Five and Six on the interpretation of 'rules of international law applicable in the relations between the parties' as provided by the Ramsar and the Biodiversity Convention. The third tier of the analysis is the focal point of the operationalisation of the principle of systemic integration where the normative weight of the external rules, as identified in tiers one and two, is ascertained in accordance with Article 31(3)(c). This involves the application of the interpretation of 'shall be taken into account, together with the context' and development of the architecture of systemic integration in Chapter Seven, in this chapter.

Chapter Eight presents the final stage of the operationalisation of the systemic integration principle from the prism of Article 31(3)(c) for the interpretation of the obligation to preserve ecosystems of international watercourses. The essence of the operationalisation framework lies in the identification of the context of Article 20, and in what way the context conditions and qualifies the incorporation of the identified external rules through interpretative means. The overriding character of 'the context' in Article 31(3)(c) produces the outcome that despite the increased importance placed on the preservation of ecosystems, and the development of these rules in environmental treaty regimes, this obligation does not have priority over other uses in the ascertainment of whether a non-navigational uses of international watercourses is equitable or reasonable.

\footnotetext{
${ }^{1685}$ It is recognised that the limitation posed by the interpretative nature of Art 31(3)(c) might not achieve a full systemic integration of rules as this would imply going beyond the role of interpretation, as evidenced in the debate on interpretation and application in legal scholarship However, this thesis does not purport to go into the controversy on the distinction between interpretation and application. See Kammerhofer, 'Systemic Integration, Legal Theory and the ILC', supra n 104.
} 
However, the actual normative weight on the obligation to preserve in light of other factors is beyond the scope of this thesis, as there is a need to identify all judicial facts that constitute other factors that have to be taken into consideration in the assessment of the equitable and reasonable non-navigational uses of international watercourses. In this case, further research for the contextualisation of the framework of operationalisation proposed in this thesis is needed. This would be a further area for research that explores the actual application of this framework in a specific context, where empirical evidence and the relevant compendium of relevant rules that are more expansive than this thesis can cover, but necessary for the actual application of the framework of operationalisation proposed in this thesis, could be undertaken.

Furthermore, it is important to note that the recognition of procedural mechanisms intrinsic to a substantive obligation in the realm of international water law illuminates the importance of the interface between international law and domestic law. The onus to preserve under Article 20, imposed firstly on an individual state to preserve ecosystems of international watercourses independent of transboundary damage; and only secondly, on watercourses states to engage in collaborative management of transboundary ecosystems; highlights the relevance of integrated water resources management at the national level of each watercourse states. The assessment of the implementation of Article 20 of the 1997 Watercourses Convention against a standard of due diligence ${ }^{1686}$ necessitates an exploration into the interaction between international law and domestic law, where the implementation of the obligation to preserve undertaken at the national level is brought into the limelight at the international level. This thesis provides the foundation where such exploration could be carried forward in further research. ${ }^{1687}$

In conclusion, Chapter Eight provides an assemblage of the outcome of analysis obtained in Chapters Two to Six and applies these outcome through the architecture developed in Chapter Seven for the systemic integration of relevant rules in accordance

\footnotetext{
${ }^{1686}$ The procedural mechanisms intrinsic to the satisfaction of the substantive obligation to preserve are discussed in Chapters Five and Six. The due diligence standard of responsibility for the implementation of the substantive obligation of the preservation of ecosystems of international watercourses is presented in the discussion on 'context' in Section 8.4.1.2.

${ }^{1687}$ The author made a preliminary exploration of the interface between international law and national law in Jing Lee, 'Multilateral Environmental Agreements - A Catalyst for Interlinkages in River Basin Management? A Case Study of Pahang River Basin, Malaysia' pp 188 - 193, in Janos J Bogardi, Jan Leentvaar, and Hans-Peter Nachtnebel (eds) with contributions from Sina Marx and Eva Riedke, River Basins and Change (Global Water System Project (GWSP), UNESCO-IHE Institute for Water Education, Bonn, 2012).
} 
with Article 31(3)(c). The next chapter of this thesis draws a general conclusion for this research by recounting the salient aspects discussed in this thesis.

\subsection{A Further Reflection}

Rules of international law that are developed through the law-making activities within the institutionalised setting mandated by treaties, and strengthened through an interpretation that takes into account its systemic environment, provide the foundation on which future cooperation of states is built upon for the resolution of international problems. ${ }^{1688}$ This is crucial in light of the increasing importance of treaty as a means of developing peaceful cooperation among states ${ }^{1689}$ against the backdrop of the right to sovereign equality of states ${ }^{1690}$ 'to take part in the solution of international questions affecting its legitimate interests, including the right to join international organisations and to become party to multilateral treaties dealing with or governing matters involving interests'. 1691

However, the states' right to exercise sovereign equality must be asserted within the boundaries set up by their duty to 'comply fully and in good faith with its international obligations'. ${ }^{1692}$ The failure of a state to observe the shared legal understanding concretised in practice in one international forum, in other fora, including the negotiation of new treaties, would not be seen as a satisfaction of its duty to 'fulfil in good faith the obligations assumed by [it] in accordance with the [UN] Charter ${ }^{1693}$ as proclaimed by the UNGA.

There is a need to acknowledge the political asymmetries or sensitivities of international watercourses that induce persistent unwillingness of states to cooperate without going into a determination of whether a state conducts itself in a manner that is in breach of its duty to cooperate under the UN Charter. ${ }^{1694}$ It is recognised that rules could be

\footnotetext{
1688 Art 1(3), Charter of the United Nations (26 June 1945, entered into force 24 October 1945) 59 Stat 1031; TS 993; 3 Bevans 1153 (hereinafter 'UN Charter').

${ }^{1689}$ Rosenne, Practice and Methods of International Law, supra n 221, at p 29.

${ }^{1690}$ UNGA, Res 2625 (XXV) 'Declaration on Principles of International Law Concerning Friendly Relations and Co-operation among States in accordance with the Charter of the United Nations' $\left(1883^{\text {rd }}\right.$ $\begin{array}{lllllll}\text { Plenary } & \text { Meeting, } & 24 & \text { October } & 1970) & \text { at } & p\end{array}$ <http://www.un.org/ga/search/view doc.asp?symbol=A/RES/2625(XXV)> accessed 14 February 2013.

${ }^{1691}$ Piet-Hein Houben, 'Principles of International Law Concerning Friendly Relations and Co-operation among States' (1967) 61(3) American Journal of International Law 703 - 736, at p 718.

${ }_{1692}$ Res 2625 (XXV) supra n 1690, at p 122, para (f) and elaboration at p 124, para (f).

${ }^{1693}$ Res 2625 (XXV) supra $\mathrm{n} 1690$, at $\mathrm{p} 124$.

${ }^{1694}$ Refer supra $\mathrm{n} 1688$.
} 
destroyed through the continuing practice of states and other international actors, although the determination of the demise of a rule of law is a matter of interpretation. ${ }^{1695}$ However, it would be hard to challenge the emergence of the obligation to preserve in international law, as evidenced in the robust development of this rule in treaty regimes mandated by MEAs despite allegation of a lack of willingness of a watercourse states to cooperate over an international watercourse, because the lack of willingness might arise from a different cause of action, and not over its shared understanding over the obligation to preserve ecosystems of international watercourses.

Against this background, in the context of the present research, the breach of a state's obligation to preserve could be dealt with under the non-compliance proceeding available within the treaty regimes of the identified MEAs, where the shared legal understanding over the interpretation and application of the obligation to preserve is strengthened within the institutions set out by these MEAs. The shared understanding to preserve ecosystems would not be impaired if a state is alleged to have refused to cooperate (where non-cooperation might not be the lack of shared understanding of the obligation to preserve). ${ }^{1696}$ A failure to cooperate does not vitiate the normative status of the obligation to preserve ecosystems of international watercourses, unless the noncooperation is due to a persistent unwillingness of states to commit to the obligation to preserve.

Instead, the duty of a state to conduct itself in a manner that promotes friendly relations and cooperation amongst states, makes it incumbent for the state to fulfil its international obligations in good faith, which drives states towards cooperation, in order to uphold the rule of law. The crystallisation of the obligation to preserve, developed through a systemic integration of the interpretation of this rule, provides the catalyst that promotes cooperation. This demonstrates the importance of an integrated approach towards treaty interpretation of an obligation to preserve ecosystems of international watercourses.

\footnotetext{
${ }^{1695}$ Refer to discussions in Section 4.4.2.1.

${ }^{1696}$ It is reminded that 'shared legal understanding' practised in a community of practice means the share understanding of members of this community as to 'what they are doing and why'. A thin community of international legal practice based in very limited shared understandings that there is a need for law in shaping international communication and interaction, can be said to exist. Brunnée and Toope, Legitimacy and Legality in International Law, supra $\mathrm{n}$ 724, at p 79. The authors elaborated in pp $15-16$ that 'a community of practice is constituted by mutual engagement rather than by shared values or goals'. See in general discussion in $\mathrm{n} 739$.
} 
The normative environment constructed by the international consensus and emerged through participation of states in various multilateralised law-making institutions, establishes the platform from which further negotiations are carried out in the spirit of peaceful cooperation amongst nation states in accordance with the UN Charter. Apart from guiding states' conduct and behaviour in accordance with the rule of law in their friendly relations and cooperation among states, ${ }^{1697}$ these shared legal understandings provide a yardstick for the assessment of whether a state undertakes its duty to fulfil the obligations assumed by it in good faith.

In this context, the operationalisation of an interpretative mechanism for the systemic integration of rules of international law relevant to the preservation of ecosystems of international watercourses strengthens the normativity of the obligation to preserve. The cross-referencing between treaty regimes galvanises international consensus of states, and imposes a standard for the assessment of good faith fulfilment of states' international obligations.

Having said that, it is vital to restate that a legal approach merely forms part of the solution to problems arising from political asymmetries in international relations. This is anticipated in the drafting of the UN Charter where it is provided that, in the event of dispute (or an allegation of non-cooperation), the pacific settlement of disputes in accordance with Article 33 of the UN Charter imposes on the UN state parties to seek a solution by negotiation, enquiry, mediation, conciliation, arbitration, judicial settlement, or to resort to regional agencies or arrangements, or other peaceful means of their own choice, failing which, would invoked the authority of the Security Council to call upon the parties to settle their dispute by such means. A genuine non-cooperation could be an indication of rogue state that is to be dealt with more appropriately under the political arm of the UN.

\footnotetext{
${ }^{1697}$ Preamble, Res 2625 (XXV) supra n 1690, at p 122. Also duty to cooperate in Art 1(3), UN Charter supra $\mathrm{n}$ 1688; Res 2625 (XXV) supra $\mathrm{n}$ 1690, at $\mathrm{p} 122$, para (d), and elaboration at $\mathrm{p} 123$.
} 
9

\title{
Chapter 9. Preservation of Ecosystems of International Watercourses and the Integration of Relevant Rules: Reflection and Conclusion
}

\author{
A WORD is dead \\ When it is said, \\ Some say. \\ I say it just \\ Begins to live \\ That day. ${ }^{1698}$
}

'Language represents the interactional phenomenon par excellence; its forms arise out of and live by interaction'. ${ }^{1699}$ The communication of words involves an initiation of a perceptual process of the mind where the direction of words communicated must be in the same contextual environment as the reciprocal expectation. ${ }^{1700}$ In the actual practice of lifting the 'more or less vagueness of language', ${ }^{1701}$ the respect for the underlying systematic structure and the understanding of the social context are important, ${ }^{1702}$ and here interpretation occupies a central role. ${ }^{1703}$

Legal interactions are an essential feature of law precisely because law's central purpose is to 'open up, maintain, and preserve the integrity of the channels through the barriers that separate them'. ${ }^{1704}$ In many other aspects, law is equated to language in 'what one could call a grammatically "imperfect" sense'. ${ }^{1705}$ The mutual adjustment of expectations in an interactional and reciprocal process in the purposive enterprise of law allows the emergence of shared understanding intended for the governance of relationships between the parties. ${ }^{1706}$ The implicit dimension of the legal order is the

\footnotetext{
1698 'LXXIX, Part One: Life' in Emily Dickinson (1830 - 1886) Complete Poems (Little, Brown and Company, Boston, 1924; Bartleby.com, 2000) <http://www.bartleby.com/113/1089.html > accessed 24 August 2012.

${ }^{1699}$ Fuller, The Morality of Law, supra n 747, at p 227.

${ }^{1700}$ Fuller, The Morality of Law, supra $\mathrm{n} 747$, at pp $227-228$.

${ }^{1701}$ A phrase lifted out from a quote in Panos Merkouris, 'Introduction: Interpretation is A Science, is An Art, is A Science', in Fitzmaurice, Elias, and Merkouris (eds) Treaty Interpretation and the VCLT, supra n 279, supra $\mathrm{n} 279$, at p 6.

${ }^{1702}$ Fuller, The Morality of Law, supra n 747, at p 229.

${ }^{1703}$ Fuller, The Morality of Law, supra n 747, at p 91. The author explained that 'With all its subtleties, the problem of interpretation occupies a sensitive, central position in the internal morality of the law. It reveals, as no other problem can, the cooperative nature of the task of maintaining legality.'

${ }^{1704}$ Fuller, The Morality of Law, supra n 747, at p 186.

1705 Marianne Constable, 'Speaking of the Imperfect: Law, Language and Justice' (2012) 9 No Foundations $58-67$, at $\mathrm{p} 59$.

${ }^{1706}$ Sartor, 'The Foundation of Legal Bindingness', supra n 569, at p 341.
} 
shared understanding that, embedded and intertwined with the criteria of legality, provides the content and practical force of law. ${ }^{1707}$

The interactional relationship is prominent and robust in the realm of international law, where rapid expansion of international legal activity is reflected in the diversification of functionally specialised but limited rule-complexes (which are also known as 'regimes') in order to respond to new technical and functional requirements. ${ }^{1708}$ These selfcontained regimes are different in terms of the interpretative theory underlying the process of interpretation, and the so-called 'specific ethos ${ }^{\text {, }}{ }^{1709}$ where preferences and orientations are articulated and strengthened through specialisation of regime. ${ }^{1710}$ Despite the highly specific objectives and the expertise and ethos that are exclusive to self-contained regimes, they do not exclude these specialised regimes from general international law.

An evolutionary and dynamic ${ }^{1711}$ interpretation that allows contemporary realities, which depart from the circumstances prevailed at the time of the drafting of the Convention but prevailing at the time of the interpretation, is necessary within a greater framework of the entire legal system where numerous legal and political interactions take place. ${ }^{1712}$ This strengthens the necessity to adopt an integrated approach in the interpretation of a rule of international law in its systemic environment, apart from the reality that any specialised regime undoubtedly receives binding force under general international law, and will always be situated in a systemic environment. ${ }^{1713}$

The role of treaty interpretation that allows an interpretation of a treaty provision in its normative environment highlights the significance of the principles of interpretation codified under Articles 31 - 33 of the 1969 Vienna Convention, ${ }^{1714}$ especially in the

\footnotetext{
${ }^{1707}$ Postema, A Treatise of Legal Philosophy and General Jurisprudence, supra n 754, at p 148. Refer to Chapter Four of this thesis.

${ }_{1708}$ Report of ILC, supra $\mathrm{n} 96$, at pp 14 and 15.

${ }^{1709}$ Report of ILC, supra $\mathrm{n} 96$, at p 90, para 170.

${ }^{1710}$ Report of ILC, supra n 96, at pp 85 and 247, para 158 and 488.

${ }^{1711}$ See Dupuy, 'Evolutionary Interpretation of Treaties: between Memory and Prophecy', supra n 782.

1712 Magdalena Forowicz, The Reception of International Law in the Court of Human Rights (Oxford University Press, Oxford, 2010) at pp 3 - 14. Gabčíkovo-Nagymaros case, supra n 1, Separate Opinion of the Vice-President Weeramantry, supra n 277, at p 31, para 53. Dupuy, 'Evolutionary Interpretation of Treaties: between Memory and Prophecy', supra n 782, at $\mathrm{p} 132$. The issue of inter-temporality is discussed in conjunction with the determination of the common intentions of the parties through an interactional understanding of international law, especially Section 4.4.1.

${ }^{1713}$ Report of ILC, supra n 96, at p 94, para 179. At p 100, para 129, it is stated that 'no regime is selfcontained. Even in the case of well-developed regimes, general law has at least two types of function'.

${ }^{1714}$ Refer to Section 1.1 of the thesis, especially supra $\mathrm{n} 21$ and $\mathrm{n} 22$.
} 
midst of a situation of fragmentation of international laws that are parallel and equivalent to each other. ${ }^{1715}$ Principles of interpretation that are dependent on the context ${ }^{1716}$ of the interpreted treaty (as stipulated in Article 31(1), (2) and (3)(a) and (b)), are insufficient to resolve the problems of fragmentation. ${ }^{1717}$ This is because the functionally-specialised nature of self-contained regimes is rules of international law extrinsic to the context of the interpreted treaty. In this respect, the unique character ${ }^{1718}$ of Article 31(3)(c) of the 1969 Vienna Convention provides a legal mechanism that allows the incorporation of parallel, equivalent norms that are in pari materia and relevant to the interpretation of a treaty term or provision. ${ }^{1719}$

Despite the specificity of ethos underlying a specialised regime, as long as there are legal interactions undertaken within the confines of the specialised regime that concern and impact on the environment and its ecosystems, there will emerge a community of practice, no matter how thin the shared understandings are. ${ }^{1720}$ The community of practice will 'cut across state boundaries and mediate between states, individuals, and human agency, on one hand, and social structures and systems, on the other'. ${ }^{1721}$ Regime specialisation is an insufficient boundary to prevent the interactions of the community of practice. It is from the understanding of international law as a communication and a type of interaction in the legal language, that a framework for the operationalisation of Article 31(3)(c) is proposed. ${ }^{1722}$

An understanding of international law from an interactional perspective where the shared legal understandings 'flourished, deepen and became complex' ${ }^{1723}$ through the

\footnotetext{
${ }^{1715}$ Refer to Section 1.1 of the thesis, especially supra $\mathrm{n} 14$.

1716 'Context' is as defined in Art 31(2) of the 1969 Vienna Convention.

${ }^{1717}$ Refer to Section 1.6.1 of the thesis.

${ }^{1718}$ Refer to discussion in supra $\mathrm{n} 246$.

${ }^{1719}$ On the interpretation of 'relevant' and the identification of relevant rules, refer to Chapter Two, in particularly Section 2.2 of this thesis.

${ }^{1720}$ The basic threshold for the emergence of a community of practice includes the '[sustenance] of mutual relationships (harmonious or not), shared approaches to interaction, shared indicators of membership, knowledge of others and their roles in the joint enterprise, shared discourses and shortcuts to communication, and common criteria for the appropriateness of actions and outcomes'. Wenger, Communities of Practice, supra n 776, at pp 131 - 133.

${ }^{1721}$ Brunnée and Toope, Legitimacy and Legality in International Law, supra n 724, at p 64. The concept of a community of practice is developed in Section 4.4.3.2 of this thesis.

1722 Report of ILC, supra n 96, at p 213 para 423. The potential of Art 31(3)(c) for the systemic integration of relevant rules has been explored by eminent scholars in light of the multiplication of treaty regimes and the fragmentation of international law. The ILC recognised the possible contribution of a discussion of the actual and potential uses of Art 31(3)(c) to the study of the fragmentation (or diversification) of international law. The proposed framework is developed through Chapters Two to Seven of this thesis whereby the operationalisation of the framework is undertaken in Chapter Eight.

${ }^{1723}$ Brunnée and Toope, Legitimacy and Legality in International Law, supra n 724, at p 69.
} 
interactional process, provide the content of the 'relevant rules of international law applicable in the relations between the parties' that shall be taken into account in the interpretative process of a treaty term or provision. It is this shared legal understanding that determines whether the rules of international law are applicable in the relations between the parties. Their applicability will depend on the collective understanding of the enterprise of law-making as to the content and the binding force of these rules. ${ }^{1724}$ As long as the shared understanding of a collective need for law to shape international communication and interaction in a given subject matter is undertaken in mutual engagement, and has emerged into a community of practice, an interactional law is said to have arisen. ${ }^{1725}$

The fragmentation of international law on the environment due to the proliferation of multilateral environmental treaty regimes has resulted in treaty congestion that affects the operational efficiency of these treaties. The difficulties resulting from the diversification of international law are real. These difficulties strengthen the assertion that even the so-called self-contained regime cannot be operated in a clinical vacuum, and be fully contracted out from general international law. A dynamic interpretation that incorporates contemporary concerns in the interpretation and subsequent application of a rule of international law are exceptionally important in the environmental regime, especially in the preservation and conservation of freshwater ecosystems. ${ }^{1726}$

Freshwater ecosystems could be said to be the most endangered ecosystems in the world, and they are facing dramatic decline far greater than most terrestrial ecosystems, despite the fact that water biodiversity provides provisioning service and supporting services that support all other ecosystem processes that sustain life on earth. ${ }^{1727}$ The scientific

\footnotetext{
${ }^{1724}$ This reflects the prevailing view of the scholar as to the possible construction of 'the parties' whereby the rule of international law must be said to be implicitly accepted or tolerated by all parties to the treaty under interpretation 'in the sense that it can reasonably be considered to express the common intentions or understanding of all members as to the meaning of the term concerned'. Pauwelyn, 'The Role of Public International Law in the WTO: How Far Can We Go?', supra n 264, at p 578. See McLachlan, 'The Principle of Systemic Integration', supra $\mathrm{n}$ 162. This aspect is discussed at length in Section 3.2.2.1 of this thesis.

${ }^{1725}$ Brunnée and Toope, Legitimacy and Legality in International Law, supra n 724, at p 79.

${ }^{1726}$ UNGA, 'Resolution 58/217 International Decade for Action, "Water for Life", 2005 - 2015', at p 1 〈http://www.un.org/ga/search/view_doc.asp?symbol=A/RES/58/217> accessed 18 November 2012. The GA emphasised that 'water is critical for sustainable development, including environmental integrity and the eradication of poverty and hunger, and is indispensable for human health and well-being'. On the need for a holistic approach, refer to Section 1.2 of this thesis.

${ }^{1727}$ David Dudgeon et al, 'Freshwater Biodiversity: Importance, Threats, Status and Conservation Challenges', supra n 338, at p 164.; and MA, Ecosystems and Human Well-Being: Synthesis, supra n 336,
} 
community has come to recognise the importance of safeguarding ecosystem integrity and the maintenance of evolutionary and ecological processes through in situ conservation of an 'unmodified assemblage of organisms' within a protected area. ${ }^{1728}$ It has now been widely recognised that protected areas are among the most effective means of conserving the biological diversity in situ that forms the natural infrastructure of the production of life-sustaining ecosystem services. ${ }^{1729}$

At the international level, the obligation to preserve freshwater ecosystems is explicitly provided in Article 20 of the 1997 Watercourses Convention. This Article represents the emergence of the obligation to preserve in the field of international water law as evidenced in the multiplication of water-specific international instruments. ${ }^{1730}$ Rules of international law relevant to the interpretation of Article 20, especially in providing the normative content for terms such as 'ecosystems' and 'preserve', are simultaneously found in Articles 2.1 and 4.1 of the Ramsar Convention; and Article 8(a) and (d) of the Biodiversity Convention. ${ }^{1731}$

Both Conventions oblige state contracting parties to designate areas of conservation where various measures have to be implemented for the protection of ecological integrity, especially the structure and functioning of the ecosystems. It is interesting to note that despite the multilateral and international status of the 1997 Watercourses Convention, Article 20 strengthens the legal status of the obligation to protect and preserve the environment within the national territory of states in accordance with the

at $\mathrm{p}$ 106. The seriousness of the current scenario on freshwater ecosystems is dealt with in Section 2.1.4 of this thesis.

${ }^{1728}$ Shelford, 'The Preservation of Natural Biotic Communities', supra n 305, Glowka, BurhenneGuilmin, and Hugh Synge, A Guide to the Convention on Biological Diversity, supra n 431, at pp $240-$ 241. R Edward Grumbine, 'What is Ecosystem Management?', supra n 322; and Trouwborst, 'Ecosystem Approach', supra n 310. The importance of the safeguard and maintenance of ecosystem integrity through preservation is discussed in Section 2.1.2 of this thesis.

${ }^{1729}$ UN Secretary-General Ban Ki-moon, 'Remarks at the High-level Event on Biodiversity', supra n 1010. Michael JB Green and James Paine, 'State of the World's Protected Areas at the End of the Twentieth Century' (Paper Presented at IUCN World Commission on Protected Areas Symposium on "Protected Areas in the $21^{\text {st }}$ Century: From Islands to Networks", Albany, Australia 24 - 29 November 1997) 〈http://oceandocs.org/bitstream/1834/867/1/Green\%2c\%20M.\%20J.\%20B1-35.pdf> accessed 24 August 2012; Published in IUCN, IUCN World Commission on Protected Areas Symposium on "Protected Areas in the $21^{\text {st }}$ Century: From Islands to Networks" Albany, Australia, 24 - 29 November 1997 (IUCN, 1997) p 35 et seq. Refer to Chapter Two of this thesis.

${ }^{1730}$ Refer to Section 1.1 of the thesis, especially supra $\mathrm{n} 9$.

${ }^{1731}$ Refer to Chapter Two for the identification of relevant rules, in particularly Section 2.3 of this thesis. 
ecosystem approach, and strengthens the relevancy of the state-centric Conventions identified for the purpose of this research. ${ }^{1732}$

The common intentions and the shared understanding of the parties as to its content and bindingness, that determines the applicability of the rules of international law from the Ramsar Convention and the Biodiversity Convention, have been assessed against the criteria of legality proposed by Fuller. ${ }^{1733}$ Apart from the determination of whether the process and outcome of the development of the rules are intertwined with criteria of legality, the assessment of the rules against the eight criteria of internal morality will reveal the product of the interactional process in the hard work of law-making in an institutionalised community of practice. ${ }^{1734}$

In the interpretation of the obligation to preserve imposed under Article 20 of the 1997 Watercourses Convention, a systemic integration of relevant rules of international law requires that these rules (the shared legal understanding developed in the interactional COP processes of the identified treaty regimes, and undertaken in a practice of legality) shall be taken into account, together with the context, in the interpretation of Article 20. 'Shall be taken into account' imposes that an interpretation that takes into account the external rule is compulsorily invoked if all conditions stipulated under Article 31(3)(c) of the 1969 Vienna Convention are satisfied. ${ }^{1735}$ However, the extent to which these rules 'shall be taken into account' is qualified, and delimitated in a way, by the context of the treaty. ${ }^{1736}$

The context of Article 20 was discovered through a thorough analysis of text and preamble of the 1997 Watercourses Convention. ${ }^{1737}$ It was found that despite the intention of the 1997 Watercourses Convention to impose the obligation to preserve the ecosystems of international watercourses on watercourses states, this intention must be read with the overall context, or the context of the entire text of the treaty. The conservation, management and protection of the watercourses, or in particular, the preservation of the watercourses, is only one of the factors to be considered in striking

\footnotetext{
1732 This outcome is noted in Chapter Eight of this thesis, in particularly in the discussion of the context of Art 20 in Section 8.4.1.

${ }^{1733}$ Refer to Chapters Five and Six, in particularly Sections 5 and 6.5 of this thesis.

1734 The product is the shared legal understanding undertaken in a practice of legality that indicates the common intentions of the parties as to the interpretation of the rule, which is 'applicable in the relations between the parties'. Refer to Sections 5 and 6.5 of this thesis.

${ }^{1735}$ Refer to Chapter Seven, in particularly Section 7.3 of this thesis.

${ }^{1736}$ Refer to Chapter Seven, in particularly Section 7.2 of this thesis.

${ }^{1737}$ Refer to Chapter Eight, in particularly Section 8.4.1 this thesis.
} 
the balance of an equitable and reasonable utilisation. Although the obligation to preserve ecosystems of international watercourses forms part of the substantive obligations under the Convention, the satisfaction of this obligation must be in accordance with the equitable and reasonable utilisation of the watercourses. ${ }^{1738}$

In this regard, the conclusion drawn in Chapter Eight is that firstly, the content and scope of the obligation to preserve ecosystems of international watercourses under Article 20 involve both the substantive components of the designation of areas as protected areas or Ramsar sites, and the procedural aspects of effective management laid out in detail under the two Conventions. Secondly, this obligation is but one factor to be taken into consideration in the determination of an equitable and reasonable utilisation of watercourses. Although the rules of international law under the two Conventions might be binding on the parties under the Convention, in the determination and interpretation of their obligation under the 1997 Watercourses Convention, the context requires that this obligation must be balanced against other factors, and does not a priori enjoy a higher hierarchy in the balancing process.

The ascertainment of the shared legal understanding implicit to a rule of international law through the interactional framework indirectly promotes cooperation in good faith between states, especially in the negotiation of new treaties where existing international obligations committed in other international law-making fora could serve as the catalyst of cooperation. Having said that, the systemic integrative potential realised through the operationalisation of Article 31(3)(c) of the 1969 Vienna Convention proposed in this research would have limited application in the face of deep intransigence between international watercourse states where occurrences of rupture in the cooperation between states are common. In this instance, a purely legal approach would be incapable of resolving genuine political conflicts, where these conflicts could be more appropriately addressed through other mechanisms provided under the UN Charter. ${ }^{1739}$

In conclusion, this thesis develops the body of knowledge on the preservation of ecosystems of international watercourses through an integrated interpretation of Article 20 of the 1997 Watercourses Convention in its normative environment, presented in the relevant provisions of the Ramsar Convention and the Biodiversity Convention. For this

\footnotetext{
${ }^{1738}$ Refer to Chapter Eight, in particularly Section 8.4.2.3 of this thesis.

${ }^{1739}$ Refer to Section 8.6 of the thesis.
} 
purpose, the thesis proposes a possible framework for the operationalisation of Article 31(3)(c) by reconstructing the conceptualisation of rules of international law through an interactional perspective in the exploration of the potential contribution of the Article to the study of the fragmentation (or diversification) of international law.

The framework of operationalisation for Article 31(3)(c) of the 1969 Vienna Convention as proposed in this thesis, offers one of the many possible perspectives in treating the issue of diversification of international law. It provides further understanding on both the problematic aspect of the fragmentation and congestion of international law and the positive aspect of the expansion of international law that caters to functional differentiation and specialised technical needs.

The analysis of Article 31(3)(c) through the prism of an interactional theory of law gave an evolutionary interpretation to 'rules of international law'. In view of the multilateral law-making processes prevalent at the international level, especially in international environmental law, and the increasingly robust institutional cooperation and linkages amongst multilateral environmental treaty regimes spurred by unprecedented advancement in environmental sciences, an interactional determination of 'rules of international law' encapsulates and explains the contemporary climate of the international (environmental) law-making process. 


\section{Bibliography}

Anne van Aaken, 'Defragmentation of Public International Law through Interpretation: A Methodological Proposal' (2009) 16 Indiana Journal of Global Legal Studies, 483 512

Abi-Saab, Georges, 'The Appellate Body and Treaty Interpretation' in Giorgio Sacerdoti and others (eds), The WTO at Ten: The Contribution of the Dispute Settlement System (Cambridge University Press 2006).

Alam, Shawkat, Md Jahid Hossain Bhuiyan, Tareq MR Chowdhury, and Erika J Techera, eds., Routledge Handbook of International Environmental Law (Routledge 2013).

Allot, Philip, 'The Concept of International Law' (1999) 10 European Journal of International Law, $31-50$.

Alvarez, José E, International Organizations as Law-makers (Oxford University Press 2005).

Alvarez, Jose E, 'The New Treaty Makers' (Keynote Address in a Symposium at Boston College law School, given in honour of Professor Cynthia Lichtenstein November 2, 2001).

Anton, Donald K, “"Treaty Congestion” in Contemporary International Environmental Law' in Shawkat Alam and others (eds), Routledge Handbook of International Environmental Law (Routledge 2013), 651 - 665.

Anwar, Sk Morshed, Cédric A Jeanneret, Lael Parrott, and Danielle J Marceau, 'Conceptualization and Implementation of a Multi-agent Model to Simulate Whalewatching Tours in the St Lawrence Estuary in Quebec, Canada' (2007) 22 Environmental Modelling and Software, 1775 - 1787.

Armenteras, Dolors, and C Max Finlayson, 'Biodiversity' in UNEP (ed), Global Environmental Outlook 5 (UNEP 2012).

Asselt, Harro van, 'Managing the Fragmentation of International Environmental Law: Forests at the Intersection of the Climate and Biodiversity Regimes' (2012) 44 International Law and Politics, 1205 - 1278. 
— ' Managing the Fragmentation of International Environmental Law: Forests at the Intersection of the Climate and Biodiversity Regimes' (2012) 44 International Law and Politics, $1205-1278$.

Asselt, Harro van, Francesco Sindico, and Michael A Mehling, 'Global Climate Change and the Fragmentation of International Law' (2008) 30 Law and Policy, 423 - 449.

Aufricht, Hans, 'Supersession of Treaties in International Law' (1952) 37 Cornell Law Quarterly, 655 - 700 .

Aust, Anthony, Modern Treaty Law and Practice (2nd edn, Cambridge University Press 2007).

Aust, Helmut Philipp, Complicity and the Law of State Responsibility (Cambridge University Press 2011).

Barber, Benjamin R, 'Conserving Politics: Michael Oakeshott and the Conversation of Political Theory' in Benjamin R Barber (ed), The Conquest of Politics. Liberal Philosophy in Democratic Times (Princeton University Press 1988), 152 - 176.

Barnett, Michael, and Raymond Duvall, 'Power in International Politics' (2005) 59 International Organization, $39-75$.

Bartels, Lorand, 'Applicable Law in WTO Dispute Settlement Proceedings' (2001) 35 Journal of World Trade, 499 - 519.

Baxter, Richard R, 'International Law in "Her Infinite Variety"' (1980) 29 International and Comparative Law Quarterly, 549 - 566.

Berman, Paul Schiff, 'A Pluralist Approach to International Law' (2007) 32 Yale Journal of International Law, $301-329$.

Beytagh, Francis X, 'Ten Years of Non-Retroactivity: A Critique and A Proposal' (1975) 61 Virginia Law Review, 1557 - 1625.

Birnie, Patricia, Alan Boyle, and Catherine Redgwell, International Law and the Environment ( $3^{\text {rd }}$ edn, Oxford University Press 2009).

Bix, Brian H, ‘A Dictionary of Legal Theory’ (Oxford University Press 2004). 
Black, Henry Campbell, Handbook on the Construction and Interpretation of the Laws (The Lawbook Exchange 2008).

Blanning, Tim, The Pursuit of Glory: Europe 1648 - 1815 (Allen Lane 2007).

Blumenfeld, S, T Chistophersen, and D Coates, Waters, Wetlands and Forests. A Review of Ecological, Economic and Policy Linkages (Secretariat of the CBD and Secretariat of the Ramsar Convention on Wetlands, 2009).

Bodansky, Daniel, 'Rules vs Standards in International Environmental Law' (2004) 98 American Society International Law Proceeding, 275 - 280.

Bogdandy, Armin von, Philipp Dann, and Matthias Goldmann, 'Developing the Publicness of Public International Law: Towards a Legal Framework for Global Governance Activities' (2008) 9 German Law Journal, 1375 - 1400.

Boyle, Alan E, 'Some Reflections on the Relationship of Treaties and Soft Law' (1999) 48 International Comparative Law Quarterly, 901 - 912.

—, 'UNCLOS III and the Process of International Law-Making' in Tafsir Malick Ndiaye and Rüdiger Wolfrum (eds), Law of the Sea, Environmental Law and Settlement of Disputes. Liber Amicorum Judge Thomas A Mensah (Martinus Nijhoff Publishers 2007), $371-388$.

_- 'Relationship between International Environmental Law and Other Branches of International Law' in Daniel Bodansky and others (eds), The Oxford Handbook of International Environmental Law (Oxford University Press 2007).

Boyle, Alan E, and Christine M Chinkin, The Making of International Law (Oxford University Press 2007).

Brandom, Robert B, Making It Explicit (Harvard University Press 1994).

—_, Articulating Reasons (Harvard University Press 2000).

Brels, Sabine, David Coates, and Flavia Loures, Transboundary Water Resources Management: the Role of International Watercourse Agreements in Implementation of the CBD (Secretariat of the CBD 2008). 
Briceño, Sálvano, 'Institutional Linkages among Multilateral Environmental Agreements: An Organizational and Educational Development Perspective' (Prepared for 'Interlinkages' International Conference on Synergies and Coordination between Multilateral Environmental Agreements, UNU, 14 - 16 July 1999).

Brierly, James Leslie, The Law of Nations (Oxford University Press 1950).

Brierly, James Leslie, Hersch Lauterpacht, and CHM Waldock, The Basis of Obligation in International Law (Clarendon Press 1958).

Brownlie, Ian, Principles of Public International Law (6th edn, Oxford University Press 2003).

Brown-Weiss, Edith, 'International Environmental Law: Contemporary Issues and the Emergence of a New World Order' (1993) 81 Georgetown Law Journal, 675 - 710.

Brunnée, Jutta, 'COPing with Consent: Law-Making under Multilateral Environmental Agreements' (2002) 15 Leiden Journal of International Law, 1 - 52.

—, 'The Stockholm Declaration and the Structure and Process of International Environmental Law' in Aldo Chircop and others (eds), The Future of Ocean Regime Building: Essays in Tribute to Douglas M Johnston (Martinus Nijhoff 2009).

Brunnée, Jutta, and Stephen J Toope, 'Environmental Security and Freshwater Resources: A Case for International Environmental Law' (1994) 5 Yearbook of International Environmental Law, $41-76$.

— , 'International Law and Constructivism: Elements of an Interactional Theory of International Law' (2000) 39 Columbia Journal of Transnational Law, 19 - 74.

Brunnée, Jutta, and Stephen John. Toope, Legitimacy and Legality in International Law (Cambridge University Press 2010).

Byers, Michael, Custom, Power and the Power of Rules (Cambridge University Press 1999).

Calder, Ian R, Blue Revolution: Integrated Land and Water Resources Management (2nd edn, Earthscan 2005). 
Cassese, Antonio, 'Remarks on Scelle's Theory of "Role Splitting" (dédoublement fonctionnel) in International Law' (1990) 1 European Journal of International Law, 210 -231 .

Castro, Paulo Canelas De, The Future of International Water Law (Shared Water Systems and Transboundary Issues, with Special Emphasis on the Iberian Peninsula. Luso-American Foundation 2000).

Chambers, W Bradnee, 'Interlinkages and the Effectiveness of Multilateral Environmental Agreements; UNU, Inter-Linkages. Synergies and Coordination between Multilateral Environmental Agreements' (UNU, Tokyo, 1999).

—, Interlinkages and the Effectiveness of Multilateral Environmental Agreements (United Nations University Press 2008).

Charnovitz, Steve, 'A World Environment Organization' (UNU Institute of Advanced Studies Project on International Environmental Governance Reform, UNU Tokyo, 2002).

Chayes, Abram, and Antonia Handler Chayes, The New Sovereignty. Compliance with International Regulatory Agreement ( $2^{\text {nd }}$ edn, Harvard University Press 1998).

Chazournes, Laurence Boisson de, 'Eaux internationals et droit international: vers l'idée de gestion commune' in Chazournes, Laurence Boisson de, and Salman MA Salman, (eds) Water Resources and International Law (Martinus Nijhoff Publishers 2005).

—, 'Freshwater and International Law: The Interplay between Universal, Regional and Basin Perspectives' (The United Nations World Water Assessment Programme, United Nations World Water Development Report 3: Water in a Changing World, Insights, UNESCO, UN-Water, 2009) <http://unesdoc.unesco.org/images/0018/001850/185080E.pdf> accessed 10 February 2013

Chinkin, Christine M, 'The Challenge of Soft Law: Development and Change in International Law' (1989) 38 International and Comparative Law Quarterly, 850 - 866.

Churchill, Robin R, and Geir Ulfstein, 'Autonomous Institutional Arrangements in Multilateral Environmental Agreements' (2000) 94 American Journal of International Law, $623-659$. 
Cohen, Harlan Grant, 'Finding International Law: Rethinking the Doctrine of Sources' (2007) 93 Iowa Law Review, 65 - 129.

Cole, JJ, YT Prairie, NF Caraco, WH McDowell, LJ Tranvik, RG Striegl, CM Duarte, and others, 'Plumbing the Global Carbon Cycle: Integrating Inland Waters into the Terrestrial Carbon Budget' (2007) 10 Ecosystems, 171 - 184.

Collin, PH, (Peter Collin Publishing 2000).

Constable, Marianne, 'Speaking of the Imperfect: Law, Language and Justice' (2012) 9 No Foundations, $58-67$.

Olivier Corten and Pierre Klein (eds.), The Vienna Conventions on the Law of Treaties: A Commentary (Oxford University Press, Oxford, New York, 2011).

Craig, Robin Kundis, 'Climate Change, Regulatory Fragmentation, and Water Triage' (2008) 79 University Colorado Law Review, 825 - 927.

D’Amato, Anthony, 'International Law, Intertemporal Problems' [1992] Encyclopedia of Public International Law, 1234.

_-, 'International Law as A Unitary System' [2008] Northwestern University School of Law Public Law and Legal Theory Series No 08-02, SSRN-id1106420.

D'Aspremont, Jean, Formalism and the Sources of International Law (Oxford University Press 2011).

Damme, Isabelle van, 'Jurisdiction, Applicable Law, and Interpretation' in Daniel Bethlehem and others (eds), Oxford Handbook of International Trade Law (Oxford University Press 2009).

Dellapenna, Joseph W, 'Foreword: Bringing the Customary International Law of Transboundary Waters into the Era of Ecology' (2001) 1 International Journal of Global Environmental Issues, $243-249$.

Dickey, Anthony, 'The Concept of Rules and the Concept of Law' (1980) 25 American Journal of Jurisprudence, $89-116$.

Dickinson, Emily, 'LXXIX, Part One: Life' in Complete Poems (Little, Brown and Company; Bartleby.com, 2000 1924). 
Dixon, Martin, Textbook on International Law (6th edn, Oxford University Press 2007).

Doelle, Meinhard, 'Climate Change and the Use of the Dispute Settlement Regime of the Law of the Sea Convention' (2006) 37 Ocean Development and International Law, $319-337$.

—, 'Integration among Global Environmental Regimes: Lessons Learned from Climate Change Mitigation' in Aldo Chircop and others (eds), The Future of Ocean Regime Building: Essays in Tribute to Douglas M Johnston (Martinus Nijhoff 2009), 63 -85 .

Dörr, Oliver, and Kirsten Schmalenbach, (eds) Vienna Convention on the Law of Treaties. A Commentary. (Springer-Verlag 2012).

Dudgeon, David, Angela H Arthington, Mark O Gessner, Zen-Ichiro Kawabata, Duncan J Knowler, Christian Lévêque, Robert J Naiman, and others, 'Freshwater Biodiversity: Importance, Threats, Status and Conservation Challenges' (2006) 81 Biological Review, $163-182$.

Dudley, Nigel, Guidelines for Applying Protected Area Management Categories (IUCN 2008).

Dupret, Baudouin, 'Legal Pluralism, Plurality of Laws, and Legal Practices: Theories, Critiques, and Praxiological Re-specification' [no date] An Open Access Initiative by EUI Legal Researchers.

Dupuy, Pierre-Marie, 'Soft Law and the International Law of the Environment' (1991) 12 Michigan Journal of International Law, 420 - 435.

— Cannizzaro (ed), The Law of Treaties Beyond the Vienna Convention (Oxford University Press 2011), 123 - 137.

Dworkin, Ronald M, Taking Rights Seriously (Duckworth 1977).

Dyzenhaus, David, The Constitution of Law: Legality in a Time of Emergency (Cambridge University Press 2006).

Ellis, Jaye, and Alison FitzGerald, 'The Precautionary Principle in International Law: Lessons from Fuller's Internal Morality' (2004) 49 McGill Law Journal, 779 - 800. 
Ehrlich, PR, AH Ehrlich, and JP Holdren, Ecoscience: Population, Resources, Environment (WH Freeman and Company 1977).

Fallon Jr, Richard H, and Daniel J Meltzer, 'New Law, Non-Retroactivity, and Constitutional Remedies' (1991) 104 Harvard Law Review, 1731 - 1833.

Farrall, Jeremy Matam, United Nations Sanctions and the Rule of Law (Cambridge University Press 2007).

Feinberg, Joel, 'Supererogation and Rules' (1961) 71 Ethics, 276 - 288.

Feldman, Alexander M, 'Evolving Treaty Obligations: A Proposal for Analysing Subsequent Practice Derived from WTO Dispute Settlement' (2009) 41 International Law and Politics, 655 - 706.

Finlayson, CM, R D’Cruz, and NC Davidson, Wetlands and Water: Ecosystem Services and Human Well-Being (World Resources Institute 2005).

Fisch, Jill E, 'Retroactivity and Legal Change: An Equilibrium Approach’ (1997) 110 Harvard Law Review, 1055 - 1123.

Fischer, J, D Lindenmayer, and A Manning, 'Biodiversity, Ecosystem Function, and Resilience: Ten Guiding Principles for Commodity Production Landscapes' (2006) 4 Frontiers in Ecology and the Environment, $80-86$.

Fischer, Joern, David B Lindenmayer, and Adrian D Manning, 'Biodiversity, Ecosystem Function, and Resilience: Ten Guiding Principles for Commodity Production Landscapes' (2006) 4 Frontiers in Ecology and the Environment, 80 - 86.

Fisher, Douglas E, 'Freshwater, Habitats, and Ecosystems' in Shawkat Alam, Md Jahid Hossain Bhuiyan, Tareq MR Chowdhury, and Erika J Techera (eds), Routledge Handbook of International Environmental Law (Routledge, 2013) 227 - 242.

Fitzmaurice, Malgosia, Olufemi Elias, and Panos Merkouris (eds), Treaty Interpretation and the Vienna Convention on the Law of Treaties: 30 Years on (Queen Mary Studies in International Law, Martinus Nijhoff 2010).

Fitzmaurice, Gerard G, 'The Foundations of the Authority of International Law and the Problem of Enforcement' (1956) 19 Modern Law Review, 1 - 13. 
—, 'Some Problems Regarding the Formal Sources of International Law' in Jan Hendrik Willem Verzijl and FM van Asbeck (eds), Symbolae Verzijl (Martinus Nijhoff 1958).

—, 'The Law and Procedure of the International Court of Justice, 1951-54' (1957) 33 British Yearbook of International Law, 203 - 293.

— 'The General Principles of International Law Considered from the Standpoint of the Rule of Law' (1957) 92-II Recueil des Cours, 1 - 228.

Forowicz, Magdalena, The Reception of International Law in the Court of Human Rights (Oxford University Press 2010).

Foundation for International Environmental Law and Development (FIELD), 'Implementation of Multilateral Environmental Agreements for Efficient Water Management' (on file with author 2005).

Francis, George, 'Ecosystem Management' (1993) 33 Natural Resources Journal, 315 345.

French, Duncan, 'Treaty Interpretation and the Incorporation of Extraneous Legal Rules' (2006) 55 International and Comparative Law Quarterly, 281 - 314.

Friedmann, Wolfgang, Law in a Changing Society (Stevens and Sons Limited 1959).

— The Changing Structure of International Law, (Columbia University Press 1964).

Fuentes, Ximena, 'The Criteria for the Equitable Utilization of International Rivers' (1996) 67 British Yearbook of International Law, 337 - 412.

Fuller, Lon F, 'Freedom as a Problem of Allocating Choice' (1968) 112 Proceedings of the American Philosophical Society, $101-106$.

Fuller, Lon L, The Law in Quest of Itself (The Foundation Press 1940).

—, 'American Legal Philosophy at Mid-Century' (1954) 6 Journal of Legal Education, $457-485$.

—_, 'Adjudication and the Rule of Law' (1960) 54 American Society of International Law Proceedings, $1-7$. 
—., 'A Reply to Professors Cohen and Dworkin' (1965) 10 Villanova Law Review, $655-666$.

—, Anatomy of Law (Frederick A Praeger 1968).

_

— $-36$.

— 'Human Interaction and the Law' (1969) 14 American Journal of Jurisprudence, 1 -36 .

Gardiner, Richard, Treaty Interpretation (Oxford University Press 2008).

Garner, Bryan A, ed., 'Black’s Law Dictionary’ (Thomson 2004).

Garver, Newton, 'Rules' in Paul Edwards (ed), Encyclopedia of Philosophy (Vol 7. Macmillan/Collier Macmillan no date), 231 - 233.

Glennon, Michael J, 'How International Rules Die' (2005) 93 Georgetown Law Journal, $939-991$.

Glowka, Lyle, Françoise Burhenne-Guilmin, and Hugh Synge, A Guide to the Convention on Biological Diversity (IUCN 1994).

Goble, Dale D, 'What are Slugs Good For? Ecosystem Services and the Conservation of Biodiversity' (2007) 22 Journal of Land Use and Environmental Law, 411 - 440.

Goldmann, Matthias, 'Inside Relative Normativity: From Sources to Standards Instruments for the Exercise of International Public Authority' (2008) 9 German Law Journal, 1865 - 1908.

Gray, John Chipman, and Roland Gray, The Nature and Sources of the Law (The Macmillan Company 1921).

Green, Michael JB, and James Paine, 'State of the World's Protected Areas at the End of the Twentieth Century' in IUCN (ed), IUCN World Commission on Protected Areas Symposium on 'Protected Areas in the 21st Century: From Islands to Networks' Albany, Australia, 24 - 29 November 1997 (IUCN 1997). 
Grumbine, R Edward, 'What is Ecosystem Management?' (1994) 8 Conservation Biology, $27-38$.

Guillaume, Gilbert, 'The Proliferation of International Judicial Bodies: The Outlook for the International Legal Order' (Speech by His Excellency Judge Gilbert Guillaume, President of the ICJ to the Sixth Committee of the UNGA, October 27, 2000).

Haeuber, Richard, 'Setting the Environmental Policy Agenda: The Case of Ecosystem Management' (1996) 36 Natural Resources Journal, 1 - 28.

Hanqin, Xue, 'Commentary. Relativity in International Water Law' (1992) 3 Colorado Journal International Environmental Law and Policy, 45 - 57.

Hart, HLA, The Concept of Law (2nd edn, Oxford University Press 1994).

Hassan, Rashid, Robert Scholes, and Neville Ash, eds., 'Chapter 1. MA Conceptual Framework' in Ecosystems and Human Well-being: Current State and Trends: Findings of the Condition and Trends Working Group (Island Press 2003), 1 - 25.

Hawkins, Joyce M, and Robert Allen, eds., (Clarendon Press 1991).

Hayek, Friedrich von, The Road to Serfdom (George Routledge and Sons 1944).

Heijnsbergen, Pieter van, International Legal Protection of Wild Fauna and Flora (IOS Press 1997).

Hey, Ellen, Reflections on an International Environmental Court (Kluwer Law International 2000).

Hicks, Bethany Lukitsch, 'Treaty Congestion in International Environmental Law: The Need for Greater International Coordination' (1999) 32 University of Richmond Law Review, 1643 - 1675 .

Higgins, Rosalyn, Problems and Process. International Law and How We Use It (Clarendon Press 1994).

—, 'Reflections from the International Court' in Malcolm D Evans (ed), International Law (2nd edn, Oxford University Press 2006), 1 - 10.

Hoof, GJH van, Rethinking the Sources of International Law (Kluwer Law and Taxation Publishers, Deventer, The Netherlands, 1983) 
Holt, Alison R, Jasmin A Godbold, Piran CL White, Anne-Michelle Slater, Eduardo G Pereira, and Martin Solan, 'Mismatches between Legislative Frameworks and Benefits Restrict the Implementation of the Ecosystem Approach in Coastal Environments' (2011) 434 Marine Ecology Progress Series, 213 - 228.

Houben, Piet-Hein, 'Principles of International Law Concerning Friendly Relations and Co-operation among States' (1967) 61(3) American Journal of International Law 703 736

Howell QC, John, and Shaheed Fatima, 'Using International Law in Domestic Courts' (Presented by Blackstone Chambers in Association with Liberty 'Focus on Public Law and Human Rights' November 18, 2005).

InterAction Council, 'Ecology and the Global Economy' (Chaired by Miguel de la Madrid, Hurtado, Amsterdam, Netherlands, February 10, 1990).

—, 'A Universal Declaration of Human Responsibility' (Report on the Conclusions and Recommendations by a High-Level Expert Group Meeting Chaired by Helmut Schmidt, 20 - 22 April 1997).

Jackson, Peter, 'A World Charter for Nature' (1983) 12 AMBIO, 133.

Jennings, Robert, and Arthur Watts, Oppenheim's International Law, vol. I (9th edn, Longman 1992).

Jennings, Robert, and Arthur Watts KCMG QC, eds., Oppenheim's International Law ( $9^{\text {th }}$ edn, Oxford University Press 2008).

Jessup, Philip C, 'The Palmas Island Arbitration' (1928) 22 American Journal of International Law, 735 - 752.

Kammerhofer, Jörg, 'Systemic Integration, Legal Theory and the ILC' (2008) 19 Finnish Yearbook of International Law, 157 - 181.

Keohane, Robert O, 'Multilateralism: An Agenda for Research' (1990) 45 Multilateralism: Old and New, $731-764$.

Kimball, Lee A, 'Institutional Linkages among Multilateral Environmental Agreements: A Structured Approach Based on Scale and Function' (Prepared for 'Interlinkages' 
International Conference on Synergies and Coordination between Multilateral Environmental Agreements, UNU, 14 - 16 July 1999).

Kingsbury, Benedict, 'International Law as Inter-Public Law' in Henry R Richardson and Melissa S Williams (eds), NOMOS XLIX: Moral Universalism and Pluralism (New York University Press 2009).

—, 'International Law as Inter-Public Law' in Henry S Richardson and Melissa S Williams (eds), Moral Universalism and Pluralism (New York University Press 2009), $167-204$.

Kingsford, Richard T, 'Conservation Management of Rivers and Wetlands under Climate Change - A Synthesis' (2011) 62 Marine and Freshwater Research, 217 - 222.

Kirk, Elizabeth, 'Maritime Zones and the Ecosystem Approach: A Mismatch?' (1999) 8 Review of European Community and International Environmental Law.

Klabbers, Jan, 'Reluctant Grundnormen: Articles 31(3)(c) and 42 of the Vienna Convention on the Law of Treaties and the Fragmentation of International Law' in Matthew Craven and others (eds), Time, History and International Law (Martinus Nijhoff 2007), $141-161$.

—, 'Constitutionalism and the Making of International Law. Fuller's Procedural Natural Law' (2008) 5 No Foundations. Journal of Extreme Legal Positivism, 84 - 112.

Korhonen, Iris M, 'Riverine Ecosystems in International Law' (1996) 36 Natural Resources Journal, $481-519$.

Koskenniemi, Martti, From Apology to Utopia: The Structure of International Legal Argument (Cambridge University Press 2005).

—, 'International Law: Between Fragmentation and Constitutionalism' (Paper Presented at Australia National University, Canberra, November 27, 2006).

Kratochwil, Friedrich, Rules Norms and Decisions: On the Conditions of Practical and Legal Reasoning in International Relations and Domestic Affairs (Cambridge University Press 1989).

- 'Legal Theory and International Law' in David Armstrong (ed), Routledge Handbook of International Law (Routledge 2009). 
Kratochwil, Friedrich V, 'How do Norms Matter?' in Michael Byers (ed), The Role of Law in International Politics: Essays in International Relations and International Law (Oxford University Press 2000).

Kress, Kenneth J, 'Legal Reasoning and Coherence Theories: Dworkin's Rights Thesis, Retroactivity, and the Linear Order of Decisions' (1984) 72 California Law Review, $369-402$.

Krisch, Nico, 'Review of Legitimacy and Legality in International Law: An Interactional Account by Jutta Brunnée and Stephen J Toope (Cambridge University Press 2010)' (2012) 106 American Journal of International Law, 203 - 209.

Kwiatkowska, Barbara, 'Southern Bluefin Tuna' (2001) 95 American Journal of International Law, $162-171$.

—, 'The Ireland v United Kingdom (Mox Plant) Case: Applying the Doctrine of Treaty Parallelism' (2003) 18 International Journal of Marine and Coastal Law, 1 - 58.

Kymlicka, Will, Liberalism, Community and Culture (Clarendon Press 1989).

Lauterpacht, Hersch, 'Decisions of Municipal Courts as A Source of International Law' (1929) 10 British Yearbook of International Law, 65 - 95.

Leir, Michael, 'Canadian Practice in International Law' (1999) 37 Canadian Yearbook of International Law, 317.

Leopold, Aldo, A Sand County Almanac and Sketches Here and There (Oxford University Press 1949).

Letsas, George, 'Strasbourg's Interpretive Ethic: Lessons for the International Lawyer' (2010) 21 European Journal of International Law, 509 - 541.

Leverington, Fiona., University of Queensland., IUCN World Commission on Protected Areas., UNEP World Conservation Monitoring Centre., and World Bank., Management Effectiveness Evaluation in Protected Areas: A Global Study (University of Queensland 2010).

Lindeman, Raymond, 'The Trophic-Dynamic Aspect of Ecology' (1942) 23 Ecology, $399-417$. 
Linderfalk, Ulf, On the Interpretation of Treaties. The Modern International Law as Expressed in the 1969 Vienna Convention on the Law of Treaties (Springer 2007).

—, 'Who are "The Parties"? Article 31, Paragraph 3(c) of the 1969 Vienna Convention and the "Principle of Systemic Integration" Revisited' (2008) 55 Netherlands International Law Review.

—, 'Doing the Right Thing for the Right Reason: Why Dynamic or Static Approaches Should be Taken in the Interpretation of Treaties' (2008) 10 International Community Law Review, 109 - 141.

Lowe, Vaughan, 'The Politics of Law-Making: Are the Method and Character of Norm Creation Changing' in Michael Byers (ed), The Role of Law in International Politics (Cambridge University Press 2000).

Maduro, Miguel Poiares, 'Foreword' in Tomer Broude and Yuval Shany (eds), MultiSourced Equivalent Norms in International Law (Hart Publishing 2011).

Marceau, Gabrielle, 'Conflict of Norms and Conflict of Jurisdictions: The Relationship between the WTO Agreement and MEAs and Other Treaties' (2001) 35 Journal of World Trade, 1081 - 1131.

—, 'WTO Dispute Settlement and Human Rights' (2002) 13 European Journal of International Law, $753-814$.

McCaffrey, Stephen C, 'The Law of International Watercourses: Some Recent Development and Unanswered Questions' (1989) 17 Denver Journal of International Law and Policy, 505.

- The Law of International Watercourses ( $2^{\text {nd }}$ edn. Oxford University Press 2007).

McDougal, Myres S, Harold D Lasswell, and W Michael Reisman, 'Theories about International law: Prologue to a Configurative Jurisprudence' (1968) 8 Virginia Journal of International Law, 188 - 194.

McGrady, Benn, 'Fragmentation of International Law or "Systemic Integration" of Treaty Regimes: EC-Biotech Products and the Proper Interpretation of Article 31(3)(c) of the Vienna Convention on the Law of Treaties' (2008) 42 Journal of World Trade, $589-618$. 
McIntyre, Owen, 'Case Law Analysis. Environmental Protection of International Rivers' (1998) 10 Journal of Environmental Law, 79 - 91.

_ , "The Emergence of an "Ecosystem Approach" to the Protection of International Watercourses under International Law' (2004) 13 Review of European Community and International Environmental Law, $1-14$.

_ ' 'The Proceduralisation and Growing Maturity of International Water Law. Case Concerning Pulp Mills on the River Uruguay (Argentina v. Uruguay), ICJ, 20 April 2010' (2010) 22 Journal of Environmental Law, 475 - 497.

McLachlan, Campbell, 'The Principle of Systemic Integration and Article 31(3)(c) of the Vienna Convention' (2005) 54 International and Comparative Law Quarterly, 279 230.

McNair, Ian, The Law of Treaties (Clarendon Press 1961).

Merkouris, Panos, 'Introduction: Interpretation is A Science, is An Art, is A Science' in Malgosia Fitzmaurice and others (eds), Treaty Interpretation and the Vienna Convention on the Law of Treaties: 30 Years on (Treaty Interpretation and the Vienna Convention on the Law of Treaties: 30 Years on 2010).

—, 'Article 31(3)(c) of the VCLT and the Principle of Systemic Integration' (PhD Queen Mary University of London 2010).

Michaels, Ralf, 'A Fuller Concept of Law Beyond the State? Thoughts on Lon Fuller's Contributions to the Jurisprudence of Transnational Dispute Resolution - A Reply to Thomas Schultz' (2011) 2 Journal of International Dispute Settlement, 417 - 426.

Millennium Ecosystem Assessment, Ecosystems and Human Well-Being: Synthesis (Island Press 2005).

Mitchell, Ronald B, 'Annual Count of Agreements in the IEA Database. Multilateral Environmental Agreements 1950 - 2012', 20122002.

Moltke, Konrad von, Whither MEAs? The Role of International Environmental Management in the Trade and Environment Agenda (International Institute for Sustainable Development 2001). 
Murphy, Colleen, 'Lon Fuller and the Moral Value of the Rule of Law' (2005) 24 Law and Philosophy, $239-262$.

Nanda, Ved P, 'The Law of the Non-navigational Uses of International Watercourses: Draft Articles on Protection and Preservation of Ecosystems, Harmful Conditions and Emergency Situations, and Protection of Water Installations' (1992) 3 Colorado Journal of International Environmental Law and Policy, 175 - 207.

Nedelsky, Jennifer, 'Communities of Judgment and Human Rights' (2000) 1 Theoretical Inquiries in Law, 245 - 282.

—_, 'Judgment, Diversity, and Relational Autonomy' in Ronald Beiner and Jennifer Nedelsky (eds), Judgment, Imagination, and Politics: Themes from Kant and Arendt (Rowman and Littlefield 2001).

Nicholson, Peter P, 'The Internal Morality of Law: Fuller and His Critics' (1974) 84 Ethics, $307-326$.

Nollkaemper, André, The Legal Regime for Transboundary Water Pollution: Between Discretion and Constraint (Martinus Nijhoff/Graham and Trotman 1993).

Oberthür, Sebastian, Thomas Gehring, and Oran R Young, (eds), Institutional Interaction in Global Environmental Governance: Synergy and Conflict among International and EU Policies (MIT Press 2006).

Oberthür, Sebastian, 'Clustering of Multilateral Environmental Agreements: Potentials and Limitations' (UNU Institute of Advanced Studies Project on International Environmental Governance Reform, UNU Tokyo, 2002).

Oberthür, Sebastian, and Olav Schram Stokke, (eds), Managing Institutional Complexity: Regime Interplay and Global Environmental Change (MIT Press 2011).

Oguamanam, Chidi, 'Biological Diversity' in Shawkat Alam and others (eds), Routledge Handbook of International Environmental Law (Routledge 2013).

Okidi, Charles Odidi, “Preservation and Protection” Under the 1991 ILC Draft Articles on the Law of International Watercourses' (1992) 3 Colorado Journal International Environmental Law and Policy, 143. 
Orakhelashvili, Alexander, 'Restrictive Interpretation of Human Rights Treaties in the Recent Jurisprudence of the European Court of Human Rights' (2003) 14 European Journal Of International Law, 529 - 568.

_- 'The Interaction between Human Rights and Humanitarian Law: Fragmentation, Conflict, Parallelism, or Convergence?' (2008) 19 The European Journal of International Law, $161-182$.

Palmer, Geoffrey, 'New Ways to Make International Environmental Law' (1992) 86 American Journal of International Law, 259 - 283.

Palmeter, David, and Petros C Mavroidis, 'The WTO Legal System: Sources of Law' (1998) 92 American Journal of International Law, 398 - 413.

Paparinskis, Martins, 'Sources of Law and Arbitral Interpretations of Pari Materia Investment Protection Rules' in Ole K Fauchald and André Nollkaemper (eds), The Practice of International and National Courts and the (De-)Fragmentation of International Law (SSRN: http://ssrn.com/abstract=1697835 (8 October 2010) Hart Publishing, Oxford 2012).

Pardy, Bruce, 'Changing Nature: The Myth of the Inevitability of Ecosystem Management' (2003) 20 Pace Environmental Law Review, 675 - 692.

Patterson, Dennis, 'After Conceptual Analysis: The Rise of Practice Theory' in Jaap C Hage and Dietmar von der Pfordten (eds), Concepts in Law (Law and Philosophy Library 88. Springer 2009).

Pauwelyn, Joost, 'The Role of Public International Law in the WTO: How Far Can We Go?' (2001) 95 American Journal of International Law, 535 - 578.

—, Conflict of Norms in Public International Law (Cambridge University Press 2003).

—, 'A Typology of Multilateral Treaty Obligations: Are WTO Obligations Bilateral or Collective in Nature?' (2003) 14 European Journal of International Law, 907 - 951.

—, 'Bridging Fragmentation and Unity: International Law as A Universe of InterConnected Islands' (2004) 25 Michigan Journal of International Law, 903 - 916. 
Pauwelyn, Joost, Ramses A Wessel, and Jan Wouters, (eds), Informal International Lawmaking (Oxford University Press 2012).

Pellet, Alain, 'Complementarity of International Treaty Law, Customary Law and NonContractual Law-Making' in Rüdiger Wolfrum and Volker Röben (eds), Development of International Law in Treaty Making (Springer 2005), 409 - 415.

Peters, Anne, Lucy Koechlin, and Gretta Fenner Zinkernagel, 'Non-State Actors as Standard Setters: Framing the Issue in An Interdisciplinary Fashion' in Anne Peters and others (eds), Non-State Actors as Standard Setters (Cambridge University Press 2009), $1-32$.

Phillips, Adrian, (ed), Economic Values of Protected Areas. Guidelines for Protected Area Managers (Best Practice Protected Area Guidelines Series No 2, IUCN, 1998).

Pokol, Béla, The Concept of Law. The Mult-Layered Legal System (Rejtjel Edition 2001).

Postel, Sandara, Dividing the Waters: Food Security, Ecosystem Health, and the New Politics of Scarcity (Worldwatch Institute 1996).

Postema, Gerald J, 'Implicit Law' (1994) 13 Law and Philosophy, 361 - 387.

—, 'Custom in International Law: A Normative Practice Account' in Amanda Perreau-Saussine and James Bernard Murphy (eds), The Nature of Customary Law: Legal, Historical and Philosophical Perspectives (Cambridge University Press 2007).

__, A Treatise of Legal Philosophy and General Jurisprudence (Springer 2011).

Postema, Gerard J, 'Implicit Law' in Willem J Witteveen and Wibren van der Burg (eds), Rediscovering Fuller: Essays on Implicit Law and Institutional Design (Amsterdam University Press 1999), 256 - 275.

Pronto, Arnold N, 'Some Thoughts on the Making of International Law' (2008) 19 European Journal of International Law, $601-616$.

Quirico, Ottavio, 'Disentangling Climate Change Governance: A Legal Perspective' (2012) 21 Review of European Community and International Environmental Law, 92 101. 
Rauschining, Dietrich, ed., The Vienna Convention on the Law of Treaties. Travaux Préparatoires (Alfred Metzner Verlag 1978).

Rawls, John, 'Two Concepts of Rules' (1955) 54 The Philosophical Review, 3 - 32.

Raz, Joseph, Practical Reason and Norms (Hutchinson 1975).

—, Between Authority and Interpretation. On the Theory of Law and Practical Reason (Oxford University Press 2009).

Reiners, William A, 'Complementary Models for Ecosystems' (1986) 127 The American Naturalist, 59 - 73.

Rieu-Clarke, Alistair S, 'The Role of Treaties in Building International Watercourse Regimes: A Legal Perspective on Existing Knowledge' (2010) 12 Water Policy, 822 831.

Rieu-Clarke, Alistair S, Patricia Wouters, and Flavia Loures, 'The Role and Relevance of the UN Convention on the Law of the Non-Navigational Uses of International Watercourses to the EU and Its Member States' (UNESCO Centre for Water Law, Policy and Science no date).

Röben, Volker, 'The Order of the UNCLOS Annex VII Arbitral Tribunal to Suspend Proceedings in the Case of the MOX Plant at Sellafield: How Much Jurisdictional Subsidiarity’ (2004) 73 Nordic Journal of International Law, 223 - 245.

Romano, Cesare, 'The Southern Bluefin Tuna Dispute: Hints of a World to Come ... Like It or Not' (2001) 32 Ocean Development and International Law, 313 - 348.

Rosenne, Shabtai, Practice and Methods of International Law (Oceana Publications 1984).

—, Developments in the Law of Treaties, 1945 - 1986 (Cambridge University Press 1989).

Salman, Salman MA, 'The Helsinki Rules, the UN Watercourses Convention and the Berlin Rules: Perspectives on International Water Law' (2007) 23 Water Resources Development, $625-640$.

Sampford, Charles, Retrospectivity and the Rule of Law (Oxford University Press 2006). 
Samson, Mélanie, 'High Hopes, Scant Resources: A World of Scepticism about the Anti-Fragmentation Function of Article 31(3)(c) of the Vienna Convention on the Law of Treaties' (2011) 24 Leiden Journal of International Law, 701 - 714.

Sanchez, Oscar Arias, 'Some Contributions to a Universal Declaration of Human Obligations', April 1997.

Sands, Philippe, 'Treaty, Custom and the Cross-fertilization of International Law' (1998) 1 Yale Human Rights and Development Law Journal, 85 - 105.

—, Lawless World. America and the Making and Breaking of Global Rules (Allen Lane 2005).

Sartor, Giovanni, 'The Foundation of Legal Bindingness' in Corrado Roversi (ed), A Treaties of Legal Philosophy and General Jurisprudence (Springer 2005).

Schachter, Oscar, 'The Twilight Existence of Non-binding International Agreements' (1977) 71 American Journal of International Law, 296 - 304.

— International Law.

_- International Law in Theory and Practice (Martinus Nijhoff Publishers 1991).

Schechter, Michael G, 'Systemic Change, International Organizations, and the Evolution of Multilateralism' in James P Muldoon Jr and others (eds), The New Dynamics of Multilateralism. Diplomacy, International Organizations, and Global Governance (Westview Press 2011), 23 - 41.

Schultz, Thomas, 'The Concept of Law in Transnational Arbitral Legal Orders and Some of Its Consequences' (2011) 2 Journal of International Dispute Settlement, 59 85.

Schwelb, Egon, 'Crimes Against Humanity' (1946) 23 British Yearbook of International Law, $178-226$.

Scott, Karen N, 'International Environmental Governance: Managing Fragmentation through Institutional Connection' (2011) 12 Melbourne Journal of International Law, 1 $-40$. 
Shany, Yuval, 'The First MOX Plant Award: The Need to Harmonize Competing Environmental Regimes and Dispute Settlement Procedures' (2004) 17 Leiden Journal of International Law, $815-827$.

Shany, Yuval, and Tomer Broude, (eds), Multi-Sourced Equivalent Norms in International Law (Hart Publishing 2011).

Shaw, Malcolm N, International Law (5 $5^{\text {th }}$ edn, Cambridge University Press 2003).

Shelford, Victor E, 'The Preservation of Natural Biotic Communities' (1933) 14 Ecology, $240-245$.

Shigeta, Yasuhiro, International Judicial Control of Environmental Protection. Standard Setting, Compliance Control and the Development of International Environmental Law by the International Judiciary (Kluwer Law International 2010).

Simma, Bruno, 'Universality of International Law from the Perspective of a Practitioner' (2009) 20 European Journal of International Law, 265 - 297.

Sinclair, Ian, The Vienna Convention on the Law of Treaties $\left(2^{\text {nd }}\right.$ edn, Manchester University Press 1984).

Smart, Michael, 'The Ramsar Convention: Its Role in Conservation and Wise Use of Wetland Biodiversity' in AJ Hails (ed), Wetlands, Biodiversity and Ramsar Convention: The Role of the Convention on Wetlands in the conservation and Wise Use of Biodiversity (Ramsar Convention Bureau 1997), Chapter 2.

Stephens, Tim, 'Multiple International Courts and the "Fragmentation" of International Environmental Law' (Legal Studies Research Paper No. 07/14, Sydney Law School, The University of Sydney, March 2007).

Summers, Robert S, Lon L Fuller (Edward Arnold 1984).

— ' 'The Formal Character of Law' (1992) 51 The Cambridge Law Journal, 242 262.

Suy, E, 'Le Préambule' in E Yakpo and T Boumedra (eds), Liber Amicorum Judge Mohammed Bedjaoui (Kluwer 1999). 
Tansley, AG, 'The Use and Abuse of Vegetational Concepts and Terms' (1935) 16 Ecology, $284-307$.

Tanzi, Attila, and Maurizio Arcari, The United Nations Convention on the Law of International Watercourses. A Framework for Sharing (Kluwer Law International 2001).

Tarlock, Dan, 'International Water Law and the Protection of River Ecosystem Integrity' (1996) 10 Brigham Young University Journal of Public Law, 181 - 211.

—, 'Ecosystems' in Daniel Bodansky and others (eds), The Oxford Handbook of International Environmental Law (Oxford University Press 2007).

Tasioulas, John, 'In Defence of Relative Normativity: Communitarian values and the Nicaragua Case' (1996) 16 Oxford Journal of Legal Studies, 85 - 128.

Teclaff, Ludwik A, 'Evolution of the River Basin Concept in National and International Water Law’ (1996) 36 Natural Resources Journal, 359 - 391.

Teclaff, Ludwik A, and Eileen Teclaff, 'International Control of Cross-Media Pollution - An Ecosystem Approach' (1987) 27 Natural Resources Journal, 21 - 53.

Thirlway, Hugh, 'The Law and Procedure of the International Court of Justice: 19601989, Part One' (1989) 60 British Yearbook of International Law, 1 - 157.

Thirlway, Hugh, 'The Law and Procedure of the International Court of Justice 19601989: Part Three' (1991) 62 British Yearbook of International Law, 1 - 75.

Tremblay, Hugo, 'An Analytical Framework for Legal Regimes Applicable to Freshwater Ecosystems' (2010) 20 Journal of Water Law, 152 - 164.

Trouwborst, Arie, 'The Precautionary Principle and the Ecosystem Approach in International Law: Differences, Similarities and Linkages' (2009) 18 Review of European Community and International Environmental Law, 26 - 37.

Twinning, William, 'Normative and Legal Pluralism: A Global Perspective' (Duke University School of Law April 7, 2009).

Twinning, William L, and David Miers, How to Do Things with Rules: A Primer of Interpretation (4th edn, Butterworths 1999). 
Tzevelekos, Vassilis P, 'The Use of Article 31(3)(c) of the VCLT in the Case Law of the ECtHR: An Effective Anti-Fragmentation Tool or A Selective Loophole for the Reinforcement of Human Rights Teleology? Between Evolution and Systemic Integration' (2010) 31 Michigan Journal of International Law, 621 - 690.

UNEP-WCMC, Review of the Biodiversity Requirements of Standards and Certification Schemes. A Snapshot of Current Practice (CBD Technical Series No 63. Secretariat of the Convention on Biological Diversity 2011).

__ ' 'The World Database on Protected Areas', January 2011.

UNEP, 'The UN-Water Status Report on the Application of Integrated Approaches to Water Resources Management' (UNEP 2012).

Velasquez, Jerry, "UNU "Interlinkages Initiative" Aims at Coherent Sustainable Development' (Environment and Development: A Three-Decade Timeline, UNU Tokyo, 1999).

Villiger, Mark E, Customary International Law and Treaties: A Study of their Interactions and Interrelations with Special Consideration of the 1969 Vienna Convention on the Law of Treaties (Martinus Nijhoff 1985).

—, Commentary on the 1969 Vienna Convention on the Law of Treaties (Martinus Nijhoff Publishers 2009).

_ “Crucible” Intended by the International Law Commission' in Enzo Cannizzaro (ed), The Law of Treaties Beyond the Vienna Convention (Oxford University Press 2011).

Vitányi, Béla, 'Treaty Interpretation in the Legal Theory of Grotius and Its Influence on Modern Doctrine' (1983) 14 Netherlands Yearbook of International Law, 41 - 67.

Voigt, Christina, Sustainable Development as a Principle of International Law: Resolving Conflicts between Climate Measures and WTO Law (Martinus Nijhoff Publishers 2009).

Wälde, Thomas, 'Introductory Note to Svea Court of Appeals: Czech Republic v CME Czech Republic BV' (2003) 42 International Legal Materials, 915. 
Wälde, Thomas W, 'Interpreting Investment Treaties: Experiences and Examples' in Christian Binder and others (eds), International Investment Law for the 21st Century. Essays in Honour of Christoph Schreuer (Oxford University Press 2009), 724 - 781.

Waldock, Humphrey, 'General Course on Public International Law' (1962) 106-II Recueil des Cours.

Waldron, Jeremy, 'Why Law - Efficacy, Freedom, or Fidelity?' (1994) 13 Law and Philosophy, $259-284$.

Watt, Arthur, The International Law Commission, 1949 - 1998, vol. II (Oxford University Press 1999).

Weinrib, Ernest J, 'Legal Formalism: On the Immanent Rationality of Law' (1988) 97 The Yale Law Journal, 949 - 1016.

Wenger, Etienne, Communities of Practice: Learning, Meaning, and Identity (Cambridge University Press 1998).

Werksman, Jacob D, 'Formal Linkages and Multilateral Environmental Agreements' (Background Paper prepared for the International Conference on Synergies and Coordination between Multilateral Environmental Agreements, UNU Tokyo 14 - 16 July 1999).

Winston, Kenneth I, 'Three Models for the Study of Law' in Willem J Witteveen and Wibren van der Burg (eds), Rediscovering Fuller: Essays on Implicit Law and Institutional Design (Amsterdam University Press 1999).

Winston, Kenneth I, ed., The Principles of Social Order: Selected Essays of Lon L Fuller (Revised. Hart Publishing 2001).

Wolfrum, Rüdiger, and Nele Matz, Conflicts in International Environmental Law (MaxPlanck-Institut für Ausländisches Öffentliches Recht und Völkerrecht, Springer-Verlag 2003).

—, Conflicts in International Environmental Law (Max-Planck-Institut für Ausländisches Öffentliches Recht und Völkerrecht, Springer-Verlag 2003). 
Wood, Jr, Harold W, 'The United Nations World Charter for Nature: The Developing Nations' Initiative to Establish Protections for the Environment' (1985) 12 Ecology Law Quarterly, 977 - 996.

Wouters, Patricia K, 'An Assessment of Recent Developments in International Watercourse Law through the Prism of the Substantive Rules Governing Use Allocation' (1996) 36 Natural Resources Journal, 417 - 439.

Wolfrum, Rüdiger and Nele Matz, Conflicts in International Environmental Law (Springer-Verlag Berlin, Heidelberg, New York, 2003)

Yasseen, Mustafa Kamil, L'interprétation des Traités d'après la Convention de Vienne sur le Droit des Traités, vol. 151 (Recueil des Cours de l'Académie de Droit International 1976).

Yasseen, Mustafa Kamil., L'Interprétation des traités d'après la Convention de Vienne sur le droit des traités (AW Sijthoff 1978).

Young, Margaret A, 'The WTO's Use of Relevant Rules of International Law: An Analysis of the Biotech Case' (2007) 56 International and Comparative Law Quarterly, $899-930$.

—, 'Fragmentation or Interaction: the WTO, Fisheries Subsidies, and International Law' (2009) 8 World Trade Review, 477 - 515.

__, 'Climate Change Law and Regime Interaction' (2011) 2 Carbon and Climate Law Review, 147 - 157.

Zemanek, Karl, 'Is the Term “Soft Law" Convenient?' in Gerhad Hafter (ed), Liber Amicorum Professor Ignaz Seidl-Hohenveldern in Honour of His 80th Birthday (Kluwer Law International 1998).

Zumbansen, Peer, 'Debating Autonomy and Procedural Justice: The Lex Mercatoria in the Context of Global Governance Debates - A Reply to Thomas Schultz' (2011) 2 Journal of International Dispute Settlement, 427 - 433. 
Cambridge University Press, 'Cambridge Advanced Learner's Dictionary and Thesaurus' (2011) <http://dictionary.cambridge.org/dictionary/british/applicable> accessed 24 May 2012

CBD Secretariat, 'History of the Convention' <http://www.cbd.int/history/ $>$ accessed 12 September 2011.

CBD, 'Cooperation and Partnership' (CBD, undated) <http://www.cbd.int/cooperation/artsdecs.shtml> accessed 28 March 2012

CBD, 'Global Implementation' (undated) <http://www.cbd.int/protected/implementation/> accessed 13 August 2012 CBD, 'Global Implementation' (undated) <http://www.cbd.int/protected/implementation/> accessed 11 August 2012 CBD, 'Inland Waters Biodiversity - Background' (undated) <http://www.cbd.int/waters/background/> accessed 3 August 2012

CBD, 'Inland Waters Biodiversity - Tool and Guidelines' (undated) <http://www.cbd.int/waters/tools.shtml> accessed 11 August 2012

CBD, 'Inland Waters Biodiversity - What is It?' (undated) <http://www.cbd.int/waters/inland-waters/> accessed 31 July 2012. CBD, 'Inland Waters Biodiversity - Background' (undated) $<$ http://www.cbd.int/waters/background/> accessed 31 July 2012

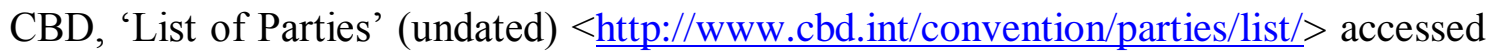
9 August 2012

CBD, 'Programme of Work' (undated) < http://www.cbd.int/protected/pow/learnmore/intro/> accessed 11 August 2012

CBD, 'Traditional Knowledge, Innovations and Practices. Introduction' (undated) <http://www.cbd.int/traditional/intro.shtml > accessed 9 August 2012

Chambers Publishers, 'Chambers $21^{\text {st }}$ Century Dictionary' <http://www.chambersharrapco.uk/chambers/features/chref/chref.py/main?query=applic $\underline{\text { able } \& \text { title }=21 \mathrm{st}>}$ accessed 24 May 2012 
Collins, 'The Collins English Dictionary' (2011) <http://www.collinsdictionary.com/dictionary/english/applicable> accessed 24 May 2012

IUCN, 'Category VI - Protected Area with Sustainable Use of Natural Resources' (10 September

<http://www.iucn.org/about/work/programmes/pa/pa_products/wcpa_categories/pa_cat egoryvi/> accessed 12 August 2012

IUCN, 'IUCN Protected Area Management Categories' (16 January 2012) <http://www.iucn.org/about/work/programmes/pa/pa_products/wcpa_categories/> accessed 30 July 2012

IUCN, 'World Parks Congress' (29 January 2010) $<$ http://www.iucn.org/about/work/programmes/pa/pa_event/wcpa_wpc/> accessed 31 July 2012

Millennium Ecosystem Assessment, 'Guide to the Millennium Assessment Reports' (2005) <http://www.maweb.org/en/index.aspx > accessed 13 September 2011

Oscar Arias Sanchez, 'Some Contributions to a Universal Declaration of Human Obligations' (April 1997) < $\underline{\text { http://interactioncouncil.org/some-contributions-universal- }}$ declaration-human-obligations> accessed 12 September 2012.

Oxford University Press, 'Oxford Dictionaries'

<http://oxforddictionaries.com/definition/applicable?view=uk > accessed 24 May 2012

Ramsar Convention on Wetlands (undated) <http://www.ramsar.org/cda/en/ramsarhome/main/ramsar/1_4000_0_> accessed 17 November 2012

Ramsar Convention, 'Brief Description of the River Basin Initiative' (28 February 2001) $<$ http://www.ramsar.org/cda/en/ramsar-news-archives-2001-brief-description-ofthe/main/ramsar/1-26-45-88\%5E21059_4000_0_> accessed 3 August 2012

Ramsar Convention, 'Synergies with Other Environment-Related Conventions and Organisations' (4 September 2009) < http://www.ramsar.org/cda/en/ramsar-aboutsynergy/main/ramsar/1-36-192 $4000 \quad 0 \quad>$ accessed 20 May 2010. 
Ramsar Convention, 'The Conference of the Contracting Parties' (8 December 2010) $<$ http://www.ramsar.org/cda/en/ramsar-about-bodies-conf-conference-of-the7690/main/ramsar/1-36-71-72\%5E7690_4000_0_> accessed 20 July 2012

Report of the World Commission on Environment and Development: Our Common Future, transmitted to the General Assembly as an Annex to document A/42/427 Development and International Co-operation: Environment <http://www.undocuments.net/wced-ocf.htm> accessed 13 September 2011

Ronald B Mitchell, 'Annual Count of Agreements in the IEA Database. Multilateral Environmental Agreements $1950 \quad-\quad 2012$ ' (2002 - 2012) $<$ http://iea.uoregon.edu/page.php?query=summarize by year\&yearstart=1950\&yearend $=2012$ \&inclusion=MEA $>$ accessed 2 November 2012. See Data from Ronald B Mitchell, 'International Environmental Agreements Database Project (Version 2012.1)' (2002-2012) <http://iea.uoregon.edu/> accessed 2 November 2012.

The Jean Monnet Center for International and Regional Economic Law and Justice, 'WTO Obligations are Bilateral Obligations' (Academy of European law online, undated) $\quad<$ http://centers.law.nyu.edu/jeanmonnet/archive/papers/02/020101-

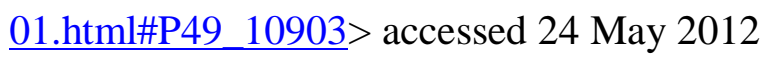

UNECE, 'The UNECE Water Convention, Helsinki, 17 March 1992' (undated) $<$ http://www.unece.org/env/water/> accessed 10 February 2013

UNEP, 'Guideline 34. International Cooperation and Coordination' (Manual on Compliance with and Enforcement of Multilateral Environmental Agreement, Division of Environmental Law and Conventions, UNEP) <http://www.uneporg/dec/onlinemanual/Compliance/InternationalCooperation/tabid/41 5/Default.aspx > accessed 25 September 2012.

UNEP, 'Synergies between the Ramsar Convention and Other MEAs' <http://www.uneporg/delc/> accessed 25 September 2012.

UNEP-WCMC, 'Biodiversity Indicators Partnership'

<http://www.bipindicators.net/pacoverage> accessed 17 August 2012 
UNEP-WCMC, 'IUCN Management Categories' (2012) < http://www.unep-

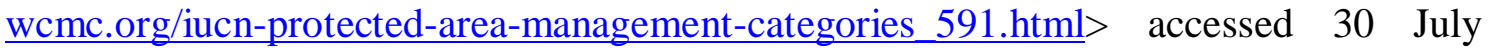
2012

UNEP-World Conservation Monitoring Centre, 'Promoting Synergies within the Cluster of Biodiversity-related Multilateral Environmental Agreements Summary Report' (April 2012) $\quad<\underline{\text { http://www.unep- }}$ wcmc.org/medialibrary/2012/04/27/ff1a00f0/MEA synergies summary for web cove r_27April2012.pdf> accessed 27 September 2012.

UNEP-World Conservation Monitoring Centre, 'Report by UNEP-WCMC on "Promoting Synergies within the Cluster of Biodiversity-related Multilateral Environmental Agreements' (2012) < http://www.unep-wcmc.org/report-by-unepwcmc-on-promoting-synergies-within-the-cluster-of-biodiversity-related-multilateralenvironmental-agreements_866.html> accessed 27 September 2012

UNESCO, 'Man and the Biosphere Programme' <http://www.unesco.org/new/en/natural-sciences/environment/ecological-sciences/manand-biosphere-programme/> accessed 9 August 2011

UNFCCC, 'Clean Development $\quad$ Mechanism $\quad$ (CDM)' $<$ http://unfccc.int/kyoto_protocol/mechanisms/clean_development_mechanism/items/27 18.php> accessed 3 March 2011

UNFCCC, 'Kyoto Protocol' <http://unfccc.int/kyoto_protocol/items/2830.php> accessed 15 September 2011

United Nations, 'International Decade for Action "WATER FOR LIFE" 2005-2015' (undated) <http://www.un.org/waterforlifedecade/quality.shtml > accessed 2 November 2012.

WTO, 'XXI. Article XX' (WTO Analytical Index: GATT 1994) <http://www.wto.org/english/res_e/booksp_e/analytic_index_e/gatt1994_07_e.htm> accessed 21 April 2012

Yale Law School Lillian Goldman Law Library, 'Charter of the International Military Tribunal' (Nuremberg Trial Proceedings Vol I, The Avalon Project. Documents in Law, 
History and Diplomacy 2008) <http://avalon.law.yale.edu/imt/imtconst.asp > accessed 3 May 2012

Yale Law School Lillian Goldman Law Library, 'London Agreement of August $8^{\text {th }}$ 1945' (Nuremberg Trial Proceedings Vol I, The Avalon Project. Documents in Law, History and Diplomacy 2008) < http://avalon.law.yale.edu/imt/imtchart.asp $>$ accessed 3 May 2012 